Florida International University

FIU Digital Commons

$11-7-2014$

\title{
Ficción Extrema: Deslizamientos en la Realidad a Través de la Relación Entre Arte y Literatura (Max Aub, Leonora Carrington y Enrique Vila-Matas)
}

Adriana Herrera

adrianaherrerat@gmail.com

Follow this and additional works at: https://digitalcommons.fiu.edu/etd

Part of the Contemporary Art Commons, Modern Art and Architecture Commons, Spanish Literature Commons, and the Theory and Criticism Commons

\section{Recommended Citation}

Herrera, Adriana, "Ficción Extrema: Deslizamientos en la Realidad a Través de la Relación Entre Arte y Literatura (Max Aub, Leonora Carrington y Enrique Vila-Matas)" (2014). FIU Electronic Theses and Dissertations. 1741.

https://digitalcommons.fiu.edu/etd/1741

This work is brought to you for free and open access by the University Graduate School at FIU Digital Commons. It has been accepted for inclusion in FIU Electronic Theses and Dissertations by an authorized administrator of FIU Digital Commons. For more information, please contact dcc@fiu.edu. 


\section{FLORIDA INTERNATIONAL UNIVERSITY \\ Miami, Florida}

FICCIÓN EXTREMA: DESLIZAMIENTOS EN LA REALIDAD A TRAVÉS DE LA

RELACIÓN ENTRE ARTE Y LITERATURA (MAX AUB, LEONORA

CARRINGTON Y ENRIQUE VILA-MATAS)

A dissertation submitted in partial fulfillment of

the requirements for the degree of

DOCTOR OF PHILOSOPHY

in

SPANISH

by

Adriana Herrera

2014 
To: Interim Dean Michael R. Heithaus

College of Arts and Sciences

This dissertation, written by Adriana Herrera, and entitled Ficción extrema: Deslizamientos en la realidad a través de la relación entre arte y literatura (Max Aub, Leonora Carrington y Enrique Vila-Matas), having been approved in respect to style and intellectual content, is referred to you for judgment.

We have read this dissertation and recommend that it be approved.

Renee Silverman

Asunción Gómez

Carol Damian

Santiago Juan-Navarro, Major Professor

Date of Defense: November 7, 2014

The dissertation of Adriana Herrera is approved.

Interim Dean Michael R. Heitaus College of Arts and Sciences

Dean Lakshmi N. Reddi University Graduate School

Florida International University, 2014 


\section{AGRADECIMIENTOS}

A cada uno de los miembros de mi comité, encabezado por el Dr Santiago JuanNavarro, por su inapreciable colaboración, aún más significativa por el aporte de sus investigaciones sobre la metaficción historiográfica. A la Dra Asunción Gómez por su incondicional apoyo, profesional y humano, desde el inicio de mi carrera; a la Dra Reneé Silverman, bajo cuya certera guía comencé a investigar la obra de Max Aub; a la Dra Carol Damian, quien ha secundado mis exploraciones curatoriales como parte de su apertura a nuevas visiones en el arte latinoamericano. Al Dr Juan Martínez, quien secundó el entusiasmo inicial para emprender esta disertación.

A mi madre, por el ejemplar valor con el que enfrentó su cáncer sin dejar de animarme a continuar escribiendo y desde la otra orilla festeja conmigo y con mi padre y

abuelo este momento. Y a mis padres adoptivos, Leonor y Álvaro, porque sustentan mi alma.

A mis cinco hijos, María de la Paz, Juan Francisco, Mariana Lucía, Manuel Andrés y María Juliana, por el amor, siempre, pero especialmente a Mariana por la luz de su infatigable trabajo como secretaria en la fase final de la disertación.

A mi esposo, Willy Castellanos, por su presencia clara en las horas de fatiga y por la invención de la felicidad cotidiana.

Al Dios de los alegres por cuyas aventuras cambió Teresa de Ávila sus amados libros de caballería. 


\begin{abstract}
OF THE DISSERTATION
FICCIÓN EXTREMA: DESLIZAMIENTOS EN LA REALIDAD A TRAVÉS DE LA

RELACIÓN ENTRE ARTE Y LITERATURA (MAX AUB, LEONORA CARRINTON

Y ENRIQUE VILA-MATAS)
\end{abstract}

by

Adriana Herrera

Florida International University, 2014

Miami, Florida

Professor Santiago Juan-Navarro, Major Professor

Si el siglo XX creó una extendida conciencia sobre las variantes de la intertextualidad en la ficción literaria, hoy enfrentamos transformaciones en la naturaleza de la ficción y sus relaciones con otras formas discursivas y/o creativas como el arte, y con la misma realidad, que es posible designar con el concepto de ficción extrema. Desde "Don Quijote" o "Las meninas" hay incursiones en la metaficción y/o autorrefecividad. Pero a partir de las vanguardias modernistas y de modo creciente en los estertores de la postmodernidad nos abocamos a un singular tipo de hipertextualidad que desbordando lo literario se apropia de prácticas artísticas (o lo contrario) como recurso para la transposición de sus ficciones, no sólo de uno a otro campo, sino para su inserción en la realidad: la ficción extrema.

Max Aub (España 1903-México 1973), Leonora Carrington (Inglaterra 1917México 2011) y Enrique Vila-Matas (España 1958), radicalizaron este tránsito o filtración de los imaginarios artísticos y literarios subvirtiendo las delimitaciones entre géneros, y la memoria de la historia del arte o de la literatura. Aub impostó la figura del pintor catalán Jusep Torres Campalans, junto con sus obras pictóricas, creadas como 
sombra o doble de Picasso. Así insertó su existencia en ciertos dominios del cubismo como un modo de meta-crítica artística. Carrington asumió un doble animal que transitó entre cuentos y cuadros y se inscribió en la memoria del surrealismo. Vila-Matas narró su "Historia abreviada de la literatura portátil" como un doble del espectro Marcel Duchamp - a su vez asaltado por otros - que reescribe la memoria del dadaísmo de tal modo que ha llegado a ser confundida con un ensayo. La revisión de las estrategias de la fícción extrema en estos autores junto con las de otros contemplados en el epilogo - Mario Bellatín, y los artistas Liliana Porter, Luis Camnitzer, José Guillermo Castillo, Ana Tisconia, Rubén Torres Llorca y Carlos Amorales - arroja nueva luz sobre sus obras, enriquece los estudios transatlánticos y revela la movilidad y multiplicación de la identidad y los deslizamientos de la ficción en la realidad como signos de tránsito a la altermodernidad. 


\section{TABLA DE CONTENIDO}

\section{CAPÍTULO}

\section{PÁGINA}

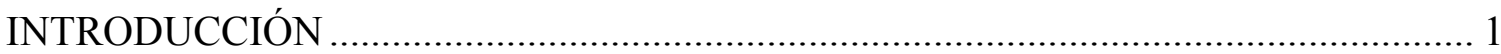

La novedad de la ficción extrema ............................................................................... 15

\section{MAX AUB Y LA FICCIÓN EXTREMA: LA INVENCIÓN DE JUSEP TORRENS}

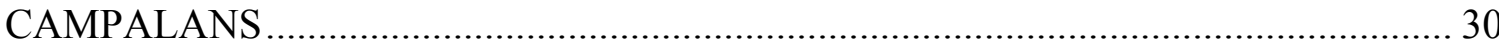

La relación especular con Picasso................................................................................... 37

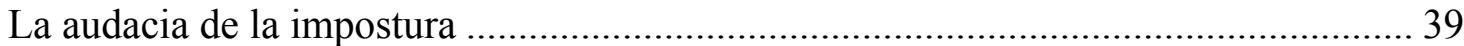

El signo errante del autor en el origen de la ficción extrema........................................ 47

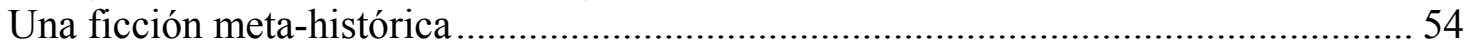

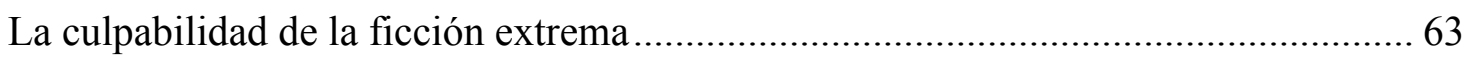

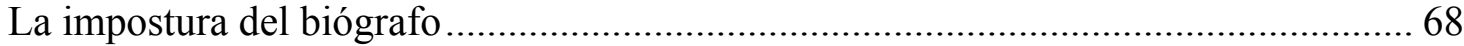

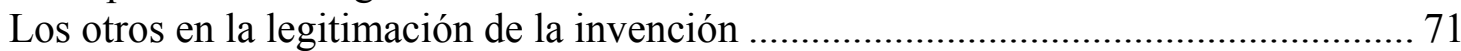

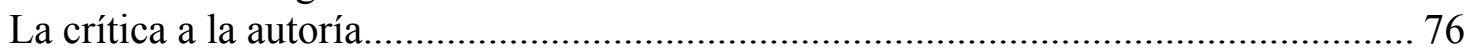

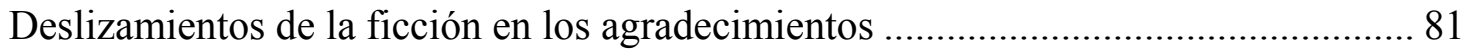

El juego de los anales: otra estrategia de la ficción extrema ......................................... 85

Composiciones cubistas en la biografía apócrifa...................................................... 93

El artificio del pintor imaginario.......................................................................... 110

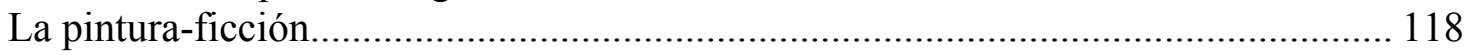

La impostura del crítico: la pintura desencantada.................................................. 155

\section{LEONORA CARRINGTON: LA MUJER-CABALLO DERRIBANDO LINDES}

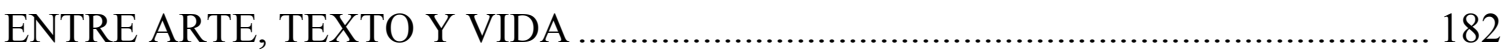

La novia del viento. Una rebelde muy hermosa .................................................. 185

Habitante de una segunda realidad ........................................................................ 194

Coser mitos: juegos de la lengua e iconografías ....................................................... 199

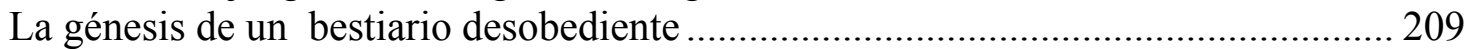

La máscara de la hiena y el desacato social ............................................................ 219

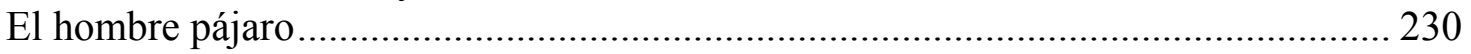

La mujer caballo y el hombre pájaro: incendios de la imaginación ............................ 262

De torneos peligrosos y juegos de damas en St Martin d'Ardèche ............................. 270

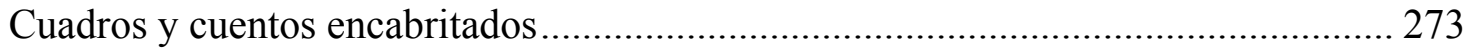

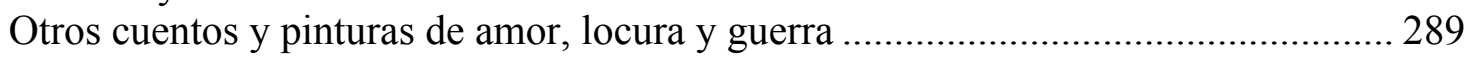

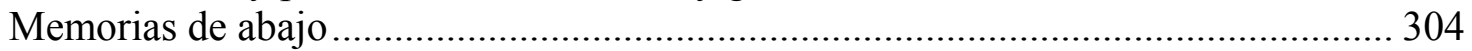

Caballos translúcidos de un viaje eterno.................................................................. 313

VILA-MATAS Y SU FICCION EXTREMA: DEL DADA AL TEXTO PORTÁTIL

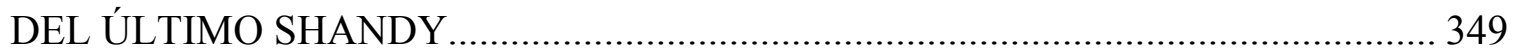

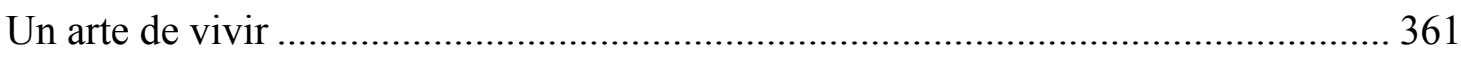

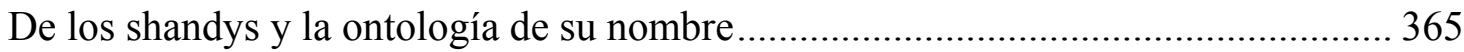

Duchamp como Odradek del narrador Vila-Matas ……………………………......... 375

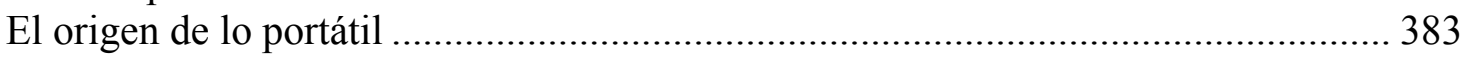


Las máquinas solteras y las visiones iniciales de las mujeres fatales de HALP........ 394

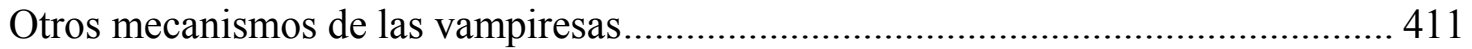

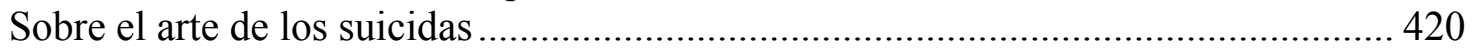

La africanidad como mapa y método textual ......................................................... 439

La escritura africana de Cendrars ............................................................... 451

Laberinto de Odradeks ........................................................................................ 459

Crowley, narrador de Historia abreviada de la literatura Portátil ............................. 463

OTROS CASOS DE FICCIÓN EXTREMA: ESCRITORES, ARTISTAS Y OTROS

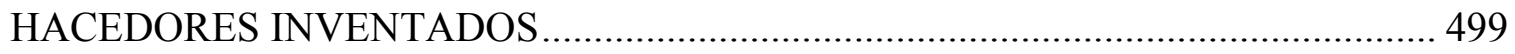

El desdoblamiento de Mario Bellatin en la figura del escritor y fotógrafo Shiki

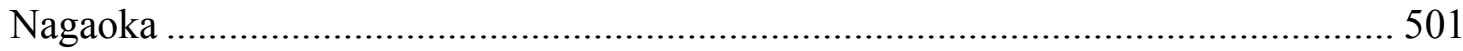

Ficcionalizar el documento fotográfico, documentar la ficción literaria.................... 508

Otros fragmentos especulares de la relación entre el no-lenguaje y la mirada de la

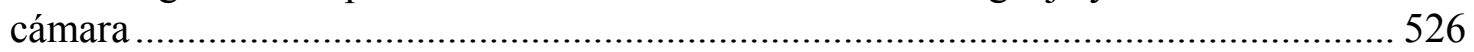

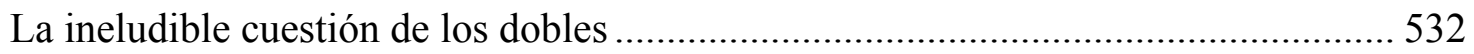

Una inmersión vertiginosa en otros casos de ficción extrema ................................ 537

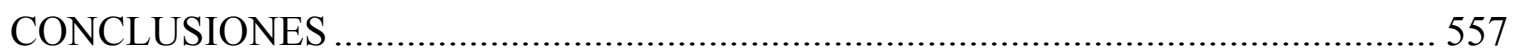

Palimpsestos de ficciones y su convergencia en modos de verdad vital ................... 562

Deslizamientos radicales en las fronteras entre géneros ..................................... 571

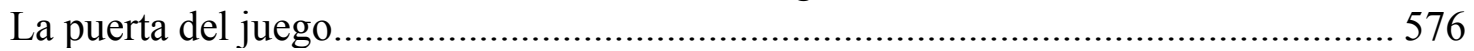

Lengua lúdica móvil, múltiple y transmigrante ................................................... 579

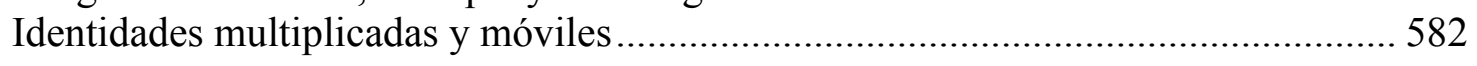

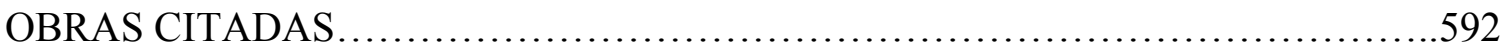

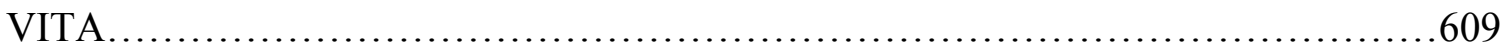




\section{TABLA DE IMÁGENES}

ILUSTRACIÓN

PÁGINA

Ilustración 1: Diego Velázquez. "Las meninas o la familia de Felipe IV"1656. Óleo sobre lienzo. Museo del Prado, Madrid

Ilustración 2: Portada de "Jusep Torres Campalans. Ingenio de la vanguardia" presentado como catálogo de su exhibición en el Centro de Arte Reina Sofía (13 de junio de 2003-23 de agosto de 2003)....

Ilustración 3: Jusep Torres Campalans, "Retrato de Picasso", 1912, Lápiz sobre cartón. Propiedad de André Malraux

Ilustración 4: Jusep Torres Campalans, "Guillaume Apollinaire" 1910, cargón.

Propiedad de Jean Cassou

Ilustración 5: Jusep Torres Campalans, "Sin título"1911, Collage, Colección Teresa Álvarez Aub

Ilustración 6: Jusep Torres Campalans, "Paisaje a los Pirineos"1912, lápiz sobre papel.

Colección Federico-David Álvarez Aub

Ilustración 7: Jusep Torres Campalans Trama Parda, 1914. Tintas de color. Propiedad de Pablo Picasso 108

Piet Mondrian Composición en gris azulado y amarillo, 1912-1913. Óleo sobre lienzo. Museo Thyssen-Bornemisza

Ilustración 8: Picasso. "Las señoritas de Aviñón"1907. Óleo sobre lienzo. Museum of Modern Art, Nueva York

Ilustración 9: Portada de una edición "de Jusep Torres Campalans".....

Ilustración 10: Jusep Torres Campalans, "Copie des roses d'Odilon Redon" Técnica mixta sobre papel. Colección Federico-David Álvarez Aub

Ilustración 11: "Odilon Redon, El nacimiento de Venus"1912, Óleo sobre lienzo Regalo de Ian Woodner Family Collection

Ilustración 12: Monograma de Jusep Torres Campalans

Ilustración 13: Jusep Torres Campalans, Don Quijote1909 Óleo sobre papel, 25,5 x 17,8 cm Colección Alí Chumacero, México. 
Ilustración 14: Catálogo de la exposición "Jusep Torres Campalans" en las Galerías Excelsior, México D.F. Fondo de cultura Económica, 1958 Colección Manuel García, Valencia

Ilustración 15: Portada Jusep Torres Campalans ..........................................................128

Ilustración 16: Jusep Torres Campalans. "Ilustración s.f" ................................................129

Ilustración 17: Foto de Vicenta Campalans Jofré y Jenaro Torres Moll ..........................130

Ilustración 18: Pablo Picasso y Jusep Torres Campalans, Barcelona1902 (foto: José

Renau)

Ilustración 19: Jusep Torres Campalans, "Calle” 1906. Guache, tinta sobre cartón. 49 x $32 \mathrm{~cm}$. Propiedad de M.O.R.

Ilustración 20: Pablo Picasso, "La Vida" Ilustración 1: Pablo Picasso, "La Vida" 1903 (Detalle) Óleo sobre lienzo. Propiedad del Cleveland Museum of Art.

Ilustración 21: Jusep Torres Campalans, "Retrato de Ana María 1907”. Guache, tinta, acuarela. Propiedad de la familia Merkel

Jusep Torres Campalans, Retrato Mujer, 1906 Guache, tinta, acuarela. Propiedad de la familia Merkel.

Picasso Autorretrato, 1907 Óleo sobre lienzo Nadodni Gallery, Praga..........................134

Ilustración 22: Jusep Torres Campalans. "El bosque de la noche/Le Bois la nuit"1912.

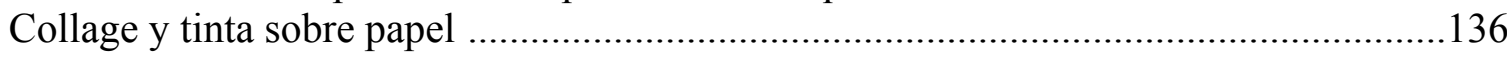

Ilustración 23: Jusep Torres Campalans, "Hotel" 1912 .................................................137

Ilustración 24: Pablo Picasso, "Guitar, Gas Jet, and Bottle"1913. Óleo, carboncillo, barniz y arena sobre lienzo.

Ilustración 25: Jusep Torres Campalans, "Cannes" ......................................................138

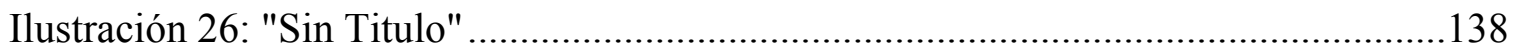

Ilustración 27: Jusep Torres Campalans, "Cabeza de Cristo"¿1907-1908? Guache tintas de color. Propiedad de M. Jean Caoulange ...............................................................140

Ilustración 28: Jusep Torres Campalans "La filla de la carbonera" 1908, acuarela. .....141 
Ilustración 29: Picasso, "Mujer delante de un espejo"1933 (Detalle) Gift of Mrs. Simon Guggenheim Moma (C) 2014 Estate of Pablo Picasso / Artists Rights Society (ARS), New York

Ilustración 30: Jusep Torres Campalans, "El rábano por las hojas"1908, Guache Propiedad de E.A

Ilustración 31: Pablo Picasso, "Pipa, vaso, diario, guitarra y botella de Vieux Marc botella"1912, Papier collé, carboncillo, tinta china, tinta de impresión, grafito y aguada sobre lienzo Peggy Guggenheim Collection

Ilustración 32: Juan Gris, "La botella de Banyuls"1914, Pasta de papel, óleo, carboncillo, lápiz y guache sobre lienzo, Kunstmuseum (Berna, Suiza).

Ilustración 33: Jusep Torres Campalans, "San Lorenzo"1908. Acuarela sobre papel Colección José Luis Martínez, México

Ilustración 34: Jusep Torres Campalans, "El pintor"1911, tinta. Perteneció a Picasso. Actualmente en Nueva York.

Ilustración 35: Atribuido a Jusep Torres Campalans, "Sin título"1912. Gouache sobre papel Colección Federico-David Álvarez Aub

Ilustración 36: Jusep Torres Campalans, "Sin título, s.f."

Ilustración 37: "Montaje IV"1912, óleo. Propiedad de J.D.C.

Ilustración 38: Jusep Torres Campalans, "Cabeza de Juan Gris"1912, óleo. Propiedad de Alfonso Reyes

Ilustración 39: Jusep Torres Campalans, "Trama persa" 1913

Ilustración 40: Jusep Torres Campalans, "Superficie calcáre"1914, guache sobre cartón. Propiedad de Jaime Torres Bodet

Ilustración 41: Jusep Torres Campalans, "El mar de Mondrian"1914, ilustración

Ilustración 42: Leonora Carrington. "Y entonces vimos a la hija del Minotauro"1953.

Óleo sobre lienzo. 23 1/2 x 27 1/2". Colección privada.

Ilustración 43: Roland Penrose, "foto" De izquierda a derecha: Lee Miller, Ady Fidelin, Nusch Éluard y Leonora Carrington. Lamb Creek Cornwall, Inglaterra 
Ilustración 44: Leonora Carrington. "La aromática cocina de la abuela Moorhead" 1975. Óleo sobre lienzo. 31 x 49”. Charles B. Goodard Center for Visual Performing Arts, Ardmore, UK

Ilustración 45: Leonora Carrington. "Sidhe, the white people of the Tuatha de Danaan"1954. Óleo sobre lienzo. Colección Privada

Ilustración 46: Leonora Carrington "Crookhey Hall"1947. Caseina sobre masonita. Colección privada.

Ilustración 47: Leonora Carrington. "Sueño de sirenas", tríptico 1963

lustración 48 _ Max Ernst. "Novia del viento"1927. Óleo sobre lienzo, 28 x 42cm. Regalo de Marc Engelhard, París, con el apoyo de Les Amis Français du Musée d'Israël à Jérusalem. .216

Ilustración 49: Lee Miller. Max Ernst en St Martin d'Ardèche 218

Ilustración 50: Leonora Carrington. "Escultura de Caballo" 218

Ilustración 51: Lee Miller. Leonora Carrington en St. Martin d'Ardèche. 218

Ilustración 52:Max Ernst y Leonora Carrington 1939 218

Ilustración 53: "Self-Portrait (Inn of the Dawn-Horse)" 1937-8. Óleo sobre lienzo. 25" 1-2" x 32" The Metropolitan Museum of Art, The Pierre and Maria-Gaetana Matisse Collection .223

Ilustración 54: "Max Ernst sobre un caballo de madera" París, 1938 @ProLitteris, Zurich: Max Ernst Museum Brühl des LVR, Stiftung Max Ernst. .226

Ilustración 55: Leonora Carrington. "Green Tea, or La Dame Ovale"1942. Colección privada. ARS, NY y DACS, Londres.

Ilustración 56: Max Ernst. "Au Rendez-vous des Amis"1922. Museum Ludwig, Colonia.

Ilustración 57: Leonardo da Vinci. "La Virgen, el Niño Jesús y Santa Ana"1510-13

Óleo sobre tabla $168 \times 112 \mathrm{~cm}(66 \times 44$ in) Museo del Louvre, París (Francia) .238

Ilustración 58: Figura picuda estudiada por Freud 1910 .238

Ilustración 59: Constantin Brancusi, "Maiastra"1911. Bronce sobre pedestral de piedra calcárea. Colección de la Tate. 
Ilustración 60: Max Ernst, Iliazd, Tempel. "Maximiliana ou L'Exercice Illégal de L'Astronomie" 1964

Ilustración 61: Lee Miller. "Leonora con Max Ernst y Paul Eluard" 1937 ......................248

Ilustración 62: Portada de "Leonora" por Elena Poniatowska...........................................248

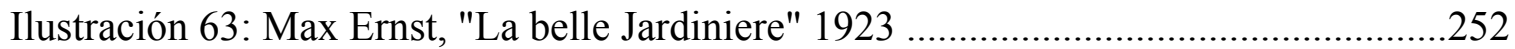

Ilustración 64: Max Ernst. Portada de "Una semana de bondad: Una novela surrealista

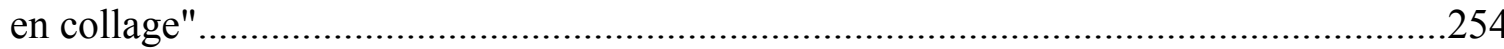

Ilustración 65: Max Ernst. Ilustración de "Una semana de bondad" ................................25

Ilustración 66:"Loplop presenta a Loplop" 1930, óleo y medio mixto sobre madera.

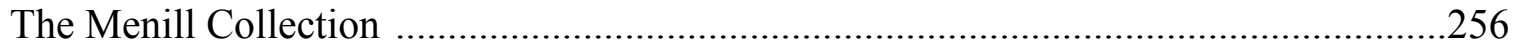

Ilustración 67: Max Ernst "Lop Lop presenta dos flores" 1930. Óleo y yeso sobre lienzo

Ilustración 68: Max Ernst. "Loplop presenta a una jovencita" Óleo, escayola y materiales mixtos sobre madera. París, Musée National d'Art Moderne, Centre Georges Pompidou

Ilustración 69: Max Ernst, "Figura humana" 1931. Moderna Museet, Stockholm, Sweden.

Ilustración 70: Max Ernst, "El ángel doméstico o el triunfo del surrealism" 1937. Óleo y escayola sobre madera. Munich, Staatsgalerie moderner Kunst ..................................261

Ilustración 71: Max Ernst. Relieve de Loplop en la casa en St Martin D'Ardèche 1938

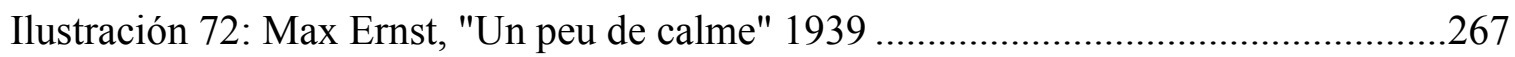

Ilustración 73: Max Ernst, "Se asemejaba ligeramente a un caballo". Collage, 1938 ....268

Ilustración 74: Leonora Carrington, "The Meal of Lord Candlestick". 1938. Óleo sobre tela, 35.5 x $46 \mathrm{~cm}$. Colección André-François Petit, París

Ilustración 75: Leonora Carrington, "The Horses of Lord Candlestick" 1938, Colección privada .276

Ilustración 76: J.J. Granville. Ilustración de "Los viajes de Gulliver" 1835 .279 
Ilustración 77: Leonora Carrington. "Portrait of Max Ernst" 1939. Oleo sobre lienzo. 20 x 10 1/2”. Private Collection

Ilustración 78: Lee Miller : Max Ernst and Leonora Carrington, St Martin d'Ardèche (France) 1939

Ilustración 79: Leonora Carrington: "La vestimenta de la novia" (L'habillement de l'épousée). 1939, Óleo sobre madera, 96 x 130cm. Venecia, Collección Peggy Guggenheim

Ilustración 80: Max Ernst, "Alicia en 39"

Ilustración 81: Max Ernst, "Alicia en el 41" Óleo sobre papel montado en lienzo Colección del MoMA

Ilustración 82: Max Ernst. "Leonora a la luz de la mañana" 1939 .296

Ilustración 83: Max Ernst, "La nature à l'aurore" 1936. Städelsches Kunst-institut.......297

Ilustración 84: Leonora Carrington: "Retrato del doctor Morales" .307

Ilustración 85: Leonora Carrington, "Down Below" 1941, Óleo sobre lienzo, Colección privada

Ilustración 86: Leonora Carrington. "Les distractions de Dagobert" 1945. Témpera al huevo sobre masonita.

Ilustración 87: Kati Horna: Leonora Carrington y Chiki Weisz el día de su boda. 1946, La fotografía fue tomada en la casa de José y Kati Horna .315

Ilustración 88: Leonora Carrington. "Tuesday"1946. Témpera al huevo sobre panel. ...318

Ilustración 89: Leonora Carrington. "The Giantees" 1950. Óleo sobre lienzo. 46 x 27", Colección privada

Ilustración 90: Leonora Carrington. "Giordano Bruno" 1964

Ilustración 91: Leonora Carrington: "The Labyrinth"1991. Óleo sobre madera, 30 x 36 ". Colección privada. .326

Ilustración 92: Leonora Carrington: "Le gran adieu" 1958 .327

Ilustración 93: Félicien Marboeuf: "Retrato de Duchamp retirando su cuadro. Desnudo bajando la escalera" 1912 .355 
Ilustración 94: Clement Cadou, "Autorretrato"

Ilustración 95: Marcel Duchamp: "Obligation pour la roulette de Monte Carlo" $1924 . .361$

Ilustración 96: Man Ray: "Bonds for Monte-Carlo roulette" 1924

Ilustración 97: Joshua Reynolds, "Retrato de Sterne" publicado en la Versión disidente de HALP.

Ilustración 98: R. Mutt (Marcel Duchamp) "Fontaine (Urinal)" 1917 ...............................367

Ilustración 99: La página en negro del "Tristram Shandy"...............................................369

Ilustración 100: Manuscrito de W.Benjamin que Vila-Matas incluye en "versión disidente de HALP"

Ilustración 101: Marcel Duchamp, "Dulcinea" 1911. Óleo sobre lienzo. (C) Artists Rights Society (ARS), New York / ADAGP, Paris / Estate of Marcel Duchamp The Louise and Walter Arensberg Collection, 1950. Museum of Philadelphia

Ilustración 102: Maleta que Vila-Matas usa como primera entrada para su "Versión disidente de HALP"

Ilustración 103: Marcel Duchamp, "L.H.O.O.Q", 1919. Dibujo sobre tarjeta postal .....384

Ilustración 104: Francis Picabia, "Mona Lisa con mostacho" "Mona Lisa con mostacho" después del original de Marcel Duchamp

Ilustración 105: Marcel Duchamp: "La boîte-en-valise"1936/1968 Paris 1936 -

Nueva York 1941 Caja de carton cubierto con cuero rojo conteniendo replicas miniaturas de obras, 69 fotos, facsímiles o reproducciones de pinturas, pegadas sobre tela negra.

Ilustración 106: Portada del primero número de la revista dadá "Cabaret Voltaire" Diseño de Hans Arp. Zurich, 1916

Ilustración 107: Man Ray. Retrato de Marcel Duchamp como Rrsose Sélavy 1921. Philadelphia Museum of Art.

Ilustración 108: Marcel Duchamp : "Belle Haleine: Eau de voilette"1921, (C) 2000 Succession Marcel Duchamp ARS, N.Y./ADAGP, Paris

Ilustración 109: "Belle da Costa Green". Tomado de toutfait el Marcel Duchamp Online Studies Journal .398 
Ilustración 110: Man Ray: "Berta Bocado" según Vila-Matas en su "Versión

disidente de Halp",

Ilustración 111: Marcel Duchamp : "La Mariée mise à nu par ses célibataires, meme" 1915-1923 Óleo, varnis, hojas de acero, alambre de aluminio y polvo en dos paneles de vidrio

Ilustración 112: "Étant donnés: $1^{\circ}$ la chute d'eau, $2^{\circ}$ le gaz d'eclairage" (Given: 1. The Waterfall, 2. The Illuminating Gas...). 1946-1966. Philadelphia Museum of Art. Vista exterior.

Ilustración 113: Portada del libro de Michael R. Taylor .405

Ilustración 114: Marcel Duchamp : “Étant donnés: $1^{\circ}$ la chute d'eau, $2^{\circ}$ le gaz d'éclairage ... (Given: 1. The Waterfall, 2.The Illuminating Gas . . . )" 1946-1966. Philadelphia Museum of Art. Vista interior..... 407

Ilustración 115: María Martins, "Impossible III” 1946 .410

Ilustración 116: Alfred Stieglitz, "Portrait of Georgia O'Keefe” 1918 .413

Ilustración 117: Georgia O'Keefe. "Nude, Serie VII 1917” Flower Shapes “(1919)”....415

Ilustración 118: Georgia O'Keeffe's "Series I White-Blue” Acuarela. Georgia O’Keefe Museum

Ilustración 119: Escritores del grupo The Others en la casa de William Carlos Williams1916. De izquierda a derecha primera fila abajo: Alanson Hartpence, Alfred Kreymborg, Williams, Skipwith Cannell; Arriba: Jean Crotti, Marcel Duchamp, Walter Arensberg, Man Ray (?), Pitts Sanborn, Maxwell Bodenheim. .418

Ilustración 120: Marcel Duchamp, “Hombre joven triste en un tren” 1912 .426

Ilustración 121: Marcel Duchamp. "La caja en la maleta” 1962 Reproducción en serie

Ilustración 122: Mario Bellatin: "La Biclicleta de Duchamp” Construida por Bellatin con restos de su propia bicicleta

Ilustración 123: Mario Bellatin: "Tres libros del proyecto 'Los cien mil libros de Mario Bellatin"” 2010. .506

Ilustración 124: Rubén Torres Llorca: Detalle de la exhibición "One of Us Can Be Wrong" 2012 
Ilustración 125: Rubén Torres Llorca, Si pierdo la "Memoria qué pureza" 1982 ...........540

Ilustración 126: Rubén Torres Llorca, "Mirror mirror on the Wall” Medio Mixto, 2012

Ilustración 127: Rubén Torres Lloca, "Si pierdo la memoria qué pureza” 2002.

Ilustración 128. Rubén Torres Llorca, "What Matters Most is how Well you Walk through the Fire", s.f.

Ilustración 129: Rubén Torres Llorca, "Make me a Mask”. 2005, Medio Mixto.

Ilustración 130: Rubén Torres Llorca, "Make me a Mask" 1996, Instalación con 16

elementos.

Ilustración 131: Rubén Torres Llorca. Panorama colección privada.

Ilustración 132: Página del catálogo “Rubén Torres Llorca Modelo para armar”. Frost Art Museum, 2006

Ilustración 133: Rubén Torres Llorca: "I refuse to Wear an Apple on my Head" 2004, medio mixto

Ilustración 134: Rubén Torres Llorca: "I Choose Not to Wear an Apple in My Head 2004", medio mixto .546

Ilustración 135: Rubén Torres Llorca: “Keep Moving Like a Shark” 2002, medio mixto 548

Ilustración 136: Rubén Torres Llorca: "Work in Progress/ Esta es tu obra”..... .548

Ilustración 137: Rubén Torres Llorca: "Better Days Ahead” 2001, Medio mixto

Ilustración 138: Rubén Torres Llorca: “Es más difícil pelear contra el imperialismo desde tu apartamento en Manhattan" 1994, Media mixta.

Ilustración 139: Carlos Amorales: "Poster de luchadores"..... 551

Ilustración 140: Carlos Amorales: “Amorales Vs Amorales”, 2003

Ilustración 141: Carlos Amorales: "La lengua de los muertos”, Fotonovela, 2012 ........554

Ilustración 142: Carlos Amorales: "Vagabundo en Francia” 2012 .556 


\section{INTRODUCCIÓN}

Las transformaciones que desde las vanguardias han afectado el conjunto de nuestra cultura han alterado la naturaleza de la ficción, sus relaciones con otras formas discursivas y creativas como el arte, y la misma definición entre sus fronteras y los dominios de la realidad. Habiéndose creado una extensa conciencia en el siglo XX de las nociones de hipertexto y metaficción, tras el anuncio del fin de la historia del arte o de la novela, en los estertores de la posmodernidad nos abocamos al surgimiento de la "fícción extrema". ¿Cómo llamar, si no, a esa singular forma de hipertextualidad en la que está presente la metaficción, como conciencia especular de la relación con las demás palabras de la literatura, pero en la cual, más allá de ésta, se advierte un deslizamiento entre campos que desafía las convenciones de géneros, las fronteras entre el arte y la literatura, y los mismos límites que separan ficción y realidad?

Ante esas novelas que desbordando lo literario se apropian de prácticas artísticas, ${ }^{1}$ o ante esas obras de arte que saliéndose de su marco crean caracteres o usan recursos literarios, de tal modo qué en ese ir y venir del arte a la literatura y viceversa, se desafían los marcos que sostienen la estructura de las artes y de la misma realidad, surge la necesidad de nombrar el concepto de "ficción extrema", y observar su naturaleza y estrategias.

Para abordar el modo en que el deslizamiento de la literatura en el arte acaba por reforzar la verosimilitud de la ficción hasta el punto de insertarla en el mundo de la vida, y, a su vez, el modo en que el uso de recursos narrativos puede otorgar un estatus de realidad a un artista ficticio, me aproximaré en los tres primero capítulos a ejemplos 
pioneros y/o paradigmáticos de la ficción extrema en la literatura hispanoamericana: el español-mexicano Max Aub (1903-1973), la inglesa-mexicana Leonora Carrington (1917-2011), y el español Enrique Vila-Matas (1908). Los tres creadores ensancharon de un modo impensado las vías de pasaje entre el arte y la literatura, y han permeado la memoria de la historia del arte o de la literatura hasta hacer lábiles las fronteras entre ficción y realidad, y permitirse modos de reimaginar la historia o de multiplicar sus identidades posibles y desafiar los lugares fijos e inamovibles del pensamiento.

Las obras elegidas de Aub y Vila-Matas y los cuentos y cuadros de Carrington contienen diversos movimientos artísticos enmarcados en la historia y reflejados en las agitadas aguas de sus osadas imaginaciones. Aub capta en su Jusep Torres Campalans el cubismo desde la ficción histórica y la biografía impostada, así como desde una forma de mordaz meta-crítica del arte moderno; Leonora (he preferido llamarla por su primer nombre) contiene y ensancha en su arte y literatura la génesis del surrealismo, desde una memoria alterna, femenina y díscola; y Vila-Matas acomete en su Historia abreviada de la literatura portátil, la reinvención del delirante espejismo dadaísta, de un modo que puede extender las fronteras de lo real, pero que permanece esencialmente fiel a los enunciados con que alteraron lo que hasta entonces se consideraba arte.

Como umbral que precede la mirada a las obras objeto de estudio — en su orden, en los capítulos I. "Max Aub y la ficción extrema: la invención de Jusep Torres Campalans", II. "Leonora Carrington: la mujer caballo derribando lindes entre arte, texto y vida", y III. "Vila-Matas y su ficción extrema: del Dadá al texto portátil del último shandy"-, me referiré brevemente tanto al concepto de intersubjetividad dialógica y al hipertexto, como al de metaficción. Es un marco clave para ir descubriendo los rasgos de 
la ficción extrema en esas obras que permean la distancia entre campos, o están apostadas justamente en lo que Graciela Speranza sitúa en un Fuera de campo — título de uno de sus libros-: un territorio que vuelve lábiles las separaciones entre arte y literatura o entre realidad y ficción.

Finalmente, en el epílogo se considerará cómo los ejercicios de la ficción extrema que se insertan de diversos modos en la realidad, no fueron sólo una expresión de esas búsquedas alucinantes de las vanguardias del siglo $\mathrm{XX}$, sino que se multiplica en este tiempo donde se expande ese proceso vertiginoso de interpolaciones de la ficción que sacude los territorios fronterizos del arte y la literatura y su interacción con la realidad.

Abordaré por ello otros casos de ficción extrema: el del escritor mexicano de origen peruano Mario Bellatin (1960) y el modo en que usa al ejercicio fotográfico para extender las fronteras de la literatura hacia registros alternos buscando desdoblar los lenguajes hasta traspasar el límite de lo indecible principalmente en su novela Shiki Nagaoka, una nariz de ficción (2006) aunque aludiré también a otros textos. El segundo caso es el de la invención del artista Juan Trepadori realizada conjuntamente por los artistas conceptuales Liliana Porter (n.1941), Luis Camnitzer (n.1937) y José Guillermo Castillo (1938-1999). Asimismo, incluiré la invención de la artista uruguaya Alicia Mihai Gazcue (n. 1949), fraguada a su vez por la misma Porter y por la investigadora y artista Ana Tiscornia (n.1951). Finalmente, a modo de una vertiginosa inmersión en otros ejemplos de ficción extrema esbozaré otras variantes en las obras del artista cubano Rubén Torres Llorca (n.1957) que construye muchas de sus obras en la instersección de la literatura y el arte, y sus juegos apócrifos, y en la representación virtual de obras inexistentes. Igualmente abordaré la invención del personaje de lucha libre Amorales vs 
Amorales, creado por el artista mexicano Carlos Amorales (1970), quien está construyendo obras abstractas utilizando medios tipográficos a través de los cuales ensaya formas alternas de traducción plástica de obras literarias.

"Yo debo responder con mi vida por aquello que he vivido y comprendido en el arte, para que todo lo vivido y comprendido no permanezca sin acción en la vida," (11) declaró en 1919 Mijail Bajtín en Arte y responsabilidad. La respuesta que Bajtín refrendó hasta el fin, con su vida y pensamiento, nos condujo a una vasta comprensión que se extendió en el siglo $\mathrm{XX}$, al punto de que adquirimos una nueva conciencia de esa alteridad que conforman todos los otros sin los cuales no sería posible el don del diálogo infinito, el "habla en el idioma del otro" en un mundo de intersubjetividades que para él no fue nunca sólo el del pensamiento, sino el de la experiencia común, puesto que "el dialogismo es inherente al lenguaje mismo" (5).

Ese modo alterno de entrar en la Torre de Babel de las letras nos sitúa así ante la experiencia humana enriquecida por la interacción dialógica, ${ }^{2}$ por el concierto de las voces polifónicas de ese diálogo inacabable que Borges sentiría como una felicidad; y nos sitúa también ante la misma visión de que ningún ser humano escribe realmente sobre una página en blanco, de modo que hemos aprehendido esa noción de la intertextualidad que en los sesenta, retomando la voz de Bajtín y su respuesta ante la vida, fue esbozada por Julia Kristeva.

Partiendo del asombro frente al lingüista ruso cuya grandeza tardó tanto en ser descubierta, justamente por el poder que se resiste a permitir la polifonía de los discursos, Kristeva extendió la comprensión de la intertextualidad en Bajtín, la palabra, el diálogo, y la novela. Su redescubrimiento del pensador que había abordado la palabra literaria, no 
como un punto fijo, sino como un "cruce de superficies textuales", como un "diálogo de varias escrituras" (Genette 2), fue posteriormente desarrollado por incontables autores hasta el punto en que llegó a ser una conciencia inseparable del imaginario de la modernidad: Todo texto se construye como mosaico de citas, todo texto es absorción y transformación de otro texto. En el lugar de la noción de intersubjetividad, se instala la de intertextualidad, y el lenguaje poético se lee, por lo menos, como doble (Kristeva 190).

Me detengo un instante en esa visión del lenguaje que "se lee por lo menos como doble" para referir al modo en que Bajtin asumió "la figura del otro en su propio discurso, esa doble procedencia y doble secuencia de experiencias, que la palabra descubierta con la firma de Voloshinov, hace accesible" (Zavala 7). Bajo el discurso monolítico del partido en la Rusia de los años veinte, y obligado por las acusaciones políticas que pesaban sobre él, Bajtin firmó sus escritos bajo el nombre de amigos, como el biólogo Kanaev, además del crítico Medvedev, o del lingüísta Voloshinov. Lo que sorprende, en medio de los debates que rodean el tema, es el recurso imaginativo que lo lleva a desdoblarse para que su escritura sobreviva, aun en la frontera donde la autoría se diluye. Así que el exilado a Lazakhstan lleva consigo no sólo los discursos ajenos, sino los propios, resguardados en voces ajenas.

En un texto que inicia con unas líneas de Derrida - “soy los dos/habría que decir lo dos,/ lo dual, lo doble,/ conozco lo que soy/lo dos..."- Iris M. Zavala escribe:

[Bajtin] pone en suspensión la autoridad para reforzar la ficción en una práctica de lenguaje orientada a la producción de seudónimos, heterónimos, máscaras - si se prefiere- que le permitan explorar los aspectos centrales de sus reflexiones ético-estéticas. (...) el suyo es un mundo heteroglósico que plantea el status de la ficción y su identidad en el mundo moderno (133). ${ }^{3}$ 
De este modo, no sólo una extendida conciencia de la intertextualidad, sino una visión renovada del carácter cuanto menos doble del lenguaje, y de la incidencia de esta comprensión en nuestra idea de la ficción, moduló la manera de aproximamos a los libros. Aprehendimos que cada texto supone un diálogo con un texto anterior, que no hay en suma, actos de literatura, sino lo que de una manera comprehensiva, Gérard Gennette llamó "hipertextualidad" en Palimpsestos: literatura en segundo grado ${ }^{4}$ libro escrito en parte sobre los rastros del cuento "Pierre Menard, autor del Quijote", de Borges.

Hay otro antecedente que es necesario evocar: desde fines del siglo XIX, André Gide acuñó un marco de mirada sin el cual no podemos entender la naturaleza de las ficciones de la postmodernidad, o de lo que puede estarse configurando como un modo de altermodernidad, según veremos: el término "mise en abîme", que abarca el infinito campo de la autoreflexividad o de las relaciones especulares en las cuales el libro está dentro del libro, la obra dentro de la obra, en un juego de reflejos que da a la mirada una conciencia insólita de la naturaleza de la ficción y del propio proceso de creación en formación. A partir de esa formulación — que Linda Hutcheon designó como mimesis del proceso, y Lucien Dällenbach retomó ampliando la conciencia del "espejo en el espejo"- una innumerable cantidad de estudios sobre el concepto ${ }^{5}$ ha extendido la comprensión de la metaficción, que abarca a su vez todo cuanto configura la literatura sobre la literatura o el arte sobre el arte, la presencia del espejo en que, dentro de una obra, ésta contempla su propio proceso de formación o, incluso, otro espejo, en un juego de reflejos infinito.

Y no sólo por la idea de que cada autor inventa a sus predecesores, o porque se trata de los dos momentos fundacionales que anteceden a la ficción extrema, sino por la 
particular relación que encontraremos en los autores aquí estudiados con el linaje de Cervantes e indirectamente de Velázquez, me detendré muy brevemente en la dimensión especular de Don Quijote y Las Meninas. Ambos forman parte de la estirpe de la ficción extrema, de una suerte de línea de descendencia indispensable para cruzar el umbral hacia su formulación en los autores arriba mencionados. Me limitaré a un par de menciones sucintas, pero ineludibles, en medio de las innumerables páginas que se han escrito en torno a ambas obras justamente encumbradas.

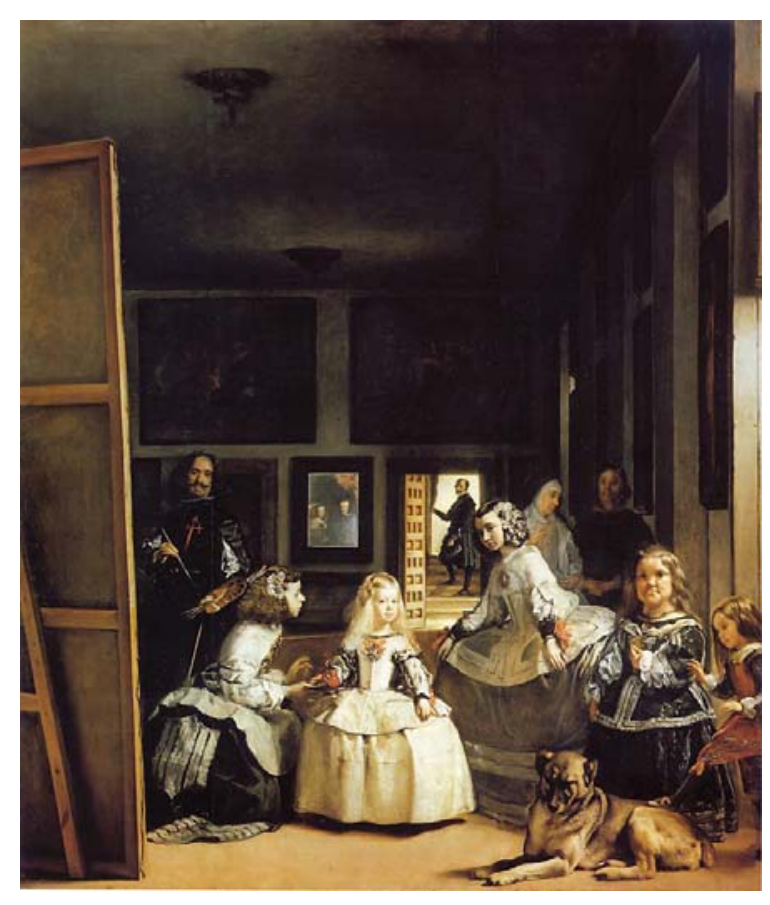

Ilustración 2: Diego Velázquez. Las meninas o la familia de Felipe IV 1656. Óleo sobre lienzo.

Museo del Prado, Madrid

En el revelador ensayo sobre las Meninas de Diego Velázquez con que Michael Foucault empieza Las palabras y las cosas — libro que nació de un fragmento de Borges, aquella magnífica cita sobre la clasificación de los animales de "cierta enciclopedia china" que incluye "los embalsamados", "las sirenas", o "los dibujados con un finísimo pincel de pelo de camello", entre otros - nos sitúa, sin nombrar inicialmente ni al autor 
ni la obra, ante la descripción del pintor que se pinta a sí mismo ejecutando un cuadro que está dentro del cuadro y cuya tela permanece invisible para los espectadores, condenados a verla sólo desde la tela en el bastidor. Su invisibilidad nos hace atender con mayor interés la inminencia de la ejecución de la obra que nunca veremos, ese instante que Foucault describe así: "Entre la fina punta del pincel y el acero de la mirada, el espectáculo va a desplegar su volumen” (13). ¿Pero qué otro volumen puede disponerse a pintar si no aquél que llena el espacio de enfrente, pues justo es hacia nosotros a donde dirige su mirada, a ese afuera del cuadro desde el cual lo contemplamos? Responde Foucault:

Desde los ojos del pintor hasta lo que ve, está trazada una línea imperiosa que no sabríamos evitar, nosotros, los que contemplamos: atraviesa el cuadro y se reúne, delante de su superficie, en ese lugar desde el que vemos al pintor que nos observa; este punteado nos alcanza irremisiblemente y nos liga a la representación del cuadro (14).

Y entonces, nos vemos vistos, tanto como le vemos, y comprendemos súbitamente, que ha bastado situar el cuadro dentro del cuadro para que la mirada atraviese el marco que lo separa de nosotros, para que desbordando la distancia entre la representación y la realidad de quien la mira, entre en nuestro propio campo y la mirada, se perciba, incesantemente entre el espectador y el pintor; un momento que Foucault describe así:

Ninguna mirada es estable o, mejor dicho, en el surco neutro de la mirada que traspasa perpendicularmente la tela, el sujeto y el objeto, el espectador y el modelo cambian su papel hasta el infinito. La tela invisible impide que la relación de las miradas llegue nunca a localizarse ni a establecerse definitivamente (14).

Pero justo por esa inestabilidad de la mirada que no se localiza definitivamente descubrimos el espejo que aparece al fondo de la escena y en éste, el reflejo de dos 
personajes que no vemos, puesto que están afuera del cuadro, justamente situados en nuestro lugar, y quizás también representados en la pintura invisible para nosotros, pero sobre todo, captados por ese mecanismo especular: el espejo contiene las siluetas de quienes observan la escena.

"El espejo va a buscar delante del cuadro lo que se contempla, pero que no es visible, para hacerlo visible en el término de la profundidad ficticia, si bien sigue indiferente a todas las miradas", escribe Foucault (17-9). Nadie, salvo nosotros que estamos frente al cuadro, ve ese espejo que atraviesa la escena y que, en lugar de duplicar la imagen de lo que vemos en frente nuestro, nos revela lo que ven sus personajes, lo que está más allá del cuadro, en una mirada que se extiende, por el reflejo del espejo, más allá del cuadro.

Tanto la mirada del pintor que se representa a sí mismo dentro del cuadro pintando una escena que pudiera contenernos a nosotros mismos, como el espejo que refleja la escena que podríamos compartir con quienes ocuparon nuestro lugar, tiempo atrás (los reyes están de pie, donde nosotros lo estamos ahora) refieren a la metaficción que refleja su propio mecanismo, y a esa zona de desbordamiento del marco, donde se vuelve flotante la frontera entre la representación y la realidad. Una clave de lo que constituirá la ficción extrema.

Por su parte, Francisco Calvo Serraller se refiere a esta misma propiedad del cuadro que Diego Velázquez (1599-1660) pintó cuatro años antes de su muerte, sin que posiblemente llegara a entender lo que sería para el futuro, si bien su lugar en el arte equivale al de Cervantes en la literatura: ${ }^{6}$ 
This blending of overlapping of linear and aerial perspective has long fascinated us as a marvel of representational art. Nevertheless, the painting attracts us more for what it suggests than for what it describes, both in terms of what we would today call virtual reality (...) This explains the prestige of the composition as a reflective representation or, in other words, a reflection of the art of representation. Luca Giordano rightly defined it as 'the theology of painting', since the limits between what is painted and what is real are completely flouted here (32).

Ese límite burlado es la zona en la cual se ubican las obras analizadas en esta disertación. Antes de entrar en ella sigo recorriendo velozmente los primeros asentamientos en este territorio. Dice Andrés Trapiello, novelista y cervantista contemporáneo ${ }^{7}$ : "A Cervantes y a Velázquez se les ha emparejado con frecuencia, y es acertado hacerlo, por cuanto tienen los dos de excesivos, de pródigos (...)" (17). Además de destacar que Cervantes tiene "tantas vidas, como las que de él circulan, y se cuentan por cientos" (18), refrenda el hecho, de todos sabido, de que Don Quijote "ha terminado por imponerse, con toda su potente realidad, a la irrealidad e inconsistencia histórica de su mismo creador" (19). ${ }^{8}$ Pero, como advierte Jean Canavaggio, uno de los mayores biógrafos de Cervantes (1547-1616), a quien considera "despreciador sutil de los valores establecidos", autor que "desacraliza todos los conformismos": "Las informaciones que [Cervantes] nos da a través de sus ficciones, son difíciles de explotar (...), ya que constantemente delega sus poderes en pseudo narradores a los que desautoriza en la primera ocasión" (19-20). Esa desautorización, desde luego, es ya un ejercicio de metaficción, en el que se cuela la veta inescapable del humor. A su vez, Martín de Riquer da cuenta de momentos tan singulares como cuando, en plena lucha con el vizcaíno, "Cervantes deja pendiente el relato, con el pretexto de que aquí lo dejó el autor de la historia de Don Quijote" (65). Y nota cómo Don Quijote finge que va tomando la 
narración de muchos autores: en el capítulo IX, estando en Toledo, el narrador "descubre la Historia de don Quijote de la Mancha escrita por Cide Hamete Benengelí, historiador arábigo". Y a partir de entonces, el Quijote "se ofrecerá a los lectores como traducción de ese fingido texto arábigo", y Cervantes se llamará así mismo "traductor" (66), hasta acabar por decirnos que algún lugar de la Mancha se debe encontrar papeles con el relato de los hechos de Don Quijote.

Pero si hay dos momentos paradigmáticos en los cuales se burla la frontera entre ficción y realidad, estos son, como es sabido, la quema de los libros precedida por el juicio que el barbero y el cura realizan en la biblioteca, y el instante en que Sancho Panza trae noticias de que se ha publicado la propia historia de sus aventuras como escudero de don Quijote. Según Ignacio Padilla, el primer propósito del "donoso escrutinio de la biblioteca de don Alonso Quijano" es la polémica que se enciende contra todos aquellos libros aquejados de la falta de verosimilitud ${ }^{9}$ o peor aún, contra aquellos que, como el mal Quijote de Avellaneda, reflejan la imitación artera, el plagio de dudosa calidad literaria (242-51). El fragmento cumbre de la aparición del Quijote dentro del Quijote ocurre en la segunda parte, cuando ya ha regresado el Caballero de la Triste Figura, don Alonso Quijano, de sus aventuras iniciales, y parece estar curado, salvo cuando se nombra el tema de la caballería. Por eso las mujeres de casa no quieren permitir a Sancho Panza que venga a perturbarlo, pero este se ingenia el modo de entrar a la habitación donde reposa el aventurero y contarle:

Me dijo [el bachiller Sansón Carrasco] que andaba ya en libros la historia de vuesa merced, con nombre de El Ingenioso HIDALGO DON QUIJOTE DE LA MANCHA; y dice que mientan a mí en ella como mi mesmo nombre de Sáncho Pamza, y á la señora Dulcinea del Toboso, con otras cosas que pasamos nosotros 
á solas, que me hice cruces de espantado, como las pudo saber el historiador que las escribió (470).

Y luego, a ruego de don Quijote, el propio bachiller lo visita trayéndole noticia de lo que ha dicho la gente del libro. "En varios momentos de esta segunda parte, la primera, el libro impreso diez años antes [1605], será aludido, alabado, criticado y comentado por los mismos seres de la 'bibliografía' del Quijote" (Riquer 100-101). Son los momentos más arriesgados de esta invención que en esas escenas precisas se anticipa siglos a lo que la modernidad y postmodernidad extenderán con una nueva consciencia.

Si bien al final de la segunda parte, don Alonso Quijano ha perdido la batalla contra la realidad, porque una vez exorcizados todos los demonios de la imaginación se resigna a no emprender aventura alguna para transformarla, su empréstito es continuado por una línea de sucesión innumerable. Resulta ineludible mencionar a Lawrence Sterne (1713-1768), que admitió haber escrito su Tristram Shandy inspirado en esa segunda parte del Quijote, y no sólo dejó espacios en blanco a disposición del espectador, sino que bien pudiera nombrarse adelantado de los suprematistas o de Ard Reindhart ${ }^{10}$ por la inserción de su página, completamente negra, en el libro precursor del posmodernismo; a Macedonio Fernández (1874-1952), que a tal punto fue "lector del Quijote" que éste es el título de uno de los libros sobre quien emprendió el empréstito del Museo de la novela eterna $;{ }^{11}$ a Kafka (1883-1924), que planteó la posibilidad, tan afín al alma de este libro, de que Don Quijote fuera en realidad una proyección de Sancho, avezado lector de aventuras; y, por supuesto, a Jorge Luis Borges (1899-1986) que contó la historia de "Pierre Menard, autor del Quijote", y refundó el infinito en cierta zona dudosa de la frontera entre ficción y realidad, precedido por Cervantes. 
“Doy gracias por aquel Alonso Quijano que, a favor de crédulo lector, logró ser don Quijote" escribió Borges, quien contó con afilado humor la historia de Menard, el hombre que buscando escribir no otro Quijote, sino el Quijote, logró producir algunas páginas que coinciden, línea por línea, con las del libro cervantino: acerca de esa versión, Borges, tan escueto en el uso de adjetivos, no se mide en adjudicarlos al llamarla "la incompleta, la subterránea, la interminablente heroica, la sinpar” (39). Creo que un fragmento del cuento, publicado en 1939, inspiró a Gean Gennette el título y la concepción de la obra Palimpsestos. Literatura en segundo grado, ${ }^{12}$ donde formula el concepto de hipertexto: "He reflexionado que es lícito ver en el Quijote 'final' una especie de palimpsesto, en el que deben translucirse los rastros tenues, pero no indescifrables — de la 'previa' escritura de nuestro amigo" (47).

Y es también hablando sobre don Quijote que Borges trae a colación una noche de las Mil y una noches: la DCII, "mágica entre las noches", pues en esa noche sucede que "el rey oye de la boca de la reina su propia historia. Oye el principio de la historia, que abarca a todas las demás, y también — de monstruoso modo — a sí misma” (57). Dirigiéndose al lector, le inquiere Borges si comprende la vasta posibilidad de esa interpolación, ${ }^{13}$ ¿por qué nos inquieta que las Mil y una noches están contenidas dentro de las Mil y una noches y el Quijote dentro del Quijote?, y responde: "Creo haber dado con la causa: tales invenciones sugieren que si los caracteres de una ficción pueden ser lectores o espectadores, podemos ser ficticios" (57). Así, establece la posibilidad de interpenetración entre la orilla de la ficción y la de la realidad, que es constitutiva de lo que aquí llamo ficción extrema. 
Pero esa modalidad de la ficción es extrema no solo por la posibilidad poética de atravesar el espejo de la ficción y no lograr definir la zona en donde termina su reflejo y comienza lo real; o de imaginar que los seres ficticios salen de la pantalla, como ocurre en The Purple Rose of Cairo de Woody Allen y en tantas otras películas; o de desbordar el marco, como si asomados al cuadro invisible de Velázquez viéramos ahí a nuestro mundo contenido; es extrema porque asalta las convenciones de los géneros en el interior de los campos creativos y traspasa sus fronteras: transita entre los dominios del arte y la literatura y con cierta frecuencia puede prefigurar un modo de relato metahistórico alterno, o infiltrar en la memoria de las historias de ambos campos, recuerdos ficticios que, sin embargo, son fieles a las verdades de su esencia.

Así, habría que mencionar, entre los herederos estelares de don Quijote, a Marcel Duchamp, a quien no sólo le gustaba el español por Don Quijote, sino que pintando a Dulcinea prefiguró la escandalosa fusión entre cubismo y futurismo que alteró las reglas del juego en el arte, e inspiró a Octavio Paz un verso que sólo puede leerse en esa conjunción en clave de la literatura y el arte sin la cual no puede tampoco, como veremos, explicarse el Gran Vidrio, que a su vez modela los principios de los conspiradores de Vila-Matas. Transcribo el poema de Paz, dedicado a Eulalio Ferrer:

\section{La Dulcinea de Duchamp:}

-Metafísica estáis. -Hago striptease.

Ardua pero plausible, la pintura cambia la blanca tela en pardo llano y en Dulcinea al polvo castellano torbellino resuelto en escultura. Transeúnte de París, en su figura molino de ficciones, inhumano 
rigor y geometría- Eros tirano

desnuda en cinco chorros su estatura.

Mujer en rotación que se disgrega

y es surtidor de sesgos y reflejos:

mientras más se desviste, más se niega.

La mente es una cámara de espejos:

invisible en el cuadro, Dulcinea

perdura: fue mujer y ya es idea (Paz La dulcinea).

No es azar que en una entrevista con Néstor García Canclini en la cuál le pregunté cómo veía esos continuos deslizamientos entre el arte y la literatura y entre la ficción y la realidad, respondiera: "Es un fenómeno que viene desde Duchamp y Borges (incluso desde Don Quijote y Tristram Shandy), pero quizá entonces eran figuras y procedimientos creativos más excepcionales. Hoy, los artistas y escritores han vuelto hábito estos deslizamientos entre realidad y ficción” (Herrera, "Estética y política” 2).

Establecida esa línea de filiaciones de visión que cada uno de los autores estudiados hace presente en sus propios trabajos de la ficción extrema — aunque por supuesto, en Max Aub y Enrique Vila-Matas es mucho más poderosa que en Leonora Carrington la impronta de don Quijote, en cuyo caso hay que hablar más de la línea sucesora de Lewis Carrol (1832-1898) y de la irreverencia sterniana-, me referiré a cómo radicalizaron la filtración de los imaginarios artísticos y literarios en la realidad subvirtiendo las géneros, y rehaciendo, con sus textos y/o cuadros, o con ambos, un modo de flotante historia del arte o de la literatura.

\section{La novedad de la ficción extrema}

Si bien la hipertextualidad nace con la literatura y hay ejemplos de metaficción que se remontan a la antigüedad, ${ }^{14}$ el concepto de ficción extrema aborda los deslizamientos de la ficción en la realidad que surgen no sólo como un desbordamiento 
del marco de la obra, sino a partir de una relación entre arte y literatura que supone una filtración en uno u otro campo, y que exige en cada autor la osadía de una libertad ligada a otras características que iremos descubriendo en los casos de Max Aub, Leonora Carrington y Enrique Vila-Matas. Pero no puedo dejar de mencionar, como clave de entrada en sus obras y vidas, un rasgo esencial de la ficción extrema que se entiende mejor desde la visión de lo dialógico y de la alteridad bajtiniana: la capacidad de asumir, dentro de sí, la posibilidad de los desdoblamientos. Sus obras están constituidas por la posibilidad de las identidades dobles, incluso múltiples, y en todo caso, móviles. Ese "lo dos" de Derrida, o el "Yo soy otro" de Rimbaud, se asume hasta un extremo que puede llegar a ser vertiginoso, pero que constituye un tácito manifiesto sobre la inagotable posibilidad de la reinvención, un acto magnífico de libertad.

Max Aub impostó no sólo la figura del pintor catalán Jusep Torres Campalans, sino sus obras pictóricas, creadas como sombra o doble de Picasso, duplicando también su deserción de un mundo en guerra y su escepticismo sobre las trampas de la estética. Exiliado en México tras la derrota de la República española y el avance nazi en Francia, hizo un viaje de retorno en esas páginas que burlan todas las convenciones de los géneros, y pintó obras a fines de los cincuenta, que no sólo fechó cuatro décadas atrás, sino que firmó con las iniciales de JTC, creando una insólita red de complicidades para ese fraude extendido que contenía una mirada penetrante sobre su época. Tanto es así que preconizó en su juego literario prácticas como el omnipotente valor de la firma que en la década siguiente a su novela, realizaría Piero Manzoni inscribiéndola como obra de arte en la piel de personas que de este modo convertiría en trabajos de arte. Al insertar la existencia de Campalans en ciertos dominios del cubismo cumplió ante todo un modo de 
meta-crítica artística, de un valor irónico que exige, para su comprensión, transitar entre la historia del arte y de la literatura.

Leonora Carrington asumió como doble la figura del caballo que enriqueció la historia del surrealismo a partir del tránsito que cumplió entre los cuentos —llenos de tanta ironía como de alusiones biográficas que arremetían contra los valores sociales del mundo aristocrático inglés del cual provenía - y sus obras pictóricas. Estas contienen igualmente una memoria de múltiples universos míticos, e irradian otro modo de poder íntimo, subjetivo, que sobrepasando los dominios de la razón impugna la irracionalidad de un mundo enloquecido al que no quiso ofrendarle ninguna forma de docilidad. Historia y biografía se convierten en espacios reflejos donde esta Alicia crecida, como lo comprendieron los más exigentes surrealistas contemporáneos, impuso una cosmovisión alterna de mundo.

Vila-Matas narra su Historia abreviada de la literatura portátil como un doble del espectro Marcel Duchamp - a su vez asaltado por otros- que reescribe la memoria del dadaísmo no sólo de tal modo que ha llegado a ser confundida con un ensayo, sino extendiendo el tránsito que Duchamp cumplió al transportar a su obra las insurrecciones del lenguaje de un Raymond Roussel, de tal modo que se apropia de los insólitos trabajos de demolición de la estética, y de la propia biografía del maravilloso artista que aniquiló la separación entre lo que era arte y lo que no, para reinventarlo en una conspiración literaria capaz de contener el espíritu vivo de las insurrecciones que transformaron la historia del arte.

En cada uno de los casos que estudiaré, como en la misma historia de Don Quijote, que no sería posible sin el viaje del caballero hacia el territorio ignoto de lo 
desconocido, el tránsito es así mismo una condición inseparable del desarrollo de las ficciones en continuo deslizamiento. Pero además del esbozo de estos rasgos característicos que iremos viendo a lo largo del cuerpo de la disertación, el concepto de ficción extrema exige, por su propia naturaleza, un abordaje interdisciplinario. Esto significa igualmente situarse en una zona de tránsito que va y viene del arte a la literatura y explica por qué uso en ciertos casos fuentes literarias para aproximarme a obras artísticas — como el ensayo de Octavio Paz para abordar el Gran Vidrio de Duchamp—, o ensayos artísticos como Ettant Donnés, de Michael R. Taylor, para arrojar luz sobre la naturaleza de las líneas ocultas que configuran el mismo transcurso de la Conspiración Shandy de Vila-Matas. Es en esa perspectiva, desde otro campo, que puedo plantear aproximaciones nuevas a obras como la de este autor, exhaustivamente estudiada desde el punto de vista literario, y consultar fuentes que están "fuera de campo"; o desplazar continuamente la mirada entre lo literario y lo artístico, e incluir la idea de la vida díscola y creativa de Leonora, o enriquecer con la consideración del desarrollo de la trayectoria de Picasso, la biografía apócrifa de Torres Campalans.

Aunque en las últimas décadas se desarrolló un cuerpo teórico basado en la teoría de la ficción en los textos posmodernos (Robert C. Spires, 1984; Brian McHale, 1987; Linda Hutcheon, 1988; Julio Ortega, 1994; Félix Martínez-Bonati, 1981), la reflexión específica acerca del tema de la ficción extrema que aparece en las postrimerías de esa posmodernidad con aportes de diversos autores señalados por Santiago Juan-Navarro, son pocos los trabajos dedicados específicamente al caso de escritores latinoamericanos que se han aventurado en las fronteras del arte, como una táctica que acaba por insertar su ficción en la realidad. Esto es justamente lo que me propongo al estudiar las estrategias a través de las cuales Carrington, Aub y Vila-Matas desarrollaron sus ficciones extremas. 
Leonora Carrington ha recibido más atención sobre su obra plástica que sobre su literatura, que siendo relativamente escasa, ofrece una valiosa vía de acceso a ésta. Sus obras son ejemplo de la tensión entre la literatura y la pintura en un modo de surrealismo que revelaba una particular ruptura de los límites entre la ficción y la realidad: el uso de un alter ego, un doble animal constituido por el caballo, que va de la literatura al arte y que es mucho, muchísimo más que una ilustración. Hay trabajos reveladores acerca de su rol como una mujer en el surrealismo y acerca de la relación de su bestiario en el arte y la vida, pero hacía falta sistematizar y ampliar el sorprendente registro del modo en que la fantástica construcción de un doble alteró su biografía y dejó un registro asombroso en la historia del arte.

En la estrategia ficcional de Max Aub, se alcanza un modo máximo de cancelación de la autoría y de la confusión entre géneros, complementada con el uso magistral de paratextos ${ }^{15}$, dentro de los cuales entrarían las propias obras de arte atribuidas a Jusep Torres Campalans, que acaban por crear un tipo de crítica sin precedentes: pintar para parodiar la vanguardia y desaparecer como autor. Y, no menos importante es la descripción que hace de "las estrategias del posmodernismo revisionista de la historia que ilumina el modo en que la metaficción historiográfica busca revisar tanto el contenido del archivo histórico como las convenciones y normas de la fícción histórica en sí misma” (Juan-Navarro 26).

Dolores Fernández Martínez ha explicado la dimensión de la leyenda que excavó los cimientos de la novela a través de la creación de la impostura del biógrafo hasta tal punto que, como Manuel Durán nota, "la credibilidad de Campalans es un fenómeno sin precedente en las biografías imaginarias" (65). En la biblioteca de Yale University (New Haven) existía una referencia a la existencia de un artista catalán llamado Jusep Torres 
Campalans. Esas estrategias convergen finalmente, en la revelación de un modo de verdad a través de lo que se ha llamado una suma de mentiras. Como veremos a través de la visión de Sebastian Faaber, uno de los grandes expertos en su trabajo, y de Antonio Muñoz Molina, quien cumplió la fantástica tarea de hacerlo entrar de modo póstumo en la Real Academia de la Lengua Española, su apócrifa reconstrucción de la historia de España y de ciertos capítulos de la historia del arte nos enseñan que cuadros y textos literarios son mentiras pero reflejan la verdad de un mundo escindido.

En el caso de Vila-Matas, su Historia abreviada de la literatura portátil ha adquirido visos legendarios por la forma en que infiltró en la memoria histórica de la vanguardia, una audaz ficción escrita de tal modo que ha llegado a hacer dudar a los lectores de su existencia histórica, hecho que se refrenda por su publicación, en la colección de ensayos, de una editorial en Alemania. La consigna dadaísta de estremecer los límites de la realidad se cumple perfectamente en la novela que cumple de un modo extraordinario la noción de écfrasis: no sólo palabras que se incorporan en los trabajos esenciales de Duchamp, sino una narración en la cual éstos devienen en subtextos que articulan el argumento. La ficción arriba así, a través de una rigurosa impostura, a la creación de la memoria de una conspiración en la mente de los lectores. Más aún: en 2003, la artista real Daniela Franco curó la exhibición L'artiste Portati en París, inspirada en la lectura de la novela de Vila-Matas.

Ahora bien, para abordar el tema de la desestabilización de las ficciones y este momento extremo, no sólo se requiere haber comprendido el umbral de la metaficción y de la hipertextualidad (incluyendo con bastante énfasis la atención a la paratextualidad), ${ }^{16}$ sino las reflexiones que llevaron a Arthur C. Danto a considerar el fin de la historia del 
arte y lo que le precedía. Es necesario recordar que fue él quien declaró que las grandes narrativas que habían definido primero el arte tradicional y luego el moderno, no sólo habían llegado a un fin, sino que el arte contemporáneo no se permitía ya ser representado ya más por ningún tipo de grandes narrativas. En términos de Hans Belting, cuyo libro sobre el fin de la historia del arte cita, la idea se sintetiza en esta expresión: "Contemporary art manifests an awareness of a history or art but not longer carries it forward" (Afer the End 5). Me interesa destacar la visión que Danto tenía acerca del papel distante de la crítica en relación específica con la percepción de artistas esenciales en los casos planteados para abordar la ficción extrema. Mencionaba, de modo particular a cuatro artistas: el dadaísta fundador del capítulo de Colonia y uno de los surrealistas de más extendida trayectoria, Max Ernst, no sólo amante de Leonora Carrington, sino con quien ella emprendió una de las aventuras pictóricas y vitales más extraordinarias en la historia del surrealismo, encarnando cada uno la figura de un animal doble; a Marcel Duchamp, cuya figura "espectral" —adjetivo que Dalí aplicaba como cumplido como se verá en el capítulo correspondiente - anima la Historia abreviada de la literatura portátil de Vila-Matas; a Alberto Giacometti, el único que no está integrado a este estudio; y finalmente a "ciertos trabajos de Picasso", cuya figura y obra es seguida como sombra, no sin humor, y al final con irreverencia, por Jusep Torres Campañans.

Transcribo la consideración que hace Danto tras excluir de esta afirmación a la crítica poderosa de Rosalind Krauss, quien discutió con simpatía a aquellos artistas a los cuales el criticismo formalista había situado en un estado de olvido crítico, especialmente bajo la influencia de Greenberg, de quien dice que no tenía modo lidiar con la obra de los artistas arriba mencionados: 
Criticism, especially under the influence of Greenberg, had no way of dealing with Max Ernst, Marcel Duchamp, or Alberto Giacometti, or even with certain works of Picasso. Greenberg had not used whatever for surrealism, which he regarded as historically retrograde. 'The antiformal, anti-aesthetic nihilism of the surrealists - inherited from Dada with all the artificial nonsense entailed - has in the end proved a blessing to the restless rich, the expatriates, and the aesthetic flaneurs who were repelled by the asceticism of modern art'. Because their aim, as Greenberg sees it, was to shock, the surrealists were obliged to cultivate the kind of virtuosity in naturalistic representation that we find in Dali (...). And the greatest sin of all, given Greenberg's vision of each medium to itself, it is possible to construct faithful duplicatex in wax, papier-mậche, or rubber of most of the recent paintings of Ernst, Dali and Tanguy. Their 'content' is conceivable, and too much so, in other terms than those of paint'. So surrealism had to be explained as outside the pale of history (Danto, After the End 113).

Ese afuera de la historia, esa imposibilidad de aproximación a sus obras desde las herramientas meramente formales, también implicó durante mucho tiempo, el predominio de una tendencia — aún sostenida por ciertos sectores - que negaba la posibilidad de referir la vida, y por ende la biografía, a la comprensión del arte. Pero por su propia naturaleza, los dominios del arte surrealista exceden estos confinamientos tanto como la idea de una visión del arte restringido a los límites de su propia materialidad. En el capítulo dedicado a Leonora, su historia de amor con Ernst forma parte de la aproximación a sus deslizamientos de la literatura al arte y viceversa; en el de Max Aub, hay algunas escenas conectadas a la vida y amores de Picasso (no puede obviarse esto, por ejemplo, al ver las Señoritas de Aviñón); y, en el caso de Vila-Matas hay una fascinación doble por la vida maravillosa que poco antes de morir declaraba Duchamp haber tenido, y por el erotismo de sus piezas, concebido como una experiencia de "retardo" (o visión diferida) que le ocupó hasta el fin de su tiempo y sólo se completó, siguiendo su voluntad, con la instalación de su última pieza, cuya existencia mantuvo en secreto hasta después de su muerte. En los tres casos de los personajes que son modos de 
doble de sus autores, el contexto de las guerras de la primera mitad del siglo XX, marca sus destinos y sus fabulaciones, e impregna sus relaciones con el arte. Torres Campalans huye de Europa cuando inicia la Gran Guerra y deja atrás toda su producción artística; Leonora,la mujer-caballo, se fabrica un refugio surreal en tiempos de la Segunda Guerra Mundial, con Ernst, uno de los más grandes artistas de su tiempo y crea con él un universo fabuloso que debía haber contenido el avance de los bárbaros, pero a cambio los inmoló, a Ernst en los campos de concentración y a ella en un manicomio; ${ }^{17}$ Duchamp, cuyo doble ficticio en la novela de Vila-Matas es Walter Benjamin, le sobrevive a éste, pero su encuentro con el narrador de la novela ocurre cerca del lugar, donde acosado por la persecución nazi, Benjamin se suicidó, poco antes de que por segunda vez, el gran dadaísta se marchara a América. El contrapunto de sus imaginaciones sin pisa está marcado por el agotamiento de las guerras, por la locura, no de la fantasía, sino de la historia.

Y, por otra parte, si, como afirma el mismo Danto, la idea subyacente de un crítico como Greenberg era la noción kantiana de que encontrar algo bello era hacer tácitamente una categoría universal de juicio; una idea que lo apartaba radicalmente de Duchamp y de los dadaístas y surrealistas que asolaron la idea establecida de la belleza; su juicio acerca del fracaso duchampiano acabó por ser más fallido que la demostración que éste hizo acerca de que la estética no era un factor esencial para definir la propiedad del arte (112). Cito a Sanouillet, porque la figura de Duchamp es tan omnipresente, como demostraré en el capítulo III, que "menardianamente" sería posible decir que es él y no Vila-Matas, el autor de la Historia abreaviada de la literatura portátil, capítulo que, en 
conjunto con los dos precedentes, completará una visión de la inestabilidad en la noción de ficción y de la emergencia de una categoría que podemos considerar extrema:

Whereas other protagonists became intoxicated in the headlong quest for all forms of significance, Duchamp found his path in the absurdity of the quest itself. Beyond laconism, silence is for him the supreme form of revolt. If it is true that for Breton 'beauty will be convulsive or will not be', for Duchamp, beauty evidently will not be (...). In 2004, five hundred personalities from the world of art voted his urinal the most influential work of the twentieth century, over Picasso and Matisse. In the final analysis, Duchamp created Dada, and Dada created Duchamp (318-320).

Sanouillete concluye que debemos agradecer a los dadaístas por haber abierto la caja de Pandora de la humanidad y por cumplir su expedición a su riesgo y peligro, hacia las siempre cambiantes fronteras de nuestra insaciable curiosidad. Después del Dadá la pregunta de qué tan lejos podemos ir, tiene una respuesta nueva: "Much futher than we had thought" (330). Ese "mucho más lejos de lo que habíamos pensado" es el horizonte de la ficción extrema.

A los numerosos estudios de la obra de Mario Bellatin, usualmente hechos desde la teoría literaria, añadiré una visión concentrada en la estrategia de la inserción de fotografías que más allá de la función aparente de la verosimilitud, supone una continuidad de otros niveles del relato: lo extiende, por así decirlo, o lo desdobla a partir de las nuevas lecturas que ofrece la conjunción entre fotos y palabras. La invención de Trepadori preconizó la crítica institucional como veremos; la construcción de Alicia Mihai Gazcue es un modo de ficción extrema no sólo hecho a dúo por Porter y Tiscornia, sino en tiempos diferidos y a través de una estrategia que cede su creación a otros sujetos del mundo del arte; y los casos de Torres Llorca y Amorales señalan el vastísimo panorama de las modalidades de la ficción extrema. 
Nos abocamos a un tiempo paralelo en su ruptura al de las vanguardias de comienzos de siglo, pero abriendo campo a un horizonte donde los incendios de la imaginación traspasan campos y prefiguran ensayos de modos inéditos de alteridad que nos sitúan ante visiones de imprevisibles consecuencias para la reinvención de la realidad común. Frente a la pregunta que formulara Brian McHale, “QQué pasa cuando diferentes mundos — la así llamada realidad empírica y la realidad del trabajo literario- se confrontan una a la otra o cuando sus marcos estructurales son violados? ¿Cuál es el modo de existencia de un texto en el mundo?" (Juan-Navarro 23), el campo de esta disertación se extiende hacia las interrelaciones de la ficción que se desliza entre las fronteras del arte y la literatura y desafía los límites mismos de la realidad. Comprender las estrategias que estos autores han usado para insertar sus ficciones en la vida abre espacios de pensamiento donde el horizonte nos lleva "mucho más lejos de lo que habíamos pensado" y nos sitúa quizás en el advenimiento de una altermodernidad en donde el sueño de hace casi un siglo de Bajtín y su interrogación por la respuesta de la propia vida, se funde con la visión de un Nicolás Bourriaud que interroga las visiones del futuro.

La comprensión de lo alterno y de lo errante que hay en el Manifiesto de Altermodernidad propuesto por Nicolás Borriaud en el marco de la cuarta edición de la Tate Triennial en 2009, guarda estrecha relación con las estrategias de la ficción extrema. Borriaud señala que en el advenimiento de la altermodernidad es determinante la hibridización cultural conectada con el saqueo sin fronteras de textos y obras; el viaje como una estrategia productora de formas y obras, y los formatos expandidos del arte (Borriaud Altermodern Manifesto). Estas características se cumplen en las ficciones 
extremas de los autores estudiados. Si la identidad misma entra en el juego del borramiento entre la ficción y la realidad, surge una expansión de los límites mismos de la imaginación a los múltiples espacios de la vida.

Estamos ante un campo de relaciones expandidas entre arte y literatura que altera la línea lábil que separa ficción y realidad e involucra múltiples modos de desplazamiento hacia un afuera de las fronteras que en última instancia permite concebir lo alterno como una visión no sólo lúdica, sino de un potencial crítico. Enumero los rasgos que iremos descubriendo como manifestaciones de ese extendido ejercicio de la ficción extrema.

- La recurrente estrategia de la con-fusión entre géneros. Se realiza haciendo pasar una relación hipertextual por otra, y enmascara de tal modo la índole de las creaciones que el resultado incide en la dificultad del lector/espectador de separar la ficción extrema de lo real.

- Sus autores exploran la posibilidad de las identidades dobles, incluso múltiples, y en todo caso, móviles. Este rasgo está conectado a la visión de lo dialógico y de la alteridad.

- La ficción extrema implica el sentido del juego en su acepción más poderosa: una lúdica que tiene la osadía de colarse en la realidad. Un humor inescapable, modulado en múltiples tonalidades forma parte de las reglas de ese juego.

-El contínuo ejercicio de la libertad de jugar con los archivos del mundo. Los autores se mueven con inaudita libertad tanto en la gran biblioteca del mundo como en el inmenso museo que de modo ubicuo reúne el cuerpo de conocimientos iconográficos y sus juegos hipertextuales. En las apropiaciones de este archivo derivadas de las estrategias de la ficción extrema subvierten los mismos ordenamientos de la cultura. 
-Los autores de la ficción extrema se ejercitan en los juegos de lenguajes transmigrantes de un campo a otro que ya nacen como traducción en su origen: son doblemente traducidos, desdoblados, sujetos a un nomadismo que marca sus desadaptaciones, sus vacíos, pero también la extensión de una ruta que los llena de nuevas significaciones y potencializa las ficciones. No sólo los escritores sino los artistas recurren a juegos textuales, liberados del sentido, y vinculados a prácticas creativas polifónicas y errantes.

- La ficción extrema propicia el juego de la multiplicidad de identidades, conexa al mismo carácter dialógico de la polifonía, y extiende el carnaval de las voces a la posibilidad de identidades alternas. Ese modo de usar la alteridad enloquecida acaba por sugerir la visión de lo alterno en la realidad.

- Los palimpsestos de ficciones convergen en modos de verdad vital. Con sus extendidos juegos de apócrifos o con sus tránsitos sin restricciones entre campos, los practicantes de la ficción extrema acaban por provocar transgresiones narrativas o visuales, que pueden llegar a insertar un modo de mentiras en las memorias de la historia del arte o de la literatura, e incluso de la historia misma, pero su interpolación está guiada por un modo de verdad que sacude los órdenes hegemónicos.

- El surgimiento de un modo de crítica especular sobre la realidad. Las osadas imposturas de la imaginación instauran una duda sobre las construcciones sociales de sentido y unos de sus efectos puede ser la creación de fisuras no sólo en la memoria de la historia o de los campos del arte y la literatura, sino en las hegemonías del mundo.

El recorrido propuesto nos abocará así a cuestionar hasta qué punto la inserción de modos de ficción en la realidad que resultan capaces de alterarla, o de revelar cuánto 
hay de ficticio en su propia construcción, acaba por construir una visión que estremece la naturaleza y los límites mismos de la realidad.

${ }^{1}$ Nótese la relación entre las relaciones hipertextuales y las posibilidades de la apropiación o intervención
artística.
${ }^{2}$ Los múltiples modos de discurso constituyen mucho más que hechos meramente verbales en tanto reflejan
y contienen a su vez los mundo sociales que los producen. Precisa Stam : "Bakhtin traces the dialogic back
to the Socratic dialogues, wich their staging on the contest of two competing discourses. He opposes the
dialogic and "poliphonic" texts of Rabelais and Dostoyevsky to the 'monologic' and 'theological' text whic
unproblematically assert a single truth. Te concept of intertextuality suggests, at the same tome, that every
text forms an intersection of textual surgaces where other texts may be read. 'The literary word,' according
to Bakhtin, 'is aware of the presence of another literary word, alongside it"' (20).

${ }^{3}$ En el mismo ensayo, Zavala trae a colación los heterónims de Pessoa, los apócrifos de Machado, y los pseudónimos de Azorín (138).

${ }^{4}$ Igualmente, el carácter dialógico del texto no se agota en sí: acaba por generar el desarrollo de la teoría de la recepción. Cada texto plantea una pregunta al lector-intérprete y su comprensión se remonta a esa pregunta que involucra un diálogo con éste, que no puede existir sin la noción de alteridad. Como sostiene Antonio Pérez Estévez, refiriéndose a la conciencia hermenéutica de Gadamer : "sabe que de un lado está el lector intérprete y del otro el pasado en su alteridad que habla por medio de un texto. La relación del lector, por tanto, con el pasado es análoga a la que se puede tener con un 'tú', con otra persona distinta" (125). El lector modelo que imaginó a su vez Umberto Eco suponía la posibilidad de que en ese momento del encuentro con el texto, éste pudiera estar ante todo un "conjunto de condiciones de felicidad" que le permitirían actualizar plenamente el texto (89).

${ }^{5}$ Santiago Juan-Navarro cita a Ihab Hassan, quien en su ensayo "The Dismemberment of Orpheus" ofrece la más comprehensiva sistematización del concepto de posmodernismo y comprende que el postmodernismo lleva consigo una particular doble visión, una tensión entre el deseo de deshacer y el de institucionalizarse. Es Hassan quien encuentra antecedentes posmodernistas en autores como Stern, entre otros. A su vez, caracteriza la visión posmodernista por la "indetermanence", un neologismo que une las palabras inderterminación e inmanencia, y que en última instancia se manifiesta en la idea de reconstruir el universo desde los signos y asumir la cultura como un sistema semiótico. Igualmente cita a McHale, quien considera el posmodernismo como una construcción discursiva y centra su estudio en la naturaleza de la ficción postmoderna y en la descripción de las estrategias que esta usa para destacar la ontología del texto y del mundo (19-24). Catalina Gaspar remite, dentro del estudio teórico de la metaficción narrativa a: Alcom 1994; Alter 1978; Barth 1978; Baudry 1971,1972; Bermur 1990; Breuer 1988; Bustillo 1995c; Dällenbach 1991; Hayle 1993; Hulme 1976; Hutchmn 19841 lotman 1984; Rose 1979; Ruthof 1981; Stoicheff 1991; Sonehill 1988 y Waugh 1990.

${ }^{6}$ Durante mucho tiempo, sostiene Calvo Serraller, la obra estuvo sujeta al mismo aislamiento producto de los 37 años que pasó como pintor de la corte al servicio de Felipe IV, a cuyo servicio entró en 1923; al progresivo aislamiento de su país que empezaba a declinar, y al aislamiento que sufrirían durante siglos sus pinturas guardadas detrás de las inexpugnables paredes del palacio en donde casi nadie las vio. Pero tampoco obtuvieron mucha atención cuando en 1819 se abrió el Museo del Prado, pues, como Calvo Serraller sostiene, la inclinación estética de la época estaba más interesada por el romanticismo. No fue sino hasta 1865, cuando Manet descubrió su obra, y calificó a Velázquez de "pintor de pintores" que se le dio el lugar que le correspondía (30-1). 
${ }^{7}$ Por supuesto, su investigación recoge incontable cantidad de trabajos precedentes, entre las cuales reivindica a Luis Astrana Marín señalando que se le denosta sin dejar de saquearlo. Otras referencias clásicas esenciales son Miguel de Unamuno, Fancisco Rico y Francisco Ayala, y los demás escritores invitados a participar en la edición que publicó la Real Academia de la Lengua Española, pero mi intención apenas es aludir a los dos más legendarios momentos en relación con la metaficción.

${ }^{8}$ Ahonda también Trapiello en que primero se lo leyó sólo como libro cómico y de risa, pero, por supuesto, no fue ésta la razón por la cual, antes de morir, Shakespeare llevó a escena uno de los episodios de Cardenio (117-221).

9 Gonzálo Torrente Ballester habla de "un principio de congruencia", enlazado a lo que llama "la conciencia de Don Quijote" que le permite elegir los elementos suficientes para que las palabras susciten en el lector la totalidad de la imagen descrita, con la fuerza de lo real. Selaña que está convencido de que las reglas dfel juego real completo bastan por sí solas para suscitar esa impresión de realidad que se apetece. Aventura que el artista de la palabra puede producir imágenes y conceptos y que unas y otros tienen su específica función en el sistema verbal del escritor... Cree, además, que entra las "definiciones e imágenes de los personajes que nos suministra el Quijote, estos tienen más fuerza que aquéllas” (70). Una discusión que se torna inútil en este pasaje abierto del arte a la literatura y viceversa.

${ }^{10}$ La comparación entre la imagen de la página en negro del Tristam Shandy y la imagen de la obra de Reinhardt puesta en una página entera, como preludio al capítulo donde Arthur C. Danto habla de su percepción, tres décadas después del fin de la historia del arte, resulta de un asombroso parecido.

${ }^{11}$ El autor de Macedonio Fernandez Lector Del Quijote. Con referencia constante a J.L. Borges (2009) es Daniel Attala.

12 También Borges habla de ficciones de primer grado - lo que ocurre "realmente" en el espacio de la ficción - y de segundo grado - lo que es soñado, o una ilusión dentro de la ilusoria realidad de la ficción.

${ }^{13}$ Término tan adecuado que Brian McHale lo adoptará -no sé si por influencia borgiana- cuando hable de la índole de las ficciones postmodernas.

${ }^{14}$ En Reflexivity in Film and Literature. From Don Quixote to Jean Luc-Godard, Robert Stam se refiere a cómo la crítica paródica de la ficción tiene precedentes en Aristófanes, Eurípides, Horacio y Ovidio. Chaucer, aclara, interviene en sus propios relatos y destruye la ilusión generada por la narrativa (1).

${ }^{15}$ No hay que olvidar que para Brian Mc Hale, la estructura ontológica de un libro descansa finalmente en el libro material y en su tipografía (Juan-Navarro 26).

16 Genette aborda como segundo tipo de transtextualidad, la paratextualidad - la relación dentro de la totalidad del trabajo literario del texto propiamente dicho con sus paratextos: títulos, prefacios, epígrafes, ilustraciones e incluso las portadas (Stam 23).

17 La frase es un hipertexto que alude a Claude Magris en una cita que no logro localizar. 


\section{MAX AUB Y LA FICCIÓN EXTREMA: LA INVENCIÓN DE JUSEP TORRENS CAMPALANS}

"If the 20th century has taught us anything, perhaps it is this: surfaces are unstable, and appearances are not, on the whole, to be trusted."

Jennifer Higgie

Entre los expatriados de la Guerra Civil Española que se exiliaron en México, la figura de Max Aub Mohrenwitz (1903-1972) fue la de un escritor sin fama que aplicó su pensamiento creador y las más osadas imposturas de la imaginación a sobrepasar los linderos entre géneros y artes, y entre ficción y realidad, hasta dar con nuevos territorios para el asombro. Nunca tuvo ni la celebridad de su amigo Luis Buñuel (1900-1983), sobre quien escribió una extraña novela biográfica que se publicó de modo póstumo ${ }^{18}$, ni el aura que rodeó al solitario León Felipe (1884-1963) ${ }^{19}$. Y sin embargo, su creación es prodigiosa, más que por los diversos campos que abarcó —obras teatrales, guiones de cine, ${ }^{20}$ ensayos, cuentos, diarios de viajes, inclasificables textos lúdicos y novelas-, por el desparpajo con que usó el juego autoral para traspasar a su antojo las fronteras entre géneros anexando sus invenciones a zonas de la realidad.

No puede, por ejemplo, afirmarse que fue poeta, pues no lo fue en sentido estricto a motu proprio, pero escribió durante largos años poemas que constituyeron la obra real creada a lo largo de la vida por uno de sus personajes imaginarios y se atrevió a hacer una antología de poemas — faltos de verdadero hálito poético según la crítica - en la cual incluyó a docenas de escritores de todos los confines del mundo, que son apócrifos, hijos de esa fantástica isla de la imaginación aubiana. Poco importa la destreza en un género determinado, frente a la osadía de los raros entrecruzamientos de sus invenciones. Aub se situó en la frontera más experimental de las vanguardias gracias a la creación de 
simulacros que burlan las demarcaciones entre realidad y ficción. Preconizó, a través de la fabulosa invención de personajes que "insertó" en la vida real, lo que aquí hemos llamado ficción extrema justamente por su deslizamiento inadvertido, solapado, en espacios de la realidad, desde donde se cuela de un modo no menos astuto, en la misma historia del arte o de la literatura.

Su genialidad en la invención de personajes que se deslizan al campo de la vida fue tal que no es raro que incluso los estudiosos se confundan con sus biografías ficticias, pues audaces estrategias creativas las hicieron deslizarse en los periódicos y registros de diversa índole y aparecer como verdaderas. Dos de sus personajes literarios, el poeta Luis Álvarez Petreña (1897-1931), ${ }^{21}$ y el artista Jusep Torres Campalans (1886-1957), ambos inventados con sus respectivas obras, desbordaron las convenciones de géneros y el terreno de las páginas para entrar — de forma apócrifa— a la historia de la literatura y del arte respectivamente, ni más ni menos que como si hubieran existido en verdad, de modo completamente ajeno a su inventor.

En una conversación informal que sostuve en enero de 2007 en Cartagena, Colombia, con José Emilio Pacheco (1939-2014), quien fue su cercano amigo, el poeta mexicano se refirió al singular gozo que había experimentado Aub al saber que Luis Álvarez Petreña, el poeta heterónimo que bajo sus artimañas creativas empezó a publicar en 1934, y cuya obra aparece aumentada en las ediciones de 1943 y 1970, había sido incluido en una antología de poesía mexicana. Los poemas, por supuesto, eran escritos por Aub, pero su autoría era atribuida a Petreña, quien no era en absoluto un genio de la literatura, sino un hombre cuya tragedia consistía en no poder ser otra cosa que escritor, aun sabiendo que su producción era mediocre. ${ }^{22}$ 
Todavía más osada es la invención de Jusep Torres Campalans, supuestamente nacido en Mollerusa, provincia de Lérida, España, el 2 de septiembre de 1986, puesto que Aub se desdobla en pintor para hacerlo verosímil y crea así una obra plástica, espejo de las vanguardias de su tiempo, que no se atribuye a sí mismo, sino al artista valenciano nacido en 1896, presentado como pionero cubista, y, tan entrañable amigo de Pablo Ruiz Picasso (1881-1973) que de modo autoreflexivo el narrador comenta: "La influencia de Picasso en Torres Campalans es otra cosa: su manera misma de ser" (90). No miente en absoluto a este respecto: a través de las argucias de Aub, quien tuvo un trato real con el genio malageño y un papel directo en la exposición de su Guernica, ${ }^{23}$ la figura de Picasso no sólo le otorga un modo de existencia derivada de esa forma de legitimidad que da la celebridad, sino que la mayor parte de su trayectoria ocurre como mímesis de los descubrimiento artísticos picassianos. Aub lo construye como una suerte de doble de Picasso en términos de su trayectoria, con el atrevimiento de sugerir que a menudo se le anticipa. Esa apropiación sólo decae en los dos últimos años de la vida artística de Jusep Torres Campalans, entre 1912 y 1914, cuando su acercamiento a Mondrian lo va apartando de Picasso, hasta que un creciente desencanto con el arte y con el mundo que se precipita en la Primera Guerra Mundial, lo lleva a abandonar todo. Entonces huye a México, tal y como su biógrafo Aub, quien apunta que el pintor decide desaparecer en 1914 sin dejar rastro. A su vez, su mayor crítico, Henry Richard Town, un experto en su obra que habría trabajado acusiosamente en el catálogo que acompañaría en 1942 su exhibición en la prestigiosa Tate de Londres, muere bajo el bombardeo de las fuerzas hitlerianas que destruyen su casa, con la fortuna de que los cuadros, preservados en un guardamuebles, se conservan. Ambas desapariciones, la voluntaria de Torres Campalans, 
equivalente a una escéptica fuga del mundo en el que ya no tiene asidero, y la involuntaria de su apócrifo crítico, reflejan la crisis de un tiempo, en el que no parece haber otro asidero que las peculiares imaginaciones del humor.

Este extraño pintor, cuya vida y obra fue recuperada por el acusioso biógrafo que ha sido considerado el más audaz de los impostores, y que el escritor Antonio Muñoz Molina comparó al héroe de Woody Allen (n. 1935), Zelig, y a la extrema habilidad de aquella secta de falsificadores que inventó el mundo total de Tlön, es la materia primordial de este capítulo que devela su relación con Max Aub. En el blanco y negro de los documentales antiguos, Zelig se mueve -según Muñoz Molina- con su "apocamiento de fantasma, con una verdad de desamparo humano, que acaba siendo menos ficticia que las vidas impostoras de los personajes públicos" (Discurso 24). Su osadía literaria es paradigmática porque desafia los propios límites del territorio literario y los extiende hasta un dominio de la fantasía en el que, paradójicamente, vuelven a encontrarse las fronteras de algo verdadero.

Sin lugar a dudas, Jusep Torres Campalans es un exponente de la habilidad que exige la ficción extrema para convertir en habitante de la realidad a un personaje que, por encima de su carácter estrafalario, no sólo logra tener exitosas exhibiciones en la vida real $-\mathrm{y}$ vender obras-, sino encarnar el complejo zeitgeist de una modernidad en crisis. Aub saquea minuciosamente la revolución cubista para hacer una biografía ficticia de este artista que firmaba con el monograma J.T.C. -y que usaré aquí a menudoconstuyéndolo como doble de Picasso, pero también como heterónimo que hace eco de su propia vida aunque tiene un talante muy distinto al suyo, y tras la máscara del biógrafo (apócrifo), hace una de las primeras formas de meta-crítica, no sólo a través de los 
múltiples niveles textuales, sino de la pintura-ficción que inventa para burlar el siglo en el que vive.

Si un lector desprevenido y ajeno al historial de Aub se encuentra con su Jusep Torres Campalans puede sucumbir a su formidable embuste y creer a pie juntillas que se trata de la biografía de un pintor auténtico — tanto en su existencia como en su pinturaque fue olvidado por su decisión de huír del mundo. En ese caso, Aub seguiría siendo el autor de la biografía, pero se borraría — como en efecto ha llegado a suceder- como inventor del personaje que pasa a existir por sí mismo, ocupando apenas la más modesta figura del biógrafo. Es un ejemplo perfecto de cómo la ficción extrema permea las demarcaciones habituales entre ficción y realidad al deslizarse de uno a otro campo a través de un tipo de interpolación que plantea la autonomía del personaje con respecto a su creador y le otorga una suerte de existencia real.

Antonio Muñoz Molina, quien escribe el epílogo del libro Max Aub. Dos vidas imaginarias, sintetiza la dimensión de su intento:

Siempre inquieto, tanteando siempre caminos posibles, había escrito esa obra maestra del pastiche casi posmoderno y de la impostura literaria, de la confusión entre lo irreal y lo inventado, que es Jusep Torres Campalans. (...) No era una persona real, pero tampoco era un personaje puramente literario, aunque fuere una criatura de ficción: deambulaba entre un reino y el otro, aparecía en una foto en blanco y negro, conversaba con Max Aub, había pintado cuadros idénticos a los cuadros de los pintores verdaderos (580).

Aub, quien, como escribió Antonio Muñoz Molina, fue “un escritor sin público y un ciudadano sin país" (580), obtuvo, a través de ese modo de reconocimiento a la existencia de su imaginario Jusep Torres Campalans; una tardía pero magnífica forma de compensar esa sensación de extrañeza y de irrealidad que a veces lo agobiaba y que estaba relacionada con la nada fácil experiencia de ser un escritor prolífico en múltiples 
géneros, pero carecer prácticamente de lectores. Y esto pese a que - ¿o precisamente porque?- la biografía apócrifa de Jusep Torres Campalans que aquí nos ocupa supone un entrecruzamiento entre la literatura y el arte que lleva el acto de invención más lejos de lo imaginado por cualquier novelista; se constituye como un texto experimental que acoge en su propia estructura literaria las estrategias plásticas del personaje que ha insertado en la misma vida; $y$, al apropiarse del desenvolvimiento de las vanguardias artísticas de comienzos de siglo, el supuesto biógrafo acaba realizando una lectura crítica del espíritu de una época.

En un momento decisivo de su trayectoria artística en París, Jusep Torres Campalans cambia el francés por el tzotzil, y la agitada vida europea de la anteguerra, por el silencio de las sierras mexicanas, y no vuelve a pintar jamás. Y aun así, no sólo tuvo exposiciones póstumas organizadas por Aub, como biógrafo, sino aún mayores exhibiciones tras la muerte de éste: una retrospectiva, de Jusep Torres Campalans, organizada entre el 13 de junio y el 23 de agosto de 2003 en el Museo Nacional Centro de Arte Reina Sofía, y en 2008, el Museo de Bellas Artes de Valencia celebró a su vez la vida y obra del pintor que acabó imitando el "preferiría no hacer" del Baterbly de Melville. ${ }^{24}$ En uno de sus encuentros con el biógrafo Aub, J.T.C. le aclara, después de un largo intercambio con respuestas monosilábicas: "No vaya a creer que me he retirado del comercio humano. No. Ni me oculto, ni hago vida de anacoreta. Dios no me llamó nunca por ese camino. No sencillamente no hago nada. Ni hablar" (237). 


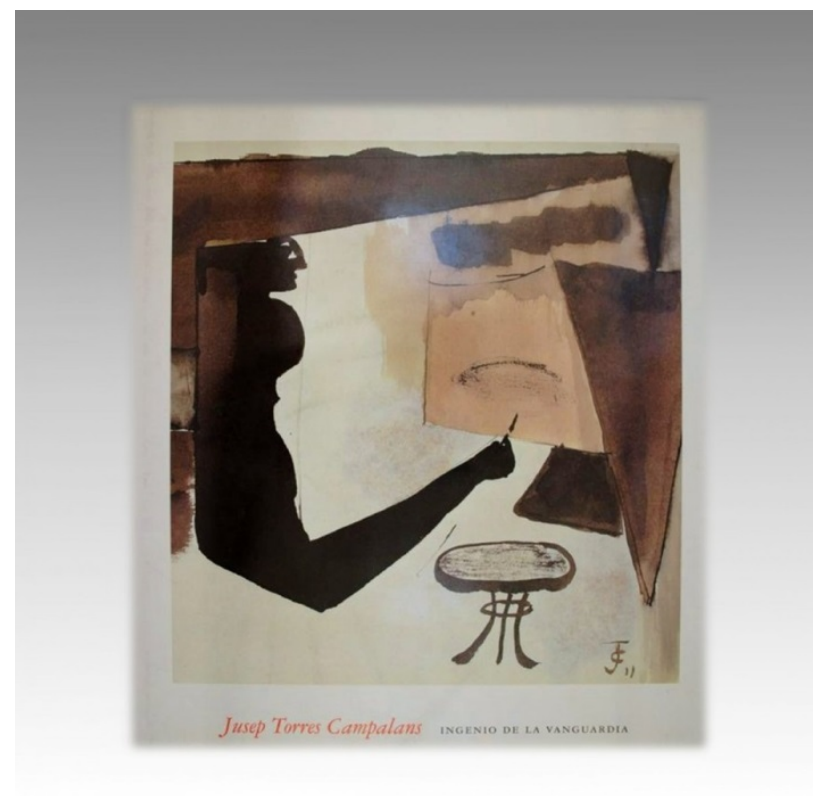

Ilustración 3: Portada de Jusep Torres Campalans. Ingenio de la vanguardia presentado como catálogo de su exhibición en el Centro de Arte Reina Sofía (13 de junio de 2003-23 de agosto de 2003).

¡Cuánto habría gozado el biógrafo apócrifo, de haber asistido a la inauguración que con toda solemnidad se realizó en 2003, año del centenario de su propio nacimiento —y del trigésimo aniversario de la muerte de Picasso- - en torno a la obra del pintor Jusep Torres Campalans! Un evento que lo convirtió en el único artista inexistente que ha tenido exhibiciones en uno de los más prestigiosos museos de España. Ese triunfo de la creación literaria que se inserta en el arte fue refrendado entonces por un catálogo oficial, publicado por la prestigiosa institución en el cual se suprimió en la portada el nombre de Max Aub, inventor del artista, en un gesto que reforzaba la existencia autónoma de Jusep Torres Campalans.

“De Jusep Torres Campañans se sabe todo porque no se sabe nada", dice Luis Miguel Enciso Rocío en un texto que prologa su exhibición en el Museo Nacional Centro de Arte Reina Sofía — en una sala próxima a aquella donde se exhibe el Guernica- 
donde cita la afirmación de Max Aub respecto a la vida y obra del pintor catalán: “¿Embaucador, yo? Ni por un maravedí... He querido hacer un libro sobre el clima moral de nuestra época, en que las artes han sustituido a la religión y a la política” (x).

\section{La relación especular con Picasso}

Jusep Torres Campalans cultiva una estrecha relación de amistad con Pablo Ruiz Picasso (1881-1973), figura astutamente elegida por Aub, puesto que el genio español fue considerado uno de los dos artistas más influyentes del siglo, ${ }^{25}$ y sin duda, el primero en encarnar el rol del artista-celebridad. ${ }^{26}$ No por azar, en la mencionada exhibición, Jusep Torres Campalans. Ingenio de la Vanguardia, las pinturas de J.T.C. se dispusieron justamente en un salón situado justo en frente del que alberga El Guernica, 1937, y a un lado de las obras de aquellos pintores con los cuales el impostado artista se relacionó en las notas de su "Cuaderno verde".

La comprensión del ejercicio de ficción extrema que cumplió Max Aub, no sólo exige ciertamente revisar la relación entre su biografía apócrifa y su vida y visiones metacríticas, sino establecer un paralelismo con el desarrollo de cubismo de Picasso que es el esqueleto que permite construir su existencia literaria y deslizarla en el terreno de una realidad atravesada por la incertidumbre.

En una entrevista concedida a André Camp, para Radio Francia, en 1961, el mismo año de la publicación de Jusep Torres Campalans, Aub declara:

Yo nací con el cubismo, bueno, apenas soy un poco más viejo: nací con el cine, si os parece mejor. Nací con Picasso... Picasso tiene exactamente la misma edad que mi madre, pero no importa, nací con Picasso. Y nací con Stravinsky, nací con Diaghilev (...) Hoy en día se puede montar una gran exposición sobre Picasso: ¡No importa! Picasso es 1906, 1907-1908, antes de ser, en 1937, El Guernica. Stravinsky es también La consagración de la primavera, es Diaghilev, son los 
ballets rusos. Es también antes de la guerra -Francia ha sido marcada- es Apollinaire, y es, aun así, 'el yo' (Malgat 26).

En sus páginas desfilan también, Ramón Casas $(1866-1932)^{27}$, Nonell (1872$1911)^{28}$, Juan Gris (1887-1927), con quien se enzarza en peleas interminables, Georges Braque (1882-1963), Modigliani (1884-1920), y Mondrian (1872-1944), de un modo decisivo, porque su figura parece ser la única que mantiene en pie en el límite de la duda misma sobre las prácticas vanguardistas, entre muchos otros artistas que construyeron la modernidad en sus lugares de origen, incluyendo a Tristán Tzara (1896-1963), que exigió de un modo más radical que ninguno el don de la libertad. Todos ellos formaron parte de las amistades de Picasso, cuya figura es en cierto modo la de los hombres de avanzada de la época y, por supuesto, la del apócrifo Jusep Torres Campalans.

En una carta personal de 1958, Aub dice que va a llevarle a Picasso su Jusep Torres Campalans. En cualquier caso, esta inserción del artista ficticio en los circuitos especializados que sigue sucediendo en la posteridad de Aub equivale a la consagración de un acto de creación que transgredió géneros y demarcaciones instaurando además un modo de crítica de arte que en lugar de recurrir al verbo usurpa el lugar de los artistas y transforma el acto de pintar y las obras resultantes (pinturas-ficción) en puro meta-arte, espejo de la creación artística que enfrentándose al mismo arte de la época, no sólo lo refleja de manera especular, sino contiene el contexto en que ha surgido y lo atraviesa desde una perspectiva meta-crítica, oblicua. Así, el gouache sobre papel Atribuido a Torres Campalans (sin título), 1912, no sólo revela cierto oficio e innegable conocimiento de técnicas como la negra pincelada gruesa y la ausencia de perspectiva que funcionan como deconstrucción lúdica de la pintura de la vanguardia de su tiempo. 


\section{La audacia de la impostura}

La maestría de Aub en el arte de la ficción extrema se sintetiza y explica con el título que da Soldevila Durante al estudio sobre su vida y obra: El compromiso de la imaginación. Como comenta a su vez Ana Calvo Revilla, la clave para situar todos estos materiales referenciales ficticios nos la proporciona el mismo Jusep Torres Campalans, cuando defiende la simulación como recurso magistral en su diario ficticio: "Queda la imaginación, gran fortuna. Puestos a mentir, hagámoslo de cara: que nadie sepa a qué carta quedarse. Solo en esa inseguridad crecemos grandes, solos, cara a cara, con el otro" (3).

La diferencia entre crear un personaje ficticio e interpolar en la historia misma a un ser inventado con una obra real que se le atribuye y que funciona per se, de modo autónomo, es esencial para establecer la noción de un tipo de ficción extrema que cumple con la consideración de Hans-Georg Gadamer: "La obra de arte aumenta el ser". Citando esa frase en su original en alemán Die Aktualität des Shönen, Zigmunt Bauman evoca el señalamiento de Ortega y Gasset respecto a cómo se agranda el mundo al añadir nuevos continentes de imaginación: "Los antiguos romanos daban ese título [auctor] a los generales que conquistaban nuevos territorios para el imperio" (17). Max Aub fue un autor en ese sentido originario y poderoso de la palabra, que viene de auctor, el que aumenta. Fue, ni más ni menos, un conquistador de las fronteras más desconocidas y extremas del territorio de la imaginación.

Pilar G. Sáenz nota en su ensayo De ambigüedades y otras violaciones en el arte de narrar, que ese recurso de la metaficción que es la presencia del propio Max Aub en el 
texto, donde aparece "como narrador y narratario, como autor de ficción y personaje fictivo" se repite en varias de sus obras:

La inserción de Max Aub en la ficción se manifiesta como una transgresión de los niveles de la narración; como ruptura de la distinción autor-personaje; es decir, de la distinción creador-criatura. El autor de ficción pierde - figurativamente- su propio poder sobre los personajes al compartir con ellos el mismo nivel narrativo $\mathrm{y}$, lo que es más, al convertirse en uno de ellos. Max Aub pasa de autor de ficción a simple transmisor de lo hallado por el ficticio Aub en Méjico, en el caso de Jusep Torres Campalans; o en un hospital de Londres, en el caso de Luis Álvarez Petreña; o bien en la colección de materiales recogidos y clasificados por el propio Max y que constituyen su póstumo Buñuel (AIH. Actas XII. 1995, 238).

Continúa Sáenz precisando cómo hay una pluralidad de estrategias en las apariciones de Max Aub en los textos: no sólo está presente en prólogos y epístolas, o en las obras plásticas de J.T.C., sino en las ilustraciones de su Juego de $\operatorname{cartas}^{29}$ y en las letras capitulares y viñetas que adornan el texto de Versiones y subversiones. Aub ha creado al ficticio Torres Campalans, y también al ilustrador Richard Falker Huntor, quien realiza dibujos para su libro Versiones y subversiones. Pero la obra gráfica de este último no ha alcanzado a insertarse en las grandes instituciones artísticas como sí lo logró el primero, no sólo con pinturas al óleo, sino con sketches que Camnitzer considera notables en su ingenioso humor, ${ }^{30}$ y que aparecen autenticados por su paródica firma, convertida en obra de arte en sí. Al tiempo, los prólogos, apéndices, y epístolas firmadas con las siglas M.A. —que predominan en Jusep Torres Campalans y Luis Alvarez Petreña- son, según Sáenz, "marcos conflictivos realidad/ficción” en ejercicios narrativos que van marcando una línea progresiva de metaficción (242).

En el libro Conceptualism in Latin American Art: Didactics of Liberation, el teórico y artista Luis Camnitzer (n. 1937) — co-inventor a su vez de un artista, como se verá en el epílogo — puntualiza la importancia de la literatura, la poesía, la política y los 
precedentes visuales, en el surgimiento del arte conceptual en el sur del continente, enfocándose en dos figuras: Jorge Luis Borges (1899-1986) y Max Aub, particularmente en su Jusep Torres Campalans. Aub, afirma, podría ser tomado como un meta-artista, un creador que llevó al Gog de Papinni "to an extreme, by fully and complexly creating a fictitious artist who starting living a life of his own... [Aub] assembled a complete and credible character with both life and work" (116).

La capacidad de Aub de hacernos sucumbir al poder de la ficción extrema, de provocar en el lector, como destaca José Antonio Pérez Bowie "una lectura no ficcional”31 de la biografía apócrifa del artista catalán proviene de una estrategia de deslizamiento entre géneros literarios y de la literatura al arte. Aub hace una hábil utilización de recursos biográficos no habituales en las narrativas de ficción como cartas intercambiadas con personajes reales de la época, fotografías, artículos que lo referencian, entrevistas personales, y una minuciosa cronología, notas monográficas, entre otros recursos como un convincente prólogo sobre el proceso de recopilación documental en el que el mismo Aub se presenta como historiador veraz. A todos estos recursos que complementan el texto narrativo con este tipo de inserciones reiteradas, J. A. Pérez Bowie los llama "paratextos ficcionales" (Ficción y realidad 6).

El mismo Camnitzer confiesa que, habiendo comprendido la broma aubiana de crear un personaje bajo la fachada de una completa investigación biográfica, tuvo él mismo la tentación de mencionar a Jusep Torres Campalans, en el lugar de Aub. Y precisa cómo también el crítico de arte mexicano Cuauthémoc Medina, considera que este libro, originalmente publicado en México en 1958, así como "Pierre Menard, Autor del Quijote”, de Borges son piezas fundamentales, precursoras: “...one of the Latin 
American avant la letre contributions to hegemonic postmodernism" (116). Através de la invención de un artista como Jusep Torres Campalans, Aub no sólo crea una formidable broma literaria —al modo de la invención de Bustos Domeq, el autor creado por Jorge Luis Borges (1899-1986) y Bioy Casares (1914-1999) — sino iconográfica. Sus pinturas son más que meta-arte: desbordan la noción de la obra que reflexiona sobre el propio proceso de creación, para hacer un abordaje en el que recurre a las apropiaciones artísticas no sólo para formular un credo estético coherente, sino para desmantelar la misma producción de un tiempo.

Como relata Camnitzer, el lanzamiento del libro de Aub estuvo precedido por una exhibición de pinturas firmadas por la signatura de sus iniciales -J.T.C.- y hubo además personalidades como Octavio Paz (1914-1965) y Alfaro Siqueiros (1896-1974) que hicieron comentarios sobre la obra citados por la prensa. Sobre la interpolación del muralista en la legitimación de las obras del pintor inexistente anota:

(...) with untypical humor pointed out that Jusep Torres Campalans is an example of "semi-non-objectivism", a movement that Siqueiros claimed to have been hoping to found of his own. His plans for this movement supposedly would have included the writing of a book titled "The Monocle of Socialist Realism vis-à-vis a Possible Marxist-Inspired Normalist Realism” (117).

Además de valorar el potencial crítico del embuste fraguado por Aub -"The author not only desmystifies the artistic scene of the begining of the twentieth century, but also introduces a wonderful confusion into it" (117) - Camnitzer destaca la autoreferencialidad cervantina, cuando introduce la descripción de sí mismo como si fuera un otro que ejerce de "tipógrafo, escritor y pintor" (oficio que en rigor nunca cumple bajo su propio nombre), y dos invenciones más, precursoras de la difícil relación entre arte gráfico y conceptualismo: El correo de Euclides y sus Juegos de cartas, que le permiten 
establecer un paralelo con Cuadro escrito de León Ferrari, ambas piezas de 1964. De hecho, aunque J.T.C. muere en 1956, este hecho, como advierte Camnitzer, no le impide seguir creando puesto que hay ejemplos de su producción artística hasta 1971, exactamente un año antes de la propia muerte de Aub, que ciertamente ocurre mientras juega a las cartas con su amigo Buñuel.

Prueba del alcance de la ficción extrema, en vida de Aub, había sido la exposición de Jusep Torres Campalans en la galería Bodley de Nueva York, anunciada por la prestigiosa Art News en el número de noviembre de 1962. El texto precisaba que el pintor había nacido el 2 de septiembre de 1886, en Molleruse en la provincia de Lérida, España. Luego, una cáustica frase explicaba luego que era invención de Max Aub, quien residía en México y hacía el recuento de cómo la exposición de pinturas y dibujos de J.T.C. en varios medios coincidía con un libro publicado por Doubleday que llevaba el nombre del pintor y había sido escrito por Aub.

La información publicada, según evoca Estelle Irizarry describía que originalmente la exhibición se había montado en la Galería Excelsior del D.F. en 1958, donde había sido anunciada como un descubrimiento reciente de un importante pintor que siendo el verdadero inventor del cubismo y gran amigo de Picasso había dejado de pintar desde 1914, año de su fuga de París al pueblo mexicano de San Cristóbal de las Casas. 


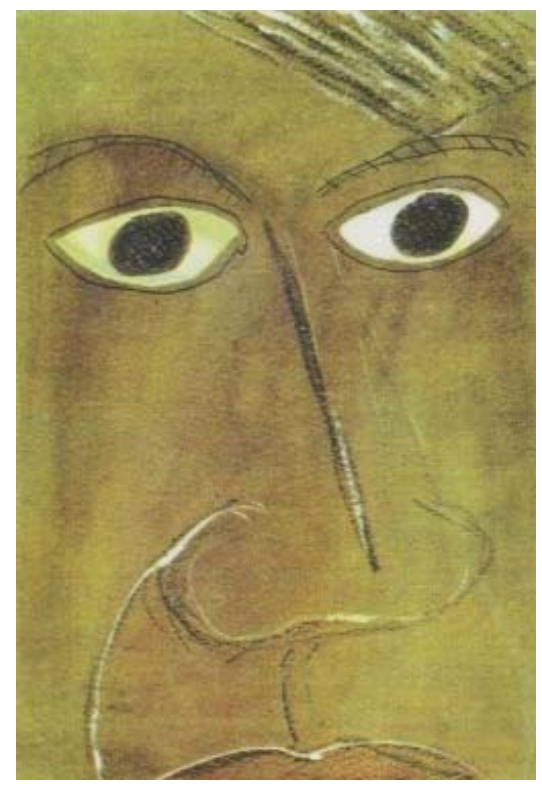

Ilustración 4: Jusep Torres Campalans, Retrato de Picasso,

1912, Lápiz sobre cartón. Propiedad de André Malraux

Se aclaraba que entonces los cuadros pequeños, y los dibujos habían sido tramados con numerosas referencias iconográficas, falsas atribuciones y dedicatorias, y que al terminar la exhibición — recibida por la crítica con interés - el mismo Aub se había presentado para aclarar la broma. La conclusión del texto que invitaba a su nueva exhibición era que de cualquier modo, para ese tiempo, Campalans, como otros tantos personajes de ficción, ya vivía. En todo caso, acierta en su apreciación de que más allá del atrevimiento de su invención, ésta tiene un valor no suficientemente comprendido como broma: "Es obvio que la broma no fue mero pasatiempo para Aub sino eje filosófico e histórico de su libro" (Cuatro bromas 403-4). Y la broma esconde la crítica de la identidad pura, en las regiones inciertas de un tiempo confuso.

Revisando los comentarios sobre la primera exhibición de Jusep Torres Campalans, Irizarry concluye que en algunos aspectos fue más fácil convencer al público de la existencia de J.T.C. que aclararle después su no-existencia. Cita a su vez el recuento 
de José R. Marra-López de la exhibición que tuvo el pintor catalán en 1958 en la Galería Excelsior del D.F., mencionando que no faltaron los críticos que de repente tuvieron recuerdos de su trato con J.T.C., y lamentaban su injusto olvido. Por su parte, el poeta Jaime García Terrés describió en un homenaje a Aub, cómo tanto él como Carlos Fuentes (1928-2012) se prestaron a la tarea de hacer real a Jusep Torres Campalans, después de haber hallado a uno de los más afamados teóricos del momento analizando las influencias de la obra. Juntos decidieron falsificar textos alusivos al pintor imaginario atribuyéndolos a firmas en boga un suplemento literario los publicó. Posteriormente se editó el conjunto de textos apócrifos en un folleto de lujo titulado Galeras.

Bien sabía Aub que colar la fícción en la realidad es demostrar su inestabilidad con la noción de que permearla es tomar reposesión de sus límites y posibilidades. O abrir, a partir de la ficción extrema, un modo expandido de acceso a lo real. Como afirma Muñoz Molina, la figura de Torres Campalans puso en evidencia

La fragilidad de los saberes sobre el mundo real y también la insidiosa virtud que a veces tienen las criaturas de la imaginación de abandonar el espacio abstracto de los libros para surgir delante de nosotros en las tres dimensiones del mismo mundo que habitamos (Dos vidas imaginarias 580).

Juan de Oleza Simó considera por su parte la novela Jusep Torres Campalans, como el gran apócrifo aubiano y la hazaña de hacer no sólo verosímil sino verdadero al pintor, le recuerda la de James MacPherson, que en el siglo XVIII dio existencia a Ossian un poeta épico del siglo III a. de C., cuyas obras publicó. Asimismo, menciona Oleza cómo, a partir de la idea de sujeto forjada desde la época clásica,

Europa se llena de máscaras: Zaratustra, Mr. Teste, Malte Laurids Brigge, Stephen Dedalus... entre los españoles: el Azorín de José Martínez Ruiz, el Alberto Díaz de Guzmán de Ramón Pérez de Ayala, el Sigüenza, de Gabriel Miró... Pero casi todos ellos tienen una naturaleza de personajes literarios más 
que de apócrifos, y actúan como un alter ego, como un doble más o menos imaginario del autor (Antagonismo de Apócrifos 6 ).

En cambio, esa pasión singular que consiste "en poblar la vida real con seres de ficción” los personajes de Antonio Machado (Abel Martín, Juan de Mairena, Jorge Meneses...) y los heterónimos de Fernando Pessoa (Alberto Caeiro, Alvaro de Campos, Ricardo Reis, Antonio Mora, Rafael Baldaya, entre tantos otros), supone el surgimiento no de personajes literarios sino de personas ficticias y autores de obra propia, con una identidad diferente a la del autor, que constituyen una "radicalización de estrategias", en la que precisamente se sitúan Luis Álvarez Petreña y Jusep Torres Campalans:

Al emanciparlos de su creador los constituye en antagonistas. Y en esa emancipación Aub va más lejos que Machado o que Pessoa. Más lejos que Machado porque el poeta sevillano no soltó nunca las riendas de sus invenciones, que además utilizó como aliados en su lucha contra Narciso y el arte autónomo, peones de una tradición que no existió y a la que a Machado le hubiera gustado pertenecer. Más lejos que Pessoa porque, si bien Pessoa es tan radical como Max en la aprehensión de la otredad, de la ajenidad de sus heterónimos, nadie fue tan lejos como Max en la pretensión de proporcionarles una realidad propia, empírica, contrastada, nadie acumuló tanta documentación, tantos artículos de prensa, tantos estudios críticos, tanta bibliografía, nadie contó con tanta complicidad de testigos reales que se prestaran a colaborar en la superchería, compartiéndola, corresponsabilizándose con ella, extrayendo por tanto la invención del ámbito de la imaginación personal para insertarla en la trama misma de la historia (Max Aub y el antagonismo).

En una entrevista sostenida con Antonio Muñoz Molina, escritor que ha librado una cruzada contra el olvido de su obra y figura, se refirió al embrujo que había ejercido sobre él, a los 20 o 21 años, la lectura de Jusep Torres Campalans, que asimiló sencillamente como la biografía de un pintor que había conocido Aub. El grado de su fascinación con ese "artificio diabólico" que se coló como una historia real, no ha cesado jamás: 
Uno se pregunta, qué necesidad había de hacer una ficción semejante. Por qué necesito hacer algo así en lugar de contar una novela. Por qué hizo todo lo que hizo para darle existencia. Y está también el hecho de que él planeó una biografía de Buñuel que en cambio quedó en nada. ¿Cuál es el secreto de que un libro de ficción nos hechice? El secreto tiene que ver con el que nos permite ver la parte de ficción que hay en lo real. Y nos permite ver lo fácilmente que podemos confundir ambas cosas... Nos advierte que puede haber relatos que son falsos o puede haber cosas que no existan de verdad y las estemos tomando por verdaderas. Y nos permite ver que lo ficticio, lo inventado pueda tener una presencia tan poderosa que sea más verdadero que lo real. Lo que le ocurre a Don Quijote es un problema de percepción (Muñoz Molina 2009).

Esa comprensión de que la realidad es un relato que hemos estructurado, constituido entre todos y que sostenemos como cierto, pero que puede ser transformada en el juego con las ficciones, no sólo es decisiva, sino quizás sea la aventura más intensa del arte. Aub fue un preconizador y un visionario. La índole de sus invenciones $-\mathrm{y}$ particularmente la creación de Jusep Torres Campalans - es inseparable de esa burla de las convenciones sobre la autoría y su desestabilización de las fronteras entre ficción y realidad que es una eje de la novela moderna que Cervantes (1547-1616) funda con Don Quijote, y que, como afirma Brenda K. Marshall contiene "momentos posmodernos" (5). En el mundo contemporáneo cada vez alcanzan mayor influjo los simulacros de esta índole, quizás como contrapartida a una era de espectáculos, en la que el culto a la figura de artistas y escritores, llega a ser incluso más fuerte que el interés por la comprensión de su obra.

\section{El signo errante del autor en el origen de la ficción extrema}

Antes de adentrarse en las implicaciones del tipo de simulacro que se propuso Max Aub Mohrenwitz resulta útil recordar la multiplicidad de su origen y el signo errante que marca su propia existencia. Hijo de padre alemán y madre francesa, nació en París, ${ }^{32}$ 
donde vivió hasta los 11 años, cuando el estallido de la Gran Guerra obligó a su familia a huir a Valencia, España, en busca de refugio. No había sido fácil para Aub, como confesó alguna vez, haber nacido en París y ser español, hijo de español, pero nacido en Alemania, y tener madre francesa, pero de origen alemán aunque de apellido eslavo, y finalmente, ser ciudadano mexicano, pero hablar español con cierto acento francés. ${ }^{33}$

Posteriormente, a los 28 años, Aub se marcha a Barcelona y allí no sólo aprende catalán, sino asume de modo fervoroso esa identidad que tres décadas después transferirá a la figura del pintor catalán Torres Campalans. Asiste a las efervescentes tertulias intelectuales, desarrolla su pasión por el teatro -fue de hecho director de El búho-y colabora con la Revista de Occidente que dirigía José Ortega y Gasset (1883-1955). En el periódico El mercantil valenciano publicó su primera caricatura en 1935: un dibujo que representaba al poeta López Picó (1886-1959). Lo hace un año antes del estallido de la Guerra Civil española que lo condenará a la ruta del exilio. Tanto el humor, como la inclinación artística temprana emergerán después en su invención de Campalans, a quien otorga el mismo año de nacimiento del poeta: 1886.

María de los Ángeles Valls Vicente se detiene en la afición de Aub por la caricatura y conecta este tipo de representación que por fuerza es analítica, de índole crítica, y anima la propia creación de Jusep Torres Campalans, que imita, pero también caricaturiza las obras de arte prominentes de su tiempo, con las influyentes caricaturas de Luis Bagaría (1882-1940). Valls Vicente cita, de hecho, la definición que éste daba a su trabajo, como un intento de plasmar "la fisonomía interior de las cosas" y señala que tampoco Campalans puede separarse del espíritu que anima la caricatura. Su modo de humor bufonesco puede esquivar en efecto las fuerzas heterónomas y hacer tambalear las 
estructuras que también en el arte sostienen las hegemonías. Las caricaturas de Aub, según nos recuerda, "desaparecieron con el primero de abril de 1939, y, en su lugar, se hizo realidad la profecía. El exilio y la muerte física se tragaron una fecunda generación de hombres que eran testigos y expresión de su tiempo" (88-99).

Aub no sólo comparte la situación del exilio con Bagaría, sino la desenfadada búsqueda de ese tipo de fisonomía en su propia época. Lúdica, humor, simulacro, transgresión de género, remoción de las fronteras entre campos, responden a una visión crítica del arte y de las manifestaciones del zeitgeist de esa Europa que sólo puede rehacerse desde un modo de memoria errante. Acierta Valls Vicente al afirmar que

El humor de Aub debe situarse en un contexto de dolor. Los retratos de Jusep Torres Campalans son un reflejo de su tiempo, reflejo de la distancia que reduce en caricaturas distorsionadas de la realidad y donde el juego de espejos propugnado por Valle-Inclán es la excusa para la representación estética (89).

Durante su residencia en Barcelona, antes del tiempo del exilio, Aub hizo un prolífico conjunto de obras que culmina con su primera incursión en un modo de ficción extrema, antecedente del artista ficticio catalán. Así, publica Geografia (1929), Los poemas cotidianos (1930), Teatro incompleto (1930), Fábula verde (1933), y Luis Álvarez Petreña $(1934)^{34}$. Esta última es la primera obra suya que se propone hacer vivir al personaje como una figura real e independiente del autor, que astutamente elige desaparecer. Una creación frente a la cual, como hemos constatado, el lector confundido por sus estrategias narrativas- puede creer que verdaderamente existió.

No llega Aub todavía a la osadía de crear un "otro" que desempeña un oficio extraliterario, alguien que traspasando sus incursiones en la gráfica, pinta de tal modo que encarna una forma sui géneris de abordar críticamente el arte de su tiempo, como hará 
cuando dé nacimiento a Jusep Torres Campalans, 24 años después. No obstante, como anota Oleza Simo, al referirse a la obra poética de Petreña que aumentará a lo largo de 33 años, ha creado un personaje destinado a burlar las demarcaciones de lo real:

(Luis Álvarez Petreña) deja en el lector la sospecha de que en cualquier momento un tercero, casi cualquier tercero, alguien llamado Max Petreña, o quizá Luis Álvarez Aub, va a retomar los fragmentos anteriores, el libro publicado en Valencia en 1934, el publicado en México en 1965, el publicado en Barcelona en 1972, y va a descubrir que sus distintos personajes no han muerto, que Laura, Luis, Tomás Covarrubias, Max, Mendizábal, Leonor, siguen vivos y disponibles para continuar ese juego enloquecido, abierto a todas las posibilidades, de una textualidad que no tuvo principio y que no puede tener fin sino interrupción, de una textualidad en la que las voces de los personajes de ficción y las voces de los personajes históricos forman parte de un mismo coro, son simultáneamente ilusorias y civiles (...). Si hay en la narrativa española contemporánea una escritura en la que se plasme ese principio clave de la Postmodernidad que es la disolución de la obra de arte literaria y la expansión de sus componentes en multiforme textualidad, ésta es sin duda Luis Alvarez Petreña (Caso 93).

En los dos años inmediatamente anteriores al estallido de la Guerra Civil española Max Aub publica Espejo de avaricia (1935) y Yo vivo (1936). En 1937, la República aún se mantiene en el poder, y hay una enorme afluencia de intelectuales que vienen a apoyarla. Aub es entonces el agregado cultural de España en la embajada de Francia y colabora con André Malraux en la filmación de $L^{\prime}$ Espoir, basada en la novela del mismo título que el imperecedero autor de La condición humana publicó justamente ese año, tras haberse alistado en la aviación de las Brigadas Internacionales, y que incluye fotografías $^{35}$. Por su parte Aub escribe en el exilio la trilogía El laberinto mágico (Campo cerrado, 1943; Campo abierto, 1951; Campo de sangre, 1945; Campo del moro, 1969; Campo de los almendros, 1968 y Campo francés, 1965) que narra acontecimientos de la Guerra Civil Española, desde esa perspectiva de los perdedores que Walter Benjamín (1892-1940) había defendido en su Tesis sobre la filosofía de la historia en 1940, poco 
antes de suicidarse en Portbou en espera de una repatriación a Alemania que lo pondría en manos de los nazis. Aub reconocía que la Guerra Civil Española había determinado la totalidad de su vida, una experiencia que no podía ser nombrada sin letras capitales. Coincide con el mediocre escritor Luis Alvarez Petreña, a quien bien conoce (puesto que lo ha inventado), en que toda su generación fue segada por la guerra. Sebastian Faber en el capítulo que dedica a Max Aub: Exile as Aporia, en su libro sobre el exilio de los españoles intelectuales en México: "Freedom is practically always available, but one has to go look for it elsewhere" (264). La búsqueda de libertad se hace furiosa a partir de la caída de la República, cuando el mismo Aub se ve confinado a prisión, y su destino se une al de los exilados que se refugian en México.

En 1939, tras la derrota de la República española, el gobierno francés lo toma prisionero por ser descendiente de un judío alemán y presunto comunista. Su esposa, Perpetua (Peua) Barajau, deja a sus tres hijas en las casas de familias amigas y se va a buscarlo a la cárcel, sólo para descubrir que lo han enviado a un campo de concentración del cual nadie da razón. Durante dos años —en los cuales Peua se refugió con las niñas en Valencia, en casa de sus padres porque los franquistas habían incautado todas las pertenencias del antiguo diplomático — no se sabe absolutamente nada de él (Max Aub nieto 2008).

Es en ese periodo cuando Max Aub crea una desgarradora imagen de la guerra: El diario de Djelfa (nombre del campo de concentración francés en Argelia), un libro originalmente escrito sobre papel cebolla para cigarrillos y un precario lápiz, que da cuenta de un horror del que poco se habla. Entre los poemas que escribió entonces hay uno dedicado a uno de los sargentos que custodiaba a los prisioneros. Su condición de tal, 
primero en Francia, y luego en Argelia, agudiza su grito contra toda forma de totalitarismo, su insurrección contra toda violencia. En medio de la ignominia de los dos años transcurridos como prisionero judío, primero en Camp Vernet, y luego en el campo de trabajos forzados de Djelfa en Algeria, Max Aub experimenta los inesperados bienes de la amistad: el entonces cónsul de México en Marsella, Gilberto Bosques ${ }^{36}$, quien había sido también el cónsul en París, amigo de sus tiempos de diplomático en esta ciudad, logra localizarlo y además de promover su liberación, obtiene para él un salvoconducto expedido por el gobierno francés. Tras una serie de vicisitudes desembarca al fin en Veracruz en 1942 sin nada entre las manos.

Antonio Muñoz Molina asiste en 1998 a una función de su pieza teatral San $\operatorname{Juan}^{37}$ en el teatro María Guerrero de Madrid y en medio del diluvio de aplausos recuerda que lo escribió en ese barco —el Serpa Pinto- que había partido de Casablanca, pero que lo había empezado a imaginar en el mucho más siniestro barco donde viajó desde Marsella a África. Ese recuerdo reaparece en uno de los artículos que publicó en el centenario de su nacimiento en la revista mexicana Letras libres. Afirma que Aub tuvo la virtud paradójica de usar la propia experiencia como material narrativo o dramático despojándola de cualquier indicio de autobiografía; una actitud que Aub evocara en su aforismo: "Veo lo que vi sin verme”. Luego, Muñoz Molina evoca cómo su propio doble viaje en barco aporta veracidad a una escritura que se desplaza más allá de la experiencia de su autor, hacia "el viaje sin destino de un grupo de judíos europeos a los que nadie quiere en ningún puerto y acaban tragados por el mar”, y que, habiendo sido escrito en 1938, es un anticipo de la gran matanza vislumbrada en un drama que en vida, nunca vio representado: 
1942, el año de la escritura de San Juan y del viaje de Max Aub a México, es también el de la conferencia de Wansee, en la que los jerarcas nazis acordaron los pormenores técnicos de la Solución Final, y el de las primeras deportaciones de judíos franceses a los campos de exterminio. San Juan, si se recapitulan con cuidado las fechas, es menos una crónica que un aterrado vaticinio (...) Regresado a España Max Aub comprende que forma parte de una gran generación de fantasmas, iguales en irrealidad los muertos y los vivos, porque el paso de los años, la cerrazón agresiva de la dictadura, las lejanías del exilio, han borrado los nombres más valiosos de la cultura española, y ni siquiera los que volvieron han logrado recuperar un poco de existencia (Escritor sin público, ciudadano sin país ).

En México, que se convertirá en su tercera y última patria, de esas manos desnudas brota un alucinante universo que abarca todos los géneros literarios ${ }^{38}-$ ensayos, diarios de viajes y crítica literaria-, y que por encima de todo, extiende el territorio de lo real gracias a un modo de imaginación que desacata los límites de lo permitido. Alfonso Reyes elogia su humor, su fantasía, y sus aplicadas invenciones, a menudo creadas en una zona fronteriza entre el arte y la literatura. Entre estas últimas se incluyen los sarcásticos apuntes de Crímenes ejemplares. En la solapa de este libro, originalmente publicado en 1951 y reeditado de modo póstumo en 2001, en una bella edición ilustrada, Aub comenta que la idea del libro se remonta a su primer drama, escrito a los 18 años, y titulado Crímenes, así como a otros antecedentes: Quevedo, Gracián, Goya y Gómez de la Serna. Al referirse a estos dos últimos aclara que ambos hicieron disparates, pero reconoce la superioridad literaria del pintor. Así, se lee en la contraportada: "De los Disparates, a los Desastres de la guerra, no hay gran distancia" (Aub, Crímenes). Esa sola frase, en la que da una supremacía literaria a Goya, destacando su furiosa capacidad narrativa, muestra la libertad con la que se permitirá transitar de uno a otro campo creativo, justamente porque como crítico puede hallar resonancias y correspondencias entre ambos lenguajes. 


\section{Una ficción metahistórica}

Otras creaciones de Max Aub escapan a los géneros tradicionales, y/o que fusionan texto e imagen como el ya mencionado Juego de cartas (1964), compuesto de 108 naipes dibujados que en su reverso tienen misivas que retratan al protagonista, Máximo Ballesteros, en una obra que antecede en casi una década la ingeniosa técnica de Calvino en El castillo de los destinos cruzados. También están los aforismos de Signos de ortografía, las fábulas político-morales que ofrecía en el Correo de Euclides, o la publicación del formidable discurso dado en su apócrifo ingreso a la Academia de la Lengua Española, que posiblemente sea más memorable que el resto de los que sí se pronunciaron en el recinto en los años posteriores a la caída de la República.

En un gesto genial, el escritor Antonio Muñoz Molina le dedicó su verdadero discurso de admisión a la Real Academia de la Lengua Española, y citó particularmente al falso discurso de ingreso que éste escribió en 1956, corrigiendo la historia a través de la ficción, de tal modo que se dirigía a una Academia de la Lengua en una España fantástica donde Miguel Hernández no habría sido encarcelado y fusilado; García Lorca (1898-1936) no habría sido atravesado por las balas; y Antonio Machado no habría tenido que morir tan lejos de las colinas y los verdes pinos que amaba.

El gesto con que Aub empastó a mediados del siglo pasado su discurso de imposible ingreso a la Real Academia de la Lengua Española, usando idéntico diseño, tipografía, encuadernación, y tal habilidad que quien no conozca detalles de la caída de la República ni de la literatura de la España de ese tiempo podría sucumbir al engaño, es un acto de resistencia contra la historia, una afirmación de lo que pudo ser, que aligera el peso de lo inexorable. Es la afirmación absoluta de la libertad creadora: un modo de 
corregir, al menos en el terreno de la imaginación humana, el curso de los acontecimientos. El cuestionamiento de la legitimidad de lo real surge como producto de la invención de Aub y termina colándose en la vida incluso después de su muerte. En el verdadero discurso de ingreso de Antonio Muñoz Molina a la Real Academia de la Lengua Española, éste se declaró heredero de la silla que debió haber ocupado Max Aub, de tal modo que el gesto con que éste confió a la escritura la posibilidad de la resistencia histórica, terminó siendo consagrado en la posteridad de un modo que nos dejó una consciencia de la historia posible que no se cumplió.

El discurso, titulado Destierro y destiempo de Max Aub, evoca así el que Aub publicó en 1956 - El teatro español sacado a la luz de las tinieblas de nuestro tiempomenciona a los demás escritores que ocupaban sillas en esa Academia: un Antonio Machado "que no habría muerto en el invierno atroz de 1939, sino mucho después, serena y dignamente, en un futuro falso, pero muy razonable, tal vez a principios de los años cincuenta, después de haber sido director del Teatro Nacional” (70). Y están también escritores que en realidad tardaron muchos años en ingresar, como Miguel Delibes, que tardó casi dos décadas en cumplir la profecía aubiana. O Francisco Ayala, nombrado por Aub en 1952, si bien su ingreso ocurrió, de facto, en 1983. Aprovechando ese diálogo “entre los vivos y los muertos” que permite la literatura, Muñoz Molina se dedica a traer la figura fantasmal de Aub al estrado que nunca llegó a pisar, consciente de que

él, que inventó a tantos personajes que parecían reales, y que tantas veces invistió a las personas reales de la dignidad fantástica de la literatura, parece ahora en gran parte la invención de un novelista, porque su figura ha sido modelada sobre todo por la lejanía y el desconocimiento (573). 
Pasqual Mas i Usó reconstruye la presentación y contenido del discurso de ingreso de Max Aub — a quien llama "inventor de la realidad de la ficción":

El folleto, fechado en Madrid de 1956, imita la tipografía de la época con pequeñas variaciones - como por ejemplo el sello editorial 'Tipografía de Archivos'-, fue editado por la revista Triunfo en $1972\left(\mathrm{n}^{\circ}\right.$ 507, 17-V-1972) y está formado por la intervención de Max Aub y la contestación de Juan Chabás, quien, obviamente, tampoco fue nombrado académico en su vida. Para el Max Aub del Discurso, la guerra civil nunca existió y, por tanto, ni la muerte, ni el exilio habían azotado España y, en consecuencia, los intelectuales y artistas habían agrandado la fructífera Generación de 1927, lo que, a la hora de nombrar la 'relación de todos los individuos que ocupan las cuarenta y cuatro sillas de la Academia y fecha de su inicio' a fecha de 1 de enero de 1957, acaba por situar la ficción en un estatuto de realidad falseada. No obstante, el Discurso hay que leerlo más allá del recurso retórico en que se sustentan, por ejemplo, un volumen apócrifo de la Enciclopedia Británica imaginado por Jorge Luis Borges y dedicado al mundo de Tlön, el inexistente libro de Aristóteles dedicado a la comedia que causa la destrucción en El nombre de la rosa de Umberto Eco, o El llibre de les mosques de Emili Teixidor (Lo real de la ficción 79).

Sin ningún discurso literalmente político, sin declaraciones ideologizadas, sino sólo a través de un ejercicio de ficción que se interpola en lo real, estamos ante un modo de construir visiones alternativas y críticas de la historia, al menos en las avenidas del pensamiento que potencialmente modifican los territorios existenciales.

Lo que Aub hace es apropiarse, para la ficción literaria y para los diversos recursos de huida de la historia, de "las palabras de la historia": “... all the 'words' that comprise the documentary evidence on which historians base their accounts of the past and also the 'words' that have been written by historians on those accounts" (vii), según las palabras con las cuales sintetiza Hayden White la idea de Jacques Rancière en el prólogo del libro que originariamente iba a llamarse justamente así, Las palabras de la historia. Pero a la vez, ese procedimiento consiste en ejercitar lo que el mismo Rancière llama "poéticas del conocimiento" y define como "a study of the set of literary 
procedures by which a discourse escapes literatura, gives itself the status of a science, and signigfies this status" (xiii). Recurriendo a los nombres de la historia, se "escapa" de la literatura en una biografía cuya perfecta simulación logra colarse en la historia del arte, no sólo porque está refrendada por un significativo grupo de obras plásticas "recobradas" por Aub, y un minucioso catálogo, cuyos detalles comentaré posteriormente, que las enumera siguiendo los procedimientos del arte, sino porque éstas constituyen en sí un comentario crítico de la época, escrito desde la perspectiva de quien ha huído, escapado en cierto modo del malestar que engendra.

Lo que White dice acerca del discurso de Rancière y éste de su época, puede ciertamente ser traspasado a Aub que habla desde una locación discursiva que altera las clasificaciones. Su obra acaba por constituir “(...) places of speech that are not designable localities but rather singular articulations between the order of speech and that of classifications" (xix). Esas singulares articulaciones de Aub que desplazan fronteras entre los campos de especialización — territorios académicos que como anota Griselda Pollock formaron una cartografía específicamente moderna del conocimiento disciplinar, asociada a la formación de los Estados Nacionales - nos abocan a lo transdisciplinar, a una desterritorialización que torna porosas las fronteras para provocar un nuevo tipo de conocimiento que refleja una de las más agudas conciencias críticas de su tiempo y que anticipa, en su peculiar momento posmoderno, el potencial que tiene la ficción de desmantelar las lecturas unívocas de la realidad.

La perspectiva de la historia de España, modificada desde la libertad de la ficción que le ha permitido crear a Aub el apócrifo discurso de ingreso a la Real Academia de la Lengua Española, tiene la virtud de contraponerse al bloque de una realidad opresiva para 
el autor, y para toda una generación de exiliados, que o bien dejaron España o vivieron en ella con la sensación de haber perdido el mundo que les pertenecía. Su impugnación puede recordar las nociones que Foucault desarrolla en Nieztche, la generalogía, la historia en tanto se aleja de la verdad, considerada como la imposición de definición de las cosas como nos hicieron pensar que eran.

Un fragmento del discurso de Muñoz Molina sintetiza magistralmente el poder de la impostura literaria de Aub:

...Quien ha sabido disentir del futuro también puede negarse a aceptar que las peores posibilidades de las cosas hubieran tenido obligatoriamente que cumplirse. No es el sueño de un derrotado: es la persistencia en la dignidad de quien habiéndolo perdido todo no renuncia a la justicia o a la validez de su causa. ¿Y no es siempre la mejor literatura una vindicación de la palabra y del sueño, un disentir de las versiones obligatorias y unánimes de lo real? Vuelvo a Cervantes: las cosas como pudieron o debieron ser. Yo sospecho que en el fatalismo acerca del pasado se esconde siempre una conformidad idéntica sobre el presente y el porvenir (...). Exiliado en México, Max Aub, tal vez para equilibrar instintivamente el agobio de las cosas que habían pasado, se complació en inventar las que pudieron o debieron pasar, del mismo modo que a Adolfo Bioy Casares le gusta especular sobre la existencia de mundos paralelos y simultáneos al nuestro en los que se van cumpliendo otros futuros (Dos vidas imaginarias 586).

Basta ese modo aubiano de proponer lo que podría haber sido para ejercer un uso alterno de la historia que es paródico, bufón y destruye el carácter monolítico de la historia con sólo la superposición de otra realidad que se desliza sobre la que fue impuesta por un poder capaz de propiciar el horror de Guernica. El gesto abre la identidad a la incertidumbre a la que se refiere Foucault: “...La historia no descubrirá una identidad olvidada; siempre pronta a renacer, sino un sistema complejo de elementos a su vez múltiples, distintos, y que ningún poder de síntesis domina” (16). Esa identidad atravesada por discontinuidades está en la génesis de un poder alterno: el de la 
imaginación que desmantela la realidad, tal y como ha sido configurada por fuerzas heterónomas. ${ }^{39}$

Al respecto, es interesante considerar la revisión del concepto de Metaficción historiográfica que hace Santiago Juan-Navarro. Por una parte cumple lo que Ihab Hassan considera que se ha exacerbado en el posmodernismo: "the will to unmake" (20) que caracteriza a los artistas posmodernos y que supone el cuestionamiento de conceptos canonizados sobre el autor, los géneros, el mismo criticismo y la propia literatura. Por otra parte, puede aplicarse al falso discurso de Aub, el desmantelamiento, a través de la apropiación apócrifa de lo que según nos recuerda Juan-Navarro constituye para Brian McHale la estructura del trabajo literario que descansa a fin de cuentas en el libro material y en su tipografía. La ficción de Aub es en ese sentido posmodernista: configura un texto esquizoide en el cual "visual and verbal discourse cross each other in polymorphic atittudes" (26) y, por último, resuena también con el postulado de Fredric Jameson al considerar el posmodernismo como un concepto que está conectado a la aparición de nuevas formas culturales.

Igualmente, siguiendo el concepto de Juan-Navarro nos encontramos frente a un tipo de metaficción historiográfica que, oponiéndose a la visión del posmodernismo como ahistórico y despolitizado relocaliza las prácticas autorreflexicas en el contexto en que se produce. Esto genera, de acuerdo a este autor una nueva concepción de la historia: "Metafiction echoes this tendency toward self-representation and makes it part of its own structure. Consequently, the distinction between separate discourses becomes blurred, as does the borderline between art and theory, fiction and reality" (40). Igualmente, la producción de Aub se ajusta al concepto de Patricia Waugh citado por Juan-Navarro: 
"Metafiction is a term given to fictional writing which self-consciously and systematically draws attention to its status as an artifact in order to pose questions about the relationship between fiction and reality" (41). Su conclusión de que esto conduce a una revisión de la historia que deja de ser un reino de eternas verdades para revelarse en toda la construcción de su artificio, se ajusta a la obra de Aub cuyo modo de reflexiviad es concientamente tramposo y lleva el artificio a la última frontera, donde se atreve, a reescribir la historia tal y como podría haber sido.

Una noción determinante en la consideración de la vida errante de Jusep Torres Campalans, quien protagoniza, según Muñoz Molina, "la más sólida y la más desvergonzada de las muchas bromas literarias de Aub" (580) es rastrear, como una pista, el posible origen del nombre que Aub le dio. Dice Irizarry que el poeta español Odón Betanzos Palacios da la clave al mencionar como génesis del personaje al autor, real, del libro El gran fraude franquista, llamado Manuel Torres Campaña, y quien tomó parte en la última etapa de la República española y se exilió, como Aub, en México. El libro de ensayos, publicado por el Instituto de Estudios Hispánicos en México, D.F., en 1957, un año antes que la novela de Aub. El propósito del tomo fue, según Torres Campaña, esbozar "los temas candentes de la situación española en el verano de 1957, tomados del orden económico, esto es, en su expresión más actual y agudizada" (5). Nos parece perfectamente posible que el nombre de Torres Campalans fuese inspirado por el de Torres Campaña (catalanizado) como tributo indirecto a este compatriota y compañero de exilio que acababa de publicar un libro que señalaba el franquismo como un fraude que procuraba encubrir sus fracasos por medio de la fantasía y el "bluff" (La broma literaria 82). 
Ante un mundo bamboleante, la creación que desestabiliza las fronteras, las convenciones típicas de los géneros y la misma percepción de lo cierto y lo incierto, es un recurso creador que permite, transitar sin dejar de sonreír, entre mundos posibles. La lectura de los textos aubianos pide, como anota Pascual Mas i Usó la aceptación de "un estrato literario nuevo":

En La gallina ciega figuran historias inventadas en un diario que pasa por real, en el Manuscrito Cuervo se presenta la realidad tomada desde el punto de vista de un ave, en Luis Álvarez Petreña el protagonista se asimila en edad y en actos a Max Aub, en Jusep Torres Campalans se asiste a la encarnación de un contemporáneo amigo de Picasso, y así, siguiendo con estas investigaciones, en el Discurso, se inventa a sí mismo, héroe de una historia falsa y protagonista de un hecho que, tal y como ocurrieron las cosas en la realidad, no se hubiera podido dar mientras la dictadura franquista mantuviera amordazadas las palabras (2).

No obstante, el mismo Aub llega a dudar del potencial impugnador de la ficción extrema y obsedido por las imágenes de lo terrible que ha vivido, pasa un largo número de años recreando las memorias de la Guerra Civil Española, ajeno al ejercicio de las mejores expresiones de la imaginación lúdica que de algún modo tiene, aunque sea en otras esferas, el poder de subvertir el orden del mundo.

En el ensayo Lujuria Roja. Aub visto por Ripstein, Pedro García-Caro aborda la ironía histórica del cuento de Aub La verdadera historia de la muerte de Francisco Franco (1960) y revela el ejercicio de una ficción que es crítica de lo real a partir de la exploración de otras alternativas de lo real:

La posibilidad de una historia alternativa -el 'y si...?'; la historia subjuntiva 'cuando caiga Franco' (19) - es lo que da a este relato uno de sus componentes más atractivos. ¿Y si un camarero mexicano harto de tanto exiliado español, de tanto grito y tanto abuso - 'varió ante todo el tono' (15)- decidiera matar a Franco y de hecho lo lograra? Efectivamente, Aub homenajea en Ignacio Jurado -Nacho, camarero del Café Español ${ }^{40}$ - la sacrificada hospitalidad mexicana que 'sufrió el éxodo ajeno como un ejército de ocupación.' (16) (...) el cuento de Aub propone una movilización política: la del inerme camarero sonorense, causada por una 
mezcla de cansancio y desesperación. Finalmente se decide por el atentado: 'resuelto el mañana, desaparecerá el ayer' (22-3).

Continúa García-Caro su análisis precisando que la narración se sitúa en el género de la historia alternativa, o "alternate history" tal y como lo propone Karen Hellekson en una formulación que incluye elementos como el replantear "el papel del individuo en el proceso histórico"(5): Aub se pregunta incesantemente por su propio papel ante la historia que lo desaloja no sólo de su patria, sino también de sus más lúdicas ficciones, que suelen ser las más extremas en su aproximación a los personajes o acontecimientos y construcciones reales.

En la cinta de grabación de una entrevista que le hace Aub a Rinstein es interesante su insistencia en indagar cuánto le había influenciado "la idea del mundo" que tenía Buñuel. De hecho, quizás la palabra más reiterativa en toda la conversación sea precisamente "mundo". En un momento, Aub declara: "No acaban de entenderlo. No acaban de comprender, eh la idea que tiene Buñuel del mundo y lo que él quiere representar y a dónde quiere llevar a los espectadores" (Ripstein Archivo Max Aub. Entrevistas Buñuel). Esa "idea del mundo" es finalmente lo determinante en los ejercicios lúdicos del mismo Aub. El de su discurso apócrifo, pero también el de esa biografía de la huida que supone la biografía de JTC plantean una deconstrucción de la historia a través de lo que Foucault llama la "genealogía de la microhistoria". Juan-Navarro cita la visión del filósofo respecto a la posibilidad de desligitimizar el presente questionando la causalidad que lo liga al pasado. Así, al centrarse en la "singularidad de eventos ocurridos por fuera la cualquier monótona finalidad", buscándolos en los "lugares menos prometedores, en lo que tendemos a considerar sin historia", el método genealogista 
histórico nos conduce a usos alternativos de la historia que, de acuerdo a la propuesta de Focault (1926-1984) abren, entre otros, la opción de un uso paródico y dirigido contra la realidad — tal como se advierte en el falso discurso de ingreso a la Real Academia Española de Aub-; y de un uso que destruye la identidad oponiéndose a la historia como la continuidad de una tradición (48-49). Si bien Juan-Navarro mantiene reservas frente al mordaz criticismo de Foucautl ante el realismo histórico, estas características reflejan en buena medida el modo en que Aub crea, a través de ficciones llenas de mentiras, realidades alternas que funcionan especularmente con su propio presente de exiliado.

Escribe Muñoz Molina:

Max Aub, que dedicó tantas energías de su voluntad, de su inteligencia y de su memoria a comprender lo que había sucedido en la guerra, no acataba su fatalidad hasta el punto de no visulmbrar las otras posibilidades mejores que no se cumplieron (Dos vidas imaginarias 584).

\section{La culpabilidad de la ficción extrema}

En México Max Aub vivió treinta años dedicado a toda clase de instigaciones literarias. Esta nación es el lugar donde la memoria de lo vivido se exacerba en la distancia y lo lleva a escribir, con la conciencia de un deber, el ciclo de novelas sobre la Guerra Civil Española, pero al mismo tiempo, acabará siendo el territorio donde recobra el derecho a la invención desatada que ya había ejercido con la creación del poeta Álvarez Petreña un par de años antes de la caída de la República. Lo cierto es que el curso de los acontecimientos históricos llegó a hacerle creer en cierto momento que ese tipo de experimentación creadora era un ejercicio literario secundario, mucho menos urgente que los recuentos realistas. Cuando el grado de violencia que alcanza la realidad parece superar las posibilidades de la lúdica creadora, Aub, se aparta de cualquier forma 
de meta-arte o meta-literatura. Entre la invención de Álvarez Petreña y la de Jusep Torres Campalans media cerca de un cuarto de siglo. Necesitará ese largo interregno para recobrar la convicción de que no hay mayor compromiso que el de la imaginación humana.

Sebastiaan Faber sintetiza este proceso con claridad:

Aub, who was deeply committed to the Republican cause and spent several years in prisons and concentration camps before he could escape to Mexico in 1942, famously declared that the times called for narrative realism. Writers like Malraux, Koestler and himself had for now to content themselves with the modest, but crucial function of chroniclers: 'Creo que no tengo derecho todavía a callar lo que vi para escribir lo que imagino', he wrote in 1946. For Aub, this commitment implied a repudiation of his own experimental avant-garde past. Although especially the first volumes of El laberinto still show stylistic traces of la Vanguardia, overall the politicized realism of El laberinto mágico reflects a strong debt to Pérez Galdo's. The omniscient narrator's relation to his characters is largely one of amused and loving empathy. While Aub's men and women are shown to be as subject to their lowly desires-love, sex, ambition, greed, vanity, stubbornness - as anyone else, they also appear as noble, valiant, and honorable. Above all, they are recognizable and likeable; they invite solidarity. For Aub, writing about Mexico and Mexicans seems to have dissolved him temporarily of his self-imposed ethical and political task of chronicling recent Spanish history, and thus allowed him more stylistic freedom (Los cuentos mexicanos 16).

Faber comprende el ciclo que lo lleva de la renuncia a la libertad imaginativa con sus juegos de autoría, como una decisión impuesta por la oscuridad de los tiempos, hasta cuando retorna en su obra lo lúdico-experimental. Se trata de una transición que le exige recrear esos tiempos en obras de corte histórico que se le imponen con una consciencia moral. Es un proceso que repiten, con variantes, algunos de los grandes creadores de su tiempo ${ }^{41}$.

No es casual que entre las apócrifas críticas que Aub incluye sobre la obra de J.T.C. elija una que destaca el interés de la generación del 98 por los parías y el hecho de 
que del mismo modo en que la literatura del 98 es triste, agobiada, lo son los cuadros de Picasso de 1900 a 1905.

El cubismo - afirma el crítico ficticio Miguel Gash, inventado por Aub para comentar la producción de Torres Campalans - reacciona en balde contra la anarquía. No era el camino ni se ha dado con él. Esa búsqueda infernal es, sin embargo, una de las expresiones más sinceras de esos años (87).

Nota Faber que si en Laberinto mágico su deuda con Pérez Galdos es notoria, en sus Cuentos mexicanos, escritos con una actitud lúdica, el referente es Esperpento, de Valle-Inclán. Pero sin duda, habría una larga lista de diálogos con autores, de inacabables discusiones con amigos mexicanos o con los mismos exiliados españoles como Luis Buñuel, a quien no sólo lo acercó su amor a Galdós, sino su extenso aporte al desarrollo del cine en México42, que incluyó su tardío retorno a los más osados juegos de la imaginación creadora. Esto resulta evidente en las cartas apócrifas de figuras como Alfonso Reyes que incluye en su máximo ejercicio literario, Jusep Torres Campalans, publicado en 1958, diez y seis años después de su arribo a México.

La afirmación de Aub respecto a que el sentido trágico de la vida que hay tanto en Picasso como en Jusep Torres Campalans, se debe no sólo a su noventiochismo, sino al hecho de que "ser español, es, desde hace años, una tragicomedia en muchos actos" (88) explica también su historia de hombre transterrado, urdiendo ficciones enmarañadas para esclarecer la tortuosa realidad. Quizá por ello, a Rosa María Grillo, la invocación de Aub la lleva a repetir el verso de Pessoa: "Il poeta è un fingitore. Finge così completamente che arriva a fingere che è dolore il dolore che davvero sente" (48).

Por otra parte, si, como Faber aventura, escribir sobre México le ayuda a Aub a regresar a ese deber autoimpuesto de hacer la crónica de la historia reciente de España, y 
le permite ganar de nuevo esa libertad de estilo que lo llevará al máximo ejercicio de lo que consideramos ficción extrema, no hay que olvidar que perteneciendo a una generación de "tras-terrados", de desheredados de la tierra, ese modo de ficción supone una construcción alterna de identidad. Según evoca, Henry Kamen cita una carta que envía Américo Castro a Aub en la cual describe a los españoles en exilio como "these poor, deluded and amiable cratures, who have no notion of who themselves are and are therefore incapable of making their own future" (304). Igualmente, evoca cómo pese a que Aub se hace ciudadano mexicano en 1956 y antes de la guerra había publicado versos, obras teatrales y prosa, cuando publica en México el ciclo de novelas El laberinto mágico, pasa prácticamente desapercibido: "His modernist style, consisting of semifictional elements and often playing games with the reader, never caugh on: few read his books and his thetrical Works did not reach the stage" (360). Sus libros se tradujeron eventualmente al francés, inglés, alemán e italiano, pero el público español no parecía interesado en leerlo, o, como aventuraba el mismo Kamen, no llegó a quienes debían haberlo leído.

Gérard Malgat relata por su parte que un curso sobre la novela de la guerra en España impartido por catedrático Jacques Maurice comprendió le reveló el valor de esa trilogía, considerada por éste como "un valioso fresco en el cruce fecundo entre la libertad y el testimonio", pese a que el autor había sido olvidado en Francia donde su obra permanecía olvidada, "como si Francia continuara maltratando la obra después de haber perseguido al hombre" (13).

Quizás por ello, Aub consideraba que la condición del exilio siempre era equívoca, porque todo exiliado estaba abocado a intentar regresar. Si bien su retorno a 
España, en el intento de escribir la biografía de Buñuel fue un intento fallido, ${ }^{43}$ la escritura de Jusep Torres Campalans, realizada una década antes, marca otro modo de regreso, es una revisitación de las vanguardias nacientes, un diálogo lúdico y placentero con la figura de Picasso, la invención de otro que crea, según llegará a sugerir, el mismo cubismo, antes de escoger un exilio voluntario en el que ya no intenta otra cosa que desaparecer puesto que le ha precedido la genialidad de la invención que le atribuye. En cierto modo, un espejo invertido de Aub, extraviado en la ausencia de lectores en México y abismado a la desaparición de todo recuerdo de sí en la propia España a donde descubre, no exento de cierto horror, que no hay rastros de sí, que las revistas en las que escribe desde América, creyendo ser leído, son publicaciones oscuras apenas leídas en minúsculos, casi inexistentes círculos de grises lectores.

Al llegar a Barcelona Aub, maestro de aforismos, exclama: "He venido, pero no he regresado". Había vivido casi treinta años sin pisar el suelo español y descubre que no hay retorno posible. En La gallina ciega, Aub escribe una nota que sirve de epígrafe al ensayo de José Ángel Sáinz, El retorno de Max Aub o la poética de un imposible: "Soy un turista al revés. Vengo a ver lo que ya no existe": Aub anticipa consecuencias irremediables tras la salida obligada de España: “[...] los que nos fuimos ya no contamos, para eso mejor nos hubiésemos quedado [...] fuimos borrados del mapa. Un auténtico remate. Nadie sabe quiénes fuimos, menos todavía lo que somos" (467-471). El efecto de esta desaparición aparece como antesala a lo que sería la "realidad futura aubiana".

El mismo Aub anota en La gallina ciega:

¿Hasta qué punto vive uno encerrado en sí que es necesario salir y verse en un espejo viejo para darse cuenta de que uno no se ve en las lunas diarias, de que se es otro, de que se fabrica uno su máscara, día a día, y que cuando cae el 
maquillaje de la costumbre y entrevé la realidad se sorprende tanto que no hay manera de creer lo que se ve? Vives en lo que fue. Vives en lo olvidado. Vives en lo falso. Lo malo es que existes y no puedes vivir, viviendo, con esto. Y vives. Vives. — Sí, a destiempo — . Estoy de acuerdo, pero creí que era otro (189, 190).

Muñoz Molina comenta sobre el retorno de Aub:

Pero al llegar a España, la constatación de la invisibilidad de su escritura deja casi de tener la pesadumbre de un fracaso para convertirse en la experiencia de una vida fantasma, de una irrealidad personal tan aguda, y tan irreversible, como la del país que buscaba y que ya no existía, borrado por una distancia mucho mayor que la de los años pasados, porque era, como él mismo escribió, 'el tiempo multiplicado por la ausencia' (Muñoz Molina).

Aub se ha convertido en otro. Mucho de ese "otro" que lleva en sí durante el largo exilio alimenta la figura de Jusep Torres Campalans, como una sombra alterna que reclama en su voluntaria elección de perderse en una tierra ajena, el control de un destino personal que el drama de la historia colectiva le sustrajo a esa generación de transterrados a la que pertenece Aub. ¿De qué materia está hecho? De un humor que es un fingimiento, mascarada, ejercicio de reír sobre la constatación de las huellas que se pierden en un mundo que se le ha vuelto, como escribiera en una pieza de teatro, blando, inseguro, bamboleante.

Como bien escribe Tuñón de Lara (1970) sobre el humor aubiano:

Ser humorista y jugar a veces al cruel, para no dejar el alma en jirones ante el dolor. [...] maestro del humor sutil o del humor negro, según lo exige el caso y el tema, temible para el adversario cuando maneja la ironía polémica, levemente zumbón al observar algunos planos - no todos- de las relaciones humanas... $(27){ }^{44}$

\section{La impostura del biógrafo}

Los deslizamientos de la ficción en la realidad o viceversa y la burla de la autoría han contenido desde El ingenioso hidalgo don Quijote de la Mancha, elementos de una 
crítica de la época y en cierto modo dan voz a los perdedores, a los rezagados de la historia. Aub se construye, no como el autor de un novelado Jusep Torres Campalans, sino como el biógrafo que relata la historia de un personaje fascinante o el amanuense que transcribe notas, cartas, y otros documentos encontrados. El libro se estructura así en siete partes: Prólogo indispensable, en el que Aub explica las circunstancias que lo llevan a realizar la biografía; Agradecimientos, que refuerzan la verosimilitud puesto que se dirigen a personajes reales; anales, una estrategia endiabladamente ingeniosa para el propósito de dar consistencia a la existencia del impostado pintor y que lo sitúa, detalladamente, en el contexto de sus contemporáneos y su tiempo; Biografia, donde Aub asume la voz narrativa del recolector de datos y narrador de una vida verdadera; Cuaderno verde, o diario y notas del mismo J.T.C.; Las conversaciones de san Cristóbal, donde el narrador cumple la función de un entrevistador que transcribe sus encuentros en México con el biografiado añadiendo juiciosas, convincentes notas que aclaran el contexto en el que estos ocurren; y, como cierre sin precedentes en la tradición literaria, a no ser por los elementos gráficos del Tristram Shandy, el genial Catálogo con comentarios que aluden al trabajo compilador de un joven crítico irlandés, Henry Richard Town, quien conoció mejor que nadie la obra del pintor catalán y las fichas descriptivas, con título, fecha, medio y descripción de cada uno de los trabajos de arte que constituyen el conjunto de la obra de Jusep Torres Campalans.

Según Aub, vio el catálogo en 1956, durante un viaje a París, en el cual le cuenta a Jean Cassou (1897-1996) su encuentro con J.T.C. en San Cristóbal de las Casas, y éste, entusiasmado, le muestra el libro que incluye las obras todavía existentes, comentando que el que se va a sorprender más es Picasso y que es una lástima que no esté en París. 
Luego anota que en realidad, dada la aversión de Cassou de enviar correos, se lo mandó el escritor mexicano Esteban Salazar y Chapela. Teniéndolo ya en las manos, Aub, que autodefine su propósito en estos términos: "Trampa, para un novelista doblado de dramaturgo, el escribir una biografía" (20), se da a la tarea de recrear su, literalmente, fantástica vida y, por ende, de inventar su pintura-ficción. Lo cierto es que el 7 de julio de 1958, Aub le envía a Salazar y Chapela un ejemplar de su Jusep Torres Campalans y éste, que previamente se había sorprendido al conocer la calidad de la creación teatral de Aub, lo lee sin descubrir la broma literaria y en una carta, como refiere Francisca Montiel Rayo en uno de los ensayos de Escritores, editoriales y revistas del exilio republicano de 1939, le escribe que había sido un acierto, poner el retrato y los cuadros de Jusep, pues "de otra forma yo habría pensado que todo era una invención". Comenta Montiel que en aquel entonces, Salazar Chapela estaba embebido en su propia novela, Desnudo en Piccadilly, acerca de la cual le había escrito a Aub en 1958. El caso es que en esa correspondencia le confesó que aunque había dudado en un momento de si las pinturas eran obra de Aub, las fotografías de los padres de J.T.C. lo habían convencido de su existencia (255-56).

Por su parte, el poeta y crítico de arte Jean Cassou, fue por cierto uno de los mayores cómplices de Aub en el trabajo de urdir lo ficticio con juegos de alusiones y complicidades reales que se tejen a menudo a modo de resistencia contra oscuras fuerzas. Tras la imaginaria sorpresa de Cassou de tener novedades de Campalans, hay un trasfondo real que alude a la crítica de la época compartida en la estrecha amistad que hubo entre Aub y este escritor francés de ascendencia mexicana y española, que se hizo miembro de la Resistencia Francesa, después de ser destituido de su cargo como curador de Museo de Arte Moderno por el régimen de Vichy. Gérard Malgat escribe que ambos 
comparten la profunda huella dejada por la Guerra Civil Española en su trayectoria personal. Sobre su libro La mémoire courte, Cassou le dice que comienza en una España que también considera suya. En Le Janous ou de la création -libro sobre el cual le comenta a Aub que encontrará a un español muy castizo- Gonzalve, el misterioso

español, que es como Aub, un aficionado al arte — y "quien se presenta como admirador de siluetas, coleccionista de obras originales, muy ocupado en inventar a un hombre cuyo capricho sería la única ley" (339). La alusión es clara: Max Aub y su Jusep Torres Campalans.

\section{Los otros en la legitimación de la invención}

Es justo en ese período en el que Aub está redactando su Jusep Torres Campalans con la complicidad de Cassou, que además fue co-fundador con Paul Rivet y otros intelectuales del Groupe de Musée de 1'Homme y quien, como evoca Malgat, durante los meses que precedieron a la edición francesa de la apócrifa biografía dedicó varios textos para destacar la originalidad de la aparición de Campalans. Su legitimación es importante sobre todo considerando que en 1945 Jean Cassou fue nombrado jefe de conservación de los museos nacionales en Francia, y permaneció 20 años en este cargo. De hecho, el folleto de presentación que escribió con ocasión de la edición francesa de la biografía de Campalans no arrojaba información escueta que permitiera identificar la naturaleza ficticia del pintor catalán. Justamente por ello, cuando el crítico Juan Luis Alborg terminó su lectura, no obstante estar al tanto de que Aub le había anunciado el libro a su colega Ignacio Soldevila Durante como una nueva novela que, "tal vez para ud. Así lo sea”, se decidió a escribirle a Aub para pedirle que aclarara el enigma de su naturaleza y éste le 
respondió enviándole el texto de Cassou, en el que, como evoca Estelle Irizarry (1979) no halló tampoco mayores luces pues "Cassou no alude para nada a la posible ficción, salvo en una frase misteriosa", pues le respondió que Jusep Torres Campalans es tan posible como Picasso; y Picasso tan hipotético como Campalans, de quien a su vez “(...) podría decirse que es tan posible como Max Aub, puesto que es una de las posibles configuraciones que ha forjado su imaginación" (Una biografía cubista). Hay que observar que, Cassou conocía bien a Picasso pues es el coautor, junto con Mary Chamot, del libro Picasso (1946) que dedica todo su sexto capítulo a Barcelona. Por otra parte, las peripecias novelescas de Aub no difieren mucho de las del narrador que lleva en el libro su nombre y que rastrea la historia de Campalans y conversa con él en Chiapas.

Aub fragua su existencia inventada no sólo desde la perspicaz confusión de géneros, sino estableciendo juegos de complicidades que ambientan, a modo de preludio, el lanzamiento de la obra. Estando en París en febrero de 1961, cuando después de que el original en español saliera en 1958, año en el cual Aub planea llevárselo a Picasso, se espera la edición en francés del libro. La edición se retrasa, y los amigos parisinos aprovechan para extender la noticia y suscitar el interés mediático. Según Gérard Malgat se escriben en francés 26 artículos sobre el libro. "El desconocido tándem CampalansAub y las relaciones de uno y otro con Picasso estimulan la curiosidad de los críticos de las artes y las letras” (150). Alice Gascar, la traductora que hace la versión al francés está convencida de la existencia de J.T.C., y mientras todos se preguntan por la complicidad de Picasso, Aub dice que éste se ha reído al observar la fotografía en que aparece con el mítico Campalans. Entre los propietarios de los cuadros aparecen Andre Malraux, que es 
uno de los mayores confabuladores con los que Aub cuenta, así como figura cercana a Picasso.

También menciona a Roger Caillois, el intelectual surrealista y coleccionista de joyas, máscaras, mariposas, que hizo publicar en la editorial Gallimard a figuras como Jorge Luis Borges, y tras estudiar a Braque y a Picasso, le dió a éste último el calificativo de "El liquidador", refiriéndose al modo en que acabó con lo que hasta él se entendía como el arte de la pintura, o al menos con su capacidad mimética. Otro supuesto coleccionista es Robert Massin, el diseñador gráfico de Gallimard, quien ciertamente era amigo de Picasso y compartía con él la amistad de Eric Satie. En la vida real, Massin atribuyó a un artículo aparecido en París con un titular que aclara la condición de "farsa" o impostura de la fantástica biografía, el poco éxito comercial de la novela apócrifa de Aub, sobre la cual se escribió mucho, pero constituyó un fracaso editorial pues la gente buscaba en este género la convicción de que se le revelaría un personaje real. En suma: se advierte de nuevo, en la elección de los coleccionistas de Jusep Torres Campalans un juego de roles - Caillois es uno de los pioneros de la ludopatía- a través del cual le transfiere relaciones que son esenciales para descifrar su relación especular con Picasso, si bien es cierto que en esta lista de nombres se encuentran algunos de sus principales confabuladores. Esta atribución de cuadros a propietarios que son reconocidas personalidades es una vez más un ejercicio del recurso de la ficción extrema de usar figuras reales, históricas, que interactúan con los caracteres ficticios de un modo que reafirma la existencia de estos últimos. Y, en el caso de Aub, se aseguró además de lograr, mediante estrategias extrínsecas al texto toda una confirmación de las afirmaciones realizadas en el contenido biográfico, con lo cual no sólo traspasa la 
frontera del oficio literario, sino que usa su tejido de relaciones que combinan la complicidad intelectual y la amistad para afianzar la presencia de Jusep Torres Campalans en lo que Husserl llamaba "el mundo de la vida", que es un mundo cultural, intersubjetivo, y está atado a nuestra experiencia perceptiva, y a la situación cotidiana de estar con los otros. La huída de J.T.C. es un espejo de las ausencias de la propia historia o de las falencias de un tiempo agrietado que anticipaba en su biografía apócrifa lo que mucho tiempo después enfrentarían teóricos como Arthur C.Danto: el fin de la historia del arte.

Aub dedica Jusep Torres Campalans a su cercano amigo André Malraux, ${ }^{45}$ a quien le une una visión de mundo, y con el cual sostendrá una correspondencia desde 1938 hasta el año de su muerte, en 1972. De hecho, como apunta uno de los mayores estudiosos de la vida y obra de Aub, Gérald Malgat acierta al recordar la relación probable que existe entre Max Torres, personaje que aparece en el libro de Malraux $L a$ corde et les souris y la personalidad de Aub y su personaje inventado. Ambos autores incursionan en la estructura fragmentada, hecha a modo de pastiche, y comparten el uso de una composición inspirada en la técnica de montaje, que conocen y disfrutan juntos, siendo al fin y al cabo cómplices en la pasión por el cine y en la realización de proyectos cinematográficos. Ese tránsito de Max Aub a la novela de Malraux, y de Jusep Torres Campalans al círculo de conocidos de ambos amigos, gracias a la impostura del biógrafo no podría haber sido construido tampoco sin la complicidad de urdir hilos que van y vienen de la narrativa a la vida, a modo de pastiches y fragmentos que acaban construyendo una realidad alterna. 
La sección dedicada propiamente a su biografía, se nutre del testimonio de Jean Cassou, de la correspondencia y declaraciones de Enrique Cabot, y a investigaciones del propio Aub, devenido en biógrafo. La vida del pintor catalán se "reconstruye" con memorias y textos ajenos que, según Aub, dicen con conocimiento lo que él hubiera tenido que recrear inventando. Como nota Vilchez Ruiz en su artículo Literatura y pintura. Jusep Torres Campalans, una novela cubista, el yo-narrador, alter ego de Aub deja lugar a otro yo narrador que expresa su discurso. Así, puntualiza, su voz puede ceder el paso a la de Enrique Cabot, que ahora narra en primera persona, de modo que es él quien pasa a contar y el narrador omnisciente desaparece. Esta polifonía se manifiesta aún más intensamente en la biografía, en tanto hace que múltiples personajes de sus distintas visiones de un único hombre: Torres Campalans (503-510).

Continúa Vilchez-Ruiz precisando que esa continua movilidad de los puntos de vista, de voces que sesuperponen, en la que el narrador aparece también como un focalizador variable, contribuye a dar fuerte verosimilitud a una historia, que, como hemos visto está caracterizada también por la abundante intertextualidad, paratextualidad y metatextualidad que vamos a encontrar en el discurso desde la primera página hasta la última, por medio de citas, artículos, alusiones y notas, que en algunas ocasiones llegaa abrumarnos completamente en ese afán de Aub porconvertir la ficción en realidad.

Y, cita cómo, en una reflexión meta-literaria, el mismo narrador se atiene a la afirmación que realiza al hablar del arte de J.T.C.: “¿Por qué pintar desde un solopunto de vista? Eso, cualquiera. Un pintor, por el hecho de serlo, tienen la obligación de abarcar más" (228). Es justamente ese el intento de Aub en su re-creación total de Jusep Torres Campalans. Evocando justamente la figura de Aub, Román Gubern trae a colación que 
Umberto Eco escribió en su Tratado que la semiótica es la ciencia que se ocupa de todo aquello que puede utilizarse para mentir, y añade que el tema de la "confusión de géneros", es aplicable enteramente a la falsa biografía del pintor Jusep Torres Campalans (11).

\section{La crítica a la autoría}

En el Prólogo indispensable de Aub, donde la mentira campea, no hay advertencia explícita sobre la presencia de ésta, pero sí una defensa conceptual constante de su naturaleza. Tras las líneas iniciales, que incluyen la reflexión de que como en 1590, Cervantes solicitó al rey la gobernación de la provincia de Soconusco, bien habría podido ocurrir que el Quijote fuera chiapaneco, Aub reproduce sin más el primer diálogo que sostuvo con Jusep cuando en la librería de la plaza de Tuxtla Gutiérrez, capital del estado de Chiapas, México. Se lo ha presentado un librero catalán, que a diferencia de Ramón Vinyes, el de Cien años de soledad, y quien fuera realmente una de las mayores influencias en la formación de García Márquez, carece de nombre ${ }^{46}$. Cuando Aub le comenta a Jusep que ha nacido en París, el artista catalán suelta un comentario — "París ¿Todavía existe?” (17) — que advierte al lector sobre la irreverente personalidad con la que se va a encontrar. Los testimonios de otras personalidades reales que lo trataron van permitiendo dilucidar a grandes rasgos la historia del pintor catalán que no quiere hablar del pasado y que eligió vivir "bajo una champa de hoja de palma" y bajar de tanto en tanto, a Tuxtla Gutiérrez, para llevarse consigo unos cuantos libros destinados a sus muchísimos nietos. 
No es gratuito tampoco que en el Prólogo indispensable de la biografía del catalán, Aub diga haber conocido a Jusep Torres Campalans, cuando éste asistió a una conferencia que él dictaba en Tuxtla, México, sobre la primera parte de Don Quijote de La Mancha, organizada para conmemorar los 350 años de la publicación. No se escapa a los editores del libro que "el autor se solaza creando un personaje análogo al Cide Hamete Benengeli, supuesto autor del Quijote" (10). En su invención del artista, Aub lleva a sus posibilidades máximas los juegos de Cervantes sobre la autoría y la apropiación de géneros diversos, usando reiteradamente falsos epígrafes y prólogos, y acomodando a su albedrío tanto personajes históricos como los nacidos de la imaginación.

Max Aub inicia la biografía de Jusep Torres Campalans con un par de epígrafes auténticos de Baltasar Gracián y José Ortega y Gasset, y uno apócrifo de un supuesto Santiago de Alvarado que anuncia la broma literaria: Según Aub, en un libro titulado Nuevo mundo caduco y alegrías de la mocedad en los años de 1871 hasta 1792, un tal Santiago de Alvarado, escribió: “¿Cómo puede haber verdad sin mentira?” (15). Resulta interesante comparar el prólogo que crea Cervantes para hablar de las aventuras de Don Quijote, y el que fragua Aub para presentar al suyo. En el primer caso, desde el inicio se señala al lector que su materia es la mentira. El mismo autor que se pretende distinto de Miguel de Cervantes invita al lector a ser libremente arte y parte (pues al fin y al cabo dará un veredicto) de un invento donde todo lo narrado es incierto. Pero justo por ello, esa historia nunca antes contada se anuncia como un divertimento. Nada mejor que entretenerse en la desfachatez con que se advierten los embustes y con que entran a 
escena las imágenes reflejas de un libro que se deleita en la creación de falacias en torno a su propia naturaleza.

El narrador de Don Quijote que está a cargo de escribir el prólogo tiene cuidado en enlazar la baja ralea de su experimento literario con la originalidad de su escritura. Advierte así al lector que escuchará asuntos "nunca imaginados de otro alguno, bien como quien se engendró en una cárcel” (9). Esa explicación sobre las circunstancias de creación de una obra surgida al margen del bienestar, espuria, en cierto modo, es coherente con el modo de dirigirse al lector para proponerle, como actitud de lectura, la misma irreverencia con que confiesa haber escrito el libro: "Y sabes lo que comúnmente se dice: que debajo de mi manto al rey mato, todo lo cual te exenta y hace libre de todo respeto y obligación" (10). La primera señal de alarma respecto a la credibilidad que pueda atribuirse al libro, o a la liberalidad con que se ha hecho uso antojadizo de los recursos literarios, aparece cuando el supuesto autor — todavía sin nombre - se describe pasmado ante el texto - "la pluma en la oreja, el codo en el bufete y la mano en la mejilla" (10)— y confiesa haber hallado la salida al impase acatando el supuesto consejo de un amigo que viéndolo en esta circunstancia le habría propuesto una fórmula para lidiar con la tarea de buscar comentarios elogiosos que sirvan de preámbulo a su libro como se estila entonces. Hasta el más incauto lector de Cervantes advierte que el dicho amigo es una invención humorística y aquí comienza su confusión no sólo por la índole del consejo, sino porque desde el mismo prólogo se perfila la incertidumbre sobre lo que puede o no creer. Ante el desdén que al narrador le provoca "andarme buscando autores que digan lo que yo me sé decir sin ellos" (11), la falsificación es la solución perfecta. La salida propuesta -hacer sonetos, epigramas, elogios, y bautizarlos con el nombre que a 
bien tenga: "El emperador de Trapisonda" (12), por ejemplo, sin temer a los bachilleres que descubran el embuste, contiene ya el juego de dobleces que voltean al derecho y al revés la propia naturaleza de la ficción. Se advierte, por supuesto, que la abierta confesión de la mentira no sólo niega el carácter de oculto que el supuesto ardid debe tener para ser eficaz y que burla por anticipado toda suspicacia, sino que termina siendo la enunciación de una verdad. El resultado de tanta torcedura en el prólogo cervantino -la mentira que revela lo real- es que al cabo el lector se torna un confidente, un inadvertido cómplice de cada fechoría narrativa.

Jean Cassou, figura central de este complot, como hemos visto, escribió por su parte:

Todo es imaginario. Los españoles lo saben muy bien. En particular Miguel de Unamuno, que pensaba que Don Quijote, personaje imaginario y a su vez creador de imaginario, había poseído toda la verdad del mundo. Por consiguiente, Don Quijote era más verdadero que ese pobre hombre supuestamente real Miguel de Cervantes. El pintor Campalans, imaginado por el escritor español Max Aub, no es menos verdadero (141).

El mismo Aub, admirador de Unamuno, en una consideración refleja de la obra, evocaba su visión de que un libro de historia puede no contener un solo dato falso y ser sin embargo una mentira en su conjunto, mientras que un texto plagado de inexactitudes podría en cambio dar un fiel reflejo de la verdad. Ese es el espíritu que defiende Cassou en La invención de Aub: "La imaginación, creadora de imaginario, es decir, de vida universal, de total verdad". No hay otro rigor ni otra verdad que la de "representar el espíritu de un tiempo en la vida y obra de Campalans" (141).

Esa mentira llevada al límite en Jusep Torres Campalans produce lo que con acierto se ha llamado un "poética del falso". Bajo ese título se convocó en 1994 en 
Salermo un encuentro de homenaje a la figura de Max Aub. En la introducción de Rosa María Grillo a las memorias del evento, repite el epígrafe atribuido por él a un autor apócrifo, otorgándole la autoría real, no sin antes destacar su manera de apelar a la libertad, con un irresistible humorismo y una voluntad lúdica y experimental: "Dopo tutto, come avrebbe detto Aub in Campalans: «Come può esistere verità senza menzogna?". El eco del "después de todo, ¿cómo puede existir verdad sin mentira?" ilumina el campo entero de la ficción extrema y oculta la sugerencia de que quizás la segunda sea un modo astuto de alcanzar la segunda (7).

Respecto a la cuestión de la mentira, Aub hace una defensa reiterada de ésta, aunque a menudo velada por el sagaz humor, en las diversas partes del libro extendiendo lo anunciado en el Prólogo. Particularmente plantea todo un tratado sobre el tema en el llamado Cuaderno verde, donde, a modo de un diario, concentra la visión de Jusep Torres Campalans sobre la estética:

¿Hay alguna virtud que asiente más la condición de hombre que decir algo a sabiendas falso dándolo por verdadero? Inventar mentira, y que los demás la crean... Forjar de la nada. Mentir: única grandeza. El arte: expresión hermosa de la mentira. La verdad, monda - si existe - , no es hermosa, dígalo la muerte. La vida humana: posibilidad de mentir, de mentirse. El arte y la política, las más altas expresiones del hombre, están hechos de mentiras. Ojo: mentir, inventar; no falsear — que es engañar, falsificar-, particularidad de endebles, vengativos enanos. No decir una cosa por otra, sino otra, nacida de la nada, de la imaginación (...) Que la verdad se vea al través, único modo de alcanzarla (...) Mentir para bien: asiéntase así el hombre en su ser (241-242).

El homenaje cervantino que hay en el texto aubiano es tal que sin más, pide a los deseosos de prólogo que se remitan al mejor:

El del Quijote. No sobraría palabra si lo trajera íntegro convertido a la intención de mil monografías de pintores que tantos compran y nadie lee, yéndole de ojos a las reproducciones; y tantas vidas de coloristas se leen en nuestros años como Amadises en los siglos cervantinos (...) (23). 
Aub no deja de dar preeminencia de cualquier modo, al imperio de la gana, haciendo eco a esa "ley del capricho" a la que aludía Cassou. Así, explica la razón por la cual decidió escribir el nombre catalán de Josep, no como lo pide su lengua, sino como lo quiso escribir: Jusep, "basándose en el oído y su real gana; de acuerdo con su manera de ser" (24).

\section{Deslizamientos de la ficción en los agradecimientos}

Para crear su ficción extrema, Max Aub no tiene ningún prurito en utilizar las páginas de agradecimientos - usualmente son empleadas por los autores de un modo que reconoce los distintos tipos de ayuda que recibieron de las personas involucradas por cualquier motivo en el proceso de realización del libro- para embarcarnos. No da puntada sin dedal en la enumeración de todos aquellos con quienes está en deuda y, sin reparo alguno, mezcla los nombres de cómplices reales, con los de personajes que jamás conoció, y con los caracteres ficticios, junto con quienes, como su mecanógrafa, fueron parte real de su ingente trabajo como biógrafo apócrifo.

Una vez más, la libertad de ficcionalizar incluso secciones reservadas para enumeraciones reales, combinando reconocidos personajes, con gente de su entorno y caracteres imaginarios, logra el efecto de fusionar la naturaleza de la ficción con la de la misma historia de la cultura, y con la propia subjetividad de la memoria cotidiana, de un modo que trastoca las coordenadas por las cuales reconocemos géneros diversos y separamos lo real de lo imaginario.

No me detendré en todos los nombres que menciona en las páginas de agradecimientos, si bien muchos de éstos irán apareciendo a lo largo del capítulo. Basta 
decir que entre las más destacadas figuras contemporáneas de Aub, muchas son personas con las cuales J.T.C. trabó amistad en París y en México. Entre éstos, además de Jean Cassou, su propio cómplice y amigo, menciona a Georges Braque, el artista más cercano a Picasso durante la fase inicial del cubismo: con él conformó un tándem que cambió la historia del arte del siglo XX. Aunque en la novela Aub dedica más espacio a sus diatribas contra Juan Gris que a la estrecha relación que tuvieron los dos primeros cubistas, entre las figuras incluidas en este listado de reconocimientos, la más cercana y determinante para el "Gran Monstruo", como tantas veces se le ha llamado a Picasso, fue Braque, quien entró a su estudio, por primera vez, nada menos que en el crucial verano de 2007, cuando está gestando el cuadro que acabaría llamándose Las señoritas de Avignon, y que será parte de una escena clave en la biografía de Jusep Torres Campalans. Entre las menciones de nombres está el del dealer Daniel-Henry Kahnweiler, gracias a cuya visión y habilidad de negociante sobrevivieron como artistas Picasso y Braque.

Una vez más, se observa en esta mención la usurpación que Aub hace de ciertos elementos biográficos de Picasso, para dar consistencia a Jusep Torres Campalans. También incluye Aub entre sus Agradecimientos de biógrafo a Francois Fosca. Este último nombre es en realidad el seudónimo que utilizó el pintor e ilustrador, ensayista y crítico suizo-francés Georges de Traz (1881- 1980) cuando publicaba biografías de pintores. Entre éstas, escribió la de Maurice Barraud (1927) y la de J. É. Liotard (1928). Por ello, la amistad atribuida con Jusep Torres Campalans es un recurso ingenioso. Por otra parte, como ensayista escribió un libro sobre la historia de la pintura suiza y entre 1944 y 1953 fue profesor de historia del arte. Para Traz -quien en los veinte había intentado una carrera como novelista, bajo el seudónimo de Peter Coram- el arte 
contemporáneo era materia de una desconfianza que J.T.C. acabará compartiendo con él, y conocía, tanto como escudriñaba de modo inquisidor, la pintura como medio. Y aparece otro nombre ante el cual siente particular gratitud: Alfonso Reyes ${ }^{47}$, el gran intelectual mexicano que secundó la creación cervantina de Josep Torres Campalans, y contribuyó con su correspondencia cómplice a la verosimilitud de la existencia del ingenioso artista de la vanguardia. Agradece asi mismo a su mujer (Péua) haberle acompañado "en tantas idas y venidas, vueltas y revueltas, en busca de datos y de certidumbre", y a los catalanes que le han permitido reunir detalles de su mocedad gracias al "evidente cuidado" que éstos ponen "acerca de cuanto puede servir a su grandeza" (27). La ralea de su humor es evidente.

Aub, como el mismo Cervantes, se quita la autoría de una parte de las páginas que vienen a continuación, pues no es sino amanuense de sus notas, si bien retiene para sí la tarea del biógrafo. Reconociéndose como "novelista doblado de dramaturgo" (20) en un recurso digno de la tradición inaugurada por Cervantes, asegura que la historia de la vida de este hombre, íntimo de Picasso y bien conocido de Alfonso Reyes, le fascinó hasta el punto de convertirlo en biógrafo. Todas las preguntas que el nuevo oficio le plantea giran sobre el hecho de que ninguna afirmación sobre un semejante puede sobrepasar en el fondo la incertidumbre. “¿Quién puede dar entera noticia de algo, sí humano?”, se interroga (20). Ante esa imposibilidad asegura haber tratado de mantenerse aparte en la relación de hechos que fue encontrando acerca de J.T.C. y de haber procurado ceñirse a la verdad. No le queda fácil al lector sospechar de ésta pues puede constatar una ingente cantidad de datos. Por ejemplo, que el gobernador de Chiapas, México, Aranda Osorio, a quien agradece haberlo invitado a la región "sin prever las consecuencias", fue realmente 
gobernador de ese estado durante el período de la elaboración de la biografía. O puede constatar que ciertamente el escritor mexicano José María Mendoza bien pudo haberle dado "la pista Odilon Redon", puesto que fue un gran conocedor del poeta y ensayista francés Guillaume Apollinaire (1880-1918), cuya obra poética estuvo profundamente influenciada por este artista -y poeta- simbolista. Y de paso, deja ahí otra pista implícita para el lector curioso pues Apollinaire fue a su vez una figura determinante para el cubismo que es uno de los ejes de la biografía de J.T.C.: de hecho, fue él quien redactó un texto que se usó a modo de manifiesto del cubismo, pues ni Picasso ni Braque ofrecían discursos teóricos sobre sus indagaciones.

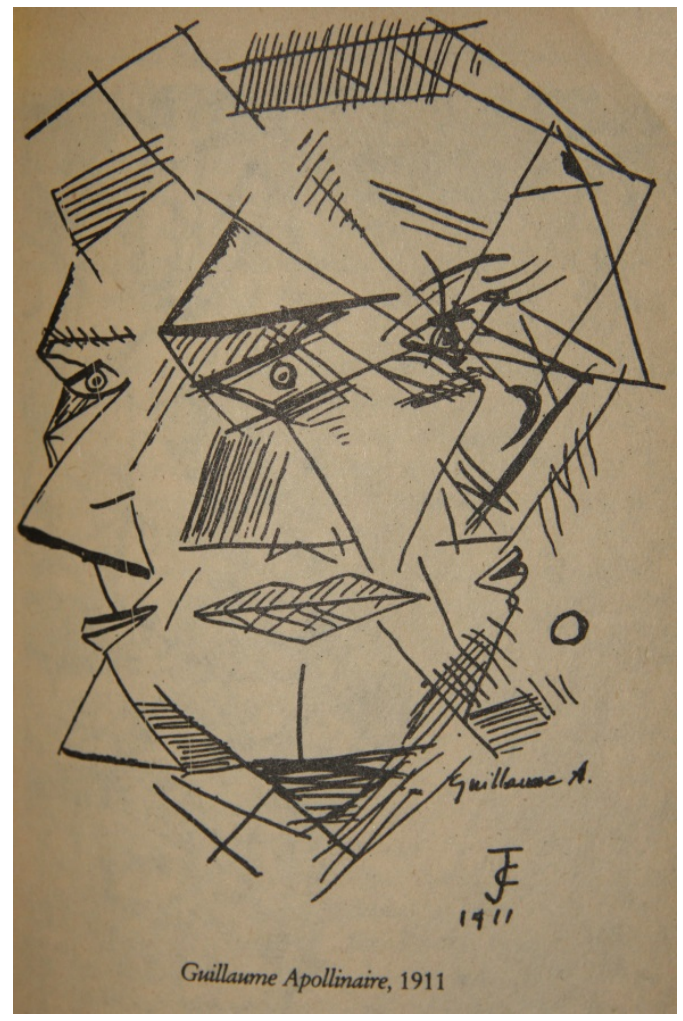

Ilustración 5: Jusep Torres Campalans, Guillaume Apollinaire 1910, cargón. Propiedad de Jean Cassou

Aub, el narrador, menciona la partida del poeta al frente de guerra y J.T.C. hace su retrato con tres perspectivas simultáneas. De nuevo se apropia de uno de los más 
cercanos amigos de Picasso, al menos hasta cuando él y Apollinaire se vieron envueltos en el confuso episodio del robo de la Monalisa del Louvre y Picasso, como Pedro con Jesús, negó conocer a Apollinaire, quien permaneció unos días preso. "No lo he visto en mi vida" le dijo a la policía (Mailler 387). ${ }^{48}$

También menciona Aub a Antonina Vallentin (1893-1957) agradeciéndole los datos y documentos que le proporcionó sobre J.T.C, y el reconocimiento se justifica en tanto ella escribió ciertamente libros biográficos sobre personalidades como El Greco, y Goya, que tanto influyeron a Picasso y sobre éste mismo, si bien este último título tiene una fecha posterior de publicación. Pero la incluye, además, porque fue autora de un libro sobre la vida de Heinrich Heine, que era uno de los poetas predilectos de Max Aub. El hecho de que la personalidad de Max Aub impregne la índole de sus personajes no nos distrae de su creación, tal vez porque logra justamente darles tal grado de existencia que andan por sí solos, como si incluso pudieran hacerlo a espaldas suyas, y de cualquier modo, difieren de él, son autónomos, caracteres heterónimos con obra propia que engulle su autoría.

\section{El juego de los anales: otra estrategia de la ficción extrema}

Aub justifica la inclusión de una cronología donde registra, sin comentarios y con pretendida apariencia de máxima objetividad, una mención de los principales nacimientos, decesos, y aconteceres en la pintura, música, literatura o descubrimientos y sucesos ocurridos entre 1886 y 1914. Son las fechas correspondientes al período transcurridos entre el año del nacimiento de Jusep Torres Campalans y en el que prefiere no pintar más. Menciona que siguiendo las historias de la pintura y las noticias más 
importantes de la época ha querido reunir los datos necesarios para que el lector recuerde el ambiente y pueda dar con la edad y circunstancias de personajes reales. Tratándose del mismo autor que compone su obra declaradamente como un rompecabezas para que el lector la arme, sorprende tanto interés en facilitar la comprensión de su lectura. El recurso es perfecto sin embargo para la inserción de datos apócrifos, esenciales para la existencia de Campalans, que se cuelan entre los reales.

Los anales resultan en extremo convincentes, porque conjugan el poder que tienen las enumeraciones de instaurar hechos, con la estrategia de los continuos deslizamientos de la realidad en la ficción. Aub insiste: "Nada escribimos de memoria en estos Anales sino estudiando y teniendo sobre nuestra mesa documentos en que apoyar todas y cada una de nuestras afirmaciones: la indispensable brevedad de los Anales nos obliga a suprimir las citas" (81). Comienza aclarando que si otorga relevancia, sobre todo, a las bellas artes y a la literatura es porque son "las mejores guías de lo pasado". Su recurrencia a los anales, según sostiene, es una estrategia para "evitar así patrañas" (29). Pero sabemos que si está usando ese recurso tomado desde el inicio de la historia que es la consignación de los anales, es justo para enredarnos en las patrañas que urde.

El carácter exhaustivo de los anales, presentados a modo de relación crónica objetiva — si no por la elección de los sucesos y personajes, sí por el tono que no contiene juicio alguno- como si realmente se tratara de una mera enumeración de hechos, refuerza la impresión de veracidad de toda la información que el libro contiene. Son pues, otro recurso que utiliza para posibilitar el triunfo de su ficción extrema que se inserta sin escrúpulo en la realidad. 
Es interesante destacar el año otorgado al nacimiento de Jusep Torres Campalans: 1886, un natalicio que comparte con artistas como los expresionistas Oscar Kokoschka —cuyas primeras obras, expuestas en Viena, habían desatado una oleada de indignación - y el belga Constant Permeke, o con el muralista Diego Rivera, y con el poeta catalán José Ma. López-Picó, además de la poeta Delmira Agustini, del novelista Ricardo Guiraldes y del historiador Salvador de Madarriaga ${ }^{49}$. Menciona también que en ese año mueren José Hernández, Emily Dickinson y Franz Liszt, entre otras figuras que permiten diferenciar la cultura del biógrafo Aub y la de J.T.C., quien según su mentado biógrafo, no era en absoluto hombre intelectualmente cultivado.

En 1903 Aub incluye su propio nombre - como haciendo eco a la inclusión de los libros cervantinos entre aquellos que Don Quijote se abstiene de arrojar al fuegoentre los nacimientos ilustres, junto con el de una lista de escritores elegidos por afinidad: el mexicano Xavier Villaurrutia y el inglés nacido en la India, George Orwell, que ciertamente nacieron ese año, y Juan de la Cabada, que nació realmente en 1899, pero que en 1937 fue uno de los intelectuales mexicanos que asistieron al Congreso de Valencia y formó parte de la comisión encabezada por Octavio Paz que dio su apoyo a la República $^{50}$. Si las referencias a las artes y las letras son universales, los sucesos que Aub menciona tienden a estar más centrados en España.

Jusep Torres Campalans simpatiza, como el mismo Aub, con el anarquismo. El culto al individualismo y la defensa de la libertad los acercan a los anarquistas, si bien en el caso del primero, nada hacía "tambalear su fe; ni creía que se opusiera a la justicia social aun traída por los métodos más radicales" (94). Por ello, en los sucesos de 1892 relata que quinientos campesinos entran en Jerez al grito de “iViva la anarquía!” y habla 
de los atentados del anarquista francés Ravachol y de su condena a muerte en la guillotina, así como de la asamblea general de delegados de la Unión Catalanistas que se realiza en Manresa. Las notas complementarias no terminan sin embargo de sorprendernos. Nos revelan que, contra toda suposición, Jusep Torres Campalans, simpatizante de los anarquistas, y opositor del franquismo, fue un hombre católico, apostólico y romano, practicante. Un inclasificable, a quien resultaba difícil inscribir en tribu alguna. "No pisa el reino de las dudas, fiel a la fe de sus padres; de una pieza, en ése como en los otros aspectos de su vida. De ello, el no haber hecho nunca caso de críticas ni de críticos" (25). Si Jusep Torres Campalans es católico y Aub judío formado en el agnosticismo ${ }^{51}$-, el primero poco culto y el segundo hombre de vasto conocimiento, ambos son igualmente catalanistas "hasta las cachas" (10). Es a este respecto, donde más se trasluce aquella unidad entre el autor y el personaje, aunque Aub se empecine en recobrar el rastro de una historia personal que el artista ha buscado borrar.

En 1908 escribe escuetamente que ha surgido la palabra cubismo. El tono neutro no permite advertir que su labor de biógrafo no habría podido cumplirse a cabalidad sin haberse sumergido en este nacimiento del movimiento vanguardista. No menciona al crítico Louis Vauxcelles que fue quien acuñó el término cubismo, más bien en tono de mofa, al referirse a las pinturas de Braque como hechas de cubos. Aub anota, en cambio el viaje de Mondrian a Bélgica, pero ni en este año, ni en muchos otros, hace ninguna alusión a Jusep Torres Campalans, quien mucho después encontrará en su obra y en los diálogos privados con el holandés pilar de toda la abstracción geométrica, un espacio de asombro, sólo reservado a su presencia. Quizás sea el único artista ante el que no esgrime, en ningún momento, sombra alguna de irreverencia o de duda. En todo caso, 
esta ausencia de la mención del protagonista tiende a hacer más verosímiles las frases que sin transición alguna entre lo veraz y lo ficticio, cuela en sus anales refiriéndose a él. Su ingenio consiste en que sólo después, en la biografía, hace responsable a Picasso de la iniciación sexual de Campalans en los prostíbulos de Barcelona y París, y sugiere que una conversación entre ambos acerca de las putas barcelonesas suscitó el legendario cuadro El burdel, que el poeta y crítico André Salmon rebautizaría oficialmente en 1920 como Les Demoiselles d'Avignon ${ }^{52}$. Como apunta Héctor Brioso Santos en Max Aub o la Historia universal del fraude:

Las noticias que se dan a cada paso del arte del malagueño no son por inventadas o recreadas menos creíbles, no por fabuladas menos intensas. Precisamente es la distancia nada beata con la que afronta Aub al famosísimo Picasso lo que hace más verosímiles las anécdotas, narradas por la técnica del personaje interpuesto: el también pintor, por inspiración picassiana, Jusep Torres. Lo mismo puede decirse del recuerdo del fantasioso Apollinaire, de Max Jacob, Braque, Delaunay, Gris... (...). ${ }^{53}$ La profusión de datos que llamaremos semirreales es enorme y exigiría un esfuerzo ingente de confrontación y documentación, una edición profusamente anotada (que no es sino el paso que le faltó a Aub para embaucarnos del todo). Hasta la firma del pintor protagonista, de iniciales mayúsculas 'colgadas' unas de otras, tiene de casi real su parecido con otros anagramas ilustres de la época: Georges Bernard Shaw o Henri de ToulousseLautrec (Brioso).

En 1910, el mismo año de la verdadera aparición de la revista Europa, de Ortega

y Gasset, que reporta, y de la manifestación de la pintura futurista en Milán, el biógrafo Aub menciona escuetamente: "Léger conoce a Picasso, a Braque y a Jusep Torres Campalans" (67). Eso es todo. Un recurso simple que homologa, de algún modo, a los tres artistas. Lo cierto es que, justo ese año, Fernan Léger (1881-1955) era parte de un grupo de vanguardistas como Metzinger o Gleizes, que, según evoca Pierre Cabanne (1921-2007), exploraban un cubismo que buscaba la herencia de Cézanne en una dirección que se apartaba de la fase del cubismo analítico propuesto por Picasso y de 
Braque, con las obras extraordinariamente parecidas que habían creado, incluso cuando hacían exploraciones en lugares distantes. De modo que con esa frase escueta, sitúa a Jusep Torres Campalans, en el "bloque" del cubismo analítico de estos dos últimos artistas, y al hacerlo transforma en una suerte de trío el tándem real que Picasso y Braque habían ido conformando.

Posteriormente, data en 1911 la introducción de letras y letreros en las telas de estos dos artistas — novedad que en efecto puede constatarse en el cuadro Mujer con guitarra (Ma Jolie), que Picasso inicia ese año, aunque termina el siguiente, y que contiene las letras de Ma Jolie, que aparecen también en La mesa del arquitecto (1912). El nombre era tanto una frase de una canción popular que presentaban en un hall musical parisino al que Picasso solía ir, como el sobrenombre de su amante de entonces, Marcelle Humbert, cuya la figura, como la de la modelo del cuento preconizador del arte abstracto que escribió Balzac, El pintor y su modelo, se integra al juego de la construcción cubista analítica, pero su contenido representacional desaparece entre planos semitransparentes, auque algunos fragmentos dejan ver trazos figurativos que remiten a su cuerpo sosteniendo un instrumento musical. 


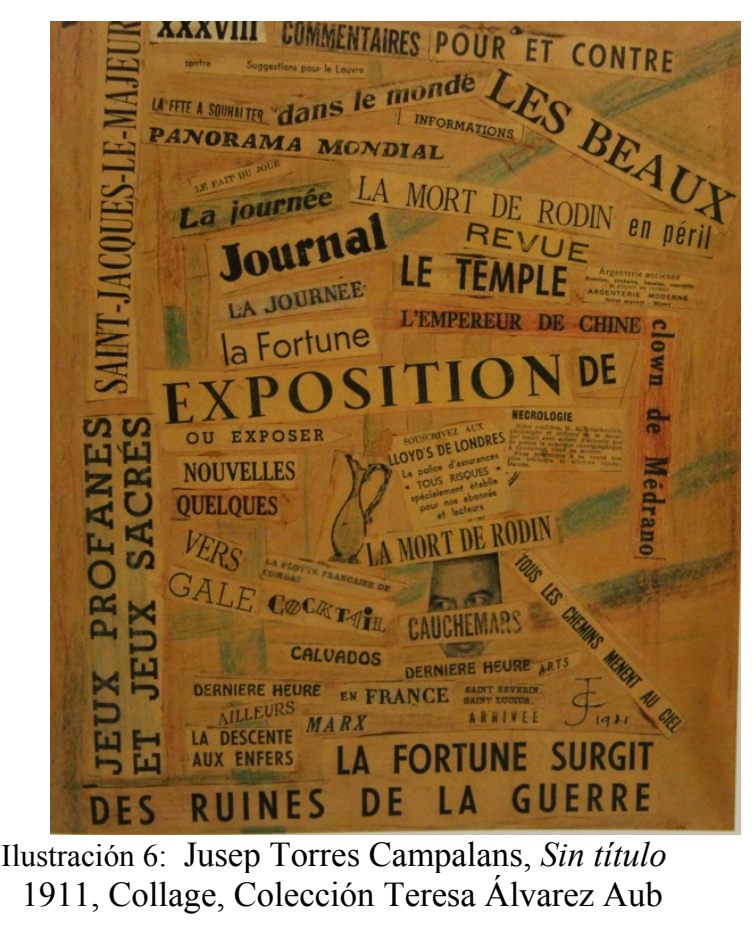

Aub sostiene en todo caso, como de pasada, que en realidad un dibujo de 1910 de Jusep Torres Campalans, incluía letreros, con lo cual viene a asentar que este acto pictórico, que anticipa la poderosa tradición conceptual del siglo $\mathrm{XX}$, fue precedido realmente por el artista catalán. Y para quien dude de ello, entre las obras correspondientes está un collage, sin título, construido con recortes de titulares de periódicos, entre los cuales pueden leerse frases que ciertamente reflejan el mundo interior de Aub — "Le fortune surgit des ruines de la guerre" o "Jeux profanes et jeux sacrés"-, y, como no, "Clown de Médrano", una clave que conduce directamente a Picasso y a la época rosa, poblada con personajes de un circo al que asistía y que inspiró profusamente a los vanguardistas. Por supuesto, un año antes Jusep Torres Campalans hace un cuadro con la técnica del collage. Las numerosas frases recortadas, compuestas, en español y en francés - “des ruins de la guerre", "La descente aux enfers", "panorama mundial" - dan cuenta del contorno del mundo que J.T.C. va a dejar, si bien Aub no se 
cuida de incluir hechos posteriores a su "deserción", como el de la muerte de Rodin, ocurrida en 1917. Pero seguramente este tipo de gestos son una señal más de alerta de una broma que contiene tanto de la verdad de un tiempo.

Una de las pinturas de J.T.C. es el óleo Pierrot, 1908, del cual dice el crítico irlandés Richard H. Town: "De las influencias de Picasso, ésta, tardía, es de las más claras (...). Una de las pocas muestras de la maestría realista de J.T.C” (313).

Y, sin duda, el investigador puede refrendar su conocimiento de los antecedentes y desarrollo de los modernistas cubistas. La parquedad resulta incluso más convincente que el exceso de menciones, sobre todo porque está echando mano del recurso de autoridad que supone el situar a J.T.C. en compañía de las figuras intelectuales y artísticas que ciertamente Aub conoció y siguió cuidadosamente. Es un tipo de recurso que refuerza constantemente en otras partes de la estructura del libro, "delegando" (es decir, impostando) lo que tiene que decir sobre su personaje en voces más autorizadas que la suya. Se atreve a inventar misivas —con el seguro beneplácito de sus remitentes - como la que lleva J.T.C. en 1914, cuando se marcha a México, con una misiva escrita de puño y letra por Alfonso Reyes y destinada a Julio Torri: “Allá va, con estas líneas en la mano, Jusep —no José— Torres Campalans, pintor catalán, que no quiere saber nada de esa guerra europea. Tampoco parece querer ya nada con la pintura. Ha perdido pies, es decir, tierra. Piensa dar con ella en México" (188).

Entre las notas que acompañan los anales, "reproduce" algunos artículos o pasajes sobre la historia y el arte en España como los de Benito Pérez Galdós, José Ramón Mélida o Ángel Salcedo Ruiz - textos sobre los cuales suponemos o asumimos que son veraces como la existencia de sus autores, sin poder confiarnos del todo en ello- junto 
con uno titulado Un fundador del cubismo: Jusep Torres Campalans, que firma Miguel Gash Guardia. El recurso una vez más es colar, junto a fuentes o personalidades reconocidas, figuras de ficción y de apócrifa dicción con las cuales echa a perder en cierto modo la tajante afirmación de Campalans: "El que habla de pintura no sabe nunca lo que dice. El que tenga que opinar, que pinte" (24). Si por una parte esa frase contiene la clave del desafío que plantea al hacer del conjunto de una obra pictórica atribuida a un personaje ficticio un modo de crítica del arte de su tiempo; por otra parte, se contradice y habla de pintura: recurriendo a la impostura de la voz de Campalans, Aub asume la misma labor del crítico que emite juicios. Pero, por supuesto, se trata de un texto en el que hablan un conjunto de voces. Volveremos a ese discurso crítico al hablar de los dibujos y cuadros de Campalans. Pero es justamente esa polifonía la que da una enorme riqueza compositiva a la novela que concibe con una estructura que refleja la aspiración cubista de descomponer la realidad. Recurso que por otra parte ayuda enormemente en la tarea de crear espacios propicios para la fuga del autor y sus juegos de ocultamiento.

\section{Composiciones cubistas en la biografía apócrifa}

En el primero de los epígrafes que anteceden el Prólogo indispensable, un fragmento tomado de El criticón de Baltasar Gracián, se expone una concepción precursora del cubismo:

He determinado valerme de la traza de aquel ingenioso pintor que, empeñado en retratar una perfección a todas luces grande viendo que los mayores esfuerzos del pincel no alcanzaban a poderla copiar toda junta con los cuatro perfiles, pues, si la pintaba de un lado, se perdían las perfecciones del otro, discurrió el modo de cómo poder expresarla enteramente. Pintó, pues, el aspecto con la debida valentía y fingió a las espaldas una clara fuente, en cuyos cristalinos reflejos se veía la otra parte contraria con toda su graciosa gentileza. Puso a un lado un grande y lúcido espejo, en cuyos fondos se lograba el perfil de la mano derecha, y al otro un 
brillante coselete, donde se representaba el de la izquierda. Y con tan bella invención pudo ofrecer a la vista todo aquel relevante conjunto de bellezas (15). ${ }^{54}$

Aub transfiere al proceso de creación literaria sus consideraciones sobre el cubismo, demostrando que también en la construcción de textos, la forma determina la percepción del espectador, y nunca es tan completa como cuando permite la descomposición de la realidad en múltiples visiones que reflejan su complejidad. Al tiempo, la ficción se convierte en un tipo de meta-crítica artística no sólo porque desmitifica la misma índole de este género, sino la creación pictórica y tiene ante todo una función especular sobre la vanguardia que se cumple con palabras tanto como con imágenes. Una labor que echa mano de la mentira y de la refinada invención de un artista para postular una estética que juega abiertamente con la apropiación paródica. Pero no ésta no es en absoluto ilegítima: de la poética de lo falso surge una panorámica sobre esa coyuntura vertiginosa que aglutinó en París antes del estallido de la Primera Guerra Mundial el paroxismo creador de las vanguardias.

La diferencia de Jusep Torres Campalans con relación a los heterónimos de Fernando Pessoa, no sólo estriba en la osadía con la cual creó una verdadera confabulación extraliteraria y extrínseca al texto para darle existencia con el apoyo de personajes reales, sino "en el terreno de las actitudes estéticas" como apunta Juan Oleza. Sostiene que, en efecto, Jusep Torres Campalans evoluciona desde una rápida fase de formación (1906-1907), influida por el Picasso azul de un par de años atrás, y por el descubrimiento de Cezanne, Gauguin y Van Gogh, pasando por su etapa de plenitud, que tiene lugar, como hemos dicho, entre 1908 y 1912, en la cual se incorpora al movimiento cubista encabezado por Picasso y Braque, hasta llegar finalmente, en sus dos últimos 
años de actividad artística (1913-14), a una identificación con la pintura abstracta, geométrica, pura, que dará lugar a la serie de las tramas, que siguen muy de cerca a las de Mondrian (1872-1944), quien le lleva 14 años y cuyo arte acaba abriendo el umbral a su silencio definitivo como artista, a su conversión en otro Baterbly.

Pablo Picasso es la fuente primordial a partir de la cual Aub concibe la travesía de Campalans hasta 1912. Es decir, se apropia de sus procesos artísticos, atribuyéndoselos a J.T.C., de tal forma que primero declara su predilección por la época azul picassiana, y se atreve a sugerir que le precedió en las prácticas protocubistas o en el uso del collage, dejando clara la antecesora y enorme influencia de Cézanne en su biografiado.

De este modo, Jusep Torres Campalans surge, en lo relacionado con la visión estética, como un cuasi doble de Picasso. Lo cierto es que, en 1943, Picasso le dijo al fotógrafo George Brassaï que Paul Cézanne (1839-1906) era "su solo y único maestro". El catálogo de la exhibición que en 2013 el Art Institute of Chicago, dedicó a los dos maestros, "Picasso and Cezanne", reconstruye ese momento seminal para Picasso, que ocurre cuando asiste a la retrospectiva de Cézanne, un año después de su muerte. Aunque Picasso conocía su obra, la experiencia de ver el conjunto de su creación en el Salon d'Automne le reveló cuán lejos había ido el postimpresionista. Junto con George Braque (1882-1963), quien visita su estudio por primera vez en el verano de 2007, y exclama frente a El burdel de Avignon, que se titulaba así en un juego de palabras con el nombre de una calle en el barrio rojo barcelonés Carrier d'Avinyo, que la experiencia visual que provoca se asemeja a comer estopa y beber petróleo ${ }^{55}$, explora el legado de Cézanne. Juntos comprenden la noción del campo del cuadro que altera el sentido de la escala e integra los distintos componentes de una escena como partes de un solo objeto. Jhon 
Elderfield (1992) sintetiza la influencia decisiva que Cézanne tuvo en las diversas direcciones que continúan esa búsqueda que lo llevó a desembocar en la destrucción de la superficie apartándose de la larga tradición de la pintura que tendía a alcanzar el máximo grado de perfección mimética. Los órdenes de la magnitud desaparecen en su pintura, y un detalle no permite distinguir si se trata de la superficie de una flor o de una tienda de campaña. Las exploraciones de Picasso y Braque sobre las técnicas de Cézanne, conducen a la plena invención del cubismo en 1909.

Daniel-Henry Kahnweiler, el marchante de arte que tuvo una visión lo suficientemente atrevida y el entusiasmo necesario para invertir en Picasso y a Braque incluso en los más duros tiempos, llegó a convertirse, por sus extensas conversaciones con ambos, en uno de los mayores conocedores sobre el origen de su cubismo. Norman Mailler transcribe una interesante revelación respecto a que para él, pintar es una forma de escribir:

Una mujer en una pintura no es una mujer; es un grupo de signos que yo leo como 'mujer' (...). Fundamentalmente la pintura nunca ha sido un espejo del mundo exterior, ni ha sido nunca parecida a la fotografia; ha sido una creación de signos que siempre fueron correctamente leídos por los contemporáneos, tras un cierto aprendizaje, desde luego. Pues bien, los cubistas crearon signos que eran incuestionablemente nuevos y esto es lo que hizo difícil leer sus cuadros durante tanto tiempo (363).

A su vez, el espacio fragmentado de las pinturas tiene un correlativo en la escritura fragmentada de Aub; la indiferenciación de los planos —atrás y adelantepuede corresponderse con el hecho de que este tipo de escritura fragmentada permitiría, al menos en varias de sus partes, intercambiar el orden, sin modificar radicalmente su contenido, y, mientras el cubismo termina el afán de representatividad, aquí se usa este 
recurso como máscara para el más osado de los experimentos literarios: la tantas veces mencionada invención de un hombre que se cuela entre los de su época.

Carmen E. Vilchez Ruiz señala que uno de los recursos con que Aub consigue en su novela esa descomposición del personaje a la manera del cuadro cubista — que el lector reconstruirá como un rompecabezas- es la inserción y superposición simultánea de "multitud de voces distintas, sueltas, y a veces inconexas, que convergen todas ellas, en un mismo punto: el de la construcción del personaje a modo de collage" (507). Nota también que entre estas voces está la del propio J.T.C. "Esta polifonía de voces -que remite al dialogismo bajtiniano- se manifiesta en el discurso narrativo no sólo por las notas, artículos, textos y aparato crítico que introduce el autor, sino porque también aparece en el propio diálogo entre personajes, cuando alguien cuenta algo haciéndose eco de las palabras de otro, o cuando el propio yo-narrador, alter ego de Aub, desaparece y aparece otro yo-narrador que toma la palabra y expresa directamente su discurso" (507). Este recurso es continuo en la parte dedicada a la biografía, donde además de una polifonía que tiene un equivalente visual, se evidencia ese dialogismo que, tal como señala Vilchez Ruiz, contiene elementos estilísticos y lingüísticos de una gran diversidad. Aub nos ofrece "multiplicidad de perspectivas y voces para poder así conformar una visión más objetiva y realista del personaje. Así, la técnica cubista y realista se entrelazan, uniendo en un mismo personaje pintura y literatura, realidad y ficción” (507).

Por su parte, Huici destaca también la concepción de una estructura conformada a modo de rompecabezas y de continuos desdoblamientos funcionales. Cita para demostrarlo aquello que le parece el más endiablado recurso de la maquinaria de Aub, según lo entrevió Estelle Irizarry: "una aleación que combina lo documental, lo narrativo 
y lo teatral" que son las aristas esenciales de su propio universo creativo (21). Carole Vinals evoca también la composición fragmentaria -que podemos conectar con la escritura cubista y con la polifonía bajtiana - diciendo que a Aub y Malraux solía reprochárseles el carácter fragmentario de su hilo narrativo que hace pensar en una acumulación de escenas evocadas a menudo sin conexión directa:

Pasan de una escena a otra, de un plano a otro sin comentarios, exactamente como en el cine. La elipsis, abundantemente utilizada les sirve también para recalcar el sentido de lo absurdo ante la guerra: si las cosas carecen de ligazón, es porque existen fisuras. La impresión general de El laberinto mágico y de L'espoir es la de fragmentos combinados: parecen mosaicos escritos en momentos diferentes. Es como si no hubiera unidad. No hay totalidad, no se puede unir lo disperso. Esa sensación que nos transmiten Aub y Malraux entronca con la intuición de Blanchot: 'Ce qui est premier, ce n'est pas la plénitude de l'être, c'est la lézarde et la fissure'. (Blanchot, 1959: 59; artículo 'Artaud'). Aub y Malraux son conscientes de esos límites. Entre imagen e imagen, hay un vacío, una frontera imposible de colmar. A esta ausencia de unidad Blanchot la llama 'la dispersion du dehors' (65).

Si los pintores cubistas no estaban obligados a copiar las formas, el color, la textura o el espacio, sino a presentar una nueva realidad en pinturas que describen los objetos en forma fragmentaria, a veces de tal modo que varios lados pueden ser vistos simultáneamente, esa libertad, parece haber concluido Aub, está a perfecta disposición del escritor, máxime cuando lo que está creando es un pintor pretendidamente cubista. Y sus aristas serán perfiles reflejos de una figura no sólo real, sino que - a diferencia de Gauguin o, peor aún, de Van Gogh, que no vendió sino un solo cuadro y se murió en la inopia - alcanzó en vida una dimensión mítica. Es obvio que el desarrollo artístico de Jusep Torres Campalans se hace eco del propio proceso de Picasso en los primeros ocho años y que Aub está trazando el curso de la pintura moderna a través de las cambiantes influencias y predilecciones del pintor catalán, quien admirar su obra a partir de la época 
azul. La elección revela que Aub sabe perfectamente que es en ese período (1901-1904) cuando Picasso encuentra un lenguaje propio.

Como anota E.H. Gombrich después de incursionar en esos temas de los desesperados de la tierra de su época azul, Picasso empieza a estudiar el arte primitivo al que también Paul Gauguin (1848-1903) había dirigido la atención, sintiendo el agotamiento del arte occidental. De hecho, aunque ya conocía su obra, la retrospectiva póstuma que le hicieron en el Salon d'Automne de Paris en 1903 y posteriormente en 1906, tuvo un efecto enorme en las pinturas de Picasso, particularmente en la dimensión monumental de las figuras ${ }^{56}$. El extraordinario poder de síntesis de Gauguin, no sólo en un sentido formal, sino por su aproximación a otras iconografías (que hoy asociaríamos al sincretismo y a la hibridación cultural), fue una experiencia poderosa para Picasso, quien, no siendo religioso, conocía el terror sagrado y la conmoción de sentir la energía de las fuerzas oscuras en contienda con los humanos y se negaba a racionalizar su arte: “Todos quieren comprender el arte. ¿Por qué no tratan de comprender el canto de un pájaro?” ( $L a$ historia del arte 577).

Depositaba la energía de lo desconocido en los imaginarios de culturas alternas depositaban la energía de lo desconocido o, en todo caso, de aquello ante lo cual carecían de herramientas de control distintas a ese otro modo de oración, de intento de acceder a lo indecible, que puede ser el arte. De hecho, de niño, la propia pintura de Picasso se había alimentado de la secreta contienda que sostuvo al pretender detener a la muerte que rondaba a su hermana Conchita, de siete años, mediante la ofrenda (culposamente incumplida) de no volver a pintar. Se dice que Picasso no firmó Paul en honor a este otro Paul (Gauguin), pero quien tan tempranamente escribió en una pintura, "Yo, el Rey", 
seguramente no lo hizo para exorcizar la sensación de no ser único, irrepetible (Norman Mailer 21).

Narra paralelamente Aub que fue el descubrimiento de Paul Gaugin, y su manera de asomarse a un mundo nuevo, no sólo a una geografía para la cual su asombro estaba aún intacto, sino a un modo de pintar desconocido, lo que indujo a Jusep Torres Campalans a comprar su Cuaderno verde. Allí anotó la primera línea, definitiva y paradójica: "No copiar" (132). Copia, en el credo estético de Aub, equivale al tipo de falsificación de quien comprende las tendencias que se imponen y se instala en éstas, ejecutando obras que nacen sin espíritu, imitaciones de los senderos que otros abren, que no pueden ser salvadas por cuenta de las teorías.

Según su amigo y biógrafo John Richardson, Picasso aprende de Gauguin el poder de la síntesis pictórica sin perder por ello la posibilidad de impregnar a la pintura una nueva profundidad. A ese aprendizaje se suma a la intensa influencia de la sombra tutelar de Cézanne, quien en una de sus cartas aconsejaba a un joven pintor en una de sus cartas de traducir la naturaleza contemplada en formas geométricas. ${ }^{57}$ Este proceso es similar al que repite Jusep Torres Campalans en cuanto a las fuentes de las que se nutre y al modo en que desemboca en el cubismo. El humor, un tipo de humor que surge de la ironía y se asoma a fronteras iconoclastas sin atravesarlas del todo, sin dejar de sostener espacios de reverencia como el que irradia la sombra picassiana, inunda todo la impostura literaria: basta pensar que, según Aub, el cuadro que anuncia la irrupción del cubismo, Las señoritas de Avignon, con las cinco prostitutas desnudas ${ }^{58}$ viene a ser en la biografía apócrifa una suerte de resultado de la aventura que Picasso emprende en el burdel de la calle barcelonesa del Carrier d'Avinyo, para remediar la virginidad prolongada de J.T.C.. 
La referencia a Picasso como guía de su iniciación en los burdeles es ideada por Aub como eco de la vida real del pintor que alimentaba su leyenda refiriéndose a las incontables veces que entre los 14 años (edad en la cual pinta con maestría el óleo religioso Primera comunión) y los 15 años, había visitado los prostíbulos del Barrio Chino de Barcelona. En su Picasso. Retrato del artista joven, Norman Mailer anota:

La leyenda de Picasso afirma que fue una personalidad de un magnetismo poco corriente, desde su primera adolescencia y a las prostitutas les resultaba irresistible incluso entonces; antes de los dieciséis años sabía más de sexo, según esta leyenda, de lo que la mayoría de los hombres llegan a saber nunca. No es ésta una imagen de la que él fuera dispar en años posteriores, pero es difícil creerla. Para comenzar, ¿de dónde sacaba el dinero? (33).

Cita luego a MacGregor-Hastie, quien en su Picasso's Women reproduce un relato de Tristan Tzara, gran amigo de Picasso, sobre cómo éste le había relatado la pérdida de esa virginidad con una muchacha que servía vino en el bar encima del cual tenía él su estudio secreto. Era una muchacha de cabello rojo y cuerpo magro, a la cual había arrinconado contra un barril (37). Jusep Torres Campalans será mucho más parco en temas de mujeres, pero la anécdota respalda la verosimilitud de su existencia a través de la propia leyenda esparcida por Picasso, quien inicialmente llamó al enorme óleo sobre tela El burdel de Avignon, pues era justamente una escena de un burdel que, como he mencionado, frecuentaba en el Carrier d'Avinyo de Barcelona ${ }^{59}$.

Después de esta escena carnavalesca, ocurre el deslumbramiento de Jusep Torres Campalans por los cuadros de la época azul de Picasso. Antes de ese instante, no había visto nunca cuadros así, "con personajes tristes, hambrientos, bañados en una atmósfera extraña. Exangües" (105-106). Picasso le explica que lo que importa son los hombres y que por eso puede pintar sin fondo. No es azar que Aub se identifique con esta época de 
Picasso particularmente pues es la que se anuncia en 1901, con la Niña con la paloma ${ }^{60}$, y comienza con una serie de retratos de su amigo Carlos Casagemas quien se suicidó ese año, cerrando así un episodio de su vida bohemia compartida con Picasso ${ }^{61}$. Respecto al óleo sobre madera La muerte de Casagemas (1901), Norman Mailler (1995) sostiene que éste es su primer cuadro importante y que lo sentía tan íntimo que se lo enseñó a muy pocos amigos. Es en Evocación. El entierro de Casagemas, cuando cambia por completo su paleta de colores radiantes a un monocromático azul oscuro, apagado, como resultado de lo que, como afirma Hans L.C. Haffé (1965) es un cambio de actitud hacia los seres humanos: no se acerca a ellos con un espíritu de observación punzante y satírica, sino con empatía y con una ternura melancólica. Pinta mendigos, ciegos, guitarristas que viven en una atmósfera donde se experimenta la soledad, el hambre, la miseria cotidiana, o artistas pobres, como entonces lo eran él y su Casagemas, cuyo suicidio lo llenó de un manto de tristeza que cubrió durante cuatro años su obra. Y, no obstante, cuando pinta su entierro flotando sobre los dolientes que rodean su cuerpo, hay una adhesión a una forma de vida enlazada a la bohemia en las figuras de mujeres desnudas, vestidas solo con medias, que aparecen, en un mundo terrenal que reemplaza las tradicionales visiones celestiales y que flotan encima de la escena mortuoria.

Pero la identificación de Aub-J.T.C. con la época azul de Picasso está relacionada con la situación social que el malagueño ciertamente observó y que los anales de la biografía apócrifa también reflejan. Como sostiene Mailler:

Las condiciones sociales en Barcelona se deterioraban. Tanto los anarquistas como los conservadores estaban en pie; los suburbios de Barcelona eran famosos en toda Europa por sus pésimas condiciones de vida; las huelgas generales y de toda clase proliferaban; algunos trabajadores habían sido tiroteados en las calles 
(...). La injusticia de la vida social en Europa en el cambio de siglo era probablemente tan palpable para él como la lepra (...) (97).

Las fechas en las que Aub enmarca la segunda etapa de la trayectoria de Jusep Torres Campalans corresponden al período seminal: 1908-1912, un período dentro del cual se enmarca en la historia del arte la evolución del cubismo de Picasso y Braque que proponen y abrazan su fase analítica a partir de una serie de procesos experimentales muy similares y a menudo simultáneos. Ya en 1909 Picasso pinta durante el verano en Horte de Ebro, un óleo como Depósito de agua, que, sin dejar de tener algún contenido referencial, crea un solo objeto constituido por la técnica del facetado o fragmentaciones geométricas. La diferencia entre la hierba y el cemento de las casas no puede apreciarse por la textura de la superficie y la misma perspectiva se ha rendido a otros valores. En la primavera de 2010, Picasso y Braque pintan cada uno un óleo sobre tela oval igualmente titulado Mujer con mandolina. El primero va aún más lejos en la descomposición de la figura femenina, que conserva rasgos que revelan una sonrisa, pero está construida de tal modo que fondo y forma se funden, y cuerpo y mandalina constituyen una misma totalidad construida con fragmentos geométricos. Cada cual retrata igualmente a uno de los marchantes de arte decisivos de la época: Picasso a Ambroise Vollard, quien lo había expuesto junto con Gauguin, y Braque a Daniel-Henry Kahnweiler, crucial para las carreras de los dos cubistas. Por supuesto, Aub narra que Vollard le compra obras a Jusep Torres Campalans.

Los paralelismos continúan a lo largo del año siguiente y las obras son asombrosamente parecidas. Picasso pinta en Céret El acordeonista en el verano de 2011, y Braque Mujer leyendo, en el otoño del mismo año ${ }^{62}$. Ni Picasso ni Braque teorizaron 
sobre la naturaleza de sus exploraciones, pero el galerista Kahnweiler definió el cubismo analítico en su famoso libro Der Weg zum Kubismus (1920) como una tentativa de capturar dentro de la unidad del cuadro la diversa cualidad tridimensional del mundo externo. Comparaba el intento de la Gestalt con el cubismo en cuanto en ese modo de visión total de los objetos logrado a partir de la descomposición de sus elementos constructivos y de su juego combinatorio, el todo prevalece frente a las partes.

Como afirma Virginia Tovar Martín, el cubismo no sólo permite la diversificación y la superposición de planos, creando representaciones que rompen la perspectiva tradicional para lograr un penetración volumétrica del espacio, sino que, "sobre todo, dota de una unidad ficcional a la imagen mediante un estilo que impone su propia necesidad de coherencia ante una realidad desmembrada" (Tovar). Por ello, el período 1908-1912 es el de los años que marcan la adhesión incondicional de Jusep Torres Campalans a Picasso, tras su admiración de las épocas precedentes en su travesía, si bien por temperamento se identifica más con la época azul que con la rosa. Es en el verano de 2012 cuando Braque, de vacaciones en Provence, encuentra un rollo con adhesivos para imprimir patrones pre-pintados y acaba usando uno que tenía unas vetas de madera falsas a modo de collage sobre una guitarra. Un gesto al que Picasso se adhiere y extendiéndolo comienza a introducir en su obra los primeros papiers collés y objetos producidos industrialmente..$^{63}$

Finalmente, también en 1912, tras un viaje a El Havre con Braque, Picasso se aparta del cubismo analítico: pinta Recuerdo del Havre con colores que hasta entonces había evitado como efecto de la casi monástica consagración de ambos en busca de descentrañar la teología profunda de las formas, oficiando como "sacerdotes del sumo 
espacio", según Mailler, ocupados de encontrar un otro lenguaje para la descomposición, o para representar el movimiento a través del tiempo y el caos urbano (403-404).

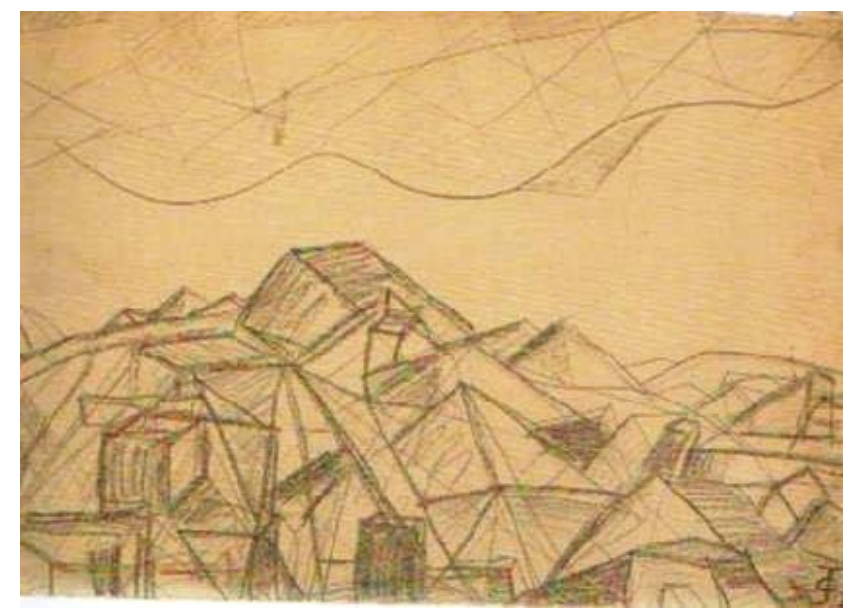

Ilustración 7: Jusep Torres Campalans, Paisaje a los Pirineos 1912, lápiz sobre papel. Colección Federico-David Álvarez Aub

Durante parte de su búsqueda analítica firmaban sus cuadros sólo en el dorso y jugaban con el anonimato, indiferentes a que sus cuadros pudieran ser confundidos. A partir de esa obra, poco a poco, Picasso se va alejando de la oscura profundidad del período analítico "y redujo el cubismo a una decoración”, según Mailler, quien sostiene que desde entonces

Animó las paredes de tal forma que aún sigue avergonzando a los decoradores: mientras que la tensión para Picasso, los primeros años del cubismo, había estado en crear organismos libres de magnitud y de carácter (es decir, que no fueran claramente figuras, bodegones, rascacielos o paisajer) y con todo de una presencia plena -criaturas de gran complejidad- el cubismo sintético frenó tales ambiciones... (405).

Es justamente en ese año cuando Jusep Torres-Campalans se distancia de la vía picassiana. Lo que resulta más interesante es ese juego aubiano entre el deslizamiento de la travesía artística de Picasso a la de Jusep Torres Campalans y al modo en que para la propia escritura de su biografía se apropia de las estrategias cubistas para estructurarla y, 
aprovechando las figuras múltiples que aparecen en el relato, se convierte a su vez en crítica del espíritu de la época.

Así, sólo hasta 1912 — fecha de la anterior obra que hábilmente Aub introduce como "atribuida" a Jusep Torres Campalans- éste sigue a Picasso, repitiendo en su propia trayectoria la del genio malageño, y entonces, cuando sólo le faltan dos años para que se niegue a pintar más, "desemboca" en la pintura del holandés Pieter Cornelis "Piet" Mondriaan, que desde seis años atrás, firmaba sólo como Mondrian, con una única a. Precisa Aub — cuyo serio conocimiento del desarrollo de las vanguardias se compagina maravillosamente con la dimensión de su broma artístico-literaria- que después de impugnar a Kandisnky, Jusep Torres Campalans hizo una amistad con Mondrian. Tiene largas conversaciones con él, por fuera de los círculos artísticos, que cierto hastío le ha llevado a dejar de frecuentar, y que llega a comprender la búsqueda del holandés que trasciende el juego de las apariencias para aspirar a "la base".

Por ello termina influenciado por sus teorías, o quizás por la comprensión de que encarnó su aspiración a inventar

una pintura que esté, que sea de verdad a la medida del hombre (...), una pintura que sirva para todos los tiempos, una pintura que no sea una moda, sino un modo de pintar. Un modo humano de pintar (...), un relámpago, nada de pupila, ni de habilidad (114).

Voy llegando a la convicción -escribe un año antes de su partida hacia Méxicode que la trama y urdimbre de los hombres varía poco de forma, sí, a lo sumo, de colores y de que podemos hacer poca cosa. Tal vez hay un hilo, un cabo, del que podemos tirar para deshacerla. Muy pocos dan con él. Yo no, desde luego; por eso las pinto (135).

Y agrega Max Aub: "El que había anatematizado la pintura abstracta de Kandinsky, sigue un proceso parecido al de Mondrian, con quien traba entonces 
amistad". Una amistad que Aub califica de "tranquila", llevándolo "a una nueva manera que solo discutía con el holandés y los pocos que lo frecuentaban". No hay que olvidar que antes de las obras de abstracción geométrica asociadas al movimiento De Stijl, también conocido como neoplasticismo, Mondrian pintó repetidamente flores como la obra, expuesta en el Museum of Modern Art, MoMA, en la exhibición Inventig Abstraction, 1910-1925. How a Radical Idea Changed Modern Art (2013), "Red Amaryllis with Blue Background" (1907) que más allá de la libre descripción del mundo natural reflejaba un interés conectado a la teosofia ${ }^{64}$. En un cuaderno de notas deja constancia de su impresión: "Para Mondrian, la hermosura, la fealdad, el bien, el mal, son apariencias. Busca la base”. Y termina influenciado por sus teorías.

Más aún: Mondrian comparte plenamente la predilección que Jusep Torres Campalans tiene, como hemos visto, por el cubismo analítico de Picasso, que no por azar coincide exactamente con la supuesta madurez de su obra y con el distanciamiento posterior a 1912. Mondrian sostenía de hecho que había partido del punto a donde Picasso había llegado después de avanzar en la dirección adecuada, pero sin ir lo suficientemente lejos. En Piet Mondrian: Toward the Abolition of Form, uno de los ensayos publicados en el catálogo de la exhibición del MoMA arriba mencionada, YveAlain Bois precisa:

As Mondrian undestood the idiom of Analytic cubism, it formally consisted in 1) a grid formation that becomes gradually more orthogonal as well as blurry before coming in contact with the edges of the canvas; and 2) a restricted, tonally even palette that undescore the growing alloverness of the distribution of rectangles. This pictorial language, he thought, was particularly adequate to his new goal, that of showing in his art the process of a kind of digitalization, one could ever say of pixelation, of the outside world solely through the horizontal\&/vertical opposition, which he was beginning to conceive as the mark of the 'universal' lying behind all 'particular' phenomena (206). 
Cuarenta años después de que Jusep Torres Campalans abandonara el arte, cuando ocurre su encuentro con Max Aub en Chiapas, Jusep Torres Campalans califica la pintura de Mondrian como "pura expresión de su pureza", en tanto declara que no le interesa el Guernica. Esta pureza guardaba relación con su propia intención creadora. Como remarca Oleza Simó, la dirección fundamental de la búsqueda del artista catalán, era hallar "un nuevo alfabeto, unas nuevas palabras, un nuevo lenguaje para la pintura, como no se cansa de repetir Torres Campalans, o si se quiere para la pintura y para la literatura, un lenguaje artístico autónomo" (Antagonismo de apócrifos, 6 ).

La "autonomía", puede ser vista como liberación de la dictadura de la realidad, paralela al proceso a través del cual Mondrián desecha el cometido de la figuración y preconiza el arte abstracto que en un momento, iluminado por la dialéctica hegeliana, desembocará en el neoplasticismo.

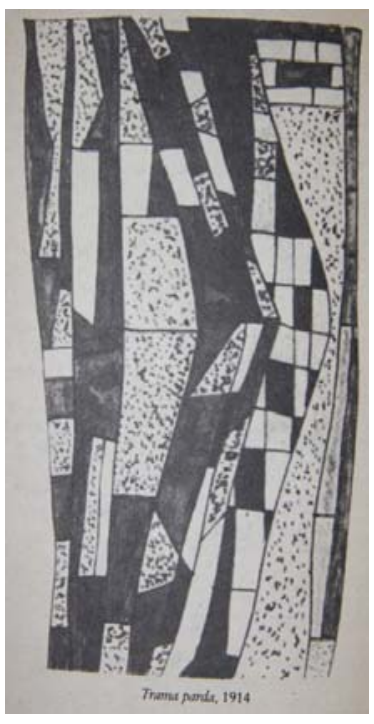

Ilustración 7: Jusep Torres Campalans Trama Parda, 1914. Tintas de color. Propiedad de Pablo Picasso

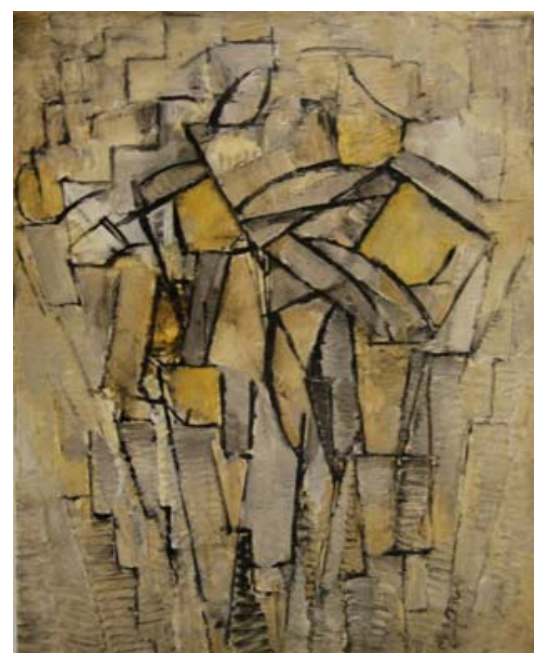

Piet Mondrian Composición en gris azulado y amarillo, 1912-1913. Óleo sobre lienzo. Museo Thyssen-Bornemisza 


\section{Sintetiza Yve-Alain Bois:}

The goal is no longer to encode the spectacle of the real Word in a geometric pattern, but to enact on canvas the laws of dialectics that governs this world (...). It is no longer the spectacle of the worlds that is encoded, but the elements of the art of painting itself -line, color, plane, each reduced to basic ciphers whose interaction constitutes a 'new reality' (227).

Y argumenta que si bien Mondrian no fue el único "utopista" entre los pioneros del arte abstracto, sí fue el más consistente. Su utopía no está lejos de la que busca J.T.C.. De hecho, por la misma época en la cual traba amistad con él, Mondrian ha tenido su encuentro con el cubismo, un período que dura hasta 1914, exactamente los dos años que coinciden con el período final de la trayectoria artística de Jusep Torres Campalans, y aún no ha asumido las indagaciones del neoplasticismo posteriores a 1920. Aub comprende ese impulso que Bois (2013) sintetiza así: "He conceived of his art and of everything else (society, man, the world at large) as in perpetual evolution toward a future universality, a utopian Golden age when art would dissolve into life" (226).

Fernando Huici, comisario de la exposición Jusep Torres Campalans. Ingenio de la Vanguardia en el Museo Nacional Centro de Arte Reina Sofía, cita las reservas de pintores como Antonio Saura, quien en El pintor imaginario considera abusiva la aplicación del término "cubista", y, sin embargo, destaca la fragmentación como uno de los factores principales de la credibilidad de la perspectiva cubista de su quimérico colega (24). Aub escribe la biografía de un personaje que crea - y renuncia - el arte de una época donde todos los hilos de la continuidad se han reventado y el ser humano se aboca a la pregunta por las reservas del arte y de la vida. 
Muchas de las consideraciones que Aub como biógrafo, o Jusep como biografiado, realizan sobre el cubismo, tienen una función meta-literaria y meta-artística sobre el propio libro y las obras que lo acompañan. Se deslizan de uno a otro terreno, ensanchando sus fronteras. De hecho, lo que explícitamente se propone al narrar la vida y obra del pintor que no dejó más rastro que un grupo de obras escondidas en un guardamuebles y un conjunto de notas dispersas, es emprender, a través de la escritura, un proceso de "descomposición, apariencia del biografiado desde distintos puntos de vista; tal vez, sin buscarlo, a la manera de un cuadro cubista" (21).

\section{El artificio del pintor imaginario}

En el ensayo El pintor imaginario, uno de los más bellos textos que se hayan escrito sobre Max Aub y su biografiado, Antonio Saura define la novela como

una enmarañada estructura, cuyo polifocal acercamiento acaba por conducirnos inexorablemente a su punto de partida. Es decir, al artificio, al centro del temblor, al propio autor al que su personaje traiciona a pesar de su empeño de verosimilitud. Demasiado fuerte la fuerza subterránea del humor, demasiado escritor el pintor con sus fantasmas prestados, demasiada trampa para tan bella trampa (91).

Línea a línea sería necesario transcribir este texto precioso que el artista y escritor español entregó a los editores, en su forma final, apenas cinco días antes de morir, en 1998, si bien lo había leído por primera vez en 1982, en la Universidad Internacional Menéndez Pelayo durante un seminario organizado en el décimo aniversario de la muerte de Aub. No se me escapa la rara casualidad de que el año de la publicación de Jusep Torres Campalans, 1958, fue el mismo en que Saura comenzó a pintar su serie de pintores imaginarios, ni otras coincidencias que acercaban sus renuncias — también en un momento de su carrera Saura abandonó la pintura al óleo, frente a la cual tenía una 
intención tan impecable como la de J.T.C.- o que, como Aub, pudiera deslizarse en un lugar fronterizo entre el arte y la literatura, como hizo con el Archivo Pintiquiniestras con 16 litografías sobre los textos de Camilo José Celá, y no me sorprende que murieran, también por azar, exactamente el mismo día, un 12 de julio. Si alguien comprendió la visión de Aub en su Jusep Torres Campalans, desde el centro del temblor, fue Saura. Tomo por ello diversos fragmentos que iluminan su biografía remitiendo al texto irremplazable que forma parte del libro Max Aub: 25 años después, dirigido por Ignacio Soldevilla y Dolores Fernández Martínez.

Lo sitúa en la cúspide de la literatura del testimonio fabulatorio y sostiene que el autor se desdobla con singular veracidad en un mundo ficticio convirtiéndose no sólo en un biógrafo de lo imaginario, "sino más bien en un investigador que indaga en el mismo proceso de la investigación", actitud de un tipo de distancia (diríamos meta-literaria) que hace posible la realidad de la obra (92). Sostiene en un juicio acerado que "Campalans resulta ser mejor escritor que pintor, mientras que el creador literario del fantasma, gran escritor, no es más que un mediocre pintor" (94). Igualmente destaca cómo los dos momentos culminantes que marcan la existencia de Campalans son la creación del cubismo, en cuyo ambiente se desarrolla, y la guerra de 1914, que lo decepciona al punto de buscar la huida, "a modo de un Rimbaud pictórico" (95), para tratar de encontrar, en un universo cultural ajeno, una vuelta a algún modo de pureza.

Contrariamente a Paul Gauguin o a Armando Reveron, el pintor venezolano cuya vida y obra Max Aub sin duda conocía - considerados ambos como los robinsones de la mitología artística, cuya pasión creativa se desarrolló en un voluntario aislamiento que constituyó verdadero estímulo creador- la dimisión de Torres Campalans, su alejamiento de la creación plástica, obedece a un verdadero hundimiento moral. Anotemos también que Marcel Duchamp (1887-1968) - 
Robinson intelectual que no se cita en el libro- pudo haber servido como lúcido modelo de renuncia (95).

Ciertamente, Aub establece desde el principio en la biografía apócrifa la fuga del lugar de origen, y el paralelo impulso de ir hasta el fondo de los múltiples espacios de la vida errante que comienza en la adolescencia de Jusep Torres Campalans. Cuenta que a los doce años éste huyó de su pueblo a Gerona, y que de ese desplazamiento surge lo que llama su obsesión de verticalidad. Como él mismo, se va a vivir a Barcelona. Pero J.T.C. lo hace persiguiendo a una actriz que lo desdeña. El viaje le permite conocer a un pintor principiante, Pablo Ruiz (Picasso), quien lo lleva a ver a Chelito, que entonces hacía furor en el teatro del Paralelo, y cuando éste le confiesa que jamás ha visto una mujer desnuda pues sigue los consejos de cierto libro escrito por un sacerdote y espera a casarse para verla, lo lleva, como ya he mencionado, al burdel, donde viven una escena que, según el narrador, inspiró el cuadro fundador del cubismo, que acabaría por llamarse, Les demoiselles d'Avignon (Las señoritas de Avignon).

Buscando huir del enrolamiento en el ejército, o del mal de amores, Jusep Torres Campalans acaba en París — haciendo eco a los desplazamientos de Picasso de Barcelona 


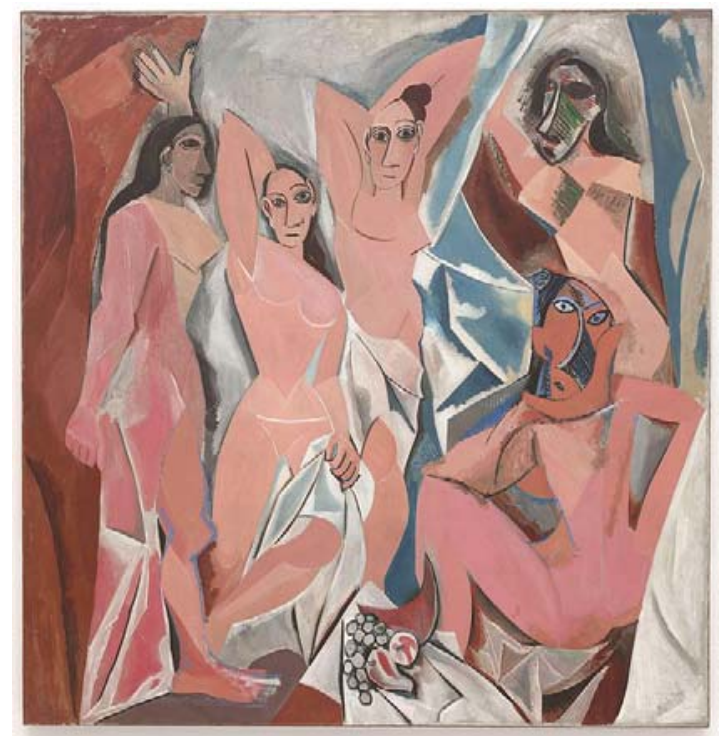

Ilustración 8: Picasso. Las señoritas de Aviñón 1907. Óleo sobre lienzo.

Museum of Modern Art, Nueva York

a esta ciudad-, donde recorre repetidamente el Louvre y descubre el mundo del arte y allí se reencuentra con Picasso y coincide con Juan Gris, a quien considera un imitador y oportunista, así como con otros artistas de la vanguardia modernista - Chirico (18881978), Modigliani, Chagall (1887-1985)—, hasta dar con Mondrián quien marca para él la frontera que antecede al silencio en su propia creación.

Tras haber vivido la Barcelona de comienzos de siglo, y el París de la belle époque, donde se aúna al sueño cubista, su distanciamiento respecto a los nacionalismos que instan a la guerra es total. Para fugarse de ésta, se marcha -como Aub mismo-a México ayudado por Alfonso Reyes, a quien no sólo le endilga la amistad de Jusep Torres Campalans, sino la tarea de ensanchar la de por sí larga correspondencia que sostenían desde 1940 y hasta la fecha de publicación de la biografía de J.T.C. ${ }^{65}$. A su hastío del mundo, a la insuficiencia de una pintura que no logra causar los incendios que sí causan las bombas, se suma el sino de los "transterrados": la compañera de Jusep Torres Campalans, Ana María Merkel ${ }^{66}$, personaje de inspiración real es amenazada por 
su nacionalidad y obligada a abandonar París en cuestión de horas. "Sólo el día en que vuelva a hundirse en la nada el sentimiento de patria podrá pensarse en un mundo justo. Un mundo..¿entiendes?, un mundo, no un país” (180), le explica J.T.C. a Alfonso Reyes, en 1914.

Dolores Fernández Martínez apunta en su ensayo Max Aub y Ana María Merkel. Ficción y realidad de una artista desconocida que en su Jusep Torres Campalans, novela "basada en una ingente documentación sobre Picasso y el ambiente artístico parisino previo a 1914”, el límite entre ficción y realidad es un rompecabezas: “Tendíamos a creer que el personaje de Ana María Merkel, la compañera del pintor, era totalmente inventado, pero esta mujer, coetánea de Max Aub, realmente existió, y la dificultosa búsqueda de su rastro nos descubre la penuria de la imagen de las mujeres artistas en la literatura, fiel reflejo de la tradicional desigualdad en el reconocimiento social de su valía" (95). Nos revela cómo Anne Marie Merkel (o Mme. Repsz) era una bella escultora alemana, delgada, con el pelo al estilo garçon, inteligente, culta y con unos enormes ojos tristes. Y sostiene que su belleza espiritual de aire medieval cautivó al famoso fotógrafo André Kertesz (1894-1985) durante su estancia en París entre 1926 y 1928. Era una de aquellas mujeres modernas que preconizaban en el Café du Dóme en Montparnasse una nueva era $^{67}$. Algunas de las fotografías de Anne Marie Merkel realizadas por Kertesz fueron reproducidas en catálogos y revistas. Una muy hermosa, de 1926, fecha muy posterior a los hechos que Aub relata en su J.T.C., se expuso en la galería Au Sacre du Printemps en 1927 y, en el mismo año, en Zaragoza, en el Tercer Salón Internacional de Fotografía.

Aub hace de J.T.C. un artista que no tiene reparo en dedicarse a pintar con la libertad financiera que le ofrece su unión con Ana María, que ocurre justo cuando en 
1907, año de la creación de "Las señoritas de Avignon", se radica en París. En la biografía apócrifa ella es también una pintora alemana fauve de pocas carnes e inteligentes ojos verdes, como la artista que retrató el húngaro Kertesz, pilar de la concepción del ensayo fotográfico. En el catálogo de las obras de Aub se refuerza el desdén con el que J.T.C. mira a las mujeres, con la anotación del crítico Town: "Como pintora su obra ofrece escaso interés" (312). Entre 1908 y 1914, época durante la cual mantiene una relación con ella, que le lleva doce años, J.T.C. pinta la mayor parte de sus cuadros.

No por azar, su período de creación más intenso se inicia el año en que se acuña el término cubismo. El catalán no lo copia: se apropia de su desarrollo artístico con la osadía que sólo el humor puede proveer. En páginas posteriores me detendré en las obras que en 1942, según Aub, estaban destinadas a una gran exhibición en Londres, aunque según su biógrafo impostado, poco o nada le importaba a J.T.C. saber lo que había sucedido con las piezas que no había podido destruir, puesto que a fines de los cincuenta, más de cuatro décadas después de su huída, ya había alcanzado lo que deseaba: "No hacer nada". 


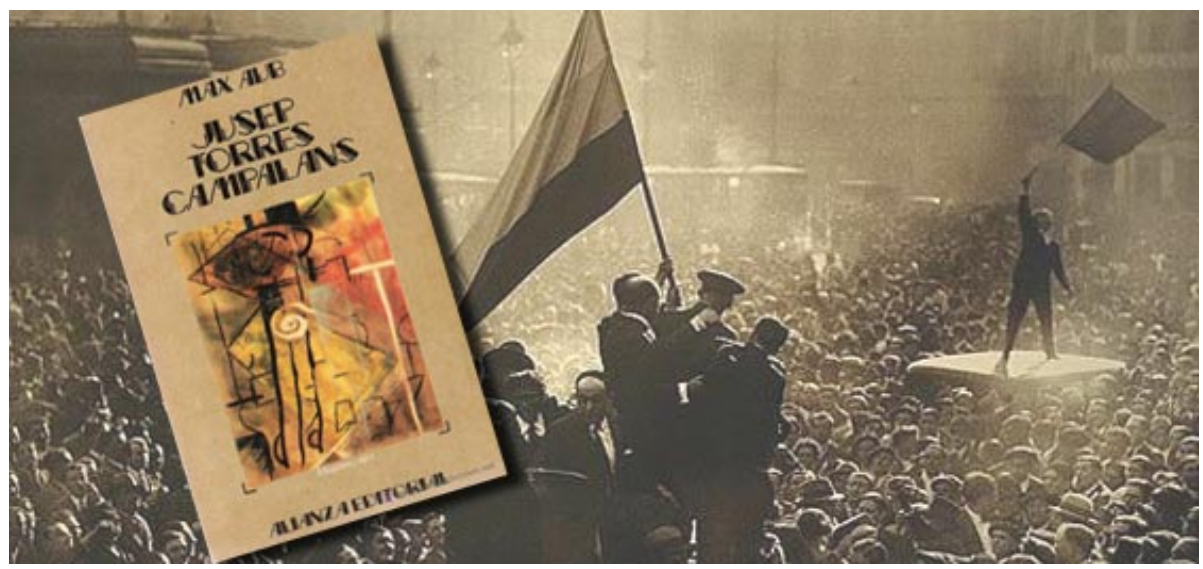

Ilustración 9: Portada de una edición de Jusep Torres Campalans.

Collage con imagen del transfondo de la guerra, encontrado en la web

La huida de Jusep Torrxces Campalans hacia México en 1914, al inicio de la Primera Guerra Mundial, marca el final de su oficio de artista y la renuncia a cuanto inicialmente había buscado con una pureza de intención que no correspondía a la habilidad de su mano. Aunque no le faltaba razón al apócrifo crítico Miguel Gash que dictamina que carecía de la calidad de un Matisse, de Picasso o de Mondrian, como Aub precisa, cada trazo de su pintura, respondía al afán incontenible de llegar más allá. Pero ese horizonte acaba por hacerse imposible en medio de la opresión de un tiempo donde el miedo, un miedo inimaginable, capaz de cercarlo todo, se anuncia, y su obra desemboca en el último límite del sinsentido: la inacción. Es obvio que en esa época de antesala de la Pimera Guerra, Aub cifra su propia experiencia en la Segunda Guerra Mundial en el momento en que escribe la obra, cerca de una década después de ésta. Al datar sus propias pinturas, en años anteriores a ambas guerras, las sitúa en la última frontera de la posibilidad, como si hiciera eco de la admonición de Theodor W Adorno, acerca de que después de Auschwitz ya no es posible escribir poesía, ni por ende, pintar. No se trata 
sólo de que sea un pintor fracasado, sino de su convicción moral respecto a que el arte ya no sirve para nada.

De facto, las obras que le atribuye Aub son mucho más tardías en cuanto a los años de su ejecución real, aunque de fecha imprecisa, pero en todo caso, anteriores a 1958, y están firmadas con el inconfundible monograma de las iniciales: J.T.C. En ese irse a otro continente que es narrado como una renuncia al arte y como un desaparecer sin dejar más rastros que una obra custodiada por un crítico que igualmente morirá bajo las bombas, estando en su propia casa, se advierte la huella del tiempo, no del biografiado, sino del que ha vivido el biógrafo apócrifo. Aub es un hombre más de esa generación entera que deserta de la Europa en guerra, donde no parecía posible ir realmente lejos del horror y las persecuciones. Una generación de exiliados que se embarca en busca de reinventar la vida en algún lugar suficientemente lejos, en una península donde la imaginación pueda crear de nuevo la posibilidad de enseñorearse sobre cualquier espacio del mundo. Jusep Torres Campalans convertido en Don Jusepe y repleto de hijos en las sierras mexicanas ha encontrado un lugar lejos del extravío europeo donde refundar la vida. El periplo marca también los sitios de la vida errante del biógrafo y sus desapariciones y reapariciones. En su propio caso, al fugarse a otro continente llevando consigo la memoria de la Guerra Civil española, renunció a los ejercicios de la ficción extrema, de la cual no volvió a haber rastro durante década y media, hasta que lo ocupó la figura de Jusep Torres Campalans.

Escribe Saura que

Para Max Aub, el exilio, a pesar de todo su dolor, a pesar de su acentuado pesimismo, fue indudablemente fructífero desde el punto de vista creativo. No fue así para su imaginado pintor, quien, a partir del momento en que la historia se 
parte en dos, siente lo abandonado - vanguardia, pero también la lucha política- como un pesado lastre que es preciso aniquilar (108-09).

Biógrafo falso y biografiado apócrifo profesan la ironía, o si se quiere la levedad de quien a fin de cuentas está más allá de todas las militancias. Un tono que se resume de modo perfecto en las últimas líneas del prólogo de la monografía simulada cuando precisamente Aub confiesa que oyó por primera vez el nombre de Jusep Torres Campalans en una cena en la que esperaba junto con Bonnard, Voillard y Maillol la llegada de Picasso:

— ¿Qué fue de él? - preguntó uno de nosotros.

-Desapareció sin dejar rastro. Tenía talento (28).

En el final de su ensayo Introducción al pintor imaginario, Saura habla de "las parcelas de misterio y poesía que habitan sus páginas y que contribuyen a crear el poder fascinante y encantatorio de esta insólita biografía" y elige, a modo de cierre, en la antesala de la huida de Jusep Torres Campalans de España a México, una escena que nos ilumina:

Al despedirse y al oír el anuncio de la visita de Rubén Darío, Torres Campalans, volviendo sobre sus pasos, le dice [a Alfonso Reyes] a modo de despedida: ¿¿Recuerda usted aquél Canto de esperanza que parece hecho para hoy -y para siempre- y que empieza 'un gran vuelo de cuervos mancha el azul celeste', ¿por qué no le pregunta si ese verso se lo dio el último Van Gogh', con esa evidente relación con la pintura de Van Gogh - y su clima de abrasador presagiotermina este fervoroso homenaje escrito desde la tumba del pintor desconocido 110).

\section{La pintura-ficción}

Fernando Huici, curador de la ya mencionada exhibición del Museo Reina Sofía de Madrid, analiza cómo fue que Aub le dio "vida en verdad verdadera" al pintor que acabará desengañado de los ideales de la vanguardia artística y de la revolución. 
Partiendo de la bibliografía temprana sobre esta "novela trampantojo" evoca la compleja síntesis entre fabulación y realismo y la "muy diestra aleación que entremezcla un caudal de datos objetivos y peripecias ficticias, personajes reales junto a otros puramente imaginarios, sin que se perciban en ningún momento las costuras que delimitan el tránsito entre contenido documental e invención" (17). Resulta clave, precisa, que para borrar la franja entre lo real y lo ficticio y lograr la aceptación de su existencia como veraz, Aub recurra a dos equívocos: la combinación entre erudición real y erudición imaginada o fingida, y a los paralelismos entre lo textual y lo plástico que son un trampantojo y alcanzan "un límite crítico de la percepción que, paradójicamente, ciega los sentidos a toda conciencia de su naturaleza ilusoria" (21).

En efecto, la casi fidedigna relación de hechos cronológicos, las alusiones verídicas, no lograrían hacer de carne y hueso a J.T.C., como de modo incontrastable lo hace la elaboración real de los trabajos de arte e imágenes pseudo-documentales que refuerzan la verosimilitud de su existencia: fotografías de atribución apócrifa, caricaturas y pinturas que copian los estilos en boga y que ha realizado, si no con gran destreza, sí con el conocimiento suficiente como para insertarlas de algún modo en el panorama del arte moderno.

En el mismo catálogo del Museo Reina Sofía, un artículo de Josep Pla da cuenta de cómo Jusep Torres Campalans "vivió intensamente el dramatismo del proceso del arte moderno: fue primero fauve, después cubista, luego cultivó el arte de los negritos; fue surrealista y, finalmente, abstracto" (148). Luego, Pla se regodea en evocar el éxito que la exposición de J.T.C. tuvo en México, a partir del instante en que el agregado cultural de la embajada de los Estados Unidos — "un señor de una agudeza extraordinaria, 
extremadamente sensible a las formas del arte más reciente"- comprara varias obras. Cuenta cómo el coleccionismo mexicano situado más à la page se volcó en adquirirlas, secundado por los críticos más notables: José de la Torre escribió: “Al fin hemos encontrado el eslabón quenos faltaba para comprender inteligentemente la pintura española" (149). Y "el profundo ensayista Jorge Malinos" acotó: "Para los que como yo hemos conocido a Torres Campalans, la exposición no ha sido, en ningún caso, una sorpresa: hace veinticinco años que considero este pintor como el verdadero iniciador de Pablo Picasso". Pla concluye que "el número de snobs, de imbéciles, de unánimes, de «gogos», de aduladores que viven en el ámbito de la sociedad es inenarrable» (150), y, en contrasposición con la recepción que tuvo entonces la obra de J.T.C., transcribe la respuesta que le dio Max Aub al crítico francés Rober Grenier cuando éste le preguntó si era pintor: “¡No señor! ¡Qué va! Hice unos dibujos que manché con tinta sobre un papel, mojé mis obras en la espita de la cocina de mi casa para darles el correspondido lavado, firmé Torres Campalans y ahí va...” (151).

En cualquier caso, su exhibición en el Museo Reina Sofía en 2003, supuso, como afirmaron los críticos, la entrada en un museo de la pintura-ficción. Juan Manuel Bonet, entonces director del Reina Sofía, reconocía que en más de una ocasión había visto el libro catalogado en el apartado de las monografías de arte, lo cual era una prueba palmaria de que la ficción estaba bien planteada, y que a través de su obra apócrifa Aub se había incorporado a la saga de escritores-pintores del 27 , entre los cuales estaban Federico García Lorca, Rafael Alberti, Agustín Espinosa, José Moreno Villa, entre otros.

Pero el propósito de su obra sobrepasaba la ilustración de obras literarias o la intención de la mera incursión pictórica: son apropiaciones estilísticas que cumplen la 
función de dar existencia real a Jusep Torres Campalans, como sólo puede la ficción extrema; pero sobre todo son un ejercicio deconstructor y crítico de la pintura de su tiempo: obras reflejas, obras bufas, obras especulares que desmitifican, obras que usan la mentira de su génesis para decir, sin decir las verdades a quemarropa del mordaz Aub.

De cualquier modo, bien vale detenerse en las distintas piezas que configuraron este juego endiablado del conjunto de una obra concebida como pintura-ficción y, hecha con los pinceles de un escepticismo extraño porque sin dejar de contener cierto grado de admiración a las primeras etapas de Picasso, o a la propuesta de Mondrian, acaba por instaurar una duda corrosiva sobre el arte moderno y sobre el tiempo que lo ha producido. La información sobre el artista catalán que paulatinamente irá pintando con mayor libertad y menor conexión a lo referencial, pero acabará hastiado del arte y mundo moderno, se construye duplicando las exploraciones modernistas, pero sobre todo la trayectoria de Picasso, y estructurándola al modo de revelaciones fragmentarias sobre las obras y los rastros biográficos perdidos o voluntariamente destruidos.

De la afición de copista por la buena letra, nace, según Aub, la inclinación por la pintura de J.T.C. y en ese interés inicial lo marca, como una clave, el simbolista Odilon Redon $^{68}$. Aub menciona que las primeras obras de J.T.C. acusan una influencia de Redon y concluye —enmascarándose bajo su voz - que "la pintura o es literatura o no es nada" (89). La elección de este precursor no obedece soloa a que su simbolismo fantástico fue un antecesor directo del surrealismo visual, sino a que la relación entre su obra y la literatura.

De hecho, fue a través de la novela de culto "À rebours" (Al revés) publicada por Joris-Karl Huysmans $(1884)^{69}$ que el arte de Redon, hasta entonces prácticamente 
desconocido, comenzó a conocerse públicamente. Retirado del mundo, el protagonista Des Esseintes invierte el horario vital y prefiere viajar con la imaginación sin moverse del sillón de su mansión, donde el arte, los textos científicos y la belleza artificial lo rodean en medio de la intensidad nocturna. Este decadentista colecciona dibujos de Redon. Como el mismo simbolista, Huysmans-Des Esseintes, profesa además un culto a Edgar Allan Poe, quien anticipa el atrevimiento aubiano creando una "broma" periodística, un temprano ejemplo de ficción extrema, por la calidad literaria de su deslizamiento en la realidad, al publicar en 1844 en el periódico Sun de New York, una serie de crónicas sobre el modo en que el europeo Mr. Monck Mason habría cruzado el atlántico en tres días. La antología publicada en seis ediciones incluía una ilustración con un diagrama del globo que aumentó su credibilidad junto con la mención de personajes reales ${ }^{70}$.

Odilon Redon recreó a su vez el universo alucinado de Poe, cuya obra conoció gracias a las traducciones de Baudelaire y de Mallarmé (1842-1898), con quien hizo a la vez una obra a dúo. Su ilustración El ojo como globo grotesco se dirige a lo infinito (1882) es parte del álbum Edgar Allan Poe y alude a la historia de este del vuelo en globo.

En la edición del libro de Max Aub, Teatro mayor, Obras completas, vol. VIII, bajo la edición de Joan Oleza Simó, y con un estudio introductorio y notas de Manuel Aznar Soler, éste establece a su vez una estrecha relación entre el tercer acto del drama San Juan y la narrativa de Allan Poe. En todo caso, la literatura alucinada del gran maestro del cuento moderno norteamericano, pilar de la literatura del suspenso y antecesor también del género de ciencia ficción, marca de modo decisivo la obra plástica de Redon ${ }^{71}$, que le es tan caro a Jusep Torres Campalans. 
Entre las obras exhibidas en el Museo Reina Sofía, hay una pieza en técnica mixta sobre papel, titulada Copia de unas rosas de Odilon Rendon, y fechada en 1907. J.T.C. toma el tema de las rosas apropiándose de una de las obsesiones del simbolista que creaba en la frontera de lo onírico ${ }^{72}$, y que después de abandonar el tenebrismo y su fijación por lo grotesco, pintó una y otra vez flores usando la luminosidad del color para recrear el universo de mitos como Ofelia.

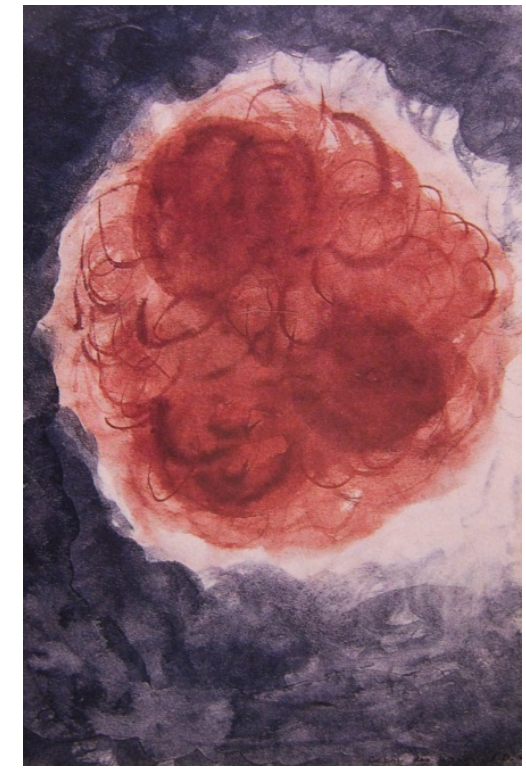

Ilustración 10: Jusep Torres Campalans, Copie des roses d'Odilon Redon 1907 Técnica mixta sobre papel. Colección Federico-David Álvarez Aub

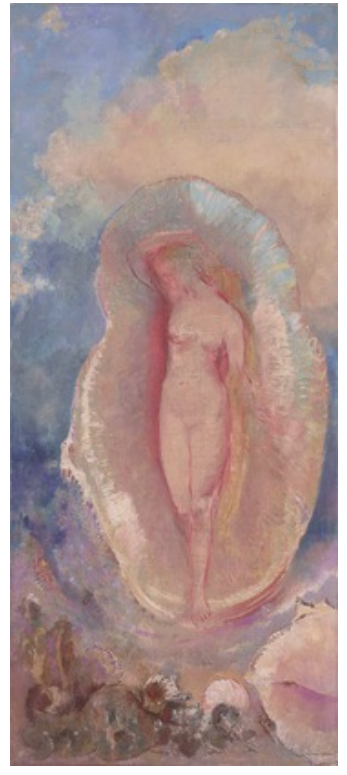

Ilustración 11: Odilon Redon, El nacimiento de Venus

1912, Óleo sobre lienzo Regalo de Ian Woodner Family Collection

$\mathrm{Su}$ "copia" en realidad no lo es pues no se inspira en un original semejante sino que lo crea al declarar que reproduce una obra inexistente. La pintura que crea un antecedente de sí, acentúa la abstracción que anticipaba Redon, con trazos rápidos, como ejercicio de la mano que se atreve a jugar. La composición puede evocar vagamente la pincelada de El nacimiento de Venus de Redon, si bien en el interior de la nube que la rodea aparece su cuerpo, representado de modo figurativo, mientras en la desenfadada 
versión de J.T.C. sólo quedan las formas sugeridas, manchones circulares de azul y rosa, separados por un luminoso manchón blanco. Lo que se advierte aquí es una lúdica deconstructora que afirma haber copiado una obra inexistente, y una visión tan voluble como el siglo en el que hace una pintura ficticia pensando en las flores decimonónicas de Redon, como si regresara con sus pinceles el germen de la modernidad que se desbocó en la vanguardia.

En su orden, el primer dibujo que Aub presenta en el libro es el monograma J.T.C. (16), formado con las iniciales del nombre de Jusep Torres Campalans que también se usó en la carátula interior del catálogo de la exhibición en el Museo Reina Sofía. Aunque aparentemente este primera representación gráfica es una exaltación de la autoría, su sentido es todo lo contrario: una burlona displicencia frente a la autoría, o más exactamente una estrategia que caricaturiza iconográficamente el culto al autor, que resulta paradójicamente esencial en su libertad creadora.

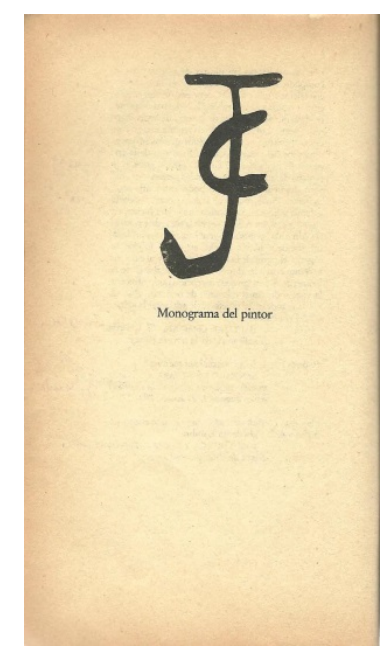

Ilustración 12: Monograma de Jusep Torres Campalans 
El origen caricaturesco de esta gráfica, que usa el mismo signo para unificar la " $J "$ de Jusep con la "T" de Torres, y le superpone un pequeña "C" puede rastrearse en la siguiente consideración que Aub atribuye a J.T.C.:

Matisse $^{73}$ me decía el otro día que los artistas japoneses de la gran época cambiaban de nombre muchas veces en sus vidas; muchos, de los más grandes, nunca firmaron sus obras. Ahora, a todos, no les importa más que su firma, la quieren vender, porque de eso se trata, de venderse; por eso voy a hacer un cuadro enorme, de cincuenta o sesenta metros por lado, en que no haya más que mi firma. Y será la obra cumbre del arte contemporáneo (25).

En una carta dirigida a Marra-López, cómplice suyo de la exhibición de

Campalans en la galería Excelsior, Aub escribe:

Lo que me ha ayudado a sobrevivir, como escritor — es decir, como hombre- es curiosamente, mi indiferencia hacia lo que pudiera parecer mi obra al público (...). El desprecio del éxito - sentimiento fundamental de los surrealistas, que nunca fueron ejemplo para mí- fue y tal vez aún es mi sentir profundo (Exile 219).

Esa mezcla de indiferencia, un rasgo clave de la radicalidad con que un Marcel Duchamp rompe la historia del arte burlando la demarcación entre lo que es y no es arte, es esencial para entender el modo en que erosiona la autoría. 


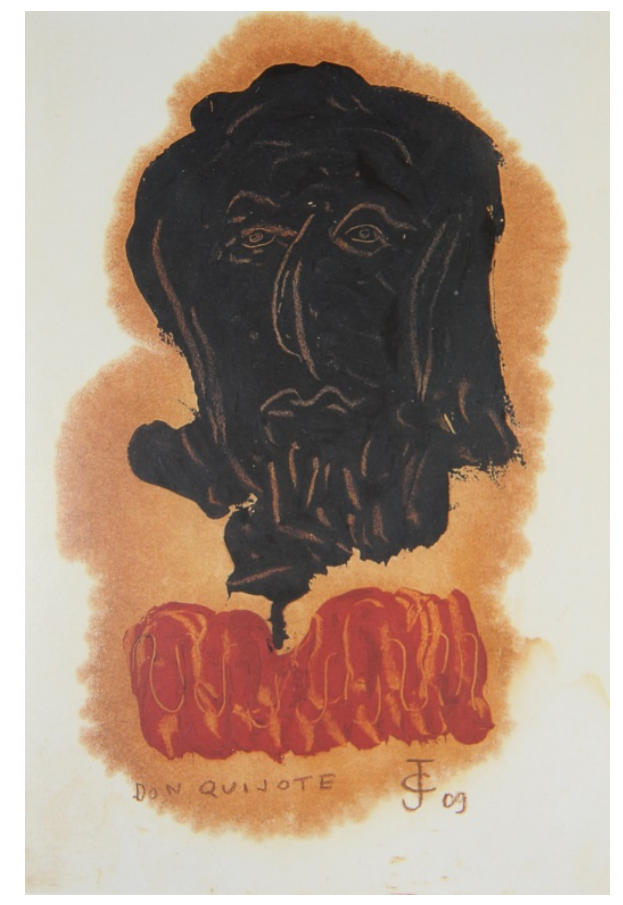

Ilustración 13: Jusep Torres Campalans, Don Quijote 1909

Óleo sobre papel, $25,5 \times 17,8 \mathrm{~cm}$

Colección Alí Chumacero, México

No es azar que también el monograma de Jusep Campalans aparezca en un óleo firmado con esta rúbrica y fechado en 1909 — dato que no da indicio sobre su fecha real de realización. La obra se titula Don Quijote y presenta en un manchón negro los trazos de un rostro masculino, cuyo contorno sugiere a la vez un perfil, una figura doble. A modo de "pedestal" de ese raro busto sombreado hay una forma roja con una suerte de jotas que son a su vez ondulaciones y abajo aparece escrito el nombre de Don Quijote. La pintura se anuncia como parte de la colección del poeta Alí Chumacero y es un guiño a su inobjetable filiación cervantina. 


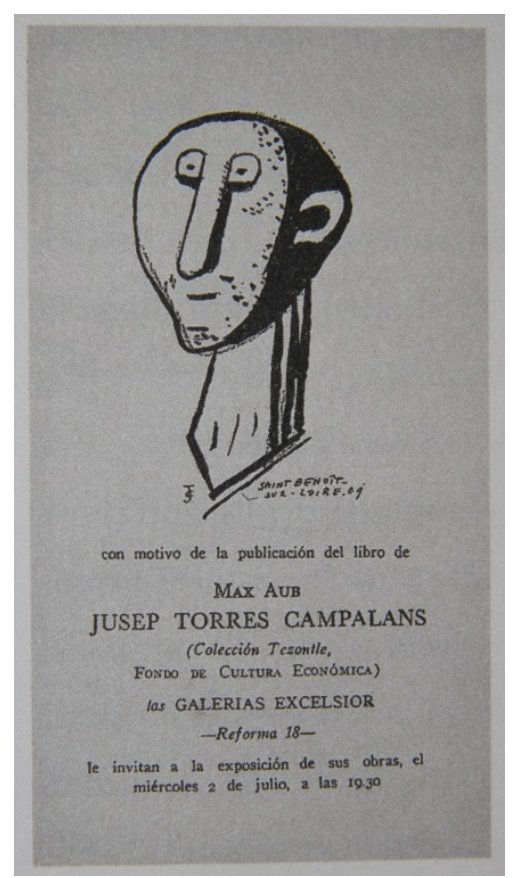

Ilustración 14: Catálogo de la exposición Jusep Torres Campalans en las Galerías Excelsior, México D.F. Fondo de cultura Económica, 1958

Colección Manuel García, Valencia

Después del monograma, hay una caricatura, posiblemente un autorretrato realizado en 1909, en el cual las facciones se construyen con semicírculos y el cuello está geometrizado. No hay ninguna alusión sobre este dibujo, salvo el lugar donde se realiza: el centenario monasterio de Sain Benoit en Sur-Loire, Francia. La imagen fue la que se usó para la invitación al lanzamiento de la "biografía" de Jusep Torres Campalans, editado en la Colección Tezontle, por el Fondo de Cultura Económica en 1958, y para el catálogo de la exposición correspondiente en las galerías Excelsior, de Ciudad de México, que tuvo lugar el "miércoles 2 de julio a las 10:30".

Una de las ediciones del libro tiene en la portada una ingeniosa guitarra en posición horizontal construida a modo de collage, como un recorte de papel periódico sobre el cual traza el diapasón y las cuerdas: obvia alusión a la época en que Picasso usó 
obsesivamente la forma de este instrumento que fue clave en los experimentos tridimensionales.

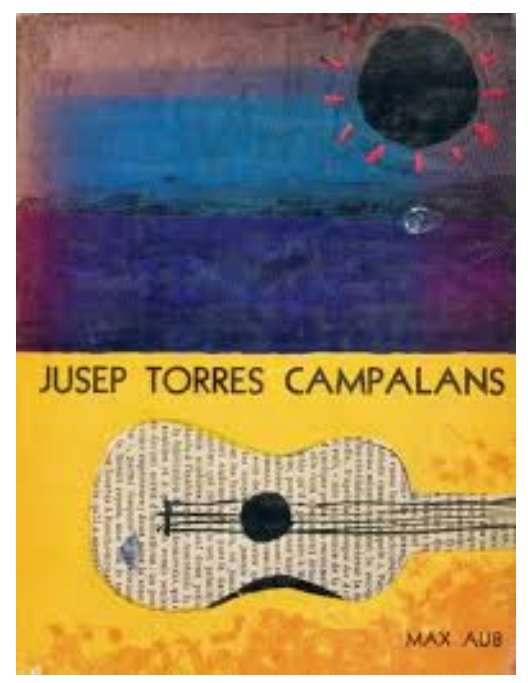

Ilustración 15: Portada Jusep Torres Campalans

En la misma página donde aparece la ilustración de un banano sin título, se incluyen a modo de notas, una serie de consideraciones sobre la pintura y la crítica. J.T.C. discute con Juan Gris en casa de "los Stein" "74, y refuta su idea de que "la pintura, debe ser, ante todo, compuesta por elementos que pertenezcan a un sistema de estética resultante de la época" (24). La paradoja es que más allá del humor socarrón de las obras pictóricas de J.T.C., la mayoría de las que se catalogan con seriedad, son reflejo de la estética de una época que a menudo se entiende mejor desde la parodia.

El narrador Aub despotrica a través de la voz impostada de Aub opinando que los que hablan de pintura se creen Dios. Y para refrendar su derecho a opinar, pinta cumpliendo paradójicamente con el precepto que ha promulgado sobre que quien desee opinar, "que pinte". Su pintura, quiéralo o no, es opinión, y tras la tosquedad de la voz de Jusep Torres Campalans, tan opuesta al discurso intelectual de Gris, hay una serie de preceptos aubianos. Por ejemplo: 
No hay que tener ideas acerca de lo que se pinta. O muy pocas. El que necesita mucho para pintar, ya no es pintor (...) ¿O creéis que Shakesperare, Velázquez 0 el Greco perdían el tiempo pensando en lo que iban a hacer? No lo hubieran hecho (25-7).

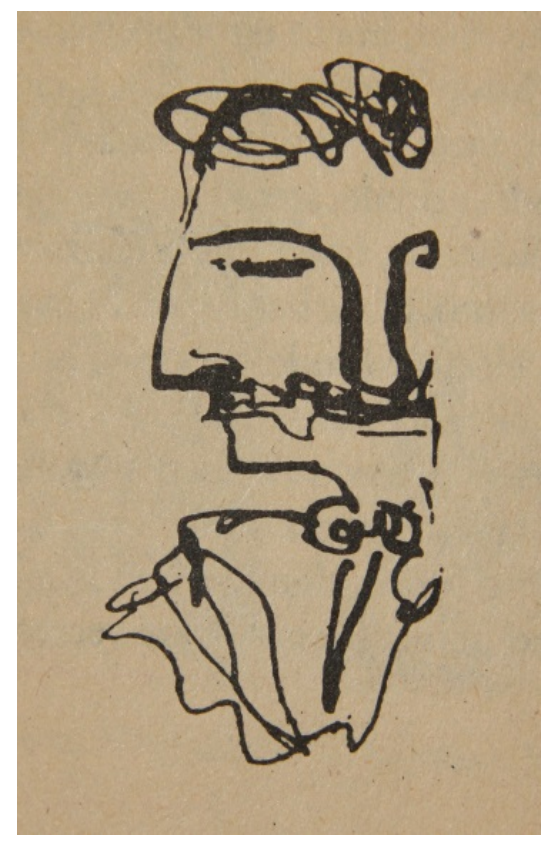

Ilustración 16: Jusep Torres Campalans. Ilustración s.f.

Pero es indudable que hay pensamiento en el acto de analizar los elementos característicos de cada movimiento para apropiárselos desde la caricatura, que a fin de cuentas, fue una de sus pasiones iniciales. Así, en la ilustración que da inicio a los anales usa el recurso cubista de representar simultáneas perspectivas. Un busto de hombre —apenas un fragmento- se representa a la vez de frente y de perfil. 


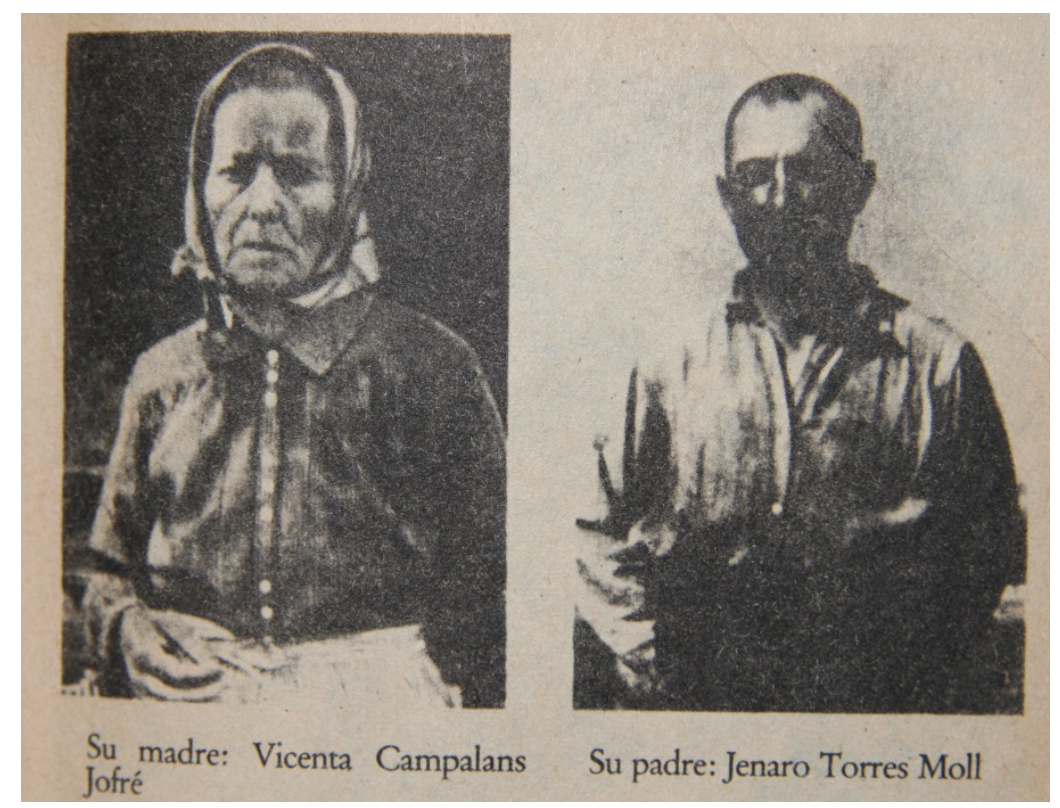

Ilustración 17: Foto de Vicenta Campalans Jofré y Jenaro Torres Moll

Luego aparecen una serie de fotografías documentales, cuya función es constituirse en prueba de existencia irrefutable: son los retratos de la madre y el padre de nuestro J.T.C.: Vicenta Campalans, una mujer campesina, y Jenaro Torres Moll. Ambos documentos pseudo-testimoniales dan vida a la estirpe del biografiado. Son en realidad fotografías tomadas por Aub en uno de sus viajes a gente en la campiña francesa. 


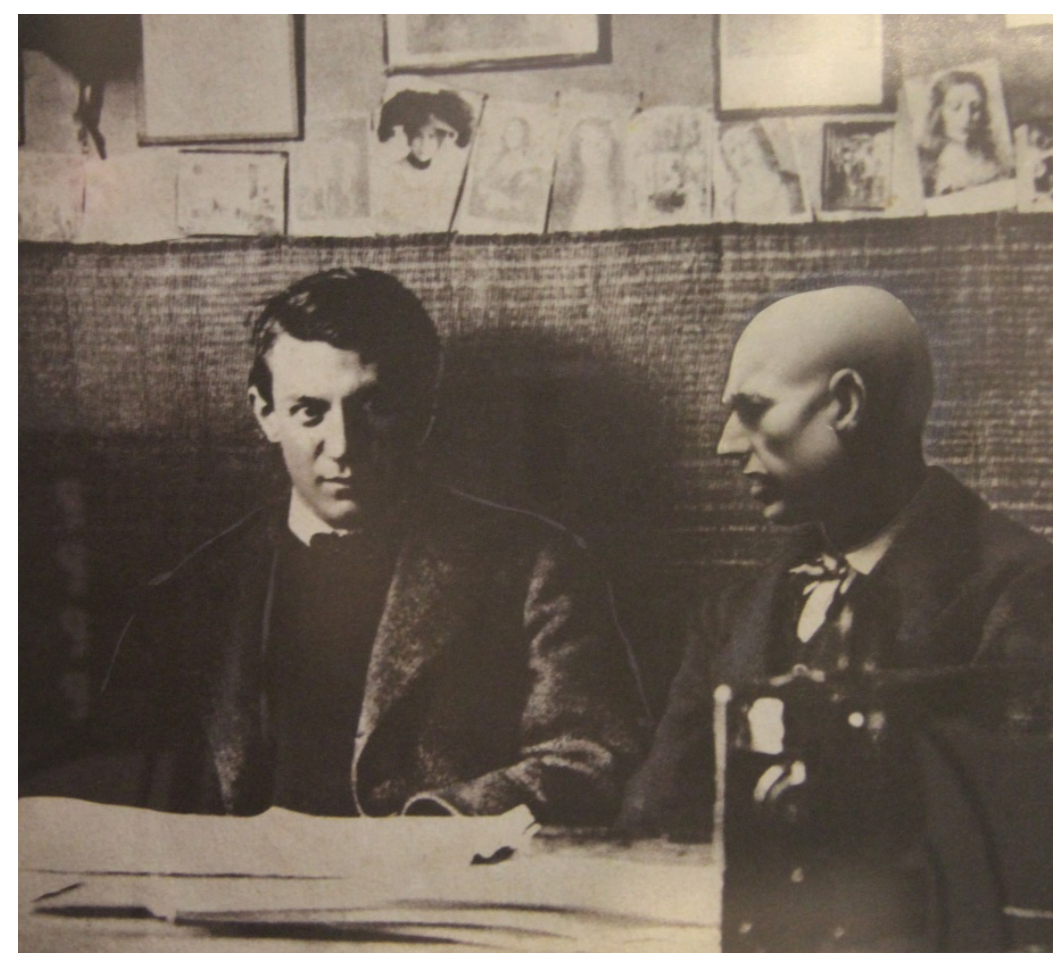

Ilustración 18: Pablo Picasso y Jusep Torres Campalans, Barcelona 1902 (foto: José Renau)

Su osadía es mayor cuando se atreve a presentar, de perfil, la figura de Jusep Torres Campalans en compañía de Picasso, atribuyendo la autoría del retrato a "José Renau" y fechándolo en 1902. La información sobre esa imagen es equívoca, pero guarda estrecha relación con la vida y mirada de Aub. El autor de la imagen (que es un fotomontaje) no es José Renau (Montoro), quien realmente fuera profesor de arte en la Escuela de Bellas Artes de San Carlos, Valencia, sino su hijo Josep Renau, artista y experto en fotomontajes afiliado al partido comunista y fundador de la Unión de Escritores y Artistas Proletarios. Aub invierte el fotomontaje de Renau situando al suplantador de Jusep Torres Campalans a la izquierda de Picasso y no a la derecha como aparecía en el fotomontaje original, donde éste se autorretrataba junto con el genio malagueño. Aub altera además la fecha de factura de la imagen pasándola de 1958 a 
1902, y se roba la identidad física de Renau para darle un rostro a J.T.C., quien es su heterónimo, al menos en términos de su producción pictórica. Pero detrás de todo este embuste hay exactitudes de otra índole: según acota Fernando Pérez Bellón, fue Renau quien, habiendo sido nombrado Director General de Bellas Artes en 1936, encargó a Picasso la realización de Guernica el 1937 para la Exposición Internacional de Artes y Técnicas de París. Los artífices del proyecto del Pabellón eran el filósofo José Gaos curador general de éste-, Renau y Aub, y los dos últimos compartirían poco después la marca de la prisión y de la errancia. Como Aub, Renau se fue a Francia al terminar la guerra en 1939, y fue llevado al campo de concentración de Argelès-sur-Mer, y también, como él, consiguió trasladarse a México, donde vivió algún tiempo. Además, a ambos los acerca la utilización consciente del legado de las vanguardias y la combinación entre lo icónico y lo textual. En Páginas negras de guerra (1933), Renau recurre a collages de textos y fotos en blanco y negro, que anticipan la serie Testigos negros de nuestro tiempo (1935-1937), realizada para la revista Nueva Cultura como un tipo peculiar de crónica. En la revista anarco-sindicalista, filiación que lo acerca a Aub, hace también fotomontajes de carácter político. De modo que, al apropiarse de la técnica de Renau y de su propia fisonomía, con esta fotografía que ya era un montaje ficticio que él lleva a una frontera extrema al publicarla como retrato de su artista imaginario, construye una clave de identidades que a un tiempo se desplazan y se reflejan entre sí. 


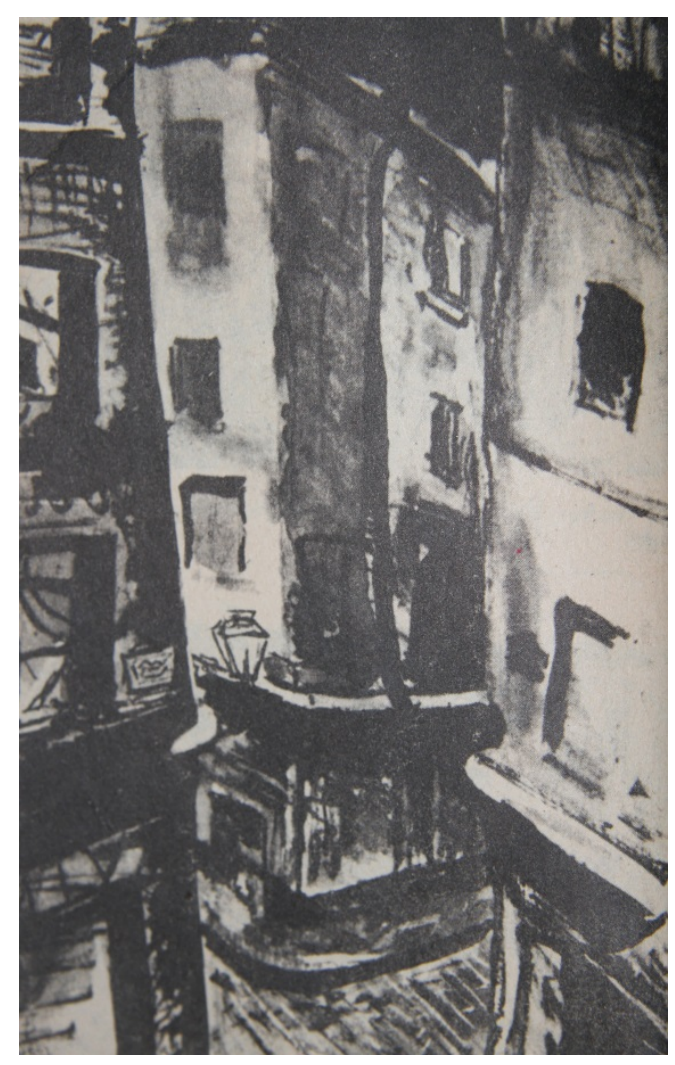

Ilustración 19: Jusep Torres Campalans, Calle 1906. Guache, tinta sobre cartón. 49 x 32cm. Propiedad de M.O.R.

Es posible, en todo caso, recorrer las páginas de la biografía de J.T.C. y hallar cierta resonancia entre obra y vida inventadas, en una correlación que por supuesto, no es más que otra red de la imaginación. Así, el supuesto recuerdo de las calles empinadas y estrechas de Gerona, a donde Jusep Torres Campalans se escapó a los 12 años, está presente en cuadros como Calle, fechado en 1906. El mentado catalogista irlandés Henry Richard Town cree, sin embargo, que ese rincón pudo estar cerca a la rue Rambuteau en París, donde J.T.C. vivió ese año, pero aclara que posiblemente la construcción ha desaparecido. Una vez más el rastro borrado se constituye como prueba arqueológica de un pasado que de este modo cobra existencia. 


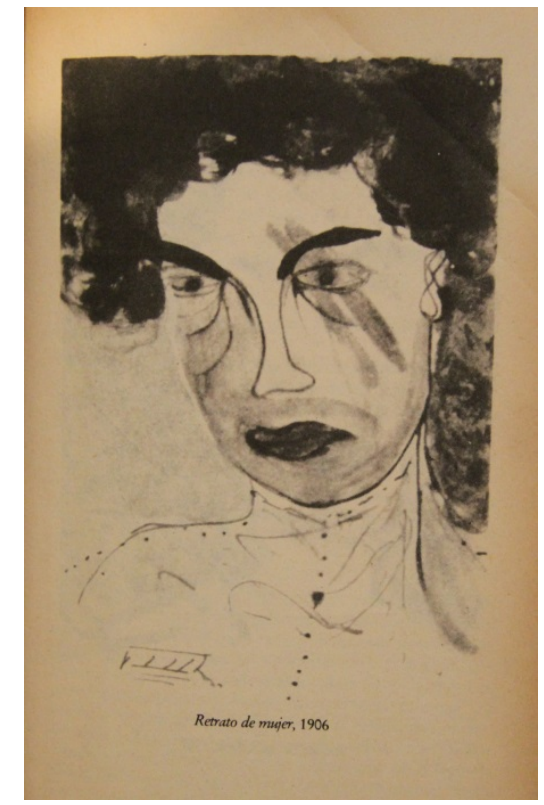

Jusep Torres Campalans, Retrato Mujer, 1906

Guache, tinta, acuarela.

Propiedad de la familia Merkel

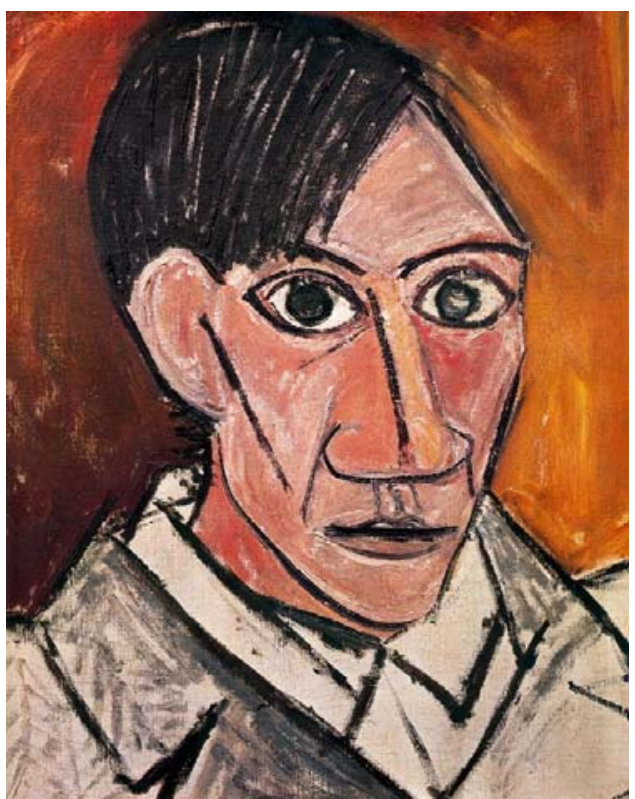

Picasso

Autorretrato, 1907

Óleo sobre lienzo

Nadodni Gallery, Praga

Un Retrato de mujer, 1906, se identifica como retrato de "Vicenta Guillén, viuda de Balanza, vive actualmente en Cullera, Valencia” (311). Y se aclara que J.T.C. también retrató al marido, pero que quemó la pieza para demostrar la poca importancia que daba al arte. Con lo cual, la pintura desaparecida duplica paradójicamente su revelancia biográfica. El retrato de la mujer tiene además cierta semejanza en términos de la composición en primer plano, y de la tosquedad de los rasgos, con el Autorretrato que Picasso pintó al óleo en 1907.

Le sigue el retrato de la compañera de J.T.C., Ana María, que tiene el carácter sombrío de los retratos de la época azul picassiana y, hay que reconocerlo, una calidad expresiva. Astutamente, en el listado de la obra, el crítico irlandés apócrifo incluye una anotación destacando justamente "la ternura" que es uno de los elementos característicos 
de esta etapa de Picasso. Aunque el estilo difiere de la época azul, la expresión melancólica es semejante.

Ilustración 21: Jusep Torres Campalans, Retrato de Ana María 1907. Guache, tinta, acuarela. Propiedad de la familia Merkel

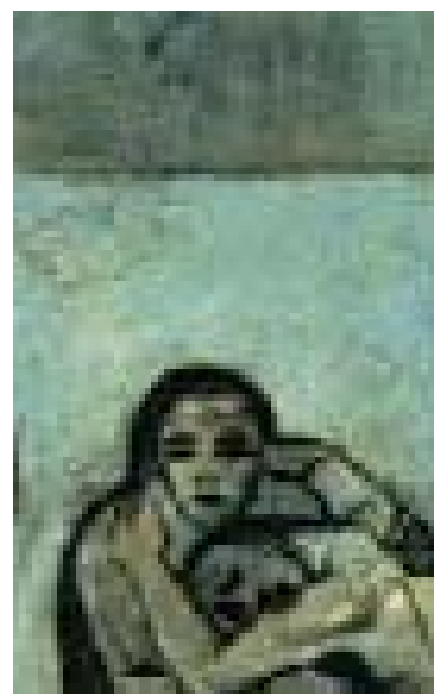

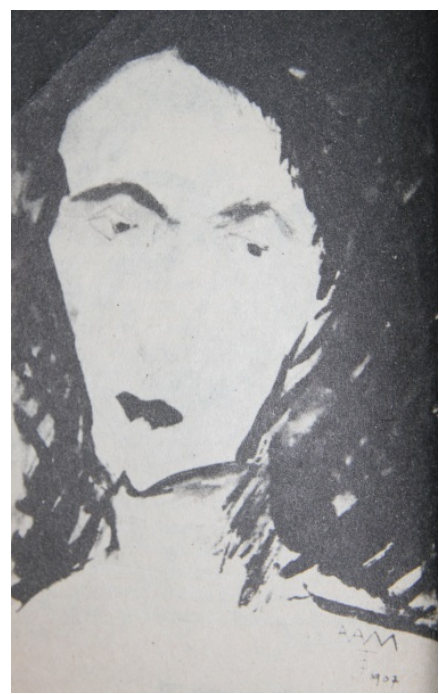

Ilustración 20: Pablo Picasso, La Vida 1903 (Detalle) Óleo sobre lienzo.

Propiedad del Cleveland Museum of Art.

Le sigue el retrato de la compañera de J.T.C., Ana María, que tiene el carácter sombrío de los retratos de la época azul picassiana y, hay que reconocerlo, una calidad expresiva. Astutamente, en el listado de la obra, el crítico irlandés apócrifo incluye una anotación destacando justamente "la ternura" que es uno de los elementos característicos 
de esta etapa de Picasso. Aunque el estilo difiere de la época azul, la expresión melancólica es semejante.

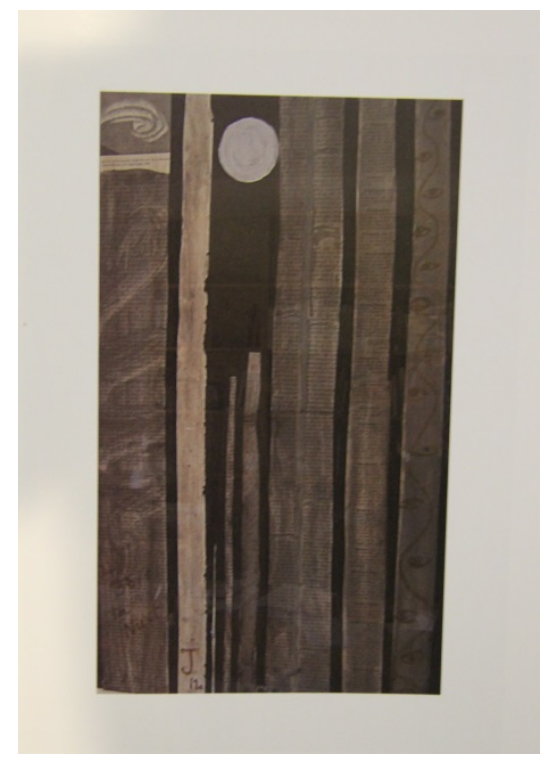

Ilustración 22: Jusep Torres Campalans. El bosque de la noche/Le Bois la nuit 1912. Collage y tinta sobre papel

No se equivoca el catalogador en calificar como el más poético y mejor logrado de la serie el cuadro El bosque de noche/ Le bois la nuit (1912). La pieza en collage y tinta sobre papel está construida con franjas verticales pintadas sobre papeles de períodico impresos que oscilan entre la abstracción y la figuración pues la forma y función de la luna los transforma en altas edificaciones. 


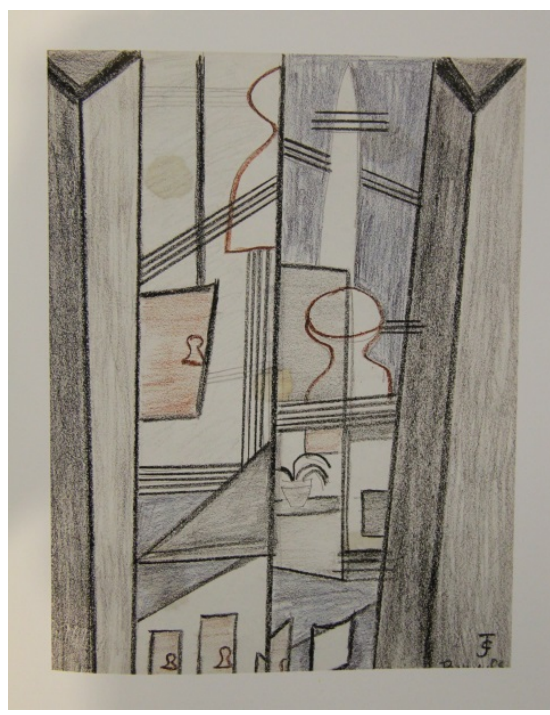

Ilustración 23: Jusep Torres Campalans, Hotel 1912

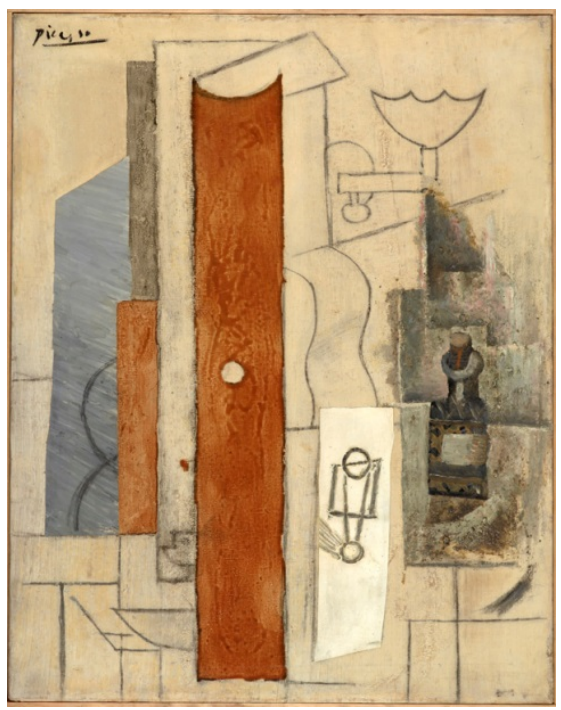

Ilustración 24: Pablo Picasso, Guitar, Gas Jet, and Bottle

1913. Óleo, carboncillo, barniz y arena sobre lienzo.

Del mismo año es Hotel, una pieza que combina la composición geométrica abstracta y alusiva a la arquitectura con elementos referenciales gráficos como siluetas de cabezas humanas representadas con máxima depuración sintética en las ventanas. El año es anterior a las que realiza Picasso en exploraciones semejantes... No hay que olvidar, por supuesto que las fechas que aparecen en todas las obras de Jusep Torres Campalans son muy anteriores a su elaboración real. 


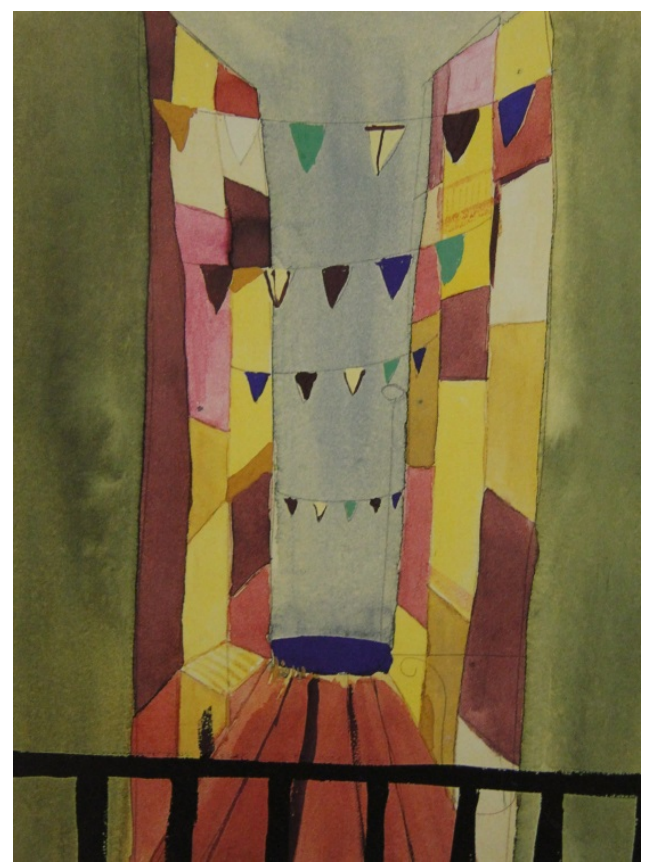

Ilustración 25: Jusep Torres Campalans, Cannes

En el gouache Cannes, datado en el mismo año, también la composición geométrica deriva de un interior arquitectónico representado desde el plano de una baranda hacia la perspectiva del cielo abierto contra el cual flotan banderillas de papel.

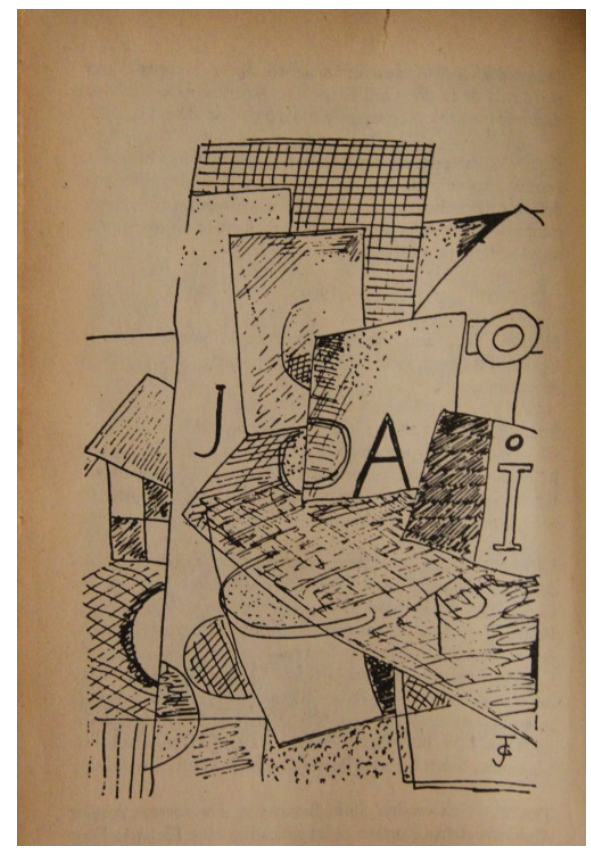

Ilustración 26: Sin Titulo 
Una obra que no aparece con título ni descripción (64), tiene la composición fragmentaria, la inclusión de letras y la referencia urbana, con perspectivas aéreas, típica del cubismo analítico. Aunque no ofrece información sobre la obra, entre los sucesos anotados en la página siguiente que corresponde a 1909, se remarca que es el año del Manifiesto Futurista de Marinetti y que Bleriot atraviesa el Canal de la Mancha en aeroplano. Ambos hechos influyen en la noción de que están surgiendo otros modelos de representación del mundo, otras perspectivas encabalgadas sobre una modernidad que se agolpa en medio de todo cuanto pronto carecerá de control.

El supuesto crítico Juvenal R. Román escribe un texto sobre Jusep Torres Campalans en el cual menciona cómo en 1908, el aviador norteamericano Wilbur Wright permaneció una hora veintiún minutos cuarenta y cho segundo y tres quintos en el aire y fue entonces cuando J.T.C. afirmó: "He aquí una nueva perspectiva: las casas aparecerán como cubos, los campos como rectángulos”. Acto sucesivo, según Aub, Picasso pintó obras como Naturaleza muerta con panes, llevando a su pintura "la influencia del nuevo punto de vista" (95). Otras piezas de J.T.C. que reflejan esta nueva visión y su progresiva disminución del afán mimético son: La fábrica d'en Romeu, 1908, Chimeneas y calor, 1910, y Paisaje, 1912.

La obra de J.T.C. Un monde juste, 1913, incluye letreros tipo cartel a modo de textos escritos en una pared y una figura redonda, negruzca, cuya circunferencia se revienta en chorreados que gotean como espejo caricaturesco de Europa en la antesala de la guerra. En Montaje, IV ,1912, hay una parodia al cubismo analítico que cumple una función especular respecto a sus propias piezas, pues entre letras y fragmentos se 
advierten elementos como la silla, la botella de vino o el diapasón de una guitarra previamente representados en otras de sus piezas.

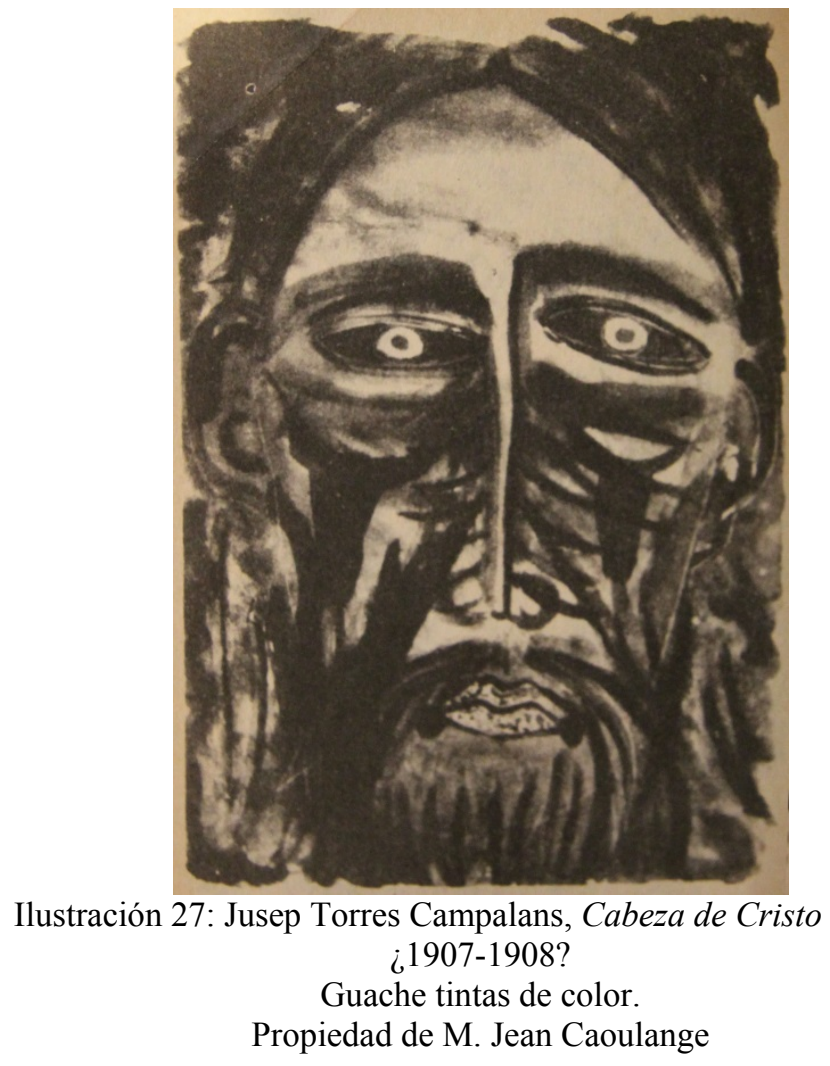

Su Cabeza de Cristo, datada, entre signos de pregunta, en 1907 o 1908, con un ingenioso recurso de dubitación que reafirma la veracidad, es una de las mejor logradas y bien podría compararse con uno de los Cristos del pintor ecuatoriano Oswaldo Guayasamín, acerca del cual la crítica Martha Traba escribió en su libro Mirar en América sin contemplación alguna, reprochándole "la truculenta temática y el aprovechamiento de algunos recursos modernistas ya debidamente acuñados por Picasso y sus fieles" (84). Comentario que bien podría haber endilgado a esta Cabeza de Cristo que el irlandés experto en su obra, Henry Richard Town, considera uno de los cuadros más importantes de la primera época: "Véase, no más, cómo ha resuelto, ibéricamente, con dos cabezas de toro, las mejillas del señor" (312). Ciertamente, la obra corresponde 
más al expresionismo de los artistas con obras derivativas de Picasso, como Guyasamín, ya muy conocido en la época real de la factura del cuadro, que al cubismo que Aub le atribuye. El tema de Cristo reaparece en Boceto para Francisco Ferrer (1909), para destacar el catalanismo de biógrafo y biografiado.

Acerca de El marino bizco (190), con el rostro ensombrecido y sin pupila en uno de los ojos, anota Town que era un retrato de un paisano suyo con media cara quemada y carcomida a consecuencia de una paletada de carbón encendido. Y explica que pasó por las manos de Robert Delaunay, mención con la cual Aub no sólo invoca una vez más el criterio de autoridad, sino muestra su conocimiento de las diversas vertientes del cubismo.

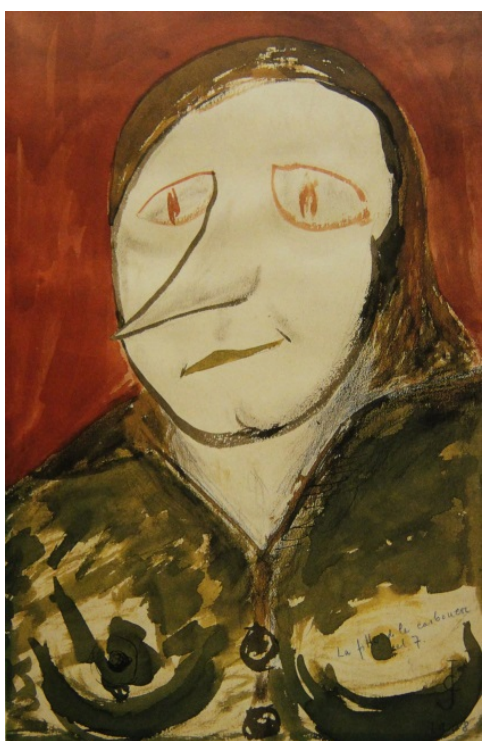

Ilustración 28: Jusep Torres Campalans La filla de la carbonera 1908, acuarela.

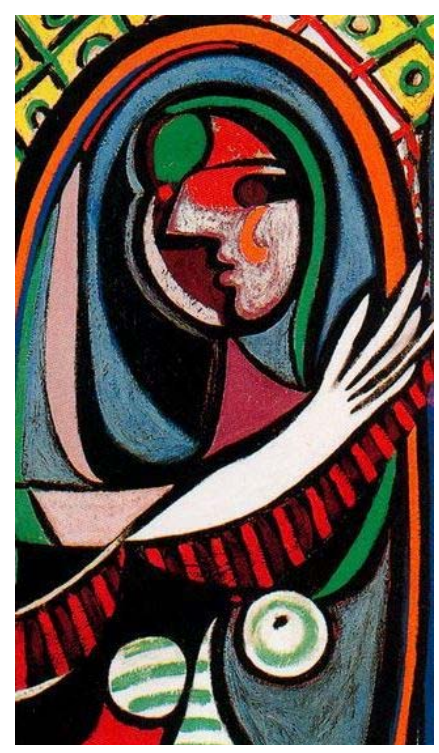

Ilustración 29: Picasso, Mujer delante de un espejo

$$
1933 \text { (Detalle) }
$$

Gift of Mrs. Simon Guggenheim Moma (C) 2014 Estate of Pablo Picasso / Artists Rights Society (ARS), New York 
En la pintura La filla de la carbonera (1908) la nariz desmesurada —un alargado triángulo- es caricaturesca, mientras los senos, desnudos al punto de que se advierten los pezones tras la oscura blusa, como si estuvieran en un primer plano y no cubiertos por la tela, recuerdan los sensuales círculos con que Picasso representó una y otra vez esta parte del cuerpo femenino, también haciendo visible el pezón tras la tela, en obras como Muchacha joven delante de un espejo, 1932, o Mujer con flor, y Desnudo acostado, del mismo año. No se le escapa en estas y otras piezas bufas (como El eterno marido, 1909) a Aub, que como diría Arthur C. Danto (2003), si hasta comienzos del siglo XX la belleza tenía tal conexión con las artes plásticas que justamente se las llamaba les beaux arts, progresivamente iríamos experimentando la pérdida de la belleza:

When Roger Fry organized his great exhibitions of Post-Impressionist art at the Grafton Gallery in London, in 1910 and 1912, the public was outraged not only by the disregard of life-likeness, which characterized so much of the modernist movement, but by the palpable absence of beauty (xvi).

Lo que el llama, "la belleza abjurada" está presente en estas astutas piezas de J.T.C. Explica Town que la referida pieza se trata de un "apunte brutal de una muchacha que parece horrible y que, sin duda, no lo fue tanto (313)". Luego, en lugar de comentar la obra desde la supuesta labor del crítico hace la infidencia de que se trató de un amorío de J.T.C. que llevó a Ana María Merkel a disgustos con los padres de la muchacha. Aub escribe un pie de nota afirmando que en una segunda edición de la biografía añadiría cómo fue el tal incidente. Sobre la pieza Retrato - que de nuevo presenta con dudosa fecha- acerca de la cual explica que es una "posible" caricatura de Max Jacob, destaca "la fealdad -no repulsiva- del modelo" (315). En su Cuaderno Verde, J.T.C. 
reflexiona: "Lo feo, ¡tan hermoso! Pintar en contra siempre. Deshacer, no dejar nada. Pegar, pegar, hasta que aparezca la gran moradura del mundo".

La belleza se asoma, sin embargo, en el retrato La lágrima frente al espejo, 1909: una gota de leche rueda desde la punta del pezón de la muchacha desnuda que se recoge el cabello largo con una mano. El crítico apócrifo apunta que es una de las pocas obras que ofrecen una influencia de Matisse. Ciertamente el gesto es similar a su Desnudo reclinado, de 1935, si bien en esa pintura la mujer aparece recostada. Pero todo es parte del juego de alusiones falsas puesto que Max Aub apunta, en serísima nota de página, que al irlandés se le escapó lo que en cambio notó el crítico Miguel Gash Guardia. Así, de nuevo las anotaciones pseudo-académicas, que no podrían formar parte de la novela de ficción, sino de la novela biográfica, contribuyen a sostener la ficción desdoblada en meta-crítica. Todavía más, Town anota en algunos casos, que determinado cuadro, pese a que aparece firmado con la característica signatura de J.T.C., es de dudosa atribución. Del mismo modo en que las negaciones de los comentarios de uno a otro crítico -ambos igualmente imaginarios- acaban por afirmar su existencia, la presunción de que algunos cuadros fueron falsificados, aumenta paradójicamente su carácter verosímil. E igualmente, todas las dubitaciones interpretativas o narrativas de Aub contribuyen a reforzar su carácter de biógrafo que se atiene a la precariedad de los datos que va encontrando. 


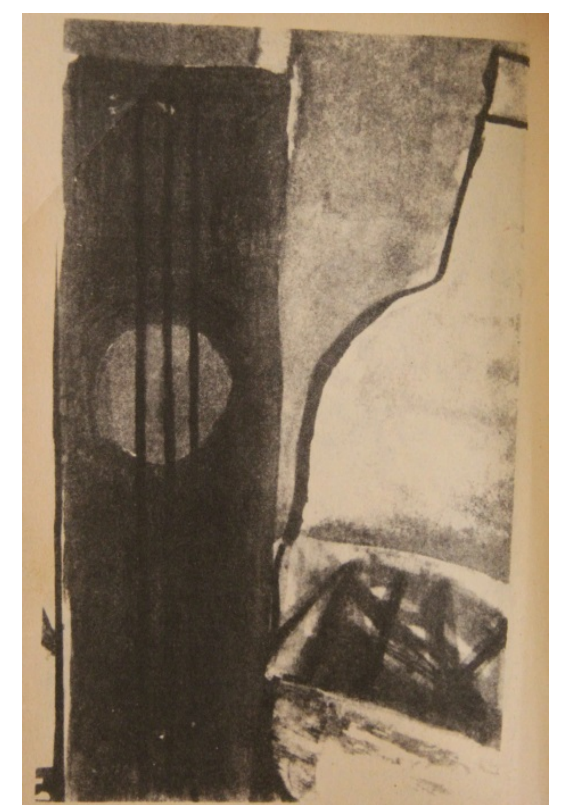

Ilustración 28: Jusep Torres Campalans, El rábano por las hojas 1908, Guache Propiedad de E.A.

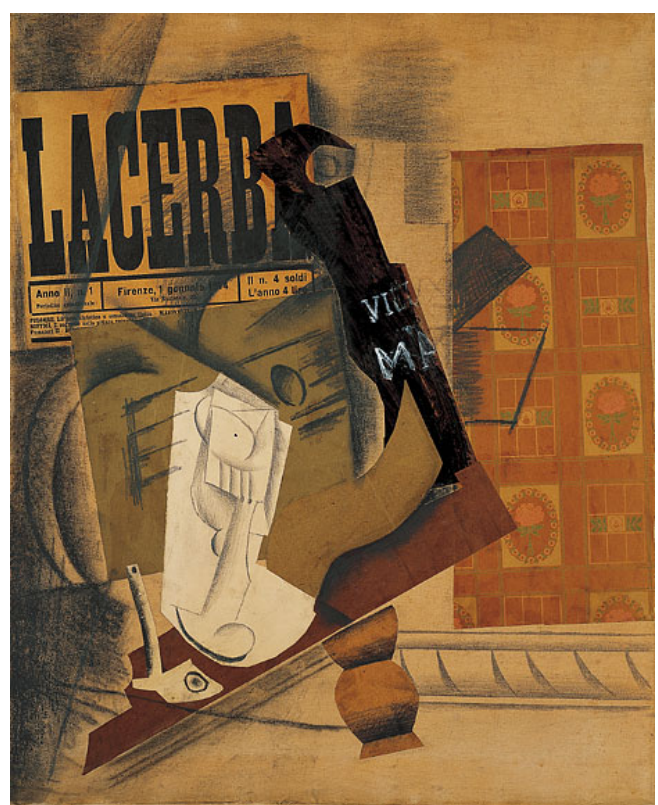

Ilustración 29: Pablo Picasso, Pipa, vaso, diario, guitarra y botella de Vieux Marc botella

1912, Papier collé, carboncillo, tinta china, tinta de impresión, grafito y aguada sobre lienzo

Peggy Guggenheim Collection

En Estudio XVI: El rábano por las hojas, 1908, que ya en su propio título advierte la

mofa se refleja el paulatino trascurso de J.T.C. hacia la abstracción. Una forma sugiere el estilizado diapasón de un instrumento musical, y a un lado hay una botella de vino, pero como la representación es fragmentaria, y en el interior del vidrio translúcido hay un incongruente manchón de trazo rápido — como un gesto de boutade - la referencialidad se diluye. Más allá de la explicación del aplicado crítico irlandés, de que J.T.C.

experimentaba aquí con dar el color de un objeto al otro, ésta pieza posiblemente guarda relación directa con una de las obras que su detestado Juan Gris compuso -La botella de Banyuls - y con su ambigüedad en la utilización de formas pictóricas y materiales. Pero al tiempo, remite a Aub, en su devastadora labor meta-crítica, cumplida 
a través de las apropiaciones de la pintura-ficción. La pieza de Gris, datada en 1914, le parecerá una imitación realizada astútamente por quien conoce las tendencias en boga y las remonta. Aub hace lo mismo a través de su heterónimo J.T.C. pero para distanciarse del arte de tu tiempo.

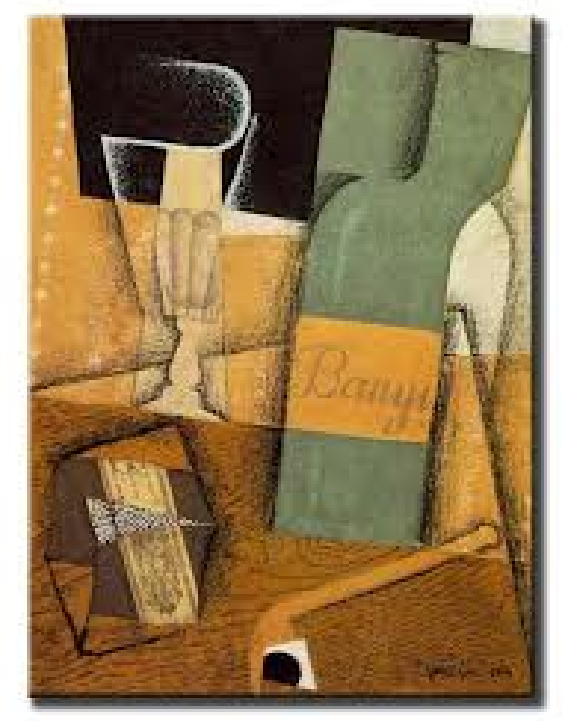

Ilustración 30: Juan Gris, La botella de Banyuls

1914, Pasta de papel, óleo, carboncillo, lápiz y guache sobre lienzo, Kunstmuseum (Berna, Suiza).

La influencia de espacios o seres a los que estuvo ligado Aub sin duda genera las pinturas, independientemente de la libertad con que J.T.C. recurre a las apropiaciones, en una actitud de amplio rango que puede ir desde su inicial admiración por Picasso hasta su desdén por Juan Gris, desde el homenaje hasta la sátira, pero que a la postre va colando, una duda sobre la naturaleza del arte moderno. De hecho, usa el humor para burlar sus cimientos y acaba por sugerir que éste ha llegado a su fin. 


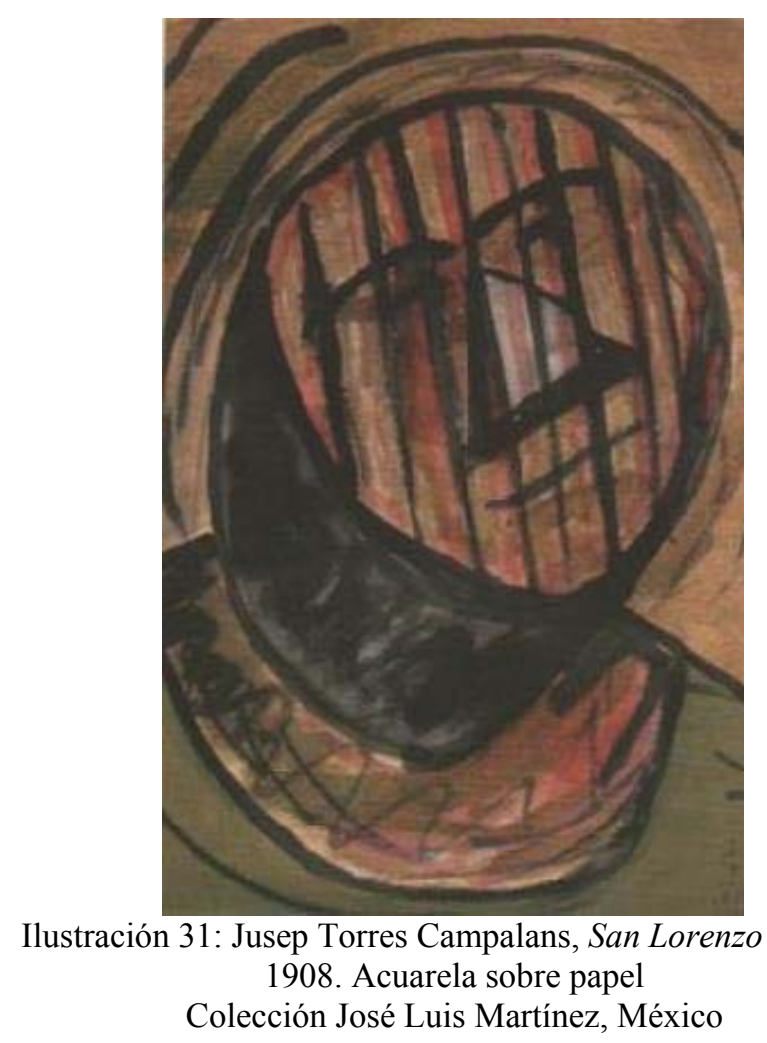

Al admitir la influencia de Picasso en J.T.C. particularmente en las obras de 1908, cuando se acuña el término cubismo, Aub desvanece la estrategia del sistemático espolamiento de su trayectoria a través de una admisión que restringe a un período su influjo. Así, dice que la acuarela San Lorenzo, estuvo "evidentemente influida por los Picasso de ese año" (313). 


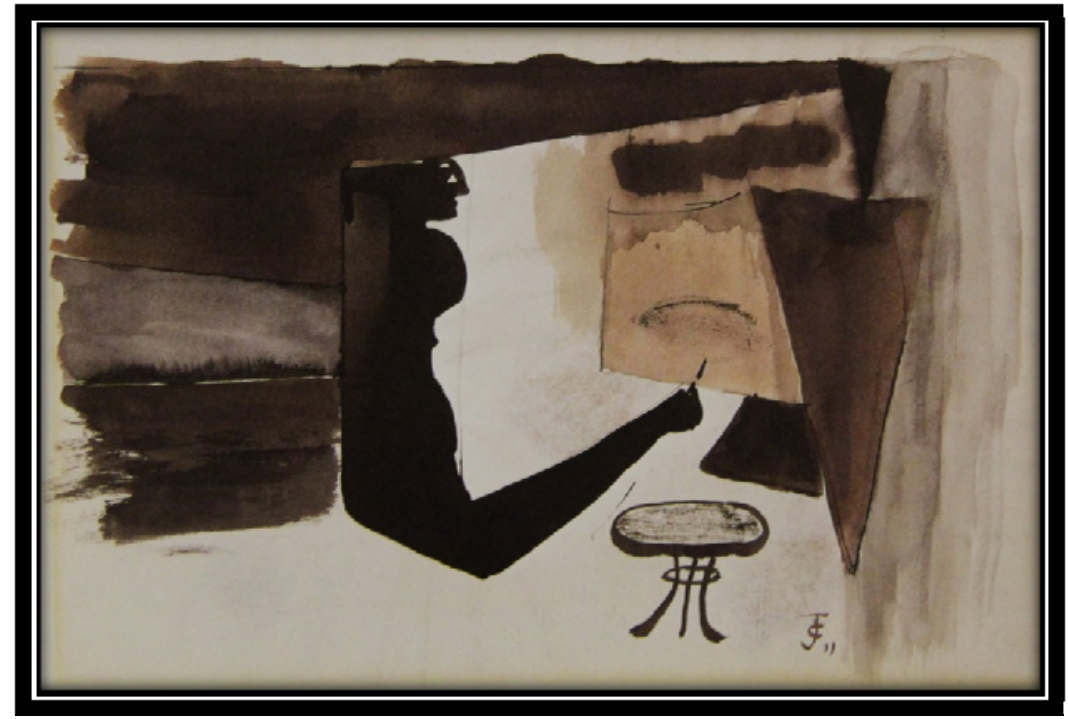

Ilustración 32: Jusep Torres pintor

1911, tinta.

Campalans, $E l$

Perteneció a Picasso.

Actualmente en Nueva York.

Respecto a la obra El pintor, 1911, explica que es de "la época del viaje a Banyuls", tomando para J.T.C. ese lugar donde en efecto Picasso y Matisse vivieron. Aclara que es un retrato de Picasso dibujando acerca del cual tiene la osadía de decir que es curiosa la influencia que ese boceto de J.T.C. tuvo en la obra del retratado, Picasso, quien según el narrador la conserva en Nueva York. Se trata en efecto de un cuadro que tiene el entusiasmo ante los nuevos lenguajes que imita: una obra meta-artística donde J.T.C. pinta a Picasso dentro del cuadro, en el acto de crear geometrías y manchas abstractas, pincel en mano frente a un lienzo que parece flotar sobre una mesa que tiene una enorme resonancia formal con su propio monograma. El cuadro, bien compuesto - la composición es una fortaleza real del dudoso pintor J.T.C. — destila humor. No menos el dibujo en tinta china Idolo, hecho en 1908, como simple copia de una estatuilla africana cuya propiedad le endorsa a Matisse y de la cual dice el catalogador apócrifo Town, que 
es prueba de que el interés por el arte negro es anterior al que tenían por éste los amigos de Picasso. En realidad era propiedad de Max Aub.

Respecto al cuadro El Homenaje a Van Gogh, 1912, Town comenta que sin duda, el último cuadro del holandés le impresionó mucho y que trabajó bastante en este óleo sobre cartón, "con resultados dudosos" y añade: "Creo que la máscara central es intento de autorretrato" (318). Lo cierto es que es una de las obras mejor logradas por J.T.C., quizás por la admiración que le profesa. Es uno de los pocos artistas que incluso al final, cuando el desencanto lo cubre todo, mantienen su adhesión: "Van Gogh, el primer gran pintor pobre, el primer gran pintor ignorante, el primer gran pintor no señorito" (204). Que en cambio, lo fueran Delacroix, Degás, Tolouse-Lautrec, y Cézanne, ya suponía para J.T.C. cierta desconfianza.

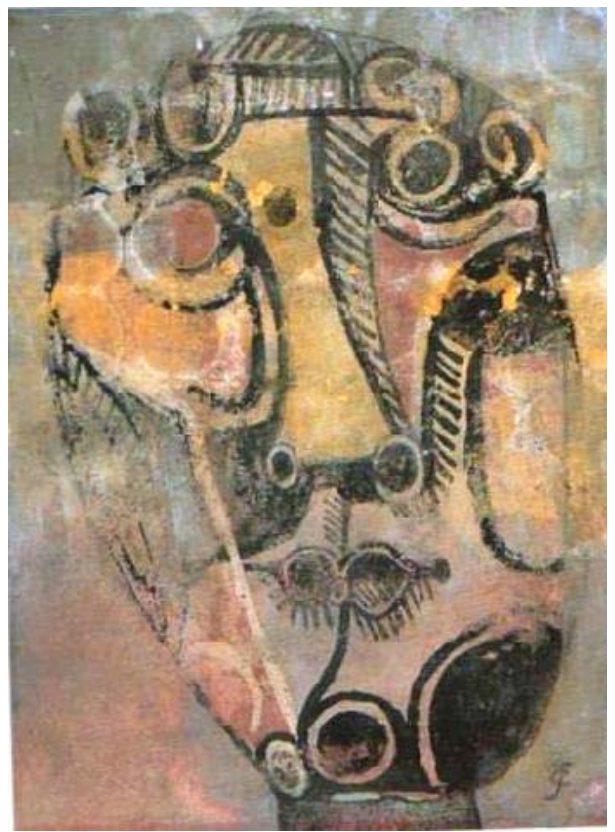

Ilustración 33: Atribuido a Jusep Torres Campalans, Sin título 1912. Gouache sobre papel Colección Federico-David Álvarez Aub 
Las Viñetas, sin fecha, copian trazos picassianos y la imitación — que ni siquiera puede calificarse de apropiación - es pobre. En cambio, la copia está muy lograda en la pieza sin título, "atribuida a Jusep Torres Campalans" que supuestamente le envía Vicente Rojo a Aub, junto con una carta escrita de su puño y letra, en 1974. El maravilloso pintor mexicano, cercanísimo amigo suyo, se presta a la fabulación y le dice haber dado con ese viejo gouache firmado con el inconfundible monograma. Su comentario es que sin duda el pintor trató de encontrar una relación directa entre las asombrosas pinturas románicas catalanas y el arte no menos asombroso de Picasso. Rojo afirma que la adquirió aunque no estaba a la altura del genio de J.T.C. y que se la envía como una curiosidad. La pieza es sin duda una de las pocas obras cubistas.

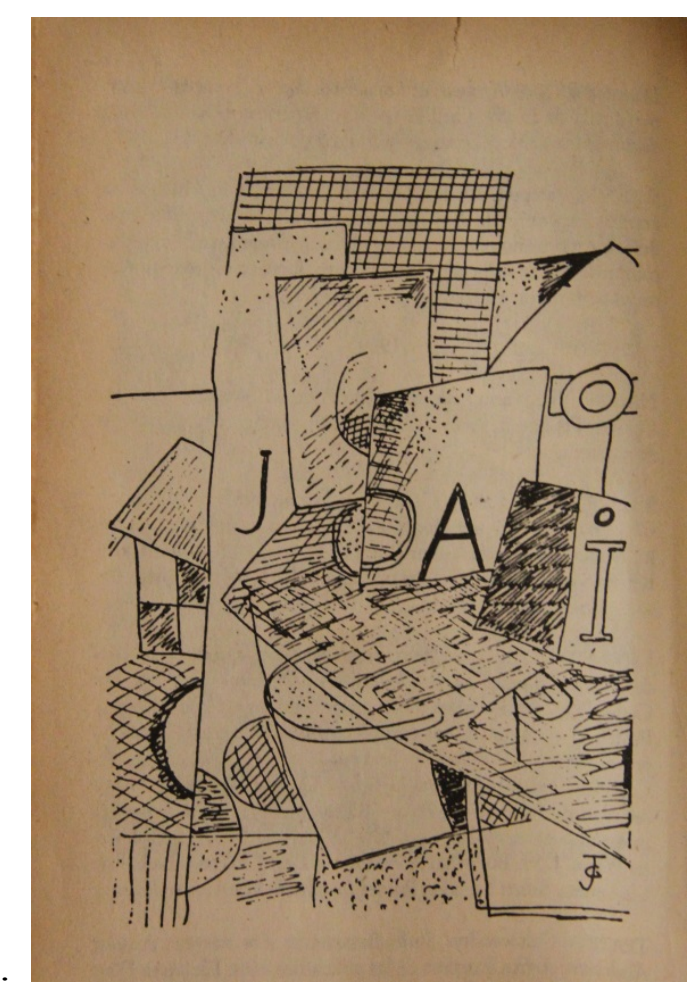

Ilustración 34: Jusep Torres Campalans, Sin título, s.f. 
Igualmente, atribuye a un dibujo de 1911, "la introducción de las letras" y dice que "posiblemente" fue hecho en casa de un arquitecto amigo de Apollinaire. La influencia acendrada del poeta que alumbró todos los ismos vanguardistas es exacta y está también en el retrato al carbón que J.T.C. le hace, antes de que, de un modo incomprensible, en 1914 lo vea buscar un uniforme y partir a la guerra de la que regresará herido y finalmente, debido a la debilidad, morirá poco después de ver la representación de su obra "Les mamelles de Tirésias".

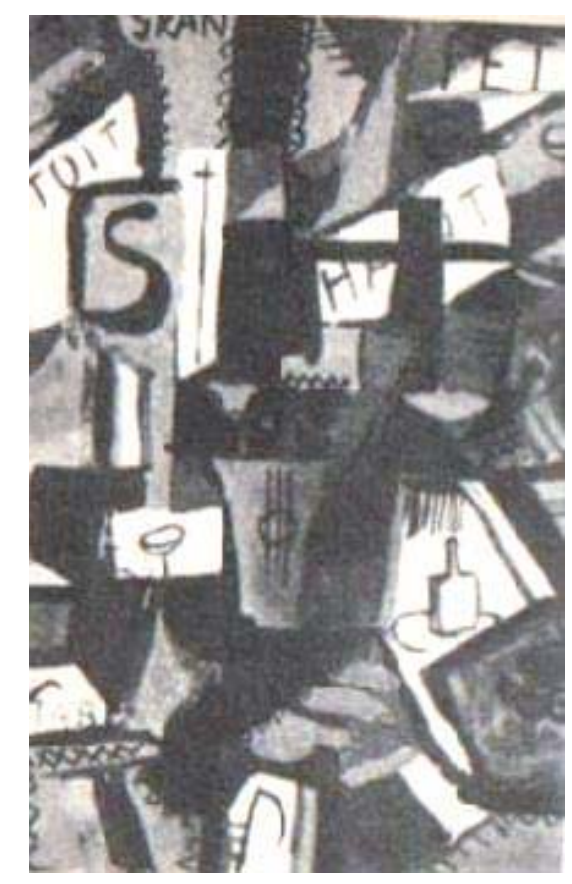

Ilustración 35: Montaje IV 1912, óleo. Propiedad de J.D.C.

El último retrato de Picasso que pinta es de 1912, una fecha coincidente con la ruptura de éste con el cubismo analítico. El calificativo de decorativo o divertimento comienza a aparecer exactamente en la época en que se señala este giro en la obra picassiana. De Montaje IV, 1912, dice Town que es una "composición decorativa" realizada "a la vuelta de un paseo por una feria popular" y del óleo Elegante que es un 
"gracioso divertimento cubista" (316-17). Eso mismo podría decirse en cierto modo de todo el libro, pero no es azar que el calificativo de decorativo lo dé justo cuando cierto sector de la crítica comienza a endilgárselo a las obras de Picasso posteriores al cubismo analítico.

El ejemplo típico de lo detestable, el fácil acomodamiento a las exigencias de la época que no responde a la necesidad interior, es, tanto para Aub como para Jusep Torres Campalans, Juan Gris, a quien se opone visceralmente. Le hace un mordaz retrato llamado La cabeza de Juan Gris, donde la obra geométrica es en realidad una representación figurativa de los lomos de los libros — no identificados - que repletan los estantes de una biblioteca.

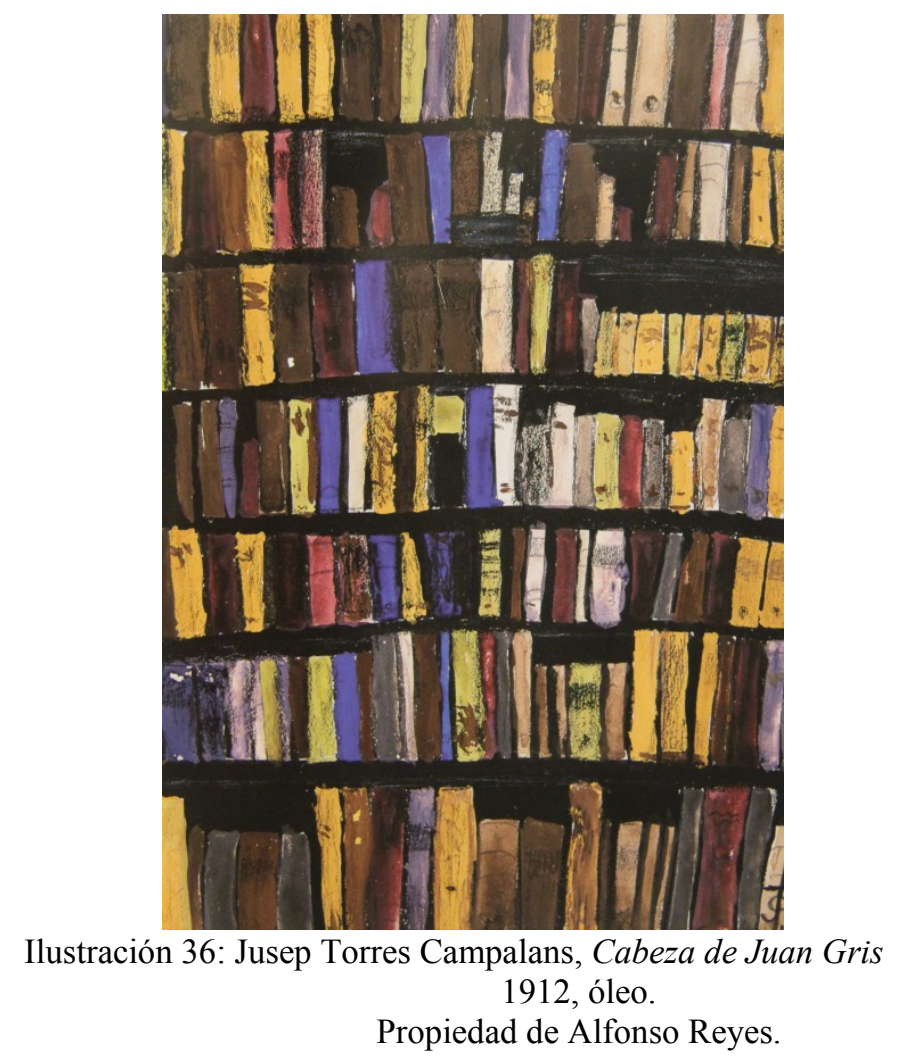

En el catálogo anotado por Town éste explica que la obra es una crítica a lo que consideraba la pedantería de Juan Gris, cuyas justificaciones teóricas del cubismo le 
enervaban. El óleo sobre el papel, de intención mordaz, es una de las obras más logradas de J.T.C. y de las que mayor difusión han tenido. Curiosamente, narra Aub que su pintura Cabeza de Juan Gris, fue la única que según su biografiado logró vender al dealer Vollard, por intervención de Ana María Merkel. Después pasó a ser propiedad de Alfonso Reyes — cómplice que describía los trabajos de humor, fantasías e invenciones de Aub como "astillas del trabajo cotidiano", escapes de la imaginación y la ironía de varios calibres - y en la realidad ha formado parte de múltiples exhibiciones, incluyendo la que en 2008 presentó el Museo Nacional de Arte de Ciudad de México: Alfonso Reyes y los territorios del arte. En esa muestra, Jusep Torres Campalans expuso ciertamente la mencionada obra, en el mismo espacio en que se presentaba el Estudio de la duquesa de alba (1796), de Francisco de Goya y Lucientes, junto con numerosos documentos y una selección de películas comentadas por Reyes, quien compartía la pasión por Goya y por el cine con Aub.

Además de El pintor, otras piezas que podrían filtrarse como si de obras serias se tratara son El pianista Maldonado, $1913^{75}$, y las tramas, que evocan a Mondrián. 


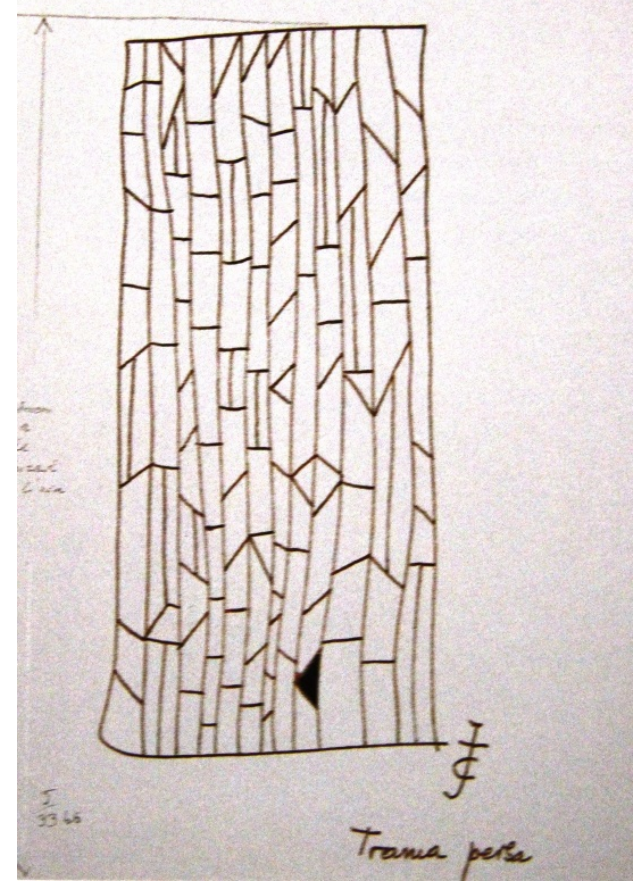

Ilustración 37: Jusep Torres Campalans, Trama persa

1913

El cuadro Trama persa, 1913, tiene una factura excelente y ese sí es una obra geométrica abstracta muy cercana al constructivismo y con un curioso triángulo verde que enriquece la obra en tinta sobre papel abriendo el espacio hacia otro plano. Además tiene anotaciones en los lados que pueden hacer pensar en una temprana concepción de la obra en proceso. El apócrifo Town califica la serie de "famosa". Acerca de otras tramas de 1914 y de la Superficie calcárea es interesante reproducir la correspondencia de Estaban Salazar y Chapela, quien en la vida real le escribe a Aub una carta en la cual se disculpa por la ingenuidad de su lectura, pues no había advertido su carácter apócrifo. La correspondencia contiene así la remarcable confesión de un profano en el arte plástico:

Además, algunos dibujos me parecen de profesional verdadero, como el Retrato del pianista, por ejemplo. Y dime, en confianza, de ti para mí: Si ese retrato lo firmara un Picasso, ¿quién descubriría que no era un Picasso sino un Aub? En confianza. Esto no quiere decir que yo no vea diferencias entre la pintura de Max 
Aub y de Picasso. Sé muy bien que Picasso es un genio y, como aquí se ha llamado en estos días, 'un coloso'. Pero hay cuadros de Picasso que los puede pintar o los habría podido pintar Max Aub (Dublin, 26 de octubre de 1958) (135).

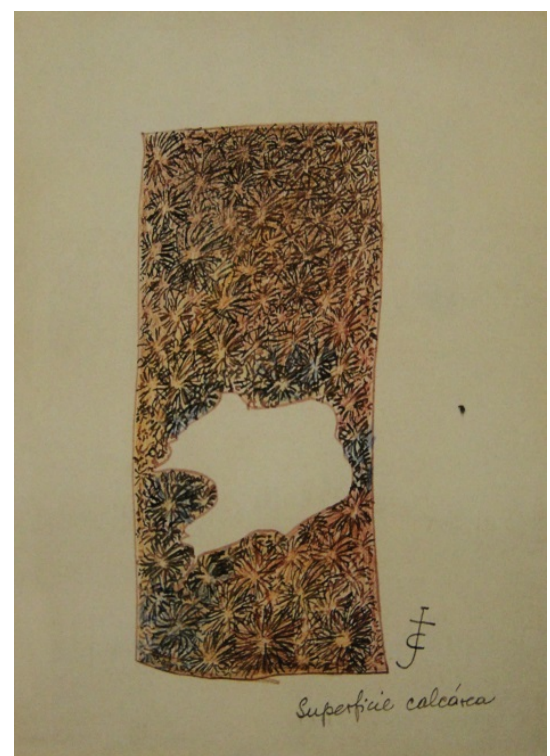

Ilustración 38: Jusep Torres Campalans, Superficie calcáre 1914, guache sobre cartón. Propiedad de Jaime Torres Bodet

Por supuesto, con mayor o menor empeño - en algunos casos excepcionales con una destreza que se soslaza en la imitación o en el fraude, todavía más que en la caricatura y la broma- Aub imitó consistentemente la creación vanguardista. A propósito, la reseña escrita por Jesús M. Lozano con ocasión de la inauguración de la exhibición de J.T.C. en 1958 en Ciudad de México y republicada en el catálogo del Museo Reina Sofía. Lozano comienza con una frase lapidaria:

Jusep Torres Campalans sí existió, y además fue un malísimo pintor cuyo espectro deambula por el mundo entero. Con esta frase cortante el único superviviente de los 'tres grandes' de la pintura mexicana, David Alfaro Siqueriros, juzgó al catalán 'descubierto' por Max Aub. (...). David Alfaro agrega: 'No lo inventó Max Aub. Lo retrató genialmente. Ese pintor Campalans es una amarga realidad histórica y no una simple ficción' (139).

Más allá de la verdadera intención del estruendoso Siqueiros, que estuvo entre los artistas e intelectuales que viajaron a España a solidarizarse con la República, la opinión 
de la desigual calidad del artista, presentado como pionero fundador del cubismo, pero en realidad copista mediano de diversas tendencias de la vanguardia, es más que atendible. Lo cual, lejos de minar el propósito de Aub, refuerza la idea del desencanto final de Jusep Torres Campalans que apunta hacia un escepticismo general frente al arte y a la época entera.

Huici nota con exactitud que por inercia se tiende a calificar a Jusep Torres Campalans de pintor cubista. En las más de 200 obras que se le adjudicaron —sólo 58 se referencian en el supuesto catálogo de Town— hay numerosas tendencias:

Lo que define ese vértigo caleidoscópico es, sin duda, el núcleo más íntimo e inconfesado del alma de Campalans, incapaz de consolidad esa curiosidad errática en una identidad vertebral del impulso creador en una fuga sin fondo que concluye con la aceptación crepuscular del fracaso (39).

Un fracaso que no sólo está en la vida y obra -errante y errática- de Campalans, sino en la modernidad misma que ha producido la vanguardia artística. Comentando la última pintura de las serie de Tramas de J.T.C, Town dice que es "uno de los cuadros más considerables que nos quedan", pero concluye: "Si alguna vez hubo una pintura desencantada, ésta es, muerta" (321).

\section{La impostura del crítico: "la pintura desencantada"}

Un diálogo que expresa hasta el fondo ese desencanto ante el arte está en la entrevista entre Aub y J.T.C. incluido en Las conversaciones de San Cristóbal. Aub quien, como hemos dicho, participó en la idea de la gestión y exhibición del Guernicale da noticias a Jusep Torres Campalans de la existencia del enorme cuadro en blanco y negro, y éste le responde que lo vio en un breviario del Fondo de Cultura. Ante la parquedad de su respuesta, Aub le pregunta sorprendido si no le interesó, y J.T.C. le 
responde: "Eso, no me interesa nada. Bebí la hez. Todo lo que he visto me confirma en mi opinión".

El lector no sabe si, se refiere a que después de haber vivido la guerra cualquier representación del horror carece de interés para él, o sise ha distanciado tanto del arte que ni siquiera una de las obras más grandes del siglo logra despertar en él la admiración.

Huici ve certeramente cómo Aub construye el simulacro de la monografía de Campalans ciñéndose a los modelos canónicos de la época en publicaciones de arte, y copiándolos de un modo paralelo al de Cervantes con los libros de caballería y otros géneros. Es decir, se apropia de la crítica artística de la época para hacer creíble a su personaje. Pero este papel es un desdoblamiento más pues se re-presenta como la voz de un escritor que fascinado por el descubrimiento del artista "interpreta", en el sentido teatral del término, eventualmente el "papel de crítico" (23). Y, sin embargo, el novelistadramaturgo convertido en supuesto biógrafo, pero ejerciendo en realidad de crítico, pretende desentenderse de este papel: "Ni hay en estas páginas nada que pueda suponerse crítica de la pintura moderna, de la que no sé más que mi gusto" (23).

Pero la paradójica relación del biógrafo apócrifo con la crítica llega hasta tal punto, que, como se advierte por un artículo incluido en el catálogo de la exhibición de Jusep Torres Campalans en el Museo Reina Sofía, Aub publica en 1962 un texto crítico firmando como su heterónimo J.T.C., así con las solas siglas, y sin importarle que para entonces llevara tres años de muerto. El artículo se titula Vicent, le Rouge, y analiza la obra de uno de los más grandes artistas del movimiento que se conoce en México como La Ruptura por su negación a seguir transitando ese "único camino" que para Siqueiros era el muralismo: Vicente Rojo. J.T.C. comienza diciendo que la exposición de Rojo no 
ha tenido el menor éxito y concluye preguntándose: “¿Qué quedará de la pintura abstracta de hoy? Dios sabe. Ahora bien, si algo sobrevive de ella, el esfuerzo, la limpieza, la autenticidad de la de Vicente Rojo atestiguará" (146-47).

En el mismo catálogo se republica un texto crítico de Pierre Mazars sobre el contenido de la novela en cuestión de Aub. "El autor de Jusep Torres Campalans también se ha divertido haciendo un pastiche de esas monografias monumentales que hoy en día se dedican al primer llegado a la pintura (...). Ha hecho la sátira de los cocineros de la pintura y de los pánfilos” (144).

\section{Según nota Huici}

Aub precisaría en diversas ocasiones que el blanco principal de la sátira implícita en la obra apunta, ante todo, hacia la crítica de arte, algo que resulta evidente en las numerosas apropiaciones paródicas de la jerga del sector que salpican sus páginas (22).

En ese sentido, hay una comprensión fundamental: la pintura-ficción es crítica de la propia vanguardia, obra que la contiene, y refleja a partir de un conocimiento que no es improvisado, con trazos que no por ser rápidos o paródicos son menos capaces de diseccionar sus elementos. Pero las numerosas páginas apócrifas, aunque también tomadas de textos reales, cumplen a su vez una función meta-crítica. Son crítica de la crítica. Espejo de un lenguaje del que Aub parece descreer, si bien paralelamente ejerce, a través del narrador que lleva su nombre, pero sobre todo, a través del heterónimo que lo suplanta como artista y como crítico, este otro tipo de labor deconstructora: no ya la burla de la autoría artística, sino la burla de la teoría que la sustenta: 
La verdad artística -decía- nunca está escondida o disfrazada. Los críticos creen que deben descubrir o desenmascarar esa verdad en las expresiones formales. De ahí que se metan siempre en camisa de once varas y no sepan lo que dicen (25).

La polifonía alcanza a este respecto una intensidad máxima porque hay múltiples

niveles desde los cuales se ejerce la labor meta-crítica sobre lo que llama "la legión de los historiadores de arte" (21):

1. Los testimonios sobre los movimientos artísticos recopilados en entrevistas ficticias con personajes reales. Así, declara que Paul Laffite, quien colaboró con los nazis llevando pintores famosos a Munich, lo recibe en seguida y dictamina que el cubismo fue un movimiento judío: "Sin los Stein, sin Kahnweiler no hubiese sobrevivido (...) Había en el cubismo cierto ingrediente mesiánico, el anuncio de un mundo nuevo. Picasso les parecía un profeta" (22).

2. Citas verdaderas de artistas o críticos identificados que reproduce y califica (o descalifica) como cuando transcribe declaraciones reales sobre el arte de su blanco de iras, Juan Gris: "Acabo de leer esta prodigiosa necedad: "Cada artista europeo sabe que el arte que cultiva es la expresión de un mundo existente que aspira a perdurar (...)» ¿No os fastidia? Juanito, dedícate a pintar y déjate de monsergas" (24).

3. Juegos intertextuales con fragmentos supuestamente transcritos a mano por J.T.C., en una "miscelánea de notas propias y ajenas" (258). Es el caso de la extensa transcripción de Palabras de un rebelde, de Kropotkin.

4. Transcripciones de largos textos escritos por críticos reales que resultan irónicas por extemporáneas o porque su inserción se realiza, a modo de collage, junto a otros textos que cuestionan su contenido. Así por ejemplo, un entusiasma panorama del arte español decimonónico está antecedido y seguido por textos históricos sobre la compleja situación política.

5. Reflexiones puntuales sobre afirmaciones de críticos reales que traspone a otros casos. Por ejemplo, cita un texto con la frase antecedente: "Lo mejor acerca de Picasso" y prosigue: "Su gran mérito consiste en haber creado lo monstruoso verosímil. Sus monstruos nacieron viables, armónicos. Nadie se atrevió más que él en el sentido de lo absurdo posible. Todas esas contorsiones, todas esas caras bestiales, todas esas muecas diabólicas, están penetradas de humanidad". Y luego puntualiza que en realidad es un texto de Baudelaire, acerca de Goya (221).

6. Artículos apócrifos de diversos críticos imaginarios como Miguel Guash Guardia, Paul Derteil o Juvenal R. Román sobre Jusep Torres Campalans, dentro de los cuales, al modo del principio de la muñeca rusa, bien puede insertar citas reales como hace, por ejemplo, cuando en una nota de Román menciona una afirmación del novelista Juan Bautista Amorós y Vázquez de Figueroa: "Mis coetáneos —escribe Silverio Lanza antes del fin del siglo- 
hacían arte para que les entendieran y les admirasen los brutos y vosotros (los modernistas) hacéis arte para que lo entiendan y lo admiren los artistas. Ese es el camino del infierno". Y luego continúa en la voz impostada: “...el artista se vengó de la sociedad haciendo un arte crítico y críptico, incomprensible para la mayoría. De ahí los ismos" (95).

7. Los textos críticos de Henry Richard Town, e imaginario investigador de la obra de J.T.C., recopilados en el catálogo destinado a su exhibición en la Tate Modern, en los cuales parodia los estilos de la época.

8. Las "Notas" que acompañan la biografía y que en varios casos contienen disgresiones académicas de Aub en torno a temas como la influencia del ancestral arte catalán en Picasso. "Cualquiera que haya visto primitivos catalanes. Pintura o escultura, no tiene por qué buscar más antecedentes a la revolución producida por las 'señoritas' de Avignon y los cuadros que las rodean (...). La composición misma de los cuadros de Picasso, de esa época fundamental, es hija de esa voluntad románica de traer a primer término la figura central, la de Dios, sin fondo determinado (...). El llamado 'período negro' debiera titularse, si se empeñan en marbetear, 'período románico catalán"”(190-91).

9. La sección "Textos de Jusep Torres Campalans" con declaraciones a periódicos, o revistas, y entrevistas. En supuestas declaraciones para el Figaro Illustre, hechas poco antes de abandonar todo, el 1 de febrero de 1914, según el biógrafo Aub J.T.C. le dice a un periodista: "Si los cuadros se parecen, y a veces nadie puede discernir con seguridad un Rafael de un Andrea del Sarto (sic) sino porque lo dicen los eruditos, no vale la pena pintar. Importa que digan con solo verlos: Picasso, Léger, Roualt (cosa que no sucede con Gris, o con Braque, fabricantes, buenos fabricantes, pero fabricantes)" (93).

10. Las consideraciones que Aub atribuye a Jusep Torres Campalans sobre el arte de su tiempo o sobre la crítica de arte y que pueden aparecer en tercera persona, cuando escribe su biografía, o a través de la voz de uno de los críticos que escriben sobre su obra y lo citan. Así por ejemplo, en la biografía, J.T.C. hace una revisión del arte de otros siglos — guiado por el gusto, sin conceptos- en sus extensos recorridos por el Louvre cuando llega a París: “...los flamencos están bien, pero todos están bien. Sólo Brueghel es más", "¿A dónde van esos infelices de Rosseau, Daubigny, Díaz o Corot, ese bobo de Millet? Dios perdone a Cabanel, a Baudry, a Meissonier, a Puvir de Chavannes, a Moreau. ¿Es que la gente no tiene ojos?" (128-29). "Si queda algo de Gris, o de Gleizes - escribió en una frase terrible - serán sus teorías" (85). Y, por otra parte Aub "transcribe" literalmente, en primera persona, las anotaciones de Jusep Torres Campalans sobre arte y crítica de arte supuestamente encontradas.

Esta última modalidad de meta-crítica, que es la materia principal del Cuaderno verde (un cuaderno escolar, en cuadernado en cartoné verde, foliado de 1 a 240), donde 
J.T.C. anotaba sus pensamientos y que le fue entregado a Aub, según explica, por Cassou, contiene numerosas afirmaciones, que ameritan ser citadas. En esta sección Jusep Torres Campalans escribe por una parte sobre sus aspiraciones artísticas, y por otra como heterónimo del Aub en el papel de crítico, enfilando sus dictámenes sobre el arte moderno. Muchas de sus afirmaciones son más emocionales que teóricas, pero no dejan de tener una intención analítica, deconstructora.

De sus aspiraciones, que conformarían una suerte de manifiesto de lo que debería ser el arte de su tiempo, señalo algunos aforismos: "El arte arde o no es" (198-99). "Ir contra el momento preciso, ir en contra del ahora, para dar a las cosas un estar perdurable" (199). "Hallar un champ vague, como dicen los franceses (...), y construir, sin ligazón con lo de atrás: como si fuese por, para analfabetos". (199). "Las manos son más exactas que la lengua" (216). "Con la materia nada podemos: queda la forma: para jugar" (201). Y hace también pequeñas disgresiones: "La pintura no debe decir nada: ha llegado la hora de hacer una pintura muda, una pintura sorda, una pintura abierta en canal; que enseñe sus tripas". "Convertir la pintura en escritura. Coger el lienzo de sorpresa" (202). "Si la luz cambia, también el espacio. Si queremos hacer algo perdurable: suprimirlos. Inventarlos". "Devolver a la pintura su sentido mágico. Pintar amuletos. Pintar trampas en las que caiga lo representado, inmortal ya” (203). “...una pintura de acción ${ }^{76}$ directa, una serie de atentados que hicieran saber a los demás que existimos, que queremos un mundo más justo... pintar dinamita, hacer estallar el lienzo" (143).

También en el Cuaderno verde, J.T.C. imparte dictámenes sobre el arte y a veces sobre la crítica de arte, que acaban por translucir su paulatino desencanto: "El que 
explica, se rebaja. Por eso todos los críticos son pequeños" (221). "El arte tiende a la espiritualidad. Pero las doctrinas, lo doctrinario, lo hacen degenerar" (253). "Matisse sí; como pura epidermis. Hermoso traje para vestir la pintura, pero ¿la pintura?" (202). "Los fauves están bien, pero se van por las ramas. ¡Las raíces, señor, las raíces!” (205). “¿Esas mujeres de Picasso? Sí y no. Buscar, no algo que no se haya hecho, sino algo no hecho, sin hacer”. "Modigliani: ¡qué gran pintor japonés!” (234). “¡Anatema sobre Wassili Kandinsky! Eso: ¡a ningún precio! Que se dedique a escribir música” (232). “¡Qué gran pintor sería Chagall si tuviera mejor gusto!" (241).

El arte abstracto es bueno para los rusos - que huyen de su realidad y de la de todos-, nunca para nosotros. El pobre Delaunay se ha dejado embaucar por Sonia, pero ya volverá. Ni Larionov, ni Rodehenko (sic) ${ }^{77}$, ni Kupka, tienen que ver con la pintura. Buscan otra cosa, relacionada con la fábrica de tejidos de Kandisnky, la arquitectura, la decoración de interiores o de hermosas tiendas, allá ellos. Artesanía (232).

Si se presentara a un ser fuera de la historia —caído del cielo-, despejado, uno o varios cuadros de Velázquez, el Greco, Goya y Picasso y le preguntaran cuál fue, a su juicio, su sucesión en el tiempo, no creo que dudara en señalar a Picasso como primitivo y como el más reciente, el más perfecto, a Velazquez. El lío se lo haría entre los otros dos. Pero Picasso, Goya, el Greco, Velázquez sería una normal sucesión para un espíritu no prevenido (231).

“ ¡Cubistas! ¿No os fastidia? Cuando lo que buscamos es exactamente lo contrario: restituir al lienzo lo que es de su superficie..." (221). "Creer que lo que hacemos es gran pintura, mentira. Preparamos la de mañana. ¿Basta?” (226).

Pocos son los que se salvan para J.T.C.:

Mondrian es aparte. Se da cuenta de que lo suyo, lo que busca, no es pintura sino un universo plástico. En la proporción -en las proporciones- hallará descanso. Le envidio (...), hombre puro, si los hay. Religión y arte. En el fondo busca una pintura mística (...) — todo tiene su razón de ser-dice. La superficie de las cosas da placer, pero el interior hace vivir. Es lo que busca en su pintura, cada vez más desnuda. Ha convertido el mar en algo inmutable, pero a la vez, en movimiento (249-253). 
En la misma página en que traza un dibujo inspirado en (y titulado como) el Mar de Mondrian, anuncia lo que seguirá: "Lo mejor, tal vez, sería no hacer nada" (253).

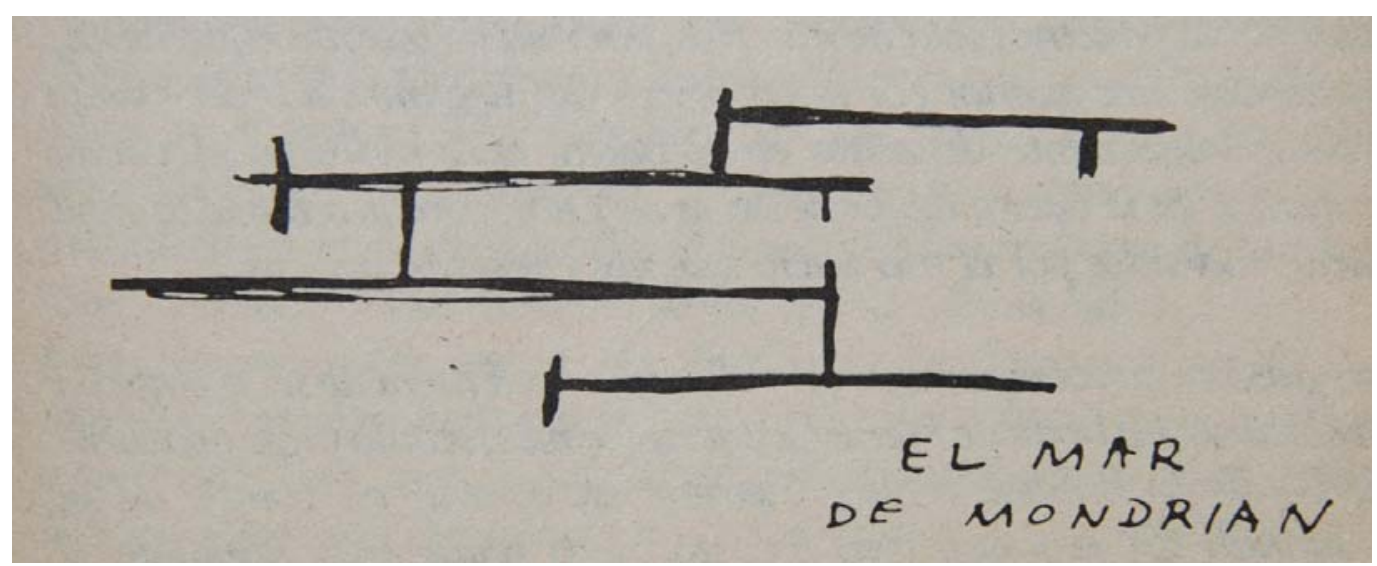

Ilustración 39: Jusep Torres Campalans, El mar de Mondrian 1914, ilustración

Y, sin embargo, enfila contra la abstracción derivada del holandés: "Todos estos abstraccionistas de hoy... Un salto atrás. Se metieron en la fosa de Mondrian y se arrastran allí como gusanos (...) «los abstractos», me río. Trampas” (295). La diatriba contra esa frontera última de la modernidad que ya anunciaba la posmodernidad es interminable: "-Pinto la pintura. ¿A dónde irán a parar? A la nada" (230).

Aub escribe con desfachatez que J.T.C., soñaba pintar, consciente de que se había roto el hilo de la continuidad en la historia del arte: "Ahora todo se acaba" (145), afirma, poco antes de marcharse a México. En la sección Las conversaciones de San Cristóbal, donde Aub transcribe sus encuentros con Jusep Torres Campalans, afirma: "Los artistas de hoy dan risa: no les importa más que su obra. Parecen cómicos —actores-. Han venido a ser exclusivamente intérpretes de una obra que, a veces no entienden" (288). De su propia obra —reflejo de la vanguardia— dice: “(...) como pintor fui un fracaso. No un fracasado. No me llamó Dios por ese camino. No pinté nada, en ningún sentido" (286). Y 
le explica que se marchó porque ya no se entendían París y él. Empezaba "la época de los falsarios" (275). Más adelante asegura que la pintura es hoy "una sociedad secreta para iniciados. Una masonería cualquiera, con sus maestros, sus grados 33, etc!” (279).

El encuentro entre Aub y J.T.C da origen a una larga serie de dictámenes. Asegura que "del arte sólo se pueden decir tonterías" o hablar de su historia. "Pero de eso a divagar del valor y de los valores, de la calidad y de las calidaades... ¡Vamos! Al que me explique por qué los ladrillos de esta fuente son rojos" (291). Su actitud es ahí similar a la molestia que solía expresar Picasso, pero particularmente se enfila contra los críticos a los que llama "anunciantes y gracias... La prueba es que sólo los hubo desde que la burguesía fue compradora: para duplicar sus dineros" (291). Mientras disuelve lentamente el azucar del café con la cucharilla, afila su lengua y dice:

La crítica - dictamina-empieza a existir cuando sirve a los intereses económicos de los pintores o de sus representantes. Es una expresión de la industrialización, como la publicidad o la propaganda. La crítica se paga siempre. Es la única «escritura» que se paga relativamente bien, de la que se puede vivir. Ma non é una cosa seria. Hay críticos desde que se compran cuadros sin encargarlos (292).

La confesión final de J.T.C. es que "Nos pusimos a darle a la pintura, a la que tenían por tal en los salones. Y la arruinamos" (298). Cree Aub, a través de su figura, en la honestidad de un empeño que con todo acabó siendo fallido. Refiriéndose a la desaparición de Jusep Torres Campalans de cuya vida ya no se sabe nada, Aub, el narrador, dice que basta que quede vivo en la imaginación de los demás y se declara satisfecho de haber cumplido un propósito que a fin de cuentas sintetiza la obra entera del pintor: "No tendieron a más mis medios, como no fuera — de paso—a enseñar, con tan 
buen ejemplo, el cobre de tanta farsa pictórica”. Es así, una declaración crítica sin cortapisa.

Al terminar los textos de Jusep Torres Campalans se comprende que no sólo era acertada la comparación de los editores entre su obra y La boca del caballo, de Joyce Car, o El coleccionista, de John Fowles, en relación con la reflexión sobre el arte contemporáneo, sino que la apócrifa biografía del catalán, hecha de dispersas aristas, de textos fragmentados, anticipa los textos teóricos que abordan el tema del fin de la historia del arte.

Ante la consideración que incluye la biografía falsa de que "Picasso, Torres Campalans — pudieron haber pintado como Murillo o David — ¿quién se lo impedía? y no quisieron" (96), el lector tiene la posibilidad de observar por sí mismo las obras del segundo. Y dudar de su valor. A diferencia de cualquier relato novelístico en el que se nos describe una pintura de notable interés y la enunciación basta para creerlo, Aub corre el riesgo de sucumbir a su propia estrategia de verosimilitud pues las obras se apartan no sólo del movimiento que J.T.C. contribuye supuestamente a fundar, sino de la misma maestría que supuestamente deberían tener. Pero cualquier impugnación de su calidad, cede ante la genialidad de su procedencia. Valen porque son ficticias y porque esa ficcionalización contiene una buena porción de verdad del espíritu del siglo XX que vio convertirse todas las utopías en pesadillas, y a las vanguardias derivar en el fin de todos los movimientos y escuelas, en lo que Arthur C. Danto nombró como el fin de la historia del arte. En su Cuaderno verde anota Jusep Torres Campalans: "El arte por el arte: imbecilidad. ¿O habéis oído hablar del arte por el no arte?” (230). 
La atrevida ficcionalización de Aub fue una autofagia singular: devorar el arte de su tiempo. Aub explica también cómo el artista de la época que ya no es el pintor de la corte, el servidor del poder ${ }^{78}$, fue echado del estado, se hizo en heterodoxo y se convirtió en modernista: un artista que "ya no pinta para todos, sino para pintores. Ya no hace obras, sino ensayos" (95). ¿Acaso puede decirse otra cosa de una obra como Jusep Torres Campalans? ¿No anticipa la fusión contemporánea entre ficción y realidad, entre novela y ensayo, la desbandada de todos los géneros o su negación? El arte, no hay duda, está cifrado para Max Aub, transeúnte de los márgenes, en una orilla alterna a la realidad de un mundo astillado: esa venganza de los artistas cubistas que la descomponen para impugnarla o para entender lo inentendible, haciendo un arte que inquieta las consciencias, que deshace la idea de lo bello instaurando en el centro el caos reflejo de la época, mueve también su propia obra literaria que es cubista en la escritura y copia el arte de su tiempo: cuadros que son mentira, literatura que es mentira. Ya decía Steiner que la poética de la libertad humana está indisolublemente unida a la mentira, esa mentira que nos permite vivir en formas como la ficción, el poema, y la utopía, o bien en una biografía y unos cuadros apócrifos.

El último cuadro que incluye en su libro se llama Superficie calcárea: en el centro de la abigarrada trama, un hueco, un vacío, la nada que anunciaba la renuncia de Jusep Torres Campalans a la pintura, su acto supremo de verdad, su deseo de pintar para los ciegos o de vislumbrar no el amarillo del trigo ni de la llama, sino "un amarillo inventado" (264). La esperanza depositada en lo que no es. Al fin y al cabo, tanto él como su inventor, Max Aub, compartían un credo que enuncia el primero bajo el título de Estética: el hombre, además de ser el único que sabe que tiene que morir, es "el único 
que miente. ¿Hay alguna virtud que asiente más la condición del hombre que decir algo a sabiendas falso dándolo por verdadero?” (241).

Lo sorprendente de este gran mentiroso que fue Max Aub es que en el fondo de todas sus patrañas, hay un rastro de ese amarillo inventado que buscaba Jusep Torres Campalans y cuando se cierra el libro, ya diluidos —o más bien confundidos— biógrafo fingidor y biografiado inexistente, el lector recuerda, repetida en boca del artista inventado, la sentencia que éste le oyó decir cuando conoció a Picasso: "Los hombres son lo único que vale la pena" (301). Las mentiras de Aub, ciertamente, nos llevan de regreso a ellos y al terreno de lo posible imaginario donde siempre hay un resquicio en el que todo puede suceder. Sucedió, por ejemplo, que en 2001 se bautizó en su honor un asteroide descubierto entonces por Rafael Ferrando, el (72827) Maxaub. Una posteridad digna para este autor pionero de la ficción extrema que murió como narró Luis Buñuel, no sin envidia, con un solo suspiro pronunciado en su apartamento de la calle Euclides, en Ciudad de México, apenas un segundo después de haber partido un mazo de cartas. No dio detalles acerca de si era la Baraja de Naipes, que Jusep Torres Campalans diseñó, exactamente medio siglo después de haberse esfumado como pintor.

\footnotetext{
${ }^{18}$ El libro póstumo de Max Aub, Luis Buñuel, Novela, fue anunciado por Editorial Vigía, con estas palabras : "La última gran obra inédita de Max Aub. Un fabuloso retrato de la primera mitad del siglo XX; una nueva mirada sobre Buñuel, el cine y las vanguardias. Una biografía única que descubre al verdadero Buñuel. Un libro imprescindible para el conocer la cultura del siglo XX".

${ }^{19}$ Hay una foto tomada en 1965 en la cual se ve a Aub y al poeta León Felipe (1884-1968), en el patio interior de una casa en Ciudad de México, que los muestra sonrientes. Conversan, sonrientes, sentados a la mesa al aire libre y en generosa compañía de varias botellas de vino. El primero decía que León Felipe, era, "él sólo, una generación aparte (...) Imagen viva, desolada y desollada de nuestra España, empalada en una misión sangrienta de la Historia". En el discurso El campo y las cenizas. Imágenes del Holocausto en la poesía española de posguerra que Sultana Wahnón pronunció en su ingreso a la Academia de las Buenas Letras de Granada, evocó cómo, buscando rebatir el dictum de Theodor W. Adorno sobre que
} 
no era posible escribir poesía después de Auschwitz, investigó a los escritores españoles exiliados y encontró a Max Aub y su drama San Juan, sobre un barco lleno de refugiados a los que ningún país deja entrar en puerto, y a León Felipe, que escribió en 1965, el mismo año de la fotografía arriba mencionada, el poema Oh, este viejo y roto violín, que Wahnón considera como fundador del género de poemas sobre el holocausto y los campos de concentración, al que también contribuyeron Miguel Hernández, Jorge Guillén y Rafael Alberti.

${ }^{20}$ Juan Rodríguez anota en La aportación del exilio republicano español al cine mexicano del libro editado por Roman Gubern Cine español en el exilio, 1936-1939 que Aub, tras escribir sobre cine en los 30, colabora con Malraux en la realización de Sierra de Teruel (adaptación de la novela L'espoir): "Fue un auténtica prueba de fuego pues Aub, además de traducir el guión y adaptar los diálogos, ejerció en la práctica de asistente de Malraux, de ayudante de dirección, de productor, de ayudante de montaje, e incluso prestó su voz a uno de los personajes. Tal experiencia le fue reconocida al escritor -que había solicitado su visado para México en 1939 poniendo Sierra de Teruel como pretexto-- cuando, después de pasar por varios campos de concentración en Argelia y Francia, se instala definitivamente en México en 1943 y ejerce, hasta 1951, como profesor de teoría y técnica cinematográfica en el Instituto Cinematográfico de México; en 1948 será nombrado asesor técnico de la Comisión Nacional de Cinematografía de la Secretaría de Gobernación, cargo que desempeña hasta el año siguiente, y entre 1950 y 1951 formará parte de la Comisión Técnico-Literaria del Banco Nacional Cinematográfico". Colaboró como guionista y dialoguista en numerosas películas. Hace el guión de Distinto amanecer (1943), de Julio Bracho -adaptación de su drama La vida conyugal- y, a partir de ahí trabaja ininterrumpidamente en este medio que se convierte en un modo de sobrevivencia. Se adapta "a las exigencias de la industria y con una transposición en imágenes que no siempre está a la altura de su talento literario". Pero le ocurre que, habiendo colaborado con Buñuel en los diálogos de Los olvidados (1950), el crédito se olvida en los títulos del filme. Entre sus colaboraciones para el cine se encuentran los guiones de El globo de Cantolla (1943), La monja alférez (1944), de Emilio Gómez Muriel, uno de los primeros éxitos de María Félix; Sinfonía de una vida (1945), de Celestino Gorostiza; La viuda celosa (1945), de Fernando Cortés (adaptación de La viuda valenciana de Lope de Vega); El charro y la dama (1949), de Fernando Cortés, adaptación de La fierecilla domada de Shakespeare; y Cárcel de mujeres (1951), entre otros. En 1949 tradujo y publicó el guión de René Clair El silencio es oro (Le silence est d'or), llevado a la pantalla en 1947; en 1965 fue jurado del Festival Internacional de Cannes; en 1968 publicó el guión de rodaje de Sierra de Teruel. Aub grabó varias entrevistas con el aragonés Luis Buñuel y con numerosos amigos y colaboradores de éste. La mala salud le impidió debutar como actor con el pequeño papel que Buñuel le había reservado en El discreto encanto de la burguesía. (GEXEL - Universitat Autònoma de Barcelona. REDER. Red de Estudios y Difusión del Exilio Republicano 4).

${ }^{21}$ Una nota de página del ensayo de Juan Oleza Simó, Luis Álvarez Petreña o la tragicomedia del yo, explica: "La escritura de Luís Alvarez Petreña se concentra en tres textos impresos en volumen, que incluyen materiales publicados en ocasiones previamente en revistas literarias o en otros libros de Max Aub. Cada una de las últimas ediciones aporta textos nuevos a la anterior, de manera que la tercera y última resulta sensiblemente ampliada con respecto a la primera. Esta se publicó en Valencia, en 1934. Le siguió la de la editorial Joaquín Mortiz, S.A., en Mexico, en 1965, y a ésta le siguió la de Barcelona, Seix Barral, 'Biblioteca Breve', de 1971. Max Aub y el laberinto español "(Actas del I Congreso Internacional sobre Max Aub) Valencia. Ayuntamiento. 1996 (93).

${ }^{22}$ Escribe Aub al respecto un Informe estríctamente confidencial de un académico español acerca de este libro, hecho por encargo para una editorial española que es "totalmente negativo" y en el cual se refiere a “... los límites de la mediocridad y la confusión que su autor parece no haber querido nunca traspasar" y luego, con la voz del supuesto informante que ha inventado establece una comparación y radical diferencia con su propia escritura : "El escritor valenciano ha tenido un desenvolvimiento literario y personal muy distinto al del autor, y su interés por el aspecto político de la literatura, le hizo plantear mal, desde el principio, el primer escrito del olvidado aragonés" (Dos vidas imaginarias 562-63). 
${ }^{23}$ En enero de 1937, siendo Aub el agregado cultural de España en París, formó parte de la delegación que fue a visitar a Picasso en París para pedirle pintar un cuadro para el pabellón de la República en la Exposición Internacional. Entre mayo y junio de 1937, lo visitó varias veces y pagó 150.000 francos por el Guernica que Picasso pintó en ese taller Según el nieto de Max Aub,quien lleva su mismo nombre y apellido, a fuerza, puesto que siendo su madre la hija de Aub no le correspondía llevar el apellido materno según la legislación mexicana, pero la familia logró imponer su voluntad, cuando los alemanes bombardearon Guernica, Aub llama a su cercano amigo Picasso y le dice: "Pablo, tienes que hacer algo, una obra, para protestar contra la ignominia de esta masacre" (Aub Max Nieto Entrevista personal con Adriana Herrera, Miami, septiembre de 2006). Poco después Picasso, que había vuelto impresionado de las manifestaciones callejeras de protesta frente a ese bombardeo contra la población española, que demostraba el principio de los sacrificios humanos que a partir de entonces se impondrían, le llamó para anunciarle que acababa de terminar un cuadro inspirado en el bombardeo: El Guernica. Picasso había asistido a las manifiestaciones acompañado de Dora Maar, la magnífica fotógrafa que entonces vivía con él en la misma casa donde Honorato de Balzac había escrito el cuento El pintor y su modelo, que describe por primera vez en la historia del mundo una pintura abstracta no geométrica sino expresionista, mucho antes de que un movimiento así pudiera tener lugar en la historia del arte. Si Picasso hasta entonces, había pensado presentar una obra inspirada en el tema, y de hecho, había realizado ilustraciones para nuevas ediciones del cuento de Balzac, tras la manifestación, y con la paralela instigación de Dora, que era muy activa políticamente, hace el cuadro que contiene todo el horror frente a la primera masacre contra una inerme población civil realizada desde el aire. La artista que, como otras mujeres de la época amantes de grandes creadores, acabó su vida confinada en el dolor y paralizada en su propia creación, documentó con fotografías en blanco y negro el maraviloso proceso de realización del cuadro, cuyos bocetos tienen en principio color y poco a poco, en una transformación que es paralela a su documentación, van perdiéndolo.

${ }^{24}$ Hago extensivo a Jusep Torres Campalans el término con el que su libro Barterbly y compañia, Enrique Vila-Matas designa a los escritores que por diversos motivos decidieron no escribir nunca más. Picasso contaba que a los 14 años, su padre, José Ruiz Blasco, profesor de arte, le había entregado sus pinceles y materiales de pintura, y jamás había vuelto a pintar. Aunque la versión es puesta en duda por Pierre Cabanne, a quien debemos algunas de las más reveladoras entrevistas con las dos figuras tutelares del arte del siglo XX, Pablo Picasso y Marcel Duchamp, fue a esa edad cuando ingresó en el curso superior de la Escuela de Dibujo de Bellas Artes de Barcelona y pinta su Muchachita descalza. A los 15 años tenía su estudio, un año después había ganado una mención en la Exposición de Bellas Artes de Madrid e ingresaba, siendo tan joven, a los cursos superiores de la Academia Real de San Fernando. Dos años después haría un retrato, hoy legendario, de Gertrude Stein.

${ }^{25}$ Octavio Paz inicia Apariencia desnuda. La obra de Marcel Duchamp con una consideración generalizada en la época: "Tal vez los dos pintores que han ejercido mayor influencia en nuestro siglo son Pablo Picasso y Marcel Duchamp. El primero, por sus obras; el segundo por una obra que es la negación misma de la moderna noción de obra. Los cambios de Picasso — sería más exacto decir : sus metamorfosis- no han cesado de sorprendernos durante más de cincuenta años; la inactividad de Duchamp no es menos sorprendente $\mathrm{y}$, a su manera, menos fecunda" (15). La posmodernidad y su relación con el arte contemporáneo, haría que la figura de este " no hacedor " eclipsara la "urgencia brutal " del primero. Hans L.C. Haffé inicia su ensayo para el libro Picasso publicado por Garzanti, Spadem, París así : "Lópera e la personalità di Pablo Picasso sono divenute già da molti anni un elemento essenziale del volto di questo nostro XX secolo. (...). L'uomo Picasso è uno dei rari 'piloti' della nostra epoca "(9). En la introducción de su libro Picasso, publicado en la colección de Miniaturas Hyperion, Andre Lecler (s.f.) lo describe así : "el más versátil, el más variado de los pintores de nuestro tiempo, y quizás de todos los tiempos " (5). Este autor transcribe algunos de los ocho nombres con los que fue bautizado : "Nepomuceno ", o "Crispiano de la Santísima Trinidad".

${ }^{26}$ En 1952, Picasso escribe una suerte de confesión en una carta a su amigo Giovanni Papini del cual las revistas francesas "Poitiers-Universite" (n¹20, abril 1978) y "Universidad Francesa" (n¹18, marzo, 1984), publicaron un extracto que a partir de entonces se ha citado en numerosas publicaciones. Augusto Geisse de 
Madrid hizo una traducción del fragmento que con motivo de la exposición "El siglo de Picasso", publicó el diario $A B C$, y que revela su plena conciencia de lo que implicaba esa conversión en una celebridad: "Dado que ya el arte -escribió Picasso- no es el alimento que nutre a los mejores, el artista puede ejercitar su talento en todos los intentos de nuevas fórmulas, en todos los caprichos de la fantasía, en todos los recursos del charlatanismo intelectual. En el arte, el pueblo ya no busca consuelo ni exaltación, pero los 'refinados', los ricos, los ociosos, los destiladores de quintaesencia buscan lo nuevo, lo extraño, lo original, lo extravagante, lo escandaloso. Y yo mismo, desde el cubismo y más allá, he contentado a esos maestros y a esos críticos con todas las rarezas cambiantes que se me pasaron por la mente, y cuanto menos las entendían, más las admiraban. Y divirtiéndome con todos esos juegos, con todas esas patrañas, he conseguido la celebridad y muy rápidamente. Y la celebridad para un pintor significa: ventas, ganancias, fortuna y riqueza. Y hoy, como usted sabe, soy célebre, soy rico. Pero a solas conmigo mismo, no tengo el valor de considerarme como artista en el sentido grande y antiguo de la palabra. ${ }^{\text {Fueron }}$ grandes pintores Giotto, Ticiano, Rembrandt y Goya; yo sólo soy un 'amuseur' público que ha entendido su época, y ha agotado en cuanto ha podido la imbecilidad, la vanidad y la codicia de sus contemporáneos. Amarga confesión la mía, más dolorosa de lo que pueda parecer, pero con el mérito de ser sincera", febrero 17 de 1988). Norman Mailler menciona que después de inventar el cubismo, vivió como Picasso, en el primer plano de la cultura occidental sesenta años y que al morir era el pintor más rico de la historia y posiblemente el más prolífico. Por el contrario, Alan Pauls cita en el artículo El virus Duchamp, una declaración del creador de los readymades hecha a Francis Steegmuller, que contradice en su caso, la visión de la celebridad. "Usted sabe que es uno de los artistas más famosos del mundo", le comenta Steegmuller. Y Duchamp: "No sé nada de eso. En primer lugar, la gente común no conoce mi nombre, mientras que la mayoría ha oído hablar de Dalí y de Picasso, e incluso de Matisse. En segundo lugar, si alguien es famoso, creo que es imposible que lo sepa. Ser famoso es como estar muerto: no creo que los muertos sepan que están muertos. Y en tercer lugar, si fuera famoso, no podría enorgullecerme demasiado; la mía sería una fama payasesca, que se remontaría a la sensación causada por el Desnudo bajando una escalera. Aunque supongo, evidentemente, que si esa clase de infamia dura ya cincuenta años, es porque entonces hay algo más que el escándalo”. Steegmuller: “¿Qué otra cosa hay?”. Duchamp: "Hay eso”. “Eso?” "Eso. Lo que no tiene nombre" (Página 12).

${ }^{27}$ Ramón Casas (1866-1932) fue una figura clave del modernismo en Barcelona y llegó a integrarse plenamente a la escena del arte en París. Abrió en Barcelona el café Els Quatre Gats confabulándose con otros tres artistas: Pere Romeu, Santiago Rusiñol, y Miguel Utrillo. Allí tuvo Picasso una de sus primeras exhibiciones y se desarrolló la vida del grupo así llamado que publicó a su vez la revista literaria $E l s$ Quatre Gats. Anterior al Café Voltaire, entre el día de su apertura, el 12 de junio de 1897, y el año del nacimiento de Aub, 1903, cuando se cerró, el café de Casas fue un epicentro del modernismo español que funcionaba en el sótano del edificio Casa Martí. Casas, cuya serie de pinturas de multitudes es muy conocida, llegó a ser miembro del salón de la Societé d'artistes françaises adquiriendo así el derecho a exhibir su pintura sin someterse al juicio de un jurado, y participó en la exposición mundial de Chicago de 1893. Su generación dejaría de mirar a la burguesía, a la que pertenecía, para retratar otros sectores. Una obra de 1900 -año en el que participa en la gran Exposition Universelle de París con un retrato del músico Eric Satie y otro de su hermana Elisa- mostraba a un guardia civil cargando contra la multitud. En 1902, lo retituló como Barcelona 1902, haciendo alusión a una huelga que tuvo lugar en Barcelona. Además de su interés social, es posible que a Aub se identificara con sus investigaciones en diseño gráfico. Como Tolouse-Lautrec (1864-1901), Casas incursionó en la ilustración y la caricatura. En 1904, estando en Madrid, hizo una serie caricaturizando a la élite madrileña, así como de Joaquín Sorolla y Agustín Querol. Diseñó también carteles para el bar y también realizó anuncios para la firma "Codorniu", fabricante de cava, o para el "Anís del Mono". Hay mucho de intención caricaturesca en el Aub que escribe la vida de su heterónimo J.T.C. y hace su obra. No hay que olvidar que, de modo póstumo, Max Aub obtuvo el Premio al Humor Negro 1981 en Francia a su libro de cuentos Crímenes ejemplares.

${ }^{28}$ El barcelonés Isidro Nonell (1972-1911), pintó, el alma de los mundos marginales de su época. En 1907, mientras su amigo cambiaba la historia del arte con el desafuero de Las señoritas de Aviñón, él pintaba su Mujer semidesnuda, mostrando delicadamente un seno, y con una expresión intimista, casi tímida, 
desalada, pero no sin espíritu. Nonell integró como el Picasso de los inicios el grupo Els Quatre Gats, cuyo nombre era el del famoso café de Barcelona, que entre el día de su apertura, el 12 de junio de 1897, y el año del nacimiento de Aub, 1903, cuando se cerró, fue un epicentro del modernismo que funcionaba en el sótano del edificio Casa Martí financiado por el pintor Ramón Casas. El nombre también hacía alusión al legendario café parisino Le Chat Noir. Cuando Picassp se instaló en Montmartre tomó, junto con su amigo Casagemas, quien se suicidaría poco después, el estudio de la Rue Gabriella de Nonell, que por entonces había regresado a Barcelona.

${ }^{29}$ Afirma Pilar G. Sáenz : "en el caso de Juego de cartas, tenemos un texto que es a la vez barajas de naipes y conjunto de epístolas, que presupone a la vez juego y lectura, donde el acto de leer está sujeto a infinitas modificaciones impuestas por las diferentes posibilidades admitidas por las reglas del juego - el número de jugadores y de bazas, la forma del reparto de cartas, la secuencia en la distribución de naipes - donde el azar multiplica ad infinitum sus posibilidades (...) Las variantes son enriquecidas por factores diversos en los que interviene el azar: número de jugadores, bazas de cartas, secuencia tanto en la lectura de cartas como en el orden en que los lectores de esas cartas intervienen" (238).

${ }^{30}$ Escribe Camnitzer: "One of his most wonderful sketches inmortalized in the book is El mar de Mondrian, It is a crude pen-an-ink drawing with some horizontal lines and vertical fragments that look like an incomplete staircase in a pathetic efort to portray fluidity" (118). El trazo es en todo caso, una temprana apropiación lúdica inspirada en la célebre pieza de Mondrian.

${ }^{31}$ La observación aparece en el ensayo de Ana Calvo Revilla "Ficción y realidad en Jusep Torres Campalans de Max Aub", donde se aproxima a la novela Jusep Torres Campalans a partir de la visión propuesta por Albaladejo Mayordomo, T. (1986), en Teoría de los mundos posibles y macroestructura narrativa. Menciona cómo los tres tipos de modelo de mundo propuestos aquí son : el mundo tipo I de lo verdadero, que corresponde al mundo real efectivo; el tipo II de lo ficcional verosímil, que es construido por el autor contando con su equivalencia en el mundo real efectivo; y el modelo de mundo tipo III, de lo ficcional inverosímil, que el autor establece sin equivalencia con el mundo real efectivo. "Max intenta presentarnos bajo la apariencia de un modelo de mundo I, -es decir, bajo la apariencia de un modelo de mundo de lo verdadero y de la reproducción del mundo real efectivo-, un modelo de mundo tipo II, de lo ficcional verosímil. La ficción se revela en el mundo narrativo de Jusep Torres Campalans como uno de los elementos fundamentales, sin el cual es imposible hacer una adecuada interpretación del hecho literario que contemplamos. Con el formato de una reproducción fidedigna de la realidad, Max Aub se inventa una historia que entra dentro de los modelos de mundo tipo II, mundos ficcionales verosímiles.

${ }^{32}$ En la cronología que presenta en su libro Jusep Torres Campalans incluye su propio nacimiento cuando se refiere a este año como el natalacio de otros intelectuales como George Orwell, Eduardo Mallea, Xavier Villaurrutia y Juan de la Cabada. Éste último fue también un fabulador desfachatado y tuvo un vínculo fuerte con España: viajó junto con Octavio Paz y otros escritores mexicanos como parte de la Liga de Escritores y Artistas Revolucionarios. LEAR, que permanecieron unos meses en España tras asistir al II Congreso Internacional de Escritores para la Defensa de la Cultura.

${ }^{33}$ Remito a la biografía escrita por Miguel Ángel Sánchez que divulga la Fundación Max Aub, donde da detalles tanto de sus ancestros, como de su infancia.Su padre, también Max Aub había nacido en Baviera y a fines del siglo XIX viajaba por España como representante comercial, un oficio que se apartaba de la tradición familiar como gentes de leyes. Hablaba español y en Sevilla trabajaba para la casa Alaska. Tras su quiebra empieza a trabajar como vendedor de bisutería fina para caballeros. "así consta en el encabezamiento de las cartas que dirigía a sus clientes y que posteriormente también utilizaría el pro como vendedor de Bisutería Fina para Caballeros, así consta en el encabezamiento de las cartas que dirigía a sus clientes y que posteriormente también utilizaría el propio Max para cualquier relación epistolar (...). Tenía inclinación por anticuarios y refinados gustos y aficiones artísticas. Narra Sánchez la placidez de una infancia con comodidad y oportunidades educativas, pero también el modo en que el estallido de la Gran Guerra, le revela la incertidumbre que envuelve todo: “... de la noche a la mañana nos convertimos de 
amigos en enemigos... En septiembre - durante la batalla del Marne - que se libraba a dos pasos, salimos hacia España; mis tíos - los hermanos de mi madre - peleaban en el ejército francés; la familia de mi padre en las filas alemanas; otro tío mío, comandante casado con una hermana de mi madre, lo era del ejército austriaco". Amigos valencianos del padre de Max le aconsejaron que no volviera a Francia. Así lo hizo, y en agosto de 1914 recibía a su familia en Barcelona. (maxaub1 Web).

${ }^{34}$ Luís Alvarez Petreña se publicó inicialmente en Valencia en 1934. Posteriormente Aub hizo dos ediciones con nuevos textos. Algunos de éstos habían aparecido con antelación en revistas literarias y en diversos títulos de suyos. Cada una de las últimas ediciones aporta textos nuevos a la anterior, de manera. En 1965 reedita la vida y obra de Luís Alvarez Petreña en la edición ampliada de Joaquín Mortiz, S.A., publicada en Mexico, y en 1971, el año anterior a su muerte Seix Barral publica en Barcelona en su colección "Biblioteca Breve", la versión más completa. Dice Oleza Simó en su ensayo Luis Álvarez Petreña o la tragicomedia del yo: "Los núcleos temáticos que proporcionan una cierta cohesión al disforme magma narrativo publicado entre 1934 y 1971 son el juego reversible (recursivo) entre Max Aub y Luis Alvarez Petreña, el discurso amoroso de Luis Alvarez Petreña a lo largo de treinta y seis años, y los textos autobiográficos del escritor Alvarez Petreña. Si tomamos por un instante este último y sólo este último núcleo, el conjunto de textos podría titularse, como lo tituló Max Aub en 1971, Vida y obra de Luis Alvarez Petreña, añadiéndole a continuación: escritor, e incluso, mal escritor, mediocre escritor, o como él mismo dejó escrito de sí mismo, escritor de grisácea condición, o como declaró en 1969, no tanto escritor como escribiente, corresponsal, diarista".

${ }^{35}$ En 1936, Malraux se marchó a España, se unió a las fuerzas republicanas y organize un escuadrón internacional aéreo que comandaba. Después de cumplir numerosas misiones aéreas en el frente, viajó a los Estados Unidos para recaudar fondos destinados a asistencia médica en España. Su novela L' Espoir (La esperanza humana), basada en sus experiencias en España, se publicó en 1937. En sus tres partes, l'Illusion lyrique, Le Manzanares (nombre del río reconquistado por los republicanos) y L'Espoir, Malraux narra los inicios de la lucha republicana en la España, que vivió el levantamiento popular contra la miseria, la naciente libertad, y la exaltación histórica de un momento en el que todo lo logrado peligraba. Comunistas y anarquistas siguen vías distintas ante el desafío histórico -la formación de líderes autoritarios o la defensa del heroísmo del individuo que se enfrenta solo al poder- pero comparten la conciencia de estar viviendo un momento épico, y un sentido de esperanza humana. El guión de $L^{\prime} E s p o i r$ fue escrito conjuntamente con Max Aub y se proyectó en el legendario cine parisino Le Gran Rex bajo el título Espoir. Sierra de Teruel. El film que produjo y dirigió en Barcelona en 1938 — con un guión escrito en tándem con Max Aub- sólo se mostró en Francia tras el fin de la Segunda Guerra Mundial y la liberación post-ocupacionista, pues habiéndose enlistado como soldado en una unidad de tanques fue hecho prisionero, aunque logró escapar a la zona libre de Francia, donde formó parte de la resistencia. En 1944 fue herido, capturado y sometido a una farsa de ejecución. Sobre la estrecha relación entre Aub y Malraux y su colaboración en el guión de L'Espoir, basado en la novela de Malraux, ver el libro editado por Gérald Malgat, André Malraux y Max Aub. La República Española. Crisol de una amistad. Cartas, notas y testimonios (1938-1972).

${ }^{36}$ En el artículo "Gilberto Bosques, el Schlinder mexicano de cuerpo entero", Diana Mandiá escribe : “El hombre que le daría a Max Aub la libertad llegó con cargo diplomático a París en 1938. Era novato en el oficio y eso que había tenido muchos: maestro de vocación y traductor, también dirigió el diario $E l$ Nacional, además de que fundó y escribió en multitud de revistas revolucionarias; de líder estudiantil maderista pasó a encargarse de la reforma educativa en los estados de Campeche, Yucatán y Tlaxcala bajo las órdenes de Venustiano Carranza, y luego a diputado de Puebla y a responsable de Geográfica Económica del Ministerio de Industria ya en los años 30. Ironías de la vida, rechaza el puesto de embajador para no estar atado a obligaciones oficiales y dedicarse al estudio de la antropología y las relaciones internacionales. La guerra le complicó la misión. La de España terminaba pero no así su tragedia”. Durante la escritura de Max Aub y Francia o la esperanza traicionada (L'atinoir, 2013), Gérard Malgat descubrió la dimensión humana de este diplomático y el resultado es el libro Gilberto Bosques. La diplomacia el servicio de la libertad (Paris-Marsella, 1939-1942). El libro rememora la ocupación de la Alemania nazi y la gesta de Bosques, quien apoyó a los republicanos exiliados y rescató a miles de judíos con un visado que 
entonces era un salvoconducto para la vida. También el escritor John Dos Passos intervino para que Aub pudiera embarcarse hacia México. Guillermo Samperio cuenta en el artículo "Max Aub o el drama del eterno exiliado" que este perdió el barco que debía llevarlo y el visado conseguido por el autor de Manhattan Transfer, y que fue por ello que debió intervenir Bosques y logró que Aub zarpara por el puerto de Casablanca en septiembre de 1942.

${ }^{37}$ S. Fontana Soler sintetiza así esta pieza teatral intemporal: "El San Juan es un buque de carga de caballos, viejo y destartalado, que lleva hacinados a bordo aproximadamente a 600 judíos. El barco se encuentra anclado frente a las costas del Asia Menor a la espera de que se les permita embarcar después de una larga travesía de tres meses. Estamos a finales del mes de julio de 1938, lo sabemos porque en un momento dado se da la noticia de la ofensiva de los republicanos españoles en el Ebro, el barco ha ido dando tumbos de un lugar a otro y nadie quiere que desembarquen, lleva a los apestados del Siglo XX (...).La obra se convierte en atemporal precisamente por esa falta de maniqueísmo y por la universalidad de lo que ocurre con el San Juan. Esta obra no trata del pueblo judío, o por lo menos no solamente, trata de los exiliados, de los desfavorecidos, de los abandonados, de los gitanos, de los homosexuales, de las mujeres, de cualquier grupo de personas que por su condición social, personal, religiosa, política, etc..., pueda ser menospreciado, expulsado, agredido, o simplemente ignorado en su desgracia" (San Juan de Max Aub Web).

${ }^{38}$ El tiempo aciago de la guerra le inspira el ciclo de novelas El laberinto mágico compuesta por Campo cerrado (1943), Campo de sangre (1945), Campo abierto (1951), Campo del moro (1963), Campo francés (1965) y Campo de los almendros (1968). Otras novelas son Las buenas intenciones (1954), con influencia galdosiana, y La calle de Valverde (1961), sobre la dictadura franquista. En 1971, tras haber regresado a España a fines de los sesenta, escribe un libro cáustico, desencantado: La gallina ciega, diario español. Ignacio Soldevila ha estudiado exhaustivamente la literatura de Aub, sobre todo la referida a la Guerra Civil Española. Para ampliar este tema, que no es la materia del presente ensayo, puede consultarse su edición crítica La obra narrativa de Max Aub, 1929-1969.

${ }^{39}$ Parafraseando a Vargas Llosa podría afirmarse que si bien su liberatura no contribuyó a cambiar la vida de manera inmediata, sí es posible decir que quienes lo leyeron fueron más capaces de percibir aquello que en la realidad andaba mal. O, como escribió Fernando Savater en una columna publicada en El País escrita a raíz de la muerte del filósofo Cornellus Castodiaris : "Las sociedades no son el mero resultado de la conjunción de procesos necesarios, sino una permanente autoinvención que establece y deroga sus normas a partir de una realidad cuyo decurso simbólico nunca es irrevocable" (Imaginación y barbarie).

${ }^{40}$ La adaptación cinematográfica de este relato que originalmente iba a llamarse Café Cortado, y que contaba con un guión escrito por Vicente Leñero junto con Manuel Matji, finalmente fue llevada a cabo por el director mexicano Arturo Ripstein, en la película La virgen de la lujuria (2002), donde según GarcíaCaro "el denso cuento de Aub queda reducido a una paródica farsa final, en realidad un apéndice o coda en blanco y negro, que se distingue claramente del resto del filme, preocupado por la obsesiva recreación de las posibles perversiones sexuales del mesero (...). Es en este aspecto de la motivación del mesero para llevar a cabo el tiranicidio, donde la historia de Aub y la de Ripstein difieren de manera radical. Donde Aub había propuesto hastío y velada xenofobia, Ripstein y Garcidiego proponen una dolorosa atracción masoquista y la búsqueda de una masculinidad perdida. La caracterización sexual del Nacho de Aub es concisa y misteriosa: "Vida sentimental nunca tuvo; carece de interés masculino: nació neutro, lo dio por bueno"(10). Una breve línea, una sugerencia apenas, que se repite a lo largo de la narración en sus relaciones con clientes y en su proxenetismo habitual, da pie a Ripstein-Garcidiego para desarrollar una intensa vida privada en la que abundan los fetiches y la lujuria reprimida, de ahí la virginidad del título. Ahora Ripstein deforma y transgrede la mecánica transposición de la historia y la traspasa a un tempo cinemático y a la vez estático y estetizante: utiliza el texto de Aub como excusa que queda diferida y pospuesta, aunque celebrada en el lugar privilegiado del epílogo. 
${ }^{41}$ En cierto modo, la renuncia temporal de Aub a los juegos de autoría, es semejante al proceso de transformación de la bellísima Tina Modotti (1896-1942) de extraordinaria fotógrafa precursora del modernismo en América, en la silenciosa y abnegada "María" que lucha codo a codo con el Comandante Carlo (Vittorio Vidali) por la defensa de Madrid, sin que, como escribió Elena Poniatowska en un número de la revista cultural Ancora dedicado a su memoria en el centenario de su nacimiento, Carlo sepa nunca "de su vida en Hollywood, de sus pininos como actriz, de sus actuaciones en las Filodramáticas del 'Little Italy', de sus lecturas de Joyce y Ezra Pound. Toda su vida intelectual se le escapa" (Ancora, 08-17-1996). Modotti llegó a México en 1939, al final de la Guerra Civil Española y muere en 1942, el año de la llegada de Aub. No obstante, alguna vez éste evocó sus conversaciones en México con Vidali. También el fotógrafo Henri Cartier-Bresson, quien había fraternizado con los surrealistas cerca de una década, se ve marcado por su conciencia política entre 1936 y 1946. Fue él quien filmó en Quinto de Ebro a los voluntarios de la Brigada Lincoln que se alistaron para luchar contra el fascismo. Como escribe Jesús Ruiz Mantilla, ese material que estuvo perdido entre 1938 y fue encontrado en Nueva York en 2010, muestra a los hombres que venían de Estados Unidos, Canadá o Gran Bretaña, a luchar contra el fascismo, y que no llevaban uniforme ni iban rapados al cero. En total, Cartier-Bresson filmó tres documentales: Victoria de la vida y España vivirá. Tras haber querido aprender cine con Buñuel, quien no lo aceptó, acabó estudiando cine documental con Paul Strand, quien lo contactó con Herbert Kline para que escribiera un guión en apoyo a la República española. Mantilla evoca el proyecto que buscaba filmar el día a día de los voluntarios, mostrar la diversidad de procedencias, los atuendos, cómo vivían, qué comían, cómo se bañaban y la distinta suerte que corrían en el frente. El filme se estrenó el 21 de mayo de 1938 antes de desaparecer. Pierre Assouline, el biógrafo de Cartier-Bresson, pensó que había sido destruido. (En la Guerra civil de Cartier-Bresson Web).

${ }^{42}$ Entre 1943 y 1951, Aub fue profesor de teoría y técnica cinematográfica del Instituto Cinematográfico de México. En 1948 asumió el cargo de asesor técnico de la Comisión Nacional de Cinematografía de la Secretaría de Gobernación. En 1949 traduce y pública el guión de René Clair El silencio es oro, y entre 1950 y 1951 formó parte de la Comisión Técnico-Literaria del Banco Nacional Cinematográfico. En México, su primera incursión en el cine fue el guión de Distinto amanecer (1943), adaptación de su pieza teatral La vida conyugal, dirigida por Julio Bracho. En 1950 colabora con los diálogos de Los olvidados de Buñuel. En 1954, coescribe con Mauricio de la Serna el guión de La desconocida, de Chano Urueta. Ese mismo año crea el guión de El globo de Cantolla (1943), sobre un argumento de Alberto Quintero Álvarez, que fue dirigida por Gilberto Martínez Solares. Al año siguiente escribe el de La monja alférez (1944), de Emilio Gómez Muriel y la lista se amplía año tras año de forma casi ininterrumpida hasta 1951: Sinfonía de una vida (1945), de Celestino Gorostiza; La viuda celosa (1945) y El charro y la dama (1949), ambas dirigidas por Fernando Cortés, entre otras. En 1965 es invitado como jurado del Festival Internacional de Cannes; en 1968 publica el guión de rodaje de Sierra de Teruel.

${ }^{43}$ Escribe Kamen: " Part of the motive for his visit was to gather material for a biography of his long-time friend Buñuel, but he was shocked that people apperead to have swept the Civil War under the carpet. He recorded his negative reactions in Blind Man's Buff (La gallina ciega, 1971), written in the form of a diary covering the two monts of his visit. The rambling verbose volume trudges page after page trough Aub's account of his profound disappointement : 'Spain has changed inside out', he observed. 'At no moment did I have the feeling of forming part of this new country which has usurped the place of the one that was here before'"(430). Muchos años después de su retorno, se publicó postumamente el libro de Aub Conversaciones con Buñuel, seguidas de 45 entrevistas con familiares, amigos y colaboradores del cineasta aragonés, con Prólogo de Federico Álvarez, Madrid, Aguilar, colección literaria, 1985. Por su parter, afirma Pilar G. Sáenz que del último texto de Max Aub solamente conocemos, en su forma final, un 'Prólogo' y una 'Posdata' que dejó escritas. "De las innumerables carpetas de documentación, coleccionadas pacientemente durante dos años según su propio testimonio, conocemos solamente las cuarenta y cinco entrevistas con familiares, amigos y colaboradores de Buñuel, que aparecen publicadas bajo el título Conversaciones con Buñuel, adoptado por Federico Alvarez. Si hemos de aceptar, y de hecho aceptamos, la intención de Max Aub de designar con el término 'novela' a esa colección de datos, impresiones y entrevistas sobre la vida y la obra de Buñuel, nos encontramos con una oportunidad única para poder 
observar el proceso de novelar en Aub y que él confiesa haber sido 'casi siempre' su método de escribir un relato" (239).

${ }^{44}$ David Felipe Arranz Lago acota: "Acerca del humorismo de Max Aub escribió Manuel Tunón de Lara que es poliédrico y difícil de definir, toda vez que el discurso de la risa aubiano adopta diferentes formas y moldes que guardan varias deudas: hacia el conceptismo quevediano, el ludibrio lingüístico de la greguería de Ramón Gómez de la Serna y una pizca del discurso valleinclanesco, del esperpento indignado reflejado ante los espejos de los callejones" (Indagaciones lingüisticas en Crímenes ejemplares de Max Aub).

${ }^{46}$ La relación de Aub con los libreros es entrañable desde la infancia. Relata Gérard Malgat en Max Aub y Francia o la esperanza traicionada que en su infancia en París, donde vivía en el número 73 de la calle Fauborurg Poissonnière, había una librería y su afable relación con el librero le permitió aprender a leer con Los miserables. " Desde que tengo uso de razón -rememoraba Aub- nada me ha atraído tanto" (20).

${ }^{47}$ El Instituto Cervantes de Madrid organizó en abril 17 de 2007 la presentación del libro Escribo conforme voy viviendo. Epistolario Alfonso Reyes - Max Aub: 1940-1959, editado por Max Aub y Alberto Enríquez Perea, con la participación del crítico de arte Manuel García, el escritor Antonio Muñoz Molina, y de Elena Aub, presidenta de la fundación Max Aub. El anuncio del evento se hizo con una reveladora cita de Perea : "Alfonso Reyes fue visto por los intelectuales españoles que empezaron a llegar a México a partir de 1939, como un conocido suyo, como alguién que los comprendía y entendía, como de la propia familia. Era el mexicano más español que habían conocido en su vida. (...) Entre los españoles que llegaron a México y que escribieron sobre el autor, Max Aub fue el mejor comprendió su espíritu (...)”. Reyes sostuvo también una larga correspondencia con Agustín Millares Carlo, Juan Rejano, y con Manuel Altolaguirre, aunque también con figuras como Valery Larbaud.

${ }^{48}$ Un joven belga que había sido boxeador, Géry Pieret, trabajó como secretario de Apollinaire y según su biógrafo Steegmuller, citado por Mailler, a éste le caía en gracia su condición de refugiado y su ingenio divertido. Cuenta que un día de 1907 le había dicho a Marie Laurencin : "Madame Marie, esta tarde voy al Louvre; ¿necesita que le traiga algo?” y regresó en efecto con dos cabezas íberas esculpidas en piedra, una de las cuales entraría en la historia del arte moderno porque se convirtió en una de las figuras retratadas en Las señoritas de Aviñón, ya que Picasso se las compró. Cuando en 1911 estalla el escándalo del robo de la Monalisa, Picasso y Apollinaire temen que sea Pieret el autor del robo. No lo era, pero a través de toda una historia digna de una novela policíaca y en la que participa el poeta y crítico de arteAndré Salmon, Picasso acaba por devolver las estatuillas al Louvre (Mailler 371-378).

${ }^{49}$ Sobre estos datos apunta José Pérez Olivares, en su ensayo De Max Torres Campalans a Jusep Aub: "No son gratuitos porque informan sobre la desaparición de una época y el comienzo de otra -o lo que es igual-, constituyen un recurso mínimo para que [el lector] asimile un carácter y una actitud. Para que comprenda, entre otras cosas, que alguien con unos antecedentes históricos como esos, no puede reaccionar de otro modo. Empezando por su origen campesino -que determina su religiosidad, honda y raigal como la de Unamuno- y terminando por su vocación anarquista, que le viene de su condición de hombre pobre nutrida desde su adolescencia por una época en que las huelgas, los mítines y atentados se suceden sin descanso (...) Aunque Jusep nunca llega -como muchos de sus amigos anarquistas- a ser un hombre de acción, toda su ideología -al menos la que se relaciona con su etapa de pintor, en París- descansa sobre tal modelo. Incluso, su manera de vestir es típica de una intelectualidad marginal y marginada de la vida social, con gusto por una bohemia que era el fruto de su rechazo al adocenamiento, a la explotación y a las normas de la sociedad imperante, que aún no había mostrado su rostro más despiadado: el de las dos guerras mundiales que se avecinaban" (...) (http://www.lajiribilla.co.cu/2003/n107_05/107_03.html).

${ }^{50}$ Manuel García crítico de arte e historiador español dedicado a investigar el periódo de la República, la Guerra Civil Española y el exilio, inicia su libro Memorias de posguerra. Material inédito de la Guerra Civil española, editado por Publicacions de la Universitat de València, con entrevistas a los artistas y escritores mexicanos que estuvieron en ese congreso como el mismo Juan de la Cabada, el intelectual 
Octavio Paz, el museógrafo Fernando Gamboa, y el artista José Chávez Morado. García ha curado varias exposiciones que guardan relación con Aub: Renau (1978), El exilio español en México (1983); El Universo de Max Aub (2003); y Josep Renau Fotomontador (2006), organizada por el IVAM y el Instituto Cervantes, a la cual, en cierto modo se anticipó Aub al usurpar su rostro para la creación apócrifa del retrato en el que Picasso aparece supuestamente con el pintor catalán.

${ }^{51}$ Aub cursó estudios en la Alianza Francesa, en el Instituto de Valencia y en la Escuela Moderna, ubicada en la plaza Pellicers. Esta era la única escuela laica de Valencia. Sus padres era agnósticos y nunca hablaron de religión en su casa.

${ }^{52}$ A Picasso nunca acabo de convencerle el nombre de " las señoritas “. En una conversación con su dealer Kahnweiler éste le dice: "Las Señoritas de Avignon, ¡cómo me irrita este título! Sabes muy bien que lo inventó [André] Salmon. Sabes muy bien que el título original era El Burdel de Avignon [un juego fonético con Avinyó, la calle del barrio rojo barcelonés]. ¿Pero sabes por qué? Porque Avignon ha sido siempre una palabra familiar para mí, y es parte de mi vida. Yo vivía a menos de dos pasos de la Calle d'Avignon, donde solía comprar mis papeles y mis acuarelas y además, como sabes, la abuela de Max [Jacob] era oriunda de Avignon. Solíamos hacer un montón de bromas sobre el cuadro. Una de las mujeres era la abuela de Max. Otra Fernande, otra Marie Laurencin, todas en un burdel en Avignon" (Citado por Mailler).

${ }^{53}$ Es un listado, en realidad, de algunos integrantes del círculo de amigos de Picasso. Con el poeta Max Jacob tuvo por ejemplo, la cercanía necesaria para hablarle de un período que odiaba recordar : cuando llegó a París después de la época azul y la galería de Dirand-Ruel lo rechazó porque la tristeza de estas pinturas no parecía interesar a los comerciantes. Obligado a alojarse en el ático del hôtel du Maroc, en la Rue Seine, vive un período aciago donde experimenta "una visión de pesadilla del perverso poder de la moda", y escribe en una carta dirigida a Jacob: "Pienso también en los días de pobreza y me entristesco cuando pienso con repulsión en aquellos españoles de la Rue de Seine" (Mailler 105). Sostiene también que gracias a Jacob, a cuya habitación se trasladó tras dejar el tenebroso hotel, comenzó a descubrir la literatura francesa, a Verlaine, y en suma, recibió, como verdadero regalo, una introducción a la poesía, y también a lo oculto : "Adicto al éter y a cualquier otra droga embriagadora a su alcance, sin duda condujo a Picasso por muchos de los caminos que llevan hacia lo oculto (...). Puesto que Dios, la catástrofe y el lenguaje de la forma eran para Picasso manifestaciones de otro mundo existente bajo el mundo de las apariencias, tuvo que haber numerosas percepciones nuevas a diario durante el tiempo que vivió con Max Jacob (109). Luego de el libro de éste, Le Roi de Boéti apareció en 1921, con revelaciones sobre ese período, su relación comenzó a agrietarse. Fernande Oliviere lo describe con frases que cita Mailler: "siempre supo divertirse divirtiendo a los demás y, cuando quería, su verbo era alucinante. Era cantante, y, si había ocasión, profesor de canto, pianista, comediante improvisado (...). Solía cantar la Langosta aérea, de Offenbach; En las orillas del Adour y tantos otros cuplés que nos hacían gratas las veladas enteras, sin cansarnos nunca" (209).

${ }^{54}$ La descripción es coincidente con la que hacían los críticos del cubismo de Picasso. Así, André Leclerc escribe : "Si muchas de sus telas parecen extrañamente complejas e indescifrables, ello se debe a que a nuestra visión, habituada a percibir un solo aspecto de las cosas, le resulta difícil apreciar varios aspectos a la vez. Picasso representa los rasgos humanos y los objetos al mismo tiempo de frente y de perfil, creando una especie de desarrollo que al ser reelaborado mediante una mirada da la sensación de movimiento. De ahí las muchachas cuyas narices están junto a las orejas y cuyos ojos están implantados de frente en sus perfiles. No obstante, es menester hacer notar que, por otras razones, Delacroix había apelado ya a este expediente en un año tan lejano como 1824 (Mailler 13).

${ }^{55}$ La reacción inicial que suscitó El burdel de Avignon fue de flagrante incomprensión, burla, rechazo. Entre 1907 y 1916, El burdel de Avignon permanece sin exhibirse. Galerie d'Antin la muestra ese último año con el título "Les demoiselles de Avignon ". Desde los veinte se conoce oficialmente con este nombre, pero, como veremos, entre el año de su factura y el de su exhibición en 1937 en Nueva York permanece enrollado la mayor parte del tiempo, ajeno por completo al reconocimiento. En cuanto Picasso mostraba su 
lienzo de ocho pies a coleccionistas, críticos de arte o artistas, enfrentaba de modo casi unánime reacciones adversas. Se cuenta que el pintor Derain decía que un día iban a encontrar a Pablo colgado detrás del enorme lienzo. Matisse, a quien tanto admiraba Picasso por la maestría del color, se horrorizó con lo que consideraba un fallido intento de pintar la cuarta dimensión, que entonces interesaba a tantos artistas.

${ }^{56}$ De hecho, Picasso había conocido su obra previamente a través de su amigo el escultor y ceramista español Paco Durrio, quien poseía algunas de sus obras y trataba de promocionarlo. A través suyo, Picasso pudo leer una edición del diario de Tahití de Gauguin, Noa Noa. Y, por otra parte, había visto algo de su trabajo en la galería de Ambroise Vollard.

${ }^{57}$ Sostiene André Leclerc: “A pesar de la influencia de Cézanne, que sostenía que todo en la Naturaleza puede ser reducido a ciertas formas geométricas, el cubismo de Picasso es puramente español y surge de la misma estructura del paisaje de su patria, con sus casas de techos regulares. Con tal estilo trata no sólo paisajes, sino también figuras humanas, que constituyen en realidad su tema preferido" (11).

${ }^{58}$ La modelo de una de éstas era en realidad, la artista francesa Fernande Oliviere, quien integraba el círculo de amigos del fundamental poeta y crítico de arte Guillaume Apollinaire (1880-1918), y a la cual retrataría en más de medio centenar de obras, durante el tiempo de su relación que se extendió: de 1904 a 1912. Norman Mailler cita copiosamente los dos libros de memorias de Oliviere: Picasso y sus amigos, y Recuerdos íntimos. Ella narra que habitaba en el número 13 de la calle Ravignan cuando descubre la presencia de un personaje "bastante singular que acababa de instalarse en la casa..." (129). Era Picasso. Sus descripciones de la relación de amistad con Apollinaire, a quien Picasso retrata varias veces en 1905 (hace también un Ex-libris, para él), y con Max Jacob, a quienes él se encontró en el bar inglés Austen's, son extensas: “(...) y dimos comienzo a aquella vida de amistad de tres puntas que duró casi hasta la guerra, sin alejarnos nunca unos de otros ni para trabajar, ni para comer, ni para divertirnos" (185). Según Picasso, como anoté atrás, otra prostituta se inspiraba en la abuela de Max Jacob, quien era oriunda de Avignon, y una tercera partía del retrato de la artista francesa e impresora Marie Laurencin (1883 -1956), quien fue una de las pocas mujeres cubistas, junto con Sonia Delaunay y otras menos conocidas como Marie Vorobieff, y Franciska Clausen. Entre 2010 y 2011 pintó el óleo "Les jeunes filles", en el que representa cuatro mujeres vestidas con túnicas que descubren parte de sus pechos, sin que exista una clara distinción con el fondo, puesto que la perspectiva se ha alterado y el paraje natural se funde con el espacio arquitectónico, los cuerpos y las frutas. Pero a diferencia de esa crudeza que provenía de las dos fuerzas liminares en pugna que inspiraron el cuadro de picasso, el eros y la muerte, la atmósfera de esta obra es de una sensualidad que unifica lo existente. Laurencin buscaba un lenguaje que unificara la cuestión de género con la revolución cubista. La obra se exhibió en el Salon des Indépendants, 1911, y pertenece al Moderna Museet, de Estocolmo. Laurencin fue miembro tanto del círculo de Picasso como de los cubistas asociados con la sección de oro como Jean Metzinger, Albert Gleizes, Robert Delaunay, Henri le Fauconnier y Francis Picabia, y exhibió con ellos también en el Salon d'Automne (1911-1912). Su fotografía "La Toilette des jeunes filles" (El baño de las jóvenes), fue exhibida en el mismo Armory Show en que se mostró el Desnudo descendiendo la escalera de Marcel Duchamp. En 1983, aniversario del centenario de su nacimiento, se abrió en la preferctura de Nagano, Japón, el Musée Marie Laurencin que alberga sus obras. Su cercanía con Apollinaire fue romántica. Como ocurriría con las mujeres surrealistas en la mayor parte de sus casos, quedaron en la memoria colectiva más como musas que como creadoras, pese a la voluntad descomunal que entonces requirieron para vivir de un modo autónomo y hacerse artistas. Mailler enmarca la época rosa de Picasso con el verso de Apollinaire: "Donde danzan desnudos los hermosos dioses rosas" y escribe: "Dispuesto a evocar toda sensación de pérdida y anhelo románticos, Apollinaire vivía con una visión igualmente poderosa del brillo y la putrefacción, de modo que pudo ofrecer el revistimiento poético necesario entonces para la visión de Picasso". Es el guía que lo lleva de la época azul a la época rosa: "Picasso necesitaba magia nueva para atreverse a dejar la época azul; Apollinaire se la proporcionó". Algunos de sus versos parecen resonar en los lienzos de Picasso: "Pisa las tablas el pálido arlequín/Saluda primero a los espectadores/Brujos y bohemios llegados/algunas hadas y los encantadores", o: "El amor pesado como un oso privado/bailó erguido cuando lo quisimos/y el pájaro azul perdió sus plumas/ y los 
mendicantes sus avemarías". Y también son decisivos su interés por el Circo de Médrano y, la furia con la que trabajaba para dominar "las fuerzas explosivas de su psique" (195-207).

${ }^{59}$ Picasso puso en primer plano una escena de desnudez en un burdel, con cinco mujeres representadas de un modo insólito, sin perspectiva en relación con el fondo, con una desmesura en su magnitud en sus carnes que parecía a punto de desbordar el lienzo e inundar el plano del espacio del propio espectador, con sus contornos delineados en gruesas líneas negras, sombras autónomas potenciando las formas hieráticas o de amenazante sensualidad contenidas en trazos angulares, con volúmenes geométricos precubistas que deconstruían siglos de tradición. Sus rostros, casi grotescos, ofendían la tradición del arte occidental y ni siquiera tenía esa deformidad de las pinturas negras de Goya, sino una iconografía que respondía a otros cánones del misterio. Lily Litvak expone en Imágenes y textos: estudios sobre literatura y pintura 18491936, el origen del nombre con su alusión erótica y hace una disección de sus múltiples niveles de significado, del doble poder evocador del eros y la muerte, así como del modo en que se apropia de recursos de períodos tan anteriores de la historia del arte occidental como el barroco o ajenos a esta tradición y, al tiempo, crea lo que estaba por venir en la historia del arte (156-57). La tensión eros-thanatos estaba en el origen de la obra que oponía los placeres de la sexualidad a la amenaza de la muerte, en un tiempo en que proliferaban las enfermedades venéreas. Picasso había hecho durante meses centenares de bocetos y pinturas preliminares. Hasta los últimos estudios preliminares mantiene los bocetos de dos hombres: un marinero y un estudiante que en alguos bocetos aparece con un libro y en otros con una calavera. Jesús Martínez Verón describe de modo somero y preciso los detalles de evolución de la obra en su artículo Las señoritas de Avignon. (artecreha) Gracias a estos trabajos previos se sabe que la obra incluía dos figuras masculinas, una de las cuales desapareció y la otra se feminizó ocultando sus facciones con una máscara ibérica. Tras decolgar el lienzo, Picasso lo lleva a su estudio donde permanece enrollada durante años. Aunque fue reproducida en el libro La Revolution Surrealiste (1925), es relativamente desconocida hasta 1937, cuando se exhibe en el Petit Palais in Paris. Picasso se la había vendido en su studio al coleccionista y diseñador de modas Jacques Doucet (1853-1929), quien creaba los vestuarios de actrices como Sarah Bernhardt (diseñó para ella el traje blanco de la obra L'Aiglon (El aguilucho). En 1927 varios cubistas entre los cuales estaban Jacques Lipchitz y Henri Laurens, colaboraron en la decoración de su casa-estudio. En la colección que legó a la Universidad de París había pinturas post-impresionistas y cubistas. Se rumora que había adquirido Las señoritas de Avignon sin desenrollarla. En 1937, fue adquirida por Germain Seligman, de la galería Jacques Seligmann \& Co. Su socio Cesar de Hauke la exhibió en la sede de la galería en Nueva York in the exhibition 20 Years in the Evolution of Picasso 1903-1923. En 1939 el Museum of Modern Art la compró gracias a las donaciones de la coleccionista Lillie P.Bliss, pues la obra de Degás se vendió para pagar la mayor parte de su valor, y el restante fue aportado por clientes de Seligman y de Hanke.

${ }^{60}$ Esta obra, aún con colores como el cabello recortado pelirojo de la pequeña niña que viste un traje blanco grisáceo del mismo color de la paloma que sostiene contra su pecho, o el naranja y rojo del balón que aparece recortado en el plano inferior, sirve de preludio a la época azul, tal y como aparece en la obra maestra de ese período, La vida (1903), donde el desamparo de los personajes, desnudos o descanzos, sólo tiene como contrapeso el gesto de sostenerse mutuamente. Las palomas fueron sus primeras modelos. Cuenta André Leclerc que la casa paterna era "alegre y hospitalaria, una especie de pajarera donde en todas partes se oía el zurear de las palomas" (6). En cuanto al período azul, asociado a España y a las gentes pobres, sostiene que en esa época Picasso "cree — para citar una expresión de su devoto amigo Jaime Sabartés- que el "Arte es hijo de la Tristeza y del Dolor " " (9). Entre fines de 1904 y 1906, sitúa la crítica el período rosa de Picasso, en el que pinta una multitud de payasos, arlequines y saltimbanquis. Un año después escandalizará con sus Señoritas de Avignon.

${ }^{61}$ Norman Mailler describe los pormenores de la relación de amistad entre el trío que conformaron Carlos Casagemas, Manuel Pallarés y Picasso quienes vivieron juntos en París con tres mujeres, que se describían como modelos y que ciertamente habían posado para Nonell y otros artistas catalanes, y no tenían reparo en asumir los roles de modelos y amantes sucesivas o compartidas por varios de ellos. En todo caso, el suicidio de Casagemas, según el escritor norteamericano que escribe una "biografía interpretativa " de la 
juventud de Picasso, tiene que ver con la impotencia experimentada frente a la modelo que le correspondía, Germaine Gargallo, y que compensa con dos actos "valientes": pedirle matrimonio y, ante su negativa, alzarse la tapa de los sesos.

${ }^{62}$ Hay notables similitudes entre ambos cuadros, donde ya no puede advertirse el rostro del retratado, y en los cuales la paleta apagada se asemeja. La representación de la realidad se subordina a la unidad estructural del cuadro; lejos de la intención impresionista de representar el instante de la visión cambiante, optan por obras que corresponden al modo de visión fragmentada: un ojo facetado que contempla desde diversos ángulos los esquemas formales de las cosas. Braque buscaba inicialmente en esa etapa representar una figura desde la planimetría, el alzado y la sección. Las sombras, por lo tanto, no responden a un punto de vista fijo sino a lo que supondría en análisis de la composición de las cosas desde diversas perspectivas.

${ }^{63}$ André Leclerc identifica con un período "verde" las experimentaciones de cuadros construidos con objetos como cartones, papeles, trozos de telas, " en los cuales predomina la más libre fantasía ". En pleno 1914, año en el que finaliza la serie de guitarras, pinta naturalezas muertas de colores brillantes como La botella de maraschino. En 1917 se marcha a Roma y allí crea, para el Ballet Ruso, la puesta en escena de Parade. "Una serenidad de fiesta cristiana, totalmente ajena al cataclismo mundial, predomina en esta obra ". La música era de su amigo Eric Satie, figura clave, como músico, en el avance de la abstracción pictórica.

${ }^{64}$ Era, en todo caso, un interés compartido por otros pioneros de la abstracción como František Kupka, Vasily Kandinsky, y Kazimir Malevich. Mondrian no pintaba ramos de flores sino una sola flor para expresar su estructura plástica. Por ello, como precisó la curadora asistente del Departamento de Dibujos e Impresiones del MoMA, Samantha Friedman: "While these faithful depictions of natural subjects might seem to be the antithesis of the reduced grids for which Mondrian became famous, they prefigure the artist's obsession with form. With this intention in mind, we can regard the amaryllis's erect stem and the chrysanthemum's dense cluster of petals as studies in form. While such works are visually far from later abstractions, the spiritual undercurrents that motivate them not only persist in, but arguably propel Kupka and Mondrian's subsequent transitions to non-figuration. The same impulse that led these artists to seek the sacred in nature's forms ultimately led them to transcend nature for something even more essential, more universal: an "ideal," in the words of Mondrian, that "is something other than the mere representation of natural appearance." http://www.moma.org/explore/inside_out/2013/01/24/avant-abstraction-kupka-andmondrian-represent.

${ }^{65}$ Ver Max Aub-Alfonso Reyes. Epistolario 1940-1959. Compilación y nota de Alberto Enríquez Perea. Colección Epistolario Max Aub, № 3. 2006. Fundación Max Aub y Biblioteca Valenciana. Web.

${ }^{66}$ La relación de Jusep Torres Campalans con Ana María y con la mujer en general podría ser una joya para los investigadores de género. Su machismo es expuesto de un modo tangencial, pero tan descarnado, que posiblemente sea una de los aspectos más verosímiles en la construcción del carácter de Jusep y en el de su fantasmagórica mujer. Ella se aviene a todo, incluyendo el aceptar sus amoríos y callar con resignación con tal de no peder la compañía del catalán. Él le concede la gracia de dejarse querer, de ser mantenido por ella, y de estar a su lado hasta que llegue el momento de marcharse. Pese a que ella misma es artista, una minuaturista, parece no poder opinar nada y su intelecto no alcanza las alturas del pensamiento de su amado, ni puede penetrar en su universo interior. Si J.T.C. soporta la presencia de su mantenedora, aunque es mayor que ella y nada bella, es por la comodidad de ser el objeto de un encendido amor ofrecido con sufrida paciencia. En cierto momento reconoce que además tiene unos pechos hermosos y hace bien el amor.

${ }^{67}$ Menciona Fernández Martínez cómo Anne Marie Merkel pasó desapercibida entre las muchas mujeres artistas -a menudo desdeñadas como tales- cuyas vidas se involucraron con los creadores de la vanguardia: "Es el caso de Jeanne Hébuterne, el desgraciado amor de Modigliani, es el caso de la escultora sueca Thora Dardel, Marie Laurencin o Meret Oppenheim. Mujeres sofisticadas como Mina Loy, Djuna Barnes, Lee 
Miller, o escandalosas como Kiki de Montparnasse, musa de Man Ray, o Youki, compañera de Foujita. De lo poco que se sabe de Merkel es que habiendo estado casada con un historiador de arte vienés, fue ella quien le enseñó a Kertesz el trabajo de Renger-Patzsch, uno de los creadores de la nueva objetividad en la fotografía.

${ }^{68}$ Odilon Redon (1840-1916), bautizado como Bertrand-Jean Redon en Burdeos, Francia, es uno de los más importantes artistas del movimiento simbolista además de grabador. A su temprana pasión por el dibujo se sumaron sus estudios de arquitectura bajo Jean-Leon-Gerome. Participó en la guerra franco-prusiana de 1870 y durante largo tiempo realizó sólo litografías y dibujos a carboncillo. De hecho, desde una perspectiva contraria a la fascinación de los impresionistas con el color, trabajó en una serie de fotografías titulada Los negros. A partir de 1890 sus litografías se tornan más luminosas hasta desembocar en el color y entonces comienza a explorar la acuarela y el óleo y a crear una obra de imprevistos colores, en la que vertía su alucinante universo interior modelado por la influencia del mito, la religión, la ciencia y, de manera muy particular, por la forma literaria de todas estas maneras de construir el relato del mundo. Redon ilustró de hecho varias publicaciones de Baudelaire así como de los científicos Armand Clavaud y Charles Darwin, y su relación con estos dos tipos de textos marca su obra. Sus incursiones en lo fantástico y el desafío de las normas impuestas por la academia de su época no sólo lo llevan a ser uno de los fundadores del famoso "Salón de los independientes", sino a convertirse en indudable precursor del movimiento surrealista.

${ }^{69}$ En un artículo titulado Al revés, otro de los practicantes de la ficción extrema, Enrique Vila-Matas, evoca a Des Esseintes, el personaje de Huysmans que se aparta de la vida mundanal del París del XIX, epicentro del arte mundial, para crear en su casa, una mansión de Fontenay-aux-Roses "un escenario para vivir intensamente (...) Huysmans odia al mundo y lo odia todo, salvo el arte y aquello que pueda resultarle sublimemente artificial". Encerrado entre libros, cuadros y perfumes, se declara a explorar las manifestaciones artísticas, hasta que "algo no previsto clausura su paraíso artificial", dice Vila-Matas, quien evoca su reconocida identificación con el doble de Huysmans citando a Beatriz Trabarais : "Des Esseintes era simplemente el Mister Hyde del futuro trapense Huysmans, del que sólo podía librarse para salvarse como escritor, y quizá como hombre, expulsándolo fuera de sí mediante la escritura y reconociendo de este modo la presencia fantasmal de su doble. (Al revés).

${ }^{70}$ Aunque el personaje de Monck Mason no era real, rendía homenaje a Thomas Monck Mason, autor del libro Account of the Late Aeronautical Expedition from London to Weilburg (1936). El aporte esencial de esta historia es el juego que desliza la ficción en la realidad, además de ser, por supuesto, una temprana forma de ciencia ficción. Se dice que inspiró posiblemente la historia de Julio Verne, El viaje al mundo en 80 días, puesto que Verne fue a su vez, un temprano admirador de Poe y de su novela Cinq semaines en ballon. En el libro The Sun and the Moon: The Remarkable True Account of Hoaxers, Showmen, Dueling Journalists, and Lunar Man-Bats in Nineteenth-Century New York, Mathew Gooldman analiza los pormenores de esta broma periodística y de otra que, según Poe, el mismo periódico habría publicado apropiándose de los principales elementos de una historia suya, sobre los habitantes lunares. La contraportada sintetiza: "A series of six articles purported to reveal the existence of life on the moon including unicorns, beavers that walked on their hind legs, and, strangest of all, four-foot-tall flying manbats. In a matter of weeks the series became the most widely circulated newspaper story of the era, and the Sun, a brash working-class upstart less than two years old, had become the most widely read newspaper in the world (...) The book overflows with larger-than-life characters, including Richard Adams Locke, the author of the moon series; a fledgling showman named P.T. Barnum, who had just brought his own hoax to New York; and the young writer Edgar Allan Poe, who was convinced that the moon series was a plagiarism of his own work".

${ }^{71} \mathrm{Y}$ no menos, influencia la obra de Charles Baudelaire (1821-1867), quien pasó 14 años de su vida traduciendo al francés a Edgar Allan Poe, cuya obra alucinante enfebrece también a otros simbolistas franceses como Mallarmé o Rimbaud. 
${ }^{72}$ Desde inicios de la década de 1890 Redon abandona el carboncillo de sus Negros y comienza a usar pasteles para pintar cuadros de colores resplandecientes que se van aproximando a la decoración. Mientras pintaba páneles para el castillo del barón Robert de Domecy escribe una carta refiriendo cómo cubre los muros con flores que son flores de sueño y una fauna imaginaria.

${ }^{73}$ Una vez más, Aub se apropia de la relación de amistad entre Picasso y Matisse para atribuírsela, con toda naturalidad a Josep Torres Campalans. A estos dos artistas reales, los presentó Gertrude Stein, y su relación estuvo siempre atravesada por un sentido de ambivalencia que se explica por cierto modo de oposición entre el dominio magistral que cada uno tenía de la forma y del color, respectivamente. Escribe Norman Mailler que Picasso declaró un avez que su ambición era ser el tenor que diera la nota más alta : "ahora tenía un rival formidable en la persona de Henri Matisse (...). La diferencia esencial era estética, es decir, profunda. La presencia de un cuadro - su arquitectura interna - era desarrollada por Matisse por medio del uso del color (...). [Para] Picasso la forma era más importante. En una ocasión exclamó incluso : 'El color debilita" ". Reproduce un diálogo en el que Picasso le comenta a Matisse : "He conseguido dominar el dibujo y busco el color; tú has dominado el color y buscas el dibujo". No hay que olvidar que por la época del Salon d'Automne de 1905, Matisse estaba rodeado de un alboroto, de un escándalo que lo situaba muy por delante de Picasso. Unas líneas magistrales de Mailler sintetizan la relación entre las dos portentosas figuras : "Amigos, pero...enemigos' dijo Gertrude. Picasso y Matisse son más que eso, por supuesto. Rivales artísticos al más alto nivel, se iluminarían y exasperarían mutuamente a lo largo de los años, cada uno estimulando el talento y galvanizando la ambición del otro". Cita igualmente una declaración reveladora de Picasso : "Se debería poder juntar lo que Matisse y yo hicimos en aquel tiempo. Nunca nadie miró la pintura de Matisse tan bien como yo. Y él, la mía..." (277-280). Es posible correlacionar las incursiones de Jusep Torres Campalans en el fauvismo - es de hecho la tendencia que atribuye a su compañera Ana María Merkel- y su concentración posterior en el cubismo, con el contraste entre el óleo sobre tela de Matisse, La alegría de vivir (1905-1906), y Las señoritas de Avignon (1907). El primero conmociona por su liberación del color y suscita reacciones encontradas que van desde el vituperio hasta la final comprensión de un coleccionista como Leo Stein de que estaba ante el cuadro más importante de la época, el segundo desconcierta al público hasta el punto de pensar que Picasso ha enloquecido. Matisse, de hecho, cree que el cuadro es una broma. Félix Feneon, un crítico, le aconsejó que se dedicara a la caricatura. Sus coleccionistas, Vollard y Derain, consideran que la obra es una suerte de suicidio pictórico.El mismo Braque estaba desconcertado. Los Stein guardaron silencio. Una reacción paralela a la que en el cuento de Balzac suscitar la obra maestra del pintor que ha trabajado diez años en el retrato de una modelo del cual se siente orgulloso hasta el paroxismo y que desconcierta por completo a los dos discípulos que han recurrido a todos los extremos para lograr verlo. Picasso guardó 25 años la tela. Las señoritas permanecieron, durante un cuarto de siglo, arrinconadas contra la pared, aunque han sido pintadas de tal modo que, en lugar de permanecer atadas a un escenario, se posicionan en el espacio de la obra con una magnitud tal en sus formas que, como han observado los críticos, pareciera que en cualquier momento van a salir del lienzo para irrumpir en el espacio del observador.

${ }^{74}$ En su ensayo "El pintor imaginario", Saura (1999) nota que Aub llama familiarmente Gertrudes a Gertrud Stein, la mecenas fundamental para la naciente vanguardia, y en torno a la cual se agrupó un grupo decisivo de intelectuales y artistas antes de la segunda guerra mundial, y que le atribuye la afirmación de que el cubismo era fundamentalmente un movimiento español (100).

${ }^{75}$ ¿Existió alguna vez un pianista español de nombre Braulio Maldonado? Es improbable. En cambio, en la época de la escritura de la novela de Aub, el mexicano izquierdista Braulio Maldonado, nacido en el mismo año que Aub, 1903 en San José del Cabo, era electo como primer gobernador constitucional del estado de Baja California después de haberse convertido en líder de los campesinos. Acerca del retrato de posible homenaje al político, escribe el crítico apócrifo Town: " Pocas veces ha logrado un pintor dar expresión más exacta del decaimiento de un hombre inteligente". Y luego, acota : "Es el ocaso de una época : la de Montmatre, la del vivir duro del primer cubismo y de tantas otras cosas" (319). El propietario es un destacado intelectual y editor mexicano : Joaquín Díez-Canedo. Lo cierto es que en este retrato Jusep Torres Campalans refleja la herencia desgarradora de las pinturas negras de Goya, quien por otra parte es 
una influencia inextricable de Picasso y de su Guernica. Su predilección por el pintor hace que Aub conspire, en la vida real, junto con Xavier de Salas, amigo desde la anteguerra, para que la obra de J.T.C. quede incorporada a los fondos del Prado. Cuando se plantea la posibilidad de colgar la obra frente a la sala donde está Velázquez, Aub insiste en que se llevará mejor con Goya, incluso literariamente.

${ }^{76}$ Si bien el término "pintura de acción”, fue acuñado por el crítico Harold Rosenberg en 1952, ni en términos teóricos o formales su sentido se equipara al que aquí le da Aub, cuyo "gesto " pictórico apunta a una crítica de la época realizada desde una zona fronteriza entre la admiración y el desdén por la vanguardia, y su intención declarada es expresión de su deseo de transformar la realidad que lo ha envuelto en su propio caos.

${ }^{77}$ Está escrito así, en lugar de Rodchenko.

${ }^{78}$ Max Aub no quiso ser tampoco jamás un servidor del poder. Se mantuvo siempre en contraposición a éste, siempre manteniendo un grito contra sus acechanzas, como cuando consideraba absurda la exaltación que hacía el PRI de León Felipe para lavar en el amor a la poesía las manchas de la sangre derramada en Tlatelolco en 1968. En su libro Exile and Cultural Hegemony, Spanish Intellectuals in Mexico, 1939-1975, Sebastiaan Faber ahonda en este aspecto. 


\section{LEONORA CARRINGTON: LA MUJER-CABALLO DERRIBANDO LINDES}

\section{ENTRE ARTE, TEXTO Y VIDA}

La exploración del concepto de ficción extrema nos aboca al modo en que ésta se incorpora al reino de lo real a través de diversos tipos de deslizamientos entre las fronteras que separan arte, texto y vida. Estas fugas o traslaciones de lo ficticio a lo real pueden producirse mediante la con-fusión intencional de géneros como la novela y el ensayo; el traspaso de estrategias de creación de personajes literarios al campo de las artes plásticas y viceversa; y diversos modos de inserción de las ficciones narrativas y/o artísticas en la historia del arte y de la literatura, y/o en las biografías de sus protagonistas.

Las vanguardias del siglo XX, particularmente el dadaísmo y el surrealismo, fueron movimientos que, no obstante su carácter efímero, ${ }^{79}$ en el caso del primero, pero difuso, de influencia perdurable ${ }^{80}$, y de gran radio de expansión en ambos casos, ${ }^{81}$ propiciaron interesantes manifestaciones de la ficción extrema. En buena parte esto se debió a la porosidad de las fronteras entre diversos campos de la creación como el arte y la literatura, abocados en el siglo XX a explorar de un modo antes impensable múltiples $\operatorname{abismos}^{82}$, y a su inseparable relación con las mismas trayectorias vitales —a menudo extremas por su desacato a las convenciones sociales - de quienes los conformaron. No es extraño que Max Ernst (1981-1976) subtitulara su libro Notes biographiques (Notas biográficas) así: Tissus de vérités et tissus de mensonges (Tejido de verdades y tejido de mentiras).

El presente capítulo profundiza en un aspecto de la ficción extrema en varias obras literarias y pictóricas de Leonora Carrington (1917-2011), una de las grandes 
desobedientes del siglo XX y, más allá de su propia renuencia a cualquier tipo de adscripción, una surrealista capaz de provocar incendios de la imaginación: la construcción de un doble de sí misma en la figura de la mujer-caballo que se desliza en su obra de la literatura al del arte y viceversa. Es doble animal, mítico, tomémico, extendió su indómito aliento también en la vida de esta escritora y artista que hizo de lo maravilloso, emparentado con un modo de "surrealidad", un dominio propio. ${ }^{83}$ Incluso antes de que siquiera hubiera escuchado mencionar las proclamas del Manifiesto surrealista de 1924, ella asumía vitalmente algunas de esas frases-bandera que se repitieron como consignas en una Europa desarticulada: "Querida imaginación: lo que amo sobre todo en ti es que tú no perdonas", "La sola palabra libertad es lo único que me exalta" (Waldberg 17).

En el prólogo para la edición en español de libro de cuentos de Leonora la Dama oval que contiene siete collages de Max Ernst creados para su lanzamiento en francés, ${ }^{84}$ Agustí Bartra se refiere al bestiario particular que ella convirtió en iconografia situando al caballo en el primer lugar de su predilección, como parte de la creación de un mundo que ante todo impone "una mitología personal de la transformación radical del universo del hombre" (9-11). Ese modo de creación de un doble capaz de levitar, una "caballa", como la llama múltiples veces Julotte Roche, se remonta a la ruptura total con la tradición de una de las familias más acaudaladas de la región de Lancashire, en Inglaterra: surge en efecto como catarsis, y es símbolo de liberación de su propia expresión no sólo pictórica y literaria, sino sexual, pues se afianza en el marco iniciático de su intensa relación amorosa y creadora con "el Pájaro Superior", o la identidad alterna de Max Ernst. Y, como se verá al detenernos en la relación entre su vida, y ciertos cuentos y cuadros, el 
doble caballo-caballa, o una figura que carece de nombre, pero feminiza el ícono del Minotauro de tal modo que en lugar de la cabeza de toro tiene la de una yegua y en lugar del cuerpo de hombre, el de una mujer, seguirá sirviéndole de símbolo de transmutación y liberación, a lo largo de sus muchas transformaciones. Se trata de una constante vital y creativa que no sólo puede rastrearse en su obra artística y literaria, sino que deja siempre una estela de empoderamiento construida desde la fuerza de una mitología propia y asociada a un universo de conocimiento feminizado por ella.

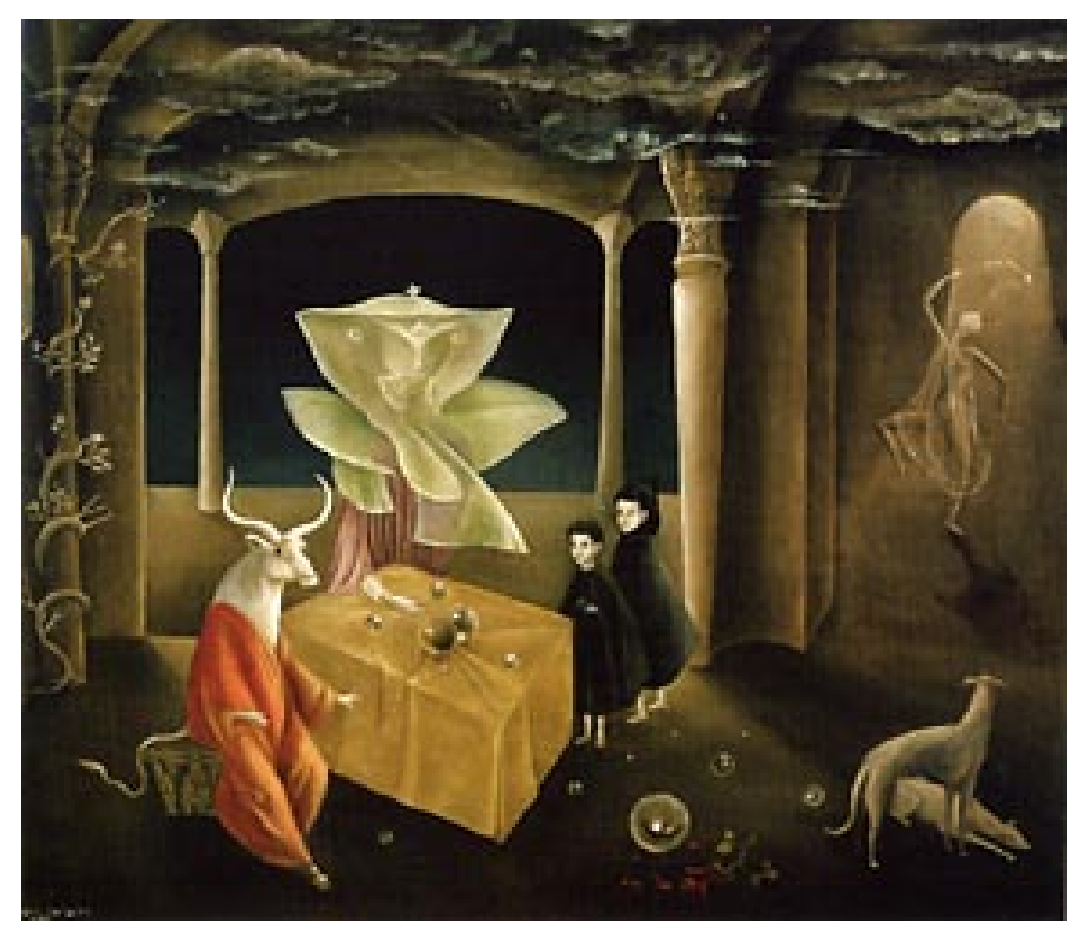

Ilustración 40: Leonora Carrington. Y entonces vimos a la hija del Minotauro 1953. Óleo sobre lienzo. $231 / 2 \times 271 \frac{1}{2} "$. Colección privada.

Mientras existen numerosas recreaciones de la figura del Minotauro esperando las inermes doncellas, no hay en la historia del arte otra versión de la figura mitológica que ella imagina al crear el cuadro And Then We Saw the Daughter of the Minotaur, (Y entonces, vimos a la hija del Minotauro), 1953, donde pinta también a sus dos pequeños 
hijos, Gabriel y Pablo, que entonces tienen seis y siete años, vestidos con capas oscuras y de pie, junto a la mesa ${ }^{85}$ en la que se sirven translúcidas esferas que parecen caer del mantel al misterioso suelo de la habitación, y donde está sentada la Hija del Minotauro, posiblemente una versión de su propia figura, con grandes cuernos coronando su apacible rostro mamífero de intensos ojos negros y pelaje blanco, y una larga túnica que cae suavemente sobre su cuerpo de mujer, pero permite ver el rabo y sus pies bovinos asomarse delicadamente.

Este capítulo es un adentrarse en la construcción de esa mitología propia que desafía en múltiples sentidos las nociones de la realidad que la rodea y que, nutriéndose de numerosas y diversas fuentes artístico-literarias, modela la vida de Leonora y produce obras personalísimas afines a las búsquedas del surrealismo. El elemento fantástico, el elemento onírico, el elemento sonámbulo y el elemento sádico —o cuanto menos cruento- que caracterizan la pintura surrealista según Werner Schmalenbach (citado por Bischoff 26) pueden rastrearse muy a menudo, todos juntos, en las creaciones de Leonora que, por otra parte, contienen claves de acceso a su vida interior, tan indómita como movida por la imperiosa curiosidad de comprender, así como a los acontecimientos biográficos que protagonizó siendo muy joven, y que además se inscriben en un tiempo histórico de máxima incertidumbre.

\section{La novia del viento. "Una rebelde muy hermosa”}

Incapaz de sujetarse a molde alguno, el apodo más conocido de Leonora es "la Novia del Viento". Así la llamó el pintor Max Ernst, en 1938, cuando leyó el prólogo con el que presentaba los cuentos sonámbulos de su joven amante, recopilados bajo el título 
La casa del miedo, ante el círculo de los surrealistas en París. ${ }^{86}$ Leonora encarnó para los miembros de ese movimiento los estereotipos femeninos idealizadas por ellos como arquetipos inspiradores ${ }^{87}$ - la imagen viva de la musa, la femme enfant, ${ }^{88}$ la figura mítica del amour fou一, y se adentró más lejos que ninguno (con excepción del proscrito Antoine Artaud) en el infierno de la sinrazón, a donde la arrojaron los vientos implacables de la guerra. "...One of those journeys from whic there is little chance of returning", de acuerdo con Jeanne Mégnen, a quien Leonora le dictó en francés las memorias de ese viaje a las regiones límites (Lepetit 209). Cuando regresó a la tierra para escribir y pintar, venía ya armada con "el casco de la locura". ${ }^{89}$ Pero ella eludió hasta el fin toda adscripción con la cual se pretendiera aprisionarla y su capacidad de desacato revistió múltiples e inesperadas formas. ${ }^{90}$ A lo largo de su vida manifestó un inconformismo con el calificativo de "surrealista", para sí misma y para una obra como la suya, inundada de "caballos en todas las ventanas", como dijera entonces Max Ernst, en pleno 1937, cuando ya Picasso había retratado el horror de la época en su Guernica, donde los caballos destazados y con las fauces abiertas, desencajadas, expresan el grito mismo de la humanidad; y como repetiría muchos años después el filósofo Fernando Savater al prologar Memorias de abajo, la versión en español de En bas o Down Below ${ }^{91}$. Reitera en ese texto que todas las obras de Leonora, pintadas y escritas, crean una impresión única de arrojo y originalidad:

Por todas las ventanas del ventilado e ingrávido universo de Leonora Carrington se asoman caballos. El tótem equino es lo más anglosajón de su fantasía. Por su inmemorial convivencia con nosotros, el caballo se metamorfosea sin escrúpulo en semihumano, nos presta su cabeza y su garbo o se resigna a los nuestros, se acomoda a fastidios o ilusiones que nos caracterizan por dentro: es rebelde y doméstico, ligero y espesamente carnal, belicoso hasta la pesadilla y víctima propiciatoria de la infancia sin prórroga ni retorno $(\mathrm{x})$. 
El mismo Savater nos recuerda que a esta rebelde que era muy hermosa y fantásticamente libre, no le debieron ser muy fáciles tampoco las relaciones con los surrealistas, cuya idea de la mujer era mucho menos emancipada de lo que su iconoclastia en otros campos nos habría hecho esperar.

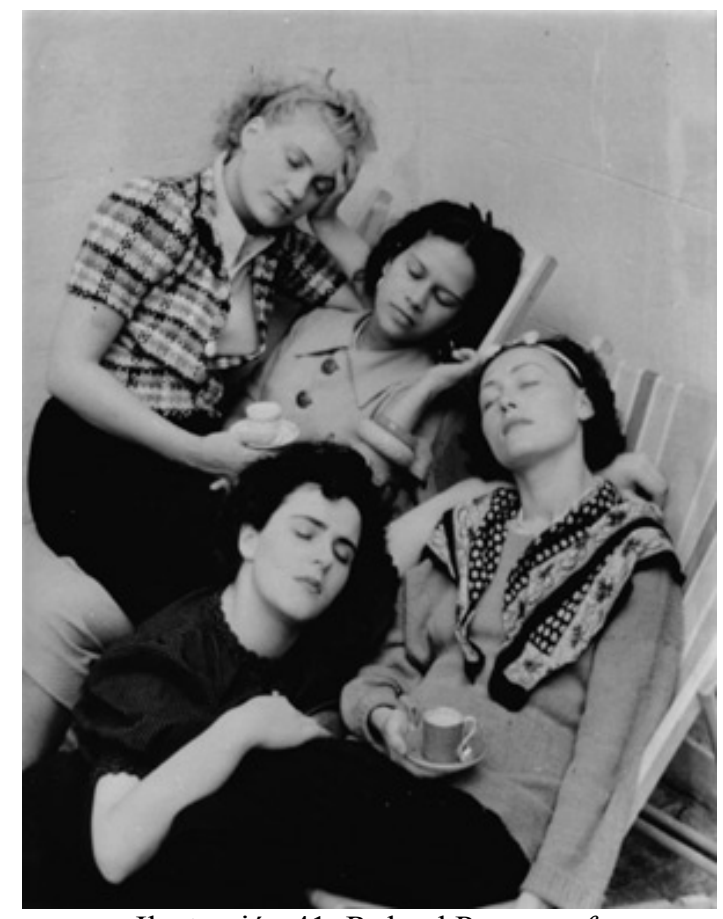

Ilustración 41: Roland Penrose, foto

De izquierda a derecha: Lee Miller, Ady Fidelin, Nusch Éluard y Leonora Carrington. Lamb Creek Cornwall, Inglaterra.

La apasionada relación de Leonora con Ernst la inserta en el círculo de París, en un tiempo compartido con el artista que llegaría a ser la figura más influyente de la posmodernidad, Marcel Duchamp, que por entonces había abandonado El gran vidrio, como se conoce a La novia desposada por sus solteros...aún, y otros artistas y poetas como Yves Tanguy, Man Ray y la bailarina Ady Fidelin, la fotógrafa Lee Miller (19071977) y su pareja, Roland Penrose, la artista Eileen Agar, y los poetas Luis Aragón y Paul Éluard (1895-1952) y Nush (1906-1946), ${ }^{92}$ entonces esposa de este último (ya Gala, con 
quien conviviera en compañía de Ernst, lo había dejado por Dali ${ }^{93}$ ), y el mismo André Breton (1896-1966), entre otras figuras de ese universo surrealista parisino en donde ella cayó como un cometa deslumbrante por su belleza y personalidad. Breton se dispone a exponerla en la galería Gradiva que había fundado bajo la premisa de crear un lugar sin edad, en cualquier lugar fuera del mundo de la razón. Mientras, Leonora trabaja junto con Ernst en la escenografía de una de las figuras precursoras del dadá y del surrealismo: el Ubú encadenado de Alfred Jarry (1873-1907), ${ }^{94}$ para la Comédie des Champs-Elysées.

Pero fueron sobre todo su imaginación febril y la autonomía de su osadía creadora las que le merecieron un inmediato reconocimiento. El historiador, artista y poeta Roland Penrose (1900-1984) $)^{95}$ pionero del surrealismo inglés, quien vivió 13 años en París antes de retornar a Inglaterra y fundar allí el movimiento con el poeta David Gascoyne, ${ }^{96}$ evoca por su parte a Leonora en estos términos: "A brillant girl whose talent was only exceded by her gifts as a painter" (Surrealism, Alchemy and Art 26). Leonora desplegaba con pasmosa naturalidad en sus cuadros y relatos una imaginación híbrida de raíces tan hondas y poderosas, que a los 20 años asombró ciertamente al mismo André Bretón, quien la consideró penetrada de una luz oculta, y sus primeras pinturas, de inmediato asociadas al surrealismo, captaron su atención y la del poeta Paul Eluard. ${ }^{97}$ Años más tarde Octavio Paz la llamaría "bruja embrujada", "sonámbula escapada de un poema de Yeats, entre las rocas blancas y el mar verde del norte" (261). La definió como "un poema que camina, que sonríe, que de repente abre una sonrisa que se convierte en un pájaro, después en pescado y desaparece" (Toriz 65). ${ }^{98}$ Por su parte, Duchamp, el "artisano" que socavó las fronteras entre objetos artísticos y cotidianos, la incluyó en la muestra de arte surrealista que curó en 1938 en el Palais des Beaux Art, París. 
Apenas dos años atrás Carrington era sólo una joven estudiante de Amédée Ozenfant (1886-1966) que entraba como visitante a "The First International Surrealist Exhibition" en Burlington Galleries, de Londres. ${ }^{99}$ En ese espacio vio por primera vez, como una revelación, un arte moderno que hacía eco a sus mundos interiores, una pintura donde no había límites entre lo permitido y lo prohibido, o entre las zonas del ensueño y la vigilia, y donde las temibles criaturas de la imaginación surgidas del miedo o de una suerte de percepciones intermedias, podían habitar de un modo inofensivo. En esa exhibición vio por primera vez la obra de Max Ernst. Pero lo clave es comprender que, como dijera agudamente Agusti Bartra, la relación con el surrealismo de Leonora Carrington no surge como el hallazgo de algo trascendente buscado desde largo tiempo, sino como "una coincidencia confirmativa de un espíritu que, desde siempre, había reconocido a la diosa en la cima argentada" (Para qué sirve la poesía 208). No hay que olvidar que otra revelación para ella sería la lectura de La diosa blanca de Robert Graves (1948) y que la relación entre el conocimiento y el universo femenino, cimentada en experiencias que se remontaban a su infancia, la llevó a transformar los oficios femeninos tradicionales, en un modo propio de oficiar rituales de creación, al modo de una hechicera contemporánea. Alejandro Jodoroswky narra un encuentro nocturno con Leonora y describe a una mujer poco común:

I saw Leonora seated on a wooden throne whose back was carved with the bust of an angel. Naked except for a Jewish prayer shawl, her gaze fixed unblinking and focused on infinity, she seemed like the figure on the prow of a ship from an ancient civilization (...) She continued to recite in English, taking no notice of my presence. I sat on the floor, facing her (...). The words poured out of her mouth like and endless river of invisible insects. I remember I few of these verses: 'I, the eye that sees nine different worlds and tells the tale of each' (Lepetit 209). 
El mismo Bartra contiene el mundo de Leonora en esta definición: "Estamos en un virgen territorio, donde el orden se somete a la aventura, la noche tiene ojos más brillantes que el día, y se puede ser feroz con inocencia" (Para qué sirve la poesía 207). Susan L. Aberth dedica por su parte numerosas páginas de su investigación sobre Leonora a la relación entre surrealismo, alquimia y cocina ${ }^{100}$, destacando el lugar que ocupan las cenas - a menudo transgresoras y relacionadas con la presencia de animales - en sus pinturas. El tema es tan vasto que podría dedicarse un libro a la presencia de la cocina (el lugar de la casa donde siempre recibía a sus visitantes) en su creación. ${ }^{101}$ Sus personajes suelen llegar a sitios donde se ofrecen los platos más inesperados, y la presencia de extrañas, incluso escalofriantes viandas, en sus relatos y pinturas es un leit motiv. Como dijera Whitney Chadwick "hay pocos relatos de Carrington sin una olla o un banquete, pocas pinturas sin la evidencia de la generosidad de la tierra..." (La realidad de la imaginación 17).

Una expresión de su genuino surrealismo vital, de su desacato e incluso del delgado filo en el que llegó a balancearse entre razón y locura, entre experimentos lúdicos y extravío, fueron, en su propia vida, los experimentos culinarios a los que sometió a los visitantes, ampliamente documentados por sus biógrafos. Lo cierto es que los banquetes reflejan la presencia de la cocina como espacio femenino donde ocurre una inversión, un ejercicio satírico en contra de las hegemonías, particularmente patriarcales, tal y como se observa en la conocida pintura The Meal of Lord Candlestick (La cena de El señor Candelero, sería la traducción literal, pero como se trata de un apelativo seguiré usando el nombre en inglés), ${ }^{102} 1938$, sobrenombre con el que designó a su propia familia, y a la cual regresaremos al entrar a la casa-bestiario en el sur de Francia donde 
"cocinó" su factura. Porque en sus festines, muy a menudo, los animales, o seres híbridos, son los que asisten al banquete, mientras una pequeña criatura humana puede ser servida.

Si Leonora llegó a declarar sarcásticamente que las mujeres surrealistas ${ }^{103}$ eran simplemente las encargadas de cocinarles a los hombres surrealistas, ella misma fue una guisandera mucho más cercana a los cocidos embrujados que a los roles asociados a la habitual preparación de los alimentos. Cosió y cocinó imágenes y materias insólitas hasta servir extraordinarios platos visuales que de algún modo constituían recetas, a su modo curativas, para su propia época. "I always did my running away alone", insistía Leonora (Aberth, Surrealism, Alchemy and Art 27). En todo caso, más allá de su negativa a ser vista sólo como una surrealista, esta mujer inglesa que se arraigó en el país de "la región más transparente", es considerada una de las más inquietantes y vigorosas artistas de filiación surrealista del siglo.

Delmari Romero Keith dice que la obra de Leonora

despliega los poderes femeninos, encubiertos tras la máscara protectora del imaginario mítico: se trata de la gran diosa, la gran madre, la gran profetiza, la druida que augura el maleficio de los tiempos de guerra; ante todo es la celta irlandesa con una temática siempre recurrente en su obra: la mujer como engendradora de vida (43).

Nótese que no dice "la vida", con lo cual quedaría asociada a la fecundidad materna, sino sólo el sustantivo vida, abierto a la incesante capacidad regenerativa, a la incesante reinvención del ser.

En el catálogo "Leonora Carrington. A Retrospective Exhibition", que se exhibió en Nueva York en el Center For Inter-American Relation en 1976, su mayor coleccionista, el excéntrico millonario Edward James, quien se llevó consigo las obras de 
René Magritte y Salvador Dalí (1904-1989) a la inacabada mansión utópica que construía en la población de Xilitla, México, ${ }^{104}$ escribe una lúcida introducción sobre la artista que ilumina la naturaleza de su viaje creativo desde la perspectiva de su furiosa autonomía. Habiendo cultivado una amistad con Picasso, y la cercanía suficiente con los dos surrealistas para hospedarlos en su casa de Londres, James admite que la obra de Leonora le impresiona profundamente por una razón:

She owes so little to the avant garde movements of the 1920's and 30's and nothing to the popular trend in art during the latter half of this century. For Leonora Carrington is one of those rare sports of nature, a spiritual mutation, who really cares so little about being discovered by the world (22).

"No entiendo — le dijo Leonora a Silvia Cherem en una entrevista en su casa de la Colonia Roma - por qué la gente insiste en pensar que yo era una niñita bajo el embrujo de Ernst... Aprendí mucho de él y me liberé; pero yo pintaba y escribía desde los cinco años" (La última surrealista 68). Una clave para entender el origen de sus visiones es que a diferencia de las búsquedas intelectuales de los surrealistas, en ella esa génesis se explica porque sencillamente era, como algunas de sus protagonistas, habitante de un mundo intermedio. Y sus pinturas crean universos visuales que no pueden comprenderse separándolos de una cosmovisión moldeada por la intensidad de la imaginación interior. Como escribe el estudiante de matemáticas Daniel Gregori Turkel en un trabajo escolar titulado "The Message of Surrealist Art: Automatism, Juxtaposition and Dreams", que cito por el interés que reviste un concepto formulado por adolescente que se inicia en el mundo adulto y por su acierto:

In preparing to analyze Surrealist art, one must keep in mind that the artist is reproducing their mind, not creating something new. The interest was in the method of reflecting one's unconscious (...). As a result, simply visual inspection of Surrealist art is futile; one must consider how it reflects the mind of the artist 
(...) The message of Surrealist art is as follows: there is a world in the mind that evades ordinary examination; we must embrace this world, our unconscious, and allow it to flourish until it becomes as understandable and ordinary as our reality, in order to create a Surreality (Turkel, "The Message of").

De niña, Leonora veía fantasmas en el laberíntico castillo neogótico atestado de antiguos espejos y de muebles que chirriaban, y luego crearía páginas y pinturas a las que el cineasta Luis Buñuel —uno de los integrantes del círculo que los surrealistas exiliados formaron en México - atribuyó la capacidad de liberarnos de la miserable realidad de nuestros días. Reed Johnson, un escritor de arte que la visitó en su casa de Ciudad de México en 2008, comienza su historia describiendo una mujer que se aleja de lo ordinario:

Phantoms come, phantoms go. They swirl around Leonora Carrington, a tiny woman of 91 with a tart intellect and a posh British accent, as she sips Earl Grey tea at her kitchen table. They rise like black vapors from the pavement of Avenue Reforma, where a menagerie of Carrington's enigmatic bronzes startle pedestrians and spook passing cars (Leonora Carrington's Spectral Presences).

Más allá de su aguda capacidad de ver y sentir —creía firmemente que los animales hablan aunque sea difícil entenderlos- anhelaba comprender, y lamentaba, al final de sus días, que no hubieramos entendido, como especie, nada. Aberth sintetiza la naturaleza de la creación de Leonora y su relación particular con el surrealismo, derivada de su habilidad como hacedora y habitante de mitos, con irrefutable claridad:

Indebted to Surrealism yet possessed of a unique vision, Carrington has the ability to construct alternate worlds, both fantastical and believable. It is this perpetual tension between the real and the imagined that lends her work it's compelling nature and is an idiom she shares with other Surrealist. Lifting the veil of ordinary sight, she permits us a momentary glimpse into another dimension where traditional spatial relationships have collapsed and where strangle entities are often frozen in gestures evocative of both ritual and dialogue (...). Leonora Carrington is a consummate mythmaker - she has always spun tales - in her artwork, in her writings, and in recounting her life (7). 


\section{Habitante de una segunda realidad}

Lourdes Andrade inicia la biografía Leonora Carrington. Historia en dos tiempos estableciendo un paralelismo entre un auto de fe ocurrido en 1612 en Lancashire, y la memoria de la joven rebelde que en 1938 huye de su casa en la misma región desafiando la autoridad paterna y los pactos sociales de su familia inglesa de clase alta, y escribe un relato titulado "La dama oval". En este cuento al que volveremos luego, narra el sacrificio por el fuego del caballo-balancín que tiene la misma personalidad de la protagonista: "La inmolación ritual del caballo, común entre los celtas, irrumpe la vida de una familia aristocrática introduciendo una realidad otra..." (9). El paralelismo confirma su apreciación esencial:

La biografía de Leonora Carrington se sucede en dos tiempos: el tiempo real, histórico, objetivo [...] y el tiempo mítico, onírico, subjetivo, el de los sueños y ensueños, aquel en el que ha podido imaginar y dar forma a sus obsesiones, a sus fantasías, a sus miedos y deseos (8).

Whitney Chadwick explica por su parte que el tema principal de muchos textos y pinturas de Leonora es "lo liminal" esa zona identificada por el antropólogo Victor Turner, donde todo puede suceder,

Un mundo de límites indefinidos entre el sueño y la vigilia; el pasado, el presente y el futuro; la vida y la muerte (...), un mundo de paisajes cambiantes donde el tiempo y el espacio se funden; la realidad no es nunca lo que parece y la conciencia se detiene en el punto exacto donde se cruzan el mundo material y el inmaterial (La realidad de la imaginación 5).

Aberth esbozó el mismo sentido espiritual de su obra:

Leonora Carrington used the act of painting to invoke and harness unseen forces. Through the depiction of communion with and between animals, the presentation of altars containing ritual sacrifices, or the drawing of magic circles and other geometric patterns, Carrington's work often serves as a perpetual summoning of the divine to manifest. Celtic goddesses, spirits of the departed, the Sidhe of the 
Tuatha Dé Danann, and other chthonic and ancient entities are called forth to serve unknown purposes or perhaps simply to demonstrate their continued existence and intervention in our supposedly secular times (Invitation, Invocation and Manifestation).

No es casual que la cita de enorme fuerza que Chadwick elige en el prefacio haya sido extraída del cuento de Leonora "La puerta de piedra". Hay un instante decisivo en que la protagonista, con una máscara y a cuatro patas, roza la nariz de un lobo y sostiene su mirada, con la convicción de que existe una zona donde ella y el lobo son uno. Leonora parecía entender el lenguaje de los animales con una naturalidad que pasmó a los surrealistas en París, pero que ella explicaba con el razonamiento obvio que le escuché, frente a una humeante taza de té inglés, en una entrevista en la cocina de su oscura casa en la colonia Roma de Chimalistac, en Ciudad de México, cuando le pregunté por esa cualidad: "Usted olvida que nosotros (los humanos) también somos animales, aunque tenemos una actitud muy estúpida frente a éstos y a menudo bastante cruel. No entendemos nada sobre los animales... Aunque realmente algunos humanos sí" (Herrera, Entrevista personal con Leonora Carrington).

En esa casa oscura y "fría como la caridad”, según ella le dijera a Cherem, no hubo nunca flores cortadas, porque le parecían cadáveres, pero en cambio el patio estaba tan invadido por la jacaranda que ella misma había plantado que se asemejaba a uno de esos bosques misteriosos, ajenos a la luz, que pueblan tantos de los parajes que pintó o escribió. El mismo James, por su parte, asevera que Leonora no se sentiría insultada si se le dijera que, de acuerdo a la doctrina pitagórica de la transmigración de las almas, su alma habitó alguna vez una fruta o un vegetal (22). 
En el ya mencionado catálogo de su exhibición retrospectiva en el Center for Inter-American Relations en Nueva York, 1976, Leonora escribiría un texto que revela su profunda empatía, no sólo por el reino animal, sino vegetal, y que sin duda guarda una conexión con su viaje al estado de Chiapas, donde a expensas del estado mexicano, que le había comisionado un mural para el Museo de Antropología, pasó un mes entre los indígenas chamulas que extrañamente no la trataron como una intrusa, sino como una mujer de visión a la que permitieron acercarse a los curanderos y a las prácticas de sus modos de conocimiento. Traduzco algunos fragmentos que aluden a esas raíces míticas que desconocen las fronteras espacio-temporales y beben de todas las fuentes:

El repollo es una rosa, la roza azul, la Rosa Alquímica, el Venado Azul (Peyote) y el alimento de Dios es el conocimiento antiguo, sólo recientemente conocido para los 'occidentales civilizados', humanos que han experimentado muchos fenómenos, y han escrito recientemente muchos libros que dan cuenta de los mundos cambiantes que esta gente ha visto cuando comen esas plantas. Aunque las propiedades de los repollos, son hasta cierto grado diferentes. También gritan cuando son arrancados de la tierra y sumergidos en el agua hirviente o la grasa. Perdónanos, repollo (23).

Durante el homenaje que en 2009 se le rindió en el Museo José Luis Cuevas de la Ciudad de México, con la presencia de los escritores Elena Poniatowska, Carlos Fuentes y Carlos Monsivais, los tres coincidieron en que su surrealismo era anterior en su origen a cualquier adscripción al movimiento. En mi artículo "Leonora Carrington. La novia del viento" cuento que Fuentes leyó un texto escrito a mano de prisa bajo la poderosa inspiración de la artista y escritora inglesa que entonces, cuando tenía 92 años como Marian Leatherby, la magnífica protagonista de su novela corta La trompeta acústica ${ }^{105}$, seguía tomando puntualmente el té en la cocina llena de aromas culinarios mexicanos en Ciudad de México. Fuentes sintetizó la particularidad de su vida y trayectoria creadora al 
identificar a Leonora Carrington con "una segunda realidad". La evocó fusionando imágenes fantásticas que provenían por igual de sus relatos y obras artísticas. Dijo haber visto, en una habitación vacía, en penumbra, donde lo de arriba y lo de abajo se confundían, un cielo sumergido y un caballo joven (el "ser doble" de la artista, que desde niña otorgó a su energía interna esa forma magnífica), pero también una silla inquieta (como tantos muebles humanizados en sus cuadros) y dos ruiseñores amenazantes (como el legendario cuadro de Ernst, que deslumbró a Leonora antes de conocerlo en persona) y ratones ciegos (como en uno de los relatos de La casa del miedo), y una hiena vestida de debutante de sociedad, acompañada de una debutante disfrazada de hiena (como aquella que aparece en su primer autorretrato y en el cuento La debutante). Vio también tres mujeres que leían un libro. Una se enardecía con un libro de Jean Cocteau (del mismo modo que en el retrato que a los 19 años Leonora hizo de su amiga Joan Powell fumando y leyendo, ella sostiene un ejemplar de Les infants terribles). ${ }^{106}$ Viéndolas, Carlos Fuentes, el soñador que evoca a Leonora, comprende que se conjuran para que los del espacio de afuera, puedan contemplar su verdad que ilumina otra realidad. "El arte es el secreto de esa (otra) realidad", confesó Fuentes, una "segunda realidad" que Leonora habitó con la más inocente naturalidad (Herrera, Entrevista personal con Leonora Carrington).

Hay una fuente de incesante libertad vital y creadora en esa "segunda realidad", o en esa vida y creación en dos tiempos simultáneos que se suceden en una zona liminal en la que el instinto aniquila la ley, la separación entre lo humano y lo animal se diluye, y no sólo hay coles que se pelean furiosamente hasta destrozarse, sino muebles animados. La lógica danza en las regiones neblinosas de un sueño que puede confundirse con lo real y 
Leonora se pinta a sí misma como una mujer con cabeza de caballo o se desdobla en un caballo al que le concede a menudo esa capacidad de levitar con la que soñaba desde niña y por la cual llegó a considerar brevemente hacerse monja, como su tía Eliza. Como otros miembros de su familia, ella aparecerá luego transfigurada en la pintura Do you Know my Aunt Eliza?, (¿Conoce a mi tía Eliza?) 1941, que continúa la tradición goyesca de la sátira eclesiástica y que Matthew Gale describe así en el texto de archivo de la Tate Modern de Londres sobre esta pieza de Carrington que forma parte de su colección: "The robed and horse-headed figure with a crucifix towers over a sinister accomplice." (Do you know my Aunt Eliza).

Pero en general, es a ella misma que se retrata desdoblándose en los caballos, como aquellos de pelaje blanco que levitan o trotan en el interior y exterior del temprano y raro autorretrato, Self-Portrait (Inn of the Dawn Horse) (Autorretrato. Posada del caballo del amanecer), 1937-38, ${ }^{107}$ una de sus pinturas más conocidas, que forma parte de la colección permanente del Metropolitan Museum in New York, y que descifraremos en su correlación con los relatos de la misma época. A diferencia de Frida Khalo que declaraba no sin cierta mordacidad no saber que era surrealista hasta cuando Breton se lo reveló y que se retrató a sí misma con tal obsesión que incluso sus naturalezas muertas tienen el carácter de auto-retratos, como ha precisado el médico, coleccionista e investigador Salomon Grimberg, quien también fue cercano amigo de Leonora y es el autor del texto que acompaña el catálogo de su exhibición en el Dallas Museum of Art, Leonora Carrington: What She Might Be, ella cultivó muy poco este género, pero en su obra literaria y pictórica abundan los rastros y alusiones biográficas. Y si bien el caballo no fue la única bestia con el cual se identificó, sin duda es la criatura que de manera más 
constante aparece en sus relatos y pinturas como representación de sí misma, o como atributo de lo que amaba o buscaba para sí.

Si Marina Warner (1988) observó que Leonora pinta el caballo como un signo de dinamismo, velocidad y soberanía, Grimberg (2008) sintetizó con reveladora precisión que el caballo representa su acceso a esa otra realidad del mundo invisible, el sustento de su realidad interna y la energía que le provee el ímpetu para trascender la irracionalidad del mundo humano. Leonora se proyecta en el caballo y/o va configurando en ese doble animal y en el fantástico imaginario de un ser híbrido — cabeza de caballo—, una expresión de la ficción extrema que más allá de traspasar las fronteras del terreno biográfico al literario y al artístico, se yergue como una fuerza que cocea: patea, se resiste, se revuelve contra las convenciones sociales, las hegemonías y las restricciones de diverso orden y de este modo cruza el umbral de una segunda realidad.

\section{Coser mitos: juegos de la lengua e iconografías}

Los seres híbridos de Leonora, a menudo translúcidos y extraviados en la oscura belleza de universos donde hay una profunda comunicación entre el reino vegetal, y animal, y entre humanos y fantasmas, ejercen una fascinación tan atemporal como el origen de los mitos o las fuentes ancestrales de las religiones y de las narraciones orales, de donde en realidad provienen. Para ella, la cualidad de dar forma o voz a las regiones más soterradas del inconsciente de la humanidad, o de convertir en tapices, esculturas o pinturas, criaturas monstruosas que hablan de las fuerzas desbocadas del instinto o de la destrucción, pero también de la seducción de lo desconocido, era un tanto un acto natural e irrefrenable tanto como una actividad ligada a la cotidianidad. "Como coser o cocinar" 
dijo Poniatowska en el homenaje que se le rindió en 2009 en el Museo José Luis Cuevas en Ciudad de México.

Antes de ahondar en las múltiples recreaciones de la figura híbrida que puebla los relatos y pinturas de Leonora es necesario remontarse a las fuentes de la imaginación literaria y artística que alimentaron el caudal de su creación fantástica. La obra plástica que realizó primero en Europa, y luego, a lo largo de la mayor parte de su vida en México —el país que le permitió escapar del acecho de la locura, tras estar confinada en 1940 en un asilo mental en Santander, España, como consecuencia de los delirios nazis que extendieron su pesadilla histórica hasta vulnerar su propia estabilidad mental— se caracteriza por una imaginación fantástica, nutrida por múltiples vertientes literarias. Entre éstas, la habilidad anglosajona para las acrobacias lingüísticas llevadas al límite de la rima musical sin sentido del humor negro; las tradiciones orales y el contacto con narraciones e iconografías provenientes de universos culturales tan diversos: la Irlanda que jamás pisó, pero que recorrió mágicamente, a través de su tradición oral; el México al que llegó inesperadamente, como Alicia al caer en el brocal del pozo, huyendo del acoso de la locura de su tiempo y del poder patriarcal, y que fue un gran caldero de donde extrajo con voracidad, y en donde vertió, una mezcla de saberes que convirtió en arte; y los símbolos de las tradiciones herméticas que la embriagaron desde cuando comenzó a atesorar libros de alquimia y ocultismo, mientras recorría como joven estudiante de arte las calles londinenses.

El escritor Pablo Weisz, uno de los dos hijos de Leonora, reconstruye la saga familiar evocado cómo el padre de ella y su abuelo, Harold Wilde Carrington, acaudalado empresario de las industrias de textiles y química, socio mayoritario de Carrington and 
Dewhurst, tenía un parentesco con Oscar Wilde (Aberth 142). La madre de Leonora, Maureen Moorhead, reclamaba estar emparentada con la prolífica novelista irlandesa del siglo XIX, Maria Eddeworth, cuyos cuentos infantiles evocan elementos fantásticos de raigambre irlandesa que Leonora fundirá luego con la imaginación de múltiples universos espirituales, provenientes de diversas culturas. Una de las influencias que encendieron su imaginación y que quizás la pusieron en contacto con la noción de la resistencia, fueron los relatos de la abuela materna que, según le contó Leonora a Manuel Ávila Camacho López en una entrevista realizada en 1974 (Aberth 12), le hablaba de los hombres que, acosados por invasores, se habían refugiado en el interior de las montañas o en el subsuelo para transmutar en oro la materia: esas historias de raíces célticas que su abuela le contó se fijaron en su memoria y la llenaron de imágenes mentales que comenzó a dibujar en papeles desde pequeña.

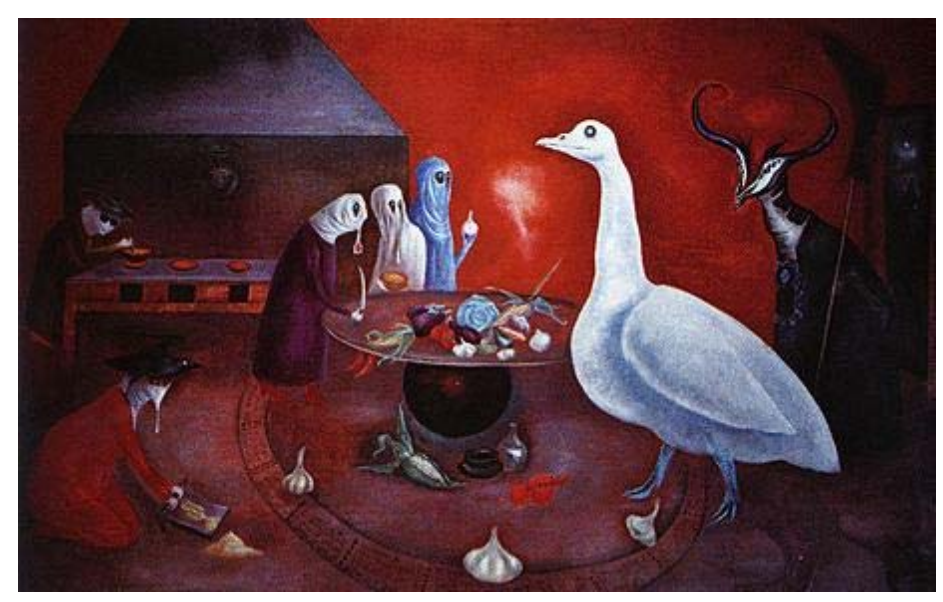

Ilustración 42: Leonora Carrington. La aromática cocina de la abuela Moorhead 1975. Óleo sobre lienzo. 31 x 49". Charles B. Goodard Center for Visual Performing Arts, Ardmore, UK

Aunque se trata de una obra de la madurez, Granmother Moorhead's Aromatic Kitchen (1975) revela que la capacidad de Leonora de sentir la vida en todos los seres proviene del legado de su línea de descendencia materna. Ajos, bazorca, repollo, y otros 
vegetales son criaturas vivas y en la tarea del cocido las figuras humanas se fantasmagorizan y empequeñecen, mientras la magnífica oca blanca con patas femeninas, y el antílope, investido de una cualidad fantástica, son caracteres que presiden la escena. Los ajos en círculos están colocados en torno al patrón circular del suelo de color rojo oscuro. Una figura también roja recoge un montículo de arena con una suerte de recogedor del que se va formando una copa. En el fondo, otra figura humana sentada a la mesa cena y mira al observador. Katharine Conley sugiere que en las pinturas y escrituras de Leonora se percibe claramente esa "vida animal" de los objetos a la cual se refirió alguna vez Artaud, considerando que era una propiedad conferida por la cámara:

Carrington suggests that every character and every space has more than one aspect and that transformations are as necessary and mundane as breathing. For her, objects do not just have a psychological function, as Breton argued in 1933, they can be animate and animals can be seen as part of humankind's tangible identity (6).

La misma autora señala que Leonora adoptó una alternativa "vida animal" para ella, repetidamente, identificándose con el caballo como su animal totémico. Y precisa que

si bien Breton adoptó también un tótem para él —el pez o delfín- porque había nacido bajo el signo de piscis, nunca construyó una alternativa identidad animal de un modo tan serio como Carrington lo hizo hasta cuando se mudó a Nueva York, durante la Segunda Guerra Mundial (Conley13).

Por su parte, Jonathan Eburne destaca que esa cocina es el sitio de encuentro entre dos figuras míticas:

... a massive white goose and a horned, cloven-headed figure entering the frame from the right, as well as a group of five shrouded figures preparing food to the left. The two sets of figures occupy seemingly incompatible symbolic registers. The kitchen-workers resemble similarly cloaked figures in other Carrington paintings, such as 'The Ancestor' (1968), 'The Magdalenes' (1986), and 'Kron Flower' (1986). Critics have long noted the autobiographical resonance of these 
figures, citing both Carrington's longstanding tendency to depict herself as an old woman (...). The kitchen's visitors, by contrast, arrive from a more explicitly mythological order, whose cosmology is indicated, however tacitly, by an inscription on the kitchen floor, which frames the painting's iconography within Celtic myths about the fairy underworld (17).

Autores como Whitney Chadwick (1994, 2011), Marina Warner (1988, 1991), Lourdes Andrade (1998, 2001), Susan L. Aberth (2004), o Silvia Cherem (2003, 2004), entre muchos otros, han investigado ampliamente el modo en que la niña nacida en 1917 en Clayton Green, cerca de Chorley, en el condado de Lancashire, Inglaterra, fusionó en una alianza de elementos únicos fuentes como los relatos célticos irlandeses transmitidos por su madre y por su nana irlandesa, Mary Kavanaugh; la literatura inglesa, particularmente Lewis Carrol, que tenía sus mismas iniciales, L.C., Jonathan Swift cuyo país Houyhnhnms le encanta porque los caballos son inteligentes y veraces, mientras los hombres son egoístas y salvajes-, James Stephens, el autor de historias fantásticas como The Crock of Gold (El cántaro de oro) así como los incontables libros de alquimia y esoterismo ${ }^{108}$ que descubrió en las librerías inglesas y que luego compartiría en México —el país más surrealista, según Breton— con su gran aliada y cómplice, la pintora española-mexicana Remedios Varo (1908-1963), ${ }^{109}$ con quien no sólo construyó un indestructible vínculo creativo que evoca en numerosos relatos, sino a quien, como apunta Dolores Fernández Martínez, llevó a explorar su vena literaria. Ambas compartían una poderosa capacidad de imaginación y experimentación y una pasión por el conocimiento oculto. Fernández Martínez anota:

En algunos de sus propios escritos aparecen ellas como protagonistas, como en 'The Hearing Trumpet', de Leonora Carrington, donde están personificadas en Marian Leatherby, feminista inglesa de 92 años que está prisionera en un castillo medieval español convertido en residencia para ancianas, y en su amiga española la pelirroja Carmella Velasques, una mujer famosa por escribir cartas a personas 
que no conoce, que está muy ocupada ideando cómo ayudar a Marian a escapar. En un cuento inédito de Varo las dos amigas se convierten en Ellen Rambsbotton, una inglesa que se interesa por los 'fenómenos somniotelepáticos' y la española Felina Caprino Mandrágora, que es una cabra cuando duerme y una mujer 'con unos ligeros cuernecillos' cuando está despierta (277).

Tras haber asistido a su exhibición "Leonora Carrington: The Celtic Surrealist" en

el Irish Museum of Modern Art, de Dublín (18 de septiembre de 2013 al 26 de enero de 2014), Darran Anderson escribe:

Indeed, she was told as a child that she was a descendant of the fabled Irish race the Tuatha Dé Danann, a charming impossibility that becomes much more than that in the hands of an artist of her calibre. If she emerged from these islands and returned to them in memory and invention, she did so via the world as evidenced here by the Surrealist Map of the World (from Variétés, 1929), in which, appropriately, Ireland and Mexico loom disproportionately large. Life, place and identity are inevitably subject to change, Carrington suggests, yet flux, and an art made from it, can act as an unlikely but effective anchor (Leonora Carrington. The Celtic Surrealist).

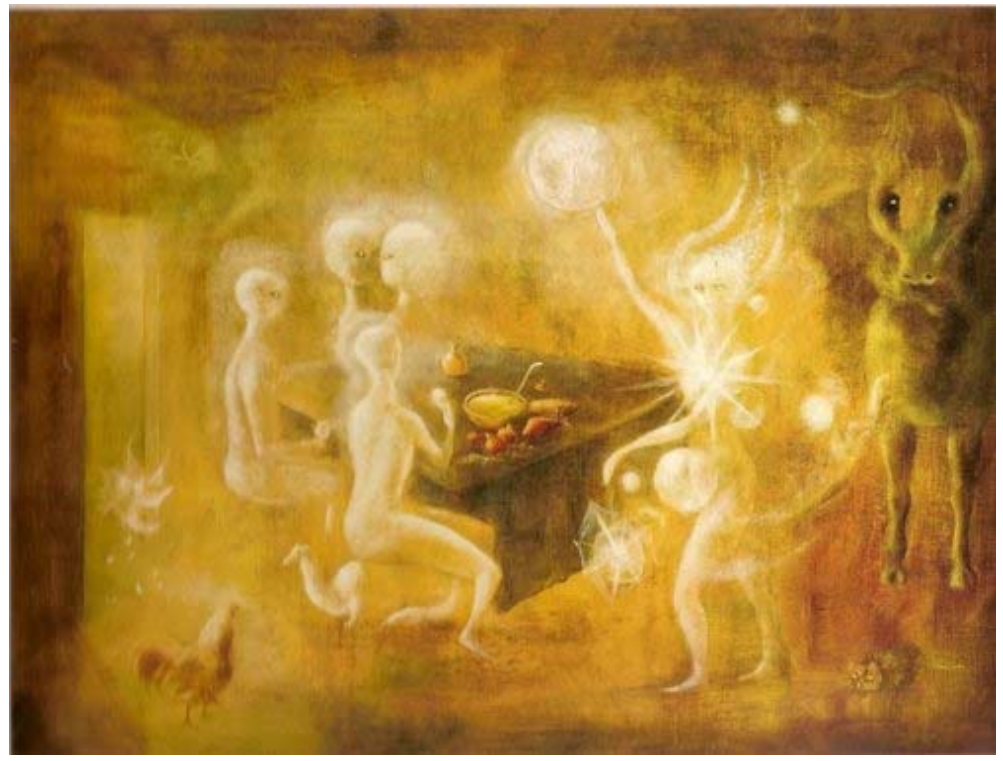

Ilustración 43: Leonora Carrington. Sidhe, the white people of the Tuatha de Danaan 1954. Óleo sobre lienzo. Colección Privada

En la pintura Sidhe, the White People of the Tuatha de Danaan, 1954, dos hombres de un blanco translúcido, luminoso, están sentados a la mesa desnudos, mientras 
una pareja de pie se difumina sobre ésta al punto que sus cuerpos parecen atravesarlos. En torno a la mesa una figura femenina parece irradiar soles y estrellas y sostener lo que pudiera ser una fabulosa tela de araña. En la misma habitación, los animales que observan, como el gallo de la derecha y el gato de la izquierda, parecen tener más consistencia corporal, como ocurre con la enorme figura tutelar que se alza de frente con inmensos ojos negros y bien pudiera ser un caballo, pero al tiempo tiene las orejas se extienden como una suerte de astas, entre las cuales, de forma apenas perceptible, pareciera danzar una figura antropomórfica. Los frutos rojos sobre la mesa surgen, como la pintura misma, como la obra entera de Leonora, de una suerte de memoria apetitosa que almacena, prepara y sirve mitos que entran en el tiempo del arte para ser transformados incesantemente.

Por otra parte, la osadía imaginativa está enlazada también, como he mencioando, a las peripecias de la lengua capaz de balancearse sobre el abismo del absurdo. Sumergida en el placer de estas lecturas infantiles no tenía idea de que Swift, Lewis Carroll (aunque también otros autores como Paul Scheebart o Christian Morgenstern) fueran las fuentes de inspiración de los dadaístas berlineses ni de sus exploraciones de la escritura fonética al estilo de los Lautgedichte de Hugo Ball, o de la Ursonate del artista Kurt Schwitters. ${ }^{110}$ Escribe Patrick Waldberg: "Dadá rompe el cristal del lenguaje y recoge sus fragmentos esparcidos para llegar a una nueva transparencia" (318). Ajena a todas esas exploraciones que ocurren mientras ella es una niña conservará sin embargo la capacidad de deleitarse con la lengua que se desliza sonoramente por el sin sentido, y el brío de ese ritmo de la lengua capaz de desbocarse hacia otras fronteras, marca su literatura y su arte. 
Andrade amplía la relación entre lenguaje lúdico y una fantasía de seres híbridos

en la mente de Leonora:

Jonathan Swift, Lewis Carrol, María Edgeworth y James Stephen van secretando sus hilos, cual afanosos arácnidos, y entramando esa red de sueños en la que Leonora se evade como en un barco fantasma. En las ignotas regiones por las que se desplaza tiene encuentros insólitos con monstruos, criaturas fabulosas que la aterrorizan, la fascinan, estrujan su fantasía. Los animales oníricos aparecen en el mundo de Leonora antes que las bestias de carne y hueso (Leyendas de la Novia del Viento 13).

A Leonora le atrae la experimentación mordaz y desobediente con el lenguaje, tanto como un universo de criaturas híbridas y, a menudo, también desobedientes. Relata Susan L. Aberth cómo, durante una entrevista que tuvo lugar en 1999 en su oscura y mágica casa en Ciudad de México, la escuchó emprender una espontánea recitación de un pasaje de Alicia en el país de las maravillas, mientras subía las escaleras, puntuando el ritmo de cada línea con el ascenso de cada escalón:

Carroll's use of parody and his 'nonsense' rhymes, such as those in Alice in Wonderland and Alice Through the Looking Glass would be accessed later as a prototype in her early Surrealist short stories and in her cryptic titling of works of art throughout her career (...). At age six Leonora began to write stories, in particular ghost stories and animal fables (...). That writing and drawing began more or less at the same time and a very early age for Carrington is a fact of some significance. First, it reveals that these two talents began on equal footing and second, that they sprang from the same imaginative source (Surrealism, Alchemy and Art 14-15).

De este modo, una lengua que se atreve al sin sentido, capaz de romper las propias reglas, puede levitar, por así decirlo, en los títulos de sus obras pictóricas o insertar rimas o líneas absurdas sin explicación alguna, obedeciendo al dictado interno de una composición que está llena de secretas insurrecciones. ${ }^{111}$ Hay un revelador ejemplo en el título de la pintura atrás mencionada, Do you Know My Aunt Eliza? que aparece escrito en el respaldo de ésta y que la artista inserta a modo de juego sonoro en " $E l$ 
pequeño Francis", un relato inspirado en la ingenua huída hacia una suerte de lugar afuera del mundo que, como se verá luego, intentaron ciertamente Leonora (encarnada en el personaje masculino que da título a la historia) y Max Ernst (tío Ubriaco), y en la rivalidad afectiva con su esposa de entonces, Marie-Berthe Aurenche (Amelia), con el surrealista alemán se había casado cuando ella era a su vez otra niña-mujer. ${ }^{112}$ En todo caso, como acota certeramente Mathew Gale:

The central passages, which focuses on Francis (the Carrington figure), concern his attempts to retain Ubriaco. On being forced to move-on by the imminent arrival of Amelia, he sings 'rather dejectedly', while cycling (Carrington 1989, p.110):

Do you know my Aunt Eliza? Wha, ha, ha, ha, haa.

She is blue but don't despise her. Wha, ha, ha, ha, haa. Now you'll excuse me laughing like I'm inclined to do But, do you know my Aunt Eliza? Wha, ha, ha, ha, haa. This curious ditty goes without explanation in the text. Recalling the nursery rhymes of childhood, in which Carrington saw parallels to Surrealist concerns, it bears a sense of deeply concealed meanings (Do you know my Ant Eliza?).

En esos relatos suyos que su hijo Pablo Weitz recomienda leer como si uno estuviera viendo sueños — Cortázar consideraba el cuento "Conejos blancos" uno de los mejores del género y lo incluyó en la antología Cuentos inolvidables- Leonora cose mitos con los retazos de imágenes que comenzó a unir en su infancia con un hilo que enlazó desde entonces las narraciones textuales a sus universos pictóricos. De 1920 a 1927, entre los tres y los diez años, habitó una gigante y laberíntica mansión que retrataría a los treinta años en la pintura que lleva por título el nombre de ésta: Crookhey Hall, 1947. En la mansión neogótica de inmensas y oscuras habitaciones, Leonora y sus tres hermanos fueron formados por una institutriz francesa y un instructor de religión, mientras la nana irlandesa les narraba historias de crímenes terribles y cuentos sobrenaturales de origen irlandés y alemán. 
Narra Andrade cómo desde niña, "Leonora exorcizaba miedos y fantasmas dibujándolos" (Historia en dos tiempos 11). En el breve y privilegiado encuentro personal que tuve con ella una tarde en su casa, afirmó que primero pintó del mismo modo en que todos los niños dibujan y que pintó en cualquier pared, pero que a diferencia de los demás niños, que un día dejan de pintar, ella siguió. Cuando le pregunté en qué momento había comenzado a escribir cuentos, respondió: "Antes de nacer. Yo pienso dijo- que uno empieza al momento de la concepción, pero uno no se acuerda".

Edward James (1976) precisa por su parte que si bien su trabajo artístico, particularmente en la década de 1940 a 1950, es en ocasiones reminiscente de Peter Brueghel o de El Bosco, esta filiación con la escuela flamenca del Renacimiento (sin duda marcada por la iconografía alquimista que también influyó a los artistas florentinos) proviene más de una fortuita afinidad del proceso imaginativo, alimentado por fuentes tan ancestrales como las leyendas gaélicas de una tierra de gigantes, unicornios, caballos casi humanos, cráneos blancos o salmones alados cabalgados por princesas que son al tiempo hechiceras: "The paintings of Leonora Carrington are not mererly painted, they are brewed" (14). El coleccionista comprende que ella ha bebido en fuentes de todos los tiempos y culturas (como quien se abrevara en la génesis del inconsciente colectivo) y que por ello hay algunas figuras de su bestiario — como los caballos-cercanas a las siluetas de la Grecia arcaica. De hecho, aplica a su imaginería artística el mismo adjetivo que se otorga a Odiseo en el Primer libro del relato de sus viajes: Polutropus, que puede ser literalmente traducido como muchas-mentes (19). Y por ello, advierte, Leonora puede derivar de la cultura helénica a la renacentista o de la céltica al período isabelino en Inglaterra. Su particular surrealismo le permitirá alcanzar un modo de inmortalidad a 
través del arte. Es posible que para su carácter cáustico, acostumbrado a dudar incesantemente, más importante que la misma posteridad fuera la conciencia de ejercer una virulenta y humorística crítica de las hegemonías contra las cuales se alzó desde niña y hasta el fin.

\section{La génesis de un bestiario desobediente}

"Diríase que en el orden de la creación, para Leonora, primero fueron los animales”, Escribe Bartra (207). En la pintura Crookhey Hall, 1947, la hierática arquitectura del castillo neogótico, reminiscente de la vivienda neogótica en que creció y conectada a la autoritaria estructura familiar paterna, aparece al fondo, circundada por un paraje verde donde pequeñas figuras femeninas o infantiles ataviadas de blanco juegan.

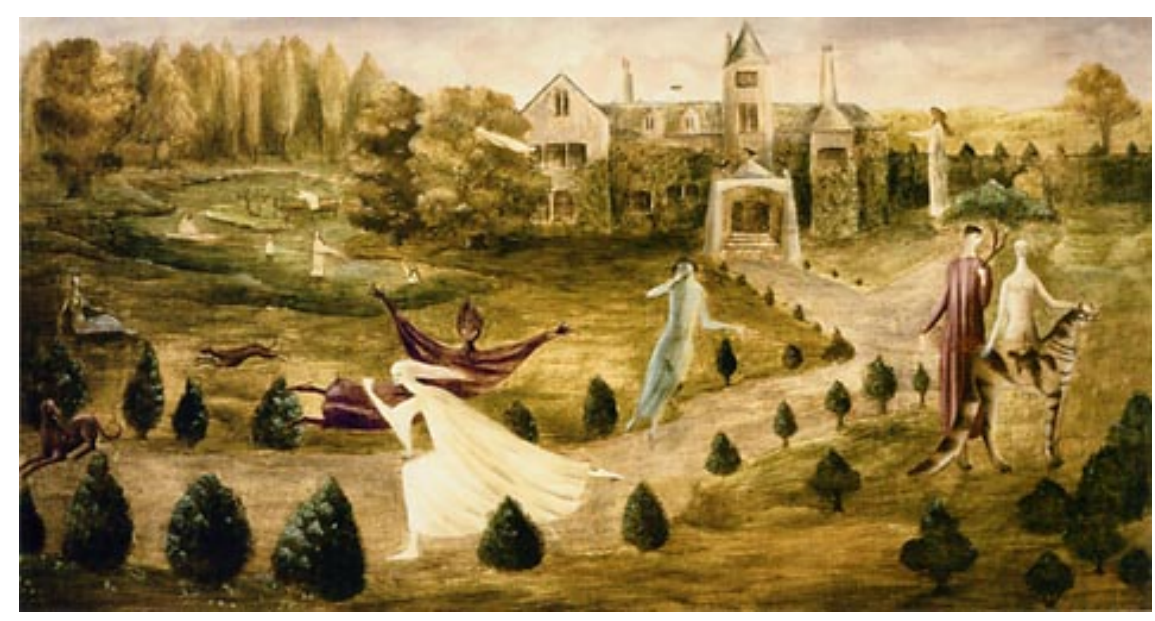

Ilustración 44: Leonora Carrington Crookhey Hall 1947. Caseina sobre masonita. Colección privada.

En el sendero que lleva de la casa hacia una arboleda que se insinúa por la representación de arbustos que aumentan paulatinamente de tamaño en tanto más se alejan de la entrada de la casa y que parece guardada por un felino salvaje, una evanescente mujer de blanco corre velozmente mientras otras figuras fantasmagóricas la observan o acechan. Atrás suyo una pareja aparece de pie e inmóvil. La mujer realiza el 
sortilegio de acariciar la cabeza y el lomo de un animal híbrido, una suerte de hienacaballo cuyos ojos deslumbrantes desafían al espectador, y que, como se verá, tiene relación con ella misma y su rebelión.

Esa forma de fiera identificación con los animales que le hizo inolvidable el día de su primera comunión cuando su madre la llevó a un pequeño zoológico en Blackpool, donde pudo ver los animales salvajes con los que solía soñar, permanece como constante en su obra plástica y literaria. Andrade evoca otra visita decisiva que tiene lugar durante su infancia: el Museo Británico.

Ahí descubre los animales fantásticos, las bestias fabulosas que ampliarán su muy rico y personal bestiario. Las sirenas, las esfinges, las bestias astrales, esos híbridos de naturaleza mítica o mágica que ocuparán un lugar preponderante en su imaginación y en su obra y que guardan relaciones de consanguineidad con los 'cadáveres exquisitos' inventados por los surrealistas, así como con las figuras fraccionadas de los collages de Max Ernst (Historia en dos tiempos 11).

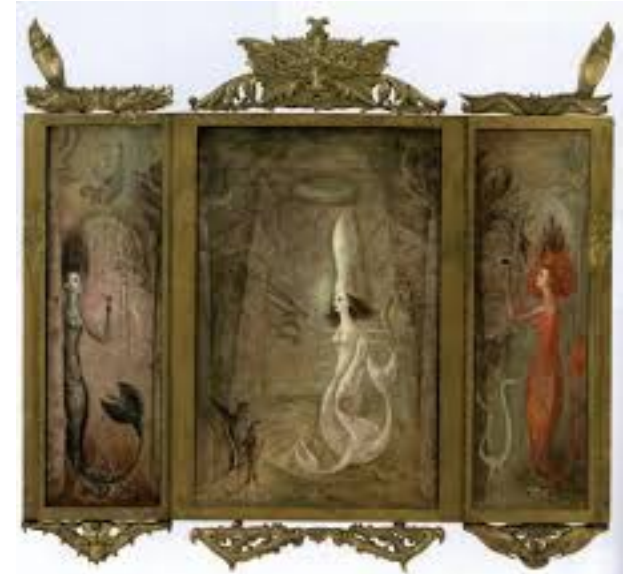

Ilustración 45: Leonora Carrington. Sueño de sirenas, tríptico 1963

En incontables ocasiones, Leonora relató su temprano amor a los caballos, que desde cuando pudo solía dibujar en ciertas paredes de la mansión y existe un retrato ecuestre de 1931 en que aparece como una bella jinete sobre su caballo Winkie. También adoraba montar a su Black Bess, su poni Shetland. Le parecía fascinante la capacidad de 
los caballos de mover sólo un pedacito de la piel para espantar una mosca. Y de niña, asombrada, intentó muchas veces hacer lo mismo. Ella y su madre montan a caballo y nadie más lo hace en la familia. Su innata conexión con los animales perdurará toda la vida.

En la novela Leonora (2011), escrita por su cercana amiga y cómplice, la escritora mexicana Elena Poniatowska, hay un diálogo que interpreta esa alianza que jamás se rompió con el mundo animal, y su paralela distancia con el mundo humano.

—Me estás diciendo que yo no soy un animal? — le pregunta atónita Leonora a su madre.

- Sí, eres un animal humano.

- Yo sé que soy un caballo, mamá, por dentro soy un caballo.

-En todo caso, eres una potranca, tienes los mismos ímpetus, la misma fuerza, te lanzas sobre los obstáculos y los brincas, pero lo que yo veo frente a mí es una niña vestida de blanco con una medalla al cuello.

-Estás equivocada, mamá, soy un caballo disfrazado de niña (10).

En la elección de "una vida animal alternativa" (Conley 2), hay un modo de desacato social, de rebelión que surge de la experiencia de sentirse más cercana a las fieras que a las gentes sujetas a las normas que ella rechaza. Su identificación con el reino animal es modelado en su temprana imaginación, como hemos visto, también por el contacto con la literatura inglesa en sus vertientes más lúdicas y de mayor juego lingüístico. Su fascinación por las bestias y por los seres híbridos surgidos de la imaginación y del juego de la lengua, se desarrolló de modo paralelo a su rechazo a las formas convencionales de autoridad y a las reglamentaciones sociales que coartaban su libertad imaginativa y su ser instintivo. Y se mantuvo toda su vida. En la visita que le hice en la sala de su casa, coincidí con una cineasta que en las visitas, ritualmente, le llevaba algún presente a los animales de Leonora. Silvia Cherem constató por su parte 
que Ramona y Monsieur, los dos gatos siameses que llegaron a su casa por su propia voluntad, caminaban sobre la mesa de la cocina exigiendo alimento. "Hablan conmigo —le explicó Leonora— son más claros que los humanos" (La última surrealista 47).

Las sagas de sus continuas expulsiones escolares comienzan a los nueve años cuando la apartan de los relatos de la institutriz Mary Kavanaugh y de la abuela irlandesa, de los "sidhes" esos pequeños seres que viven bajo tierra, o de las historias de las hienas que tienen dos piedras en los ojos que sirven para predecir el futuro, y la llevan a estudiar con las religiosas de hábitos negros que a ella le parecen "lomos de jabalí". Viendo que toca bien el piano, las religiosas desean que forme parte del coro, pero ella se aparece con una sierra a la que hace chirriar y sostiene que es su violín y que se propone dar con este instrumento un concierto que no es permitido. A una de las monjas, después de haber visto que el pájaro irlandés aguzanieve se ha posado en su ventana, Leonora, de nueve años, le pronostica: "Reverenda madre, le quedan pocos días de vida" (Poniatowska 2733). Lo cierto es que entre las estatuas, grabados y vitrales que adornaban su casa del siglo XIX había numerosas figuras de extraños pájaros que Leonora incorporaría a su bestiario personal. Pero sus labores de niña-pitonisa zurda —a la que parecía inútil inmovilizarle la mano izquierda amarrándosela a la silla — acaban mal: la expulsan y la historia se repite de modo invariable en los colegios religiosos. Como concluye Savater:

No debía ser fácil intentar domar a esta yegua bravía de pura raza, ni siquiera olvidar que se la estaba intentando domar (...), es decir, que se pretendía robar educadamente su curiosidad y secuestrar con guante blanco su fantasía. Ella, desde luego, no lo consintió (xi).

Numerosas investigaciones han recreado su radical rechazo a estas instituciones educativas que satirizará en su posterior obra pictórica. La indignación que desde niña 
Leonora sentía porque no le permitían hacer cosas que los niños sí podían, como trepar a los árboles, se fue convirtiendo en un "centro escondido", según le comentó una vez a Elena Urrutia:

Interiormente hay una especie de centro escondido que se pone furioso y a los hombres les da mucho miedo esta furia que se sabe expresar. Esta furia yo la he expresado en la manera que me ha sido posible, dentro de mis límites, en la pintura y en la poca cosa que he escrito (Leonora Carrington, artista y escritora).

De su modo de coser mitos y de ese "centro escondido" puede rastrearse la génesis de su bestiario desobediente. En Leonora, Poniatowska evoca cómo la niña única mujer de los cuatro hijos- habitada por las leyendas celtas de su abuela irlandesa se negó a ser transformada en una joven inglesa casamentera, y pudo más su voluntad irreductible que los esfuerzos de su madre, quien a pesar de haberla presentado para tal fin a la Corte de Jorge V en Londres, en 1934, y luego en el Palacio de Buckingham, acabaría ayudándola a estudiar pintura, primero en Florencia, a donde la envían a los 15 años y luego en Londres. Allí descubre la técnica al temple del Medioevo, y entra en contacto con el temprano Renacimiento así como con las obras producidas por los pintores flamencos que descubrieron el óleo. Escribe Julotte Roche:

Ahí, descubre a los artistas que más le influyeron (...) aquellos que le enseñaron a disfrutar los colores, la tierra quemada, el bermellón, el otro: la escuela de Siena, los maestros de los siglos XIII y XIV, Sasseta, Francesco di Giogo y Giovanni de Paolo (33).

Luego asiste la escuela de pintura de Miss Penrose, de quien ella tendría burlones recuerdos, y más tarde, tras un corto paso por la Chelsea School of Art de Kidres, se matricula en la Academia que Amédée Ozenfant (1886-1966) había abierto en Londres. Bajo su tutela artística, Leonora se sujeta, se deja guiar por primera vez, pues si bien el purismo de su maestro ofrecía poco estímulo para dibujar sus mundos imaginativos, 
aprendió con él la idea de la perfección técnica en el oficio y la importancia del íntimo conocimiento de los materiales. ${ }^{113}$

De este modo, la muchachita inmanejable que parecía incapaz de reconocer reglas, a la que las monjas de diversos colegios consideraban completamente inepta para la convivencia, se sometió a dibujar una misma manzana durante meses enteros, bajo la guía de este artista que, cuando ella tenía apenas un año de nacida, había compartido una exhibición con Charles-Edouard Jeanneret (después conocido como Le Corbusier), y creado también con él, en un ensayo legendario, los principios de la corriente purista en el cubismo. Leonora respeta la disciplina del oficio y la insistencia del maestro en revelarles la química de todo el material que utilizaban, incluyendo el papel y los lápices; pero la radical separación entre representación y vida interior que guiaban a Ozenfant, es ajena a su propia avidez mental. Mientras pinta la manzana de la disciplina, nutre su imaginación visual con textos de alquimia que compra en las tiendas de libros usados pues sus padres han restringido sus entradas hasta el extremo con la esperanza de que, acostumbrada a los mimos de una vida llena de lujo y comodidad, desista de su obsesión por la imaginación artística. En cambio, no cesa en nutrirla con los nuevos hallazgos.

Le fascina La rama dorada de Frazer, y con un regalo que le da su madre cuando asisten, juntas, a la "First International Exhibition of Surrealism": el libro "Surrealism" de Herbert Read, cuya portada, la pintura de Max Ernst, Deux enfants sont menacés par un rossignol (Dos niños amenazados por un ruiseñor), $1924,{ }^{114}$ se convierte para ella en una revelación incandescente. Hay un desacato, un humor oscuro y vital en esa obra ejecutada por el pintor alemán, apenas tres años después de haber producido sus primeros collages y fundado con su coterráneo Johannes Theodor Baargeld ${ }^{115}$ (Alfred Emanuel 
Ferdinand Gruenwald) (1892-1927), el efímero capítulo del movimiento Dadá en Colonia, al que luego se unió Jean (Hans) Arp (1886-1966). ${ }^{116}$

En 1936, cuando Leonora descubre su obra, Ernst lleva década y media envuelto en las actividades surrealistas. De hecho, la fecha de elaboración de la obra coincide con el año de la fundación del surrealismo, y él la concibe como una frontera que la culminación o consecuencia de sus tempranos collages, pero también un adiós a una técnica, y una puesta en crisis no sólo de la bidimensionalidad de la pintura, sino de los límites de lo racional.

Patrick Waldberg reconoce en su ensayo Surrealismo que el gran trabajo destructivo, negativo que pregonaba el fundador del Movimiento Dadá, Tristan Tzara (1896-1963), ${ }^{117}$ y que estaba ligado a la desarticulación de las formas plásticas, paralela a la de los tradicionales valores morales, no podía perpetuarse ni satisfacer a los jóvenes que buscaban otra sensibilidad en el mundo, pero permitía lo que Breton definió como un estado de disponibilidad perfecta $(9)^{118}$ Algo semejante era la expectación que tenía Leonora frente al encuentro personal con Ernst, propiciado poco después del regalo de su madre, gracias a Ursula Goldfinger, su condiscípula en la Academia Ozenfant, casada con el reconocido arquitecto húngaro Ernest Goldfinger, amigo del pintor, y quien ofrecía una cena en su honor.

Todas las rebeliones escolares empalidecen frente a la transgresión que supuso la huida de Leonora del hogar paterno y del mismo Londres, para reencontrarse en París con Max Ernst, el pintor que conoció a los 20 años, y que conformó con ella una de las parejas más míticas de la historia del arte. La intensidad de su encuentro les abrió a ambos múltiples mundos intermedios precedidos por la conformación de esa fantástica 
pareja constituida por ella, la "Novia del viento", ${ }^{119}$ como llamó Ernst a la bella creadora que deslumbraba con su imaginación desbocada, y que llevaba en sí a una mujer-caballo, y por él, el Pájaro Loplop o el Ave Superior, doble de Ernst; una pareja que produjo algunas de las obras más memorables de la historia del surrealismo durante el tiempo en que ingenuamente se refugiaron en una finca en el sur de Francia, cerrando los ojos a las fieras del mundo real y a la cacería nazi contra una parte de la humanidad. Pese a haber sido cercados por el horror del siglo y habiendo sido alcanzados por sus llamas —ella en el confinamiento de un manicomio y él en los sucesivos campos de concentración a donde fue enviado por los franceses colaboracionistas - sobrevivieron y continuaron creando, irremediablemente separados, una obra independiente y prodigiosa en la que ocasionalmente habría vestigios de su encuentro, como se verá en páginas posteriores.

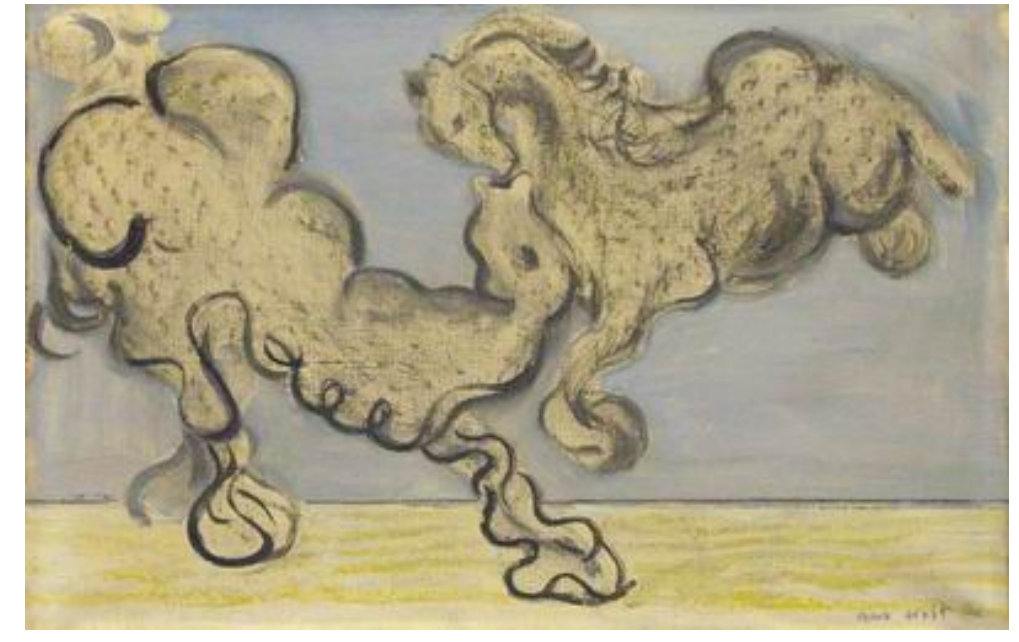

Ilustración 46_ Max Ernst. Novia del viento 1927. Óleo sobre lienzo, 28 x $42 \mathrm{~cm}$.

Regalo de Marc Engelhard, París, con el apoyo de Les Amis Français du Musée d'Israël à Jérusalem.

Una década antes de conocer a Leonora, Ernst ya había asociado visualmente el apelativo La Novia del Viento a caballos que levitan como la figura equina alada que se besa con otra en el cuadro así apelado, mientras la muerte, cuyo rostro aparece sobre las 
ancas, contempla. A mediados de los 20 , los torbellinos que pinta son "novias del viento" salidas de la Noche de Walpurgis: "Now I see young witches naked and bare..., and finally in the hunter who evokes the satanism in the opera, Der Freischütz" (Spies 79).

Susan Rubin Suleiman menciona una antigua creencia de los pueblos germánicos que recupera Grimm, y que refiere cómo la Novia del Viento es atraída por el cazador, para enfatizar cómo Ernst asociaba la sexualidad desbocada con los caballos. Si en los cuadros que pintó en 1927 abordaba el tema como una cabalgata entre dos, en los posteriores dibujos que hará cuando evoque a Leonora desde el campo de concetración de Les Milles, la figura que predomina, como consideraremos luego, es la de una mujer caballo (132).

Aunque en The Bird Superior Meets the Bride of the Wind: Leonora Carrington and Max Ernest, Susan Suleiman se pregunta: "What are the positive and negative effects for both parties of any relationship between a young artist just starting out and an older more established figure, possibly a 'genius' who acts as both mentor and lover?” (105), la apasionada relación que prosiguió a esa cena inicial en la que Ernst no dudó en meter sus dedos en la espuma del champagne que amenazaba con derramarse del vaso que sostenía Leonora, supuso un mutuo deslumbramiento con los mundos nuevos que para ambos se entreabrieron.

Leonora apenas había dejado la adolescencia, pero era una criatura alucinada, capaz de conducirlo de nuevo a los pasadizos de Lewis Carroll, que también le habían fascinado a él, y a las obras de M.R. James, y de seguirlo en las lecturas del romanticismo alemán y francés y en las visiones de Carl Gustav Jung, como sólo podría haberlo hecho alguien que se deslizaba en los mundos "liminares", y que aceptaba desde niña la visión 
fugaz de fantasmas y otras criaturas, y estaba convencida de poder entenderse con los animales como otra bestezuela. Darran Anderson cita una declaración de Leonora: "If gods exist, I don't believe they have human form", she claimed. "I prefer to envision deities with the appearance of zebras, cats or birds" (The celtic surrealist).

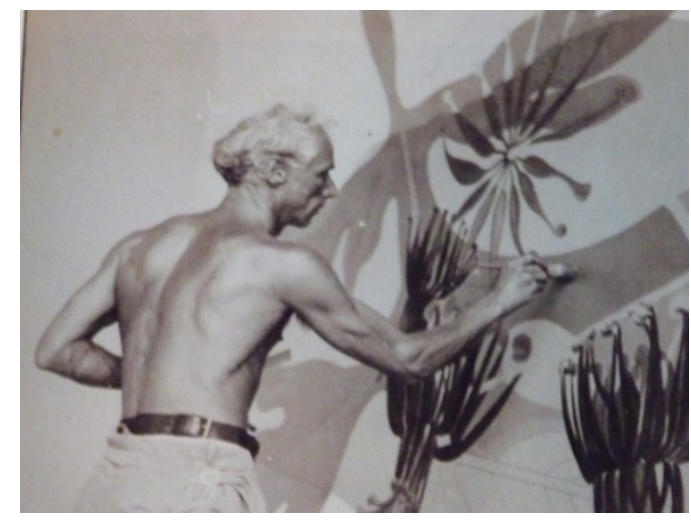

Ilustración 49: Lee Miller. Max Ernst en St Martin d'Ardèche 1938

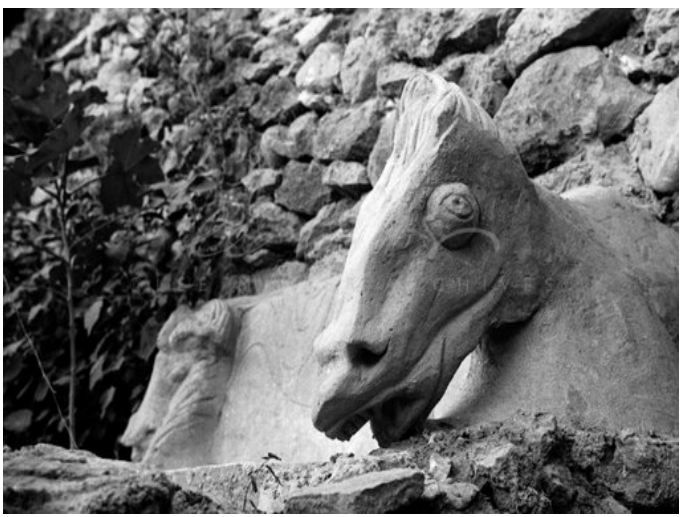

Ilustración 50: Leonora Carrington. Escultura de Caballo 1938

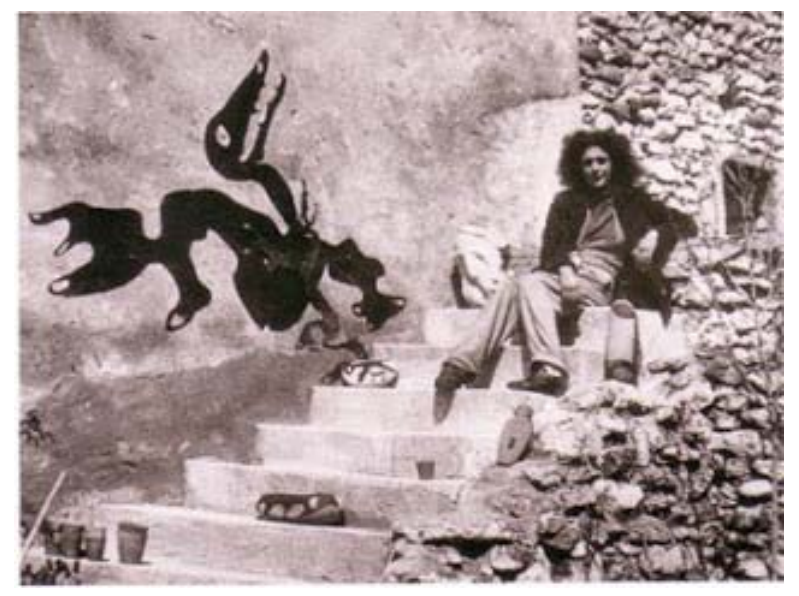

Ilustración 51: Lee Miller. Leonora Carrington en St. Martin d'Ardèche

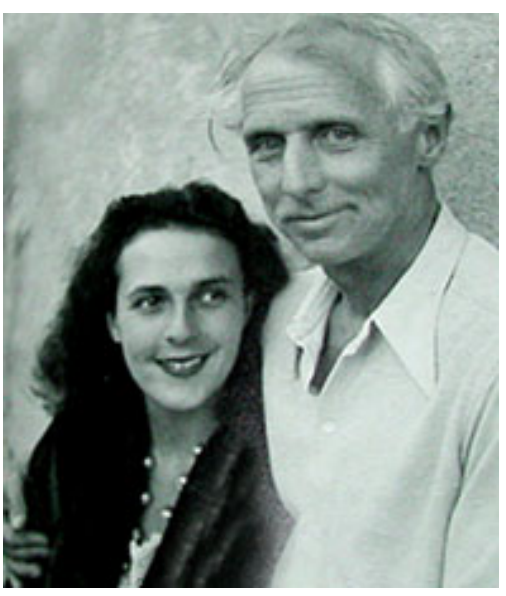

Ilustración 52:Max Ernst y Leonora Carrington 1939

Antes de entrar en el universo conjunto que Leonora y Max Ernst desplegaron durante los dos años en que estos dos personajes irreductibles y únicos, capaces de 
desdoblarse en un bestiario tan propio como desobediente, se refugiaron en la casa de campo en Saint-Martin-d'Ardèche, cerca de Aviñón, identificados "el caballo blanco de la leyenda céltica" y "Lop Lop", el Ave Superior (Chadwick 9) regresaré a dos cuentos, iniciáticos a su modo, en que Leonora expresa su rechazo a las expectativas sociales que pesaban sobre ella tras ser presentada en sociedad, lo que para ella equivalía, según le dijo a Cherem, a entrar en el "mercado del matrimonio" (La última surrealista 48).

\section{La máscara de la hiena y el desacato social}

Desdoblándose en la figura de una hiena en la cual deposita la furia suficiente para cumplir ritos caníbales con tal de liberarse a sí misma, y tranzando una alianza con su doble caballo, Leonora cumple, a través de dos relatos iniciáticos a su modo, la ruptura decisiva con el mundo de la infancia. Son textos que subvierten los ritos sociales de inclusión y afirman la fuerza inamovible del instinto y la imaginación, tanto como el poder incontenible de la iniciación sexual.

El cuento de Leonora Carrington "La debutante" (c.1934) es un autorretrato realizado en el descubrimiento del hechizo del mundo instintivo frente a la mordaza social. Es una sátira mordaz que caricaturiza su presentación en sociedad, que tuvo realmente lugar en el palacio de Buckingham. Joanna Moorhead, sobrina nieta por la línea materna de Leonora Carrington, quien fue en busca del rastro de la oveja negra de la acaudalada familia, escribió una serie de artículos sobre su encuentro en el diario londinense The Guardian. De hecho, cuando fue a México a buscar esa misteriosa pariente que había desaparecido no tenía idea de su vida artística. Menciona que sus padres se habían hecho millonarios y estaban atentos al potencial de su hija de mantener 
su estatus social. Según ella, después de experimentar el choque de la expulsión de su hija de dos escuelas asociadas a conventos (las monjas de New Hall les habían dicho que no cooperaba ni en el trabajo ni en el juego en la institución) la pareja hizo planes para lanzarla como debutante. Leonora se rebeló inicialmente pero al final consintió asistir a cambio de que se la dejara estudiar arte, primero en Florencia y luego en Londres.

But while she was eagerly embracing a future as a painter, her parents were busily organizing her presentation to George V at Buckingham Palace. During a visit to the royal enclosure at Ascot, she protested at the fact that women were not allowed to place their own bets, and sat resolutely reading Aldous Huxley's Eyeless in Gaza instead. During her coming-out ball, she plotted a short story (later published) in which she dressed a hyena in her trailing robes and sent the animal to the party in her place (Leonora Carrington Obituary).

El inicio del cuento "La debutante", incluido en el libro Leonora Carrington. La casa del miedo. Memorias de abajo, reafirma una alianza con el mundo animal que refleja su desdén por el universo social: "En la época en que fui debutante, solía ir a menudo al parque zoológico. Iba tan a menudo, que conocía más a los animales que a las chicas de mi edad" (35). Las libretas de su propia infancia estaban llenas de caballos, melenas, hocicos y animales del zoológico.

En la tradición de la mejor literatura inglesa, el tono confesional desvía el recuento de los males asociados a la obligación de ser presentada en sociedad, por el sendero de un humor que recurre, más que con toda naturalidad, con virulenta ironía, a lo fantástico, para colar un desacato en el orden de las razones sociales. La protagonista se hace muy amiga de una joven hiena a la que le enseña francés a cambio de que ésta le deje aprender su lengua. Refiere que en una fecha precisa, el 1 de mayo de $1934-$ exactamente el mismo año de la propia presentación de Leonora en la corte de Jorge V, donde fue glamorosamente fotografiada por Cecil Beaton y posiblemente de la escritura 
del propio cuento - tras sufrir noches enteras por la expectativa del baile organizado en su honor, decidió visitar a la hiena quien, pese a no saber bailar, acepta complacida asistir en su lugar. Tras llevarla en un taxi a casa y resolver el problema del atuendo con un vestido largo y guantes que ocultan sus pezuñas, solucionan el problema del rostro arrancándoselo a Marie, la criada, en una escena muy rápida que la protagonista prefiere de todos modos no ver, pues la hiena la devora sin dejar nada más que los pies, que guarda en una bolsa para cenar más tarde, y el rostro con el que se prepara para debutar.

Aunque la resistencia de la protagonista a esa solución criminal es primero de orden práctico — considera que la criada "se morirá en cuanto pierda la cara: alguien encontrará su cadáver y nos meterán a la cárcel”, según le dice a la hiena (39)—, y luego de una compasión bastante flexible — le basta pedirle a la hiena que mate rápidamente a la criada antes de arrancarle la cara y devorarla - el motivo es imperativo: "Desde luego, no lo habría hecho si no odiara tanto los bailes" (39). Irónica, humorísticamente, con la indiferencia de una crueldad que no acata dogmas morales, expresa así que un crimen le parece más aceptable que condescender con los ritos sociales — como ése del baile de presentación - y que sólo en esa única ocasión de su debut aceptó cumplir en su vida real.

Advirtiendo a la hiena que no debe acercarse a su madre — "aparte de ella, no conozco a nadie" (36), afirma la protagonista del cuento, quien, por cierto, comparte con Leonora el hecho de que la madre sea el único vínculo que la une a su mundo familiarlogra escabullir el compromiso. De este modo, la hiena baja a cumplir su papel de debutante, mientras la protagonista se entrega "a la paz y al descanso", sin un ápice de remordimiento, leyendo Los viajes de Gulliver, una historia en la que Swift no sólo hacía 
en esa historia una mordaz crítica a la sociedad de Dublín, sino esgrimía, como Leonora, una cierta convicción en la superioridad de los equinos sobre los animales humanos.

En todo caso, la placidez dura poco: primero irrumpe un premonitorio murciélago en la ventana, dando grititos, y luego entra la madre en la habitación, presa de furia, y le refiere que la criatura que ocupaba su sitio se ha negado a comer pasteles al sentarse a la mesa y que a cambio, se ha arrancado y comido la cara que le servía de máscara antes de desaparecer de un salto por la ventana. Leonora prefiere sin duda, ser la bestia indómita que asume un rostro que no pertenece a su rango social y que, saltando por encima de todas las convenciones sociales, reafirma, por encima de todo, su ser incontenible e instintivo. "Leonora se arropaba con sus máscaras y telarañas. Acompañada de caballos voladores, parlantes y festivos, de aristócratas hienas disfrazadas de duquesas, de hadas peludas, cerdos gigantes, cabras, mandriles, unicornios y gatos, lograba defenderse, a su manera, del conformismo" (La última surrealista 283).

Por su parte, Andrade remarca cómo si bien la hiena no asume en ningún otro cuento un papel de similar importancia al del caballo, en éste se erige como alter ego de la debutante.

...nuevamente entran en juego los disfraces, los antifaces, las indefiniciones; nuevamente la identidad es incierta, oscila entre la bestia y la joven, entre la humanidad y la animalidad (...). La inmolación implica la integración de la propia bestialidad. Podría tratarse también, como en las culturas 'primitivas', de un ritual de pubertad (Leyendas de la Novia del Viento 32).

El temprano y poderoso autorretrato The Inn of the Dawn Horse, (Posada del caballo del amanecer), 1937-1938, perteneciente al Metropolitan Museum of Art, The Pierre and Maria-Caetana Matisse Collection, y uno de los más estudiados en la obra de Leonora, tiene diversas correspondencias no sólo con su relato La debutante, sino con La 
dama oval, y su iconografía puede servir como acceso a un universo fantástico-surrealista que contiene claves de su propia vida.

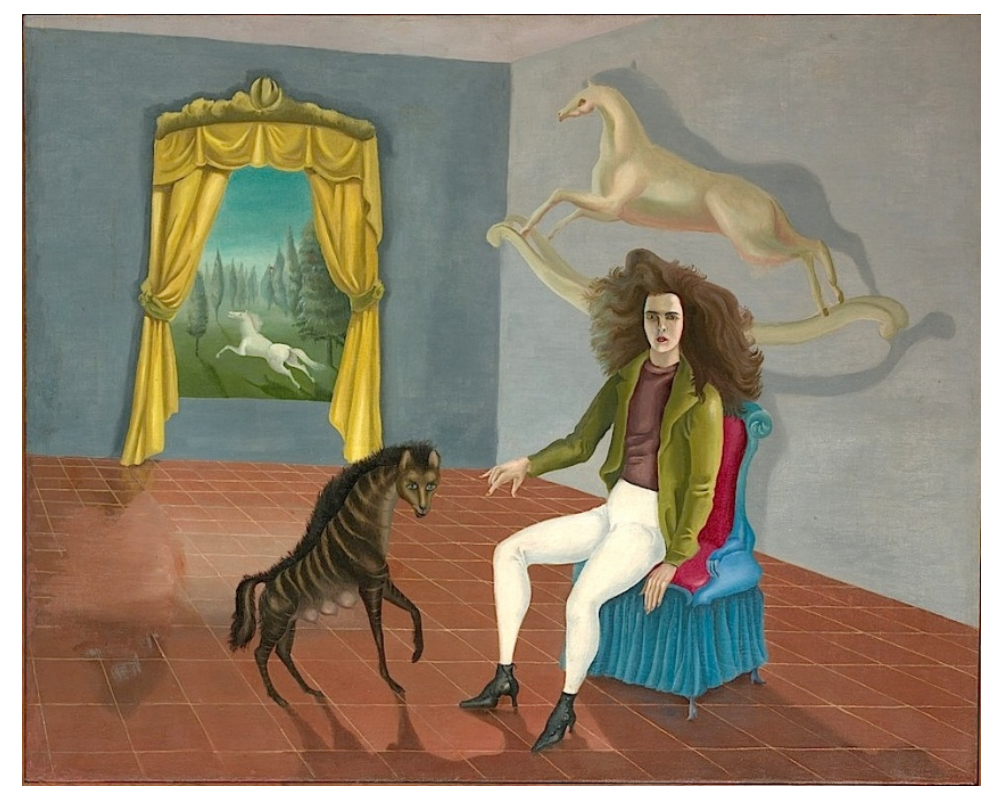

Ilustración 47: Self-Portrait (Inn of the Dawn-Horse),

1937-8. Óleo sobre lienzo. 25" 1-2" x 32"

The Metropolitan Museum of Art, The Pierre and Maria-Gaetana Matisse Collection

Leonora está sentada en una silla de falda azul, que se sostiene no sobre patas sino sobre minúsculos botines azules que le transfieren atributos femeninos, y que está acolchonada en su interior con un mullido cojín rojo, sucedáneo de la vulva. Lleva un ceñido pantalón de amazona, ${ }^{120}$ y parece dirigir, con la postura de su mano derecha, el paso alzado de la hiena que está enfrente de ella y que mira sin titubear al espectador. La sombra de las patas de la hiena y la sombra de los botines victorianos de Leonora, junto con la de la silla misma, se funden en una sola sombra que se extiende en el tablado del suelo sugiriendo la unidad de sus seres. El imantado cabello oscuro con un halo verdoso de Leonora es semejante al de la chaqueta de amazona que lleva y al pelambre rayado de la hiena que evidentemente está amamantando: es una figura nutriente del propio poder 
creador de la artista que se desdobla por una parte en su imagen, tan fiera e indómita como las figuras del plano inferior del cuadro. Las piernas separadas de Leonora hacen eco a los pasos de la hiena. Por otra parte, en el plano superior, las sombras de la parte alta de la silla, de la melena de Leonora y del magnífico balancín con un caballo blanco que levita sobre su cabeza, como si gravitara en la habitación, se funden y se duplican en la escena que se observa afuera, tras los cortinajes dorados que sirven de marco a una ventana en la otra pared de color azul: un caballo real blanco corre libre o más bien parece volar sobre el suelo en el trasfondo de una arboleda de verdes cipreses bajo un cielo tan azul como la propia pared. Se trata de una representación alada del propio vuelo de la imaginación y de la capacidad creativa que está ocurriendo justo en ese período en el cual, sin temblar ante la amenaza del padre que le advierte no volver a ensombrecer la puerta de su casa con su presencia si se marcha a París siguiendo a Ernst, Leonora se ha trasladado en efecto a ese epicentro surrealista y vive su intensa relación erótica con él, mientras crea un universo artístico-literario que sobrepasará la contingencia de lo biográfico. El caballito de madera es en realidad un retrato del que Max Ernst ha comprado en una tienda de antigüedades y en uno de los catálogos del surrealista la portada será su autorretrato montando el caballito mecedora. No hay en esta pintura ni mecanismo de represión sexual, ni sublimación del instinto: ambas fuerzas, liberación y creación coexisten en un espacio de plena afirmación de la naturaleza de la artista que cumple una suerte de doble iniciación. Si bien es cierto que en la tradición popular de Inglaterra el caballo blanco puede significar un presagio de muerte, también en términos arquetípicos es el portador de la luz o del fuego. 
Como Alyce Mahon deduce de la contemplación del autorretrato y de la lectura de La debutante y de La dama oval afirmando que Leonora retrata su fuerza erótica a través del simbolismo animal. "Carrington portrays her erotic force through animal symbolism (...) The hyena symbolizes not only the young woman's desire for freedom but also her untamed, sexual self" (140). Coincide igualmente con Katharine Talbot y Marina Warner en su visión del significado de la hiena:

The Hyena symbolizes not only the Young woman's desire for freedom but also her untamed, sexual self (...). A similar theme emerges in another story, 'The Oval Lady', shedding further light again on Carrington's animal symbolism in the painting as indicative of the threat untamed, bestial sexuality poses to 'civilized' society (...) Undoubtedly, the horse, like the Hyena, is a symbol of Carrington's unbridled desire, her creative energy and determination (141).

Los registros literarios del desdoblamiento de Leonora en la figura de un caballo blanco son múltiples y no sólo pertenecientes a la época de sus primeros cuentos, como veremos en La dama oval. Andrade, retomando un recuerdo de Memorias de abajo de Leonora, señala que ella vive la muerte ritual a partir de su extraña filiación con las bestias, con las cuales sostenía un "acuerdo" que tenía lugar a través de la piel, mediante una especie de lenguaje del tacto. Explica cómo, esa atracción que desde niña experimentó con los animales del zoológico, por los cuales sentía tanta fascinación como por las criaturas híbridas de su imaginación, hace que los convierta en inquietos habitantes de su mundo interior que expresan su desasosiego social. Un desasosiego que con frecuencia le atrae el castigo (58-59). En sus relatos, hay numerosos castigos contra la indómita naturaleza de sus protagonistas, pero es justamente en el cuento La dama oval, donde establece una suerte de pacto de sangre con el doble del caballo, el blanco, maravilloso caballito de balancín que pintó en Self-Portrait: Inn of the Dawn Horse 
(Autorretrato: posada del Caballo del Amanecer). El tiempo de la escritura del cuento corresponde al inicio de su vida con Max Ernst, quien posará montando un caballo de madera.

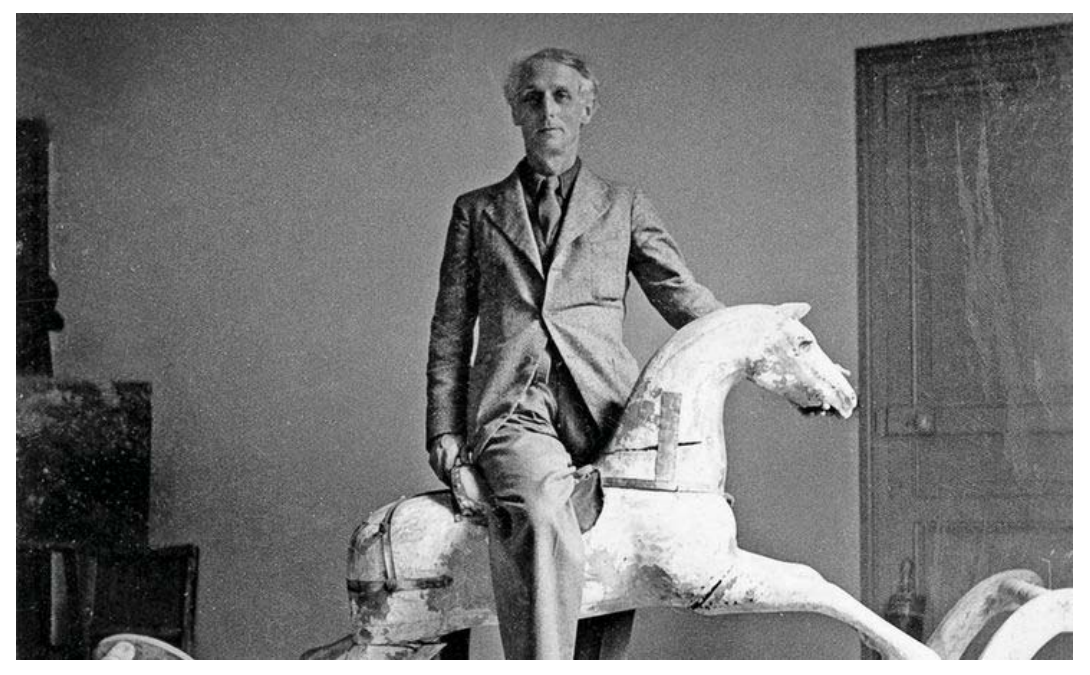

Ilustración 48: Max Ernst sobre un caballo de madera París, 1938

CProLitteris, Zurich: Max Ernst Museum Brühl des LVR, Stiftung Max Ernst

En La dama oval, también incluido en su primer libro de cuentos, La casa del miedo, como en muchas otras de sus historias, Matilde, la narradora, es atraída hacia el interior de una casa misteriosa por la figura de una mujer que observa desde afuera; la ve en el marco de una ventana, donde nada se mueve salvo la pluma de faisán que lleva en el pelo. Alta, altísima, como algunas mujeres de sus cuadros, la dama está rodeada de muebles tan alargados como ella, quien tiene por lo menos tres metros de estatura y un semblante que parece triste, pero en verdad oculta una furia terrible contra su padre. Lucracia, como se llama la dama oval, sólo tiene 16 años. Pese a que le ha confesado a Matilde que no come ni bebe en protesta contra su padre, la invita a tomar té y devora 20 platos de pasta, mientras anuncia que imagina su cortejo fúnebre con cuatro caballos negros. En realidad, fantasea con morir de hambre, sólo para fastidiarlo. Tras la opulenta 
cena, Lucrecia, como se llama la delgada giganta, la lleva a su cuarto de juegos, donde está “Tártaro” su caballo de balancín, que se mueve por sí solo y detesta también al padre de su dueña. Poco después aparece la urraca Matilde que sabe hablar y Lucrecia propone un juego: "Hagamos como que éramos caballos. Voy a convertirme en caballo: con un poco de nieve, resultará más convincente" anuncia y le dice a Matilde, la narradora, que ella será caballo también. Apenas pronunciado el conjuro comienza a danzar histéricamente sobre la cabeza de Tártaro mientras Lucrecia se arroja a la nieve y grita: “Todos somos caballos!’” (31).

Lucrecia se transforma entonces en un caballo hermoso, "de un blanco cegador, con sus cuatro patas finas como agujas y una crin que le caía como agua alrededor de su cara larga" (32). Entretanto, Tártaro parece centellear aunque sólo se ven sus ojos, cubiertos de nieve. El paroxismo termina cuando irrumpe una vieja ama de llaves que le recuerda que el padre le tiene prohibido ese juego ridículo. Como Lucrecia sigue jugando y riendo pese a sus amenazas, la vieja salta sobre su "lomo" y le mete a la fuerza un "freno entre los dientes" y así la arrastra hasta la larga mesa en donde un anciano, "con la figura más geométrica del mundo" pronunciará la condena inapelable: quemar a Tártaro, ya que ella es demasiado mayor para jugar con él. El padre, con suavísimas maneras, le recuerda que es por su bien, mientras brotan lágrimas de los ojos del caballo que deshacen la nieve y se convierten en un charco de agua en el que Lucrecia se arrodilla pidiendo una clemencia que no llega. Matilde se tapa los oídos poco después para no oír más los espantosos relinchos del cuarto de arriba, "como si un animal estuviese sufriendo torturas extremas" (31-34). 
Si en el cuento La debutante hay un rechazo radical a la vida establecida por su condición de género y clase, de acuerdo a las expectativas familiares; y en el cuadro SelfPortrait: Inn of the Dawn Horse (Autorretrato: posada del Caballo del Amanecer), una violenta reafirmación de su libertad imaginativa y sexual, en La dama oval la negación a la expulsión del territorio de la infancia y la ira contra el poder represor equivalen a otro modo de rebelión frente a los impedimentos que se le quieren imponer a la capacidad de transformar la opacidad de lo real con lo fantástico, como hace al cubrir de nieve, por la pura fuerza del juego, el interior de una habitación cubierta. La correlación entre el caballo blanco de madera que levita sobre la cabellera oscura de Leonora en su autorretrato y la inseparabilidad de Lucrecia y Tártaro, es evidente. Ambos caballitos tienen la posibilidad de ser alados y traer mensajes de regiones ignotas, y ambos personajes femeninos han sufrido castigos por su naturaleza indómita.

No imagina Leonora cuando escribe ese cuento en 1938 cuán terribles y monstruosos serán los castigos, las torturas, que experimentará en su propio cuerpo dos años después, ni cómo su propio padre enviará emisarios dispuestos a sepultarla en vida, por "su propio bien", confinándola en la remota África, y sólo la librará la vigilancia de su instintiva rebeldía. Antes de ello, habrá un interregno donde las zonas de la fantasía permearán la vida hasta crear un lugar en la tierra donde ella y Ernst materializarán un bestiario fabuloso y cada uno creará varias de las más importantes obras de su trayectoria. 


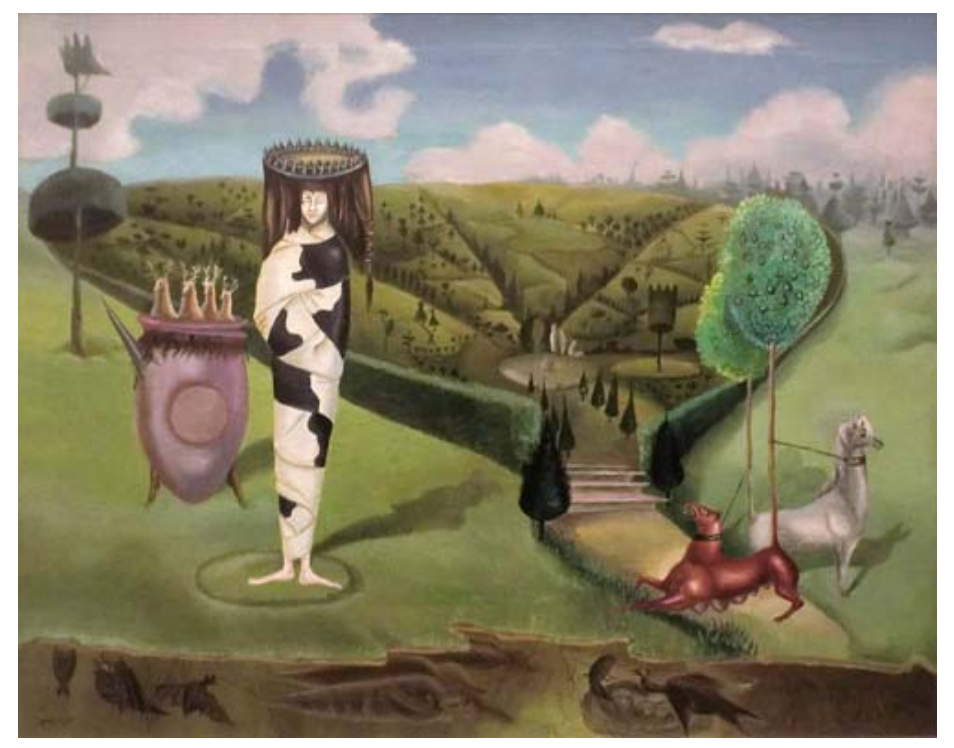

Ilustración 49: Leonora Carrington. Green Tea, or La Dame Ovale 1942. Colección privada. ARS, NY y DACS, Londres.

En 1942 Leonora pinta el cuadro Green Tea or La Dame Ovale (Té verde o la Dama Oval), en el que aparece retratada la altísima figura de Lucrecia, en un paraje que guarda profunda relación con el que rodeaba la mansión de Crookey Hall. Sobre la cabeza de la Dama Oval hay un bosque circular que repite el cerco de los árboles. Ella está ataviada con un vestido-mortaja que contiene sus manos y sus pies, y que puede ser reminiscente de las ataduras que para entonces habrá experimentado en el manicomio donde fue encerrada en Santander, España. Dos caballos, rojo y blanco, aparecen amarrada al tronco de dos árboles y la relación con el "saco de fuerza" de la Dama Oval es evidente, si bien la tela que la ata está pintada de manchones negros, como una piel animal. Mientras el caballo blanco permanece impasible y con los ojos cerrados, los ojos humanos que caracterizan a muchos de sus caballos están inmensamente abiertos en la yegua negra que lucha encabritada, y que, como la hiena de su autorretrato, tiene múltiples, hinchadas tetas que sugieren que amamanta. Esta imagen se relaciona con un 
sueño o visión que tuvo poco antes de que le aplicaran cardiazol, en 1940, y en la cual veía dos potros amarrados y luchando entre sí, como se verá más adelante. Una suerte de caldero con cuatro venados puede evocar las cacerías del padre que ella encontraba absurdas y duplicar el sentido de constricción que hay, más allá de su inmovilidad, en las hieráticas posturas que sostienen todos los animales — salvo la yegua indómita- y la misma dama en cuya cabeza una construcción circular puede evocar una suerte de ruedo. En el primer plano inferior la pintura sugiere una visión de corte, como si aún con los ojos cerrados, la dama pudiera mirar el reino de las criaturas que están bajo la tierra. Hay mucha vida, muchas otras vidas agazapadas en las capas de pintura. La copa superior de un árbol, a su vez, puede sugerir una cabeza de animal. Todo está animado y habitado por infinidad de presencias que nos rodean.

\section{El hombre pájaro}

Antes de entrar en la casa-bestiario que la mujer caballo y el hombre-ave crearán de un modo que materializa sus propias mitologías en obras de arte que traspasan las eras, es necesario remontarse al origen del hombre-ave, a la gestación del doble de Max Ernst, el Pájaro Superior, cuyo mito se iluminó de un modo tan intenso como fugaz cuando se acercó al de la mujer-caballo. Esto sucederá cuando, como escribió Julotte Roche, investigadora que vive en el pueblo francés de Saint Martin d'Ardèche, ha ocurrido que "A la Novia del Viento le presentan a Loplop. El que es pájaro, a la que es caballa" (36).

El modo en que ambos narran con extraño humor, con afilada fantasía, sus respectivos nacimientos, muestra una filiación común, que de algún modo trae implícito el signo de la ruptura con las tradiciones que les precedieron. Según evoca Andrade, en 
su texto autobiográfico Jezzamatháticas o introducción al maravilloso proceso de pintar,

Leonora refiere que llegó al mundo en

Muy curiosas circunstancias, en un enehexagrama, matemáticamente. La única persona presente en mi nacimiento fue nuestro querido, fiel y viejo fox terrier, Boozy, y un aparato de rayos X para esterilizar vacas. Mi madre se hallaba ausente, a la sazón (Leyendas de la novia del viento 17).

Por su parte, en su biografía de mentiras y verdades entrecruzadas, Ernst escribe:

The 2nd of April (1891) at 9:45 a.m Max Ernst had his first contact with the sensible world, when he came out of the egg which his mother had laid in the eagle's nest $\&$ which the bird had brooded for seven years (Warlik 7). ${ }^{121}$

Los une la capacidad transgresora, la facilidad con que producen modos de escándalo que marcan rupturas no sólo en el terreno de sus vidas sino en el de la historia del arte, y un agudo sentido lúdico que de algún modo une su espanto con el juego creador, y hace estallar las fronteras entre la vida y el arte.

La primera imagen que tenemos de Max Ernst es su retrato, a la edad de cinco años, como niño Jesús, hecho por su padre, Philipp Ernst, pintor aficionado y director de una escuela de sordomudos. Según la versión difundida por sus biógrafos, esta pintura se originó cuando, queriendo dilucidar el secreto de los hilos telegráficos, Max Ernst niño se escapa de casa con un palo de escoba provisto de un hilo delgado y se encamina hacia las vías del tren, pues cuando pasa los hace temblar con su movimiento. En su autobiografía, llena de mitos autoconstruidos, según advierten Werner Spies (1975), M. E. Warlick (2001) y Ulrich Bischoff (2003), Ernst refiere que iba vestido con túnica roja y los viajeros lo veían semejante al Santo Niño, así que él asumió con toda naturalidad la mágica identidad. Apenas el niño explorador alcanza el terraplén de la vía, lo pillan y lo llevan a casa, donde su padre se enfurece inicialmente al escucharlo decir que es el Santo 
Niño, pero acaba pintando un retrato suyo como si lo fuera, con una mano alzada que tiene el poder de transformar el mundo. ${ }^{122}$ La obra alcanza, por la identidad del retratado, una identidad inesperada.

Patrick Waldberg afirma que Max Ernst, su amigo, estaba destinado a convertirse en el "ilustre forjador de sueños", título de una de sus obras y narra cómo, de niño, antes de dormirse contemplaba fijamente un panel de caoba y en las vetas y nudos de la madera veía cambiantes escenas fantásticas: cien mil palomas, selvas, ciudades, mares y soles, motivos que luego reaparecerán en pinturas llenas de seres híbridos y mundos ocultos, de un erotismo latente que desconoce las fronteras entre cuerpos vegetales, animales y humanos, entre lo macro y lo micro, y donde la materia sueña las formas más allá del control de la mano del artista que se limita a seguirlas. Décadas después de esas visiones primigenias del niño soñador, en 1925, mirando el viejo parquet de madera de un hotel en Gran Bretaña, Max Ernst concebirá la técnica del frottage en el instante es que se le ocurre poner unas hojas de dibujo sobre las desvencijadas tiras del suelo de madera y restregándolas con la mina del lápiz, “calca” por primera vez los mundos subterráneos que esconden. En su autobiografía evoca, con una fecha exacta, el 10 de agosto de 1925, las circunstancias que rodearon el descubrimiento, y confiesa haber quedado sorprendido por la repentina fuerza que habían adquirido sus facultades visionarias, así como por la alucinante sucesión de imágenes contrapuestas o sobrepuestas en distintas capas; una sucesión que asociaba a la intensidad y rapidez de los recuerdos eróticos. La cercanía entre eros e imaginación — no exenta de la presencia del instinto destructivo, en juego con la fuerza del thanatos - era compartida por Breton que insistía en que el mundo 
debería llegar a ver a través de los ojos de Eros y creía en su poder radical de transformación.

La práctica visual seguía los comentarios de Da Vinci (1452 -1519) en su tratado de la pintura sobre los inventos admirables que podían surgir al contemplar las manchas de las paredes, la ceniza o las nubes y arroyos. Estamos en el reino de las analogías, reencontrado por el surrealismo y cuyo sentido Max Ernst puso en evidencia con incomparable capacidad de renovación a lo largo de su vida.

De esa experimentación surge su serie Historia natural: "Using materials that he found in nature, such as leaves and pieces of wood. He placed them underneath a sheet of paper and made an impression of their shape and texture by rubbing", explica la guía de visitantes de su más reciente retrospectiva: Max Ernst, en la Fondation Beyeler de Basel, Suiza (26 de mayo- septiembre 8 de 2013). Completaba luego las formas reveladas con extraños títulos surgidos de lo que él consideraba la "irritación de sus facultades visionarias". Así, abría la puerta de un reino que conjuga el azar de la materia creadora de formas y la lúdica de la lengua que se entrevera con éstas expandiendo su propio campo. De hecho, Max Ernst escribía poesía y Paul Éluard afirma en El poeta y su sombra, que los títulos de sus collages eran un ejemplo perfecto de lo que consideraba "los poemas de los pintores" (29).

Ernst fragua, como han visto todos sus estudiosos y como se evidencia en los textos que acompañaron su exhibición retrospectiva en el Guggenheim, escándalos en los cánones de la historia del arte, insurrecciones de la percepción, tanto como de la moral de su tiempo. Sus collages desbordan las propuestas cubistas en muchos sentidos. Como se anota en la guía de visitantes de su reciente retrospectiva en la Fondation Beyeler: 
Max Ernst simulates a collage by cleverly concealing the original pattern in some places and allowing it to show through in others. Instead of creating a new pictorial whole from indi- vidual fragments, as in a collage, he intervenes in an existing image. At the time, this was an entirely new approach (Max Ernst 2).

Es también el inventor del frottage que revela, mediante el frote de una superficie, las formas imaginativas que yacen en la materia dormidas y que desata vetas de asociaciones inconscientes; y del grattage que realiza raspando o arañando el óleo. La decalcomanía, que su descubridor Óscar Domínguez esparciendo pintura en algunas partes del canvas que luego presionaba con vidrio o una hoja de papel, y finalmente interveníacon un pincel que transformaba las estructuras encontradas, fue retomada por Ernst quien comenzó a presionar con lienzos usados. Igualmente, su invención de la oscilación se anticipa a la pintura de acción. Ernst la describía así:

Attach a one or two meter long cord to an empty tin can, drill a small hole in the bottom, and fill the can with liquid paint. Swing the can at the end of the cord back and forth over a canvas lying flat, guide the can with movements of the hands, arms, shoulders, and the whole body. Drip surprising lines onto the canvas in this manner. The game of combinations can then begin (Berger).

Son métodos que antes de él no se han explorado sistemáticamente, y suponen desconocidos modos de "pintar" que no sólo eluden la aplicación directa del color, sino que convierten al pintor en un observador del azar de las formas ocultas en la materia. En Au dela peinture, Ernst (1936) evocaba un día lluvioso en un pueblo sobre el Rhin, en el que su excitada mirada se sintió provocada por un catálogo impreso. Era un anuncio que ilustraba objetos relacionados con temas científicos -investigaciones minealógicas, microscópicas, palenteológicas - que le hicieron descubrir imágenes que siendo figurativas le eran tan absurdas y remotas que comprendió otro modo de acercarse a los elementos de la figuración: 
(...) a sudden intensification of my faculties of sight - a hallucinatory succession of contradictory images, double, triple, multiple, superimposed upon each other with the persistence and rapidity characteristic of amorous memories and visions of somnolescence. These images, in turn, provoke new planes of understanding. They encounter an unknown - new and non- conformist. By simply painting or drawing, it suffices to add to the illustrations a color, a line, a landscape foreign to the objects represented - a desert, a sky, a geological section, a floor, a single straight horizontal expressing the horizon, and so forth. These changes, record a faithful and fixed image of my hallucination. They transform the banal pages of advertisement into dramas which reveal my most secret desires (Waldman 34).

$\mathrm{Al}$ volver de la guerra había concebido sus primeros collages ${ }^{123}$ con recortes de manuales de divulgación científica, ilustraciones de novelas, escenas de viajes, láminas paleontológicas. El collage llegaría a ser para Ernst, como evoca Kim Grant, "The first effective automatic technique for reproducing unconscious thought, and he cited both Lautréamont and Breton to support the notion of 'systematic displacement' as a Surrealist means for subverting ordinary conscious thought"(315). Ninguno de los surrealistas se adhirió tanto en su obra a la comparación de Lautréamont que se ha repetido incesantemente también en nuestro siglo: "Bello como el encuentro fortuito, sobre una mesa de disección, de una máquina de coser y un paraguas". ${ }^{124} \mathrm{Y}$, de hecho, se considera que ese pasaje poético fue generalizado por Ernst al definir la técnica del collage como "la explotación sistemática del encuentro fortuito o artificialmente provodado de dos o más realidades distantes sobre un plano inadecuado y el destello poético que se filtra a través del intersticio entre esas realidades que se han acercado" (Waldman 34).

Al tiempo, los frottages que agrupa y publica como Histoire Naturelle (Historia natural), marcan una clara ruptura con la máquina estética del Dadá y revelan el renovado interés de Ernst en los fenómenos naturales, según Waldman: una nueva y especial visión de la naturaleza en la cual los fenómenos naturales se transforman en imágenes de 
potentes fuerzas cosmológicas. La imaginería simbólica de algunos trabajos es cercana a Redon. Como él, aspira a encontrar una visión interior, el espíritu, el intelecto. Precisa también que incluso las más complejas imágenes se realizaron sin ningún dibujo:

In many, multiple textures are used, the sources of which are rarely identifiable. These textures are metamorphosed into images which are always natural: birds, plants, animals, some fairly realistic, some strange and mysterious. It is a transformation of texture into form (...) (39).

Hay otra experiencia fundamental en la construcción de su propio mito que se remonta a su adolescencia y que reaparecerá luego como un eje vital y artístico determinante en esa relación suya con el surrealismo que provee marcos alternos de contemplación del mundo. La noche en que su hermanita Loni nació, el pájaro que Max Ernst amaba, una cacatúa de color rosa, murió. Ése es el origen afectivo de Loplop, el Pájaro Superior, el animal doble de Ernst. "Hice una peligrosa confusión entre pájaros y humanos", le hace decir Poniatowska (2011) en su novela Leonora, donde narra que enterró al ave en el jardín y luego tuvo una crisis nerviosa.

Diane Waldman describe estos episodios decisivos de su infancia así:

At the age of three his father took him on an outing to the forest surrounding Brühl. There, to the child's astonishment, the density of the foliage transformed day into night. Exhilarated and frightened, Max retained a vivid impression of the forest. Subsequently the forest became a symbol of night for him, and night assumed the mantle, as Novalis has stated, of 'the place of revelations.' When he was six, his elder sister Maria, with whom he had been very close, died, and death began to play a crucial role in his existence. In 1906, when he was fifteen, he discovered the death of his favorite bird, a pink cockatoo, at the same time his youngest sister Loni was born, and the linking of bird and human became indelibly imprinted in his mind. Forest, intertwined with bird, alternated as a place of freedom and imprisonment (15). 
Werner Spies cita sus tempranas Notas biográficas: “...in the boy's mind remains a voluntary if irrational confounding of the images of human beings with birds and other creatures; and this is reflected in the emblems of his art" (10).

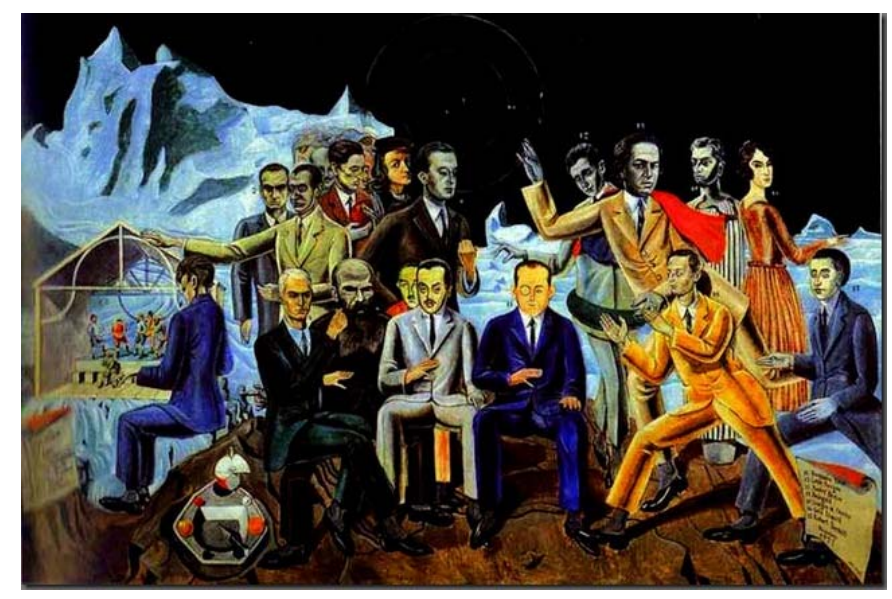

Ilustración 50: Max Ernst. Au Rendez-vous des Amis 1922. Museum Ludwig, Colonia.

Recalca que Ernst no disuadió a sus amigos de identificar a Loplop como su alterego y, en consecuencia, así lo asumieron Paul Eluard y Jacques Viot, quien lo identifica en un texto con un ave de presa que incursiona a solas en un bosque de aquellos que no se encuentran en las historias de caza. Y añadía, según cita Spies:

What he has taught us turns every opinion upside down. Most people, for instance, think that birds fly. I give only one example but add that, according to Max Ernst, even men might fly if only the stopped letting themselves be tamed (10).

En 1930, Max Ernst describía a su "doppelgänger" como un fantasma privado atado a su persona, algunas veces alado e invariablemente masculino. Man Ray (18901976) tituló uno de los muchos retratos que le hizo como "Max Ernst, pintor, hombrepájaro" y, como apunta Jhon Russell —autor del libro Max Ernst: Life and Work, 1964-, pronto el hombre-pájaro pronto se convirtió en una compañía de repertorio de una sola persona. En una reseña suya sobre el libro Max Ernst. Loplop. The Artist in the 
Third Person, 1983, ubica la génesis de Loplop, la figura picuda, en la presencia del pájaro que Freud abstrajo silueteando la túnica que envuelve a la virgen en el cuadro de da Vinci, Virgen, Niño y Santa Ana, y acerca del cual había publicado en 1910 el ensayo Leonardo da Vinci. Una memoria de su infancia. ${ }^{125}$

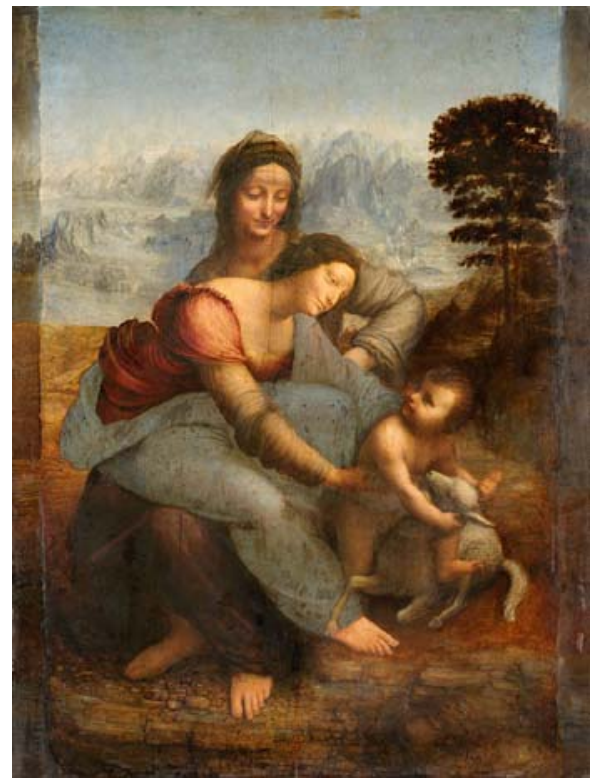

Ilustración 57: Leonardo da Vinci. $L a$ Virgen, el Niño Jesús y Santa Ana 1510-13 Óleo sobre tabla $168 \times 112 \mathrm{~cm}(66 \times 44$ in $)$ Museo del Louvre, París (Francia)

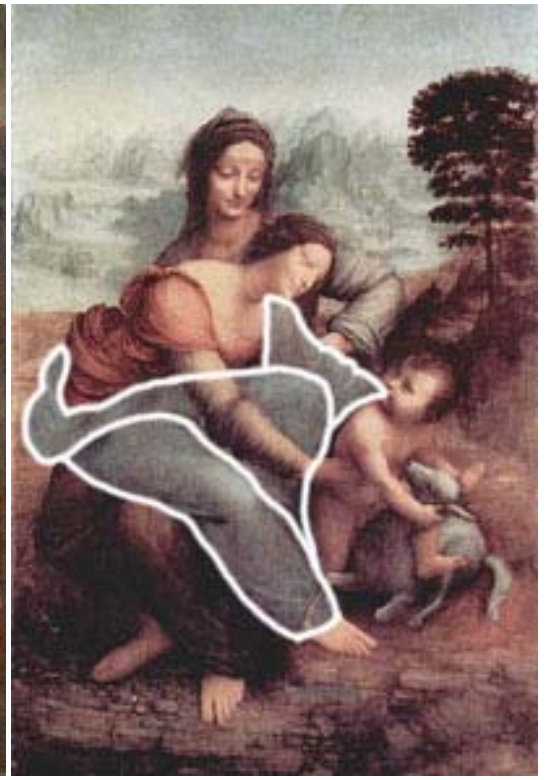

Ilustración 58: Figura picuda estudiada por Freud 1910

Independientemente de que con posterioridad se demostrara que la traducción hecha de la palabra "cuervo" era inexacta pues Leonardo se refería a otros pequeños pájaros, y por tanto esa confusión rompía las conexiones mitológicas con la antigüedad y sus significados arquetípicos, es muy posible que Ernst sintiera fascinación con la revelación de esa figura en un cuadro clásico. El escandaloso cuadro de 1924 donde la Virgen castiga al pequeño Jesús se entiende mucho mejor desde esa mirada iconoclasta freudiana que lo precedió. Por su parte, Spies, menciona otros antecedentes de la historia 
del arte como Maiastra, Bird in Space, o Chimera, de Constantin Brancusi (1876-1957), quien abordó el tema de los pájaros en incontables variaciones, puesto que lo que buscaba expresar, ante todo, era "la esencia del vuelo" (citado por Spies 33). Pero Ernst, ajeno a la síntesis contaminación visual.

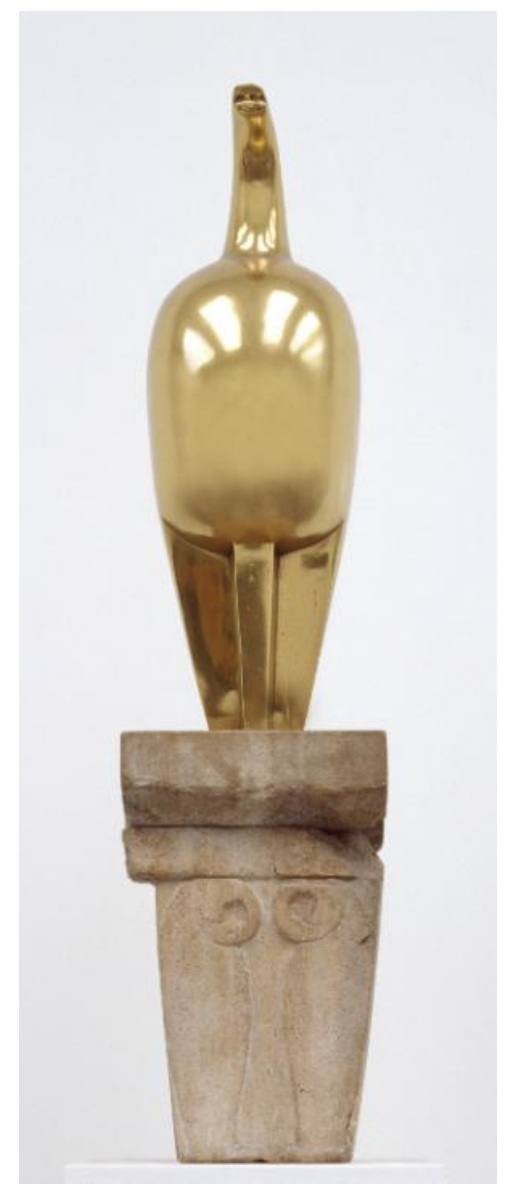

Ilustración 51: Constantin Brancusi, Maiastra

1911. Bronce sobre pedestral de piedra calcárea.

Colección de la Tate.

De hecho, Loplop le permite delinear una postura estética dentro del grupo de los surrealistas, en la que fundamentalmente defiende su libertad. Ernst es un espíritu omnímodo, voraz, con una curiosidad inextinguible, no en vano el creador de una serie de 
técnicas novedosas y capaz de abarcar diversísimos medios y lenguajes y su doble le da una flexibilidad a todos los límites insospechada:

The basic scaffolding of the Loplop figure, draped in ever new variations, allowed him to pass the variety of his techniques and his themes in review (...). Loplop assists in giving comprehensible order to the artist's multifarious materials and motifs (...) Loplop put in his appearance at a time when Max Ernst borke his reserve to formulate his aesthetic and theoretical position within Surrealism (Spies 76-79).

Por otra parte, resulta interesante la comparación que hace Spies entre el Loplop de Ernst y la figura del Minotauro de Picasso. Si este último es una metáfora, o un híbrido de mitología personal y estado mental, el primero es realmente una figura que hace de Ernst, el artista, una tercera persona, otro-yo. Sugiere Spies que el modelo se remonta a los románticos, de Alraum (la tradición de la raíz antropomórfica de la Mandrágora) al Golem o a la criatura de Spalanzani de E.T.A. Hoffmann (Spies 78). Una completa distancia con su doppelgänger dota a Loplop de un carácter reflexivo ${ }^{126}$.

Lo esencial es el proceso de deconstrucción de la noción de realidad que proviene del mismo nacimiento de los collages donde aparece Loplop. Ernst rememoraba que sólo por azar, cuando usaban por ejemplo las páginas de un catálogo de demostraciones físicas o anatómicas, en el momento en que unían elementos figurativos distantes comenzaban a ver una sucesión de alucinantes imágenes contradictorias (36):

Loplop-Max Ernst, bird and bird-character, tempted the spectador deeper and deeper into a labytinth of illusion and feigned illusion. (...) Puzzles and bewilderments of this kind appear throughout the Loplop suite, visual conundrums in which the line between invented and quoted form has been purposely blurred (Spies 43).

La temprana identificación con un animal que es una proyección de sí tan fuerte que configua un doble, un desplazamiento de la identidad, tanto como el carácter 
indomable y la adhesión a los dominios de una libertad tan propia como incomparable, son rasgos que emparentan a Ernst con Leonora. Ambos, además desconfían de lo real, o lo asumen como "un laberinto de ilusión y fingida, autoconsciente ilusión", y los períodos más intensos de la aparición de sus dobles se concentra en un tiempo corto donde soplan de modo más fuerte que nunca los vientos de la guerra, si bien, caballos y aves conservarán en sus obras un aura mítica. En todo caso, este artista que ensoñaba un centenar de palomas desde niño y que podía aventurarse por la línea del horizonte para descifrar un misterio —o para huir de la casa parterna, según Waldman— antes de llegar a la edad de la razón, tomó el nombre del pájaro de Ferdinad Lop, un poeta callejero, conocido por Loplop, que solía frecuentar las calles del barrio latino en París, y se autobautizó como el Vogelobre Loplop, ("vogel” en alemán es ave y "oberste” es superior) a cuyas presentaciones regresaremos. Lo cierto es que su identificación con el ave, que luego sería el doble de sí, el Pájaro Superior es tan fuerte como la de Leonora con el caballo y ambos animales totémicos tienen entre sus atributos el de un intenso erotismo que desafía toda suerte de hegemonías, que extiende sus alas o cocea y se desboca contra la fuerza contendora de la ley.

Ernst es conciente de su ser. En una cita que se incluyó en la gran retrospectiva en el Guggenheim y que ha sido citada infinidad de veces, declaró:

My roamings, my itch, my impatience, my doubts, my beliefs, my hallucinations, my refusals to submit to any discipline including my own, the sporadic visits of perturbation, ma soeur, la fêmme 100 tetes, have not created a climate conducive to a serene and smiling life's work. My work is like my behavior -not harmonious inthe sense of the classical composers, not even in the sense of the classic revolucionaries. Subversive, uneven and contradictory, to he specialist of art, culture, logic, morals its unacceptable (citado por Spies 77).

Waldman se refiere a sus tempranos ataques de la tradición: 
Two paintings of 1909, both entitled Landscape with Sun, reveal an artist in transition, vehemently attacking the academic tradition, of which his father's painting was but one example, rampant in Germany in the early 1900's. (...) Between 1909 and the onset of World War I, Ernst became thoroughly conversant with the latest developments in the European avant-garde. He participated directly in much of the furious artistic activity in Germany ${ }^{127}(15)$.

Si Leonora caricaturiza su presentación en sociedad, Ernst tiene, desde sus años escolares en un liceo de Brühl, una visión irónica que se evidencia en sus dibujos escolares. La ceremonia de bachillerato, según Ulrich Bischof (2003) “deja de ser una broma inocente y se convierte en una caricatura de toda una clase social" (8). Tras graduarse en 1910, Max había comenzado a estudiar letras en la universidad de Bonn y finalmente había optado por la pintura, interesado por el fauvismo y el naciente expresionismo.

1913 es un año decisivo en su formación pues según Werner Spies $^{128}$, fue entonces cuando leyó La interpretación de los sueños y El chiste y su relación con el inconsciente, ${ }^{129}$ libros que van a marcar su relación con las fuerzas oníricas e irracionales y con el poder penetrante del humor, que en su obra se manifestará en perennes "bromas" visuales y de palabras; fue también el año en que participó en la exhibición del "Erster Deutscher Herbstsalon” junto con Klee, Kandinsky, Chagall, Delaunay y Macke; el año en que visitó París y decidió que regresaría a vivir allí; y fue el año en que August Macke $^{130}$ le presentó a Robert Delaunay y a Guillaume Apollinaire en su casa en Bonn. Para el mismo Macke el encuentro con Delaunay, que había tenido lugar en París un año atrás, había sido una revelación y su estilo, que Apollinaire llamó “orfismo” marcó sus exploraciones tanto como el concepto de simultaneidad de los futuristas italianos. Para Ernst fue crucial el encuentro con Apollinaire, con quien tanta afinidad tendrían pues ambos creaban para los exaltados, y sabían de lo antiguo y lo nuevo "todo lo que un 
hombre solo podría saber de ambos". Sus caligramas abren nuevas vías para los sentidos de la mente. Y, de hecho, la primera referencia al término "su-realisme" apareció en un artículo de Apollinaire publicado con ocasión de la presentación del ballet de Erik Satie "Parade" en 1917, en el Theatre du Chatelet de París.

Waldman anota:

In Katharina Ondulata and other related collages of 1920 Ernst combines mechanical and anthropomorphic forms in irrational juxtaposition (...). The title reinforces the double meaning. In other collages titles are deliberately misleading; there is almost always a complex visual and verbal dialogue. Often the titles are extremely important in themselves as poetic, humorous elements. Ernst referred to them as verbal collage, which he described as: 'What is a phallustrade? It is a product of alchemy, composed of the following elements: autostrade, balustrade, and a certain number of phalluses. A phallustrade is a verbal collage!' The displacement of the object from its normal context was Dada's answer to conventional pictorial narrative (15).

Existe una relación entre el desarrollo del collage dadaísta, que se diferencia de los papier collé cubistas, y que combina el azar inicial y la planeada intervención lúdica posterior de un modo que se vincula con la génesis de la poesía maldita y con juegos extremos del lenguaje. 


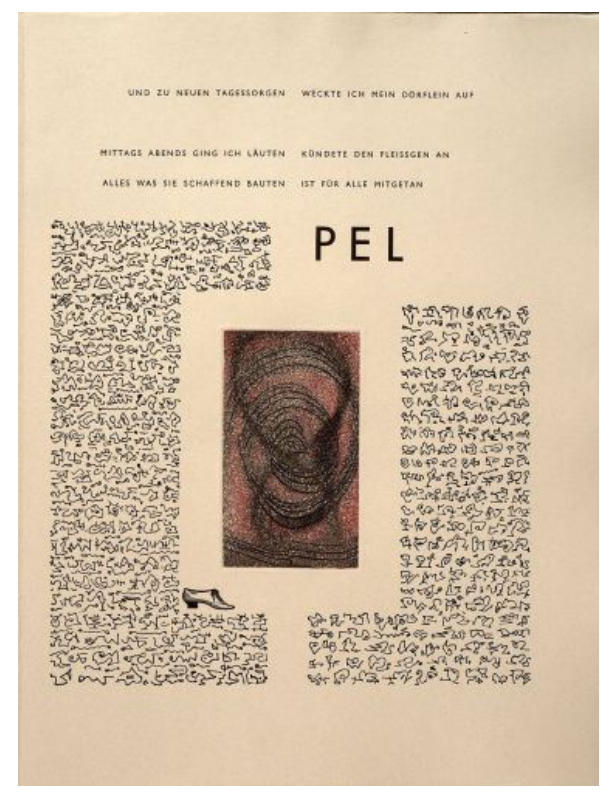

Ilustración 52: Max Ernst, Iliazd, Tempel. Maximiliana ou L'Exercice Illégal de L'Astronomie 1964.

Medio siglo después de su encuentro con Apollinaire, Ernst hace un extraordinario libro artístico que revela coincidente afinidad con el placer de Leonora ante un lenguaje capaz de sobrepasar el sentido: Maximiliana ou L'Exercice Illégal de L'Astronomie (Maximiliana o el ejercicio ilegal de la astronomía). 34 aguafuertes y aguatintas que hacen eco de las que hiciera en el libro Éloignée du Soleil (Alejado del sol) se publicaron en una edición limitada a 75 copias firmadas por Ernst y el diseñador vanguardista "Iliazd" (Ilia Zdanevich), y con textos de Guillaume Tempel, un desconocido astrónomo y litrógrafo alemán que descubrió el planeta 65 , que nombró después del Emperador Maximiliano II, y que acabó llamándose Cybele. Iliazd diseñó el texto a partir de los diarios de Tempel, de sus cartas y poemas, y dio énfasis a sus descubrimientos astronómicos y a su espíritu independente e indomable. Pero lo más notable es que Ernst diseñó un lenguaje secreto para el libro. Como anota Jhon Russell:

The supreme achievement of the post-war years in book-form is uncontestably the Maximiliana ou L'Exercice Illégal de L'Astronomie which was published in 1964. 
(...) Max Ernst designed a secret language; page after page of cursive script that never repeats itself, never drops into recognizable imagery and never divagates, equally, into any alphabet know to us (...) But above all they are an act of homage to one who was, like Max Ernst himself, a lifelong watcher of the skies, inward and outward (Max Ernst: Life and Work 201-202).

En 1919, después de volver de la guerra Ernst había repudiado las convenciones sociales, lingüísticas y artísticas de un mundo que alimentó el horror. Pero su camino es muy distinto de la vanguardia de sus coterráneos George Grosz, Otto Dix y Max Beckmann, que también han pasado esa muerte en vida que fue la Gran Guerra y pintan la huella del horror y su repudio a la hipocresía moral de la República de Weimar, con una distorsión de las formas que tiene como antecedente las pinturas negras de Francisco de Goya. Cuando en 1916 abre sus puertas el "Cabaret Voltaire", un nombre escogido por Hugo Ball para rendir homenaje al gran sarcástico del iluminismo inglés, ${ }^{131}$ Max Ernst está aún en el frente, y al regresar, volverá con el humor oscuro de quien ha bajado al infierno y retorna, dispuesto a reírse de sus enterradores. Hará de su ciudad un escenario lapidario, una Colonia Dadá capaz de blasfemar burlando todo cuanto parecía sostener los valores de un tiempo lleno de gusanos negros.

El texto del catálogo publicado con ocasión de la retrospectiva de Max Ernst en el Centro Georges Pompidou de 1991, hace eco de esta visión:

Nosotros, hombres jóvenes, regresamos de la guerra como alelados, y nuestra indignación necesitaba un derivativo. Lo encontró espontáneamente en violentas ofensas a las bases de la civilización que había traído la guerra, en afrentas al idioma, a la sintaxis, la lógica, la literatura, la pintura, etcétera (Roche 23).

Waldberg (1970) asegura:

El dadaísmo se manifestará con su máxima violencia en las naciones que fueron más directamente antagonistas en aquel conflicto: Alemania y Francia. Vencedores y vencidos rechazan con igual horror una civilización que hizo 
posible la matanza, las iglesias que asumieron su abyección y las élites que la glorificaron (288).

Prueba de cuánta razón tiene en ello es justamente la amistad entre Paul Éluard y Ernst, que en la Primera Guerra combatieron en frentes opuestos y forjaron luego un vínculo inquebrantable. Esos hombres "murieron durante cuatro años y, cuando en 1918, vuelven a nacer, nunca más habrá quien les quite su libertad. Hay que tomar en cuenta ese pasado que explica buena parte de sus provocaciones y sus errancias limítrofes" (Roche 11).

Al final de la guerra, cuando está viviendo en Colonia, ésta se encontraba ocupada por los británicos y el movimiento Dadá, según evoca J ohn Rusell, tenía un carácter subversivo. Empieza entonces a trabajar con imágenes encontradas, pequeñas. Fueron este tipo de imágenes trabajadas en collage, y que tenían un “elemento clandestino autobiográfico" las que le envió por correo, envuelto en papel marrón, a André Breton para su presentación en París en 1921 (Behind The Magical Images).

Eluard tenía tanto deseo de conocer a Ernst, después de haber visto sus collages, que viajó con su esposa de entonces, Gala (1894-1982), a conocerlo en noviembre de ese mismo año. Se hicieron amigos de inmediato y pasaron el otoño planeando un libro de poesía para el cual Ernst contribuiría con ilustraciones. El resultado fue Répetitions (Repeticiones), publicado en 1922. El mismo año escribieron los poemas en prosa de Les Malheurs des inmortels (El infortunio de los inmortales). Trabajaron en numerosos proyectos que reflejan su fé en el valor de las invenciones colectivas. (Montagu 27).

Max Ernst, herido en la cabeza en la guerra a la que había entrado a los 23 años, esgrimía una negación absoluta de la lógica de los poderes. La reivindicación del absurdo 
es un modo de invertir la violencia colectiva que estructura el mundo en que ha vivido.

De lo que se trata, realmente, es de su revolucionaria instauración de un "mirar otro".

Roche cita las palabras que Eluard escribió en 1936:

En febrero de 1917, Max Ernst y yo estábamos en el frente, a un kilómetro apenas el uno del otro. El artillero alemán Max Ernst bombardeaba las trincheras en las que yo, soldado francés de infantería, estaba de guardia. Tres años después, éramos los mejores amigos del mundo y desde entonces luchamos juntos, con tesón, por la misma causa, la de la completa emancipación del hombre. ${ }^{132}$

"Envuelto en plumas que lo devoran y abandonado al mar. Su sombra es vuelo, vuelo de pájaros en libertad”, escribirá Paul Éluard en un poema inspirado en él en 1926. Juntos, de hecho, fraguarán un libro a dos manos, en plena exploración de la dilución de los límites de la autoría. Se habían conocido en 1914, pero la guerra los había separado. Al regresar de la Gran Guerra, cada uno proveniente de un frente distinto, crean una conjunción única de fuerzas creativas. Cuando estalla la Guerra Civil Española quieren alistarse juntos en el Frente Internacional, pero Malraux los rechaza declarando que buscaba hombres que no supieran pintar. "El río desciende como un huevo y nosotros somos los pájaros" (31) escribe también Eluard en El poeta y su sombra. 


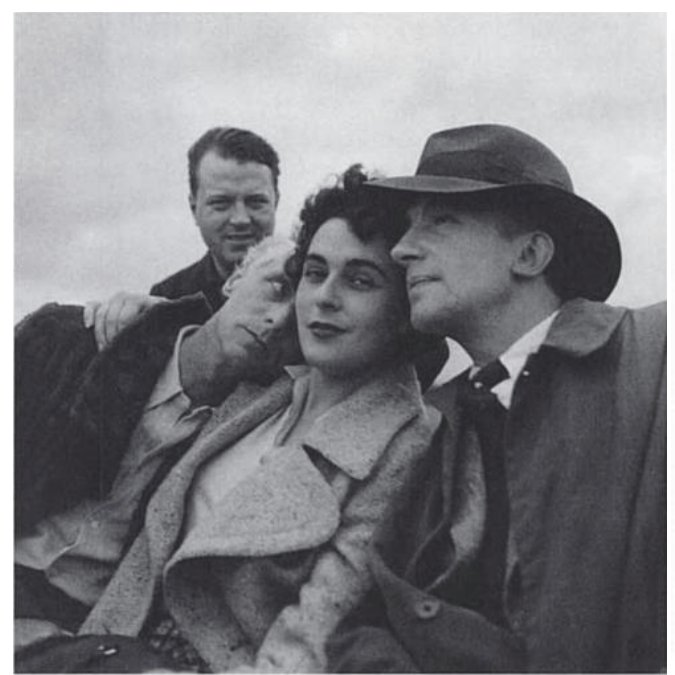

Ilustración 61: Lee Miller. Leonora con Max Ernst y Paul Eluard 1937

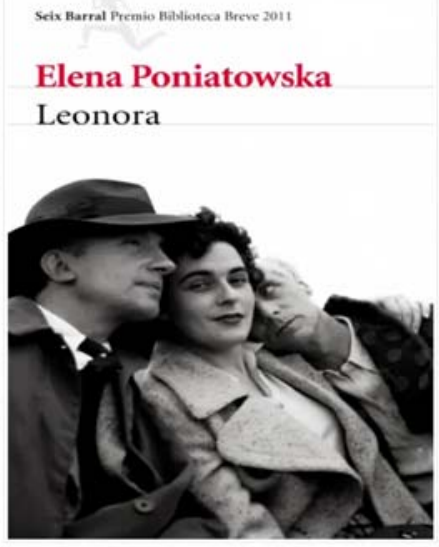

Ilustración 62: Portada de Leonora por Elena Poniatowska

Ernst sintetiza esos años de una manera prodigiosa: "Max Ernst died on 1 August

1914. He was resurrected on 11 November 1918 as a young man who wanted to be a magician and find the myth of his time." (Max Ernst 6).

La portada del libro de Poniatowska Leonora (2011), es una fotografía tomada por Lee Miller en 1937, en la que aparecen las cabezas juntas de Paul Éluard mirando al horizonte, ella mirando en dirección a la cámara, y Max Ernst con la cabeza reclinada en el hombro de Leonora y los ojos fijos en ella. Según narra Poniatowska, él le contó a su joven amante que años atrás, Hans Arp (1886-1966) "se salvó de ser reclutado porque se encueró delate de las autoridades; el escándalo desarma a los timoratos” (107). Y sin duda, sus obras feroces escandalizan al espectador:

Durero, Blake, Gustave Doré se revolcarían en su tumba al verse amamantando al León de los Belfort, su hocico sobre el pecho de una hetaira. Max los ha convertido en asesinos, en bandidos nocturnos, en aves carroñeras, en padrotes, en animales impuros que violan a la mujer y la destazan. Una nueva realidad antes invisible, ahora sale a la superficie explorada por la agudeza de su mente (...) Mujeres desveladas ofrecen su trasero al general condecorado, al arzobispo, al 
dandy, a la esfinge. Max Ernst, el rey de los pájaros, todavía trae adentro a la Bella Durmiente, a la Reina Roja (Poniatowska 66-67).

Al regresar a Colonia, Ernst había encontrado, como he mencionado atrás, un cómplice que muere tempranamente y pasa a la posteridad como un ingeniero del escándalo: Johannes Theodor Baargeld, seudónimo de Alfred Grundewald. De su obra pionera — fotomontajes y ensamblajes — no se conserva nada, pero logró hacer del Dadá de Colonia una instancia de provocación sin precedente. Juntos publicaron el Boletín D y luego, con Jean (Hans) Arp, organizaron en la cervecería Winter la exhibición dadaista "Dada Vorfrühling” (Dada primavera temprana) que fue cerrada por obscena, y por crear escándalo público en 1920.

El cargo se retiró de cualquier manera, cuando el "obsceno" desnudo frontal resultó ser una impresión de la pintura Adam and Eve de Durero que Ernst había incorporado a una de las esculturas (Sabine T. Kriebel 231). Así se extinguió —en ese punto geográfico - la rama Dadá que habían llamado Zentrale W/3 (Zentrale Weststupidien/3). En el poster que colocaron allí anunciando al "amado Dada Baargeld", y al "temido Dadamax Ernst". Es de esta figura que derivará después la aparición de Loplop. La exhibición escandalosa preconiza los happenings (el público debía pasar por unos urinarios y destruir a hachazos un objeto de madera fabricado por Ernst), el performance (una adolescente vestida de blanco recitaba poemas obscenos) y las obras colectivas y efímeras (los tres exhibían papeles desgarrados y collages pioneros ${ }^{133}$ ), para no hablar de piezas como el acuario de Baargeld con agua teñida de rojo en cuyo fondo había un despertador junto a un supuesto brazo femenino (Sanouillet 175-183). 
Y sin embargo, el escándalo per se no es el signo equivalente al espíritu dadaista. Al respecto es interesante esta consideración de Ernst, citada por Waldman en el catálogo de su retrospectiva en el Guggenheim, editado por Werner Spies (1975):

Contrary to general belief, Dada did not want to shock the bourgeoisie. They were already shocked enough. No, Dada was a rebellious upsurge of vital energy and rage; it resulted from the absurdity, the whole immense Schweinerei of the imbecilic war. We young people came back from the war in a state of stupefaction, and our rage had to find expression somehow or other. This we did quite naturally through attacks on the foundations of the civilization responsible for the war. ... Our enthusiasm encompassed total revolution (20).

La Estación Dadá de 1921 en París incluyó en su explícita programación una excursión a la iglesia de Saint-Julien-le-Pauvre, que no tenía ninguna intención anticlerical ${ }^{134}$ y era más bien un ejercicio ligado a las célebres caminatas dadaístas, y la exhibición de Max Ernst en Sans Pareil, entre otros eventos. Los surrealistas Louis Aragon, Tristan Tzara, Benjamin Péret, Breton y Jaques Rigaut, quien se suicidaría seis años más tarde, prepararon la exhibición haciendo todos los marcos ellos mismos con materiales de segunda mano en la habitación de Breton en el Hótel des Écoles, rue Delambre. El número 19 de la revista dadaísta Littérature anunció la exhibición advirtiendo a las damas que se les pedía llevar todas sus joyas. Notas extravagantes de prensa atrajeron al fin y al cabo a la socialité parisina. Un dadaísta escondido en un closet llamaba a las celebridades que aparecían por su nombre con algunas incordiándolas con ciertas bromas como "Cuidado. Ahí viene Isadora Duncán”, "Rogerd Allan ha perdido sus dientes", y lo cierto es que fueron apareciendo figuras como René Clair, André Gidé, la baronesa Frachon. Rigaut (1898-1929) hacía una cuenta rigurosa de los carros y las perlas de las mujeres. Los gestos para espantar a la burguesía fueron múltiples. Entre éstos, cuando los espectadores se disponían a alzar sus copas y beber, Tzara anunció que 
uno de los vasos, sólo uno, había sido "envenenado" con un purgante. Las obras eran trabajos mecano-plásticos inspirados en formas mecánicas, objetos misceláneos, pinturas, dibujos y sobre todo collages (Sanouillet 180-2). ${ }^{135}$

Acierta Waldberg cuando afirma:

(...) si fuera preciso designar, en pintura, a un Mago del Surrealismo - y no hacemos aquí más que recoger la opinión de hombres como Duchamp, Man Ray, Masson, Miró, Tanguy, Magritte, Char, Giacometti, Hérold y algunos otros-, sólo uno encarnó de un extremo a otro de su actividad y de su pensamiento lo que el surrealismo deseaba realizar, y fue precisamente Max Ernst (26). ${ }^{136}$

Desde comienzos de los años veinte las figuras de aves pueblan los cuadros de Ernst. Inicialmente pinta palomas. La más famosa, por su fuerza erótica, y porque pretendió ser denigrada en esa certera selección que se agrupó en la exposición auspiciada por Hitler, "Entartete Kunst" (Arte degenerado), buscando exhibir lo censurable para los nazis en el arte — que a la postre conformaría una curaduría de las obras más memorables de la época—, fue La belle jardinière (La bella jardinera) 1923, considerada un insulto a la mujer alemana. Aunque la obra desapareció en 1937 en Düsseldorf, desde cuando fue confiscado por los nazis que cuatro años atrás habían incluido a Ernst en la lista de los proscritos del régimen, existen documentaciones en blanco y negro que muestran de frente a la figura femenina que ofrece una extraña forma de desnudez: en su pecho, donde no se delinean los senos, un chaleco cumple la función de piel y se entreabre hacia el oscuro interior del cuerpo. Hay referencias a La Belle Jardiniere como una figura de madera que se mofa de la Madonna de Rafael del mismo título 'La Belle Jardiniere' de 1507, ahora en el Louvre, y una referencia a la tienda con el mismo nombre en Paris. (Waldman 31) 
Entre las caderas y la pelvis la frontera del adentro y el afuera se pierde y desde la parte superior del muslo hasta el pubis su cuerpo se funde con el de una paloma blanca. La mujer está de pie, inmensa y rodeada de un paisaje surrealista, y tras ella se delinea, apenas dibujada, quizás como si el espectador pudiera ver la proyección de su imaginación femenina, la figura de un hombre desnudo y tatuado que sólo lleva por traje collares en el cuello y frutos y hojas que cubren sus caderas y su sexo.

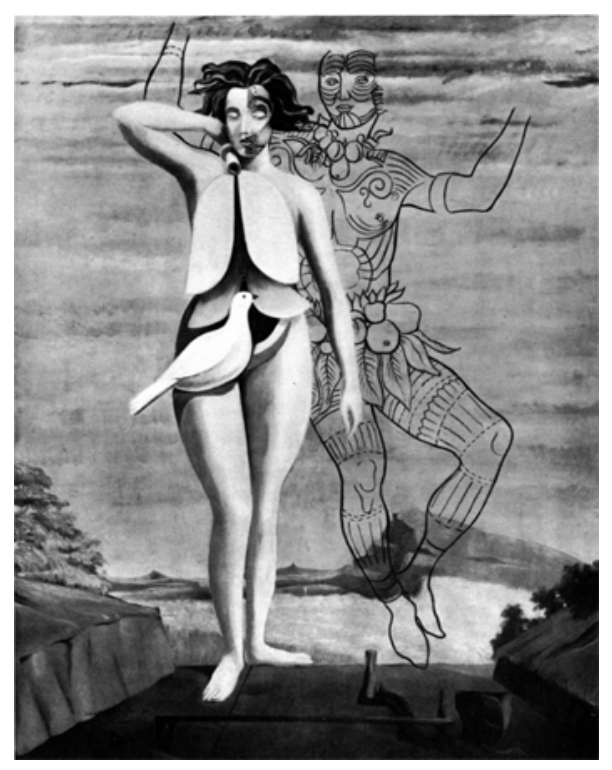

Ilustración 53: Max Ernst, La belle Jardiniere 1923

Quince años después de la elaboración de La bella jardinera, en el Diccionario abreviado del surrealismo de 1938, publicado cuando Ernst vive con otra bella jardinera, Leonora, se explica que añade al nombre de Max Ernst el alias "Vogelobre Loplop" y se lo define como pintor, poética y teórico del surrealismo desde los comienzos del movimiento. Concluye Bischoff:

Se puede hablar, por tanto, de una clara identificación del artista con este pájaro de ficción. Max Ernst aparece 'en persona' dentro de sus obras, o bien en su firma, o bien en forma de pájaro (47). 
Waldman aborda la presencia de aves en la obra de Ernst a mediados de los años veintes, un período muy prolífico: "Certain works of this phase with half-bird, halfhuman shapes, like One Night of Love or The Beautiful Season, 1925, with its gentle horse, reflect brief moments of tranquility" (40). Particularmente en ese cuadro nota similitudes con la obra de Picasso y sus elementos monumentales, el uso de múltiples perspectivas, derivadas de Chirico, que reaparece en esa obra, y detalles como las formas biomórficas y la cabeza de toro, típica de la imaginería de Picasso, así como un eroticismo más explícito. Anota, por otra parte: "The bird is the reservoir of multiple symbolic meanings: among other possibilities it stands for Ernst himself; enclosed within the intertwining male and female forms it appears to represent maternity and procreation.” (40). Según Waldman, la pintura La bella estación, 1925, y el frottage del mismo título son recapitulaciones del más temprano collage Un peu malade le cheval (Un pequeño caballo enfermo),1920. Una figura similar reaparece en el collage de 1931, Loplop presenta a Paul Eluard. La forma del caballo, mitad esqueleto, mitad recubierto de carne evoca también las obras del mural de 1923 que Ernst hizo en la casa de Eluard, cuyo título traducido es: La realidad no puede ser vista como yo soy. De hecho, él rechaza la abstracción pura para optar por "metáforas poéticas de la realidad" (Waldman $16)$.

En 1926, el mismo año en que Ernst rapta a la joven de 18 años que será su primera esposa, con la aquiescencia de la banda surrealista, pinta uno de los cuadros que forman parte de la historia del arte transgresor y que desandaba los hilos de la existencia hasta reencontrar el motivo de su retrato de niño y pervertirlo con un gesto que negaba no sólo los parámetros de los cuales provenía sino la experiencia entera de una generación y 
proclamaba, con su iconoclastia, otro sendero: La vierge corrigeant l'Enfant Jésus devant trois témoins, 1926. (La Virgen castigando al Niño Jesús delante de tres testigos). Los testigos eran André Breton, Paul Eluard y él mismo. El cuadro fue condenado públicamente por el arzobispo de Colonia.

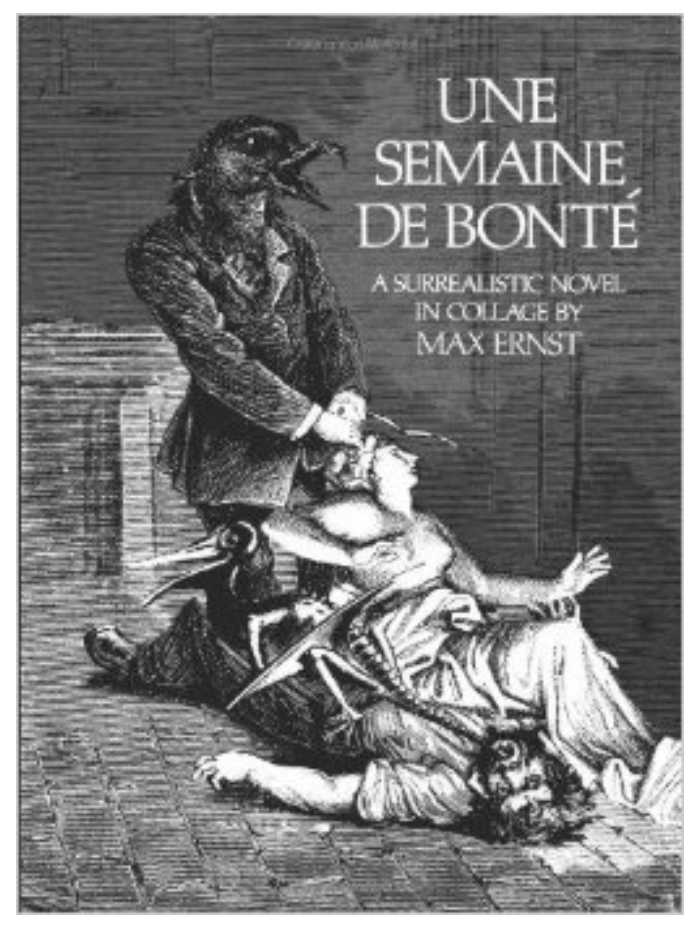

Ilustración 54: Max Ernst. Portada de Una semana de bondad: Una novela surrealista en collage

Entre 1929 y 1939, de modo paralelo a los óleos de gran formato pintados con las técnicas del frottage y del grattage, producirá una serie de estampas-collages o "novelas gráficas" como Une semaine de bonté (Una semana de bondad) y La femme 100 têtes (La mujer de cien cabezas), que yuxtapone 147 collages en una extraña trama y es reconocida como la novela ilustrada de mayor influencia sobre el surrealismo. La combinatoria permite crear una extraña trama a partir de elementos tomados de ilustraciones y revistas decimonónicas. 
En sus Notes pour une biographie, Enst describe así la aparición de Loplop:

La Femme 100 têtes, a novel containing about one hundred anf fifty pasted-paper pictures, accompanying text and a Note for the Reader by André Breton, appeared from Editions du Carrefour... The second important character in the novel, Loplop, Bird Superior, became more and more central: Loplop introduces a young girl; a human beign; The sea in a cage; A young chimera in evening dress (Spies, Max Ernst Loplop 10).

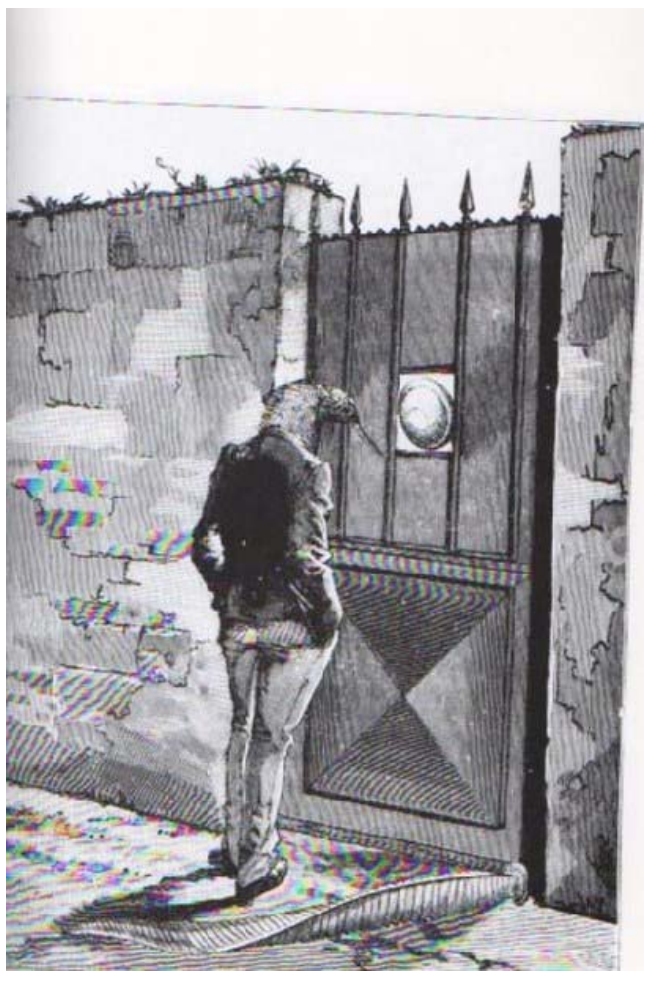

Ilustración 55: Max Ernst. Ilustración de Una semana de bondad.

Más de la mitad de las imágenes son apropiaciones de folletines ilustrados. Es ahí donde — como escribe Ulrich Bischoff- por primera vez en la obra del artista, aparece en varios títulos el nombre de Loplop. Junto con "Vogelobre Hornebom" (Voge es pájaro en alemán) —nombre inventado por Ernst—actúa Loplop en repetidas ocasiones como narrador; protagonista e incluso como avión de reconocimiento — Loplop suministra luz a los faroles de París. Este 'fantasma privado' como le llamara Ernst, entra en escena como representante del artista y asume —entre otros — el papel de empresario: "Loplop presenta" (47). 


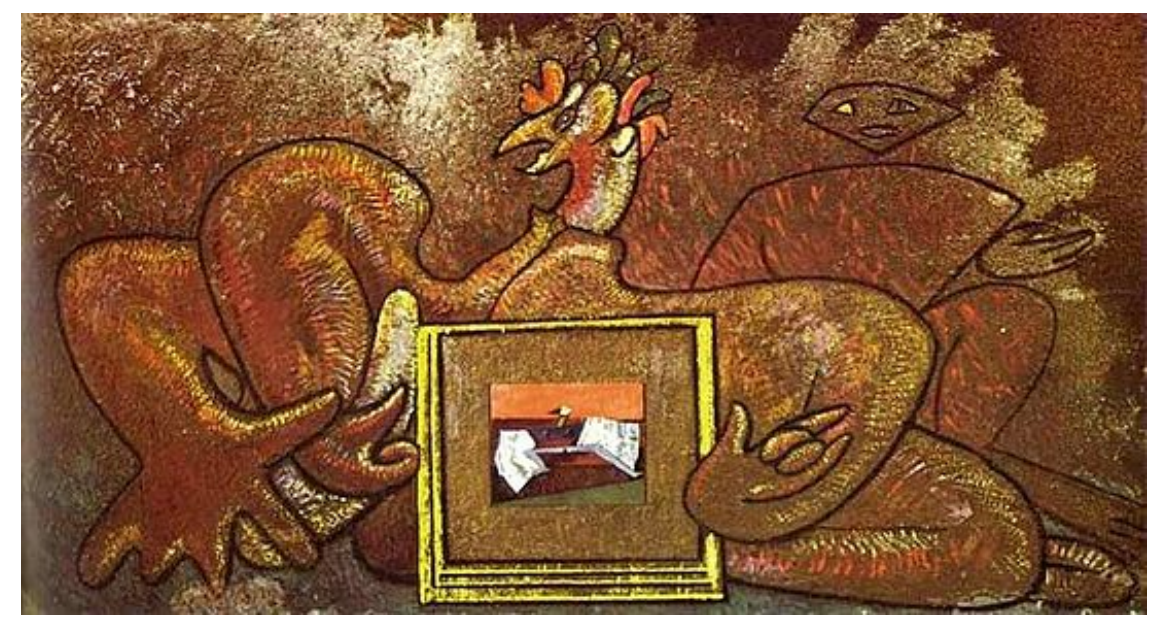

Ilustración 56:Loplop presenta a Loplop

1930, óleo y medio mixto sobre madera. The Menill Collection

En Loplop présente Loplop (Loplop presenta a Loplop) 1930, el principio de la “matrioska" o muñeca rusa, o de la obra especular que se contiene a sí misma se cumple con el retrato escenográfico del doble de Max Ernst. Un pájaro enorme de copete y cuatro anchas alas, tres de las cuatro culminan en manos, sostiene el marco en cuyo interior asoma una versión pequeña de la cabeza de Loplop con alas en forma de conchas entre una suerte de tablones y libros prensados. Detrás, una figura antropomórfica contempla la escena con la mano abierta repitiendo el principio del observador observado. El cuadro guarda relación con La edad de oro, filmada ese mismo año por Luis Buñuel. En el film una parte de la escenografía era una cabaña hecha con tablas de madera recubiertas de escayola, que le evocaron a Ernst las paredes de Leonardo. Después de servir de decorado, las tablas sirvieron como fondos de cuadros. Ernst las usó como objetos encontrados, como superficies ya preparadas que provenían de un ámbito surrealista y que intervenía a su vez. 


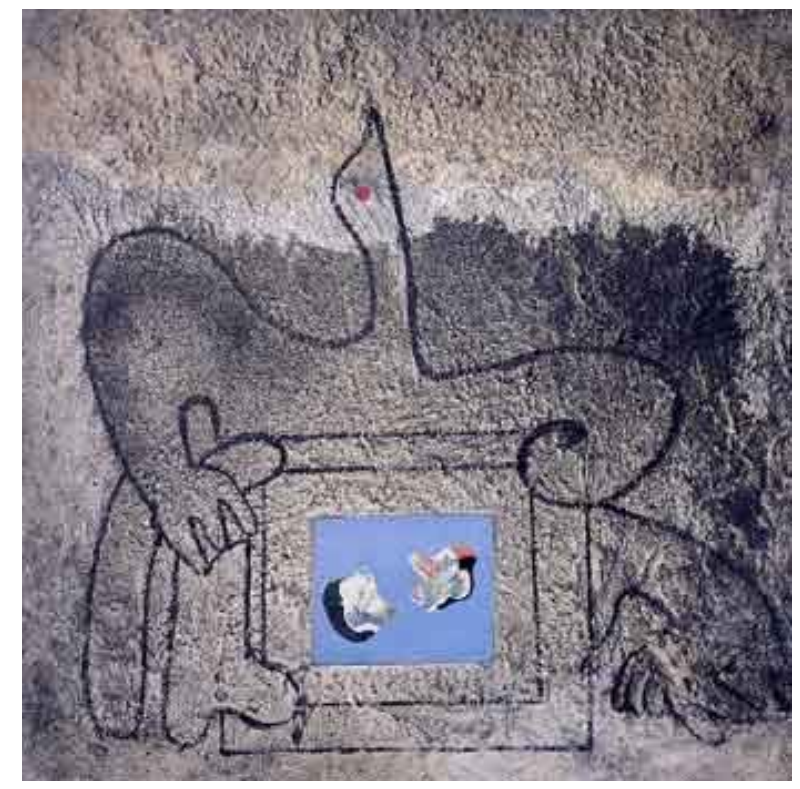

Ilustración 57: Max Ernst Lop Lop presenta dos flores 1930. Óleo y yeso sobre lienzo

En sus notas autobiográficas, Max Ernst presenta a Loplop, su otro-yo, como segundo personaje principal de la novela Loplop, alias Vogelobre Hornebom. En el catálogo de una exposición de 1930 aparece una frase reveladora "Loplop presenta a Loplop (fantasma privado encadenado a Max Ernst, algunas veces alado, pero siempre masculino)". Loplop aparece en algunos cuadros de alusiones eróticas: "Loplop présente une fleur o Figure anthropomorfe et fleur coquillage (Loplop presenta una flor o Figura antropomórfica y flor concha". El cuerpo del ave-alter ego es el caballete en el que se han dejado las obras.

Loplop no ofrece ninguna explicación de los cuadros que presenta. No establece ninguna relación ni crea ningún vínculo de unión entre las partes de la obra agrupadas en forma de collage, que se caracterizan por un tratamiento técnico distinto en cada caso. Loplop, que sobre todo es insolente, nos implica en un juego de confusiones visual. Mezcla irónicamente referencias a cuadros y decoraciones móviles artísticas y relativiza las referencias a la realidad y los engaños ilusionistas (...) Cualquier tipo de dramatismo está fuera de lugar, indicación que se visualiza plenamente en un cuadro de Loplop posterior, Loplop presenta la Marsellesa (...). En el cuadro no hay nada que deba tomarse en serio; la representación misma es un engaño. Apoyándose en la técnica del frottage, 
Max Ernst compone su dibujo con las estructuras más diversas, que, por su heterogeneidad alteran y cuestionan la clásica unidad plástica (Max Ernst).

Explica Bischoff:

El acto de presentar como tal pasa a ser el verdadero objeto del trabajo artístico. Así, Raoul Hausman (1886-1971), cofundador del movimiento dadaísta de Berlín, y Kurt Schwitters (1887-1948), que residió en Hanover hasta su emigración en 1937, se presentaron al público en 1920, como 'los creadores del presentismo (49).

Equivale a la conciencia que tenía el mismo Ernst de crear desde un más allá de la pintura, de tal modo que la propia obra refleja especularmente no sólo el acto creador sino el juego entre éste y la realidad que de algún modo saquea derruyendo categorías.

Bischoff describe la aparición de Loplop en medio de La Forêt embaumée (E1 bosque embalsamado) así: "La posibilidad de atravesarlo sin ser atrapados por él, se da a entender de manera simbólica por medio de la línea punteada — alusión al hilvanado en patrones de ropa—que perfila su silueta" (52). No hay intención de representación en el sentido tradicional, sino una inclusión de la presencia del Ave Superior que es el propio artista en la obra que está haciendo de tal modo que basta insinuarse con un pseudohilvanado. Lo que se descose, entre tanto, es la propia noción de la pintura que asaltó incesantemente. 


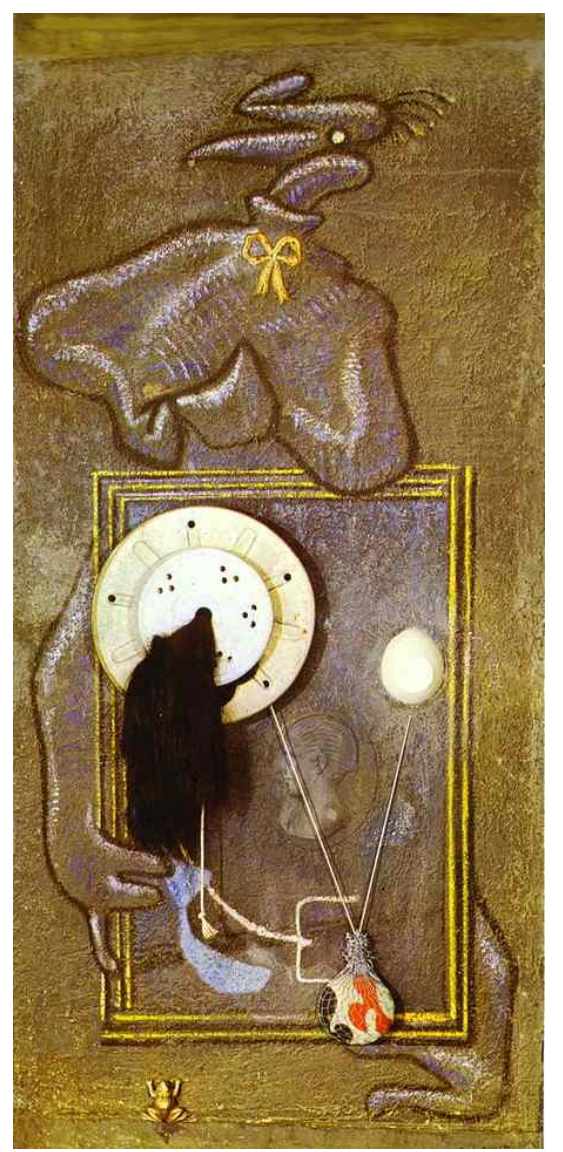

Ilustración 58: Max Ernst. Loplop presenta a una jovencita.

Óleo, escayola y materiales mixtos sobre madera. París, Musée National d'Art Moderne, Centre Georges Pompidou

En Loplop présente une jeune fille (Loplop presenta a una jovencita), 1930, también usa un bastidor del filme de Buñuel en el que él mismo tuvo un corto papel. Esta vez Loplop aparece con un lazo amarillo que hace las veces de corbatín, situado en la parte superior de la pintura y bajo sus dos alas-brazos aparece el marco de un cuadro sobre el cual parece apoyarse mientras sus otras dos extremidades, alas o patasterminadas en dedos prensadores sostienen el cuadro que presenta. En el interior de éste se observa el perfil del busto de la jovencita en un medallón, rodeado por un objeto con dos formas circulares, un molde de platos, al que se adhiere una suerte de mancha negra semejante a un mechón de pelo — ¿y por qué no la piel extendida de un roedor? — que a 
su vez se eleva desde uno de los dedos de Loplop de donde pende una cobata azul. Cordones, hilos templados que forman una suerte de equilibrio entre los círculos y figuras ovales, un huevo o una piedra pintada con manchas rojas y negras, y una pequeña rana en la parte inferior del marco, completan el conjunto. Explica Bischoff: "El ave sostiene prisionera a la joven ofreciéndola a los ávidos ojos del espectador. La rana podría recordar en este contexto el cuento de La princesa y la rana" (50).

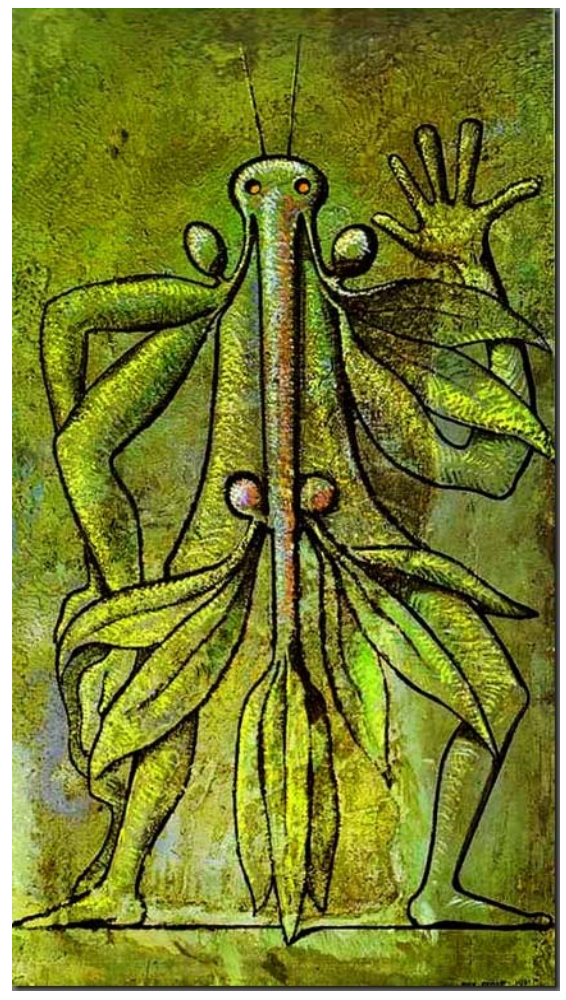

Ilustración 59: Max Ernst, Figura humana 1931. Moderna Museet, Stockholm, Sweden

En el cuadro Figure humaine (Figura humana), 1931, Loplop es un hombrepájaro, pero también un hombre árbol o un pájaro-árbol de hojas lanceoladas, y no menos un saltamontes. El inocultable erotismo de la pintura en óleo y escayola sobre madera va más allá de la desafiante sexualidad de la figura retratada de frente, con las piernas separadas y de tal forma que axis es fálico y el rostro del hombre-ave-insecto-vegetal a su 
vez es la punta del sexo: el eros se enraíza en la indiferenciación entre los reinos, ${ }^{137}$ en una suerte de lúbrica fusión que es también una constante en las pinturas de Leonora Carrington o en figuras como Virginia Fur, una criatura del bosque tan maravillosa e híbrida, tan desafiante y lujuriosa como la de esta pintura de Ernst. Como en esa historia de amor entre ese personaje femenino y un jabalí exótico y poderoso, a la que volveremos más adelante, en la vida real de Max Ernst y Leonora habrá fuerzas incontrolables y violentas que los separan y sajan de un tajo esa celebración de eros y arte que fue su vida en Saint-Martin d'Ardèche, donde ellos y sus dobles míticos produjeron un bestiario fantástico testigo de un capítulo esencial del surrealismo en los años inmediatamente posteriores al fin de la Guerra Civil Española.

Refiriéndose a cuadros como La joie de vivre (La alegría de vivir), 1936-37, que a Ernst le conmovía profundamente, Bischoff (2003) aclara que es una añoranza falsa, en medio de un mundo en el que rige la ley de la destrucción, y amplía su visión con la descripción de L'ange du foyer (El ángel doméstico), 1937:

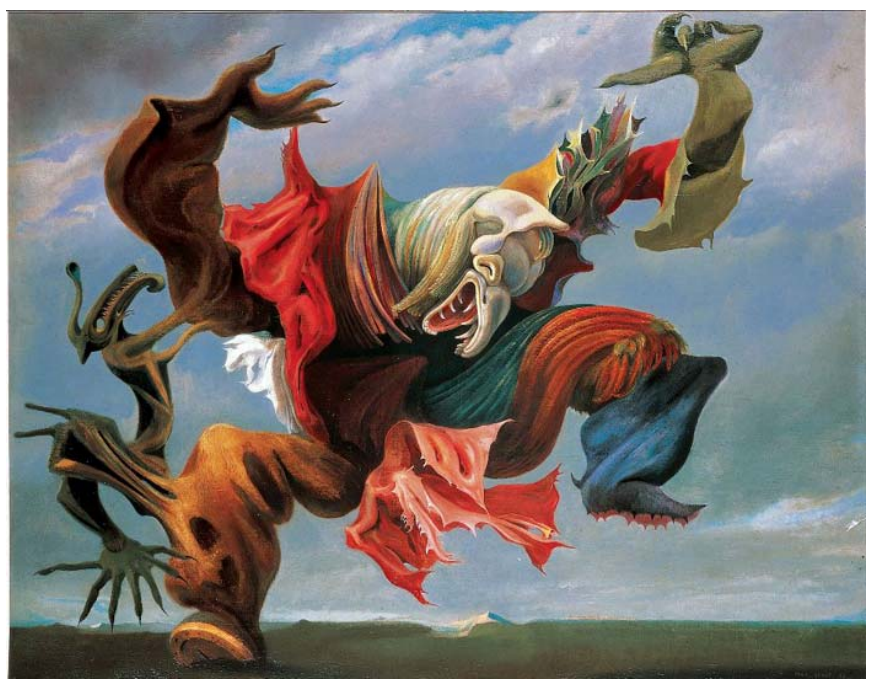

Ilustración 60: Max Ernst, El ángel doméstico o el triunfo del surrealism 1937. Óleo y escayola sobre madera. Munich, Staatsgalerie moderner Kunst 
La crítica de la cultura como método de desenmascarar el decoro burgués, el empleo de temas consagrados — bíblicos, mitológicos- en contextos profanos y triviales, todo ello es parte de una estrategia encaminada a "desintoxicar" el conjunto de las tradiciones pictóricas occidentales, que Ernst aplica como un hábil director de teatro para propiciar el desarrollo de una nueva percepción del mundo. Esa tendencia "ilustrada" de su obra, rara vez se manifestó de un modo tan concreto como en las tres versiones que forman la serie El ángel doméstico, de 1937 (...) Max Ernst declaró más tarde sobre el sentido de ese cuadro:

El 'Ángel doméstico' es un cuadro que pinté tras la derrota de los republicanos en España. Naturalmente, se trata de un título irónico para una bestia exterminadora que arrasa y destruye todo lo que se encuentra a su paso. Esa es la impresión que entonces tuve de lo que podría ocurrir en el mundo, y con ello no me equivoqué (...) Es Loplop, el representante del Surrealismo, a quien vemos aquí, tratando en vano de impedir que el ángel exterminador continúe su labor de devastación (...). La desesperada impotencia que encierra este cuadro, sólo puede apreciarse si se tiene en cuenta que el artista había decidido alistarse en una de las Brigadas Internacionales para luchar en defensa de la República (60-64).

La mujer caballo y el hombre pájaro: incendios de la imaginación

Entre las primavera de 1938 y de 1939, Max Ernst y Leonora montan en bicicleta, se tienden al sol, viven en un lugar imantado. Leonora da nombres lúdicos a sus bicicletas y prepara platillos mistificados, pinta con tinta negra la sémola de trigo y la sirve sobre hielo, según cuenta Julotte Roche investigadorra habitante Saint-Martin D'Ardèche que recrea ese período de la estadía del hombre-ave y de la mujer-caballa en Max y Leonora de tal modo que despliega el universo creativo en medio de un tiempo histórico que se cernía sobre ellos, aunque pretendieran ignorarlo:

Esa casa, que volvieron habitable, será algo más que una simple casa. Es que en ella viven un pájaro y una caballa, y por tanto será rodeada, magnificada, por seres que Max Ernst instala sobre las paredes (...). Max construye la cabeza de su 
gigante en el suelo (...), la cabeza está ahí arriba, a cuatro metros del suelo, la cabeza de su Loplop, el pico para siempre abierto sobre un grito inarticulado, Loplop, su doble, su genio familiar, inscrito en el cemento. Loplop, su pájaro de niño que nunca murió. En la cima del contrafuerte forma los hombros del gigante. El gigante sólo posee la parte superior del cuerpo, cabeza, hombros y brazos. Luego, el contrafuerte se abre hacia el piso y entonces Max modela, sobre el concreto, un pequeño Loplop desnudo y alado, el sexo cubierto por una hoja poderosa, un ala levantada en señal de bienvenida, la otra plegada como si iniciara su descenso, su extracción del cuerpo grande (...) La giganta a su lado modera esos gritos humanos (...) La mano de la giganta sale del marco, va paralela al suelo, con breve ademán tranquilizador, la cabeza un poco ladeada para escuchar y enrollada en un pez que es la comida del pájaro Loplop (57-58).

Según Whitney Chadwick comenzaron la restauración de la casa en la primavera de 1938 y vivieron allí el verano. Meses atrás, el 17 de enero de 1938, se había inaugurado en París la exhibición surrealista en la que el taxi lluvioso, lleno de caracoles vivos de Dalí, recibía a la gente. A la entrada entregaban una linterna pues la exhibición se desarrollaba en la oscuridad, entre ruidos selváticos y bolsas colgadas en el techo por Duchamp. En la calle había maniquíes de cera, y entre éstos estaba, muy ligera de ropa, La viuda alegre de Ernst. Leonora, que entonces había exhibido sus primeras obras pictóricas, El asesino silencioso y ¿Qué haremos mañana, Amelie?, se encargó de plantar el jardín en St Martin d'Ardèche — de niña, en Croockey Hall, solía saludar a las plantas y flores, organizó la cocina, que también allí sería un escenario esencial de su osadía creativa -y no menos de su angustia-, y pintó un panel para el interior, incluyendo una imagen algo tenebrosa de un híbrido de mujer, caballo y sirena a la vez. (La realidad de la imaginación, 12-14). Un cuento sobre el jardín que puede considerarse directo antecesor de Aura, escrito por Carlos Fuentes en 1962, es escrito por ella en ese período de 1937 a 1940, en el que cabrán las experiencias más próximas al paraíso y al infierno para Leonora y para Max. ${ }^{138}$ 
Después de trabajar con los albañiles del pueblo para renovar la construcción y

hacer una cisterna que guarda el agua de la lluvia, por su parte Ernst empieza a hacer frescos, relieves y esculturas de animales fantásticos. Como describe Chadwick:

This bestiary, as well as the couple's paintings, and the collages Ernst produced for the short stories Carrington was writing at the time, provide ample evidence of their mutual involvement in each other's creative practices. Their works mingled themes, images and psychic avatars, from Ernst's Bride of the Wind and Loplop The Superior of the Birds, to Carrington's horses. These alter egos, which include images of liberation as well as transitional beings that challenged the oppositional stability of terms like male/female, animal/human, mythic/real were soon absorbed into a developing mythology of the surrealist couple. Linking all of these imaginary creations were the bird and horse hybrids that by 1938 were central to both artists' personal mythologies of individual freedom, as well as surrealism's embrace of a notion of the couple that challenged dominant postWorld War I bourgeois norms (La realidad de la imaginación 1 ).

Los relieves en cemento que crean en su casa de St Martin d'Ardèche presentan, como apunta Bishoff "superficies rugosas, aptas para presentar animales medievales de fábula" (80). En la pared exterior de la casa aún permanecer tres personajes que tienen tanto de mitológico como de desatado humor.

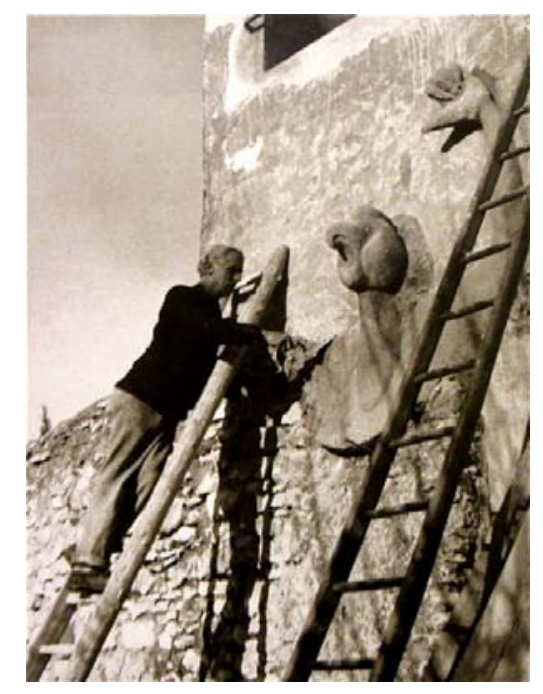

Ilustración 61: Max Ernst. Relieve de Loplop en la casa en St Martin D'Ardèche 1938. 
Ernst es un hombre-pájaro con ojos como "dos hermosos peces azules", su cabello está formado por "blancos, vaporosos plumones al sol" y lo que más le gusta del mundo son las piedras calientes. Así lo describe Leonora en la figura de Ubriaco, en tío de Pequeño Francis. Puede ver criaturas fantásticas en las rocas, en los cipreses — sembró uno a la entrada de la casa—, en las vetas de la madera y capturarlas en sus frotages, grattages, decalcomanías y oscilaciones, todas técnicas inventadas por él, además de sus relieves, pinturas y esculturas. Además de las representaciones multiplicadas del Pájaro Loplop en la casa de St Martin D'Ardèche hay una cabeza de Minotauro y una sirena alada, mitad mujer, mitad serpiente, entre otras quimeras y máscaras de ojos redondos que engullen cabezas de peces, y un mosaico en el suelo decorado con un murciélago.

El 13 de noviembre de 1938 compran otra extensión de tierra para poblarla de seres y juegos. Del fantástico mundo que ambos contruyeron en un tiempo de una intensidad tan intensa como sólo lo fugaz permite, proviene la legendaria introducción a los cuentos surrealistas de Leonora que escribió Max Ernst, para presentarla en París ante sus amigos, ex compañeros del sueño demoledor dadaísta y cofrades de la nueva aventura surrealista. Elijo algunos párrafos del texto, tan revelador como ineludible sobre la vida de ambos en la casa del sur de Francia a donde se refugiaron desde el verano de 1938, huyendo del acoso de Marie-Berthe y creyendo que nada podría vulnerarlos, aunque los vientos de guerra soplan con fuerza:

Acostado en el umbral de la casa única, pero de imponentes dimensiones de una ciudad hecha de piedras de trueno, están dos ruiseñores estrechamente abrazados. El silencio del sol preside sus retozos, el sol se quita su falda negra y su blusa blanca (...). ¿Es éste el hombre al que llaman Loplop, el superior de los pájaros, a causa de su carácter suave y feroz? (...) Y la mujer, cuyo brazo más alto rodea un 
delgado hilillo de sangre, no debe de ser otra que la Novia del viento. Caballos en cada ventana (...).¿Quién es la Novia del viento? ¿Sabe leer? ¿Sabe escribir en francés sin cometer faltas? ¿Qué leña enciende para calentarse?

La calienta su vida intensa, su misterio, su poesía. No ha leído nada, sino que lo ha bebido todo. No sabe leer. Y sin embargo, la vio el ruiseñor sentada en la piedra del manantial, leyendo. Y aunque estaba leyendo para sí, los animales y los caballos la escuchaban admirados.

Porque estaba leyendo la casa del miedo, esta historia verídica que ahora vais a leer, esta historia escrita con lengua hermosa, pura y fiel. Max Ernst, 1938 ( $L a$ casa del miedo, 12).

Suelen bajar desnudos al río mientras ella imagina a Lucrecia, la altísima dama de 16 años, con su extraña belleza, de una blancura cegadora, con una crin que cae en torno a su larga cara como si fuera agua. Sobre un armario empotrado en el muro, al lado de la cocina que Leonora vuelve un lugar efervescente -recoge hierbas, hongos, experimenta platos lúdicos que saborean con Ernst- Leonora pinta también un caballo que se suma a los múltiples seres fantásticos de la casa. Entre las pinturas de ese período que mezcla la intimidad y la creatividad febril con la vida a resguardo del mundo, hay una obra de Ernst, Un peu de calme (Un poco de calma), 1938 que -como otra realizada en 1940, Le fascinant cyprès (El fascinante ciprés) - oculta en las intrincadas formas vegetales, numerosos seres híbridos, mimetizados de tal modo que no es posible separar los reinos: lo que se nos pide es sumergirnos, mimetizarnos también en sus paisajes imantados en donde, como en los mundos de Leonora, todo está animado, todo respira. 


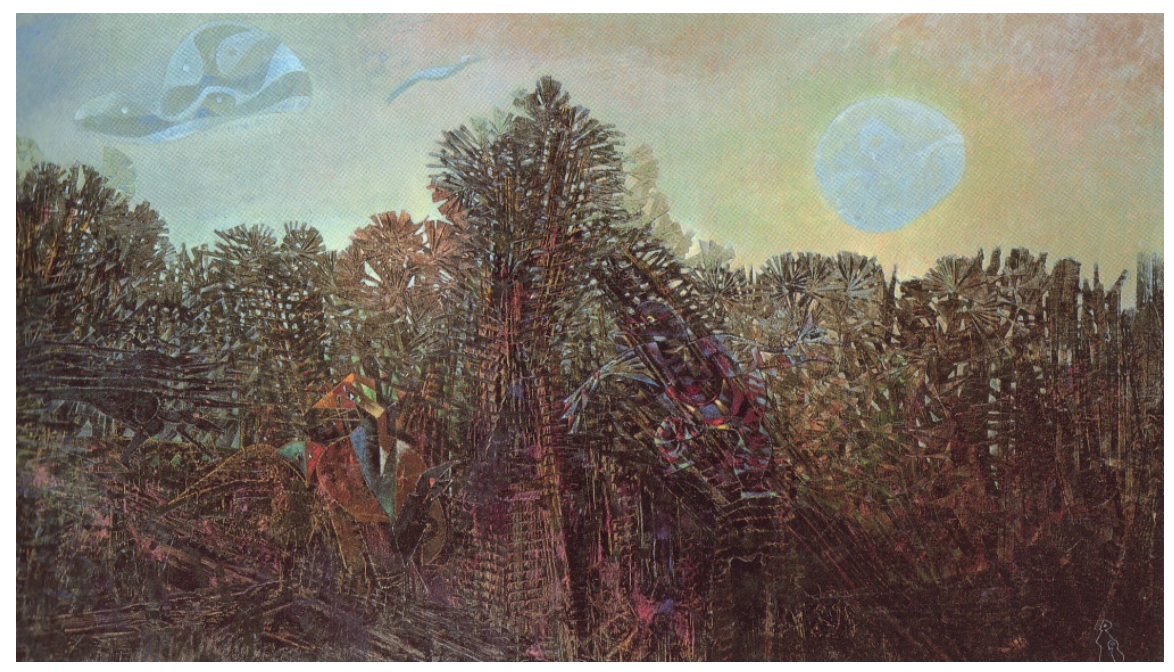

Ilustración 62: Max Ernst, Un peu de calme 1939

Un peu de calme (Un poco de calma) es una pieza de inmensa lúdica, en la cual es necesario adentrarse para descubrir el auto-retrato de Ernst-Loplop a la derecha, el ave con piernas humanas, inmensa, avanzando con soberanía en su paisaje, vestido con una suerte de atuendo de confeti de múltiples colores en ese mundo donde los árboles podrían semejar altos ringletes multiplicados y hay figuras de insectos y criaturas que parecen coloridas esculturas de papel, pero que son casi imperceptibles entre las geometrías de una vegetación animada como una feria, donde también el cielo juega y se rebela contra la lógica y sol semiazul e irregular puede alzarse con autonomía. En el plano inferior, a la derecha, de modo casi invisible, se delinean dos pequeños seres inmersos en el paisaje.

The title, A Moment of Calm, downplays this smoldering tension while at the same time evoking the proverbial calm before the storm. We are looking at a natural world that has turned threatening and sinister. In hindsight, the catastrophe to which Max Ernst is alluding is all too easy to recognize: the picture was painted on the eve of the Second World War, whose outbreak would spell internment, flight, and exile for the artist. In 1939 the world presents itself as an impenetrable thicket offering no avenues of escape. Max Ernst painted A Moment of Calm for the walls of his living room in southern France. After rediscovering the picture, which was long believed lost, he extensively reworked it (Max Ernst). 
Entre las ilustraciones que Ernst hace en esos días de baños interminables al sol, están las de La casa del miedo. Una de éstas es el collage titulado Caballa, equivalente al prefacio en la frase Loplop presenta a la Desposada del Viento: representa a una mujer de estrecha cintura, falda de plumas, con una desafiante mano en la cintura y otra sobre el puño de un bastón dibujado a modo de pata de animal, torso erguido e indómitos mechones de cabello negro que caen como serpientes enroscadas sobre una máscara de caballo inseparable de su rostro. Su título es: "Se asemejaba ligeramente a un caballo"139 (13). El bastón-pata de animal en el cual se apoya, lleva un corbatín, que se correlaciona con los atuendos distintivos del Pájaro Lop-lop, y en cuyo centro la imaginación óptica puede hacernos ver una pequeña figura antropo-zoomórfica.

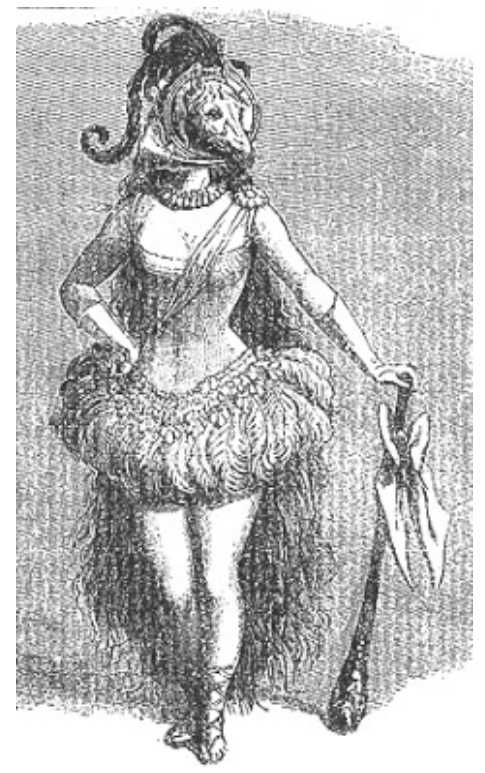

Ilustración 63: Max Ernst, Se asemejaba ligeramente a un caballo. Collage, 1938

El personaje, la Señora de la Casa del Miedo, se presenta como mucho más fea que un caballo, pero en el juego de la no-lógica que permite el género fantástico, las 
ilustraciones la recrean como una figura femenina tan oscura como atrayente. En la segunda ocasión en que aparece dibujada, la mujer-caballo surge entre un juego de perspectivas de tal modo que se desdobla, insinuando el movimiento, como si simultáneamente evocara la secuencias fotográficas del caballo en movimiento del inglés Eadweard Muybridge y el Desnudo descendiendo la escalera de Marcel Duchamp. La mujer-caballo aparece desdoblada, pero de tal modo que una de sus figuras desciende la escalera, con sus fuertes piernas recubiertas de malla y el tupido rabo de caballo brotando de las nalgas, y la otra figura, su doble, sube el primer escalón mientras sostiene la cabeza equina. Un hombrecillo en el tope de la escalera parece querer alcanzarla mientras en una diagonal marcada por líneas visibles, hay una suerte de podio con figuras delineadas de rostros menos humanos que caballunos. El efecto es una elipsis de tiempo que tiene lugar en el mismo espacio y reúne las dos direcciones del desplazamiento.

En el cuento inicial, La casa del miedo, de indudable filiación con las incursiones de la Alicia de Lewis Carroll en mundos donde los animales son criaturas antropomórficas y hay invitaciones a festines y mordaces sentencias pronunciadas en su relato por un caballo "que no era un caballo corriente" y que tras invitarla a un edificio con pavimento de turquesa, le anuncia una fiesta a la que se ha hecho merecedora pues le ha parecido a su anfitrión más interesante que los huéspedes habituales: "Se me da muy bien distinguir entre gente ordinaria y gente que sabe comprender", espeta el caballo (16).

Si bien, mientras escribía, Leonora leía Las flores del mal, de Baudelaire y le confesaba a la pintora Leonor Fini que sus poemas le hacían pensar en cuadros, no está exento de razón Bartra cuando nota: 
Para mí, Leonora Carrington está más cerca de Andersen que de Lautréamont o de Gerard de Nerval. De un Andersen que hubiese heredado de la Alicia de Lewis Carrol, del aguijón de Swift y del Blake de Los cantos de inocencia. Cuentos éstos de metamorfosis donde palpitan tres de los grandes mitos modernos: el alma, lo inconsciente y la poesía (La casa del miedo 12).

La protagonista del cuento confiesa que tiene pocos amigos y se alegra de contar entre estos a un caballo. Está tan aburrida como Alicia antes de encontrarse con el conejo de las horas: "Soy una persona muy aburrida, a pesar de mi enorme inteligencia (...). Soy una reclusa" (16-17). El caballo la lleva galopando sobre su crin, entre "todos los caballos del mundo" que corren hacia el Castillo de la Señora del Miedo, construido con piedras que contienen el frío del invierno. El juego que ésta propone para agasajarlos se suma a la tradición de la literatura del "non-sense", mezclando una cuenta de números hacia atrás, con el marcar simultáneamente el compás de tres tonadas con las patas.

Mientras los caballos patean estruendosamente —un leitmotiv que aparece en varios cuentos y relatos como El pequeño Francis o Cuando iban por el sendero en bicicleta -, la protagonista sólo espera no ser vista, pero tiene la sensación de que ocurre todo lo contrario. El relato termina en un "pero..." que abre paso al absurdo. Es interesante cotejar el deseo de no ser vista con la consciencia de ser mirada como un ser extraño, sin duda poco corriente, por los habitantes de Saint-Martin D'Ardèche. Una sensación que se intensificará después, cuando Ernst sea apresado y ella escuche sus propios pasos resonando en la inmensa soledad del mundo que acecha.

\section{De torneos peligrosos y juegos de damas en St Martin d'Ardèche}

La noción de metamorfosis es esencial tanto para Leonora como para Max Ernst $^{140}$ y resulta clave para comprender la capacidad de incesante transformación que comparten, la naturaleza híbrida de las múltiples criaturas que crean, y la naturaleza de 
sus dobles de pájaro y caballa, correlacionados también con la visión animista que desde antes de conocerse formaba parte de sus mundos interiores. Cada uno había experimentado visiones que fundían no sólo los reinos, sino lo animado y lo inanimado. Por eso Leonora puede conducirlo al brocal del pozo y precipitarse con él en su interior. La pintura Alice en 39, de Ernst (Alicia en 39), es una recreación de Leonora que Ernst hará en el campo de prisión de Les Milles, a la que volveré luego.

Ambos comparten la devoción por Lewis Carrol, pero además, como nota Catriona McAra en su ensayo "Surrealism's Curiosity: Lewis Carroll and the FemmeEnfant" la figura de Alicia permite descubrir y describir la curiosidad — característica que para Leonora era una fuerza primordial en su relación con el mundo- como una estrategia epistemológica en las narrativas visuales surrealistas. McAara cita el vaticinio que hacía Breton al contemplar las pinturas cubistas - "La mente nos habla obstinadamente de un nuevo continente y cada cual tiene el poder de acompañar a una cada vez más bella Alicia al País de las Maravillas" - para remontarse a la fascinación que ejerce entre los surrelistas la figura de la niña-mujer que cae al pozo o atraviesa el espejo en su curiosa búsqueda del conocimiento. ${ }^{141} \mathrm{Y}$, con toda razón, advierte: "Ernst tended to identify his partners with Carrolles Alice, perhaps most explicitly during his involvement with Carrington" (9). Al referirse a los dos retratos de ella como Alicia que pintó en 1939 y 1941 destaca que la sitúa en paisajes fantásticos conjurados por el método de la decalcomanía y el hecho de que Leonora aparece en ambos cuadros como una Alicia erotizada, en pleno desarrollo femenino, y sólo vestida a medias. Cita entonces el comentario de Louis Aragon: 
Ernst is extending the narrative; Alice after Alice, as a grown-up, more woman than child: It is as if Alice were to grow up in Wonderland [...] and you were to meet her one day, to re-discover her enchantment, now filled with love and terror. Max Ernst became her guardian when you had forgotten her (9).

Hay además una interesante precisión sobre la simultánea recreación de Alicia como doble de Leonora, pero también como alter-ego de sí mismo:

Though Ernst often idealized his current partner in the guise of the femmeenfant ${ }^{142}$, Alice also served as his alter ego - as she had for Carroll. Ernst's other alter ego, the bird familiar Loplop, appears to nestle the Carrington/ Alice figure in the 1939 Alice work, and by the 1941 version we find her wrapped in his feathers, no doubt in response to Carrington's earlier Portrait of Max Ernst (1938), which had portrayed Ernst in a red feathered gown (9).

En el cuento de Leonora La orden real, traducido del inglés al francés para la primera edición de La Dame ovale (1937-1938) que Max Ernst ilustra con siete collages que le dedica: "Para Leonora, magnífica y desnuda", la protagonista alquila un caballo y un carruaje porque su chofer ha enterrado su coche para que salgan setas y debe acudir a la invitación de la reina, a la que encuentra bañándose en leche de cabra y entre esponjas vivas. Esta la manda a presidir la cámara de gobierno ese día, en lugar suyo, de un modo paralelo al de la joven debutante que envía a la hiena al baile para reemplazarla. En la reunión de la cámara se decide que alguien debe asesinar a la reina y la elección de quién lo hará se definirá mediante un juego de damas. Cuando la suerte recae en la protagonista, por ser la única que no ha hecho trampa (Leonora era tan desafiantemente honesta que se dio el lujo de no hacerla nunca), ésta intenta huir de la tarea fatal refugiándose en una alameda, pero un ciprés echa a correr persiguiéndola y ella teme tanto "sus ramas peludas y negras" que no encuentra otra salida que cumplir la orden. A medida que se acerca con la reina a la casa de fieras donde ha decidido que la arrojará, lo único que hace es cantar para darse valor. Menos mal que Leonora no tuvo que hacer 
nada semejante cuando en 2010 recibió La Orden Real del Imperio Británico. Entonces, tenía casi los mismos años que la genial protagonista de su novela La trompeta acústica, ${ }^{143}$ Marian Leatherbay, que a los 92 años preside una insurrección en el asilo de ancianos donde está confinada. Pero en el momento en que Leonora escribe ese cuento, a fines de los años treinta, es una mujer muy joven que crea con furor y que sin duda, se asoma al espejo donde se mira Alicia y encuentra un alter ego de su insaciable curiosidad. Aún no ha perdido su rostro.

Cuadros y cuentos encabritados

Leonora pinta también entonces obras que también pasarán a la historia. Hace dos de sus cuadros más encabritados, surgidos de una lucha contra "el padre" — que es y será también todo el sistema de poder que la acorralará hasta casi destruirla — tan violenta como la de la Dama oval: The Meal of Lord Candlestick ${ }^{144} 1938$, y The Horses of Lord Candlestick 1938.

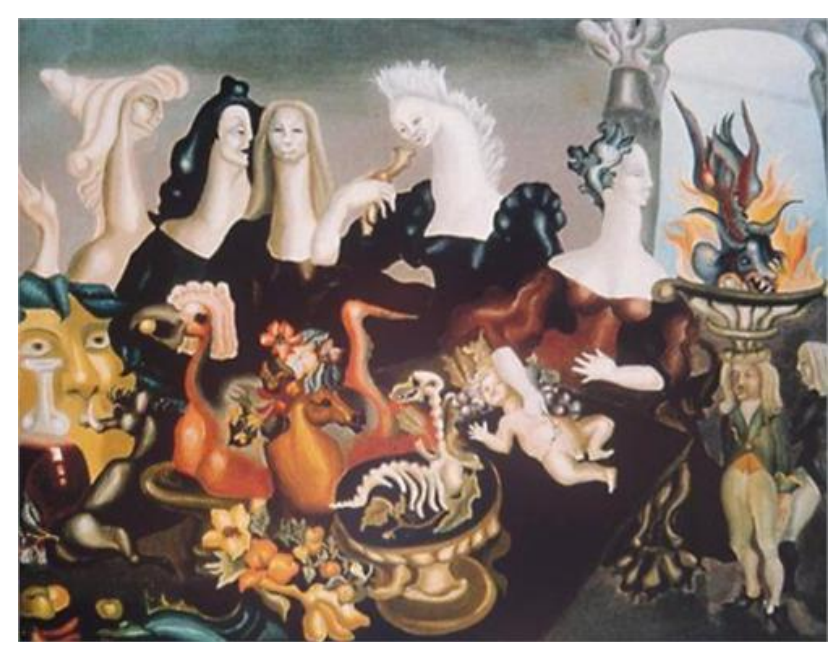

Ilustración 64: Leonora Carrington, The Meal of Lord Candlestick.

1938. Óleo sobre tela, 35.5 x $46 \mathrm{~cm}$.

Colección André-François Petit, París. 
El primero de estos cuadros, considerado, con razón por Aberth "the most blasphemous and satiric" (39) muestra un grupo de figuras femeninas de cuellos tan largos como figuras equinas. Una de estas tiene crin blanca en lugar de cabellos y se lleva a la boca una figura animal sin piel. En el extraño banquete se sirve un esqueleto de pato que parece vigilante, un flamenco rosado más vivo que muerto, y otras aves rodeadas de esas flores cortadas que Leonora asociaba a cadáveres. Pero lo más sorprendente de la cena es su canibalismo: una de las damas de blanco rostro hinca con aparente delicadeza un tenedor en el vientre de un bebé vivo de cuya tierna carne gotea sangre. Aberth se pregunta, como un modo de cuestionamiento que contiene su propia reafirmación si estamos en Crookhey Hall como podría ser visto a través de los lentes de la rebelión de Leonora y explica:

... 'Candlestick' was the code name she invented for her family, and so the 'Lord' in the title presumably refers to her father. He is present in the lower left portion of the painting in the form of a bloated green head with leaves for hair and wide staring eyes, but with no mouth he cannot partake of, or criticize, the revelry (...) The Meal of Lord Candlestick inverts the established order of things, questioning notions of class, religion, gender, maternity and the bestial ${ }^{145}(41)$.

Chadwick ha encontrado nuevos elementos de comprensión de los banquetes grotescos de las pinturas y relatos de este período anterior a las detenciones de Max Ernst, en las cartas que Leonora envió a la amiga que entonces sentía más cercana, la artista nacida en Argentina, y educada en Trieste, Italia, Leonor Fini, una surrealista que se negó a acatar la dictadura de la imaginación que Breton imponía. ${ }^{146}$ Como veremos, a medida que aumenta su asco frente al entorno que la rodea, aparecerán platos más cruentos y excesivos, y cuando el absurdo histórico esté estrechando su cerco, será más 
problemática su propia relación con la comida, mayor su tristeza y más cercano irá sintiendo el aliento de la locura. Constata Chadwick:

(...) in the period before Ernst's arrest, a period in which her short stories reveal a growing reliance on psychological displacement. Disquieting, often sinister meanings are projected onto mundane objects, or recontextualized within expressions of culinary excess, gluttony, wicked satire and human/animal substitutions that dominate both Carrington's early paintings and stories, and accounts of life at Saint-Martin during the summer of 1939. They begin with the first paintings Carrington exhibited with the surrealists in the Paris and Amsterdam exhibitions [organized by Georges Hugnet] and include The Horses of Lord Candlestick and The Meal of Lord Candlestick (D'Un jour à l'autre 6). ${ }^{147}$

En la pintura y en la escritura de Leonora hay una furia y una catarsis liberadora que no se remonta sólo a su enfrentamiento con el padre o a la ruptura familiar que, por otra parte, no es absoluta, puesto que el dinero de su madre la había ayudado a subvencionar en 1937 el apartamento que compartía con Max en la Rue Jacob y luego, a adquirir, en noviembre de 1938, el terreno en torno a la casa fantástica que han ido transformando juntos. Su furia es anterior, es ancestral, y su rebelión contra las hegemonías, quizás de un modo inconsciente, remueve los autos de fe contra las brujas de Lancashire de siglos atrás. ${ }^{148}$ Es ciertamente como dijera Octavio Paz, como si una bruja escapada de un poema de Yeats (1865-1939) fuera quien escribe o pinta, como si una de las conocedoras de pócimas y calderos que Jules Michelet (1862) recobró para una memoria que desafía las llamas de la inquisición, ${ }^{149}$ regresara dispuesta a llenar páginas y lienzos con la fuerza de universos que desafían las leyes patriarcales: “¿Cuándo empieza la bruja? Lo digo sin vacilar: ‘En las épocas de desesperación'” (4). De hecho, en su libro La bruja, se menciona el apodo que Ernst elige transferir a Leonora, la Novia del Viento. ${ }^{150}$ 
Ambos parecían dispuestos a ignorar que intentaban la construcción de un paraíso propio en medio del avance de una época de desesperación. El desafío de los cuentos y pinturas de Leonora y el de los textos, pinturas y esculturas de Max Ernst durante esa época es una convocación creativa contra la fuerza tanática que acabará arrasando su mundo. Aberth (2004) sostiene que mientras Ernst esculpe sus figuras guardianas en concreto, Leonora forma las suyas en pinturas. "Although both artists were simultaneously engaged in creating monstruous figures to repel evil, their respective demons were different" (41).

Whitney Chadwick e Isabel de Courtrivron destacan la identificación que existe en los cuentos y pinturas de Leonora entre el caballo salvaje y la mujer joven: "Sirven de gesto de liberación de poder o de rebelión contra las ataduras sociales y sexuales" (135). Así ocurre con el caballo blanco de su autorretrato, pero también con Los caballos de Lord Candlestick.

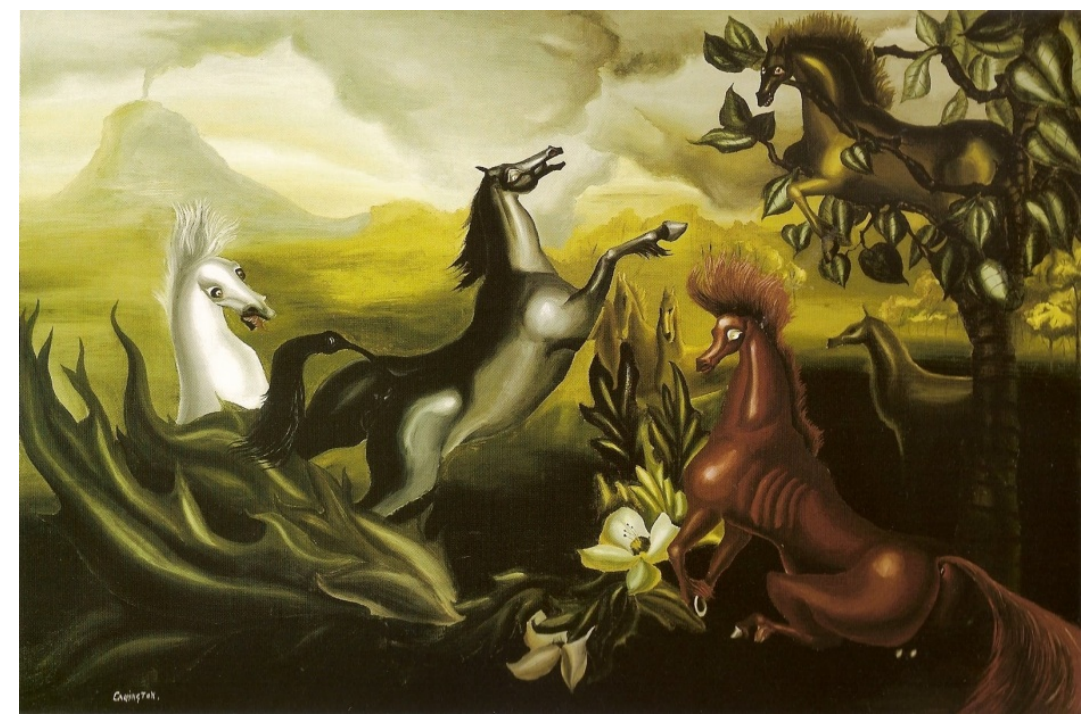

Ilustración 65: Leonora Carrington, The Horses of Lord Candlestick 1938, Colección privada. 
El caballo blanco de afilados colmillos no parece esta vez ser Leonora: sus ojos desorbitados están fijos en las ancas separadas y el rabo alzado de la salvaje yegua negra —ella, la indómita mujer joven— que relincha, levanta encabritada sus patas libres de cascos entre elementos que forman un círculo en torno suyo: las nubes, que son lo único que se alza sobre su cabeza, y el volcán humeante a su espalda, que curiosamente parece anticipar la vista del Popocatépetl entre el cielo nublado de la Ciudad de México, donde Leonora vivirá un día. Pero entonces Leonora no puede siquiera adivinar dónde vivirá la mayor parte de su vida, y es posible que, como aventuran Chadwick y Courtrivron el volcán guarde relación con el interés de su amante, Ernst, por los volcanes que él relacionaba con los bosques salvajes y desnudos de Oceanía en Los misterios del bosque (135).

A los pies de la yegua negra, la hierba verde forma una especie de mágica llamarada, como si fuera una ardiente planta semi-animada que culmina en una forma fálica no muy visible, pero dirigida hacia la magnolia de abiertos pétalos blancos. Bajo las patas alzadas de la yegua, se observa en el horizonte lejano la protectora figura de tres caballos que representan una manada protectora. En la parte izquierda de la pintura hay otros tres caballos: uno rojo de crines alzadas, sentado en posición de reposo; uno marrón casi verdoso, mimetizado con el árbol de hojas acorazonadas en donde se encuentra, no levitando, sino con la cabeza entre las ramas en forma de horquilla, y las patas traseras sobre una crisálida; y un caballo del mismo color verduzco, representado de medio lado, casi como una estatua en postura hierática, a modo de otro guardián. Si bien la atmósfera está cargada de sensualidad y de iconografías ligadas a una reafirmación desafiante de la sexualidad, hay también una conciencia paralela de un modo de transgresión que hace 
necesario no sólo en resguardarse en círculos aislados, sino convocar figuras guardianes o protectoras. Como efecto de la misma atmósfera de tensiones íntimas y colectivas que rodea la factura del cuadro y que penden como una espada de Damocles sobre ese tiempo de placer construido y defendido a espaldas del mundo, se advierte un agudo sentido de vulnerabilidad. Quizás la bravía yegua está en mayor peligro de lo que querría admitir.

En todo caso, ese abandono que simbólicamente equivale para Leonora a ser asesinada, es apenas el preludio de los sucesivos e involuntarios abandonos a los cuales la sujetará un Ernst perseguido por la jauría de un mundo enloquecido durante la Segunda Guerra Mundial. Darran Anderson (2013) conecta Los caballos de Lord Candlestick con el reino de los Houyhnhnms, del también surrealista céltico Jonathan Swift. ${ }^{151}$ Es muy posible que las ilustraciones de los libros de Gulliver alimentaran en Leonora la natural posibilidad de retratarlos antropomorfizándolos, y que también la marcaran las múltiples representaciones de caballos de Giorgio de Chirico — un predecesor clave en cierto momento- para Ernst, pues no sólo eran figuras de bestias ligadas a personajes de la mitología sino animales a un tiempo semidivinos y semihumanos que constituyen una extensión del alma de los héroes que los cabalgan. 


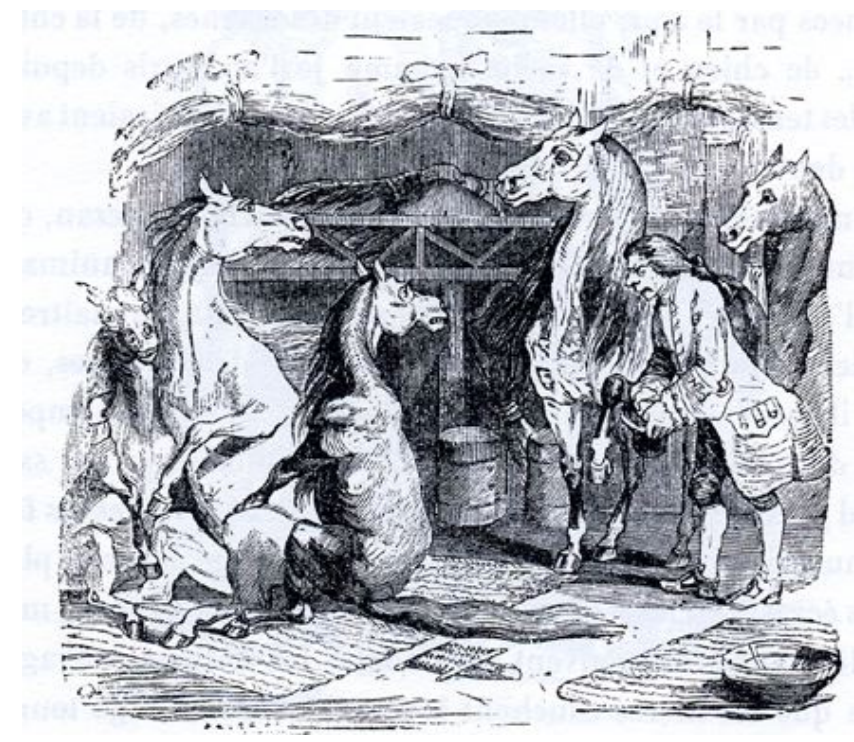

Ilustración 66: J.J. Granville. Ilustración de Los viajes de Gulliver $1835^{152}$

Ciertamente, en los Caballos de Lord Candlestick ${ }^{153}$ Leonora muestra su predilección por un mundo semejante al idílico reino de Houyhnhnms, habitados por nobles, amables caballos, mientras sus congéneres se le asemejan a la despreciable raza de criaturas humanas llamados Yahoos que Swift describe en Los viajes de Gulliver. Los caballos se horrorizan cuando el viajero les narra, en principio con un orgullo del que acabará avergonzado, las cosas que pueden hacer los humanos. Así se advierte en este pasaje:

And being no stranger to the art of war, I gave him a description of cannons, culverins, muskets, carabines, pistols, bullets, powder, swords, bayonets, battles, sieges, retreats, attacks, undermines, countermines, bombardments, sea fights, ships sunk with a thousand men, twenty thousand killed on each side, dying groans, limbs flying in the air, smoke, noise, confusion, trampling to death under horses' feet, flight, pursuit, victory; fields strewed with carcasses, left for food to dogs and wolves and birds of prey; plundering, stripping, ravishing, burning, and destroying. And to set forth the valour of my own dear countrymen, I assured him, 'that I had seen them blow up a hundred enemies at once in a siege, and as many in a ship, and beheld the dead bodies drop down in pieces from the clouds, to the great diversion of the spectators' (302). 
De tal modo, esa Leonora de 21 años que pinta Los caballos de Lord Candlestick, en un tiempo coetáneo con el de su transgresión de las normas a cambio de la experiencia de un modo de pasión y de fervor creativo que roza el peligroso paroxismo, no sólo esgrime su adhesión a un modo de libertad en este universo de caballos, sino la noción de un refugio a resguardo de los humanos que enarbolan banderas de guerra. Las fuerzas violentas que se ciernen sobre su tiempo parecer estar afuera de los linderos de la casa de St Martin d'Ardeche, pero no será posible crear, dentro de ésta, un círculo de protección que les impida arrasar el mundo que ella ha construido con Max Ernst con ese deseo — tan ardiente como imposible — de que dure para siempre. El desacato de Leonora y su desdén por cualquier constricción tendrá un alto precio.

Chadwick y Courtrivron dan una doble lectura a la obra: por una parte, como he mencionado, advierten la reafirmadora identificación entre el caballo salvaje y la mujer joven, pero por otra, la correlacionan con los efectos ambivalentes de la relación de Leonora con Ernst, marcada por una constante zozobra íntima que proviene del miedo a ser abandonada (130-135). Presionado por Marie Berthe Aurenche, que en 1938 lleva 11 años casada con Ernst, él la deja sola un tiempo en St Martin d'Ardeche, en el cual Leonora escribe su novela corta El pequeño Francis. Es un relato inseparable del trío amoroso. Max es el irresistible tío Ubriaco, de cabello blanco y ojos como peces, ella es Francis, el adolescente sobrino inglés que va a visitarlo, y Amelia es la posesiva hija de Ubriaco (Marie Berthe), de la cual se esconden, durante un tiempo feliz en el sur de Francia hasta cuando logra convencerlo de que la siga. El dolor de Francis ante la ausencia de Ubriaco es tan intenso que su cabeza se vuelve una cabeza de caballo. ${ }^{154}$ Amelia, valiéndose de tretas, se la destrozará a martillazos. Luego manda el cadáver a 
Inglaterra, a donde un desesperado Ubriaco acude a verlo y no puede oponer a la muerte nada más que el gesto de pintar el ataud blanco con rayas negras y amarillas, exactamente el mismo color de las medias que Leonora le pondrá a su amante en el legendario retrato que hace de él en 1939: Portrait of Max Ernst.

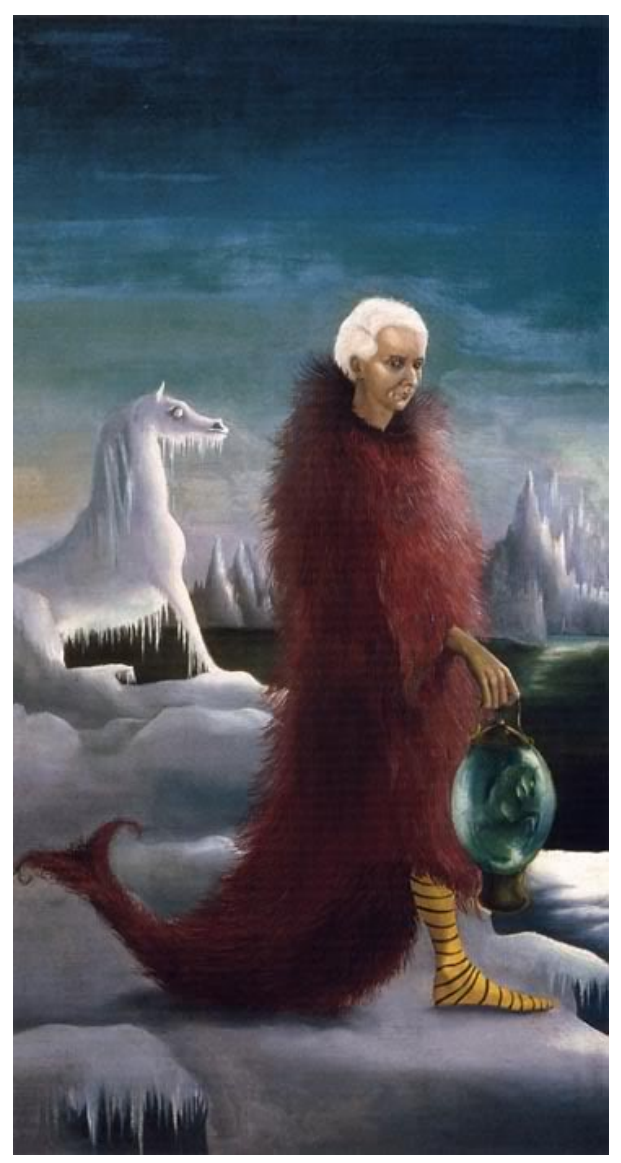

Ilustración 67: Leonora Carrington. Portrait of Max Ernst 1939. Oleo sobre lienzo. 20 × 10 1/2”. Private Collection.

De pie, con el maravilloso cabello blanco y los ojos que arrojan otro modo de claridad sobre el mundo — rasgos que a Leonora le fascinan y que atribuirá en varias historias suyas a personajes masculinos investidos de la capacidad de abrir puertas de juego y visión- Max Ernst parece encaminarse hacia un lugar que no se ve, pero al que 
se dirige, con la fuerza lúdica de sus medias amarillas a rayas, pues es el único ser que se mueve en ese mundo donde todo está congelado. Su figura recuerda la propia descripción de sí mismo, cuando Loplop presentó a la Novia del viento:

Mirad a ese hombre: con el agua hasta las rodillas, se yergue orgulloso. Violentas caricias han dejado huellas luminosas en su cuerpo soberbio y nacarado. ¿Qué hace ese hombre de mirada turquesa y labios encendidos, de deseos generosos? Ese hombre está dando alegría al paisaje (11).

En ese mundo pintado donde hace tanto frío como el que Leonora irá sintiendo, cada vez con mayor intensidad (a medida que pasen los días y los meses de la guerra que los separará), la figura maravillosa de su amante se calienta con su propio cuerpo, magníficamente recubierto de una tupida piel rojiza que lo cubre desde el cuello hasta la cola en punta de pez. Los árboles están congelados y, como en el autorretrato de Leonora que tituló Posada del caballo del amanecer, hay dos caballos. Sólo que aquí no levitan, ni se encabritan, ni se sacuden la nieve felices como en la historia de La dama oval: están congelados. El primero, al fondo de la figura de Max Ernst, parece estar sentado en sus patas traseras, mientras las patas delanteras se sostienen rectas y él mira un universo incierto. Sus ojos enormes, humanos, están cubiertos de hielo. En la mano derecha, el artista sostiene una extraña lámpara oval, que tiene el color verde-azul de la atmósfera. Pero no hay fuego en su interior, ni otra lumbre distinta a la del brillo del pequeño caballo blanco - la propia Leonora- que quizás sólo él podría llevar a un lugar más tibio, a donde quiera que fuera que se encaminara.

Fiona Bradley (1997) nota cómo la pintura recrea al artista hombre como una figura mística de transformación y rescate. Semejante a un pájaro y a un pez, parece capaz de liberar y revivir al caballo congelado (Leonora) detrás suyo y también al que 
está atrapado en la linterna de vidrio que carga: "If the bird and the horse may be read as totemic substitutions for Carrington and Ernst, the picture perhaps reverses conventional Surrealis male/female behavior: Carrington may be claiming Ernst as her "muse"' (53). Lo cierto es que la tristeza que irá congelando a Leonora apenas unos meses después no va a encontrar otro camino de liberación que la furia creadora, que surge sin que por ello sea posible detener las horas atormentadas.

Cuando íbamos por el sendero en bicicleta es uno de los cuentos más poderosos de Leonora dedicados a ese modo de pasión que llega a ser "una forma de locura que tiene algo de sagrado" (47), como advierte Lourdes Andrade (Leonora Carrington. Leyendas de la Novia del Viento 2001). Por una parte, contiene una visión de un entrelazamiento tan absoluto como fugaz entre dos seres, y por otra - como el relato de El pequeño Francis - un desbocado enfrentamiento a muerte con la figura de un tercero que los separa. Pero a diferencia del frágil sobrino inglés que se deja aplastar la cabeza, encontramos una magnífica Virginia Fur que huele a hierbas y animales, es respetada por las criaturas de la montaña, vive en un pueblo abandonado por los hombres con la salvaje libertad de una joven bruja que corre rauda en bicicleta y puede proveerse cuanto necesita en sus cacerías nocturnas: "Las zarzas retraían sus espinas, como esconden sus gatos las uñas. Era digno de ver: cincuenta gatos negros, otros tantos amarillos y luego ella; y no podías estar seguro de que fuera una criatura humana" (11).

Un día, seguido por el "repugnante olor a ser humano", aparece el contendor: San Alejandro: su figura representa toda la represión eclesiástica que Leonora odia desde la infancia, y también la fe católica a la que en la vida real Marie Berthe se aferra para salvar su matrimonio, escudando así su dependencia. San Alejandro viene a pedirle a 
Virginia que lo deje salvar su alma, pero ella le responde que la cambió por un kilo de trufas y le aconseja que vaya a pedírsela a Igname, el Jabalí. San Alejandro insiste y le invita a dejarse enterrar en su cementerio. Virginia piensa en las vajillas de oro de las iglesias y le pide que la invite a cenar junto con su centenar de gatos. El monje acepta y al llegar a sus aposentos seguido de este extraño séquito hace aparecer un cordero invocando a Jesucristo, pero cuando su voz se quiebra, el cordero cae al suelo y los gatos cenan con él. Virginia cruza el monte velozmente en su bicicleta llevando mariposas y murciélagos en su pelo y se traga un ruiseñor ciego que se cuela en su boca. "Jesuscristo ha muerto y nosotros hemos cenado magníficamente", exclama, sacrílega. (15) Es entonces cuando encuentra al bello jabalí Igname que tiene ojo de cíclope, la piel espesa y rojiza como aquella que cubre a Ernst en el retrato que Leonora hace de él, y se adorna con insectos y bestezuelas muertas. Una noche, mientras Igname se baña a la luz de la luna decide llevarse a Virginia como su amante. Y aparece ante ella, espléndido "con su atavío de amor" (16) hecho con sangre de conejo y numerosas bestezuelas muertas y vivas. Virginia está cocinando cuando él le declara su amor. Ella maldice las palabras de amor pues teme la belleza de Igname, pero se lanza en una danza de éxtasis en torno suyo. Hacen al amor cubiertos por una montaña de gatos. Una mañana Virginia Fur ve a unos cazadores que la aterran por la fealdad y torpeza de movimientos típicos de los humanos. Aquí se advierte, una vez más, un eco de la predilección de Leonora por los otros reinos, y el hondo sentido de unidad con éstos, paralelo a su desconfianza del género humano. La indómita Virginia sale a advertir a su amante pero descubre que lo han matado junto a mil pájaros y 40 liebres y otros tantos ciervos. San Alejandro es quien les ha dado señas a los cazadores a cambio de unas monedas. De regreso a su cocina, 
Virginia pare siete jabatos pero sólo conserva uno, el más parecido a Igname, "por sentimentalismo", y los demás los prepara como un banquete funerario que comparte con sus gatos. La bicicleta, los gatos y Virginia se funde con los árboles y el viento —al modo de las jóvenes brujas - sus sombras cruzan a extraordinaria velocidad las laderas. Susurran algo que no se entiende y los pájaros responden que están hartos de las condenadas estupideces de San Francisco — una vez más ataca cuanto representa a la Iglesia- cuando creen que es a este santo a quien buscan. Al enterarse de que es a San Alejandro, igual exclaman: "Matadlo". Todos los animales salen de sus madrigueras para pedir lo mismo y entonces aparece un número infinito de caballos encabritados que salen al galope relinchando y golpeando la tierra con sus pezuñas. "Matadlo, muerte al sucio Alejandro!"' (19). Dos viejas que una manada de cabras encuentra repulsivas, les compran a los cazadores el cadáver de Igname y lo llevan a un convento donde una de éstas piensa retirarse. Las monjas son descritas de modo repulsivo: tienen carnes grises y tasan en dinero todo alojamiento y por supuesto, las indulgencias. San Alejandro llega a oficiar la misa, mientras el altar se va llenando de gatos dorados y negros y un enorme tejón se le sube a la cabeza y millones de pájaros nocturnos ocultan el techo del templo gritando: “Muerte a San Alejandro!” (20). Así son las dos especies es desbandada: caballos y aves las que vociferan a un solo coro la sentencia de muerte. San Alejandro sale de la misa seguido de un cortejo de animales a la opiosa cena que comparte con las monjas y las mujeres viejas y afirma estar tan embebido en la oración que no los percibe. Pero apenas la madre superiora anuncia con una pequeña trompeta de cuero que anuncia: “El jabalí!” irrumpen todos los animales del bosque y se organiza un tumulto en el que apenas puede 
distingirse una figura humana, que, montada sobre una bicicleta, da vueltas a increíble velocidad, gritando a su vez: “¡Matadlo!” (24).

Esta Virginia que es una sola con los gatos, los caballos y los pájaros, no puede impedir la separación de su amante, pero no por ello se convierte en víctima: conjura todos los reinos para vengarse y da otro cuerpo al jabalí formado por todos los cuerpos que acuden en su ayuda. Por supuesto, hay una estrecha relación entre eros y muerte, y una curiosa forma de duplicación entre el instante culmen del amor que Virginia Fur e Igname realizan bajo una montaña de gatos y el tumulto furioso orquestado por ella en su bicicleta que apenas se nombra al jabalí se cierne sobre el cuerpo del arzobispo. La constante mordacidad contra la Iglesia auna a la vez la memoria opresiva de la infancia de Leonora, con el papel de una parte de esta institución en la recién terminada Guerra Civil Española que hizo considerar a Ernst la posibilidad de alistarse para defender la República.

Otra historia de imaginación desbocada, es El séptimo caballo. Hevalino es, como Virginia Fur, una criatura de aspecto extraño, medio desnuda, y de cabello tan largo que se enreda en una zarza. No puede precisarse si es mujer o animal. Vive en un jardín enmarañado donde hay esculturas abandonadas y está fascinada por un pájaro que posa con su pico peludo y tan abierto que le entran y salen mariposas nocturnas y pequeños insectos y no sólo es capaz de cenarse la noche, sino de ver lo que está más allá de su alcance. A Hevalino, que es hembra, la acompaña un séquito de seis caballos. Un día la descubre enredada en el jardín, Mildred, la odiosa esposa del "amigo de los caballos", Phillipe, una mujer tan “desagradablemente virtuosa," (81), según él, que jamás visita su lecho, pero pregona que está embarazada, y le reprocha dejar entrar seres desagradables 
en el jardín. Molesto, Phillipe se retira al ático y abre la ventana. Entonces los seis caballos desbocados pasan al galope bajo ésta, seguidos de Hevalino. Ella lo ve con "la cara luminosa y blanca como la nieve" y él cuenta siete caballos al galope y cogiendo al séptimo por la crin salta sobre su lomo. "La yegua corría como si fuera a reventarle el corazón. Entre tanto, un inmenso amor embargó a Philip: le parecía que había nacido a lomos de esa hermosa yegua negra, y que ambos eran una sola criatura" (82). Tras esa noche de paroxismo, cuando amanece todos los caballos están en su establo, pero el mozo de cuadra les limpia el sudor y el barro de la noche con una sonrisa. Cuando Philip le pregunta cuántos caballos tiene él le dice que son seis. El hallazgo que ocurre a la noche siguiente: el cadáver de Mildred, pisoteada, hace que el mozo reafirme que todos son mansos como corderos. Nadie puede explicar, sin embargo, la aparición de un potrillo deforme que se mete en el séptimo establo vacío. A menos que se recuerde que Hevalino ha dicho que "está dispuesto a odiar setenta y siete millones de años sin pararse a descansar" (77). De nuevo en esta historia, la protagonista, cumple una venganza y reafirma la furiosa danza del amor. Los elementos fantásticos, la naturaleza híbrida o doble de los personajes - Hevalino y el potro; Philip, el amigo de los caballos y el pájaro capaz de devorarse la noche y adivinar lo que sucederá-, se deslizan del campo de la vida creativa a la biografía y regresan poseídos de un alma que recoge el latido de los tiempos.

Bajo la alucinación del "amor loco" Leonora y Ernst parecen creer que ellos y sus criaturas imaginarias podrán conjurar, afuera de los muros de St Martin d'Ardèche, el horror que se avecina. Como escribe Roche: 
Max y Leonora penetran en las cuevas, las simas, las grietas de aquí. Max flota en el goteo de las cavernas, las dulzuras de los orificios, están dentro de la matriz y escucha cómo la te el corazón del mundo...Se acabó el ruido de botas de los bárbaros, '¡que me dejen amar a Leonora!', que se me deje oír la tierra, que se me acepte fascinado por los cipreses (...). Max siembra un ciprés muy cerca de su puerta (66).

En la posdata de una carta que Leonora le había enviado a Man Ray antes de marcharse al sur de Francia, le pedía proteger su aislamiento y le recomendaba no decirle a nadie dónde se encontraban, exceptuando a Paul Eluard y a Nush. Pero poco a poco había ido llegando visitas que se sumaron al paroxismo creativo ${ }^{155}$ de ese tiempo compartido y alimentado con la presencia de otros artistas como Leonor Fini o el mismo Ray y Lee Miller, cuyas fotografías preservarán la memoria de esa casa-oasis que no mucho después se verá cercado por el avance de los poderes oscuros.

Max Ernst desoye las advertencias de su hijo Jimmy Ernst respecto a los nazis que ya han invadido Polonia, su insistencia en que escape a América, y cree ingenuamente estar protegido en Francia, haciendo caso omiso de que independientemente de que figure entre las listas negras de los proscritos por Hitler, su sola nacionalidad lo transforma en un enemigo potencial de Francia. "Tenemos del lado nuestro la lógica y la moral y son más fuertes que el ruido de las botas y las arengas histéricas”, le dice a Jimmy, que casi cuarenta años después escribirá las memorias de un niño del surrealismo. “QQué inconsciente eres, Max! — Le advierte Roland Pensore, que los visita acompañado de Lee Miller-. En toda Francia se habla de la inminencia de la guerra y tú solo la pintas" (Poniatowska 134). 
Hay un retrato de Leonora y Max de 1939 en el que él sonríe con una suerte de abandono feliz, muy poco antes de su detención, con los ojos cerrados. El período de intensa felicidad que ambos recordarán siempre, es de una extendida y ciega sonrisa.

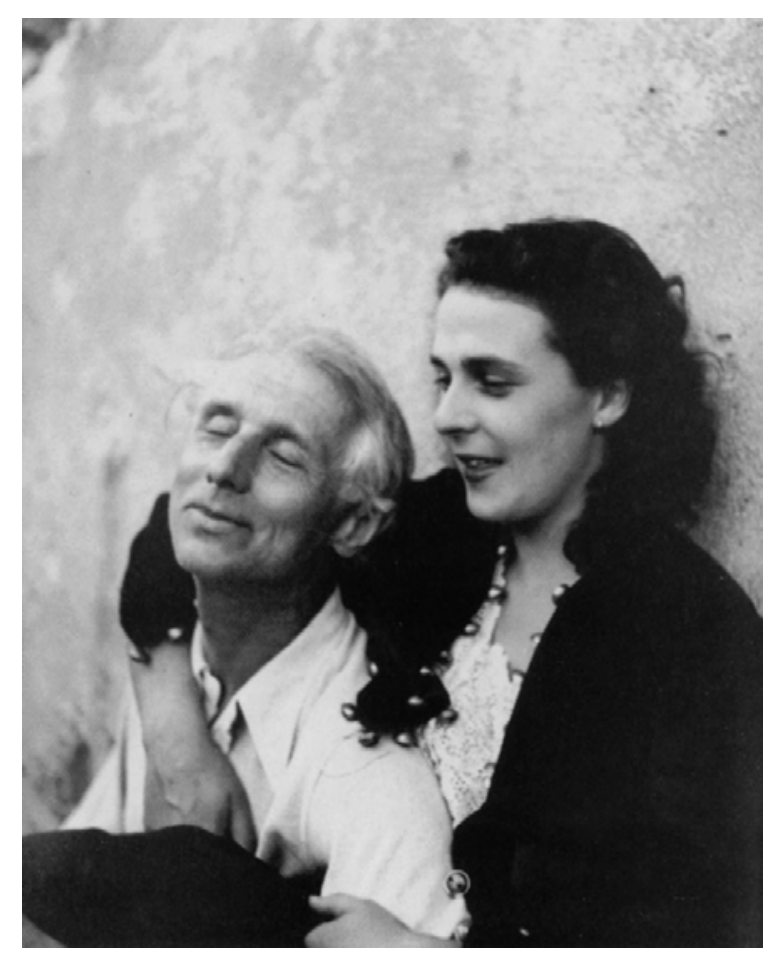

Ilustración 68: Lee Miller : Max Ernst and Leonora Carrington, St Martin d'Ardèche (France) 1939

Ellos quieren no saber, pero lo grotesco, lo amenazante, avanza y sus obras contienen más consciencia de ese acoso que ellos mismos. “¿Crees que el pasado muere?", pregunta la protagonista de un cuento de Leonora. "Sí", responde otra. "El presente le corta la garganta".

\section{Otros cuentos y pinturas de amor, locura y guerra}

En 1939, acompañado por los animales mitológicos propios y de Leonora, en la casa que desearían fuera realmente custodiada por las figuras tutelares del Minotauro y de la sirena, mientras los pavos reales verdaderos se tropiezan con el Loplop lúdico junto al 
cual Leonora se deja retratar, Max Ernst pinta otro cuadro relacionado con Leonora: L'habillement de l'épousée (La vestimenta de la novia), uno de sus cuadros más fascinantes. Se advierte la duplicación especular de la novia que añarece desnuda y ataviada, no con un velo blanco, sino con una suerte de tupida capa roja que la cubre desde la cabeza hasta los pies ${ }^{156}$, a modo de una capa abierta que revela su desnudez.

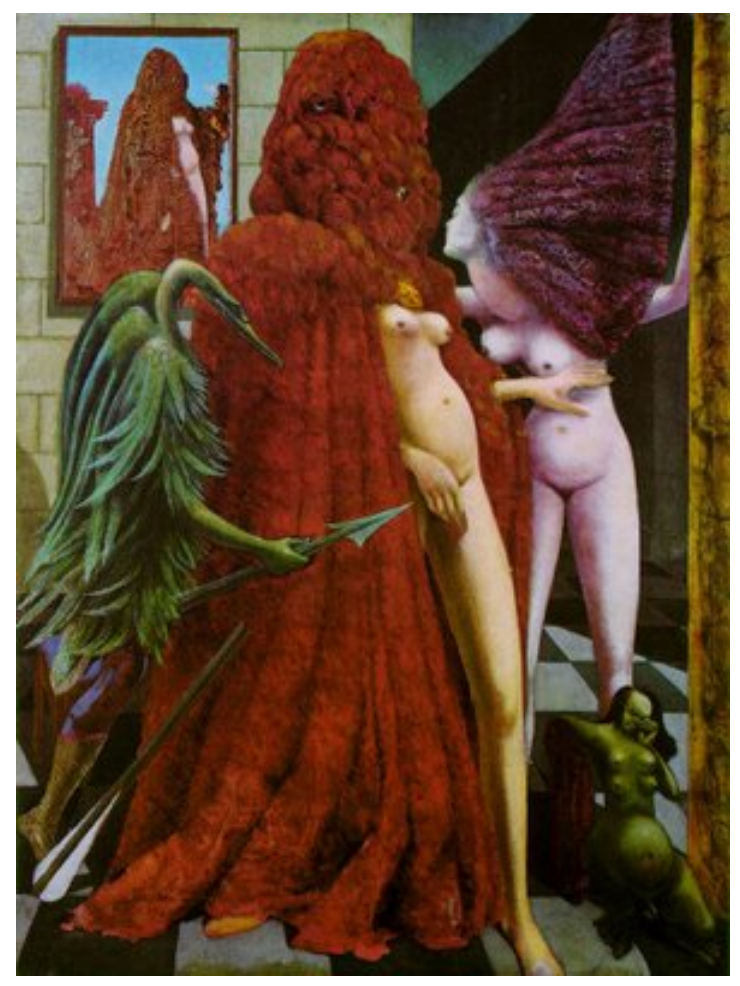

Ilustración 69: Leonora Carrington: La vestimenta de la novia (L'habillement de 1'épousée). 1939, Óleo sobre madera, 96 x $130 \mathrm{~cm}$.

Venecia, Collección Peggy Guggenheim

Una figura de defensa, hombre de plumaje y piel verde con alargada cabeza de pájaro y lanza en la mano, escolta a la novia descubierta que expone sus senos, su vientre, sus largas piernas a la vista, mientras múltiples caras están ocultas en la tupida cobertura roja que parece crecer cubriendo por completo el lugar del rostro: en su lugar hay ojos acechantes y multiplicados y una extraña cara masculina superpuesta sobre sus senos. 
El ave aparece en el primer plano sosteniendo el arma puntiguada que es una extensión de sus plumas punzantes, y a sus pies (humanos) hay otra herramienta — ¿arma, remo? - cuya punta no vemos pues penetra la vestimenta de la novia que extiende una de sus manos hasta casi tocar - en un gesto que puede imponer una distancia o una advertencia-, el doble de sí misma, que aparece sin manto alguno, completamente desnuda, con una frondrosa cabellera de color rojo oscuro y extrañamente suspendida en el aire. Esta otra novia sin velo dirige la mirada dirigida al fondo, desde una escena noctura y mira a su vez una nueva duplicación de la novia a pleno día. Mientras esas dos imágenes de la novia están de pie sobre un tablero a modo de juego de damas, esta otra duplicación aparece en un extraño cuadro-ventana-espejo, detrás de una pared de ladrillo, en un afuera luminoso sin gendarmes ni armas. Su imagen extiende el juego entre la pintura y el espejo o la ventana de Las meninas de Velázquez, pero además invierte la lógica del reflejo pues en lugar de reproducir a la novia de espalda, la duplica, de frente, en una mañana clara donde ella está también ataviada de rojo y con los senos expuestos, pero no hay a su lado sombra de guardián alguno. A los pies de la representación de la novia en primer plano, una repugnante figura hermafrodita, con doble cara, cuatro senos, vientre hinchado, y piel verdosa se restriega los ojos en un gesto que sugiere el llanto. Para Bischoff (2003) el sentido del cuadro es "un disimulado aviso ante el peligro de una posible boda de la novia francesa con los bárbaros alemanes" (64).

Sin importar que en la exhibición de arte degenerado que Hitler y Goebels auspiciaron, se hubiera colocado un cartel que tildaba La bella jardinera, de Max Ernst, como "insulto a la mujer alemana", tras la declaración de guerra de 1938 entre Francia y Alemania, Ernst, que siempre sintió a Francia como un lugar para expandirse, pasa 
automáticanente a ser considerado "extranjero enemigo". En razón de esa clasificación los guardias franceses irrumpen en su casa-paraíso y lo internan en la prisión de Largentière (en la misma región de Ardèche), a donde deben concentrarse "los súbditos del Reich”. El capitán le concede tres horas de libertad al día a cambio de que le pinte un recuerdo de la prisión. Leonora se aloja cerca de la prisión y viaja continuamente a llevar y traer colores y lienzos. El cuadrito encargado, según narra Roche, le horroriza al capitán, quien le dice que "no tiene derecho a pintar cuadros de ese tipo" (68), repitiendo la anécdota de los gendarmes alemanes que estando frente a una foto del Guernica en casa de Picasso, le preguntan si es él quien ha hecho ese horror y el responde: "No, fueron ustedes". Ernst dura seis semanas en ese campo y el 20 de octubre lo transfieren al campo de Les Milles, cerca de Aix-en-Provence, donde las mayoría de los 1800 “súbditos del Reich”, son antinazis.

Leonora deja entonces la casa-paraíso en Saint-Martin D'Ardeche, alquila un cuarto en las inmediaciones y cada mediodía le lleva comida y pinturas. Logra que le permitan caminar a su lado dentro del campo, donde también está prisionero Hans Bellmer (1902-1975), ${ }^{157}$ quien hace un retrato de Max en el que su cara es un muro de ladrillos. Max dibuja incesantemente un rostro de mujer. Pinta entonces Alice en 39. Es un cuadro pequeño, portátil, “como un ícono", según escribe Roche:

Leonora-Alice arrastra a Max en su sueño y él la pinta de verdad, son los rasgos de Leonora, su piel, su cabello. Toda esta pintura musgo-liquen vegetal no es pintura de los bosques del norte. Es contenida, en una bola cerrada como los árboles del sur concentrados en luchar con los elementos, con el mistral que los tuerce y la pintura de Max se aprieta en una tensión extremada sobre el exacto dolor contenido (...). Cada centímetro de piel de árbol del carrascal lleva las cicatrices de contención expresada (60). 


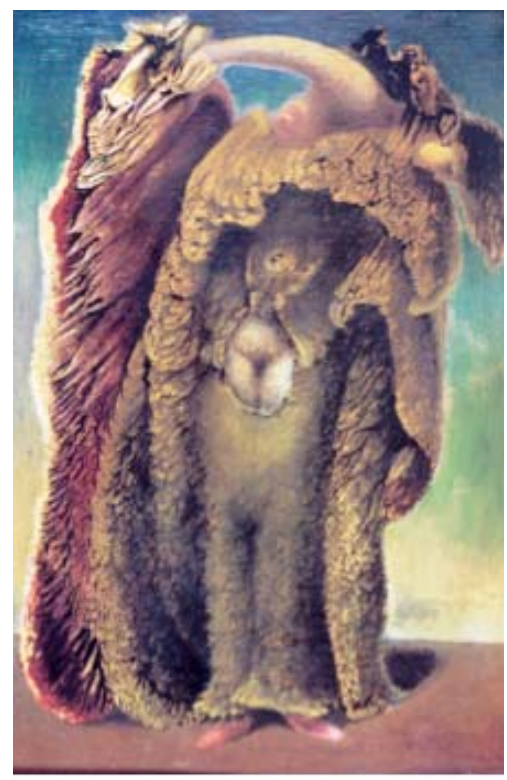

Ilustración 70: Max Ernst, Alicia en 39

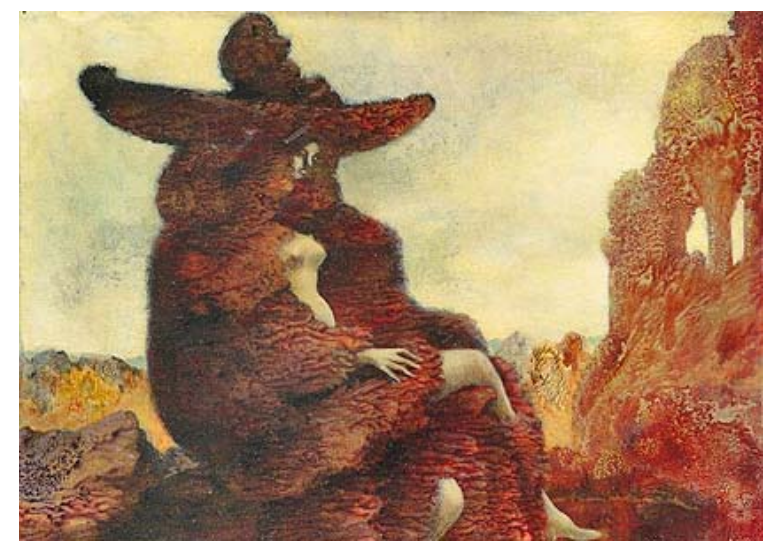

Ilustración 71: Max Ernst, Alicia en el 41 Óleo sobre papel montado en lienzo Colección del MoMA

Esa Leonora-Alicia en 39 enorme que se inclina sobre sí tiene un doble tan alto como ella, del que sólo se ve la cabeza caballuna. Su trinco se duplica vestido y desnudo, dejando ver el publis, y el inmenso manto musgoso que la cubre se desdobla en el lado derecho formando la cabeza de un ave de presa que dirige su pico al sexo de ella, pero está cobijada por los enormes brazos alados. La Leonora-Alicia pintada en 1941, cuando 
ya ella está ausente, tiene por ropaje la piel del mundo y se asemeja, más que a una fantástica Alicia, a un Atlas femenino que lleva su peso, sentada, y sin moverse, sobre los hombros y la cabeza. Su sombrero es una suerte de barcaza cargada y ella parece sobrellevarlo todo, serenamente, incluyendo la estatuaria gigantesca de una tosca cabeza masculina. Cuando Leonora llega al campo, con alimentos y pinturas, atraviesa con su presencia el umbral de la prisión y le recuerda a Ernst la posibilidad de la fantasía que ahora es a un tiempo la memoria del paisaje de su cuerpo y la capacidad, compartida por ambos, de fundirse con los elementos de la naturaleza, de ocultarse, de fugarse, entre las vetas de la madera, por dentro de la piel de las piedras, oyendo los chillidos de los pájaros y el relincho de los caballos, hacia otra realidad. En Les Milles Ernst pinta una nueva serie de dibujos titulada La novia del viento. Predomina en estos una figura que -Susan Rubin Suleiman describe así:

(...) es una mezcla de caballo y mujer que se alza sobre dos patas curvas, vistas de espaldas, con cabeza de caballo y largas y flotantes crines que también podrían ser la melena de una mujer. Esta figura fue añadida más adelante a otras figuras de yeguas, algunas de las cuales aparecen apareándose con el pájaro Loplop en el poema visual titulado 'Primer conversación memorable con la quimera', que se publicó en el de la revista $V V V$ de Nueva York en junio de 1942 (132).

No obstante, a medida que pasan los días, la calidad de las legumbres que Leonora consigue cada vez es peor y se racionan. En las cartas que envía a Leonor Fini y que Chadwick (2011) ha recobrado para la historia del surrealismo, expresa su angustia por la delgadez de Max, su horror cuando los gendarmes destripan los tomates buscando en ellos mensajes escondidos, su creciente asco por la comida. Entonces se intensifican los banquetes cruentos, desaforados de sus cuentos, y la presencia de los caballos.

...she says that he appears gaunt and although she brings food to him every day, he grows thinner and thinner. 'This torments me horribly', she adds, and I cry 
with impotent rage. "'I am becoming very distracted and believe myself back in the convent, when I carry things to Max to eat, the guards squash the tomatoes and cheese and make incisions in the sausage in order to see if there are not some letters inside! I laugh with rage. I speak to no one and I am filled with contempt for people. This life is unendurable. If only I could speak for an hour, if I were able to name the pigs and say what I think of people, if I could [indecipherable word] on people for their folly and their pestilential and foul mediocrity. ... While waiting I eat plates of bile, thickened and greenish like vomit. I am sickened and I have a permanent diarrhea as if my body is not able to contain all my disgust (D'un jour à l'autre 13).

Es una pesadilla que se intensificará con los ciclos en los que por breves períodos de tiempo, Ernst logrará salir del campo, pero sólo para ser víctima de nuevo de otro acecho. La indómita Leonora que ha dejado el aristocrático entorno de Inglaterra para seguir a Max Ernst hasta París, donde fue celebrada como una Alicia crecida y desobediente, capaz de dejarlo todo por el amor loco, y que escribió y pintó febrilmente desde en la casa-refugio donde creyeron alcanzar la tierra prometida, es también una extranjera en ese pueblo del sur de Francia, una rara joven embrujada, "la inglesita" que se quita la ropa sin miramientos a la orilla del río, cada vez más sola, sintiendo cada vez más frío, y un cerco amenazante que lentamente le quita el apetito y la enreda, mientras ella intenta sostenerse, busca reservas de poder dentro de sí, que lentamente se irán agotando. Esos interregnos en los que reaparece un Max que ha logrado salir de los campos son particularmente violentos por su promesa de paraíso restaurado y porque imponen una vez más, con espadas de fuego, la experiencia de terrorificos ángeles de guerra que de nuevo los expulsan de éste.

Tres meses y 20 días después de su primer arresto, en la cárcel de Largentière a donde deben concentrarse los extranjeros, el 23 de diciembre de 1939, Ernst es liberado gracias a la intervención de su amigo Paul Éluard, que le escribe una carta al entonces 
presidente de la república, Albert Sarraut. Pasa la Navidad con Leonora en St Marin d'Ardèche y pinta, uno de sus cuadros célebres: Leonora dans la Lumière matinale (Leonora a la luz de la mañana). ${ }^{158}$

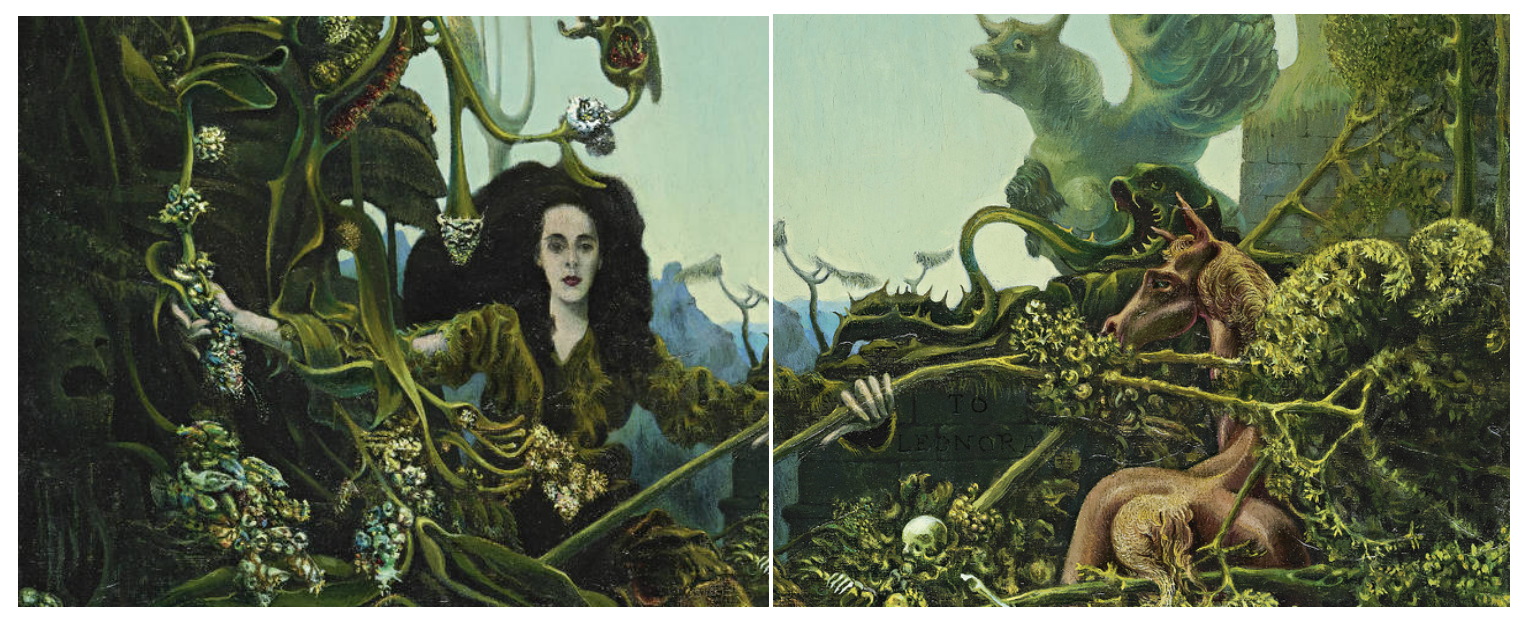

Ilustración 72: Max Ernst. Leonora a la luz de la mañana 1939

El cuadro capta la visión de Ernst cuando encuentra a Leonora al regreso a la casa en St Martin d'Ardèche. Ella está vestida de líquen, de hierbas, es una sola entre las lianas y las profusas plantas que ha hecho florecen fantásticamente en su jardín, se abre paso y mira al pintor con su inmensa cabellera negra, sobre la cual caen sensuales plantas fálicas. A su izquierda, una figura fundida con el mundo vegetal con pico de pájaro y profundas cavidades la mira mientras ella abre la mañana apartando con su mano los arbustos.

En el lado derecho, aparece su figura tutelar, una caballa roja de marcadas ancas, que la mira, y hay un muro-homenaje donde puede leerse la dedicatoria: "To Leonora". Ella es la dueña del paisaje y no parece temer el esqueleto que yace en el jardín, ni las fauces espinadas de la figura marina, especie de pez-pulpo, quizás porque más atrás, hay una figura protectora, extraña suerte de minotauro emplumado que la mira y la custodia. 
El cuadro guarda relación con otro, realizado un año antes de conocerla, en 1936, donde la figura de un enorme pájaro es la del dueño de la aurora.

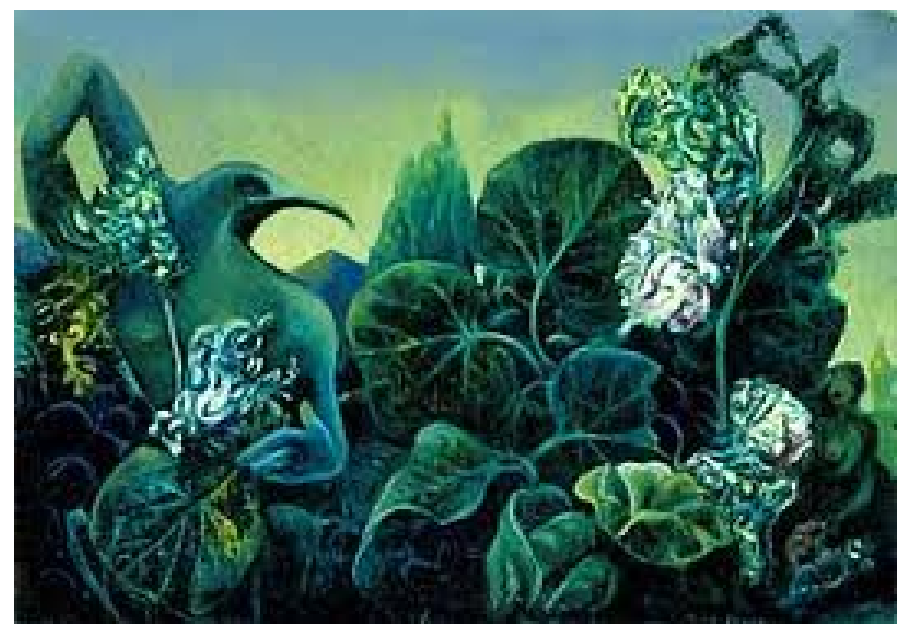

Ilustración 73: Max Ernst, La nature à l'aurore 1936. Städelsches Kunst-institut.

Pero lo cierto es que esta mujer bella y poderosa es mucho más vulnerable y se acerca al tiempo en que por primera vez en su existencia comprenderá que puede ser destruida. Todavía, sin embargo, tienen tiempo para crear, juntos, un cuadro que se titula Encuentro: "Carrington hizo la parte izquierda, donde se ve a una mujer-caballo parecida a la figura de [su obra] Mujer y pájaro; también pintó el paisaje volcánico del fondo" (Suleiman 135).

En la primavera de 1940 Hitler invade Dinamarca y Noruega. Hay aviones de caza alemanes sobrevolando Francia. El 12 de mayo el gobierno reabre el campo de Les Milles: hay edictos para los alemanes residentes en Francia de 17 a 65 años. A la mañana siguiente, llegan los gendarmes. Roche describe así la escena:

Loplop es el primero en avisar, lanza un grito de humano a su mitad humana que se levanta, su mitad humana que se niega a ver pero mira a los gendarmes franceses armados con fusiles que se le acercan y le ponen las esposas. Loplop se apaga, Max agarra el alma de Loplop que huye volando, el bajorrelieve está muerto. 
Max baja el sendero, con un gendarme a cada lado.

Cuando voltea, ve a un caballo blanco alelado en la puerta (76).

Max Ernst es trasladado de nuevo a Les Milles. Leonora está ahora en la casa del miedo. De la literal náusea que le produce lo que está sucediendo surgen las extrañas cenas de sus historias y de la ira nacen caballos y caballos. Caballos desorbitados que llegan a hacerla confesar, en un momento, que teme no ser ya capaz de pintar más que los caballos que la obsesionan. La locura cabalga dentro de ella, cercándola, mientras vuelve a Saint Martin D'Ardèche a alimentar a los gatos y cena con ellos y siente el aliento de un horror invisible pisándole los talones. Escribe, como anota Chadwick de un modo tan desesperado como premonitorio a Leonor Fini: "I will burn with rage until my destruction is complete...but NEVER NEVER will I become passive or docile" ( $D^{\prime} U n$ jour à l'autre 4).

En algún momento, entre 1937 y 1940, es decir, antes de cumplir 23 años, escribe el cuento Vuela, paloma! Por el contenido de la historia, es muy probable que no haya sido escrito en el año inicial de su encuentro con Ernst, ni en 1938, cuando están aislados del mundo construyendo su propio paraíso, sino después del otoño de 1939, cuando ellos y su mundo se irán congelando. Desde un balcón, la protagonista ve a alguien que viene a verla acercándose:

Pensé que era una mujer, su cabello largo, liso, llegaba hasta la crin del caballo. El caballo era grande, de huesos fuertes y redondos; y era una exptraña mezcla de sombras rosadas y púrpuras, del color de las ciruelas maduras, de ese color que llaman ruano. De todos los animales, el caballo es el único que tiene ese color rosado (28).

En realidad quien lo cabalga no es una mujer: es Ferdinand, el emisario de Célestin des Airlines-Drues. La protagonista, una pintora que se llama de un modo muy 
parecido a Leonora -Eleanor-, acude al ruego de este personaje que le pide llevar consigo pinceles y caballete. Arriba a la mansión al ocaso y tras la visión de un coche fúnebre tirado por cuatro caballos de la misma raza que la del heraldo, pero negros, instala su caballete en el claro de un bosque, donde esperan la llegada de la noche. Entonces aparece una multitud de gentes cubiertas con velos, que hablan en voz baja y de vez en cuando ríen de modo estridente. Hablan de la mujer que habrá de pintar: Madame des Airlines-Drues, recién muerta. De pronto aparece el caballero que tiene el rostro de una oveja y le pide retratar —con "un parecido absolutamente perfecto" (33) - el cadáver de una joven que como Leonora es hermosa y tiene una abundante mata de pelo negro y sedosa, y ya está empezando a descomponerse pues lleva dos semanas muerta. Quienes la rodean juegan a hacer volar palomas a su alrededor mientras ella pinta, abstrayéndose a tal punto en su oficio, que no advierte que se ha quedado sola con el cadáver de la joven. Satisfecha con el retrato se retira para verlo en conjunto y descubre que la cara del lienzo es la suya.

No daba crédito a mis ojos. Sin embargo, al comparar el modelo con el retrato, comprobé que su fidelidad era innegable. Cuanto más miraba el cadáver, más sorprendente era el parecido con esos rasgos pálidos. Sobre el lienzo, en cambio, la cara era incuestionablemente mía (34).

Celestine la felicita por haber logrado su cometido y la invita a descansar en el estudio de Madame des Airlines-Drues, que encuentra lleno de numerosos trajes de disfraz. Allí encuentra un diario con su nombre en la portada escrito en letra infantil y una nota que comienza: "Querida Eleanor" y sigue con una larga misiva en la que le explica que ese día es su cumpleaños "y naturalmente, el tuyo" (36). Entonces le cuenta que la noche de bodas vio un individuo vestido con plumas blancas y alas de ángel que 
acabó por revelársele como el mismo Celestín: "Si las plumas eran blancas, su cuerpo era cegadoramente igual". Llevaba medias a rayas (como las que Leonora ha pintado en el retrato de Ernst). Pero el esposo levita. No la toca. La deja sola. A partir de ese momento, Madame se queda viviendo en su estudio donde un criado le trae cosas dulces para comer y se obsesiona mirándose en el espejo. Le dice a Eleanor que siente tanta tristeza que su cuerpo se ha vuelto transparente y que su propia cara le resulta cada vez más brumosa, por lo cual ha intentado pintar su rostro pero le ha resultado imposible. En cambio, los objetos no sólo van cobrando consistencia, sino que los muebles que son antiguos han empezado a echar brotes, como si fueran troncos jóvenes. Luego la carta se torna más delirante y narra la reaparición de Célestin seguido de individuos vestidos de ovejas. La dama insiste en que ella sólo se pone disfraces para hacerse más sólida. Habla de la suavidad de las manos de Célestin que hace elevar las de quienes lo rodean al grito de "Vuela, paloma" un juego que a ella le gustaba de niña. En el punto en que el diario se interrumpe, justo después de que la voz de él se ha elevado diciendo: “iVUELA, CÉLESTIN!” (39). Eleonora se vuelve hacia el retrato y descubre que el lienzo está vacío. No se atreve a mirarse en el espejo pues teme lo que encontrará. Ahora, sus manos, a diferencia de las muy suaves de Célestin, están heladas.

El cuento, de estructura perfecta en el género fantástico, y plagado de referencias especulares, contiene la intensidad de la angustia de un tiempo que no mucho después adquirirá una dimensión de horror en donde no será posible para Leonora distinguir la pesadilla del mundo de sus propias alucinaciones. Escribe, ciertamente, con una tristeza que es tan intensa que le parece que se ha vuelto transparente. El emisario de Célestin —que es la encarnación de un modo de ausencia tan atroz que equivale a la muerte-, 
llega en un caballo de maravilloso pelambre para llevar a Eleanora al lugar donde le pedirán oficiar la perfección de su arte aunque esté circundada de un olor a muerte. Cuando ella logra revelar el misterio de ese rostro, que es el suyo propio, marcado por el abandono, pasa a ocupar el lugar de la mujer del inasible Célestin, hombre-pájaro de suavísimas manos y plumones blancos, que como Ernst - con cuya descripción coincide—, suele dejarla sola. El grito de "Vuela, Célestin" que aparece originalmente en mayúsculas, equivale no sólo al fin del juego, sino a la proclamación de una ausencia que la despoja de su propio rostro. Por eso la batalla furiosa que tendrá que librar para no amar de tal modo que la ausencia de alguien equivalga al galope interior de la muerte.

La joven amada y muerta, es el pasado de Eleanor y es también lo que le espera. El encuentro con la otra que es ella supone el descubrimiento de su más alto grado de perfección artística, pero también su condena. Ese arte-espejo que la contiene a sí misma, la revela de un modo tan perfecto, que puede despojar de su rostro a Eleonora, que funciona como un doble de la propia Leonora. La intensa ansiedad de las ausencias de Ernst, sujeto al irracional tratamiento de todos los alemanes residentes en Francia como enemigos de guerra y prisioneros, justo después del interregno en el que él había dejado temporalmente a Leonora para calmar a Marie Berthe, y había regresado a ella, agudiza al extremo su impotencia. Las gradaciones del horror se van sumando a esa ausencia involuntaria pero no por ello menos terrible: el miedo de ser una extranjera en un país desconocido cercado por la guerra, las súbitas irrupciones de los gendarmes en la casa, las idas y venidas a las inmediaciones de la prisión, la violencia de los guardias estripando los alimentos, el avance de Alemania sobre Francia, la cercan y le producen una náusea y un miedo agudo en crescendo. Entonces comienza una lucha incesante 
contra su propia dependencia frente a Ernst. Lo odia por la tristeza que le infringe cuando no está, porque se consume esperándolo, porque la muerte los rodea y puede volverse su propio rostro. Porque ella se está enloqueciendo en una espera que ocurre en medio de un tiempo de infinita incertidumbre colectiva. Es un sentimiento irracional, porque está llegando al límite en que la pasión es sólo sufrimiento y las fronteras entre el dolor propio y común son confusas.

En otro cuento escrito tres décadas después, El cadáver feliz, 1971, un joven llora la ausencia de la mujer de la que está enamorado -joven blanca/moteada yegua/.../Mechón de pelo negro atrapado en una espina;/pasó ella veloz/Ya no está ahora. (208) - y acepta la ayuda de un "cadáver feliz" para buscarla. Pero en medio de un sendero lleno de espanto, justo cuando se aboca a las puertas del infierno, el enamorado decide regresar: “...Puesto que ya has olvidado a la chica blanca del caballo moteado como olvidan los que van camino del infierno" (211). Leonora está camino del infierno. Irse de St Martin d'Ardèche, olvidar, equivale a salvarse. No sólo de los gendarmes nazis que avanzan, sino de sí misma, de sus fantasmas, de la tristeza enloquecedora que la está poseyendo. Pero huir de la casa compartida no le permitirá acallar un estado de ansiedad y dolor que se acrecentará incluso al cruzar la frontera de España, donde cree que los muertos de la reciente guerra le reprochan su impotencia.

Los cuentos de esa época, con su fantasía gótica, su iconografía macabra, son un reflejo - embrumado y no obstante exacto- de la angustia tan íntima como colectiva de la época. Y contienen retratos de Ernst, hechos con tanto amor como desesperación, con tanta pasión como furia y con tanto deseo de liberarse de su poder como urgencia de convocarlo una vez más. Como si encarnara una de las imagenes reiterativas de sus 
pinturas y cuentos: las sombras de dos caballos amarrados el uno al otro que luchan ferozmente entre sí, hasta disolverse. "Tienes que ser libre, libre para matar y gritar, libre para arrancarle el pelo y libre para echar a correr sólo para volver riendo" (70), le aconseja en uno de sus cuentos una mujer vieja a la joven que espera a quien ama con una ansiedad tan violenta que la consume. En los cuentos de esta época que se extiende primero de 1937 a 1940, y luego se reanuda en Nueva York, en 1942, con relatos como Esperando, Leonora alternan descenlaces en los que la protagonista pierde su rostro o muere, con aquellos donde el triunfo equivale a una implacable venganza contra quienes separan a los amantes, y con la muerte ritual del amado cumplida por las protagonistas como un modo simultáneo de retenerlo y liberarse del miedo al abandono.

La descripción de Monsieur de Cyril de Guindre, en el cuento así titulado, hace eco al retrato que Leonora le hizo a Ernst: él aparece descansando en "su lecho azul hielo", puede moverse como una serpiente, y "a pesar de sus años, es muy guapo": su rostro es el de una orquídea albina, su "ávida boca violeta es una abeorquídea venenosa como un insecto lunar”, y ella se pregunta: “¿Dónde podría encontrarse un animal de pelo tan raro como su cabello?" (44). Como Drusille, una de las Dos hermanas, esa Leonora tan joven como osada y tan osada como capaz de una imaginación encabritada, podría decir, tras las ausencias de Ernst, "yo no he tenido otra cosa que soledad durante demasiado tiempo" (57) y estar dispuesta, como su personaje, a beberse la sangre del amado para retenerlo. O puede verse reflejada en la joven de Esperando,con el pelo desgreñado, tan absorta que un insecto se para en su boca sin que ella se mueva, porque espera a Fernando y ya no le quedan lágrimas: "He probado a pellizcarme los pechos y 
pensar en la muerte; no me ha servido de nada" (73). En este relato ocurre un revelador diálogo entre dos mujeres:

-El pasado- dijo Elizabeth, soltando a los perros-. El adorable y vivo pasado. Hay que revolcarse, revolcarse literalmente en él. ¿Cómo puede nadie ser persona de calidad si elimina sus espectros a fuerza de sentido común?

Se volvió hace Margaret con ferocidad y se rió en su cara.

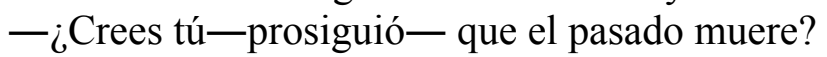

—Sí- dijo Margaret—. Sí; si el presente lo deguella (74).

Pero incluso sabiendo que el pasado ha sido degollado, Elizabeth sigue convocándolo. Cuando ve dos ratones saltar de las sábanas arrugadas exclama: "Ha habido tanto amor aquí dentro que hasta los ratones vuelven... Es como el tictac del reloj; tienes que poner mucha atención para oírlo; luego, una vez que lo has oído, no puedes dejarlo de oír" (75). Por eso se pone algodones en los oídos. No quiere oír ese tictac, pero tampoco "los ruidos de fuera", que la aturden.

En el libro que Leonora dictará en 1943 cuando ha ido y regresado del infierno, Down Below (Memorias de abajo) cuenta cómo, después de que se llevaron a Ernst la última vez — tras haber pasado juntos los días festivos de diciembre de 1939-, esutvo 24 horas provocándose vómitos con agua de azahar:

Esperaba aliviar mi sufrimiento con estos espasmos que me sacudían el estómago como terremotos (...) Había visto la injusticia de la sociedad, quería limpiarme yo misma primeramente y luego ir más allá. Mi estómago era el espejo de la tierra... (156).

\section{Memorias de abajo}

El miedo y la incertidumbre crecen entre mayo y junio hasta lo indecible. Leonora no soporta comer. Se va debilitando. Una pareja de amigos de Leonora, Catherine y Michel, pasa de visita a St Martin d'Ardèche y la encuentra en un estado lamentable. Le aconsejan que huya con ellos hacia España antes de que los cerquen las botas alemanas. 
El hotelero, Vigne, a quien le debe alimentos, vinos, la conmina a pagarle. Leonora no tiene efectivo. Le deja un papel en el que le otroga poder a su mujer, Rose, para obrar en nombre de ella. Les deja la casa y toda la obra. Leonora ya no está en posesión de sí misma. Huye dejando vestidos, libros, cuentos, obras. Empaca todas sus posesiones en una maleta que tiene, debajo de su nombre, "una plaquita de latón en la que estaba escrita la palabra REVELACIÓN" (Memorias 158) ${ }^{159}$.

En algún punto del camino, donde se detienen a descansar en un paraje, hace un pacto con la montaña que rememorará después y que revela ciertamente hasta qué punto la cercanía de sus personajes con las criaturas de la naturaleza, en las que encuentran aliados incomparablemente más confiables que en los humanos, corresponde a su propia relación con ellas:

Me propuse a mí misma un acuerdo con los animales: con los caballos, las cabras, las aves. Tuvo lugar a través de la piel, mediante una especie de lenguaje del 'tacto' que encuentro difícil describir, ahora que mis sentidos han perdido la agudeza de percepción que entonces poseían. El hecho es que era capaz de acercarme a animales que los demás seres humanos hacían huir precipitadamente (161).

Así puede intercambiar caricias con una manada de caballos que huyen cuando sus amigos se acercan. Quizás, la reserva de confianza que ese pacto le provee, sea una de las fuentes de las que extraerá fuerza cuando esté a punto de ser completamente destruida. En el camino a España la demencia le da caza. Ese olor a muerte que era un motivo constante en muchos de sus cuentos ha traspasado las fronteras y se ha colado en la realidad. Ahora huele la muerte en su propio cuerpo, y hay lugares donde se acrecienta esa percepción. Le ocurre en la población de Perpiñán, al sur de Francia, donde el aire le huele a muerte, incluso sin que sepa entonces que hay un inmenso cementerio militar. $\mathrm{Su}$ 
estado de desasosiego llega a ser tan intenso que se agarrota hasta el punto de que pierde el control de sus movimientos al llegar a Andorra: "De noche, mis nervios exacerbados imitaban el ruido del río que corría sin cesar sobre rocas, hipnótico y monótono" (160).

Llega a creer que es realmente Alicia en 39 o la reencarnación de Isabel de Inglaterra: que puede o debe sostener sola el peso del mundo que está congelado bajo el embrujo de los nazis. La llegada a España exacerba aún más su estado: "Pensé que era mi reino; que su tierra roja era la sangre seca de la Guerra Civil" (162). Cree que Madrid es el estómago del mundo y ella la elegida para devolver la salud a ese órgano digestivo. En un hotel de Madrid la violan unos oficiales requetés. La dejan en un parque con la ropa destrozada y cuando llega al hotel pasa esa y las noches siguientes bañándose una y otra vez con agua fría. La presencia de Van Ghent, un holandés que le enseña un pasaporte plagado de esvásticas la desquicia aún más e imagina que la Guerra Mundial está dirigida hipnóticamente por Hitler y personas como este hombre. Se aparece en el Consulado de Inglaterra para informar al cónsul que hay un complot para destruir el mundo y que ella podrá salvarlo. Por intermediación de su padre acaban encerrándola primero en una habitación del Ritz donde comienzan a medicarla. Temporalmente la llevan a un sanatorio de monjas que, tal como le ocurría con las escuelas de su infancia, son incapaces de controlarla. Una mañana la visita un médico que escucha su versión del complot y ordena llevarla a un sanatorio en Santander. Le inyectan anestesia. La llevan dormida a la puerta del infierno a donde entra el 25 de agosto de 1940. "Y me entregaron como un cadáver al doctor Morales", en Santander. Es la entrada a Down Below, Memorias de abajo. 


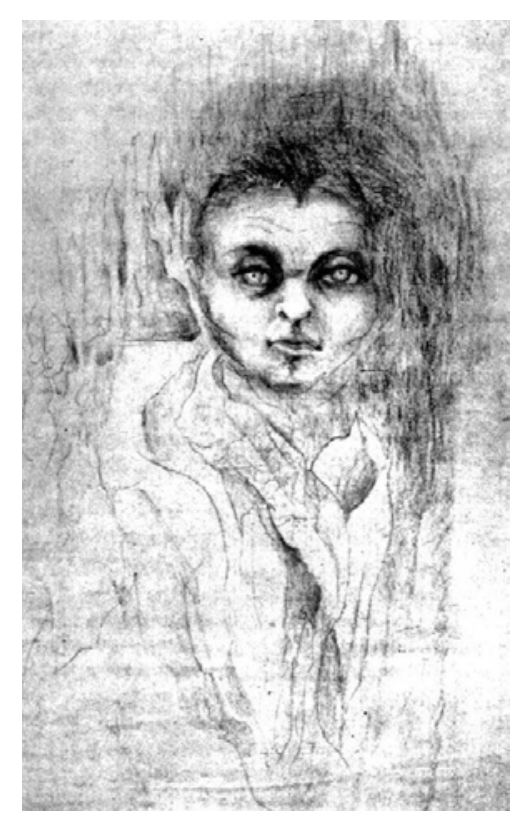

Ilustración 74: Leonora Carrington: Retrato del doctor Morales.

Para imaginar lo que vivió, encerrada en un pabellón para locos peligrosos e incurables, a los 23 años, es necesario leer las memorias que escribiría exactamente tres años después, a instancias de Pierre Mabille, el médico surrealista que también había abandonado Francia en 1940. Y ver la pintura que titula exactamente así, Down Below, y a la cual me referiré más adelante. Cuando Mabille lee el texto le dice que es una visionaria que ha escrito un tratado del sufrimiento y que nunca debieron someterla al horror que le impusieron al aplicarle Cardiazol, un medicamento que producía terribles convulsiones. Leonora dice que escribe el libro para conservarse lúcida y para conservar una posibilidad a la que jamás renunciará: “...ponerme y quitarme a voluntad la máscara que va a ser mi escudo contra la hostilidad del conformismo" (155).

Se despierta con las manos y los pies atados con correas de cuero. Don Mariano le había obligado a tomar alimento con unas cánulas introducidas por la nariz. Después habrá sucesivos episodios en los que Leonora intenta defenderse y se encuentra atada 
como un animal salvaje puesto que, según le dicen, ha saltado a lo alto del armario con la agilidad de un mono, ha bramado, rugido como un león, gañido, ladrado.

No sé cuánto tiempo permanecí atada y desnuda. Yací varios días y noches sobre mis propios excrementos, orina y sudor, torturada por los mosquitos, cuyas picaduras me pusieron un cuerpo horrible: creía que eran los espíritus de todos los españoles apastados, que me echaban en cara mi internamiento, mi falta de inteligencia y mi sumisión (...)

Creía que había un templo druida que había sido construido para ella...Creía que el mundo estaba congelado y que le correspondía a ella volverlo a poner en movimiento (Memorias de abajo 182).

Antes de que le apliquen cardiozol, al que llama el "Gran Mal epiléptico", tiene

un sueño que ha escrito antes, en los cuentos. Ve a dos grandes caballos atados el uno al otro:

Yo esperaba impaciente a que saltaran la valla. Tras largas vacilaciones, saltaron y bajaron la ladera al galope. De repente, se separó de ellos un caballo blanco, desaparecieron los dos caballos grandes y uno quedó nada en el sendero salvo el potro, que cayó rodando hasta abajo, donde quedó tendido de espaldas, moribundo. El potro blanco era yo (188).

Si se tiene en cuenta la visión de Chadwick sobre su obsesión por los caballos en ese período, se comprende que está llegando al punto límite del agotamiento:

Both the growing obsession with horses and the physical revulsion at the sight of food would shape her psychic response to the trauma; they also build upon a familiar visual and literary iconography of these years. Beyond all other images in her painting and writing at this time (and later), it is the horse that emerges as the most powerful signifier of psychic energy and freedom ( $D^{\prime}$ Un jour à l'autre 5). 


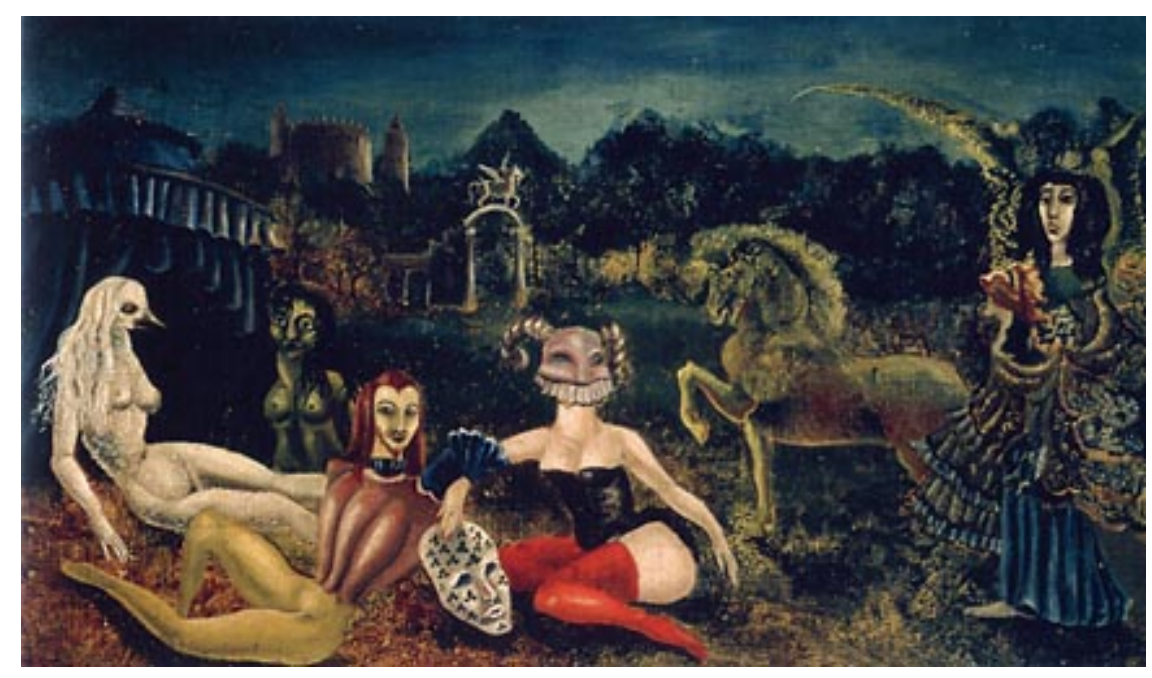

Ilustración 75: Leonora Carrington, Down Below 1941, Óleo sobre lienzo, Colección privada

La pintura que evoca esa estación en el infierno se titula Down Below, como sus "memorias de abajo" de la misma estación en el infierno. En un paraje nocturno se representa el jardín interior del asilo. La figura central, una mujer en traje de cabaret con medias rojas, podría parece placidamente sentada, pero en lugar del rostro tiene una máscara sin boca, o con una hilera de dientes gigantes que cubren desde la nariz hasta la barbilla. En la mano tiene una suerte de pulsera de tela azul, que duplica el cortinaje del asilo en donde está encerrada y sostiene una máscara blanca y masculina en la mano, cuya postura es forzada, como si una fuerza le torciera la muñeca. A su lado, hay otra figura mutilada: parece a primera vista una mujer, pero es un hombre que lleva en el cuello la misma tela azul del cortinaje. No tiene brazos ni manos, sino una suerte de pechera superpuesta, y el tronco desnudo carece de sexo. Otra figura de mujer, termina en una siniestra cabeza depájaro de ojos y pico negro y largo pelo blanco y aún hay otra mujer retratada desnuda con la mirada fija y el semblante inexpresivo del mismo tono verde-azul del paraje. Sólo aparece la mitad de su cuerpo. Frente a esas imágenes de 
desmembramiento, Leonora se retrata de pie y pese a que su faldón tiene también el cortinaje azul, se dibuja alas brillantes e iluminadas, como el mismo potro que está a su lado con la pata alzada, en una posición de trote que duplica la escultura que se ve en el umbral del asilo: un caballo con alas que bien podrían ser las de la jinete que lo monta. La pintura, ejecutada muy poco después de su salida del asilo, cuando vivió la experiencia de comprender que podía ser destruida, marca un sendero de liberación.

Condenada a estar en el pabellón de los locos peligrosos e incurables, padece el más insoportable de los sufrimientos: "la mirada de los demás" (193), hasta cuando comprende que actuar con sumisión será el único modo de salvarse. Con la intervención de un médico pariente que ejerce en Santander, un empleado de la compañía de su padre, la Imperial Chemical obtiene permiso para sacarla algunas horas del infierno. La lleva a cenar y le advierte que su familia la tiene destinada a ir a un manicomio en Suráfrica, a menos que acepte que él le ponga un piso. Ella se niega. Acompañada de una enfermera alemana que la ha cuidado en el sanatorio, llega a Lisboa donde debía tomar una embarcación para ser confinada. Pero Leonora está advertida y mucho más lúcida de lo que sus guardianes imaginan: recuerda que Renato Leduc, un intelectual mexicano a quien Picasso le había presentado en París, y con quien había departido brevemente en Madrid, es el asesor cultural del consulado mexicano en Lisboa. Así que convence a la acompañante que debe ir al baño, y se asegura de buscarlo en una cafetería con dos puertas, para escaparse por la salida de atrás, como en efecto lo hace. Toma un taxi y le pide que la lleve al consulado, donde se negará a irse hasta que llegue Leduc, quien encuentra una ingeniosa salida: casarse con ella. Viajan ya como esposos a Nueva York, donde van a coincidir con la bandada de artistas e intelectuales que lograron huir a 
América ayudados en parte por figuras como Varian Fry o Peggy Guggenheim, con quien a su vez se casa Max Ernst. En la autobiografía de su hijo Jimmy, él rememora que nunca, en toda su vida, vio una expresión semejante en el rostro de su padre -una incomparable mezcla de exaltación y desolación - a la que tenía la primera vez que se encontró con Leonora en Nueva York. Para entonces, ya había regresado a Saint Martin d'Ardèche, descubierto el traspaso desesperado de la casa, y pintando, entre otros cuadros, L'Europe après la pluie II, (Esuropa después de la lluvia), 1942, donde aparecen él y Leonora despidiéndose de cuanto fue su mundo. Una Europa que los ha expulsado arrojándolos a la orilla sin retorno de lo insalvable.

Muchos años después, un día de agosto de 2009, un colectivo de arte contemporáneo, el Grupo Surrealista de Madrid, conformado por Eugenio Castro y Noé Ortega, se desplazan al Parque Morales, "lugar donde se asentaba originalmente la clínica del médico nazi, con el propósito de llevar a cabo una exploración psicogeográfica del lugar”. Una vez les informan que aún existe la famosa clínica, se encaminan a ella dispuestos a cumplir una venganza simbólica, puesto que guardan una furiosa memoria de este episodio de la represión psiquiátrica, que conocieron a través de las Versiones del surrealismo de César Moro. A la media noche, escriben frases delirantes en las paredes, buscando "exorcizar el dolor de Leonora" (gruposurrealistademadrid.org).

Al llegar a Nueva York en 1942, Leonora escribe dos cuentos ya citados, El séptimo caballo y Esperando, que contienen la cifra de la indecible angustia de esas horas de un extravío infringido por la guerra y por la violencia de los tratamientos, y concibe el relato que Julio Cortázar (1914-1984) consideraba maestro en el género fantástico, Conejos blancos, donde una joven entra, por curiosidad, por mórbida atracción, a una 
casa de la que no saldrá jamás, porque el magma del espacio toma posesión de su propio cuerpo. Fue en esa época cuando en un mismo número, un periódico en Nueva York publicó un texto escrito por Leonora —El Pájaro Superior, Max Ernst- y el legendario retrato que él le había pintado en St Martin d'Ardèche, Leonora a la luz de la mañana. Una luz que duró tan poco. En ese año en que coinciden en Nueva York, cada uno casado con alguien que no ama, ella sigue escribiendo historias que contienen la intensidad de su relación con Ernst, y él sigue pintándola, mujer caballo que parte hacia lo ignoto, pero es innegable que el pasado ha sido degollado y están frente a lo irreparable. En el verano de 1942, Leonora se marcha con Leduc a México: nunca más volverán a verse.

El afán impostergable de ella, que hasta el final encontrará difícil nombrar ese tiempo sin sentir el vértigo de lo abisal, será sólo uno: crear un universo tan poderoso como propio. En las décadas siguientes escribirá otros textos y novelas $\operatorname{cortas}^{160}$, pero nunca con la frecuencia y la intensidad de los años en los que la figura de la caballa fue equivalente a su insurrección frente al padre, a la desbocada carrera de una libertad sin freno, al deseo de construir un pequeño paraiso a salvo del horror, y a la memoria desbocada de las pérdidas en medio de un mundo en guerra.

Germaine Gómez Haro (2011) hace una síntesis de lo que ocurre después de ese instante en que Leonora escapa por la puerta trasera y halla un "salvador" en Leduc, quien tomó su mano para ayudarla a saltar por encima del abismo en una vertiginosa decisión que cambiará no sólo su vida sino la constancia con la que inscribió su nombre en la historia del arte:

De Nueva York siguen el periplo hacia México, país que adopta como propio y donde permanecerá el resto de sus días. Integrada al grupo de artistas surrealistas transterrados en el que figuraban Benjamin Péret y Remedios Varo, Gunther 
Gerszo, Luis Buñuel, José y Kati Horna, Edward James, Esteban Francés, entre otras presencias fugaces, Leonora se divorcia de Renato y se casa con el fotógrafo húngaro Emerico Chiki Weisz (...). Su vida serena y discreta transcurre entre la ardua dedicación a su creación plástica y el oficio literario, y el estudio de las ciencias ocultas, la alanimal squimia, la mística, la cábala, la astrología, las tradiciones espiritistas, el chamanismo, de cuyas fuentes brotan numerosas referencias en su pintura (...) (Leonora Carrington La Inasible).

En cualquier caso, esa otra puerta de salida del retrete le permite continuar una creación prodigiosa e incesante que colindará con la historia del surrealismo en México, pero que hasta sus luminosos 94 años, se adherirá a un sendero único, inclasificable, en el que los pactos con los seres de todos los parajes de éste y otros mundos, se cumplirán no sólo en sus pinturas, sino en esculturas, tapices y pocos, exquisitos textos que seguirán entretejiendo alusiones míticas con un afinadísimo, culto humor. A los 93 años, cuando la visité en su casa y quise ahondar en su relación totémica con el caballo, se limitó a responderme, a lo Stein: "Un caballo es un caballo, es un caballo...”.

\section{Caballos translúcidos de un viaje eterno}

En las pinturas que Leonora hace después de su llegada a México, en 1943, y particularmente cuando se hace madre, el espacio doméstico de sus pinturas se transforma en un lugar sagrado, habitado por lo invisible (Aberth 57). Y, dejando atrás la repulsión por la comida que experimentó en 1940 tras la invasión nazi, recobra la cocina como un espacio alquímico, algo que ya había comenzado a experimentar de nuevo en Nueva York, donde Breton fue víctima de sus experimentos gastronómicos. Sin perder su poder hipnótico, ni la intensidad imaginativa, sus pinturas se transforman y encuentran

otra luz y técnicas como las veladuras, nuevos universos fantásticos a veces pintados entre transparencias. 
Janeth Kaplan ha descrito el poder del vínculo que Leonora Carrington y Remedios Varo, exiliadas que habían coincidido en París, construyeron al reencontrarse en México. Dice, con toda razón, que emprendieron el viaje a "la noche abismal de la memoria femenina", en palabras de Adrienne Rich y que juntas sondearon "las posibilidades del poder creativo de la mujer", si bien la influencia de la obra de Carrington marca los senderos posteriores de Varo, a quien su obra le devolvió la potencia de la imaginación encandilada. Asomándose a los libros de alquimia, cosiendo, cocinando, haciendo muñecas, y volcando todas sus visiones en el arte crearon universos comunes alimentados por la vida doméstica, los cuentos de hadas y sus inextinguibles espacios oníricos (226).

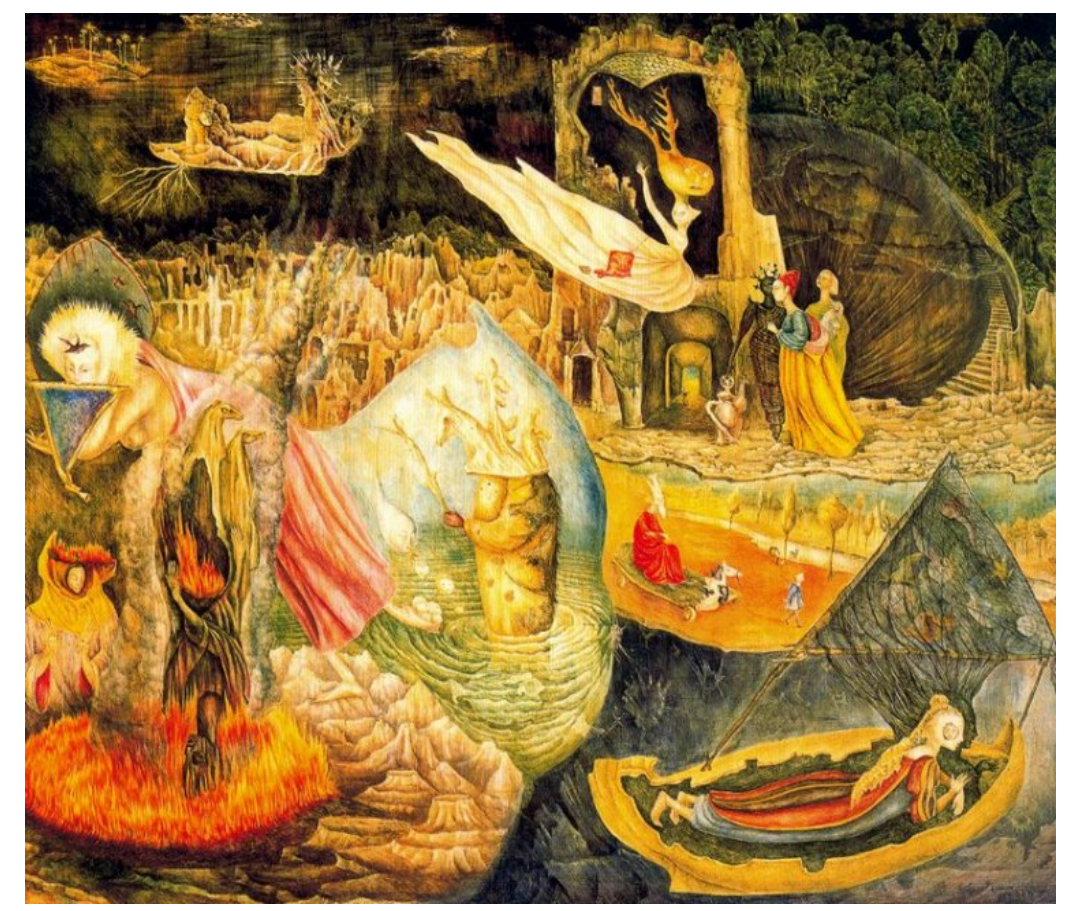

Ilustración 76: Leonora Carrington. Les distractions de Dagobert 1945. Témpera al huevo sobre masonita.

En Las distracciones de Dagoberto, 1945, hay figuras de niños en medio de las múltiples travesías de los personajes que recorren mundos. En un paraje una pequeña 
niña de traje azul tira de un caballo de manchas blancas y negras que da movilidad a un carrito de madera donde viaja, de pie, una figura barbada de manto rojo, quizás un rey. El paraje es soleado. Bajo este universo, en el plano inferior a la derecha, surge otro paraje: el cuerpo extendido de una mujer joven da forma a una barcaza que parece rodearla como una cáscara y transportarla en el aire; ella viaja protegida por una figura masculina cuyo cuerpo se funde a la vez con la estructura de la barcaza y de cuyos cabellos surge una vela de viento translúcida y llena de figuras maravillosas. En el rostro de perfil de la mujer puede verse la cara de un niño pequeño. En el mismo cuadro, se cumplen rituales de agua y fuego, y hay largas escalinatas y umbrales, volcanes y arboledas, y numerosos submundos que conviven de modo simultáneo y armonioso. Pero en la parte inferior izquierda hay un lugar que arde en llamas, un infierno, del que sin duda, la pareja ha escapado. Un tema que se repite en pinturas posteriores como veremos.

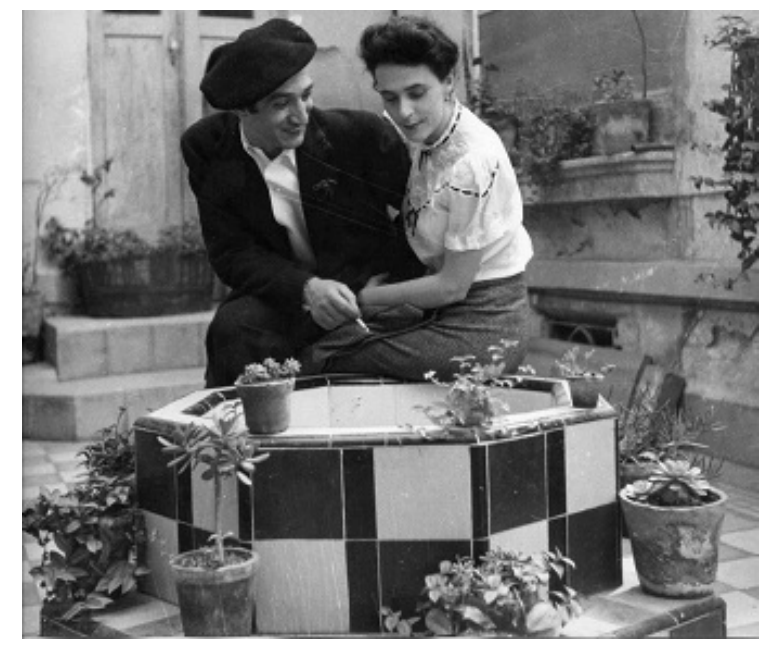

Ilustración 77: Kati Horna: Leonora Carrington y Chiki Weisz el día de su boda. 1946, La fotografía fue tomada en la casa de José y Kati Horna

Poco después de pintar Las distracciones de Dagoberto, Leonora se casa con el fotógrafo Emerico "Chiki" Weisz, que tuvo un papel fundamental en la documentación de la Guerra Civil Española y nace su primer hijo, Gabriel. En 1947, después del 
nacimiento de su hijo Pablo, Leonora pinta Chiki, ton pays (Chiki, tu país) una pintura prodigiosa en la que aparecen ella misma y Weisz fundido en una sóla figura y cubiertos por una tela roja, a modo de carruage, flotando y coronados por arboledas. En el catálogo de Sotheby's donde esta pintura salió a subasta en 2009 (estimada en un valor entre 1.2 y 1.6 millones de dólares) se calificaba como un cuadro excepcional, reafirmando la representación de la pareja flotante que se eleva por encima del infierno que aparece en la parte inferior izquierda del cuadro. Ambos, ciertamente, habían salido de lugares del infierno contiguos. Como narra Silvia Cherem (2007) Imre Weisz, nombre que se españolizó como Emerico Weisz Schwarz, cuyos apellidos en alemán significan blanco y negro, nació en Budapest, Hungría, en 1911, país que dejó en compañía de un amigo y extraordinario colega de oficio, el fotógrafo Ernö Andrei Friedman. Juntos llegan a pie a Berlín, donde permanecieron hasta el ascenso de Hitler, en 1933. Entonces, emigraron y de nuevo emprendieron camino hasta llegar, también a pie, a París, donde el fotógrafo David Seymour les ayudó a trabajar como reporteros gráficos de la revista Regards, cubriendo las movilizaciones del Frente Popular español. En julio de 1936, cuando ya Ernö había adoptado el nombre con el que escribiría la leyenda del más grande fotógrafo documental de guerra en la primera mitad del siglo XX, Robert Capa, se trasladan al frente para apoyar la causa republicana y se mantienen allí, junto con el fotógrafo Maurice Ochshorn, hasta la retirada en Cataluña. Posteriormente Weisz trabajó en la agencia de Magnum, fundada por Capa y Seymour en París, pero en 1940 corrió un destino similar al de Max Ernst: bajo el acoso del régimen de Vichy fue capturado y trasladado a un campo de concentración francés en Marruecos. Cuando logró escapar se ocultó en Marsella, donde vivían aglutinados los refugiados surrealistas como el poeta 
Benjamín Peret y Remedios Varo. Juntos se embarcaron en el "Serpa Pinto", el último barco que salió de Europa llevando judíos rumbo a América y arribaron a Veracruz el 1 de octubre de 1942. Dos años después, en 1944, en una reunión en casa de Katy y José Horna, Weisz conoció a Leonora, quien vivía entonces con Remedios Varo y Peret. Vivieron juntos 61 años. Pablo Weisz ha declarado que sus padres intentaron crear, con el arte, una realidad aparte de la guerra que habían dejado atrás. Weisz instaló su cuarto oscuro en su propia casa en la calle de Chihuahua y nunca más quiso cruzar una frontera. Cuando lo enterraron Leonora Carrington y sus hijos escribieron en su lápida una frase en hebreo: "Esto también pasará" (Cherem, Diario Reforma).

En 1949 Leonora hace una escultura única en la historia del surrealismo porque se trata de un objeto hecho para un niño: cuna. $\mathrm{Si}$, como apuntan los catalogadores de la casa de subastas de Chirstie's las camas tuvieron un elevado estatus en la iconografía del surrealismo como el locus de sus exploraciones de la sexualidad, los sueños y el inconsciente, la Cuna de Leonora refleja su "larga fascinación con el mágico potencial de la infancia": "Like the fairy tales she was so fond of reading, here was a bed shaped like a boat that could metaphorically sail a child into the wondrous land of dreams". En los cincuentas comienza a experimentar pintando sobre objetos de madera confeccionados por José Horna. A comienzos de los cincuenta hace dos esculturas que manifiestan su indestructible alianza con los reinos animales: Cat Woman (Mujer gato), 1951, una escultura de tamaño humano, cubierta con pasajes y figuras híbridas de animales, y $I$ Want to Be an Insect (Quiero ser un insecto), y en 1954 pinta una serie de caballos un disco construido para girar como un trompo. En el catálogo de Christie's sobre su obra Cuna, hay una precisa descripción de su obra en este tiempo: 
For a woman so dedicated to elevating the status of woman by reclaiming the magical powers of domesticity La cuna can be seen as directly related to her painting from 1947, Night Nursery Everything, which shows a child, in a barklike cradle suspended magically in the air, watching mysterious figures cavorting in the nursery. Like other pieces of surrealist furniture, La cuna is meant to transcend the merely functional, and instead transport both the viewer and the fortunate child into the fertile realm of dreams (Christie's).

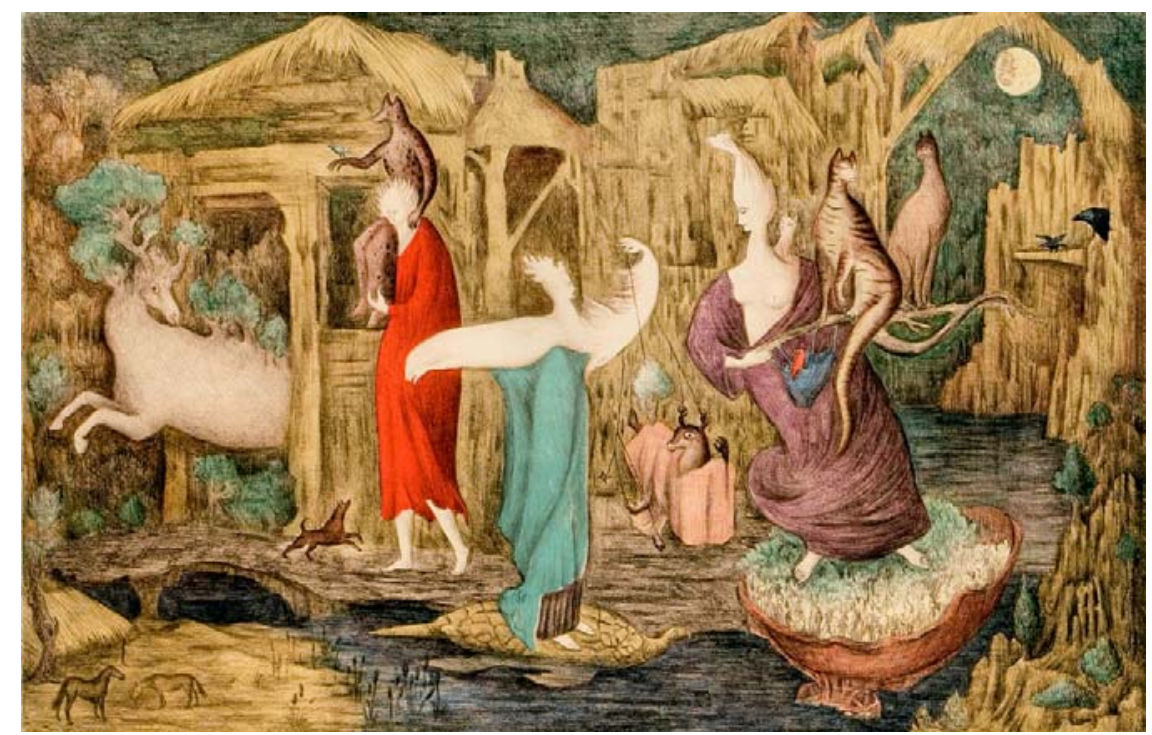

Ilustración 78: Leonora Carrington. Tuesday

1946. Témpera al huevo sobre panel.

En la pintura Tuesday, de 1946, el paraje natural tiene la forma del interior de una casa en la que entra la luna y caben estanques y orillas. Las tres figuras femeninas son tan luminosas que sus rasgos apenas se notan. La mujer del centro, vestida de aguamarina, alza los brazos alados, semejantes a los de un ave blanca y mira una de sus manos como si detuviera en el gesto de alguna danza. Las otras dos mujeres llevan consigo animales antropomórficos. Una, con una túnica semejante al color rosa "ruano" que Leonora le otorga a uno de los caballos de sus cuentos, tiene el pecho desnudo, y sostiene una rama en la que se posan tranquilamente varias bestias fantásticas. Un inmenso gato que sonríe, un animal de piel a rayas y rostro humano, y un pequeño gato que parece nacer de su espalda. Otra figura humana, de manto rojo, carga suavemente sobre su hombro un felino 
de piernas humanas que a su vez extiende el brazo para que en él se pose una pequeña ave. $\mathrm{Y}$ al fondo, entre el interior y el exterior de la casa-paraje, está la figura maravillosa de un caballo blanco sobre cuyo lomo y cabeza crecen verdes arbustos. En la parte inferior, a la orilla de un riachuelo, pastan tranquilamente dos pequeños caballos. Lo que se advierte, a cambio de la lucha y el combate de la pintura de otros tiempos, es la visión de un mundo de vínculos renovados entre todos los reinos.

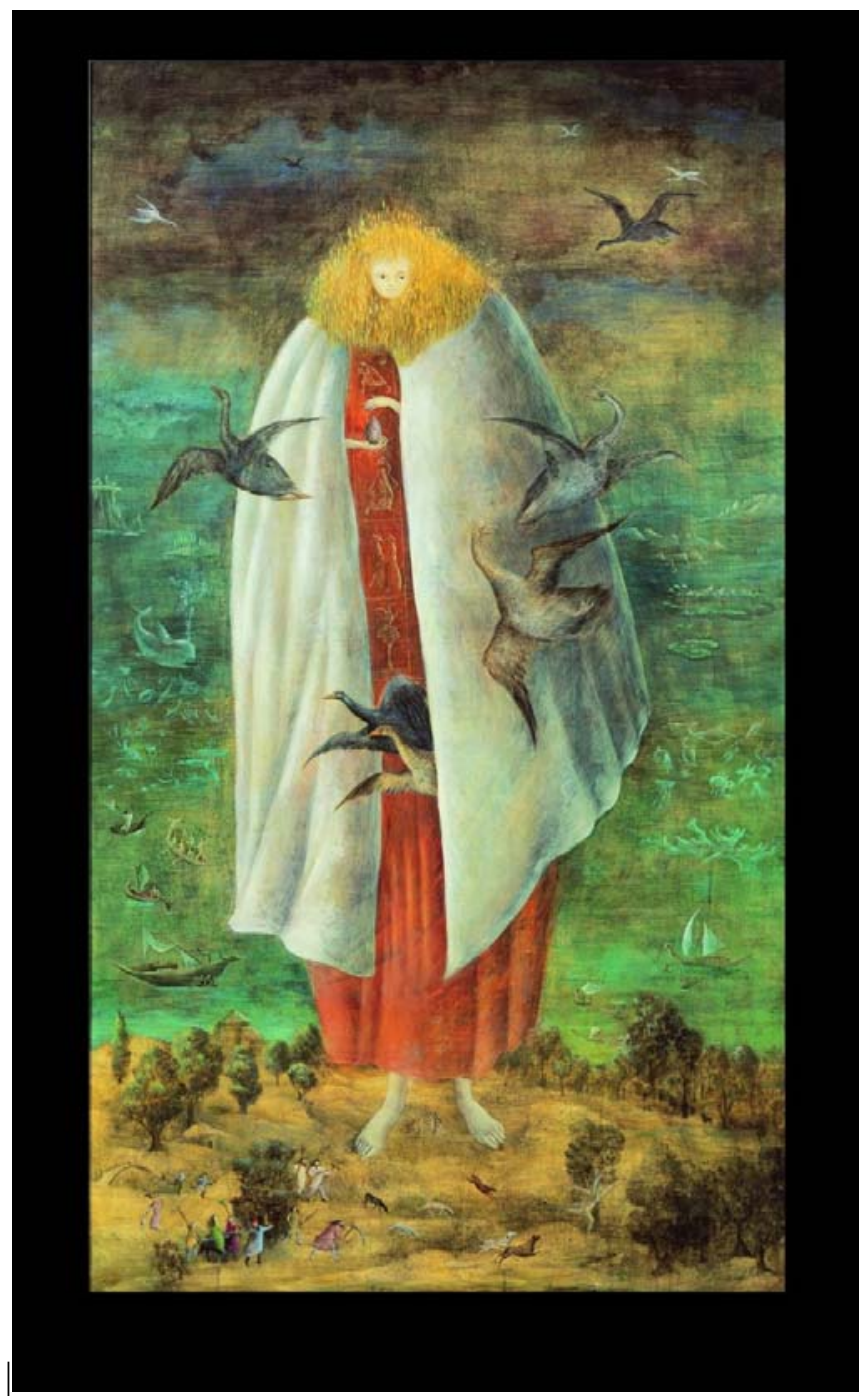

Ilustración 79: Leonora Carrington. The Giantees 1950. Óleo sobre lienzo. 46 x 27”, Colección privada 
Una década después de haber retornado del descenso a la frontera del pavor y del delirio, Leonora pinta una giganta. Pero no es la Alicia fantástica que carga el peso del mundo. Es una mujer que está de pie, descalza, sobre un valle en donde los hombres, tan pequeños que son casi invisibles, están de cacería, y su tronco se eleva por encima del mar y sus criaturas hasta llegar a los confines del cielo donde comienza la noche. De tu capa blanca parecen nacer todas las aves del mundo, y en su pecho cubierto con una túnica roja, están dibujados los niveles del misterio. Delicadamente sostiene el mismo objeto que en La trompeta acústica, se describe con una adivinanza: La corneta acústica se enuncia esta adivinanza: "Tengo un sombrero blanco sobre cabeza y cola. Sin falta llevo mis sombreros todo el tiempo. Mi cintura arde alrededor de mi panza. Siempre giro en círculos, aunque no tengo piernas" (188): el huevo. Por eso, esta pintura cósmica y serena, de indescriptible belleza, se conoce también como La guardiana del huevo.

La década de los cincuenta es de una creatividad prodigiosa en la que además está rodeada en México de un poderoso círculo de creadores, entre los cuales, además de los atrás mencionados, figuras Luis Buñuel, Wolfgang Paalen, y Alice Rahon. En 1953, una década después de haber escrito Memorias de abajo pinta la arquitectura fantástica de The Flying Ur Jar, que nos traslada a ese otro tiempo, mítico, del que habla Andrade. Los portales de la ciudad, vistos desde arribla, forman laberintos dorados, y sobre los puentes, en las terrazas, se observa la silueta de hombres y mujeres que llevan en sus cabezas un sombrero contenedor de mundos, como la Dama Oval y como tantos otros personajes. Algunos están armados con largas lanzas, pero no hay combate. Muchos marchan sobre caballos y hay también, en la terraza más alta, hacia donde asciende un carruaje, tres pequeñas siluetas de figuras híbridas. En el plano inferior un caballo blanco, casi 
translúcido, vigila. Y en otra terraza, hay una gigante cabeza de caballo, que se hunde en la piedra porque no es densa: está hecha de luz. Por encima de todo el paraje se eleva como un artefacto flotante una esfera aplanada, como una cebolla, con dos personajes femeninos cuyso cuerpos son garras blancas translúcidas. Y de modo casi invisible, en donde la ciudad — que bien puede evocar el antiguo zigurat de la ciudad sumeria de Ur que señala el título y que fue levantado a Nanna, la luna-, se funde con el cielo rojo, se observa la pequeña silueta de un caballo negro y una mujer acróbata que lo monta, portando una pequeña antorcha de fuego.

Sería exhaustivo y hasta cierto punto innecesario continuar enumerando las numerosas pinturas en las cuales aparecen caballos que van transformándose y adquieren una cualidad distinta de vuelo. Pueden ser figuras prometeicas, pero en lugar de enfrentarse con los dioses y poderes, coceando y pateando, ofician otro modo de magia. Lo cierto es que Leonora fue dejando de ser la encabritada mujer caballo, para encarnar en su laberinto doméstico la magnífica Minotaura, como en el mismo 1953, se pinta a sí misma en ese cuadro maravilloso que se titula "Y entonces, ellos vieron a la hija del Minotauro", en el que aparece desplegando mundos para sus dos pequeños hijos. Hasta el final continuará siendo una mujer exigente, impaciente con la imbecilidad humana, de inagotable ternura con todas las formas de vida, y capaz de multiplicar infinitamente en sus pinturas y obras tridimensionales las imágenes de su secreto tacto con el mundo, de su pacto con las bestias, de sus rituales de vida.

El deslumbramiento que para ella significó la maternidad no hizo menos intensa su naturaleza ignea. Mantuvo una mordaz lucidez semejante a la de su Marian Leatherby. Después de los 90 años, cuando un grupo de esculturas inspiradas en los personajes de 
sus cuadros llenaron toda la extensión del Paseo de la Reforma en Ciudad de México, concibió la idea de recorrerlo - muy a lo Virginia Fur - pero no en una bicileta vertiginosa como su personaje, sino en motocicleta.

\section{Leonora, Giordana}

La legendaria galerista Inés Amor, tía de Poniatowska, escribió en el catálogo de su exhibición retrospectiva de 1975 en el Center for Interamericans Relations, de Nueva York:

She had to descend Down Below! And to cut free from all her sentimental ballast for the sake of finding her absolute freedom which was indispensable in order for her to discover that New World, which she now bestows upon us (25).

Tres décadas y media más tarde, Leonora escribió un texto —en el catálogo de la exhibición retrospectiva en los Estados Unidos que itineró de Nueva York a Austin, Texas- evocando a las Furias, cuyo santuario fue enterrado, y dice que éstas prometieron a las mujeres que retornarían, desde lo más hondo del miedo y la vergüenza y finalmente romperían las puertas de la prisión, restaurando los misterios que fueron violados, robados o destruidos. Leonora misma parece haber retornado para pronunciar en cada pincelada un secreto milenario. Por eso escribe: “The Red Queen told Alice that we should walk backwards slowly in order to arrive there faster and faster (...) Footprints are face to face with the firmament" (24). 


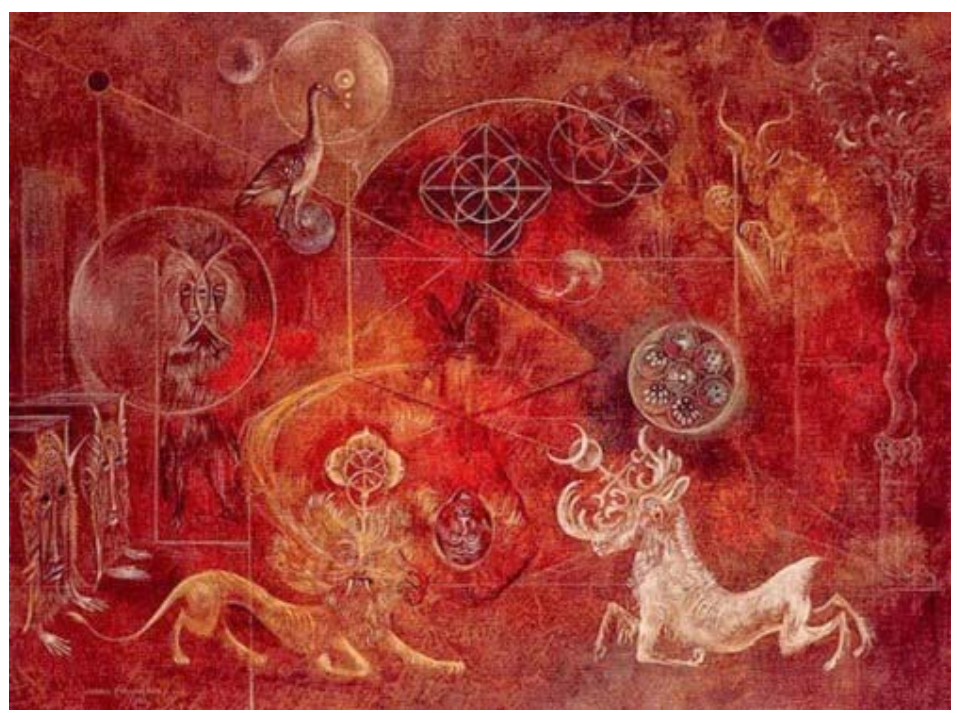

Ilustración 80: Leonora Carrington. Giordano Bruno

1964

En 1964, en su pintura Giordano Bruno, tan llena de símbolos herméticos como aquellos que buscaba el astrólogo para expandir su comprensión del universo infinito: hay figuras geométricas translúcidas que pueden contener el tronco de una figura híbrida y andrógina de dos cabezas ${ }^{161}$; o servir de rueda a un faisán maravilloso; o dar cuerpo al rostro de dos figuras hieráticas cuyos cuerpos son cubos y sus rostros se asemejan a madriles; o sugerir umbrales donde las líneas extendidas de triángulos unifican soles negros y planetas; o gravitar sobre animales simbólicos como el león de colmillos o el caballo blanco, que lleva en la cabeza el casco alado y cadúceo de Mercurio o de Hermes, el mensajero de los dioses, mientras el tronco corresponde más a la cabra que es, junto con el gallo, el animal que acompañaba a este dios mensajero encargado de conducir las almas de los muertos. En la cultura celta, todos los caballos eran considerados sagrados, y sus cadáveres eran sepultados para evitar que los devoraran los buitres. En el caso de esta pintura, no estamos ante la yegua blanca, sino ante un ser híbrido con cabeza de caballo, pero el casco está formado por una cornamenta de ciervo y acompañado por el símbolo 
mencionado de Mercurio que lo inviste de la función de conector de mundos: es una figura que puede traspasar los umbrales y guiar el paso a través de un universo concebido con infinitos y diversos niveles.

Entre las cabezas del león y del caballo, el observador descubre observa la cabeza invertida de un hombre que — se advierte después de una contemplación pausada— ha sido colgado de los pies, amarrados: Giordano Bruno, ante cuya figura se postran las dos luminosas bestias. El sabio mantiene los ojos abiertos, con la misma actitud con que pronunció su célebre última frase: "Tremate forse piu voi nel pronunciare la sentenza che io nel riceverla" (Tembláis más vosotros al pronunciar la sentencia que yo al recibirla), antes de que la Inquisición sellara su lengua quemándola con hierro. Como contraposición a su muerte hay diversas representaciones de la figura geométrica sagrada de la flor de la vida que se compone de varios círculos superpuestos y dispuestos de modo uniforme. A veces, como ocurre en las iconografías esotéricas que Leonora leía con avidez, los círculos no se cierran y dan lugar a arcos, y es probable que aludan también a las ruedas nemotécnicas del mallorquino Ramon Llul, que Giordano Bruno estudió con profunda admiración. En tal caso esta representación mística de las las formas fundamentales del tiempo y el espacio supone una afirmación de la fuente de la vida, y de su interconectividad: señalan el principio constructor del universo que el filósofo y astrónomo buscaba, pero también la inmortalidad última de quien fuera el primero en afirmar la infinidad del mundo. El rojo que pudiera ser el fuego en el que arde es también el color que unifica todos los campos, lo de abajo y lo de arriba, y que reafirma la unidad fundamental de lo existente. Leonora está representando la visión de la Mónada de Giordano Bruno (1591) quien sostenía que una figura particular podía evocar 
todas las cosas. Y cree, como su heredero en el siglo XVII, Johanes Kepler, escribiera en su Harmonices mundi (1619) que hay arquetipos para la creación del mundo.

De un modo no sólo instintivo, sino profundamente ligado a su ser, como una experiencia ontológica de una mujer que realmente podía oír gritar las coles cuando eran arrancadas de la tierra y les pedía perdón, Leonora reivindica en Giordano Bruno —en México vivió un tiempo en una calle que tenía su nombre- la propia legitimidad de su conocimiento rebelde. La descripción que en la Historia de la filosofía de Zeferino González (1831-1894) se hace sobre la cosmovisión del monje nacido en Nola a mediados del siglo XVI, es afin a Leonora y su arte, que estuvo a punto de ser amordazado para siempre en el manicomio español:

Para Jordano Bruno, como para los pitagóricos, Dios es la mónada primitiva, el ser absoluto, del cual emanan todas las cosas y que constituye la esencia de todas ellas. Esta mónada primitiva, al desenvolverse, produce y engendra todos los seres que aparecen en el Universo, de manera que su substancia está en todas las substancias singulares o fenomenales, $\mathrm{y}$ a todas las informa, vivifica y anima. El universo puede concebirse, por lo tanto, como un animal inmenso, cuyas partes todas, desde las más nobles y grandes hasta las más pequeñas, se hallan vivificadas y animadas por la substancia o mónada divina, que es como el alma universal del mundo (...) (Historia de la Filosofía Tomo III).

La tarde de un martes - como todos los martes al final de sus días- mientras Leonora cenaba con su hijo Pablo Weisz, conversaban. Hablaban acerca de cómo, "se pierde el sentido de una visualidad interna porque todo lo visual parece atravesar por las máquinas" (Dibujo, pintura y grabado 7) y, a instancias de Leonora, acuerdan hacer al alimón un pequeño libro, con poemas de Weiz, y pinturas o grabados de ella. Los textos de Weisz guardan ante todo una resonancia con esa poderosa visualidad interna que produjo una cosmogonía intransferible. Elijo, uno, que quizás contiene la imagen de su 
transcurso en este universo. Su título es el mismo del óleo sobre lino que lo acompaña: Laberinto, 1991.

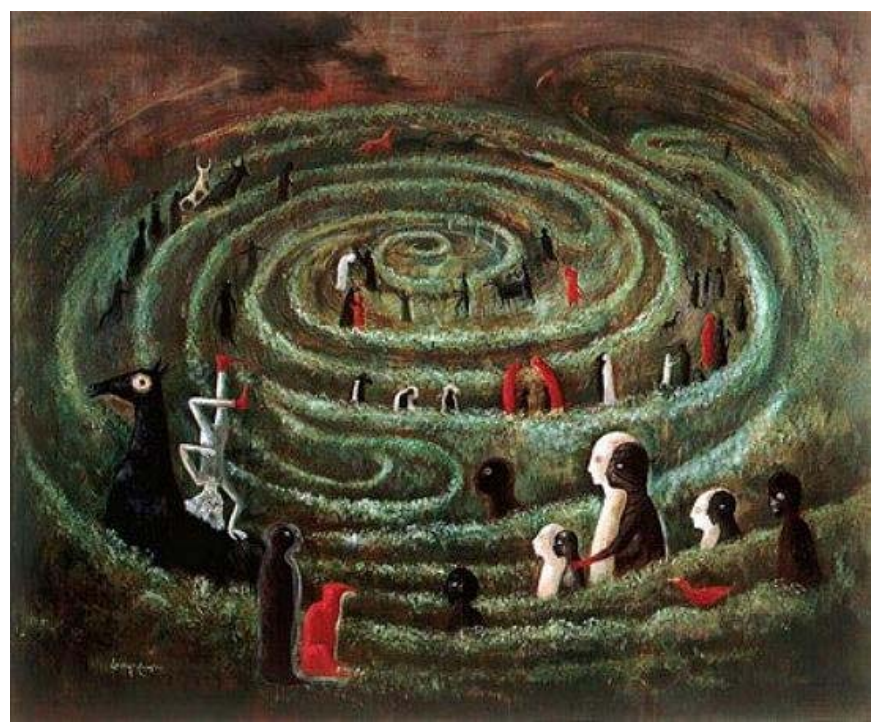

Ilustración 81: Leonora Carrington: The Labyrinth 1991. Óleo sobre madera, 30 x 36". Colección privada.

El corcel maravillado

Cabalga sobre su alma malabar

Al predicamento de

Sus pensamientos más

Profundos.

(.......)

Cuando comienza en serio el juego fantasmal reina el caos de la Dama de Luz ${ }^{162}$ (Dibujo, pintura y grabado 34).

La dama de Luz, la acróbata de botines rojos, está parada de cabeza sobre el corcel negro, cuyos ojos inmensos son los de una criatura maravillada hasta el fin y no puede saberse si va o viene del centro del laberinto. La vemos en el círculo más externo de su estructura. Es un laberinto que parece trenzado con hierba y que al tiempo tiene una cualidad móvil, como si aún no terminara su trazado. Ella, la acróbata, alter ego de 
Leonora, toda vestida de blanco sobre el magnífico alazán negro al que confía su equilibrio, es la única figura femenina entre todas las criaturas humanas y animales que marchan lentamente a veces en parejas, y que en lugar de buscar la salida del laberinto caminan adentrándose hasta su último centro. Pablo Weisz escribió que al final Leonora se encaminó lentamente hacia la muerte. La imagino evocando la lectura del Bardo Todol tibetano que le gustaba leer, ese inicio que augura que entraremos en los imaginarios que creamos, como fruto de nuestras diversas percepciones, y la visualizo en un paraje semejante a aquél que creó en su pintura Le gran adieu, con la geometría arquetípica del laberinto que fue, como el caballo, una imagen recurrente en su obra. ${ }^{163}$ En el universo que pinta en esta obra se fusionan la vida y la muerte, el caballo ${ }^{164}$ y el laberinto, el ser y su sombra, en el sentido jungiano.

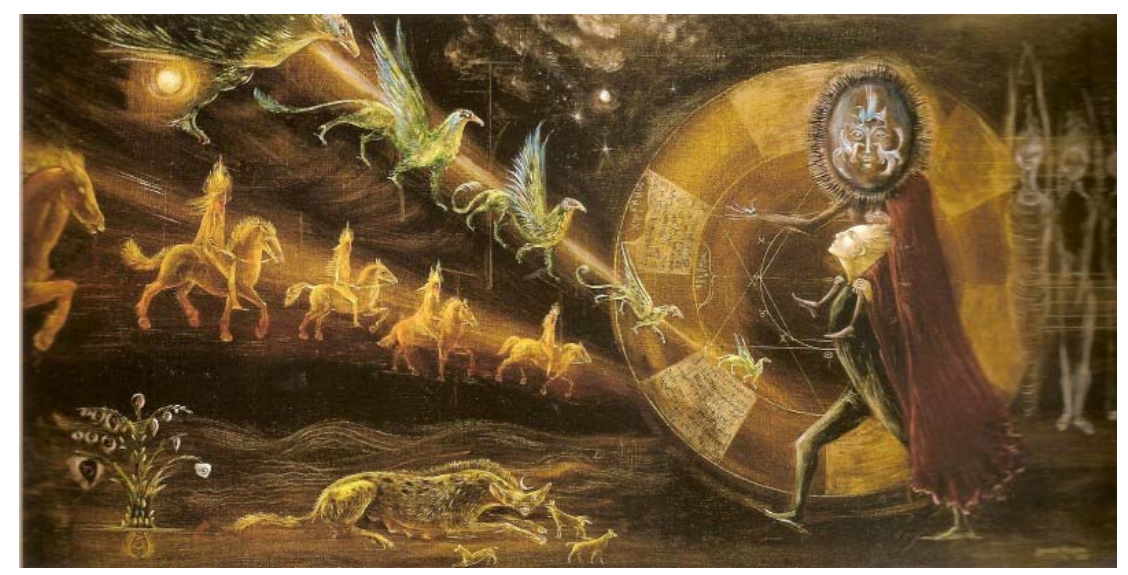

Ilustración 82: Leonora Carrington: Le gran adieu 1958

Veinte años después de su autorretrato Posada del caballo del amanecer, 193738, de nuevo vemos la hiena que amamanta y míticos caballos. La hiena de El gran adiós, 1958, es enorme y está en reposo: proporcionalmente su cuerpo tiene el tamaño de las laderas, mientras caballos tan pequeños que podrían confundirse con perros merodean 
a su alrededor. Las flores de la planta mágica a su lado tienen rostros y hay una doble marcha que parece mover el mundo. Una figura humana carga a otra criatura de manto rojo y cabeza oval, translúcida, en cuyas mejillas se repiten como espejos las híbridas esfinges aladas que caminan dirigiendose hacia adentro de la rueda de fuego que el hombre hacen rodar a medida que anda. Bajo las esfinges que marchan, otra multitud se dirige en la misma dirección: son corceles dorados montados por jinetes que aún teniendo piernas forman centauros pues sus cuerpos se funden con los de los caballos en la gran marcha cósmica que cumplen, caminando lentamente hacia el centro del misterio. Es una obra que transforma los animales dobles de sí misma, la hiena y los caballos, en figuras cósmicas que encaran un camino sin fin.

Toda la obra pictórica de Leonora es en cierto modo laberíntica: se sustenta de estructuras arquetípicas y se adentra en "el pensamiento del misterio". Dice Humberto Eco que desde Grecia, el pensamiento de la razón se propuso encontrar un orden que permitiera reducir la complejidad del laberinto, cuya imagen milenaria nos ha hablado desde siempre de la condición humana o cósmica (14):

Mientras el laberinto lo evocaba la imaginación, el pensamiento de la Razón procuraba eliminarlo. Naturalmente, cuanto más procuraba el pensamiento de la razón eliminarlo, más la Razón mística -o lo que es lo mismo el pensamiento del Misterio- lo reformulaba, y la historia del pensamiento hermético, desde la Cábala y el Renacimiento hasta nuestros días, está ahí para demostrarlo (15).

Cada uno de los tramos del laberinto que Leonora pintó y transitó extiende el hilo de Ariadna que se multiplica en direcciones simultáneas, pero acaba siendo una recta que permite transitar lentamente hacia la frontera de la muerte de la que en realidad se puede hablar tan poco como del origen último del arte. Como le dijera Leonora a la inglesa descendiente de sus antepasados que llegó a buscarla un día, siguiendo el rastro de 
aquella desheredada que había desaparecido y cuyos pasos estaban, para los suyos, cubiertos de una estela de silencio: "Usted está haciendo un esfuerzo desesperado por intelectualizar y está perdiendo su tiempo. Las visiones del arte provienen de otro lugar" (Leonora Carrington: Britain's lost surrealist).

Quizás ese modo de extrema ficción que supuso el deslizamiento del animal totémico de Leonora entre los universos escritos, pintados y vividos, y la fuerza que extrajo de todos los caballos que habitaron sus mundos nos permita imaginar otro estado de vinculación con lo existente. Como escribió Darran Anderson, quien advierte que su obra nos permite comprender no sólo que el arte y la imaginación pueden liberar nuestro pensamiento, sino que atentamos al cerrar la imaginación en cada oportunidad posible:

En un sentido, el modo en que ella miraba el mundo existió mucho antes de ese grupo de lunáticos profesionales que fueron los surrealistas, mucho antes que Bosh y Brueghel, mucho antes incluso que los primeros mitos memorizados. Con sus miradas de caracteres, narrativas y escenarios, sus pinturas sugieren no sólo que el arte y la imaginación pueden liberar nuestro prensamiento, sino también, por implicación, que atentamos al cerrar la imaginación ante cada posible oportunidad. En un sentido, el modo en que ella miraba el mundo existió mucho antes que ese grupo de lunáticos profesionales de los surrealistas, muchos antes que Bosch y Brueghel, mucho antes incluso que los primeros mitos recordados. Nació cuando nosotros nacimos y de desvanecerá solo cuando lo hagamos. Y aun así, en todas sus exploraciones de la tradición colectiva, Carrington fue y permanecerá, única (Leonora Carrington: de Celtic Surrealist). ${ }^{165}$

No es azar que en el obituario de Max Ernst que Jhon Russell escribió en The New York Times el 2 de abril de 1976, la frase con la que cierra se asemeje tanto y revele, una vez más, la profunda afinidad de estos dos seres que en su conjunción, pero también de modo individual e independiente, crearon un capítulo fascinante del poder de los deslizamientos del arte en los múltiples campos vitales: "Todavía había magia en la punta de sus dedos, como si tuviera el mismo dominio del lenguaje, la altiva y fiera 
postura ante la vida (...). Él se mantuvo hasta el fin como era: único en su especie” (Max Ernst, Catalytic Figure in 20th Century Art, Dies). ${ }^{166}$

Sobre todos los cultos cuya iconografía Leonora Carrington conjugó, en un cocido embrujado y con una mano indómita hasta el fin, Leonora Carrington se empoderó, desdoblando las fronteras del pensamiento hasta alcanzar el territorio de una imaginación que no se inclinó ante nada. Y ofició, en los dominios de la creación insperable de la vida, el arte de la ficción extrema.

${ }^{79}$ La vida del movimiento se suele enmarcar entre 1916 y 1922. El 1 de febrero de 1916 el joven poeta y director de teatro alemán Hugo Ball, traductor de León Bloy, pacifista y "bakunista", y su mujer, Emmy Jennings, bailarina y música, transformaron la taberna de mala nota del barrio popular Niederdorf, de Zurich, en el Cabaret Voltaire, un lugar al que regresaremos en el capítulo III. Ese mismo año, según Jean Arp, Tristan Tzara pronunció el nombre "Dadá" por vez primera: “Dadá se inventa en la boca". Ball congregó, de acuerdo a Patric Waldberg (1970) " a todo cuanto en el Zurich no suizo había destacado entre los poetas, artistas y músicos (...) a su alrededor se congregaron muy pronto Tristan Tzara, Jean Arp, Sophie Taubert, Marcel Janko, Walter Serner, Chirstian Schad, Hans Richter, Augusto Giacometti y otros...". En las veladas se exhibía a Picasso, a Artur Segal, a Arp y a Janko, y se leían poemas de Jarry, Laforgue, Rimbaud, Apollinaire, Max Jacob y André Salmon, además de las poesías simultaneístas de Henri Barzun y Fernand Divoire. Arthur Rubinstein interpretaba a Saint-Saens y no dejaban de escuchar las música de ruidos del futurista Luigi Russolo o las sonorizaciones de Edgar Varese: " De hecho, todas las corrientes poéticas y artísticas de la inmediata preguerra se amasaban en esta marmita intelectual de donde habría de surgir como el diablo de una caja de sorpresas, el 6 de febrero de 1916, si se da crédito a la leyenda, el mágico nombre Dadá (290-293). 1922 marca las dispersiones y desavenencias, irresueltas tensiones entre Tzara y Breton y entre éste y Picabia, particularmente a partir del "juicio" a Maurice Barrés. Entre estas fechas, según el mismo Waldberg, Tzara mantuvo esta "pureza del absurdo, esta súper negación activista que aseguró su fama (...). Su función de perturbador, la explosión de sus sarcasmos, así como el aquelarre verbal al que se entregó con más abandono que los demás, han podido hacer olvidar a veces la rara y preciosa calidad de su aportación poética" (295). Ya en 1921, Francis Picabia - a quien Waldberg llama “ el príncipe de la cuerda floja espiritual "- escribía en Esprit Noveau: “El espíritu Dadá sólo ha existido realmente durante tres o cuatro años. Fue expresado por Marcel Duchamp y por mí, a fines de 1912. Huelsenbeck, Tzara o Ball le proporcionaron el 'nombre clave' de Dadá en 1916. Con esta palabra, el movimiento alcanzó su cenit, pero continuó su evolución, con la aportación por nuestra parte del máximo posible de vida... Dadá me hace pensar en un cigarrillo que deja en torno a sí un olor agradable. La marca de estos cigarrillos se ha agotado, y cuenta con que un hombre de talento sabrá darle un nuevo nombre. Pero no pensemos ya más en el pasado, a pesar del olor de los cigarrillos. La vida no es más que una sombra: conservemos la ilusión de que nuestra cabeza la sobrepase ". (309) El Museum of Modern Art, MoMA, que fue el primero en mostrar en Estados Unidos una exhibición de dadaístas y surrealistas, extiende la duración del movimiento dadaísta hasta 1924. La exhibición de 2006, "Dada at MoMA", organizada por Michelle Elligott, archivista del museo, se anunció con un texto que evaluaba así el movimiento: "Dada sprang forth in Zurich, Berlin, Hannover, Cologne, New York, and Paris between 1916 and 1924. One of the most influential avant-garde movements of the early twentieth century, it was multifaceted and style-resistant, born in response to the disasters of World War I and an emerging modern media and machine culture. Dada artists led a creative revolution that boldly embraced and caustically criticized modernity itself. Pursuing innovative strategies of art making that included abstraction, chance 
procedures, collage, photomontage, readymades, performances, and media pranks, Dadaists created an abiding legacy for the century to come". El MoMA montó diversas exhibiciones dedicadas a investigar el movimiento Dadá, entre otros temas, como Fantastic Art, Dada, Surrealism (1936-37), Collage (1948), y Dada, Surrealism and Their Heritage (1968).

${ }^{80}$ Poco después de la muerte de Breton, Monte Ávila Editores reunió una serie de testimonios clave sobre el movimiento bajo el título La revolución surrealista a través de André Breton. En su ensayo El mañana Jugador. Sobre el porvenir del surrealismo, Maurice Blanchot escribió : “ “..el surrealismo, inseparable de Breton, lleve o no ese nombre, está llamado, por la fuerza misma que Breton le ha dado, a afirmarse como siempre futuro o como si jamás hubiera llegado a su meta: sin porvenir, sin presente, sin pasado " (13). En El surrealismo a pesar de todo, el artista Andres Masson, que por cierto fue el último en ser incorporado a la lista de Breton, hace una lúcida reflexión que evoca la sinceridad de la indignación surrealista, el poco tiempo que se requirió para que sus actos intelectualmente subversivos fueran apoyados por las mentes más inteligentes; el hecho de que hubo "una moral de club" con rehabilitaciones tan arbitrarias como las condenas, y la ironía de que lejos de lo previsto por quienes se adhirieron con una suerte de salvaje esperanza al Manifiesto surrealista de 1924 y a su moral de acción, ni la ética, ni la política se desviaron debido al movimiento surrealista, que a cambio, trascendió en otros campos. Describe Masson, con agudeza, en qué triunfó el surrealismo: " Dar al mundo erótico una mitología del deseo (...); imponer con insistencia y sin reservas a Sade y a Lautremont; hacer de Freud una figura casi popular (tal vez injustamente); intervenir, y ello fortuitamente, en las variaciones del gusto; inquietar a escritores, pintores y cineastas; y en menor grado, cambiar el decorado de la vida - trastornar las vidrieras de los comercios desde la Quinta Avenida hasta la rue Saint-Honoré, es algo". Y concluye : "Un movimiento se propone cambiar los valores. Fracasa. Lo que no se propone (al menos principalmente) : una estética que obsesiona, de influencia planetaria, triunfa. Seamos buenos jugadores : si bien el surrealismo no ha creado un nuevo orden, diremos, a pesar de todo, que el surrealismo no ha dejado de tener importancia si se acepta que puede tenerla, para animar una existencia, alguna otra cosa que no sean los imperativos de la razón ” (42).

${ }^{81}$ Dada in Paris, de Michel Sanouillet, originalmente una tesis presentada en la Sorbona en 1965, publicada en una edición en francés ampliada y revisada por Michel Sanouillet en 2005, editada en inglés en 2009 por Massachusetts Institute of Thecnology, que lanzó en 2012 su primera edición de bolsillo en inglés, es posiblemente el estudio más profundo y comprensivo de este movimiento que alcanzó en la Ciudad Luz, tras la llegada de Tzara, en 1920, su máximo potencial de expansión, una renovación inusitada cuando ya se estaba extinguiendo en otros lugares como Zurich. Da igualmente cuenta de su compleja relación con el surrealismo que a partir de El manifiesto surrealista de 1924 de Breton, cuando, según Sanouillet, acabó transformándose, de una fuerza lírica y un clima de exarcerbada revuelta en un movimiento que explica sus intenciones y métodos y que se purifica, diluye y esteriliza en cierto modo. Además de su extensa investigación, y de un apéndice que compila la correspondencia entre Tristan Tzara y André Breton y entre ambos y Francis Picabia, entre otros documentos reveladores, Sanouillet, quien entrevistó y construyó una relación con muchas de las grandes figuras que lideraron el dadaísmo, aporta conclusiones reveladoras y cada vez más compartidas por historiadores del arte y curadores. Entre otras, reconoce la influencia determinante de Marcel Duchamp, el más emblemático artista dadá, pese a su voluntaria actitud de " borrarse ", y a su reserva a lo largo de numerosos eventos dadá : "It is clear that the 'Dada Spirit' would probably never have adopted the multiple, unequivocal, and varied forms that explain its current status without the presence before, during and after the movement's manifestations of a unifying, free electron: Marcel Duchamp. It is only through him that we can eventually sketch out a radically original structure of Dadaist 'thought' " (317).

${ }^{82}$ Como afirma Ulrich Bischoff: “El dadaísmo y el surrealismo no habrían sido posibles sin el descubrimiento consciente de lo inconsciente. Sólo así, teniendo en cuenta este trasfondo, se comprende por qué lo aleatorio, lo incoherente y lo erótico ocupan un lugar tan preponderante en la obra de los dadaístas y de los primeros surrealistas " (13). 
${ }^{83}$ En la inacabada obra de Michel Leiris sobre lo maravilloso, se plantea una relación entre Le merveilleux "moderne", y el surrealismo. Para él, según acota Ángel Luis Luján Atienza en Lo maravilloso moderno surrealista y el lenguaje de la poesía infantil y popular "lo maravilloso es "en suma, todo lo que puede resumir este término aún misterioso e impreciso: la SURREALIDAD [SURRÉALITÉ]" (Leiris, 2000: 4849)". Jemima Montagu aúnta que los artistas y escritores que formaron el núcleo de los disidentes surrealistas, que rompieron con Breton en 1929, se reagruparon en torno a Geoges Bataille. Leiris cofundó con él la revista surrealista "Documents", en la cual se hicieron paralelos entre el arte de los niños, el arte de la prehistoria y los trabajos automáticos de los surrealistas. "One issue even juxtaposed images of Miro's paintings wuth drawings by a six-year-old. Both Miró and Masson began to be viewed as artist who exemplified an untutored innocence, where imagery springs directily from the unconscious." (57).

${ }^{84}$ La Dame Ovale fue publicado en 1939 en París por Éditions G.L.M. y reunía un grupo de cuentos creados por Leonora entre 1937 y 1940. La primera edición fue de 535 ejemplares. Kathrine Talbot y Marina Warner tradujeron al inglés por primera vez los cuentos La dama oval, La debutante, La orden real, Un enamorado, y Tío Sam Carrington.

${ }^{85}$ Aberth hace una anotación clave sobre la mesa como objeto conector de mundos: " The tables hold items that we assume relate to their impenetrable narratives, in the case of the former an array of crystal spheres and in the later an assortment of foodstuffs (...)And Then They Saw the Daughter of the Minotaur (1954) and Hunt Breakfast (1956) are full of intriguing characters frozen in solemn gestures of iconic import. The tables hold items that we assume relate to their impenetrable narratives, in the case of the former an array of crystal spheres and in the later an assortment of foodstuffs. Sidhe, the White People of the Tuatha de Danaan of 1954 portrays the spectral sorceresses of the ancient Irish fairy race gathered about a table in a communal meal. The Chair, Daghda Tuatha de Danaan (1955), and AB EO QUOD (1956), the most hermetic works of her entire oeuvre, have as their focus a table upon which a large white egg and a rose comingle in an alchemical exchange of milky fluids. In all of these paintings the table acts as a doorway between the terrestrial and spiritual worlds, and the kitchen is now both the artist's studio and the alchemists lab. The full implication of what it means for domestic feminine space to become occult space imbues these works with a radical gravitas (The Alchemical Kitchen: At Home with Leonora Carrington 11).

${ }^{86}$ Patrick Waldberg evoca la importancia que tuvo París para el movimiento : "Sería traicionar la verdad del surrealismo el silenciar la función desempeñada por París — cierto París nocturno, mágico-erótico, asombroso y oculto - en la cristalización de la energía emocional y de la sensibilidad surrealistas. Los paseos y las citas en lugares convenidos no representaban simples pasatiempos o encuentros anodinos, sino más bien etapas de un ritual (...). Los jóvenes buscadores de oro perseguían una sacralización de todos los instantes, tanto en la calle como en los establecimientos elegidos para las confrontaciones y el diálogo" (15). Tal y como se leía en el primer número de La Révolution Surréaliste: "Los autómatas ya se multiplican y sueñan. En los cafés piden con prisa algo para escribir, las vetas del mármol son las gráficas de su evasión y sus coches van solos al bosque" (21).

${ }^{87}$ En el prólogo de La dama oval, Agustí Bartra menciona que el médico y escritor Pierre Mabille que fue profesor de la Escuela de Antropología en París, y perteneció al Círculo más cercano a Breton, evocaba cómo Leonora Carrington había aparecido antes de la guerra en el medio surrealista parisiense "como un personaje maravilloso. Delgada, morena, las cejas espesas, los ojos brillando con un fuego singular, sorprendía por una belleza que evocaba las princesas de la Escocia legendaria (sic), esos seres de gran ligereza que se escapan por los techos de los castillos medievales para galopar sobre caballos blancos salvajes y desvanecerse a una vuelta del camino de la landa..." (11). Dice a su vez Poniatowska que a Leonora no le importó demasiado que confundiera Irlanda por Escocia, dada la belleza de su frase evocadora.

${ }^{88}$ Marina Warner la describe en su introducción a The House of Fear (La casa del miedo), originalmente titulado La maison de la peur desde la perspectiva de lo que el grupo de hombres surrealistas ve en 
Leonora a su llegada a París : "Leonora Carrington was a very striking young woman with her oval face an black eyes, her long black hair and slender limbs; in her artlessness and innate, innocent perversity she seemed to have sprung out of the dream world as if directly summoned by the voices of the Surrealist at their authomatic séances, a real-life femme enfant who speacks of desire and has not yet grown up enough to grasp the full implication of what she says" (6). Warner y Paul de Angelis colaboraron con Leonora en la revisión de los textos traducidos del francés al inglés. La Maison de la peu (La casa del miedo) fue publicada en París como folleto en 1938 por Henri Parisot, quien decidió no corregir su ortografía. El tiraje de la primera edición fue de 120 ejemplares.

${ }^{89}$ El catálogo de la exhibición de sus pinturas y dibujos en la Pierre Matisse Gallery de 1948, que constituyó su primera muestra en los Estados Unidos, estaba encabezado por la cita de la literatura griega clásica que tanto apreciaban los surrealistas: "I am armed with madness for a long voyage" (James 11).

${ }^{90}$ Narra Aberth como habiéndose escapado a París sin ningún tipo de ajuar adecuado acompañó a Ernst a una fiesta que ofrecía el diseñador Marcel Rochas. Siguiendo al pie de la letra el consejo de su amiga la princesa Marie de Gramont, quien ante su preocupación de qué ponerse le respondió que bastaba con su belleza natural, escogió por atuendo sencillamente una sábana, a modo de toga, y se despojó de ésta en medio de la acalorada fiesta, quedando desnuda frente a todos. Al tiempo, como le dijo a Silvia Cherem, quien logró entrevistarla después de una verdadera cacería porque a ella no le interesaba hablar ni con periodistas, ni con académicos, se negó siempre "a ser objeto ". "Ella no coopera, no le interesa ", notó Cherem. "Desconfiada y frágil, se abriga en un caparazón de hostilidad. Asegura que la fama mata las relaciones y humilla al ser convirtiéndolo en un monstruo de consumo ". (Gatopardo, 2003, p.46).

${ }^{91}$ El título original de las memorias que Leonora le dictó a Jeanne Mégnen, la esposa del psiquiatra surrealista Pierre Mabille, era el término francés "En Bas".

${ }^{92}$ Una de las fotografías más icónicas de las mujeres del círculo surrealista fue tomada en Lambe Creek, Cornwall, Inglaterra, en ese 1937, por Roland Penrose : Lee Miller aparece sentada en las piernas de la bailarina Ady Fidelin, y Leonora Carrington apoya su mano derecha en el regazo de Nush Eluard. Las cuatro se ven en un plano medio y con los ojos cerrados, en una postura que haría pensar que se quedaron dormidas, de no ser por las tazas de café rebosante que Lee y Nusch sostienen perfectamente en sus manos. Hay una escena que nunca se fotografió pero que aparece recreada en investigaciones y novelas : las cuatro danzando desnudas una noche en la campiña inglesa, iluminadas por los faros de los autos de sus compañeros surrealistas. Poco después Leonora abandona Inglaterra y jamás volverá a ensombrecer la puerta de la casa del padre. Desde cuando llega de Londres, se instala con Max Ernst en el 12, rue Jacob.

${ }^{93}$ Jemima Montagu apunta : "Eluard and Gala had married when they were both very young and quicky discovered that their voracious sexual appetites were not suited to the monogamy of a conventional relationsship. However, although Eluard's love poetry was fuelled by idealisation of women, Gala remained his most constant muse. Their open marriage tolerated many affaris until Gala fell in love with Salvador Dali in 1929." (27).

${ }^{94}$ El Ubu roi, de Alfred Jarry (1873-1907), había sido ascendido por Max Ernst a Ubu Imperator en su obra, de 1923, un óleo sobre tela, que lo recreaba como una inmensa construcción-trompo, con un rostro caricaturesco, y largos cabellos verdinegros, deslizándose por un paraje desértico bajo un cielo azul, en el que un alargado pincel hace un trazo que a la vez puede ser una sencilla línea vertical con su sombra, e insinuar la arista translúcida de una puerta de vidrio que, como en muchas obras de Ernst, empuja a un más allá del plano visible hacia una consciencia teatral de la propia pintura que remite a su proceso e inquieta al observador. Las recreaciones de Ubú fueron múltiples. Es posible que una de las más controvertidas fuera el Retrato de Ubú, una fotografía de Dora Maar de 1936, que formó parte de la exhibición de objetos surrealistas en la galería Charles Ratton y se convirtió en una imagen icónica porque la artista nunca reveló cuál era el feto de animal real que fotografió en primer plano para recrear de un modo siniestro su figura malévola. 
${ }^{95}$ Es justamente la visita de amigos que realizan en 1939 Lee Miller y Roland Penrose — quienes viajaban desde Londres para pasar el verano con Éluard y Picasso - lo que permite el registro fotográfico de las obras extraordinarias que han creado Max y Leonora en la casa que comparten en el pueblo francés SaintMartin d'Ardèche y a la que han convertido en algo vivo.

96 Juntos organizaron la primera exhibición internacional del surrealismo en Inglaterra en estrecha colaboración con Edouard Mesens, Breton y Éluard, con frecuentes viajes entre París y Londres. Herbert Read se trepa en un colchón el día de la inauguración, 11 de junio de 1936, para pronunciar su discurso surrealista. Al tiempo, instigada por Savador Dalí, Sheila Legge se paseaba por Trafalgar rodeada de palomas, con un largo vestido de raso, la cara cubierta de rosas, empuñando en una mano una pierna artificial y en la otra una costilla de cerdo. Las fotografías de esta " fantasma surrealista" se volvieron icónicas. Durante tres semanas hay eventos en los que participan los invitados extranjeros. André Breton, vestido completamente de verde, da una conferencia titulada "Límites no fronteras del surrealismo"; Éluard convoca a "La evidencia poética". Dalí aparece en traje de buzo. Como narra Julotte Roche: "Acaba de pintar Premonición de la guerra civil; espera una cita con Sigmund Freud refugiado en Londres, pero ese día Dalí habla de su amor por Gala. ¿Es tanta la emoción que parece que vacila? En ese día canicular, Dalí se salva de asfixiarse, se estaba ahogando en medio de los cientos de personas que han venido a ver los cuadros de Picasso, Magritte, Duchamp, Mand Ray y Max Ernst " (36). Aunque no es el tema de este ensayo, es interesante mencionar la relación de correspondencia-diferencia que existe entre dos obras de Dalí que son las únicas para las cuales escribió un poema complementario: El gran masturbador (1929) y La metamorfosis de Narciso (1937), una obra en la que ya manifiesta su relación con los surrealistas tanto como el decisivo advenimiento de Gala en su vida.

${ }^{97}$ En su Manifiesto, Breton incluyó, a modo de nota de pie de página una lista de artistas que a excepción de Ucello, eran todos modernos : Seurat, Moreau, Matisse, Derain, Picasso, Braque, Duchampo, Picabia, De Chirico, Klee, Man Ray, Ernst y Masson. Si bien inicialmente el surrealismo se consideró un documento definitorio para determinados escritores y se asoció a la producción de textos automáticos que supuestamente revelarían el funcionamiento real del pensamiento, fuera de todo control moral o estético; la definición de arte surrealista visual iría consolidándose, como acota Kim Gran (2005) en Surrealism and the Visual Arts a partir de ensayos como el de Max Morise Les Yeux Enchntés.

${ }^{98}$ Lévi-Strauss fue también embrujado por ella. Narra Fernando Savater en su prólogo del libro de Carrington Memorias de abajo, la historia de una tarde en la que Octavio Paz lo invitó a una cena en su casa en la que departirían con el gran antropólogo de Lo crudo y lo cocido y con Leonora Carrington que a última hora se excusó por alguna indisposición. Cuenta Savater que al enterarse de que no vendría, LéviStrauss, que hasta entonces le parecía "seco, agilado, omnisapiente, envuelto en el aura natural de inteligencia más implacable que he tenido nunca la ocasión de percibir", comentó que prefería que no hubiera podido asistir. Ante la sorpresa de los otros dos comensales, explicó : "La conocí hace treinta años. Era tan hermosa y estuve tan enamorado de ella, que no sé cómo habría soportado verla hoy".

${ }^{99}$ También en 1936, otra joven artista, Dorothea Tanning (1910-2012), quien contraerá matrimonio con Max Ernst una década después y vivirá con él hasta cuando éste muera en 1976, entra por primera vez a una exhibición que le revela el alcance del avant garde europeo de las dos últimas décadas: "Fantastic Art, Dada and Surrealism", curada por Alfred H. Barr en el Museum of Modern Art en Nueva York. Seis años más tarde, en el invierno de 1942, conocería a Max Ernst en una fiesta, que precedió la visita a su estudio, donde el surrealista se entusiasmó con el autorretrato que ella había creado con ocasión de su cumpleaños número 30. Tanning, con una blusa desgarrada que libera sus senos desnudos, mueve con la mano derecha la perilla de una de las múltiples puertas que se repiten entre los vanos de entradas y puertas dispuestas de tal modo que sugieren la idea de lo especular o lo infinito. La falda que lleva está formada por elementos orgánicos, y, como en los paisajes de Ernst donde la naturaleza devora la civilización, se entreveran formas corpóreas humanas y seres vegetales. A sus pies se levanta, como doble anímico, un pequeño animal mitológico, con alas negras, garras y rostro de murciélago, que según Alyce Mahon (2007) describe en Eroticism \& Art, es una criatura nocturna asociada a los espíritus de los muertos, o con el continente 
Lemuria que para los teósofos seguidores de Madame Blavatsky había estado habitado por gente con mágicos poderes. Concluye Mahon: "Tanning again creates an uncanny architectural space within which to stage female erotic power". En relación con otra pintura precedente del mismo año, Children's Game, precisa: "Tanning does not depict typical childish make-belief but a nightmare image of two girls in white Victorian-style nightdresses ripping wallpaper off the wall, a third child's legs and feet visible and seemingly lifeless in the foreground. As they rip the wallpaper it combust, flames becoming the wild hair of one as well as consummating the image of a naked woman underneath the wallpaper. The power of the child-woman, so vital for many male Surrealists, is given particularly violent edge as ripping cloth, hair, and paper shreds all evoke the electric power and this erotic potential of the young girl. These girls are half Lewis Carroll's Alice in Wonderland, half the Marquis de Sade's re-educated Eugénie! (153). Fue Ernst quien sugirió el título "Birthday" para la obra que entonces no lo tenía y consideró su inclusión en la exhibición de mujeres artistas que se preparaba para The Art of This Century Gallery, la galería de la filántropo y coleccionista Peggy Guggenheim, quien entonces estaba casada con él. En las memorias de Dorothea Tanning, "Between Lives", 2001, ella cuenta que el día en que un coleccionista expresó su interés en comprar la obra, Ernst enfatizó que no estaba a la venta pues esa pintura era parte de la vida de ambos. Hoy pertenece al Philadelphia Museum of Art. Los dos artistas, también jugadores de ajedrez, como aparecen en algunas fotografías, se casaron en Hollywood en una boda doble compartida por la pareja que formaron Man Ray y Juliet Browner, y vivieron una vida que tuvo como escenario lugares tan diversos como Sedona, en Arizona, donde construyeron una casa en una zona desértica a la que se acercaban amigos surrealistas como Rolland Penrose y Lee Miller o Yves Tanguy, tal como había ocurrido en la casa al sur de Francia que compartieron Max y Leonora, y otros legendarios artistas y creadores como el fotógrafo Henri Cartier-Bresson, el bailarín y coreógrafo George Balanchine o el artista Pavel Tchelitchew, que colaboró estrechamente con él en su compañía Les Ballets 1933 y el magnífico Dylan Thomas.

${ }^{100}$ En el cuerpo de este capítulo todas las referencias de Susan L Aberth son tomadas de su libro "Surrealism, Alchemy and Art", exceptuando algunos fragmento de un artículo suyo que se citan en las notas complementarias.

${ }^{101}$ En su ensayo "Carrington's Kitchen”, Katharine Conley hace una introducción que sintetiza algunas de las referencias clave sobre las implicaciones de la cocina de Leonora: "Everyone who has written about visiting Leonora Carrington in Mexico describes her kitchen. Edward James in 1948 called it a 'combined kitchen, nursery, bedroom, kennel and junk store' in a state of disorder that was 'apocalyptic.' 'For Carrington, everything begins in the kitchen,' Germaine Rouvre explained in the 1970s. Silvia Cherem, in the catalogue to the recent exhibition of Carrington's work in Dallas, describes the kitchen as 'a dining room, sitting room, and place to receive visitors,' centered on 'an old round table covered with plastic, surrounded by four chairs that resent the passing of time.' In the catalogue to another recent exhibition, Surreal Friends (2010), Stefan van Raay describes having 'had the great privilege of sitting around her kitchen table in Mexico City many times.' Homero Aridjis tells a similar tale of being led into the kitchen by Carrington: 'Once seated, she offered tea, tequila, or whiskey and took advantage of our visit to smoke a cigarette. On the cupboards and the refrigerator were post cards with reproductions of works of art featuring cats as well as the royal family of England and Princess Diana (...)Carrington's kitchen was her living, talking, and thinking space. It was her intellectual hub, her equivalent of Breton's study in Paris, as Jonathan Eburne has persuasively argued. Carrington's accumulation of various 'systems of knowledge production' that are visible in her paintings, wherein she actively mixes Celtic, English, Tibetan, Mayan, and indigenous Mexican traditions, constitutes an 'archival effect,' according to Eburne, comparable to Breton's accumulation of practices, which similarly stand as evidence that surrealism 'lived under an archival drive. (...)It was not a place where a visitor could feel completely at ease. Aberth explains how moving to Mexico in the 1940s prompted Carrington to develop her sense of "kitchens as magically charged spaces used to concoct potions, weave spells, prepare herbs and conduct alchemical "cooking" experiments.' The conversation and cooking that 'charged' the space were generative of Carrington's art and were both distinctly female in nature, if not always conventionally feminine. Her choice of the kitchen as a domestic space traditionally dominated by women was deliberate, even as she challenged sexist assumptions about the limits of what women could do.' " 
${ }^{102}$ En la pintura así titulada, como nota Aberth Leonora introduce un tema que aparecerá posteriormente en numerosas obras : la cena ritual sobre una mesa-altar.

${ }^{103}$ En el ensayo de Whitney Chadwick "D’Un jour à l'autre: A Tale of Love, War and Friendship", la autora profundiza en la relación de amistad y creación que surgió entre Leonora Carrington y Leonor Fini y revela un capítulo clave oscurecido por la poca atención que desde el inicio se ha prestado a las mujeres surrealistas. Tal y como precisa en la síntesis de introducción: "Surrealist histories tell us little, if anything, about the friendship that developed between the painters Leonora Carrington and Leonor Fini in the late 1930s, or about the importance of the intellectual and artistic exchange that took place between the two after Max Ernst"s arrest and imprisonment in 1939. Fini is primarily noted in surrealist literature for her refusal to join the movement officially and her resistance to Bretones authority. Carrington "es years in France before World War II are most often chronicled in relation to the better-known Ernst. The friendship is documented in letters written by Carrington to Fini in the autumn and winter of 1939. The correspondence that began in Paris in 1937, and intensified after Ernst" s arrest, affirms the strength of the bonds that existed among the surrealists, male and female. It also encourages a reassessment of the significance and enabling quality of female friendships for women artists in the surrealist circle. While the letters do not change the facts of Ernst"s imprisonment, or Carrington"s subsequent mental collapse (documented in Down Below, published in 1944), they provide important new material about Carrington"s creative life and her state of mind during this critical period. They point to the admiration of the younger artist for the already successful and independent Fini. And they register an independent creative intelligence that enabled Carrington to internalize trauma, register its effects viscerally and verbally and, ultimately, transmute its dynamics into artistic expression" (...) "Fini, interviewed at her summer home in St. Dyé-sur-Loire in 1982, observed with passion that in her view Carrington, "though never a surrealist ... was a true revolutionary!" (Papers of Surrealism, Issue 9, Summer 2011, pp12).

${ }^{105}$ Leonora Carrington escribió The Hearing Trumpet a fines de la década de 1950, cuando estaba en sus cuarentas, pero la novela, que contiene un ingenioso desafío al culto social a la juventud y es un canto al poder de la amistad femenina, sólo se publicó en 1976.

${ }^{106}$ En "Women Artist and The Surrealist Movement", Whitney Chadwick ve en ese retrato un signo de la temprana rebelión de Leonora puesto que el libro de Cocteau, publicado seis años antes, en 1930, había sido adoptado como una suerte de manifiesto por los adolescentes. Analiza cómo la desafiante boina, el humo del cigarro, la postura masculina, le dan una cualidad demoníaca, respecto a los valores establecidos de la época (68).

${ }^{107} \mathrm{Al}$ culto ancestral a los caballos que llevaba en la sangre celta que alimentaba sus venas y en la experiencia de asociarlo a ese vuelo al viento que por alguna razón sus hermanos no disfrutaban o apreciaban como ella y su madre, de modo que la relación con el caballo se enraiza en su infancia con el mundo femenino, seguramente Leonora sumó su conocimiento de la historia del arte. Los caballos aparecen, por ejemplo, en La adoración de los magos, de Tintoretto, en la Historia de Nastagio, de Botticelli, en las escenas infernales de El Bosco, en los dibujos apocalípticos de Durero, y en incontables retratos de nobles como en el que Ticiano hizo de Carlos V, y son figuras que hablan también de los instintos como en el Rapto de las doncellas de Rubens. Pero los caballos de Leonora son ante todo figuras especulares de otro poder, de ese ejercicio de sofisticada, aguda curiosidad, que pedía de sí misma: volverse de adentro hacia afuera, ir hasta el revés de sí, sin despreciar nada, sin ignorar nada. Son imágenes de una visión femenina de empoderamiento.

${ }^{108}$ Susan L. Aberth ahonda en el tema correlacionándolo con la configuración de una visión artística que tiene su fundamento en el simbolismo de las tradiciones religiosas y en su habilidad de mezclar referencias culturales. Narra que en París, Carrington conoció a Kurt Seligman y que estrechó con él su amistad en Nueva York, años antes de que éste publicara el libro que revela su profundo conocimiento en estas materias: The history of Magic (New York: Pantheon Books). "Not only did she embed alchemical 
symbols into the fabric of her magical realms, but her mixing of diverse religious an pictorial influences reflect her use of a theoretical alchemy (68).

109 Remedios Varo sintió tanto rechazo a la formación católica de su niñez, como Leonora. Leía infatigablemente a Alejandro Dumas, Verne, y Edgar Allan Poe y, como Leonora, fue habitante de un mundo intermedio, en el que las fronteras entre imaginación y realidad se diluían. Janet A. Kaplan escribe en Remedios Varo. Unexpected Journeys: "Varo believed throughout her life in the power of such dream images and in the blurring of boundaries between them and walking reality. She first developed these magical ideas in fanciful stories that she wrote as a child and buried for privacy beneath the stones of her bedroom floor. Thus began her preoccupations with an imagined subterranean life lived secretly under floors, behind walls, and within furniture (18). Juntas habían tenido como pareja a surrealistas mucho mayores que ellas, pero poseían sus propios reinos imaginativos. Exiladas en México, habiendo huido de la jauría fascista que asolaba Europa, emprendieron jornadas por los universos del ocultismo y saquearon las posibilidades de la cocina convirtiendo ese espacio en un lugar de confabulaciones alquímicas. Fue Remedios Varo quien enseñó a Leonora a coser muñecas, otra de las ocupaciones "femeninas" que juntas subvirtieron con un modo curioso de abrazar, entrecruzar, e invertir el conocimiento tradicional. Chadwick (1994) anota que su amistad las llevó a crear imágenes de transformación mágica y espiritual. Sus experimentaciones incluían materiales encontrados en los mercados de Ciudad de México, que las fascinaron por igual: hierbas, semillas, copal. Remedios Varo se rodeaba de cuarzos y Leonora Carrington "usaba la cocina como laboratorio alquímico, elaboraba pociones y mezclas especiales y divertidas (...) Juntas hacían experimentos pseudocientíficos e inventaban recetas mágicas. Varo inscribía "recetas y consejos para ahuyentar los sueños inoportunos, el insomnio y los desiertos de arenas movedizas bajo la cama" que tienen su origen en la adopción que el surrealismo hace del hermetismo.

${ }^{110}$ Kurt Schwitters (1887-1948) no entró en el movimiento Dadá berlinés porque Richard Huelsenbeck no quiso aceptarlo (lo calificaba de burgués y provinciano como lo evoca Roger Cardinal (1997) y si bien en Colonia Max Ernst lo recibió cordialmente, acabó instalando en Hannover su propio movimiento: Merz y creando en su casa una obra incesantemente transformada, su hoy legendario Merzbau, que crecía como un organismo vivo que a diferencia de las de Duchamp sería intransportable y creció -con materiales encontrados diariamente, incluyendo los objetos que tomaba de los visitantes - hasta atravesar el techo. En el dossier URSONATE del catálogo de la exposición en el IVAM sobre Kurt Schwitters, de 1995, se reproduce un texto, probablemente escrito por Isabelle Ewig: "La Ursonate (Moholy-Nagy reproduce esta palabra compuesta de difícil traducción como "sonata primordial", Arp prefiere "presilábica"), también llamada Sonate in Urlauten (Sonata en sonidos primitivos), nació en 1921, al regreso de la gira AntidadaMerz-Presentismus de Schwitters y Hausmann en Praga; surgió de la repetición compulsiva de Schwitters del primer motivo de un poema-cartel de Hausmann, "fmsbw" (...)Como toda partitura, la Ursonate también ha sido abeto de "interpretaciones" muy numerosas: Max Ernst dió una versión muy libre de ella en el transcurso de una velada en 1964, Ernst Schwitters la recitó íntegra en casa de Philip Granville en 1956. (http://www.costis.org/x/schwitters/audio/ursonate01.mp3) Más recientemente, Jaap Blonk, Eberhard Blum, Eric Erfurth y Arnulf Appel han dado diferentes versiones de ella. Las únicas imágenes que quedan de Schwitters recitando la Ursonate son fotografias (las de Man Ray en 1936, de Ernst Schwitters en 1944 y una lámina del álbum familiar que se puede datar de los años treinta). Un proyecto de film propuesto por Hans Richter en 1946 no pudo realizarse.". (http://www.merzmail.net/ivan1ursonate.htm) Transcribo la Introducción de Ursonante, de la cual pueden encontrarse diversas interpretaciones, incluyendo una animación visual de Daniel Rosales:

${ }^{111}$ Catriona McAra repasa la decisiva influencia de Lewis Carroll entre los surrealistas y compila una serie de trabajos teóricos de la posmodernidad inspirados en su figura : "Gilles Deleuze famously made use of the

Alice books in his Logic of Sense (1969), in terms of paradox and the undoing of fixed identity. Susan Stewart's book Nonsense (1978) surrealistically juxtaposed Bretonian and Carrollian language games, a play of puns and portmanteaus, enabling separate realities to collide. Recent readings have not only reclaimed Alice as a desiring body in her own right, but have suggested that she functions as the 
embodiment of the author or reader. Some of the most interesting interpretations have reread Carroll's Alice in terms of her " dysmorphic " bodily preoccupations and epistemological crisis".

http://www.surrealismcentre.ac.uk/papersofsurrealism/journal9/acrobat_files/McAra\%2013.9.11.pdf

${ }^{112}$ Max Ernst la había conocido en 1926 cuando exponía en la galería Van Leer en París. Él tenía 35 años y ella era una bella jovencita de 18 años que después de estudiar en el Convent desde Oiseaux, modelaba para madame Chanel antes de trabajar en la galería que años después dirigiría, cumpliendo un papel clave para varios artistas de la época. Max la rapta, el padre lo denuncia, envía gendarmes, pide que detengan al seductor y, sigue, según la expresión de Roche, "un corto de cine mudo" en el que Breton grita: "Se equivocan, ¡Max Ernst soy yo! ” y entre la confusión los enamorados escapan en un taxi. Se casan luego, en 1927. "Al principio del matrimonio, Max está tan prendado con la fantasía de Marié-Berthe. Ella recorta y despedaza sus vestidos, sus sombreros, fácilmente invita a la banda surrealista a cenar y para cuatro ofrece lo que era cena para uno, alargada con tres litros de agua. Max ríe, encantado. (Marié-Berthe) es inasible, los surrealistas la adoran, con sus bucles rubios apretados en la cabeza, parece un estárlet del cine, tiene veinte años, garabatea un retrato de Breton y él, dicen, la toma de modelo para su libro Nadja " (27). Por lo demás, en un diálogo que Poniatowska crea entre la esposa de Breton Jacqueline Lamba y Leonora, ésta le dice que Breton le aseguró que ella era su Nadja en un principio, pero que jamás la presenta como pintora y que lo cierto es que la verdadera Nadja acabó en un manicomio sin que él intentara nada para salvarla. En todo caso, Marie-Berthe pasa de ser adorada por los surrealistas a convertirse en un fastidio. La relación de Max Ernst y Leonora la hace asumir papeles de mujer víctimizada y victimizante, traicionada y trágica, capaz de emprender dramas de suicidios fracasados y de perseguir a su esposo con una obsesión mística que al cabo no impedirá que éste la deje por Peggy Guggenheim.

113 Ozenfant tenía un profundo interés en investigar la fuente de la emoción estética humana y estaba convencido de que las obras de arte no eran el resultado de una concepción estética abstracta sino de un significado artístico alcanzado a través de la maestría de la técnica. La capacidad artística de moldear la materia de acuerdo con las necesidades humanas eran la base de un sistema estético. Explica Kim Grant en "Surrealism and the Visual Arts" una de las diferencias clave entre puristas y surrealistas : "In the case of automatic writing, as Breton stated, it is the physic contact with pen and paper that both stimulates and concretizes the flow of thought. For the purists, a more traditional concept of technical mastery obtained, but they also consider the artwork as the result of a direct interaction between mind and material. The primary difference between Breton's theory of automatic writing and the Purist's theory of artistic creation, and it is an enormous difference, lies in their respective conceptions of the fundamental nature of human mind. For Breton, automatic writing was proof of the essential and irreducibly multiplicitous nature of thought and the human mind; for the purist, art was proof of the inherently rational, logical and ordering tendencies of the mind" (42).

${ }^{114}$ Uno de los aspectos más interesantes de esta obra es que, como señala Ulrich Bischoff (2003) "los planos de realidad se confunden gracias a la utilización de una puertecilla real de madera -que recuerda las rejas de una jaula que Ernst había construido-, y al simulacro de arquitectura sugerido por el marco y el tirador de madera" (33). Por otra parte, lo absurdo irrumpe en tanto no se comprende por qué la presencia del pequeño ruiseñor que sobrevuela la puerta puede desatar tanto pánico como para que una jovencita emprenda la carrera, blandiendo un cuchillo, y otra figura yazca en el prado donde se eleva una extraña casa sin ventanas, con una suerte de espátula por puerta, y en cuyo techo, una figura adulta masculina sostiene a un pequeño más bien fantasmal mientras estira su mano hacia la perilla que insinúa la posibilidad de que al abrirla surja otra escena o exista otro plano detrás del que contemplamos. Entre las interpretaciones autobiográficas de la pintura se ha sugerido como alusión, la conocida muerte de su hermana, ocurrida en 1897, y una de las alucinaciones de su infancia cuando un panel de Madera contiguo a su cama tomaba el aspecto de un ojo, una nariz, la cabeza de un pájaro, o un ruiseñor amenazante, según evocara Ernst, admitiendo que la obra hablaba de lo irracional.

${ }^{115}$ Después de servir como voluntario en la Primera Guerra Mundial, Baargeld abraza el pacifismo. Entre febrero y marzo de 1919 edita varios números de la revista satírica Der Ventilator. Su relación con el 
movimiento Dadá comienza con la alianza que establece con Ernst (y contra el expresionismo). Designándose como el grupo D (por Dadá) realizan una exhibición en la junto con su propio trabajo muestran pintores aficionados y productos industriales. En la exhibición "Dada-Vorfrühling ", en 1920, el grupo se nominó Dada W/3 e inclutó a Hans Arp y a Picabia. Baargeld utilizó el seudónimo Zentrodada para publicar los boletines dadaístas. Escribí poesía además de crear dibujos y ensamblajes y los poemas sin sentido de Arp lo llevan a hacer una suerte de poemas-collages. De acuerdo con los archivos del Museum of Modern Art de Nueva York, sus papeles se perdieron, probablemente destruidos y de su obra sólo se conservan 28 piezas, todas realizadas entre 1919 y 1920. De éstas, sólo una decena sobreviven como obras originales, otras siete son reproducciones, y de las demás 11 sólo se conocen sus títulos. En cambio, existen registros de sus creaciones literarias entre 1917 y 1926. Walter Vitt (2009) anota: "Baargeld's originality as a draughtsman is evident in several extant drawings, notably in the photomontage Typical Vertical Split Representing the Dada Baargeld (1920; Zurich, Ksthaus), in which he mounted a photograph of his own truncated head on to the Venus de Milo's torso set on a table without legs; his irreverent criticism is directed not only at the reverence for antiquity but more specifically at the tradition of sculptures displayed on plinths. Other works include The Red King (1920; New York, MOMA), a rendering in ink of an unworkable machine against a patterned wallpaper; The Human Eye and a Fish, the Latter Petrified (ink and collage, 1920; New York, MOMA), which anticipates Surrealism in its motif of a pierced eye; and Beetles (ink, 1920; New York, MOMA), in which a collection of lines and blots, together with finished and apparently incomplete images of beetles, allude to the process of drawing itself. As a 'pure' Dadaist Baargeld declined to pursue his artistic career after the demise of the movement. He became a professional mountaineer, using the name Isaiah, achieving a number of first ascents in the $1920 \mathrm{~s}$, and he took landscape photographs, particularly of the Alps (Cologne, Mus. Ludwig). He died during a snowstorm while descending the Aiguille de Bionnassay ". http://www.moma.org/collection/artist.php?artist_id=263

${ }^{116}$ Jean (Hans) Arp nació en Alsacia, una región qie se disputaban Francia y Alemania. Tras estudiar el la Ecoles des Arts Decoratifs en Estrasburgo y en la Académie Julian de París, conoció en Wimar a Ernst, Kandisnky y Klee y pasó luego cuatro años aislado en Suiza, en exploraciones que lo condujeron a la abstracción. En 1912 conoció a Sonia y Robert Delaunay en París, y coincidió con Kandinsky y los artistas del grupo "Blaeu Reiter", (El Jinete Azul) en Munich y comenzó a participar en sus exhibiciones. Cofundó com Tzara y Hugo Ball en Zurich el movimiento Dadá. Sus collages y relieves en madera fueron paralelos a la creación de sus poemas en francés y alemán. El método que utilizó en obras como Composición, 1920 consistió en : "...tearing up bits of papers and letting them fall arbitrarily to a pice of coloured paper." (Swinglehurst 19). A fines de los años veinte, estando ya casado con la artista Sophie Tauber y siendo parte del movimiento surrealista del que lo expulsaría luego Breton, en un episodio que dividiría a los miembros de la cofradía, hizo relieves con configuraciones poéticas y experimentó con composiciones dictadas por el azar.

${ }^{117}$ Durante la Primer Guerra Mundial, el rumano de origenTristan Tzara (Samuel Rosenstock/Rosenstein) escribió el primero de los textos dadaístas: "La Premiére Aventure cèleste de Monsieur Antipyrine" (1916). Posteriormente publicó su Manifiesto Dadá (1918), Conferencia sobre Dadá (1922), y Siete manifiestos Dadá (1924). Junto con Breton, Philippe Soupault, y Louis Aragon abrazó el escándalo como método y la desintegración del lenguaje como medio para remover el universo social de su tiempo.

${ }^{118}$ En su ensayo Surrealismo cita un exaltado texto inédito que Louis Aragon escribió en 1921 y que Roger Garaudy cita a su vez en L'Ítinéraire d'Aragon, París, 1961: "Había en nuestras intenciones una grandeza que escapa, un deseo que sin embargo participaba más del infinito de cuanto hoy podría creerse. No se sabía nunca, finalmente, qué efectos tendría una actitud nuestra: los acontecimientos podrán tomar un cariz imprevisto, no hay más que un paso de una imagen a la realidad; de pronto podíamos transportarnos, del modo más inesperado, a un nivel absolutamente distinto y desencadenar una máquina para trastornar el mundo". Walberg precisa: "Lo que habían experimentado individualmente los románticos: 'el sueño es una segunda vida' (Nerval), se hizo objeto de una verdadera revelación colectiva y se convirtió en el punto de partida de la búsqueda minuciosa de cada instante, con intención de transformar radicalmente los modos de sentir, de aprehender, y de concebir el mundo. En el umbral del sueño se halla la clave de la inspiración, y 
es el seno del subconsciente y, más allá, en las zonas ocultas de la vida inconsciente, donde se percibe el eco de la oscuridad" (9-10).

119 En 1914, el exrpesionista austríaco Oskar Kokoschka, incluido como Ernst, en la exhibición nazi de Arte Degenerado, había pintado un cuadro titulado La Novia del Viento o la Tempestad, en el que aparecía unido a su amante perdida, Alma Mahler, de quien estaba profundamente enamorado. La figura, está ligada a la mitología germánica y a los relatos románticos de hechiceras conocedoras de secretos de la naturaleza $\mathrm{y}$ herederas de las tradiciones paganas furiosamente perseguidas por inquisidores y reformistas.

${ }^{120}$ Hay poco que agregar al extenso y certero análisis que hace Aberth de esta obra. Comienza por describir detalladamente su atuendo andrógino -"Dressed in closely fitted riding clothes, she is seated with legs spread in a pose whose masculinity is reinforced by the absence of breasts under her shirt. Her jacket is sylvan green, her shirt an earthy brown and her bright white pants accentuate the curves of her muscular thighs. Forgoing utilitarian paddock boots, her pointy, black lace-up boots hint at Victorian-fetish and a menacing female sexuality (...) This androgynous Leonora is perched on a chair facing a lactating hyena both chair and animal serving to reveal aspects of her subversive rebellion against traditional femininity (...). The upholstered and skirted, boudoir-style chair marks yet another first in this painting anthropomorphic, sentient furniture (...). The carved armrest is hand-like, mirroring the figure left's hand, while the legs terminate in small, carved boots (...). Taking things a step futher, the read seat atop the skirted bottom of the chair could be viewed as the artist's genital doppelganger. Enthroned within the chair's vaginal centre, Carrington announces and owns her newly found sexual power" (32).

121 M. E. Warlick (2001) precisa que Ernst escribió esta introducción para un número de la revista View (1942) dedicado a su obra y anota que en su biografía mítica, Ernst explicó hechos de su infancia que sirvieron repetidamente como punto de partida para los temas de su arte (7).

${ }^{122}$ Apunta Bischoff: "La importancia conferida aquí a los hilos telegráficos, se refleja en el número de estudios al óleo que Ernst le dedicó en 1912 a ese motivo. Las vías del ferrocarril, los hilos telegráficos y los guardavías - personas iniciadas en esos "misterios" —, simbolizan la añoranza del muchacho de traspasar los límites del terruño (8).

${ }^{123}$ Dos pinturas de 1919 _ "Familienausflug" (Excursión familiar) y Aquis Submersus — son hechas a partir de apropiaciones de las obras de Marc Chagall y de Chirico y Carrà respectivamente, de tal modo que logra giros insospechados. Pero a partir el collage se convierte en el centro de su producción. Su punto de partida serán los objetos marginales, usados y a menudo pasados de moda. Pequeñas piezas de madera halladas al azar, hormas de sombreros, tiestos, escayola, caracteres tipográficos, son los materiales usados para sus primeros cuadros tridimensionales. Es importante destacar que, como precisa Ulrich Bischoff (2003), más importantes que los collages de objetos, son los collages compuestos de materiales gráficos, a menudo libros de texto algo anticuados, relativos a todas las ramas del saber. El collage primero y luego el frotagge y el grattage no fueron para Ernst sólo técnicas nuevas sino el eje de una producción artística que descubría en estas aplicaciones vías de acceso al inconsciente. Ernst leyó acuciosamente a Freud y no tuvo como Breton en ciertos momentos, una reticencia a que se correlacionaran los métodos surrealistas con el psicoanálisis, ni tampoco con lo paranormal.

${ }^{124}$ En el texto de Max Ernst, "Au-delà de la peinture" (1936) se recrean esa relación que, por supuesto, pasa también por la "alucinación de las palabras" de El barco ebrio de Rimbaud : "Je m'habituai à l'hallucination simple : je voyais très franchement une mosquée à la place d'une église, une école de tambours faite par des anges, des calèches sur les routes du ciel, un salon au fond d'un lac; les monstres, les mystères, un titre de vaudeville dressait des épouvantes devant moi. Puis j'expliquai mes sophismes magiques avec l'hallucination des mots !". (http://www.mag4.net/Rimbaud/poesies/Alchimie.html) En relación con su pieza, "La Femme 100 têtes" (La mujer de cien c), escribe su famosa frase inspirada en Lautremont y el encuentro de un paraguas y una máquina sobre una mesa de disección: "Je suis tenté d'y voir l'exploitation de la rencontre fortuite de deux réalités distantes sur un plan non-convenant (...)". 
125 Muy posteriormente, aproximadamente un siglo después, los curadores del Museo del Louvre encontraron una serie de casi invisibles dibujos trazados en la parte de atrás de la obra. Entre éstos está la cabeza de un caballo y media calavera.

${ }^{126}$ Precisa Spies, que en la figura de Rrose Sélavy, Duchamp lleva al máximo extremo la figura del doppelgänger : su creación equivale al desapego de sí, a la invención de una figura para cumplir su suicidio artístico (79).

${ }^{127}$ Esa febril actividad puede sintetizarse así : el grupo "Die Briicke" ya había sido establecido en 1905 por Kirchner, Schmitt-Rottluff y Heckel en Dresden. En 1909 Kandinsky, Jawlensky y Miinter habían formado el grupo "The Neue Kiinstlervereiningung" en Munich, que incluía a Campendonk y Karl Otten, estudiante de Freud que trabó amistad con Ernst. In 1910 Herwarth Walden estableció en Berlín la influyente publicación "Der Sturm"; en 1911 se formó "Der Blaue Reiter", El Jinete Azul, integrado por Kandinsky, Klee, Marc, Jawlensky y Macke, quien sería un mentor para Ernst. En 1912 al asistir en Colonia a la famosa exhibición "Sonderbund", que incluía obra de van Gogh, Cezanne, Gauguin, Munch, Picasso, Kirchner y Heckel, Ernst tomó la decisión de ser un artista más allá de los deseos de su familia y escribió artículos sobre el arte y sus posibilidades (Waldman 17).

${ }^{128}$ El historiador de arte alemán Werner Spies siempre fue considerado el gran experto en su vida y obra, y era el encargado de autenticar sus obras. Un escándalo relacionado con la autenticación de un grupo de obras, consideradas falsas, y elaboradas por Wolfgang Beltracchi, entre éstas "La Forêt (2)", vendida a uno de los mayores coleccionistas de obras surrealistas, Danniel Fillipachi, afectó su reputación. No obstante, es uno de los grandes expertos en Max Ernst y organizó con Julia Drost la exhibición Max Ernst exhibida en 2013 por la Fondation Beyeler de Suiza.

129 En esa época visitaba un asilo de enfermos mentales cercano a su vecindario en Colonia, y, anticipándose al pivotal libro de Prinzhorn, planeaba escribir un libro sobre el arte de quienes padecían diferentes formas de locura.

${ }^{130}$ August Make (1887-1914) fue una figura clave en el grupo expresionista "El Jinete azul". Como en el caso de Ernst, su padre pintaba. En el tiempo final de su corta vida, emprende un viaje a Tunisia en 1914 con Paul Klee y Louis Moilliet y su atmósfera marcó la luz de las pinturas de ese período que contienen elementos expresionistas y fauvistas por su afán de expresar las sensaciones interiores a través de las distorsiones no sólo de la forma sino del color. En el segundo mes de la Primera Guerra Mundial, estando en el frente alemán de Champagne en Francia, fue abatido. Su última pintura "Farewell" refleja la tristeza del comienzo de la guerra. Sin duda su muerte crea un sentido de orfandad asociado al repudio de la guerra en Ernst que regresará de ésta dispuesto a arrasar la coartada de grandes valores que la han permitido.

${ }^{131}$ Según Leah Dickerman: “ ...Voltaire already fascinated Ball during their time in Berlin, specially in his role as a fierce opponent of organized religion and his mocking hostility to sectarian virtue" (21). La autora reconstruye la historia que precedió a esta apertura: "Ball aproached Jan Eprraim, the owner of the Holländosche Meierei Café at Spiegelgasse I, and proposed starting an avant-garde cabarete, arguing that it would be popular with intellectuals and draws a crowd (...). While many German Localities, concerned with political opposition, limited the free séech during wartime, the Swiss focused on maintaining morals. (...). Tzara evokes the ambience in his 'Chronique zurichoise,' calling the Spiegelgasse 'the most obscure of streets in the shadow of architectural ribas, where you find discreet detectives amid red street lamps.' Nonetheless, the unassuming café room already had a cultural pedigree; it was the site in 1914 of the Cabaret Pantagruel. " (21).

${ }^{132}$ Invitado por Breton en 1925 a exponer sus collages en París, Max Ernst conocerá a Paul Éluard y a su mujer de entonces, Gala. Tan fuerte es la seducción que la pareja ejerce sobre él que deja definitivamente Alemania, a su esposa, la crítica de arte Luise Straus, y a su hijo Hans Ulrich Ernst, "Jimmy", y alcanza a los Éluard en Francia, donde vivirán los tres juntos. Paul le dio su pasaporte a Max para que cruzara la 
frontera. Se instalaron en Faubonne donde Max vivía con una falsa identidad y sobrevivía fabricando joyas. En esa casa hizo grandes frescos en los que surgía la mano de Gala, con los dedos cruzados como piernas. "Gala que tiene en su mano el hilo invisible que reúne esas tres almas", escribe Roche. Su convivencia era una forma de acción conectada a esa búsqueda de emancipación con la que buscaban "afirmar desesperadamente con la propia vida, a través de la obra y de la conducta" (24).

${ }^{133}$ Si para Ernst los collages fueron la expresión del automatismo surrealista, un método que permitía aflorar el inconsciente, el descubrimiento paralelo de Arp de los Papiers dechirés sucedió cuando frustrado por la imposibilidad de alcanzar la perfección que buscaba en un dibujo, desgarró la hoja en pedazos y después de tirarlos al suelo vio que la disposición creada por el azar alcanzaba la innovación plástica que buscaba.

${ }^{134}$ La intención de esta caminata que fue anunciada como intento para remediar la incompetencia de los guías, como parte de una serie de visitas a lugares seleccionados, sobre todo aquellos que no tienen razón de existir, en lugar de insistir en lo pintoresco, históricamente interesante o sentimental. La caminata, declarada urgente - "tomar parte en nuestra primera visita será volverse consciente del progreso humano, de la posible destrucción, y de la necesidad real de proseguir nuestra acción" se anunciaba bajo la supervisión de Gabrielle Buffet, Louis Aragon, Arp, André Breton, Paul Éluard, Th. Fraenkel, J. Hussar, Benjamin Péret, Francis Picabia, Georges Ribemonst-Dessaignes, Jacques Rigaut, Phillipe Soupault y Tristan Tzara. Los dadaístas, como sugiere Michael Sanouillet, "had intended to speak from the window of a nearby hotel, then had thought of simply keeping silent and walking about here and there, glaring each other until the audience got exasperated" (179). Pero Breton, Tzara ty Raymond Ducan acabaron hablando por una hora y media, y la audiencia acabó por dispersarse no sin que se les ofrecieran sorpresivos sobres que contenían frases, retratos, tarjetas de presentación de negocio, pedazos de ropa, paisajes, y dibujos obscenos.

${ }^{135}$ Como precisa Michel Sanouillet, el término collage se confundía entonces con las formas artísticas popularizadas por los cubistas y no resultaba fácil comprender el uso que Ernst usaba elementos no artísticos como estampas, periódicos, o papeles pegados como estimulantes poéticos, metáforas visuales que podían evocar correspondencias semejantes a los sueños o incluso de un tipo pre-surrealistaJosé de la Colina explica en un artículo dedicado a los collages de Ernst la diferencia entre los papeles u objetos que Braque y Picasso pegaban en sus cuadros con una función plástica y "el collage ernstiano", que "es una composición de fragmentos de grabados reunidos y pegados en una nueva 'escena', para producir una insólita imagen en el sentido surrealista, es decir: un encuentro insólito que provoque en quien lo ve un efecto emocional, una "visión" onírica". Concluye, certeramente, cómo "la heteróclita realidad que todos cotidianamente vivimos en el orden/caos de las ciudades es un inmenso collage vivo, una folletinesca novela gráfica, un sueño y a veces una pesadilla que, a la manera de Max Ernst, unen el espanto a la ironía, o viceversa" $" 135$. (Letras Libres, 10-23-2010).

136 "A los collages compuestos de materiales ajenos al arte que, tienen por fin consumar la ruptura con la tradición artística se vienen a sumar en París cuadros al óleo de gran formato, magistralmente pintados desde el punto de vista técnico, en los que se tratan temas académicos clásicos provenientes de la mitología o de la historia (...). Como un mago, el pintor toca los objetos, sanos y profanos, para transformarlos. Y así como el mago oculta los trucos de los que se vale para ejecutar sus actos de magia, así también oculta Max Ernst el origen de los materiales usados en sus cuadros" (Bischoff 24).

${ }^{137}$ La descripción que hace Ulrich Bischoff (2003) del cuadro de Ernst La alegría de vivir coincide con esa lujuria de la indiferenciación, si bien incluye otro elemento que es la pugna entre naturaleza y civilización; una pugna que no tiene que ver con la afirmación erótica sino con el afán del dominio tecnológico, y que sin embargo, resuelve de otro modo en sus pinturas mecano-mórficas: “... una jungla impenetrable impide todo acceso a la mirada del espectador. Si se mira con detenimiento, se reconocerán figuras humanas en el laberinto de las plantas tropicales. Una Eva desnuda trata de coger, adormecida y como en trance, una fruta abierta que se encuentra a sus espaldas. Sobre su cabeza puede verse el rostro de un hombre entrado en 
años con un gran bigote. A primera vista, ambas formas parecen pertenecer al esbelto cuerpo femenino. Se han adaptado a su entorno y su color verde les sirve de camuflaje. En un suelo intransitable crecen plantas que, con sus extrañas ramificaciones y frutas, recuerdan a seres vivos. Aquí resulta imposible distinguir entre animales y plantas. Las que alcanzan el cielo en el lado izquierdo, le ofrecen pomposamente al espectador sus exuberantes frutos amarillos y azules. Sólo un paso separa la alegría de vivir de la voracidad de vivir (57).

${ }^{138}$ La sensualidad y el carácter embrujado del jardín alucinante, la relación entre un joven y una vieja que aparece en una doble forma como una mujer de belleza irresistible, la atmósfera de embriaguez que concentra el sexo y la decadencia, el deseo y la muerte, la imposibilidad de salir de la casa-jardín están presentes en el relato de Leonora Carrington, Abatido por la tristeza, posiblemente escrito en alguno de los sucesivos períodos de ausencia de Max Ernst. Transcribo algunos fragmentos por la importancia que reviste el evocar este relato como pilar de la literatura fantástica mexicana: "Abatido por la tristeza, me dirigí hacia las montañas donde los cipreses crecían tan puntiagudos que habrían podido tomarse por brazos, donde las zarzas tenían las espinas grandes como garras. Llegué a un jardín invadido de trepadoras y yerbas de extrañas flores. A través de una ancha verja, vi a una viejecita cuidando sus enmarañadas plantas. Iba vestida de encaje malva, con un gran sombrero de otra época. El sombrero, adornado con plumas de pavo real, lo llevaba ladeado y se le salía el cabello por todos lados. Interrumpí mi melancólico paseo y pedí a la mujer un vaso de agua, porque tenía sed.-Te daré de beber -dijo ella con coquetería, poniéndose una flor detrás de su oreja grande-. Entra en mi jardín. Con asombrosa agilidad, saltó a donde yo estaba y me tomó de la mano. El jardín estaba poblado de viejas esculturas de animales, en distintos grados de deterioro. Había toda clase de plantas profusamente mezcladas que prosperaban con tropical esplendor (...)-Yo siempre llevo ropa interior de color azul pavo real -prosiguió Arabelle-. De seda, naturalmente; toda adornada con ojetes bordados. Los ojetes son para mirar; ¿adivinas... qué? " (...)A la luz de las velas vi de repente a una joven de pie junto a Arabelle. Había llegado silenciosa y misteriosamente. Era hermosa. Su vestido negro se fundía con las sombras que la rodeaban, y tuve la impresión de que su rostro flotaba en el espacio ".

${ }^{139}$ En el libro de Leonora Carrington, La maison de la peur, París, 1938, p. 2, aparece titulado en el original francés con una frase equivalente a Ella se parecía ligeramente a un caballo. En el libro de Roche (2001) aparece sólo como Caballa (p.64).

${ }^{140}$ Como anota Darran Anderson: "One Surrealistic theme that Carrington certainly developed was that of metamorphosis. Beyond the parlour games, pareidolia and optical illusions of others, Carrington developed an art more profoundly concerned with change. As pointed out by the curator Seán Kissane, metamorphosis is rife in her work. Figures appear between one form and another. The image of the chrysalis is a recurring one ". http://www.studiointernational.com/index.php/leonora-carrington-the-celtic-surrealist

${ }^{141}$ Como apunta McAra: “That same year, Carroll's drawing of the Gryphon and Mock Turtle was included in the Fantastic Art, Dada and Surrealism exhibition at the Museum of Modern Art in New York a show which traced the prehistory of the movement, placing Carroll alongside such artists as Bosch, Brueghel, Hogarth, Fuseli, Blake and Redon, as representing a fantastic, alternative view " to Enlightened, bourgeois rationality (...)Breton continued to include Carroll in his many lists of influential writers, most especially in the Dictionnaire abrégé du surréalisme (1938), which he compiled with Eluard, and the “Anthologie de l'humour noir" (1939/1947), which again cites the Gryphon and Mock Turtle episode. Three poems by Carroll, written during his youth in the 1840s for his journal " The Refectory Umbrella", then appeared in French in the December 1939 issue of the surrealist magazine l'usage de la Parole. Here Carroll's name appears in the contents pages alongside Gaston Bachelard, Paul Eluard, Marcel Duchamp and others, as if he were himself a member of the movement. Later, Carroll's fictional Alice character was included alongside Freud, Sade and other surrealist heroes in the mock-Tarot Jeu de Marseille (1940-41), which was reproduced in the surrealist magazine VVV in 1943. That same year Duchamp designed a flyer for an exhibition at the Julien Levy gallery entitled Through the Big End of the Opera Glass which cunningly echoed Carrolles Through the Looking Glass (1869), and employed similar chess-like imagery. 
Reflecting on surrealism in 1953, Breton continued to cite Carroll as an important precursor, alongside Lautréamont, Rimbaud and Mallarmé" (p.2-3).

${ }^{142}$ Como he mencionado, existía una diferencia notable de edad con la segunda esposa de Max Ernest, Marie Berthe Aurenche, con la misma Leonora y, posteriormente a su relación, repetirá el mismo patrón con Dora Tanning. Reproduzco un esclarecedor fragmento del ensayo de Catrina McAra sobre el prototipo de la femme-enfant: "So who or what was this notorious child-woman? Chadwick claims the femmeenfant 'prototype' to be the androgynous figure that appears in a photomontage under the title L'Ecriture Automatique in La Révolution Surréaliste 9-10 (October 1927), and further identifies Meret Oppenheim, and Ernst's second wife, Marie-Berthe Aurenche, as some of the first living incarnations of the femmeenfant: the former famed for her fur-covered tea-cup and spoon Object (1936) (which one might read through Carroll's Mad Tea Party episode); the latter associated with Ernst's collage novel Rêve d'une petite fille qui voulut entrer au Carmel (1930).28 There Ernst represented his devout twenty-year-old wife, Aurenche (b. 1910), in the guise of a little girl of a similar age and in similar attire to John Tenniel's Alice illustrations. Later, between 1936 and 1939, Ernst became romantically associated with the twenty-year old artist and writer Leonora Carrington (b. 1917) who, as we will see, developed an affiliation to Carroll's Alice due to her English identity. By the time Ernst became involved with Tanning (b. 1910) in the 1940s, she was already in her early thirties - but still considered to be a femme-enfant, as a second generation surrealist some nineteen years younger than her husband Ernst". Añade que también Picasso estuvo siempre acompañado de mujeres mucho más jóvenes como Marie-Thérèse Walter y Dora Maar (1907-97). Lo mismo ocurría en la relación entre Man Ray y Lee Miller y que la fascinación de Breton por el carácter de su personaje Nadja seguía esta misma tendencia : "Nadja perches on a slippery scale between fiction and reality. Later, Breton"s wife Jacqueline Lamba (1910-93), whom he met when she was in her mid-twenties, would serve as the apex of this emotional investment in young women. It has been suggested that Carroll himself was in love with the real Alice Liddell".

\footnotetext{
${ }^{143}$ Leonora escribe esta novela corta en la que revisita el tema del confinamiento, pero con una perspectiva que es completamente ajena al desgarramiento y la angustia inenarrables de Memorias de abajo : hay un derroche de humor, de ironía fantástica y un enfrentamiento sin atenuantes con el tema de la vejez. Pero al tiempo, hay un sentido de liberadora mordacidad y una última reafirmación de la libertad como ejercicio no sólo posible sino indestructible. Leonora ha vuelto, en cierto modo, a sentirse indestructible. Esa sensación que conoció a fines de los años 30 y que perdió en el confinamiento de 1940. Aunque escribió La trompeta acústica en la década del sesenta, esta novela corta y alucinada se publicó por primera vez en 1974 en Francia.
}

${ }^{144}$ Otros cuadros que involucran cenas son : Pastoral (1950), “ Three Women Beyond the Table ” (1951), “ The Hunt Breakfast” (1956), y Lepidópteros (1969).

${ }^{145}$ En el artículo "The Alchemical Kitchen: At Home with Leonora Carrington”, Aberth da otros elementos complementarios como el hecho de que ha transformado las nociones católicas de su formación en un banquete caníbal blasfemo. Hay también un aspecto interesante : "The table bears a striking resemblance to the one located in the Great Hall at her parental estate of Crookhey Hall (...) Animal/human hybrid women devour an unholy feast with gusto, in particular a male infant lying on a bed of grapes" (3).

146 Transcribo parte de la conferencia de Julie Byrd "Les Femmes Surrealistes" presentada en la "Interdisciplinary Cross-Cultural Conference" en University of Illinois (3-3-1995), sobre las pinturas de Leonor Fini ejecutados en la década de los años treinta : "In her life as well as her art, Fini continually advanced this idea of an absolute beautiful, autonomous, and authoritarian woman governed by passion. She was born in Buenos Aires, Argentina, but spent her childhood in Trieste (...). Fini met Leonora Carrington in 1937 and the two became very close friends. They decided to spend part of the summer together that year. Fini later included a full length portrait of Carrington in her painting The Alclove: An Interior With Three Women. In it she reveals Carrington as a woman warrior, "a true revolutionary," autonomous and released from the image of femininity created by man. ( Chadwick, p. 82 )." Fini refuses 
to accept the world defined by man so she uses painting as a method of creating a world designed by female desires. By placing the woman at the center of the these compositions, and making her experience of the world paramount, she asserts a female consciousness that has no need of manifestos, theories, or proselytizing. In Leonor Fini's works, the masculine and feminine images are always presented in a sexual confrontation but the eroticism in her work is diffused during the scene and is not centered on specific images...at no time does the female body become objectified as it so often does in the work of Delvaux, Masson, Magritte (Chadwick p. 87). Profound belief in the ability to shape the exterior world according to one's desire is rare among women of Fini's generation. Cultivating her own individuality, she placed her own freedom and autonomy to a degree that seems the embodiment of the surrealist ideal, but that was, in fact, equaled by few surrealists.

${ }^{147}$ Peggy Guggenheim, la coleccionista que jugó un papel crucial en la salvación de la vida y obra de un grupo de artistas clave y que se convertirá en la tercera esposa oficial de Max Ernst, comprará poco después en París este cuadro de Leonora, cuya presencia como ardiente fantasma en la memoria de Ernst siempre recelará. La historia que se cuenta es que antes de conocer a Ernst, pensaba adquirir un cuadro suyo, pero viendo éste de Leonora, duda y opta finalmente por comprar el que será uno de sus cuadros más comentados.

${ }^{148}$ En Leyendas de la Novia del Viento. Leonora Carrington escritora, Lourdes Andrade dice que en compensación a los sufrimientos padecidos por las brujas de Lancanshire, en la comedia La invención del mole, Leonora propone que el arzobispo de Canterbury sea sacrificado en la corte del rey méxica y que se le ase y sirva en un banquete.

${ }^{149}$ En 1964, Leonora pinta una de las obras monocromáticas más extraordinarias de su vida : “ The Burning of Giorgano Bruno", que comentaré más adelante y que es un modo de enfrentamiento artístico a los confinamientos mentales.

${ }^{150} \mathrm{Al}$ comienzo de su libro, escribe Michelet: “¿Dónde podía vivir la novia del diablo y del mal encarnado, que tanto bien hizo, según el decir del gran médico del Renacimiento? Cuando en Basilea, 1527, Paracelso quemó toda la medicina, declaró no saber nada fuera de lo que había aprendido de las brujas" (2). Luego, en otro pasaje narra una suerte de rito de paso de la desesperación al empoderamiento a través de la alianza con lo prohibido: “...la mujer se vio como la triste planta de las landas, sin raíz, arrastrada por el viento, llevada, castigada, golpeada inhumanamente; se hubiera dicho que ella era un pólipo grisáceo, anguloso, que sólo tiene adherencia para ser quebrado mejor. El niño lo pisotea. La gente dice, burlona: "Es la novia del viento". Ella reía ultrajantemente de sí misma, al compararse, pero desde el fondo del agujero oscuro, se levantó una voz: "Ignorante, tonta...no sabes lo que dices... esta planta, que se retuerce en esta forma, tiene derecho a despreciar a muchas hierbas gruesas y vulgares. Gira, pero es completa en sí misma, con flores y simiente. Debes parecértele. Sé tú raíz y en medio del torbellino mismo, llevarás todavía las flores, nuestras flores, como las que nacen del polvo de los sepulcros y de las cenizas de los volcanes. "La primera flor de Satanás te la doy hoy para que sepas cuál es mi primer nombre, mi antiguo poder. Yo fui, yo soy eI rey de los muertos...."(42). Muchas de las protagonistas de los cuentos de Leonora, como Druisille, descrita por Andrade (2001) no sólo pertenecen a la noche: "La oscuridad no sólo la rodea. También la habita. Tiene el alma poblada de sombras (...) Druisille es una criatura en cuyo espíritu se abren cavidades desconcertantes, abismales, hacia los dominios de la oscuridad (...) Posee, entre otros atributos aterradores, cabellos viperinos, lo mismo que Medusa. Este elemento la asocia con otros personajes femeninos - diosas, heroínas, hechiceras— que han pactado una alianza corporal con la serpiente" (41).

${ }^{151}$ Precisa sin embargo, que el punto culminante de esa influencia novelística se aprecia en una de las más extraordinarias pinturas de Leonora: "The Giantess (The Guardian of the Egg), 1947, in which the main character is all-conquering and yet handicapped by her size, beset by wild geese (a common trope of Irish folklore). It is a curiously out of time image, with the background seascape more akin to a Renaissance masterpiece than a modern work". 
${ }^{152}$ El ilustrador francés J. J. Grandville (1803-1847), tuvo predilección por los relatos que ironizaban la sociedad de su tiempo. Entre las litografías satíricas que realizó están "La Vie privée et publique des animaux ". A partir de 1935, cuando se instaura la censura para las caricaturas en los períodicos, ilustra novelas como Robinson Crusoe, Don Quijote y Los viajes de Gulliver.

${ }^{153}$ En honor a la verdad, ni el padre de Leonora, a quien designa como "Candlestick" en sus obras, ni sus tres hermanos varones, parecían tener interés en cabalgar los caballos: ella y su madre, las mujeres de casa eran las avezadas jinetes.

${ }^{154}$ El tema de la ausencia del amante o el miedo a ésta es reiterativo en sus cuentos. En Las hermanas, Drusille ama tan desesperadamente a Jumart que se bebe toda su sangre para retenerlo. Lourdes Andrade comenta en Leyendas de la novia del viento que Duisille " no es propiamente vampiro ni claramente una bruja ni es verdaderamente un fantasma; es un ser infinitamente más inquietante en cuanto que es equívoca. No podemos clasificarla entre los monstruos conocidos; no podemos definirla sino como una mujer ". (47)

${ }^{155}$ Entre las esculturas que Ernst realizó en la casa de Saint-Martin d'Ardèche, declarada en Francia monumento nacional desde 1991 se encontraban: La sirena y el Minotauro sobre los muros del jardín, la Sirena Alada, los bustos de un pez y una tortuga, un relieve exterior de Loplop, un mosaico en el suelo decorado con un murciélago, un banco esculpido. Entre las pinturas que Ernst hizo desde la adquisición de la casa hasta 1940 están Un peu de calme, varias versiones -algunas en decalcomanía- Le Fascinant ciprès, "Swampangel", "La toilette de la mariée ou" l'habillement de l'épousée", "La rencontre", hecho con la colaboración de Leonora, "L'Europe après la pluie", "Leonora dans la Lumière matinale", "Alice en 39" y los grabados que ilustraron La dama oval y el "la dame ovale" y el prefacio de "la maison de la peur".

${ }^{156}$ Un año atras, el surrealista Paul Delvaux había pintado en su cuadro La llamada de la noche, mujeres de tupidas cabelleras que se extienden hasta los pies, formadas por largas ramas repletas de hojas.

${ }^{157}$ Bellmer (1902-1975) se había acercado a George Grosz, y su influencia crítica lo llevó a abandonar sus estudios de ingeniería en 1924. Entonces comenzó a trabajar como artista comercial e ilustró publicaciones Dadá como Eisenbahnglück oder der Antifreud (1925) del filósofo y escritor alemán "Mynona", seudónimo acrónimo de Anonym, de Salomo Friedlander. A partir de la llegada de los Nazis al poder, anuncia que dejará de realizar cualquier trabajo que pudiera llegar a ser útil al estado. Su nueva carrera como artista comieza construyendo una muñeca de tamaño natural que evoca los encuentros de iniciación sexual que tuvo de adolescente en un jardín, donde escapaba del autoritarismo de su padre, así como la producción musical que hizo Jacques Offenbach de los cuentos de Hoffmann. Peter Webb (1909) precisa: "By its provocative eroticism it would strike a blow against tyranny and authority. This first Doll, built with the help of his brother from broom handles, metal rods, carved wood and plaster of Paris, contained a small panorama enabling scenes lit by a torch bulb to be seen through the navel. Bellmer published ten photographs of this work as Die Puppe (Karlsruhe, 1934), accompanied by a short introduction in the form of an intricate prose poem in which he clearly demonstrated how the seemingly innocent games of the young child had developed into the far from innocent sexual fantasies of the adult. Bellmer felt artistically isolated and vulnerable in Berlin, where far less provocative works had been branded degenerate by the Nazis. Having read about Surrealism in art magazines, he sent a copy of Die Puppe to André Breton and Paul Eluard in Paris; the publication of the photographs in the Surrealist magazine Minotaure in December 1934 caused enormous excitement among members of the group, who immediately appreciated the Doll as an ideal Surrealist object because of its conjunction of desire and revolt. Bellmer was acclaimed and adopted by the Surrealists during a short visit to Paris at Eluard's invitation in February 1935". http://www.moma.org/collection/artist.php?artist_id=452.

Una calle con sus elaborados maniqués se exhibió en la Exposition Internationale du Surréalisme en la Galerie Beaux-Arts de París en 1938, donde también participó Leonora. Ese mismo año había escapado de los naziz a París con una de sus muñecas. Una década después un volumen con fotografías intervernidas a mano con tinta, "Les Jeux de la poupée" (París, 1949), incorporaría poemas de Eluard. Se trata de muñecas violadas cuya expresión de sufrimiento se ha conectado con escenas del cine expresionista 
alemán. Sus dibujos e impresiones ilustraron posteriormente textos eróticos de autores como Sade, Baudelaire, Bataille o de la poeta Ulrica Zurn, que fue su compañera durante 16 años.

${ }^{158}$ Un periódico de Nueva York publicará dos años después una imagen del cuadro, en el mismo número para el que Leonora escribe el texto El Pájaro Superior, Max Ernst (Chadwick y Courtrivron 135).

${ }^{159}$ Las notas de este aparte son tomadas del libro de Leonora Carrington Memorias de abajo.

${ }^{160}$ La puerta de piedra se publicó en México en los 40's y fue publicado en francés como "La porte de pierre" por Henry Parisot, Editions Flammarion, 1976. El manuscrito completo en inglés fue publicado por primera vez por St. Marin Press, Nueva York, 1977. El hombre neutro, escrito en los 50's en México fue publicado en francés por la revista Le surrealisme, même, num. 2, París, 1957. Cuento mexicano fue escrito en los 70's en México y se publicó, parcialmente en Le neveau commerce, núms.30-31, 1975. La trompetilla acústica fue traducida del inglés al español por Renato Rodríguez en 1977 para Monte Avila Editores. La anécdota es que Renato solía decir que hubiera preferido escribiría que traducirla. Los cuentos "Et in bellicus lunarum medicalis" de los 60's y La invención del mole, escrito en los 70's fueron traducidos por Francisco Torres Oliver y Stella Mastrangelo para la primera edición mexicana de Siglo XXI editores, 1992.

${ }^{161}$ El tema de lo andrógino sería extenso y revelador en la obra de Carrington. Warner y Chadwick y Courtrivron, entre otras investigadoras han analizado su presencia en obras como el autorretrato Posada del caballo del amanecer. En una de las pinturas más misteriosas, El Rarvarok, 1963, hay dos caballos, uno blanco y otro negro, que rompen los parámetros de representación de la mujer-caballo. Sus cuerpos son de equinos, pero tienen senos de mujer y sus rostros, sin embargo son masculinos. Arrastran un carruaje en el que viaja una figura de abundante cabello largo, y aunque se mueven en un paisaje exterior aparecen en el interior de un espacio, como si más que una ventana del tamaño de una pared, su imagen correspondiera a una proyección. Al pie de esta escena hay una mujer en el suelo, con los ojos abiertos, como si estuviera en un estado de trance, escoltada por dos animales, posiblemente zorros o lobos, mientras una serie de figuras masculinas que recuerdan a sacerdotes de diversos tiempos y credos -asirio-babilónicos, hebreos, posibles monjes- observan, hieráticos.

${ }^{162}$ La traducción de este verso es propia. Me resulta más adecuada que la que ofrece el libro: "el Caos gobierna de Doncella de Luz".

${ }^{163}$ El laberinto aparece, de modo central en pinturas como Forbidden Fruit (Fruta prohibida), 1969, caso en el cual su forma proviene del mismo cuerpo de una serpiente pero puede leerse en muchos de sus cielos y en numerosas obras. Así, es apenas una estela blanca, pero epicéntrica, en The Candle Game (El juego de la vela), 1988. Se sugiere, igualmente en la obra "Sacrament at Minos" (Sacramento en Minos) 1954, donde la travesía corresponde a un combate interior que vuelve al tema recurrente del potro blanco y negro que luchan entre sí. El potro blanco devora en esta obra la cabeza del negro, que aparece decapitado. Pero entonces, en una imagen prodigiosa, su propia cabeza es ahora negra.

${ }^{164}$ Para el escenario de su obra teatral Penélope, 1959, puesta sobre las tablas por una de las figuras más fantásticas del planeta, el escritor, cineasta de originalidad incomparable, y creador de múltiples géneros, Alejandro Jodorowsky, Leonora hizo una prodigiosa cabeza tridimensional de un caballo.

165 El ensayo, Leonora Carrington. The Celtic Surrealist fue publicado por la revista virtual www.studiointernational.com/index.php/leonora-carrington-the-celtic-surrealist (08-12-2013). El texto original dice: "In one sense, the way she looked at the world existed long before that group of professional lunatics the Surrealists, long before Bosch and Brueghel, long before the first recorded myths even. It was born when we were and will vanish only when we do. And yet, for all her explorations of collective lore, Carrington was, and remains, unique". 
In this ability to see fusion through transformation and hybridity, Carrington recognizes what anthropologist Edmund Carpenter identified as typical of the perception of visual puns that Pacific Northwest Coast inhabitants found in their masks, whether Kwakiutl masks or Yup'ik masks of the sort Breton owned, with faces that ripple back and forth between human and animal.

In reference to the drawing of a rabbit that looks like a duck from a different angle used by Ludwig Wittgenstein to illustrate his Philosophical Investigations, Carpenter argues that Wittgenstein's 'thesis is that you can only experience one at a time. But supposing you experienced both of them as a single image. And I think this is what the native people did. They recognized rabbit-duck not as alternatives but as a single form.' Carpenter believes the surrealists also recognized and appreciated this notion of simultaneity. This fused perception came easily to Carrington, who was unafraid of the association of spells and magic with the occult, an association Breton only accepted openly in the 1950s when he wrote L'Art magique (1957), partly because earlier he was motivated to represent surrealism as different from spiritualism and to make clear that his movement, indebted to psychoanalysis, had nothing to do with superstition or the supernatural, as he fiercely asserts in 'The Mediums Enter.'

In Carrington's case, her transformation of kitchens in her paintings and stories into hybrid spaces as settings for the hybrid figures she brought to life exemplifies her more materialized philosophical version of surrealism, in an eminently practical environment. Her embodied vision of what Breton identified as transformisme extended beyond the ritual of the masked dance. In her world such ritual happened every day in the kitchen, not just in dream or automatic trance but in reality. For Carrington the tools needed for all aspects of surrealist work, at its most magical as well as at its most practical, were situated in the furnace of her creative thought, the kitchen out of which all her paintings, drawings, sculptures, tapestries, and stories emerged.

${ }^{166}$ La cita original en inglés es: "There was still magic in his fingers' ends, just as he had the same command of language, the same upright and fiery stance before life (...). He carried himself to the end as what he was: the only one of his kind". 


\section{VILA-MATAS Y SU FICCION EXTREMA: DEL DADA AL TEXTO PORTÁTIL DEL ÚLTIMO SHANDY}

"La alteridad, el misterio de nuestra verdadera identidad personal es uno de mis temas preferidos, según los críticos" Enrique Vila-Matas

“Toda máscara es, también, un espejo (y a la inversa)" Gerard Gennette

"Sólo se pueden entender algunas cosas desde las fronteras, sea de los paisajes o del pensamiento"

Albert Lladó

En 1985, el español Enrique Vila-Matas (n. 1948) publicó su Historia Abreviada de la Literatura Portátil, una obra que ha adquirido visos legendarios por el modo en que infiltró en la memoria histórica de las vanguardias de los años 20, muy particularmente del dadaísmo y del surrealismo, una ficción sobre una conjura protagonizada por sus pioneros en distintas ciudades del mundo. La narración de los hechos se desliza entre lo biográfico, la historia del arte y de la literatura, y la ficción, como un relato híbrido que deriva por diversos géneros, pero combina lo apócrifo con lo verosímil con tal sagacidad que puede llegar a convencer a los lectores de la existencia histórica de un complot fraguado por 27 personajes, entre los cuales se encuentran figuras tan reales como Tristan Tzara, Man Ray, Blaise Cendrars, Max Ernst, Valery Larbaud, Scott Fitzgerald, Georgia O’Keffe, César Vallejo, García Lorca, Walter Benjamin, Aleister Crowley, y la figura tutelar de Marcel Duchamp; todos ellos involucrados en la delirante conjura de una sociedad secreta dedicada a estremecer los límites de la realidad.

Aunque la "Conspiración Shandy" -llamada así por el célebre libro de Lawrence Sterne (1713-1768), ${ }^{167}$ entre otras razones que considaré más adelante- es una invención que se adhiere a ese linaje que va de Cervantes, a Sterne, a Kafka y a Borges, y que 
saquea la historia del dadaísmo y de sus obras inconclusas, así como su propia filiación con los experimentos de la lengua, en diversos lugares se la ha asumido como una conjura real develada por Vila-Matas en su HALP. De hecho, en Alemania el libro fue publicado por la editorial Surkhamp Verlag en su colección de ensayos.

Con este deslizamiento en la historia de las vanguardias, la citada conspiración se refrenda como un caso ejemplar de ficción extrema: no sólo es un tipo de invención que simula su veracidad histórica mediante procedimientos como la con-fusión de géneros y el borgiano entremezclamientos de personajes, hechos, o referencias bibliográficas con otros apócrifos o ficticios, que fue practicado desde la modernidad de modo paradigmático por el inmortal inventor de la biblioteca infinita. Estas estrategias han sido usadas de tal modo que ha logrado desbordar las demarcaciones entre la literatura y el arte y entre ambos campos y la vida real y se ha ramificado en un sinnúmero de infiltraciones de diversos géneros. En cierto modo, estas características se relaciones con lo que el teórico Nicolás Borriaud entrevee como el advenimiento de la altermodernidad o del arte altermoderno que supone la hibridización cultural conectada con el saqueo sin fronteras de textos y obras; el viaje como una estrategia productora de formas y obras, que resulta un hilo conductor en HALP; y los formatos expandidos del arte (Borriaud Conferencia). Estas tres características se cumplen perfectamente en el caso de la ficción extrema de HALP, que adicionalmente involucra, como he mencionado, la posibilidad de la multiplicación de la otredad. Si la identidad misma entra en el juego del borramiento entre la ficción y la realidad, surge una expansión de los límites mismos de la imaginación y nos avocamos a la continua opción de reinventarse no sólo en el campo de 
la escritura misma sino viajando del arte a la literatura y de las fronteras de estos campos, diluidas por acción de la misma ficción extrema, a los múltiples espacios de la vida.

Una declaración del propio Vila-Matas - "No hay día en que no vea cada vez más borradas por mis propios pies las fronteras entre la realidad y la ficción sobre las que bailo" (Aunque no entendamos nada 13) - arroja luz sobre la naturaleza de un ejercicio literario lúdico que tiene una naturaleza semejante a un laberinto de espejos, sobre todo por el continuo juego con las identidades múltiples, la incertidumbre entre lo factual y lo fantástico, y los incesantes asaltos intertextuales. Constituye así un ejemplo del uso de estrategias de la ficción extrema como la con-fusión de géneros —entre la novela y el ensayo, entre la biografía propia y la ficción que se apropia de otros relatos biográficos-, y de los desdoblamientos autorales conectados además con la estrategia del viaje y el efecto de un nomadismo que desplaza las fronteras entre campos de creación y/o de acción y puede llegar a incluir la proyección de otras identidades o roles posibles para el autor. Por ejemplo, el escritor incorporado a prácticas como las curadurías contemporáneas, como efecto inesperado, pero no menos digno de festejo, de sus ficciones extremas. Ese ha sido el caso de Vila-Matas como veremos.

Si por una parte los recurrentes juegos intertextuales de HALP remiten a universos literarios existentes o apócrifos creando una hibridez entre ensayo y ficción que desemboca en una sofisticada construcción de verosimilitud reforzada por su carácter metatextual; por otra, la estructura subyacente de la conjura proviene en gran medida de la obra y de la vida de Marcel Duchamp, a quien Vila-Matas asume en HALP como su doble, en un punto bastante avanzado del relato, tal como pasa con el tardío nacimiento de Tristram Shandy. Aunque en el libro no cita nunca la famosa entrevista -imborrable 
para él一, que le hiciera Pierre Cabanne a Duchamp, quien quiera que haya leído Conversaciones con Marcel Duchamp advertirá la extraordinaria similitud que existe entre los principios de vida y la visión del arte de este "anartista" que a sus setenta y nueve años, afirmaba haber tenido "una vida absolutamente maravillosa", frase que VilaMatas invoca justamente para contar su experiencia con el encuentro de este texto y que reutilizó en 2011 como título de una antología de sus ensayos.

No se equivocó en su papel de visionario André Breton cuando apenas en 1934, el mismo año de la aparición de La Caja verde que extiende el inacabado Gran vidrio a una forma de infinito diálogo textual comprimido en 96 notas, escribió sobre Duchamp describiendo que se maravillaba de ver cómo Duchamp guardaba intacta "toda su potencia de anticipación" y declaraba sobre él: "Conviene mantenerlo luminosamente erguido para las barcas futuras sobre una civilización que termina" (99).

El narrador de Historia Abreviada de la Literatura Portátil lo escoge como doble apropiándose, extendiendo con este juego textual su vida, declaraciones y obras artísticas, que ahora resultan transportadas, traducidas al espacio de una novela que se presenta como ensayo, tal como corresponde a la índole de su ficción extrema. El influjo de quien sin adscribirse a ningún movimiento es considerado el más grande artista dadá de todos los tiempos, no se explicita en toda su implicación en HALP, o está contenido en la admisión de que su espíritu puede tomar posesión del narrador. Pero Vila-Matas explicita las circunstancias de su deslumbramiento con la personaldiad de Duchamp en el blog de su página web, donde, bajo el título de Versión disidente de Historia abreviada de la literatura portátil incorpora metaliterariamente el propio proceso de construcción del libro, designado con la abreviatura HALP. 
Habiendo renunciado durante décadas a exhibir o hacer nada, como otro doble del Baterbly de Melville (1819-1891), Duchamp tiene una influencia omnipresente en las manifestaciones de la posmodernidad en el arte, que puede refrendarse o cuestionar, pero que en ningún caso puede ser ignorada. Sería tan extenso enumerar los artistas en los cuales ha influido que quizás la mejor manera de ejemplificar el grado de su influencia sea una obra plástica que el compositor John Cage (1912-1992) hizo en 1969, un año después de la muerte de Duchamp y que tituló Not Wanting to Say Anything about Marcel $^{168}$. Y esto, pese a que declaraba que en el fondo era enormemente perezoso, que le gustaba vivir, respirar, más que trabajar, y que no creía que el trabajo que había hecho pudiera tener ninguna clase de importancia en el futuro. Su arte $-\mathrm{y}$ esto es una clave para la lectura de HALP — podría ser el de vivir: cada segundo, cada respiración es un trabajo que se inscribe en ninguna parte, y que no es visual, ni cerebral, sino una suerte de constante euforia $^{169}$ ajena a la obsesión por la inmortalidad de la obra pues creía que de cualquier manera, la posteridad era una forma del espectador (Cabanne 72).

El mismo Vila-Matas, en un paratexto de HALP, reflexiona sobre la paradoja de la personalidad de Duchamp, que sin duda origina en buena parte el espíritu de su novela:

En realidad, frente a los groseros esfuerzos de Dalí por ser visto, frente al trabajo metódico y obsesivo de Picasso, frente a los antojos teóricos de Metzinger, Duchamp siempre fue un artista que no se caracterizó precisamente por su voluntad de llamar la atención, ni por su entrega desmedida al trabajo, ni por sus fatigas teóricas (...) ¿Qué hace que Duchamp, que no hizo casi nada, siga presente y las estrellas de Picasso y Dalí y otros maestros se estén apagando? La clave podría estar en su ironía y su escepticismo y en haber tomado distancias con lo que los románticos entendían como la religión del arte. 'Me temo que en arte soy agnóstico', le dice a Cabanne en un momento de este libro de conversaciones que después de releerlo creo que influyó en mi obra (el subsayado es mío), y no tanto en mi vida, aunque me ha permitido tener la conciencia, si cabe más clara, de que he podido conocer el choque de al menos dos tensiones siempre: la 
necesidad de estar y no estar al mismo tiempo (Una vida absolutamente maravillosa).

Lo cierto es que en HALP el narrador tiene el propio nombre de Vila-Matas, pero surge como expresión de su desdoblamiento en otro, asume una otredad en continuo desplazamiento, mientras en gran parte usa el universo duchampiano para estructurar la falsa historia de la literatura portátil que de todos modos contiene el espíritu deconstructor de un movimiento que demostró la inestabilidad de todas las nociones en un mundo que se precipitó en la guerra. De hecho, los portátiles se definen en HALP como 'los miembros de una sociedad secreta que conspiraba para nada y desde la nada"' (47).

Aunque el curso de los desdoblamientos de lugar a un intrincado laberinto en donde distinguir la verdad de la mentira equivaldría a limpiar los establos divinos, la libertad con que Vila-Matas trastoca fuentes y fechas, hechos y espacios, mantiene el humor feroz con que dadaístas y surrealistas abatieron las nociones de la inmutable realidad. Por algo, en su "versión disidente" de HALP cita una frase de John Banville: "Sabemos todo, nos han dado toda la información, pero no nos han explicado nada. No puede explicarse. Creo que ésta es la única razón para dedicarse al arte, mostrar el absoluto misterio de las cosas" (El ayudante de Vilnius).

Por ello, incluso para quienes la conjura resulta improbable, contiene un modo de verdad que responde a la irrefutable existencia de una “comunidad del espíritu”, según el calificativo de Jean-Yves Jouannais (n. 1964) en su libro Artistes sans oeuvres. I Would prefer not to ${ }^{170}$. Cuando este autor se tomó la libertad de incluir un Shandy que sería el número 28 al hablar de HALP, el propio Vila-Matas, de manera consecuente con su 
ficción extrema, no consideró al comprar el libro en una librería que se trataba de un error, sino, como él mismo cuenta en su página virtual, se dedicó a indagar en la identidad añadida y no dudó en refrendar su legitimidad y amistarse con el autor que había "aumentado" la ficción en cuanto se aseguró de que el personaje, un tal Félicien Marboeuf, era realmente un Shandy.

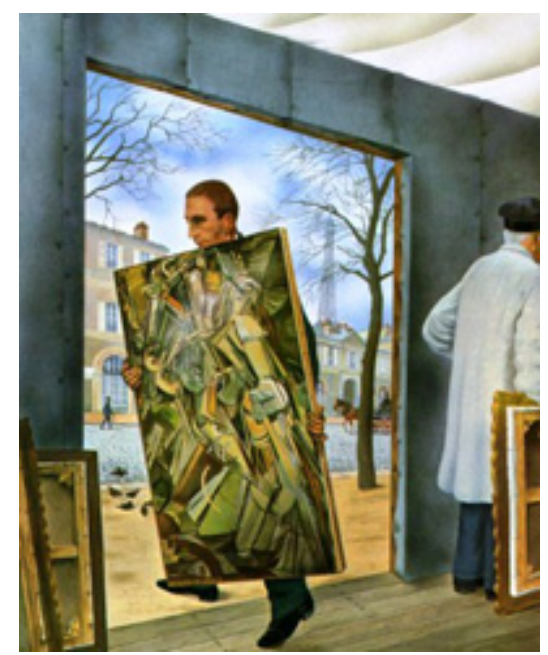

Ilustración 83: Félicien Marboeuf: Retrato de Duchamp retirando su cuadro. Desnudo bajando la escalera 1912.

Según Jouannais, que obviamente es quien más sabe de Marboeuf, puesto que se ha dedicado a insertarlo aquí y allá, era un muy famoso un escritor sin obras, que sólo había ejecutado un cuadro en su vida: justamente un retrato del momento en que Marcel Duchamp recoge su Desnudo bajando la escalera que ha sido incomprensiblemente censurado por sus propios cofrades. La anécdota es conocida: el cuadro iba a exhibirse en la apertura del Salon des Indépendants de 1913, pero Albert Gleizes (1881-1953) le pide a sus hermanos - pintores que tenían cierto nombre en la época, particularmente Gaston (Jacques Villon) (1875-1963) - que le sugieran retirar el cuadro o cambiarle el título que le resulta incomprensible frente a la imagen de una figura abstracta en movimiento. Sobre 
éste incidente Duchamp le dijo a Cabanne que el grupo más avanzado de la época, estaba aterrado con su pieza (9). No puso objeción: recogió su cuadro y se lo llevó. Fue un incidente que definió el resto de su vida artística y que marcó su distancia frente a los grupos. Luego lo exhibió en ese escenario del Armory Show de 1913, donde desató un escándalo que ya forma parte de la historia del arte. Vila-Matas, convencido y entusiasmado con el nuevo personaje escribió un prólogo en la siguiente edición del libro de Jean-Yves Jouannais, donde confiesa que buscando pruebas de su existencia encontró que se le consideraba el más grande de entre los escritores que no escribieron nunca y era ciudadano de honor de Glooscap, una ciudad ficticia minuciosamente creada por Alain Bublex (n. 1961), en algún punto del Canadá, que ciertamente podría haber sido uno de los miembros de la secta de los falsarios de Tlön. En el prólogo, acaba confesando que al cabo él visitó, acompañado por Jouannais, los suburbios de la ciudad que son "un lugar maravillosamente único y sobre todo, muy portátil” (El ayudante de Vilnius). ${ }^{171}$ Entre estos principios postulados por y para sus miembros, no sólo es indispensable esa adhesión a la soltería que se enuncia tomándola literalmente del libro de Cabanne, y a la cual regresaremos, sino la idea duchampiana de la levedad necesaria para dar en cualquier momento un giro al destino, como él mismo lo hizo en momentos que no pueden separarse de la historia del arte del siglo XX, pues aunque apenas creó obra, su visión sigue modelando las prácticas artísticas del siglo XXI.

La prueba de la existencia de Félicien Marboeuf, su Retrato de Duchamp, es una ingeniosa prolongación del alcance de HALP y demuestra el potencial que tienen las ficciones extremas de propagarse de manera insospechada. La extraña paradoja de HALP es que en lugar de seguir la voluntaria renuncia a la continuación de la obra por la que en 
algún momento optaron varios shandy, ha permitido que después de terminada dentro de sus páginas la conspiración Shandy, siga propalándose a otros territorios y empujado los límites usuales de la ficción. Ahora no sólo existe una estrella llamada como su ficticio punto geográfico de partida, Portactiv —una suerte de hipertexto astronómico- y portales y revistas en abierta construcción dedicados a los shandy, y la página ya mencionada en la que el autor, incapaz de seguir la aparente inactividad de Duchamp cuya vida y opiniones u obras estructuran la conjura - sigue añadiendo detalles que transforman la historia contada; sino que de hecho, él mismo se ha filtrado en el universo real del arte contemporáneo, como participante a quien invitan a hablar en compañía de quien posiblemente sea el más conocido curador del mundo contemporáneo, y ha llegado incluso a fraguar la existencia de un artista con obras. O con muebles. Porque después del fin de la conjura Shandy que detallaré más adelante, ha aparecido un tal Clement Cadou que sólo pintó muebles y a todos les puso el mismo título: Autorretrato. ${ }^{172}$ Claro está que continúa la asociación en la historia de la pintura de la silla como proyección del propio artista, como su autorretrato.

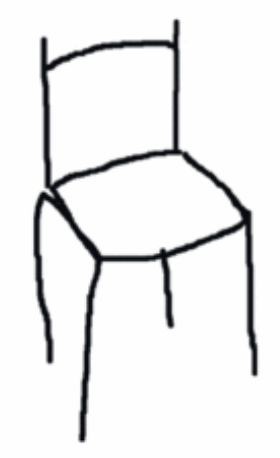

Ilustración 84: Clement Cadou, Autorretrato 
Como anota Mariola Rosario Padró en Domicilio desconocido, si para Enrique Vila-Matas, poner una cita es "como lanzar una bengala de aviso y requerir cómplices" su narrativa "encierra un sinnúmero de complicidades textuales y extratextuales, desde la biblioteca de referencias y acotaciones reales e inventadas hasta la exigencia de un lector activo, preparado y consciente de su papel como punto final en el pacto creativo" (Padró).

Partiendo de esta perspectiva, la estrategia de abordaje de HALP que propongo consiste en desentrañar su relación con la vida, sobre todo a partir de la entrevista con Cabanne, que no tomaré en su versión original sino en la traducción coloquial que hizo en México el artista Damián Ortega (n. 1974) invitando a un grupo de artistas a traducir para su país la conversación original y que se publicó como parte de un proyecto artístico, y con dos obras particulares de Duchamp, en torno a las cuales no sólo se despliega toda la reflexión metaliteraria de la novela, sino se realizan ejercicios de duplicación y de reapropiación literaria de determinadas prácticas artísticas. La hibridez de HALP obedece a una génesis curiosa pues si deriva gran parte de su relato de la obra y creación de Duchamp, a su vez, éste desarrolló las obras que cambiaron radicalmente la historia del arte del siglo XX a partir de su encuentro decisivo con un texto literario: Impresiones del África, de Raymond Roussel (1877-1933). De hecho, en The Salt Seller, él mismo declaró: "I felt that as a painter it was much better to be influenced by a writer than by another painter" (The Salt Seller). En el aparte relacionado con el viaje de los conspiradores al continente negro ampliaré este punto. En todo caso, si la ficción ha llegado a ser extrema es también porque ha sido capaz de deslizarse generando espacios de interacción con el arte para el autor y para activos shandys que se apropian de la 
denominación de los conjurados y continúan por su cuenta la existencia de la conspiración.

De este modo, un grupo de artistas encabezado por la artista mexicana residente en París, Daniela Franco organizó en París en 2003 una exhibición de artistas portátiles que declaron su filiación con la Conspiración Shandy y que contó con la presencia real del escritor: l'artiste portatif(El artista portátil). Franco explicaba que el proyecto estaba inspirado en la conspiración Shandy (un informe ficticio de una sociedad de escritores creado por Walter Benjamin (1892-1940) y Marcel Duchamp entre otros), tomado de la historia abreviada de la literatura portátil de Vila-Matas, quien también colaboraba con el proyecto (Franco). Si bien se aclaraba desde el comienzo su naturaleza de ficción, se extendían sus efectos a un proyecto artístico real aclarando las características que se requerían para ser parte de la sociedad Shandy y que repetiremos varias veces: un gran grado de locura, una pérdida de grandes propósitos, una tensa relación con el doble, simpatía por la oscuridad y un nomadismo incansable, se destacaban en ese orden aclarando que otro requerimiento indispensable era tener un cuerpo de trabajo fácilmente transportable, leve, que pudiera viajar en una maleta (Franco).

En todo caso, este deslizamiento de la conjura literaria en el terreno de las prácticas artísticas y de la vida es perfectamente acorde a la intención inicial de VilaMatas quien, fiel a la visión que abrió para él la existencia de Duchamp, pretendió escribir en HALP un texto que supusiera "no solamente la historia de la conspiración en los años veinte de los shandys", sino "una instigación a la conversión de la vida propia en un arte" (Doble Shandy). Si bien es cierto que la invención de la conspiración Shandy o Sociedad Secreta de los Portátiles aprovecha las filiaciones literarias, la caótica y dispersa 
historia del dadaísmo - cuyas redes se extendieron de Alemania a Nueva York y estuvieron ancladas a un espacio superpuesto a África—se sustenta con una vasta investigación que incluye como fuentes no sólo textos apócrifos, sino correspondencias verídicas, diarios personales, publicaciones de la época, biografías, catálogos y textos de $\operatorname{arte}^{173}$, y se construye como una estructura que ante todo duplica ciertas obras y actitudes vitales de Duchamp, esa amalgama que realiza entre ficción y realidad no encara un desafío epistemológico, no se ocupa de diferenciar lo subjetivo de lo objetivo, ni de proponer un conocimiento en cuanto tal, sino de transmitir una experiencia vital, un estado de ser, o de inacción, o de euforia creativa, que se propaga más allá de las páginas.

En HALP nos enfrentamos en efecto a un texto que más allá de la posmodernidad preconiza la altermodernidad en tanto no sólo da continuidad a la práctica del libre uso y saqueo de cruciales referencias de la historia del arte y de la literatura que preconizaron las vanguardias, sino extrapola su proyección del cuerpo textual a ámbitos de la vida real. Y para hacerlo usa diversas estrategias entre las cuales la otredad ligada al acto de la escritura puede suponer no sólo la invención de caracteres, sino su deslizamiento en campos extraliterarios, el hecho de que estos caracteres ficiticios acaben haciendo obras reales $\mathrm{o}$, cuanto menos, generando exhibiciones de arte y paseándose en estas o llevando a su inventor a hacerlo. Nos avocamos a un incesante juego de duplicaciones, dobles que se desdoblan, narradores que se multiplican y empiezan a deslizarse y aparecer en inadvertidos espacios como espejos de la libertad de poder crearse incesantemente o de la multiplicidad del artista en una era caracterizada por la aparición de lo altermoderno, término que el teórico francés Nicolas Bourriaud (1965- ) lanzó en el mundo del arte en la Trienal de la Tate de 2009. "Quizás la literatura sea eso: inventar otra vida que bien 
pudiera ser la nuestra, inventar un doble", especula Vila-Matas en El mal de Montano (16), quien escribe con el eco en sus oídos de un verso de Rimbaud (1854-1891): “Je suis un autre". Sólo que la multiplicación de la alteridad adquiere tales dimensiones en los ejercicios de la ficción extrema que a menudo habría que exclamar: "Yo soy otros".

\section{Un arte de vivir}

Para adentrarse en la travesía de HALP que es laberíntica y no tiene una salida definitiva pues desemboca en la vida y su inagotable artificio creador, el punto de partida propuesto es la génesis de la propia obra, no sólo según lo cuenta el narrador-testigo que busca desentrañar la Historia Abreviada de la Literatura Portátil y que de hecho la narra en primera persona; sino de acuerdo a lo que el propio Vila-Matas ha expuesto en diversos textos y en la página virtual dedicada a la conjura portátil. Pero antes, es indispensable establecer, desde el inicio de esta travesía, el influjo vital que tuvo la lectura de Conversaciones con Duchamp en Vila-Matas, origen real de la Conspiración Shandy.

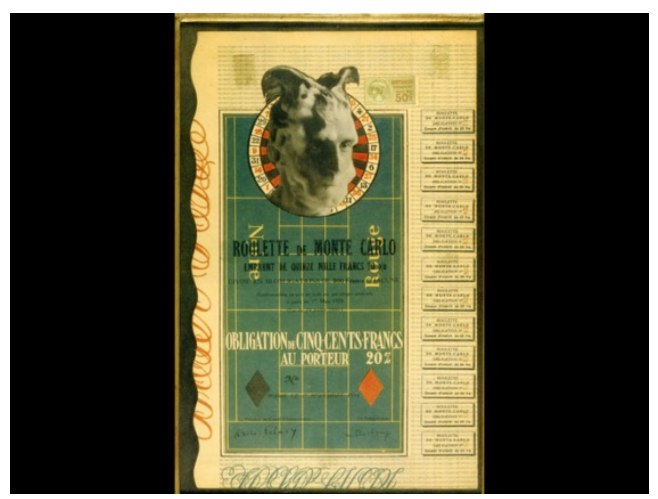

Ilustración 95: Marcel Duchamp: Obligation pour la roulette de Monte Carlo 1924
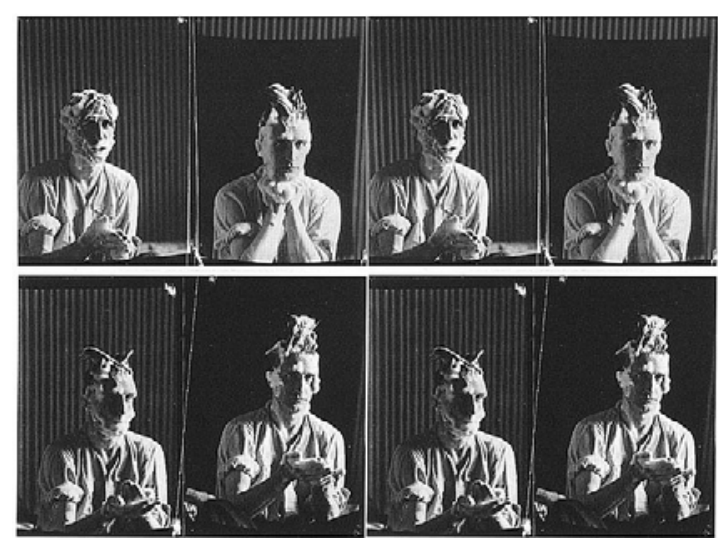

Ilustración 96: Man Ray: Bonds for MonteCarlo roulette 1924 
Vila-Matas narra en su página digital cómo en 1972 (cuatro años después de la muerte de Marcel Duchamp) vio en el escaparate de una librería el libro Conversaciones con Marcel Duchamp, de Pierre Cabanne, que tenía una portada que le fascinó: una reproducción de "Obligation pour la roulette de Monte Carlo", un "readymade" (nombre con que se conoce el uso del objeto encontrado a partir de Duchamp) que era una fotografía de su propio rostro cubierto de espuma hasta el pelo en puntas en medio de un bono de casino, y una contraportada con una frase no menos atractiva escrita por André Bretón: "Duchamp no sólo fue uno de los hombres más inteligentes (y para muchos el más molesto) de este siglo, sino también uno de los más enigmáticos" (Una vida maravillosa).

Muy pronto, esa entrevista con Duchamp se convirtió para el futuro autor que entonces apenas tenía 24 años, en su "biblia personal", y de hecho nunca se ha separado de éste. Lo mantiene en un estante a la izquierda del escritorio donde se ha movido en las últimas cuatro décadas, desde cuando, venciendo su impulso de holgazanería y de convertirse en un autor sin obras, estando en África — continente donde se inicia la conjura- escribió su primer libro. Lo que le fascinó, según evoca, no fue tanto ese hombre que todo el tiempo estaba a punto de dejar de ser un artista, sino el hecho de que a sus setenta y nueve años sostuviera que había tenido "una vida absolutamente maravillosa" ${ }^{174}$ y propusiera "un estilo ágil de conducta y de relaciones con el arte y con el mundo para quien quisiera sacar provecho de su involuntaria lección" (Una vida maravillosa). En ese libro encontró respuestas que funcionaban como pistas para moverse de tal modo en la vida, que al final de esta fuera posible proclamar que había sido 
maravillosa. Estaba frente a un hombre que se llamaba a sí mismo anartista y que se consideraba afortunado de "pasar a través de las gotas" pues había comprendido que:

Ni era necesario sujetarse a la obligación de trabajar ni debía cargarse a la vida con demasiado peso, con demasiadas cosas por hacer, aquello a lo que se llama una mujer, niños, una casa en el campo, un coche, etcétera. Y lo comprendí felizmente muy pronto. Eso me ha permitido vivir mucho tiempo como soltero mucho más fácilmente que si hubiera tenido que entrentarme con todas las dificultades normales de la vida. En el fondo, es lo principal (12).

Esta cita, literalmente tomada de la entrevista de Cabanne, es puesta en HALP como un comentario que hace Duchamp al músico Edgar Varese (1883-1965) y cumple el oficio de establecer el primer principio, en consecuencia, de los miembros de la Conjura Shandy: "Funcionar como una máquina soltera". La obra más conocida de Duchamp, La Novia desnudada por sus solteros, aún, o El gran vidrio, cuyo sentido ha ocupado incontables tratados, y jamás ha sido dilucidada del todo porque justamente, pese a su complejo mecanismo erótico, es ajena e indiferente a las lógicas establecidas, no sólo podría sintetizarse justamente en ese principio, sino que la expresión que Duchamp usó para el conjunto de su parte inferior es "máquina soltera”. Así que si bien el narrador no nombra explícitamente esta pieza icónica, irradia la génesis del texto. Más adelante retomaré el tema, pero aquí lo importante es señalar que la aparición de la cita de Duchamp constituye un guiño que remite a su visión y obra, y a esta entrevista vertebral para la concepción total de HALP, aunque su fuente no se mencione en el libro. No aparece, por ejemplo, entre las dos decenas de obras citadas que Vila-Matas incluye como no tendría que hacerse en novela alguna, justamente para deslizarse desde la confusión de géneros, hacia la vida, y que por supuesto, mezcla títulos reales con otros inexistentes. 
La "máquina" por otra parte, está legada a una exaltación de la modernidad que fue abrazada por las vanguardias. Francis Picabia (1879-1953), cuyo espíritu incendiario deslumbraba a Duchamp, con quien ciertamente abrió el capítulo Dadá en Nueva York, y en uno de los principales conjuradores de HALP, que retrata de modo fidedigno la cercanía del vínculo entre ambos, publicó un revelador artículo en The New York Tribune en 1915, con esta consideración:

The machine has become more than a mere adjunct of life. It is really part of human life...perhaps the very soul. In seeking forms though which to interpretet ideas or by which expose human characteristics I have come to length upon the form which appears most brilliantly plastic and fraught with symbolism. I have enlisted the machinery of the modern world, and introduced it in my studio (Watson 239).

De cualquier modo, no fue en 1972 de su encuentro con la entrevista a Marcel Duchamp, cuando Vila-Matas acometió la escritura de HALP, sino en 1985, cuando se publicó gracias a una serie de coincidencias que el autor narra en la página virtual sobre su invención, aunque no menciona que justo mientras la escribía la Fundación Joan Miró, de su ciudad natal, Barcelona, realizaba la exhibición Marcel Duchamp. Así, narra que un elogio de su editor Jorge Herralde acerca de un artículo sobre los shandys publicado en La Vanguardia le hizo lanzarse a la escritura de HALP. A su vez, el artículo había surgido después de haber visto, en 1983, una exposición sobre "Máquinas solteras de la literatura”, en el Grand Palais de París. ${ }^{175}$

De modo anecdótico refiere Vila-Matas también que por ese tiempo llevaba de bar en bar un libro de aforismos de Cristóbal Serra (1922-2012) y que uno de éstos hablaba de las ventajas de la brevedad. En sus páginas anotó un primer título tentativo, Breve Historia de la Literatura móvil, que a la postre se modificó en el que da origen a la 
abreviatura HALP. Y que todo esto ocurrió “en una terraza al sol, muy lejos de La Polilla. Y muy cerca de Sterne". De modo que, antes de continuar estableciendo la relación entre la obra de Duchamp, sus respuestas a Pierre Cabanne y la estructura narrativa de HALP, sobre todo en lo referente a los principios que sostienen esa comunidad de espíritu de los portátiles, es imprescindible detenerse en el origen de esta noción y del nombre de la conspiración Shandy que el narrador inicia en 1924, año en que se ha disuelto el movimiento Dadá.

\section{De los shandys y la ontología de su nombre}

En el prólogo de HALP, Vila-Matas aclara que los shandys adoptaron este nombre en referencia al dialecto de algunas zonas del condado de Yorkshire, donde significa indistintamente "alegre, voluble y chiflado" (10). La elección del condado obedece a que allí vivió Lawrence Sterne, autor del Tristram Shandy, buena parte de su vida. Más adelante añade que en las instrucciones cifradas que remitían a la librería Shakespeare and Company, de Sylvia Beach, donde se reunían los conspiradores en París, la primera frase, que decía: "Si Hablas Alto Nunca Digas Yo", contenía como mayúsculas las letras que formaban la palabra shandy ${ }^{176}$. 


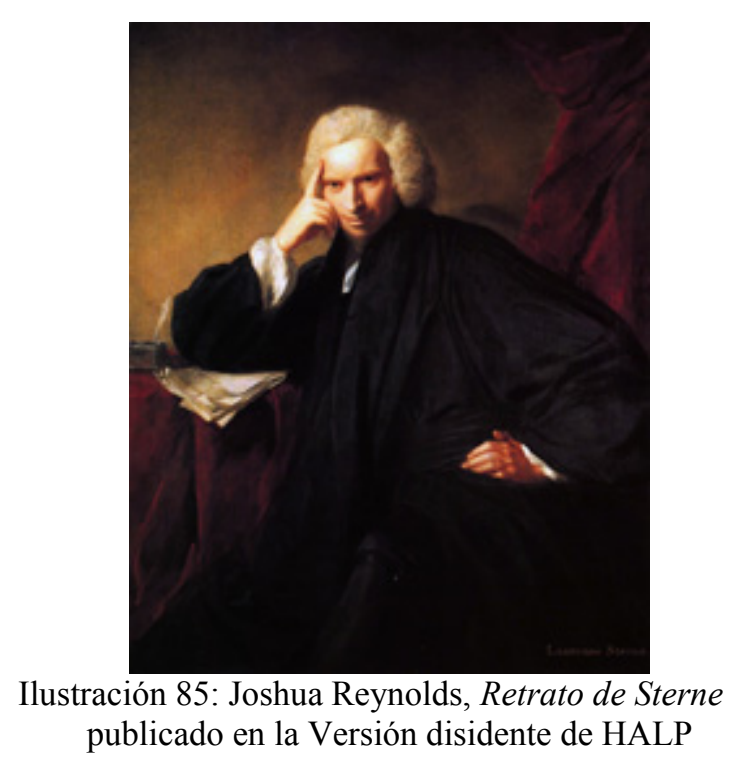

Luego, asumiendo el pleno derecho a la contradicción, el narrador añade que más allá de la explícita referencia a Sterne, la palabra shandy tenía un significado alcohólico, puesto que en Londres "es una bebida habitual, que consiste en una cerveza amarga combinada con limonada o cerveza de jengibre" (40-41). Además de la autobiográfica relación del autor con la bebida, que sólo dejó impelido por una serie crisis de salud, existía ciertamente una atmósfera etílica entre los vanguardistas que curiosamente se acrecentó cuando dadaístas y surrealistas vinieron a los Estados Unidos en la antesala o durante la Primera Guerra.

Ahora bien, el juramento que sirve para entrar a formar parte de la sociedad secreta es una cita tomada del Tristram Shandy: "La seriedad es un continente misterioso del cuerpo que sirve para ocultar los defectos de la mente" (43). Y, esa seriedad, tan asociada al yo, tiende a minarse con los desdoblamientos que pueblan este libro. 


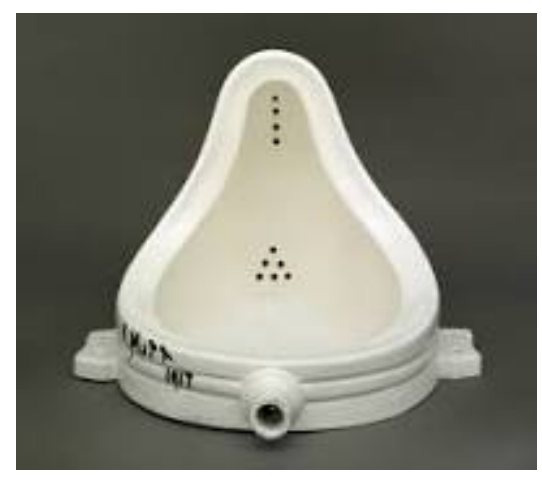

Ilustración 86: R. Mutt (Marcel Duchamp) Fontaine (Urinal) 1917

Aunque no se menciona en el libro, uno de los máximos actos ejemplares de los desdoblamientos, varias veces comentado por Vila-Matas, fue el del famoso urinal que Duchamp tituló "Fontaine" y envió como una obra a la Society of Independent Artist de Nueva York en 1917, en la cual actuaba como jurado, desdiciendo de su autoría, y ocultándose bajo el seudónimo de R.Mutt ${ }^{177}$. Por supuesto, como ya sabe, retiró no sólo la obra, sino su participación como jurado cuando ésta fue rechazada. Shandy se asocia tanto a los desdoblamientos, como a una exaltación de la individualidad no domesticada por nada, salvo por un sentido del humor que puede enfilarse contra sí, justo como en este acto con el cual Duchamp, puso a prueba el límite de las vanguardias.

Vila-Matas describe su pertenencia a la Sociedad de Amigos de Tristram que se reúnen cada 24 de noviembre, a celebrar el aniversario del nacimiento de Sterne, oriundo de Clonmel (Irlanda) y su filiación cervantina. Evoca, risueño, cómo también Sterne embiste las solemnes novelas de sus contemporáneos, con su asombroso contenido narrativo, sus digresiones y los comentarios eruditos omnipresentes. En el texto, destaca las siguientes características como corolario del Tristram Shandy:

Su gran exhibición de ironía cervantina, sus asombrosas complicidades con el lector, la utilización del flujo de conciencia que otros luego dirían que habían 
ellos inventado. Y por inventar que no quede: en Sterne encontramos una fabulosa capacidad freudiana para la asociación de ideas. Es un libro extraordinario en el que su protagonista no quiere nacer porque no quiere morir (...) Me fascina esta novela tramada con un tenue hilo de narración y unos monólogos donde los recuerdos reales - como en la mejor de las hoy tan en boga autoficcionesocupan muchas veces el lugar de los sucesos imaginados (En el país de Tristram).

Menciona en el mismo artículo la figura de Ernst Jünger (1895-1998), que entre combate y combate leía el Tristram como una "fuente de diversión y energía en medio del desastre bélico" (El ayudante de Vilnius). El comentario arroja luz indirecta, pero decisiva sobre la estructura de los acontecimientos en HALP, que no obstante declararse situado entre 1924, año del fin del Dadá y del Manifiesto Surrealista de Breton, y 1925, incluye hechos decisivos que tuvieron lugar durante la Segunda Guerra Mundial como el suicidio de Benjamin en Portbou.

En HALP sólo dos veces se menciona, de paso, a Sterne, pero, como se ha dicho una frase suya es la consigna de los conspirados ${ }^{178}$. Y, en la página virtual de la novela, aparece su figura tutelar, que, como resulta evidente en el artículo sobre El país de Tristram, tiene filiación cervantina y alimenta, a su vez, toda la posterior tradición auto reflexiva y la misma meta-literatura y aquellas obras especulares que se deslizan del texto a la imagen o visceversa y reflejan el propio proceso de creación ${ }^{179}$. En la novela de Sterne hay una páginas en blanco, signos gráficos, una página completamente negra, espacios lúdicos y de inmenso humor para que el lector participe. 

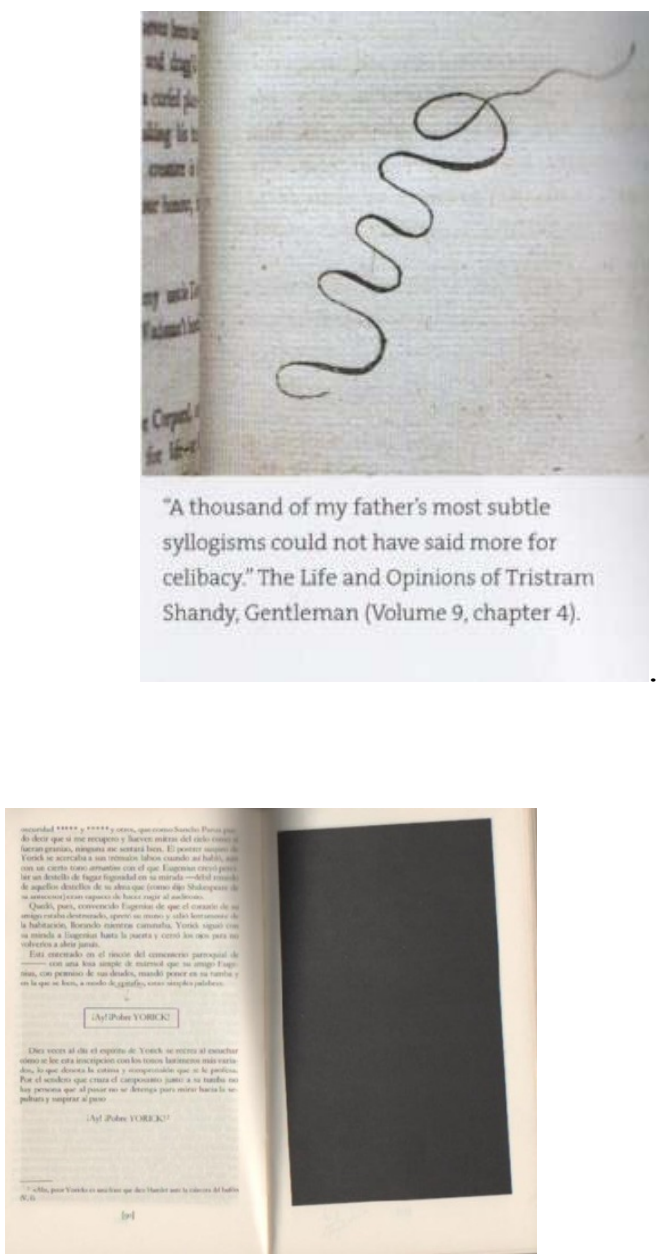

Ilustración 99: La página en negro del Tristram Shandy
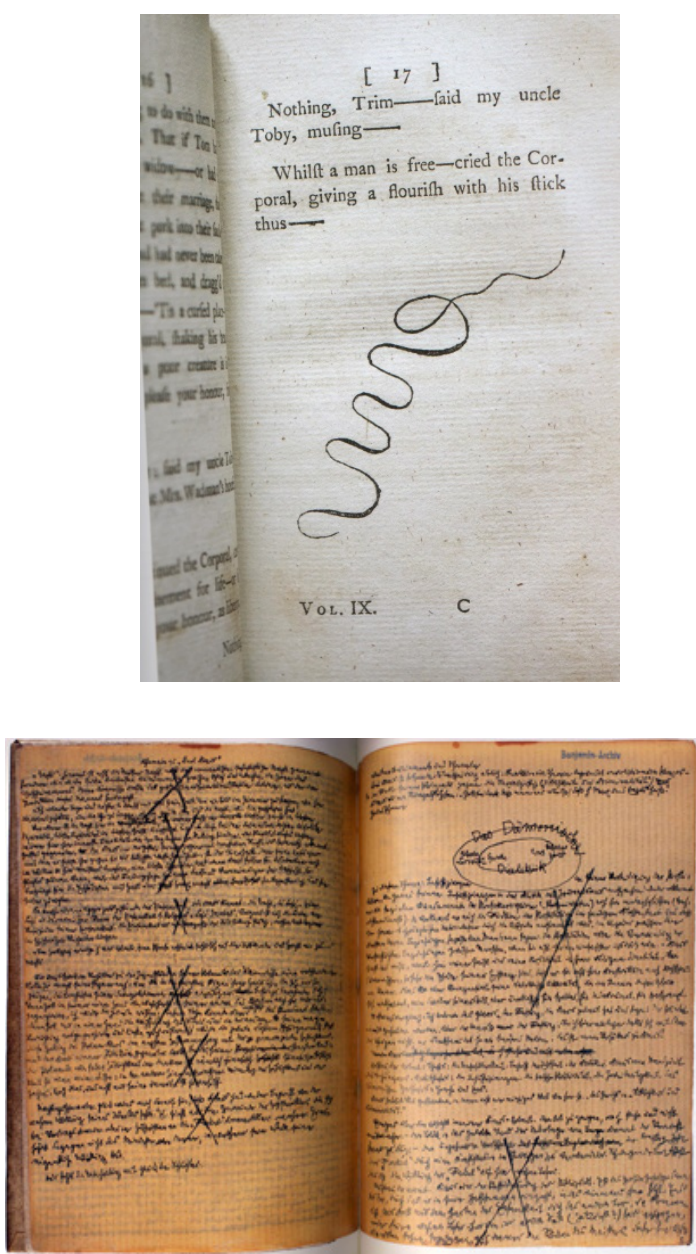

Ilustración 100: Manuscrito de W.Benjamin que

Vila-Matas incluye en versión disidente de HALP

Como dice David Rokeby, la novela de Sterne, 1766, es un temprano ejemplo de

literatura que alienta la participación y la interpretación subjetiva:

Throughout the book, the reader's expectations and assumptions are variously addressed in a surprisingly post-modern manner. An example is found in Chapters 37 and 38 of Volume 6.

Let love therefore be what it will, - my uncle Toby fell into it.

- And possible, gentle reader, with such a temptation

- so wouldst thou: For neverdid thy eyes behold, or thy concupiscence covet any thing in this world, more concupiscible than widow Wadman.

To conceive this right, - call for pen and ink - here's paper ready to your hand.

- Sit down, Sir, paint her to your own mind - as like your mistress as you can 
- as unlike your wife as your conscience will let you ---- 'tis all one to me ---please but your own fancy in it. [a continuación viene la página en blanco] (...) (Rokeby).

Continúa Rokeby: "For a brief moment, Sterne clarifies the mirror provided by the text, showing us ourselves staring into the page. Marcel Duchamp expresses the idea of the artwork as a mirror in his work The Bride Stripped Bare by Her Bachelors, Even" (Rokebey). Otro aspecto que une a Sterne y a Duchamp es la noción de la obra inacabada. El primero no puede ir más allá de la narración del primer año del Tristram, el segundo abandona en 1923 definitivamente La Novia desnudada por sus solteros, aún, también conocida como El gran vidrio (Duchamp la subtitulaba en realidad Retraso en vidrio o Tal vez un cuadro de visagra, por los juegos lingüísticos con su material y estructura), aunque continúa trabajando en la Caja verde ${ }^{180}$ que publica once años después y que contiene sus notas de trabajos sobre esta pieza ancilar a la que regresaré luego. Aunque muertos con un siglo de diferencia, el primero en 1868 y el segundo en 1968, año hasta el cual continuó escribiendo sus notas, Sterne y Duchamp son figuras profundamente afines y coincidían en la fascinación tan filosófica como humorística por la máquina del pensamiento y sus trabajos absurdos.

Numerosos párrafos en el libro de Vila-Matas transcriben o parafrasean —aunque también citan apócrifamente- a otras referencias, y terminan llevando, en última instancia, a un modo de humor que es iniciático en un oficio al que se le pide, ante todo, derrotar la opacidad del mundo con una risa en la que el yo se desdobla, cambia de nombre, transmigra a otros e incluso se configura colectivamente. Como dice Julia Otxoa, en su escritura se advierte 
un collage fluido que avanza engarzándose mediante un ars combinatoria que funde el tiempo del narrador con el de otros autores y obras de la literatura universal, hasta lograr esa identidad coral, poliédrica, cuestionándose a sí misma desde la ironía y la paradoja (31).

No se trata sólo de que la traducción al español de The Life and Opinions of Tristram Shandy, Gentleman 1776, de Laurence Stern sea el libro "rey" de la biblioteca de Vila-Matas (Santander y Abadía). La elección del nombre de la conspiración obedece a la elección de recurrir a un objeto encontrado, ya listo, que contiene justamente ese espíritu lúdico, altamente subversor de lo establecido por el Dadá y establecer un hilo de filiación del dadaísmo con esta obra y, por esta vía, con su predecesor cervantino, Don Quijote de la Mancha. Ambos libros establecen anticipaciones de falsificaciones, apropiaciones, una aguda autoconsciencia del proceso creativo, y una penetrante crítica de su propio tiempo, que tendrán continuidad en la obra posterior no sólo de escritores, sino de artistas como el mismo Duchamp, a su vez retomada por Vila-Matas en este libro caprichoso - si se quiere capcioso - que construye a partir de fabulaciones una impecable genealogía de la irreverencia como la saludabilísima práctica cultural ${ }^{181}$. 


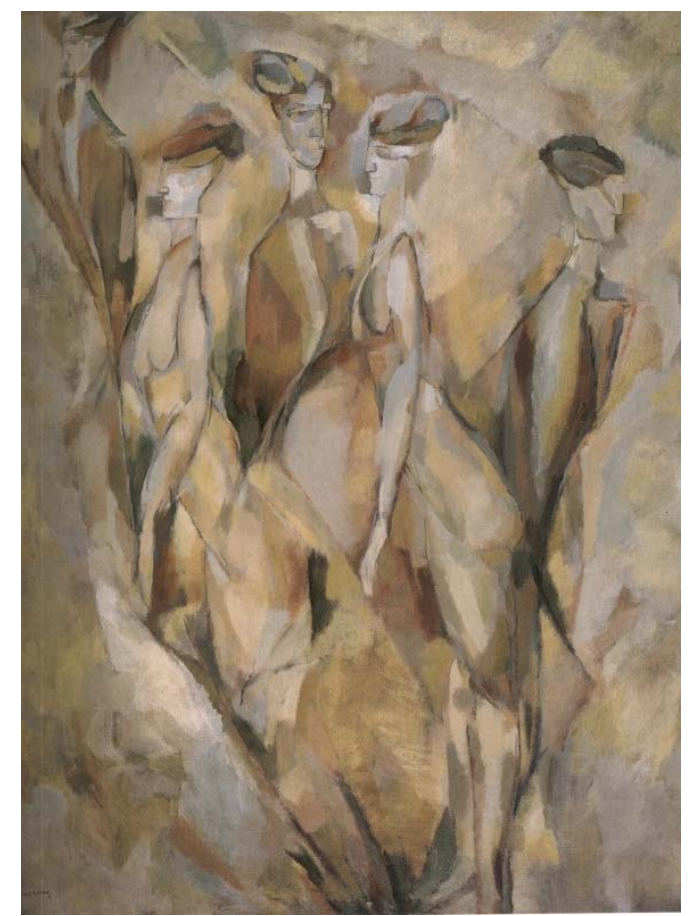

Ilustración 87: Marcel Duchamp, Dulcinea

1911. Óleo sobre lienzo.

(C) Artists Rights Society (ARS), New York / ADAGP, Paris / Estate of Marcel Duchamp

The Louise and Walter Arensberg Collection, 1950. Museum of Philadelphia

Tanto Sterne como Duchamp tienen -y extienden- hilos cervantinos. El primero reconoce en la segunda parte de Don Quijote el libro predecesor de su Tristram Shandy. El segundo lo evoca en una de sus obras emblemáticas: Retardo o Dulcinea ${ }^{182}$. Duchamp retrata en efecto a una transeúnte que cruza la plaza, "una muchacha entrevista, amada y nunca vista otra vez" (Paz 18). En esta cita, la recreación del ensayista Octavio Paz es mucho más poética que la que evocación escueta de la pieza que éste hace en su conversación con Cabanne cuando le dice que Dulcinea es una mujer que conoció en la Avenida de Neuilly, a quien veía de vez en cuando irse a comer, pero con la que nunca habló porque no era siquiera cuestión de acercarse. Paseaba a su perro, vivía en la zona, y eso era todo. De cualquier modo, como nota Hopkins, en la elección del nombre de la pieza, tanto como en el carácter de su representación, aparentemente ha transpuesto una 
identidad literaria a la figura femenina: "Dulcinea was the idealizaded village girl in Cervantes's Don Quixote, whom the besotted hero never spoke to"(44). La pintura, realizada en 1911, con una figura compuesta por cinco siluetas femeninas que se funden, es, con "la descomposición y superposición de las posiciones de un cuerpo en marcha, una prefiguración del Desnudo que desciende una escalera" (Paz 18), que a su vez concibe después de ilustrar un poema de Laforgue. Y, por supuesto, es una obra sobre el deseo no consumado, sobre el "amor" que únicamente existe en la mente de quien convierte a otro ser en el objeto de su imaginación. En esa medida, es una obra relacionada con la soltería, estado permanente elegido por Duchamp que comparten todos los miembros de la conjura pues son solterones, o si están casados, deben actuar como si no lo estuvieran. Octavio Paz recuerda la admiración de Duchamp por Lafortgue, cuya famosa expresión "Célibat, célibat, tout n'est que célibat" puede remitir al mundo como la representación de un yo solterón (116).

Lo que Vila-Matas hace es justamente escribir sobre esos intersticios una concatenación de hechos que entrelaza lo que fueron múltiples y heterogéneas manifestaciones del espíritu dadá en una conspiración que a la postre tiene como misterio el de la misma naturaleza del arte, asumido -y en esto fueron maestros Tzara y Duchamp - como un credo vital, pues fue leyendo el Tristram que Vila-Matas descubrió que la vida es shandy. Si el "espíritu innovador" del shandy está estrechamente ligado a la libertad de transitar por las creaciones de otros y de apropiárselas con la impunidad con que el mismo Stern saqueó la segunda parte de Don Quijote para crear un libro de incontrastable autenticidad; la "ausencia de grandes propósitos" está ligada a las acciones 
de Duchamp, de las cuales hace Vila-Matas una fantástica recreación que lleva más allá de los límites de la realidad. Como nota José María Pozuelo Yvancos:

El principio germinal que da sentido a toda la literatura de Vila-Matas y que encuentra en el propio Quijote (que se prolonga en su Montano) su principal argumento; la hipotética distinción entre novela y mundo, entre libros y realidad es indecible y afirmarla es tan artificial como su negación. Vila-Matas ha concebido su propio proyecto literario como un comentario al arte de la novela, entendida como red de caminos trazados en el imaginario humano (...). Transitar por tal red o verse atrapado en ella no tendría un origen ni un final, como tampoco el viaje de K., sino una prolongada figura especular del propio mundo de texto intercomunicados que los configuran y que remite en última instancia a las paradojas del laberinto vital y simultáneamente literario de quienes se encuentran enfermos de literatura (34).

La parodia como gesto, el humor como consigna, la irreverencia como punto de fuga, son paradójicamente un modo de esquivar las mentiras sistemáticas que se sostienen en la percepción adocenada. Mofa, invenciones, burla de la autoría, impune canibalismo literario $\mathrm{y}$, por encima de todo, desconfianza de todos los absolutos incluyendo el de la misma existencia de una realidad autónoma e independiente de las ficciones - son estrategias que contaminan la producción artística y literaria con deslizamientos que buscan un modo de visión que transita libremente no sólo del arte a la literatura, sino que esquiva las celdas del pensamiento donde se engendran los órdenes monstruosos, las respuestas definitivas, y que suponen una interactividad que parte de la incorporación de lo especular.

Para abrir la puerta del juego que propone Vila-Matas en el libro-artefacto, estructurado a partir de una serie de principios asumidos por los conspiradores, donde mezcla el destino y la obra de figuras que siguen influyendo nuestro tiempo, con sus propias invenciones para desentrañar (¿o extender?), ese modo de visión, quiero 
remitirme a la declaración de intención sobre su escritura que dio en una reciente entrevista:

Me dedico a la ficción. Pero busco a través de ella la verdad. Parece paradójico. Ya lo digo en Dietario voluble: Está todavía por escribirse la historia de todos aquellos escritores — desde Montaigne y Cervantes hasta Kafka, Musil, Beckett, Perec - que lucharon con un esfuerzo titánico contra toda forma de fingimiento o de impostura. Una lucha de evidente acento paradójico, pues quienes así combatieron fueron escritores que vivieron anegados hasta el cuello en el mundo de la artificialidad y de la ficción. Sea como fuere, de esa tensión han surgido las más grandes páginas de la literatura contemporánea (Santander \& Abadía).

La escritura de Vila-Matas apuesta justamente a enlazar momentos de un clímax,

de un largo acto de libertad iconoclasta que tenía estallidos sucesivos, instantes reveladores, cambiantes en escenarios ubicuos y, con una total fidelidad a la atmósfera que rodeó a estos conspiradores y a sus visiones - pero no necesariamente a sus hechos - fragua los detalles de la sociedad secreta shandy. Su intento "miniaturiza", reduce a un cortísimo libro de 127 páginas, la historia y la biografía de los más avezados vanguardistas de los años 20 y 30 . Incluye, como Cervantes, a los artistas y escritores que juzga suficientemente lúcidos y leves para ser integrados a su libro y, por supuesto, para formar parte de una conspiración que no existió ciertamente del modo en que él la propone, pero que sin duda estuvo presente en los efectos que sus obras produjeron en Europa y América, al extender el arte del escándalo, poco antes de que la sociedad tomara la vía fácil del espectáculo.

\section{Duchamp como Odradek del narrador Vila-Matas}

Existen similitudes de espíritu, tanto como diferencias circunstanciales respecto al modo en que el encuentro entre el narrador intradiegético Vila-Matas, y Marcel Duchamp, se narra en la novela y se aclara fuera de ésta en entrevistas o textos del autor 
que aluden a lo real. Rodrigo Fresán, escritor y amigo de Vila-Matas escribió un párrafo respecto a Exploradores del abismo que es perfectamente aplicable al caso de HALP, donde comenta que a diferencia de Borges y de su célebre declaración de que "al otro Borges es a quien le suceden las cosas", en el caso de este autor, quienquiera que lea sus libros, entrevistas o columnas, sabe perfectamente que:

Vila-Matas no tiene otro Vila-Matas (...) No sólo porque en el panorama de la literatura en español Vila-Matas sea uno de esos raros y admirables fenómenos que empiezan y terminan en sí mismos, sino porque también uno de sus rasgos más precisos y reconocibles es el de haberse procurado primero una vida que estuviese a la altura de su obra y, enseguida, una obra que estuviese a la altura de las obras que él más admira y que son ya parte de su vida.

La cita es un enmascaramiento de los muchos desdoblamientos de ese único VilaMatas puesto que, como ya se ha visto, eso de procurarse una vida a la altura de la obra, y una obra que estuviese a la altura de las obras que admira (Rodrigo Fresán), remite en buena medida a la actitud vital de Duchamp que abraza como doble explícitamente en la novela, y al modo en que HALP se sitúa no sólo a la altura de La maleta en la valija y La Novia desnudada por sus solteros, aún, conocida también como El gran Vidrio (Fresán), sino conteniéndolas, como veremos más adelante.

En HALP, el origen de la novela se narra como una construcción en "abyme", el procedimiento que, como advierte McHale, refleja en una escala en miniatura la estructura narrativa en la cual aparece. Además, justifica la construcción de un texto que duplica los principios vitales y la obra de Duchamp, a través de un procedimiento de usurpación que desplaza lo vital y lo artístico a lo literario, narrando cómo, más allá de su elección e incluso de su voluntad, Duchamp lo habita nada menos que como su Odradek. El resultado — asociado a la ficción posmoderna y más que a esta a lo que hemos llamado 
altermodernidad-, es la aparición de una clase de entre-mundos, de un espacio, que, como el mismo Mc Hale afirma, puede verse como una zona en la que es posible la transmigración de caracteres (53-58).

El narrador en primera persona aparece en el prólogo, sin revelar nunca su nombre, pero fungiendose desde la primera persona como el propio Vila-Matas, y enuncia los principios que agruparon a miembros de la conjura Shandy para advertir al lector que se encuentra "en disposición de afirmar que la sociedad portátil existió más allá de los lejanos horizonte de la imaginación de sus componentes", a los que identifica como amantes de la escritura "cuando ésta se convierte en la experiencia más divertida y también la más radical" (o extrema, añadiría) (14).

A continuación, en el primer capítulo, "Oscuridad y magia", aclara que debe a una breve conversación con Marcel Duchamp —además de a un libro inédito de Picabia, artista que tuvo un influjo poderoso sobre el propio Duchamp- las informaciones decisivas sobre la participación de las mujeres fatales en la fundación de la sociedad secreta, tema erótico que constituye un eje en la obra de Duchamp y que analizaré más adelante. No es, sin embargo, sino hasta poco antes de la mitad del libro, en el capítulo "Laberinto de odradeks", cuando cita, como un recuerdo, "tan intenso" que siempre lo evoca en presente, el espacio donde ocurrió este encuentro: la terraza de un café de Port Bou, un lugar esencial pues fue ahí — justo a unas cuadras del hotel en donde Walter Benjamín "se vio obligado a quitarse la vida" y 27 años después de que esto sucediera $^{183}$ - cuando Duchamp le reveló la existencia de la sociedad shandy que hasta entonces ignoraba (14). 
En el interior del café, un Vila-Matas intra-diegético descorcha una botella de champaña $y$, dado el extraordinario comportamiento del corcho que se queda en equilibrio en la varilla de las cortinas, el mismo Duchamp le inicia en el misterio de cierto inquilinos negros u odradeks (dobles semi-humanos de origen kafkiano, a los cuales dedicaré un aparte) que habitan los laberintos interiores de los portátiles. Esta revelación ocurre después de que Duchamp le cuenta que fue Benjamín quien permitió que los conspiradores continuaran viajando sin otro fin que seguir contándose historias.

Esa iniciación en la existencia de los Odradeks o dobles fantasmales que acechaban a los shandys bajo distintas formas susurrantes, a menudo inmiscuyéndose en sus labores literarias es una clave de su ficción extrema. No en vano, las explicaciones respecto a las peculiaridades de los Odradeks de Skip Canell, Ramón Gómez de la Serna (1888-1963), Juan Gris, o de Salvador Dalí (que tomaba la forma de un violín masturbador) sirven de preludio al momento cumbre de la revelación de la usurpación de la identidad. Al termino del capítulo, antes de desaparecer de un instante a otro, Duchamp le advierte a Vila-Matas que vaya con cuidado con ese tapón de champán que puede ser su odradek y tener a su vez un golem (otra criatura ligada a Praga por la mística literaria del rabí Judah Koew ben Bazalel y por el libro de Gustav Meyrink, otro shandy). Pero acto seguido, el propio narrador, dejando de lado estas criaturas fantásticas, da una clave especular de HALP al preguntar —o más bien revelar— in media res: “¿Será Duchamp mi odradek?” (64). Pregunta que más adelante una ofrece una salida cuando el narrador aventura que quizás los fantasmas de los cerebros portátiles "sean simplemente la literatura escrita por ellos" (96). La sola formulación de la inquietud refrenda, según concluye, el simple hecho de que en su propia escritura está repitiendo la ruta errática, 
nómade, de los Shandy que emprendían un viaje que en cierto modo era un movimiento inútil, pues carecía de fin, fueran a donde fueran: "Sólo buscaban viajar contándose historias" (55).

Como sugiere Katarzyna Olga Beilin: "La otredad surge en la narrativa de Enrique Vila-Matas mediante el concepto de odradek, que la recuerda incluso fonéticamente (...) Los odradeks llevan a la otredad, que es la esencia misma del arte" (56). Tenía que ser justamente Duchamp el iniciador de "uno de los aspectos más enigmáticos del shandysmo: la existencia de unos inquilinos negros, que se hospedaron en los laberintos interiores de todos los portátiles" (56), puesto que al fin y al cabo, el propio narrador entreverá que Duchamp puede ser su otro yo, su odradek.

De este modo, desde el punto de vista intradiegético Duchamp le revela al VilaMatas narrador la conspiración para que pueda narrarla y toma posesión de él convirtiéndolo en su doble. El lector pacta en consentirlo así sepa que ni la conjura exisitó ni el narrador intercambió palabra alguna con Duchamp en su vida. Pero ocurre que en la frontera exterior del libro, Duchamp es ciertamente la figura que inspira HALP, cuyo espíritu está invadido de las prácticas duchampianas.

La siguiente aparición auto-reflexiva del yo narrativo que está escribiendo HALP ocurre después de contar que la paz entre los portátiles de Trieste y de París —un poco distanciados por diferencias temporales respecto al ocio y a la creación febril— se selló el mismo día en que, durante una cena en homenaje a Pyecraft, el obeso personaje de H.G. Wells (1866-1946) que debe llenar de plomo sus bolsillos para compensar su pérdida de gravedad, Duchamp afirmó que una de las Bellas Artes era el parasitismo. Vila-Matas confiesa que debió irse con un maletín lleno de plomo a la isla de Córcega debido a que 
su obsesión por lo shandy había desembocado en "la parálisis progresiva" (92) de su Olivetti Lettera 35. Allí descubre que su obsesión es portátil pues se cuela incluso en los sueños en los que ve ciertas experiencias de Aleister Crowley (1875-1947) tras un telón en el que aparece el anagrama Shandy dibujado por Duchamp, y debe repetirse varias veces — con alivio- que él no es ciertamente Crowley. Pero la sola sospecha revela que ciertamente, en algún momento, Crowley desplaza al Vila-Matas narrador y es quien asume la voz que cuenta una parte de HALP. Su figura, como parte central, sobre todo en la disolución de la conjura Shandy es una intervención del narrador que si bien recrea la historia del dadaísmo en términos de la cofradía real entre algunos de sus miembros, como ocurre con el estrecho vínculo entre Picabia, Man Ray y Duchamp por ejemplo, se toma la libertad de introducir a Aleister Crowley entre los más afines dadaístas, cuando sólo hay una conexión entre el autor de La novia desnudada por sus solteros, aún y el ocultista. Hablaré sobre ésta relación posible en el aparte sobre las mujeres fatales.

En tal caso, citando apócrifamente The Confessions of Aleister Crowley, que en realidad están divididas en 96 capítulos, el narrador dice que este libro está compuesto de 27 fragmentos (número eco de los conspirados incluidos en HALP) en el que repite de 27 maneras distintas que los "bocángeles" -como éste designa a los portátiles- se la pasaban en las tumbonas y que, a modo de odradeks, debía cargarlos sobre sus hombros. La veracidad del fragmento - uno de los más delirantes de HALP — se refuerza con dos escritos inexistentes de los también portátiles Man Ray y Tzara, y otro texto apócrifo presentado como pasaje del ensayo real de Walter Benjamín, a quien considera "alma gemela de Duchamp" (11) y, desde esa perspectiva es, sino otro doble del narrador, si una sombra, iluminada, muy cercana a lo más profundo de esta historia que usa el humor 
como estrategia de levedad, pero que no deja de estar tensada por hilos tan nostálgicos como el mundo de entreguerras que rodeó a los conjurados.

No hay que olvidar que es muy cerca del hotel donde un desesperado Benjamin, asediado por los muy reales nazis, decide quitarse la vida, donde tiene lugar el ficticio encuentro entre el Vila-Matas narrador y Duchamp. La cadena de alusiones intertextuales incluye a Maurice Blanchot (1907-2003), quien en su real "Faux pas" explicó que los odradeks que nos acompañan podrían ser simplemente "la forma que las cosas asumen en el olvido" y que el narrador Vila-Matas acaba conectando con la expresión sobre "el silencio de los emboscados" hallada en el Tristram Shandy. Esas cosas olvidadas, ya irreconocibles, que viajan con nosotros y que acaban emboscándonos (96).

En ese fragmento, el último en el que Vila-Matas narra una acción en la novela, hay una atmósfera de nostalgia, una pena ante lo irreparable de las muertes que desgraciadamente no fueron fantásticas, aunque sí producidas por el delirio de las voraces utopías del siglo XX, y su sombra cubre en ese momento todos los juegos intertextuales de esas presencias fantasmales de los grandes hombres aniquilados por el peso de la historia que viajan con nosotros y nos asaltan de improviso, provocando quizás la misma inacción que justificaba el maestro de Benjamin, Teodoro W. Adorno (1903-1969), después de Auschwitz.

Pues ahora y aquí —escribe el propio W. Benjamin - no hay esperanza mientras cada destino aterrador, cada destino oscuro, sea discutido en sus detalles una hora tras otra por la prensa, analizado en sus causas más ficticias y en sus más ficticias consecuencias, lo cual no nos ayuda a conocer esas oscuras fuerzas a que nuestra vida está sujeta (Calle de dirección única 37).

Sobre esta nostalgia, cifrada en la figura del "alma gemela de Duchamp", pero más bien su afín-opuesto, su complementario, hay que recordar un dato histórico: cuando 
en octubre de 1940, la filósofa judía Hannah Arendt (1906-1975), pasó por Portbou, antes de proseguir su precipitada huída a América, en busca de la tumba de su amigo y cofrade, no pudo encontrarla pues siendo judío, exiliado y posiblemente suicida, había sido enterrado en una lápida sin nombre. Tampoco pudo encontrar el maletín con un manuscrito que llevaba poco antes de su muerte. ${ }^{184}$ Hoy existen dos rutas Walter Benjamin: una en las calles de Portbou y otra que sigue los pasos de su huída de Banyuls a Portbou. Al respecto, es iluminador recordar que para Vila-Matas, un sentido de la narrativa es "recuperar las vidas perdidas de la gente" (156).

Duchamp le habla del "involuntario suicida" (afirmaba haber tenido "una vida absolutamente maravillosa afirmaba haber tenido" (54) y de cómo es éste fue quien los convocó a todos en Praga, sólo para que el viaje shandy continuara, sin ningún fin. Así que a esa atmósfera interior melancólica se yuxtapone la actitud vital que permite la aventura narrada en HALP y que de hecho se describe dos veces literalmente: en el prólogo se explica que desde el inicio nada era tan deseable como que la conjura portátil se convirtiera en "la exaltación espectacular de lo que surge y desaparece con la arrogante velocidad del relámpago de la insolencia" (14). Luego, en el penúltimo capítulo, titulado "El arte de la insolencia", se repite esa última frase, añadiendo: "Y hay que tener en cuenta que la insolencia, cuando se manifiesta, lo hace siempre en relación con los demás, por un movimiento que tiene en cuenta, intensamente al otro; es la expresión de un Yo rebelde, escandaloso, imperecedero...” (112).

La aparición de ese yo no es ajena a la entrega a los odradeks, fantasmas del recuerdo, presencias súbitas de los otros, dobles o gemelos por íntima afinidad, pues del caos que sus apariciones engendran nace la literatura portátil. El yo que escribe las vidas 
imaginarias de los otros se asume intensamente como éstos y, justo antes de concluir el relato, se sitúa en Sevilla — punto final de la conjura, coincidente con el del homenaje a Góngora (1561-1627) que fundó la generación del 27-y, asumiéndose como el último Shandy, el narrador habla por una única vez de sí mismo en tercera persona en un párrafo especular que justifica la brevedad de HALP:

Piensa que su intensidad y atención exhaustiva de melancólico fijan límites naturales a la longitud con que él puede haber explícitas sus ideas sobre la literatura y la vida, y decide concluir el libro que está escribiendo para que así éste termine justo a tiempo, antes de autodestruirse (121).

A fin de cuentas, sólo cuando se disuelve la historia de la conjura ésta comienza a ser realmente portátil y se trasvasa de la existencia en el papel a la del mundo, donde, como hemos visto, tuvo lugar de otro modo el encuentro con la vida real y maravillosa de Marcel Duchamp, que sucedió a través de un libro hallado en el escaparate con collage desconcertante que revelaba la libertad extrema del personaje sobre el cual se trataba.

El origen de lo portátil

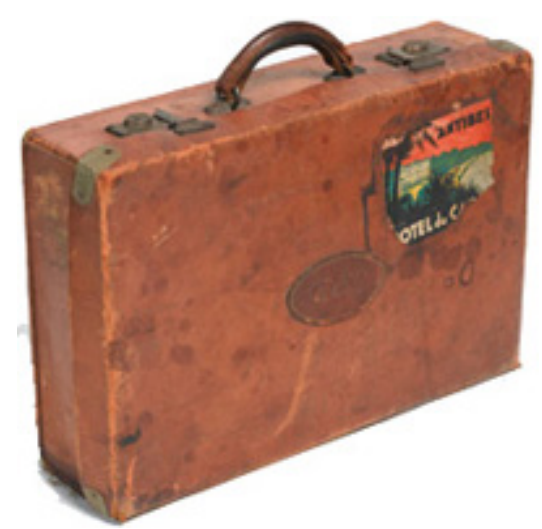

Ilustración 88: Maleta que Vila-Matas usa como primera entrada para su Versión disidente de HALP

En el prólogo de HALP, Vila-Matas dice que el pílar sobre el cual se edificó es:

Una historia es europea en sus orígenes y tan ligera como la maleta-escritorio con la que Paul Morand recorría en trenes de lujo la iluminada Europa nocturna: escritorio móvil que inspiró a Marcel Duchamp su 'boîte-en-valise', sin duda, el intento más genial de exaltar lo portátil en arte. La caja-maleta de Duchap, que 
contenía todas sus obras, no tardó en convertirse en el anagrama de la literatura portátil (9).

El atributo esencial de su Historia de la literatura es su carácter portátil. El término es usado a lo largo de la novela como sinónimo de shandy. Los conspiradores son llamados también los portátiles. La boîte-en-valise (La caja en la maleta) en la que llevaba Duchamp llevaba reproducciones en miniatura (otro aspecto esencial de la estructura de HALP) de todas sus obras, es "el anagrama de la literatura portátil" y "el símbolo en el que se reconocieron los primeros shandys" (9-10). Todos reconocen además, el inicio del Wilhelm Meister de Goethe (1749-1832) donde aparece un teatro de marionetas portátil. Y, para no traicionar el mismo espíritu de libertad que los convoca se aclara que ese anagrama fue retocado por Jaques Rigaut, por quien en efecto Duchamp experimentaba gran simpatía, y que el gesto inauguró una avalancha de nuevas profanaciones del anagrama duchampiano.

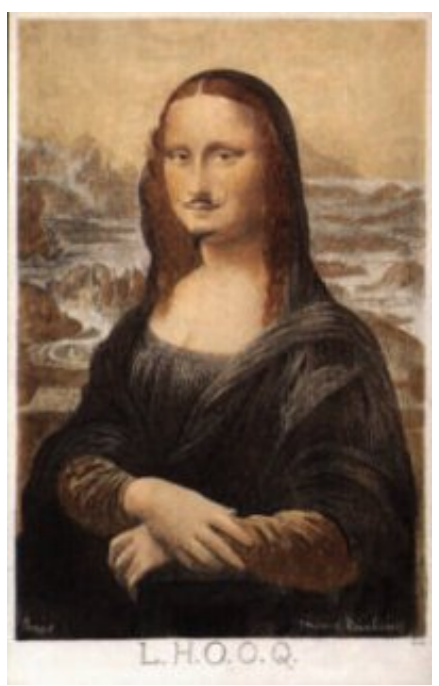

Ilustración 89: Marcel Duchamp, L.H.O.O.Q, ${ }^{185}$ 1919. Dibujo sobre tarjeta postal

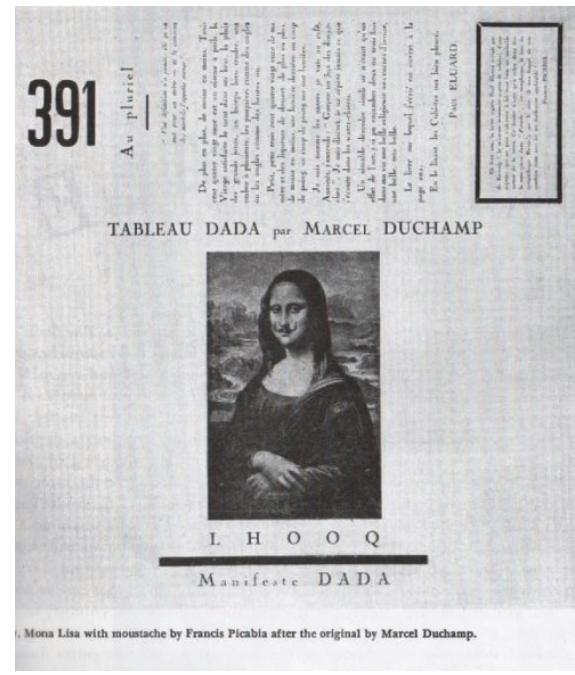

Ilustración 104: Francis Picabia, Mona Lisa con mostacho después del original de Marcel Duchamp 
Son profanaciones hechas a la tradición de la historia del arte que se extenderán a partir de los gestos de esos shandy a la reciente historia del arte contemporáneo, donde no sólo habría que citar la tarjeta postal en la que Duchamp volvió andrógina a la legendaria Gioconda, sino la publicación en la revista 391, donde siguiendo las instrucciones de Duchamp Picabia la intervino a su vez en un juego de autorías tan desenfadado que el crédito con el que se presentó, ni siquiera menciona el nombre de Leonardo da Vinci, aunque obviamente la intervención se hacía sobre una pieza tan icónica en el renacimiento como lo sería Fontaine de Duchamp en el siglo XX. Y la saga continúa, como un virus: Sherrie Levine (n. 1947) convirtiendo el Urinal de Duchamp en un Buda, o Hiroshi Sugimoto (n. 1948) haciendo de El Gran Vidrio y de la Caja-Maleta una sola pieza fotografiada y convertida en una obra minimalista de madera japonesa, para no mencionar la misma lista de intervenciones de la Monalisa -incluyendo la que dibujó en salsa de chocolate Vik Muniz (n. 1961) — sino todo aquel innumerable arte que según Nicolas Bourriad (n. 1947\\65), se funda en su obra para generar "un nuevo arte de la post producción que desde los noventa tiende a abolir la distinción tradicional entre producción y consumo, creación y copia, ready-made y obra original” (Speranza 21). ${ }^{186}$

En cierto modo, Vila-Matas duplica la legendaria Caja-maleta en un gesto que no sólo preconizaba la levedad, sino la legitimidad de la copia. Reduce volúmenes de obras, largos años de vida de los conspiradores dadaístas y la intrincada historia de una de las expresiones más extremas de la vanguardia, a los gestos esenciales, a escenas cruciales que muestran de modo magistralmente sintetizado, el espíritu de una irreverencia que, si no fue útil, por lo menos resulta divertida y permite agitar las aguas del horror que anegaron el siglo. 
El museo portátil de Duchamp —un empréstito que realizó entre 1938 y 1942, mientras Hitler avanzaba sobre Europa — partía de la consideración de que todo lo importante que había hecho podía contenerse en el interior de una pequeña maleta. Contenía 68 reproducciones.

Empecé - le dijo a Cabanne - la primera edición de veinte copias en 1938, y no estuvo terminada sino hasta que me fui a Estados Unidos en 1942. Tuve que llevármela en partes hasta la frontera. Estuve haciendo viajes, yendo y viniendo varias veces, haciéndome pasar por vendedor de quesos (Cabanne 73).

Hizo el arco, los compartimentos, las gavetas de varias ediciones que fue sacando de Francia.

El tono en que narra esto no revela la ansiedad del invento que realmente supone la tarea de salvaguardar la obra, miniaturizada, sacándola de un continente en el que avanza el peor tipo de totalitarismo y llevándola consigo. El viaje de Duchamp de 1942 es, como el de Ernst, en cuya casa en América residirá un tiempo, un viaje de huída. El recurso de miniaturizar todo lo hecho hasta entonces es una estrategia que cuela, en las narices de los guardias fronterizos, una visión que se contrapone a todo control monolítico. 


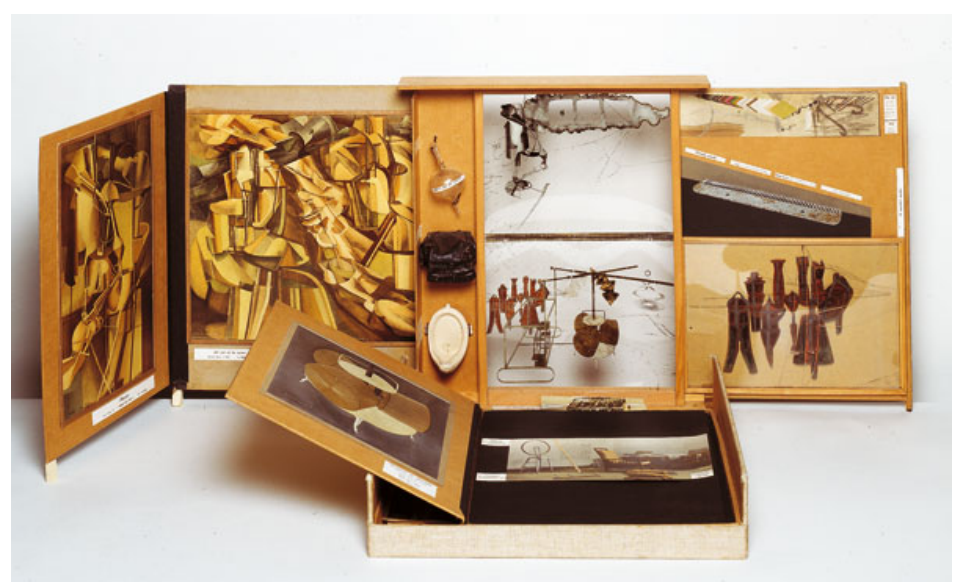

Ilustración 90: Marcel Duchamp: La boîte-en-valise

1936/1968 Paris 1936 - Nueva York 1941 Caja de carton cubierto con cuero rojo conteniendo replicas miniaturas de obras, 69 fotos, facsímiles o reproducciones de pinturas, pegadas sobre tela negra.

La obra presentaba, según el crítico José Roca:

Una edición de facsimilares o versiones en escala reducida de sus obras más representativas (desde el Desnudo bajando la escalera, hasta El gran vidrio, pasando por muchos de sus ready-mades), con el fin de que las obras tuvieran un auditorio más amplio, como sucede con la gráfica. La complejidad de cada edición hizo que Duchamp controlara detalladamente cada paso de la producción, resultando en una serie de objetos de estatus particular, ni originales ni copias o todo ello a la vez (Museos).

De modo que alteró con ese gesto la frontera entre ambos tipos de objetos, de un modo paralelo al que Borges plantea en Pierre Menard (1766-1844). La relación entre el readymade, el estallido de las nociones de autoría y originalidad, del original y la copia, de la miniaturización de la letra y/o de las obras, y su carácter portátil, modela el empréstito de HALP y la propia miniaturización que emprende Vila-Matas, cuando sintetiza, ya desde el prólogo, tanto el espíritu como los principios bajo los cuales se agrupan los miembros de la conspiración Shandy.

Graciela Speranza advierte que si bien Walter Benjamin y Duchamp se encontraron en la vida real una única vez, tenían una sintonía respecto al interés en la comprensión del impacto de los nuevos medios de reproducción en el arte. Pero mientras 
el primero publica un ensayo sobre la destrucción del aura en la reproducción de las imágenes; el segundo avanza en la dirección contraria. No sólo emprende, en efecto,

Una denonadada empresa de destrucción de la marca personal del artista y el carácter meramente retiniano de la obra de arte, sino que explora una frontera móvil entre el original y la copia. Borra la huella de la mano y el aura, pero al mismo tiempo, las recupera trabajosamente con métodos artesanales de reproducción, ready-mades asistidos, obras de estatus dudoso entre la obra única y la reproducción. En esa franja lábil de híbridos, inspira o prefigura una amplia gama de prácticas estéticas centradas en la copia, el plagio, el apócrifo, la apropiación, los múltiples y la serialidad con que el arte investigará las posibilidades de la repetitio cum variatio, la repetición y la diferencia (Speranza 23).

En la Caja-maleta también incluía juegos de palabras, copiados sobre papel pautado. Cuando Pierre Cabanne se los recuerda como una colección de readymades impresos, modificados, le dice que no sabe porqué les llamaron readymades y que él cree haber llamado a los textos "patadas en todos los géneros":

“...el otro día me llegó uno. Es bonito. En esas fechas también hice una portada para André Breton: una puerta-ventana con ladrillos. También fue hecha por Lévis-Mano. Usé todo eso en mi Caja-maleta, las mandé cortar y pedí cuatrocientas copias extras para mí, fue una forma de economizar un poco" (75$6)$.

Pero realmente, más allá de las duplicaciones en miniatura — aspecto ligado a lo portátil que interesa a varios shandy-; más allá de esa nueva forma de las reproducciones que inquietaban a su alma gemela, Walter Benjamín, lo que Duchamp cargaba al dejar atrás la frontera de un país ocupado por los nazis, era "un arte de vivir". Y esto se refleja en el capítulo "Postal de Crowley", donde Vila-Matas deja que sea escritor ocultista amigo de Pessoa, quien cuente el inicio de la conjura, atribuyéndolo a Tristram Tzara, y a una clave contenida en su libro Historia portative de la littérature abregé (Historia portátil de la literatura abreviada), supuestamente incluida en sus Sept 
Manifestes Dadá. L'espion des realistes et una histoire inédite (Manifiestos Dadá de septiembre. El espía realista y una nueva historia):

No tener un sistema que proponer, sólo un arte de vivir. (el subrayado es mío) En cierto sentido, más que literatura es vida. Para Tzara [para Vila-Matas], su libro es la única construcción literaria posible, la única transcripción de quien no puede creer ni en la verosimilitud de la Historia ni en el carácter metafóricamente histórico de toda novelización (81).

El recurso usado por Vila-Matas en esta cita apócrifa es una astuta estrategia de la ficción extrema ya preconizada por los grandes modernistas, pues repite el gesto de los falsificadores del tomo de la enciclopedia Tlön, que cada vez va encontrando más imitadores: consiste en insertar en un libro real que, como se cita en la lista de obras ingeniosamente añadida al final, fue realmente publicado por J.J. Pauvert (1926-2014), París, 1963.

Lo cierto es que Tzara sí fue el iniciador del dadaísmo cuyos principios están contenidos en "Sept Manifestes DADA" y la publicación incluye "Lampisteries" (Habitaciones encendidas) además de ilustraciones de Picabia. Pero en ninguno de los manifiestos Dadá de Tzara hay rastro de historia alguna de la supuesta Historia portátil de la literatura abreviada, si bien esta insersión que hace Vila-Matas es especular: recurre a lo apócrifo para revelar que el espíritu total de la novela que nos presenta, Historia abreviada de la literatura portátil, es de hecho un reflejo del nacimiento espléndido del dadaísmo y de su ocaso. La génesis que otorga a HALP es tan apócrifa como verídica en su esencia. ${ }^{187}$

En el Manifiesto del Señor Antipirina se aclara que el arte no es cosa seria: "L'art n'est pas sérieux" (Tzara, 17). Esta misma noción, como hemos visto, explícitamente tomada del Tristram Shandy, se convierte en la contraseña de iniciación de los 
conspiradores que deben repetir, a modo de juramento su convicción de que la seriedad sólo sirve "para ocultar los defectos de la mente" (43). Además, con un procedimiento similar al que usa Vila-Matas para decir que su historia no tiene importancia, el Manifiesto Dadá de 1918 asevera que la palabra DADA carece de ésta y que no se ocupa -como tampoco HALP- de arreglar la prosa a manera de evidencia absoluta, irrefutable. Todo lo contrario. Las refutaciones de lo que se asegura en una parte proliferan en otra. En ciertos capítulos, como en el de "Las tumbonas", los Shandy encarnan ampliamente el precepto Dadá de estar en contra de la acción, pero en otros se entregan a una febrilidad confabuladora que hace eco a su principio de contradicción. Tzara afirma, por su parte:

Yo escribo este manifiesto para mostrar que pueden ejecutarse juntas las acciones opuestas, en una sola y fresca respiración; yo estoy en contra de la acción; a favor de la continua contradicción, y también de la afirmación, no estoy ni en favor ni en contra y no lo explico porque odio el sentido común ${ }^{188}$ (Tzara 20).

Lo que en cambio se respeta en el Manifiesto Dadá y se duplica, como apropiación en HALP, es la diversión, como estrategia para combatir el tedio. "Dándole al arte el impulso de la simplicidad suprema, la novedad, es humano y fiel a la diversión impulsiva, vibrante, para crucificar el aburrimiento"189 (Tzara 20). Y, de modo coherente con el funcionamiento de las máquinas solteras de HALP, que son vitales tanto en la obra de Duchamp como en su visión, los Manifiestos aluden a "los infortunios de la vida conyugal" (Tzara 21), y a la libertad de no pertenecer en la que se complace la historia de Vila-Matas. Si sus 27 conspiradores han aceptado un modo de pertenencia, son justamente los saboteadores de ésta, como Aleister Crowley, figura que, siendo real no tuvo parte en el dadaismo, pero que el autor cuela entre los participantes reales de este movimiento fugaz que no extingue de cualquier modo su luz. Es el controvertido escritor 
esotérico Crowley quien fragua la disolución de la conjura pues no resiste la tentación de revelar sus nociones y estructuras. Por supuesto, resulta un bienaventurado traidor pues permite salvaguardar la esencia contradictoria y autodestructiva de la conspiración, tan inexistente en su argumento, como ficticia en su espíritu, y que sólo así, disolviéndose, se mantiene fiel a su índole. La descripción que HALP hace en la voz de Crowley sobre la historia portátil de la literatura abreviada de Tzara es obviamente meta-literaria y habla de un tipo de literatura que no tiene un sistema que proponer, "sólo un arte de vivir". Algo que encarna lo que incialmente deslumbró a Vila-Matas respecto a Duchamp. Y que a su vez se define especularmente en un párrafo por completo autorreferencial:

Su libro es la única construcción literaria posible, la única trascripción de quien no puede creer ni en la verosimilitud de la Historia ni en el carácter metafóricamente histórico de toda novelización. El libro ofrecerá esbozos de las costumbres y vida de los shandys a través de un medio más original que los habitualmente adoptados por la novela (81).

HALP se apropia de dos actitudes esenciales de los Manifiestos de Tzara: la consciencia de su inutilidad, y una paralela autocomplacencia en una reflexividad sin límite sobre los principios que propone y que generan un universo propio que ofrece infinidad de posibilidades de desciframiento al espectador:

Un cuadro es el arte de hacer que se encuentren dos líneas geométricamente comprobadas paralelas, en un lienzo, ante nuestros ojos, en la realidad de un mundo transpuesto según nuevas condiciones y posibilidades. Este mundo no está especificado ni definido en la obra, sino que pertenece en sus innumerables variaciones al espectador ${ }^{190}$ (Tzara 25 ). 


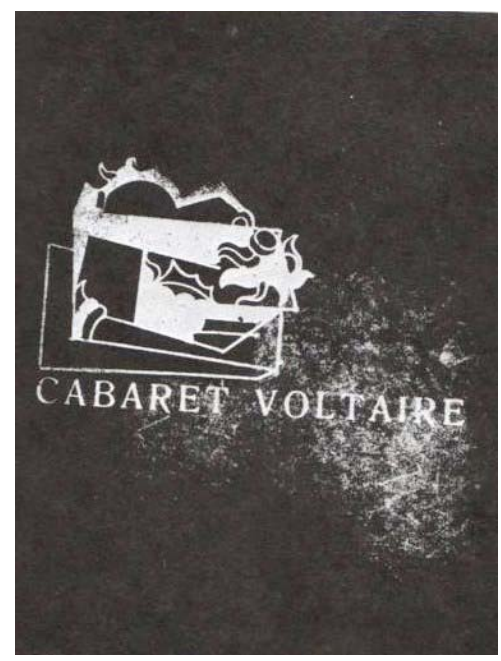

Ilustración 91: Portada del primero número de la revista dadá Cabaret Voltaire. Diseño de Hans Arp. Zurich, 1916

Por otra parte, la atención a la poesía negra, y al arte negro, que Tzara incluye ciertamente en los capítulos de Lampisteries (Habitaciones encendidas) se trasvasa, tanto por esta vía, como a través de las alusiones a la obra de Raymond Roussel, y a la admiración de Picabia por él, "contagiada" a Duchamp con un efecto definitivo sobre su obra. Desde 1919 en el Cabaret Voltaire, Tzara organizaba en realidad "noches de negros", donde Marcel Janco (1895-1984) exhibía máscaras inspiradas en los ritmos africanos (el culto al sonido aprendido de Apollinaire y de Rouseel era absoluto) y textos híbridos, compuestos a partir de la disonancia. Veladas a las que asistieron Shandys como Duchamp, Breton, Philippe Soupault y Picabia, todos adeptos de conspirar contra los lenguajes.

Lo "negro" es una búsqueda no del continente de donde salió la humanidad, sino de lo puro, intocado, de lo primigenio en la mente. Es desde ahí que tanto Tzara como Picasso (1881-1973) y los demás cumplirán eso que Vila-Matas, desafiando la corrección política, llama "simpatía por la negritud" y que implica un reconocimiento al carácter 
visionario del continente que les hacía decir: El arte en la infancia de los tiempos era la oración. Madera y piedra fueron verdad (...).La boca contiene el poder de las tinieblas, sustancia invisible, la bondad, el miedo, la sabiduría, la creación, el fuego (88).

Y quizás, en medio de la adhesión compartida -y paradójica— al culto al arte, la afirmación de Tzara respecto a que "nos hacen falta obras fuertes, rectas, precisas e incomprendidas para siempre" $(31)^{191}$ puede ser una ventana para asomarse tanto a las obras del reluctante Marcel Duchamp, como a la sombra que arroja en HALP. No hay una figura más influyente en el arte contemporáneo de la segunda mitad del siglo XXI que este hombre que se identificó con la enigmática sonrisa de la Monalisa y no temió masculinizar el rostro de ella, o retratarse a sí mismo como la misteriosa Rrose Selávy, y que pese a su propia elusiva sonrisa contra cualquier forma de adhesión, cumplió más que nadie la aspiración dadaísta de socavar de modo irrevocable las nociones de lo que hasta su aparición se consideraba arte. Basta pensar no sólo en el uso y el abuso del readymade duchampiano o en las secuelas de las apropiaciones iconoclastas, sino en las recreaciones literarias de su vida y sus prácticas, como HALP para comprender hasta dónde se extiende la influencia dadaísta por la vía duchampiana.

Puntualiza al respecto Michel Sanouillete:

Whereas other protagonists became intoxicated in the headlong quest for all forms of significance, Duchamp found his path in the absurdity of the quest itself. Beyond laconism, silence is for him the supreme form of revolt. If it is true that for Breton 'beauty will be convulsive or will not be', for Duchamp, beauty evidently will not be (...). In 2004, five hundred personalities from the world of art voted his urinal the most influential work of the twenti-eth century, over Picasso and Matisse. In the final analysis, Duchamp created Dada, and Dada created Duchamp (318-320). 
Sanouillete concluye que debemos agradecer a los dadaístas por haber abierto la caja de Pandora de la humanidad y por cumplir su expedición a su riesgo y peligro, hacia las siempre cambiantes fronteras de nuestra insaciable curiosidad. Después del Dadá la pregunta de qué tan lejos podemos ir, tiene una respuesta nueva: "Much futher tham we had thought" (330). Basta pensar que la misma HALP es una extensión de este movimiento fulgurante que se extinguió en apariencia y fue absorbido por el fuego bretoniano y que, como veremos en el epílogo, sigue irradiando nuevas formas derivadas de su rebelión contra las lógicas de un mundo en combustión donde sólo los trabajos de la imaginación y el humor parecían ofrecer una posibilidad sin fin. Si en ninguno de los Manifiestos se incluye -sería un contrasentido demasiado pesado- una historia de la literatura portátil, en cambio la noción que incluso en la edición francesa se define como el "selfcleptómano", aquel que se auto-roba, el tipo de cleptómano que roba elementos de sí, es inherente a HALP y a la literatura en la que Vila-Matas ha extendido la broma de la conspiración.

\section{Las máquinas solteras y las visiones iniciales de las mujeres fatales de HALP}

Los principios que Vila-Matas dilucida y reanima con un sentido lúdico literario — funcionamiento de máquinas solteras, sexualidad extrema, ausencia de grandes propósitos, nomadismo infatigable, tensa convivencia con la figura del doble, simpatía por la negritud, cultivar el arte de la insolencia - son autorreflexivos. El primero, ya lo hemos visto, tiene su origen en la declaración de Duchamp a Cabanne, sobre la soltería, como principio de vida, pero también presente en sus obras, de donde salen las máquinas solteras. El segundo principio, indispensable para pertenecer a la sociedad de los 
portátiles es que la obra no sea pesada y cupiera fácilmente en un maletín se relaciona, como hemos visto, con la Caja en la maleta de Duchamp que hizo portable toda su obra.

Ambos principios están contenidos en la concepción y construcción de esa extraordinaria máquina soltera que es el La Novia desnudada por sus solteros...aún, o Gran vidrio, un mecanismo del deseo que tiene el mismo carácter andrógino de su nombre, pues es una gran máquina soltera que contiene a nueve solteros en el plano inferior, pero también al complemento indispensable de éstos: la mujer fatal. Así que, la obra, pintada en el prodigioso material transparente que le da su segundo nombre, contiene nueve máquinas-hombres solteros y una novia virgen — pero no casta—, y aun cuando está movida por la imaginación deseante, no deja de ser, en conjunto una máquina soltera, de la que hablaré más extensamente luego. Igualmente, la Caja verde, obra que contiene todas las notas del proceso de pensamiento que han generado el Gran Vidrio, es portátil. En suma, es el campo de visión de Duchamp, a quien se le presenta de súbido en HALP, "la imagen de una persona célibe, imposible, gratuita y delirante, es decir: un artista portátil, o, lo que es lo mismo, alguien a quien uno puede llevar tranquilamente a cualquier parte" (13) lo que genera la estructura en movimiento de la Historia Abreviada de la Literatura Portátil.

Las primeras pinturas de máquinas de Duchamp asemejan dibujos técnicos de maquinarias, pero funcionan como mecanismos contenedores de los invisibles procesos del pensamiento que lo seducen más que nada. Su Molino de café, 1911, se retoma posteriormente en la Máquina soltera del Gran Vidrio, cuyo sentido, como veremos, está conectado al misterio del deseo sexual. Aunque se dice que no dejó der ser un ajedrecista mediocre, la tensión extrema de los movimientos en la mente del jugador, anteriores al 
movimiento, le fascinaban al punto de que le dio al ajedrez un culto que se negó a dar al arte. Solía decir que era agnóstico en materia de arte. En tal caso, toda la parafernalia de engranajes, pistones, circulación, activación de movimiento, ocupa su atención mental y manual, y, sobre todo, lo lleva a hacer algo completamente insólito: diseñar un mecanismo, una suerte de máquina incrustada, inscrita, en un vidrio transparente, donde hace visible lo más invisible y poderoso de ese eros que es vital como se advierte en el desdoblamiento que el mismo Duchamp realiza, como una broma deconstructora al retratarse como un mujer, Rose Sélavy (inicialmente con una r y luego con dos).

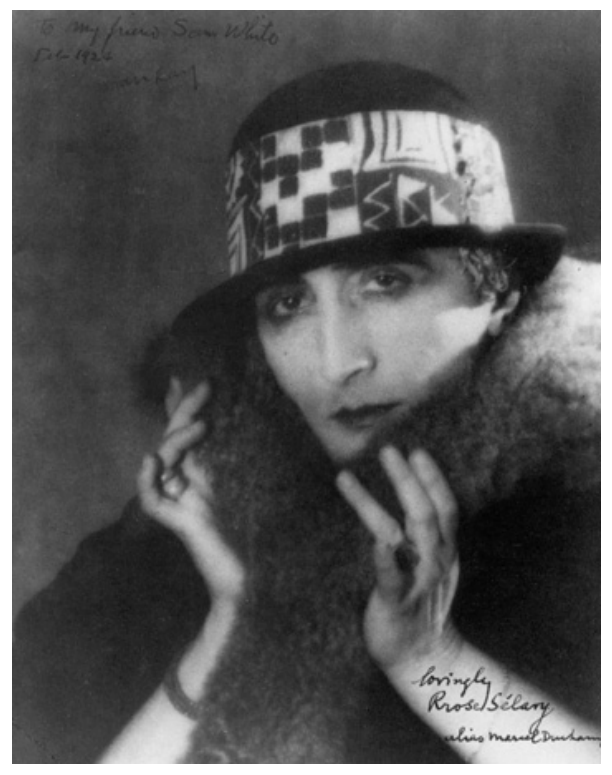

Ilustración 92: Man Ray. Retrato de Marcel Duchamp como Rrsose Sélavy 1921. Philadelphia Museum of Art.

En este punto, es necesario detenerse en la figura de Rrose Sélavy como doble fatal del propio Duchamp. El nombre, un juego verbal, suena al pronunciarse en francés como "Eros, c'est la vie" (Eros es la vida) o cómo "Arroser la vie" (hacer de la vida un brindis), expresiones conectadas a una visión vital del entusiasmo y de un eros, que sin embargo o se frustra, o puede desembocar en la oscuridad de una frontera, donde se ha 
perdido la cabeza y la imaginación exacerbada tiene la apariencia de la muerte. O en todo caso, sugiere lo que el título de una canción de Kip Hanraham (n. 1954): "Desire Develops on the Edge”. Sélavy apareció después de una serie de fotografías de 1921 en las que Man Ray retrató a Duchamp disfrazado de mujer. Volveré más adelante a su figura, a partir de la cual configura HALP el mapa del viaje. Por ahora, basta su aparición, y su fatalidad.

Duchamp convirtió el nombre en un heterónimo para alguna parte de sus notas escritas y de obras firmadas por él: entre éstas, la conocida escultura "Why Not Sneeze, Rose Sélavy?", realizada el mismo año de las fotografías, 1921 a modo de un ensamblaje con materiales encontrados como un termómetro y cubos de mármol que asemejaban cubos de azucar dentro de una jaula de pájaros. Sélavy firma la botella de perfume de Belle Haleine, y el filme Cinema Anémic (anagrama de cinema) de $1926 .{ }^{192}$
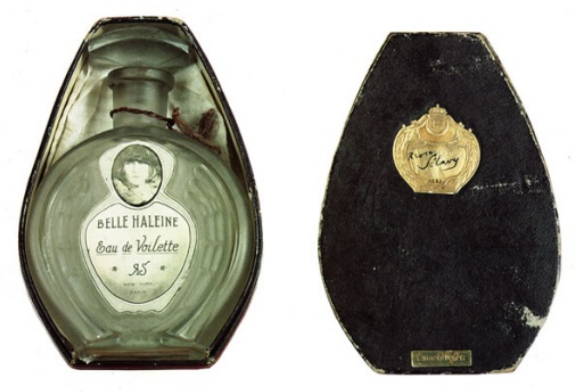

Ilustración 93: Marcel Duchamp : Belle Haleine: Eau de voilette 1921, (C) 2000 Succession Marcel Duchamp ARS, N.Y./ADAGP, Paris

Y aquí surge una conexión, la única vinculación aparente entre Duchamp y Aleister Crowley, dos figuras vertebrales de HALP que en la vida real sólo se relacionaron al parecer por su relación con una "mujer fatal": Belle da Costa Greene, a quien este ocultista que cumplió un papel como espía británico en los Estados Unidos, menciona entre los muchos personajes femeninos de "Record of the Beast" ${ }^{193}$ En algún 
momento Duchamp y Crowley fueron empleados de la librería J.P. Morgan, pagados por ella. Esta talentosa librera graduada de Princenton, de vida bohemia y ancestros africanos que oscurecían su piel y aumentaban su belleza, llegó a acumular un poder inaudito no sólo para su época sino para cualquier tiempo, como librera y coleccionista de arte y valiosos libros. (Samuels 286). En las décadas en que dirigió la Pierpont Morgan Library y el Museo de J.P. Morgan de Nueva York, incorporó arte islámico, y construyó la más prestigiosa colección privada de incunables, raros manuscritos y libros de arte de América.

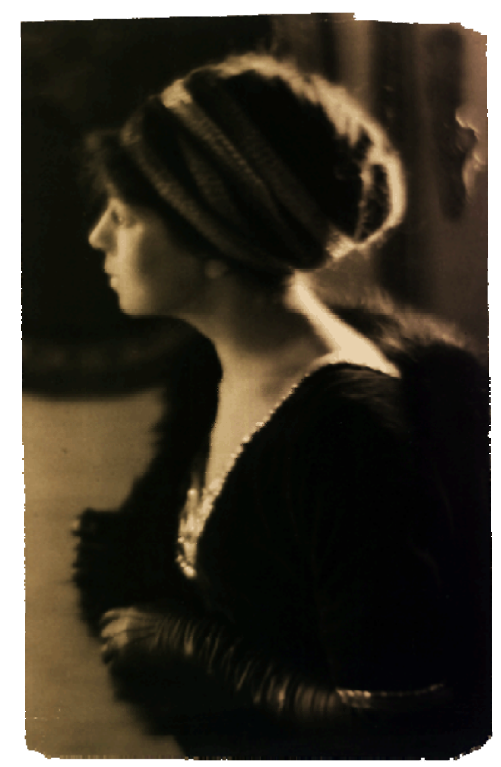

Ilustración 94: Belle da Costa Green.

Tomado de toutfait el Marcel Duchamp Online Studies Journal

La poderosa Belle da Costa Greene contrató a Duchamp como librero, y pagaba de su propio bolsillo su sueldo, en un inusual arreglo que cubrió sus necesidades financieras por dos años (Tomkins 155), aunque su trabajo sólo duró unos meses, porque no le complació, y algunos estudiosos ven un "negro pun" en el readymade hecho con el frasco de perfume que lleva justamente su nombre, Belle, el rostro del propio Duchamp 
vestido de mujer y retratado por Man Ray, y que firma Rrose Sélavy, con una doble r que constrasta la que ella había quitado de su apellido para impostar que era lusitano. ${ }^{194} \mathrm{El}$ papel de las mujeres fatales, desde luego, puede contener el peligro de algún modo de destrucción.

El segundo capítulo de HALP, “Oscuridad y magia”, se narra, parafraseando un apócrifo relato de Picabia, la aparición de Berta Bocado dentro de una gabardina, en "un balcón en forma de flauta pigmea hecha de rama de papaya" (17), que estaba situado justamente frente al Cabaret Voltaire de Zurich. Fue en este escenario donde Tzara lanzó su proclamación sin pretensión en 1918.

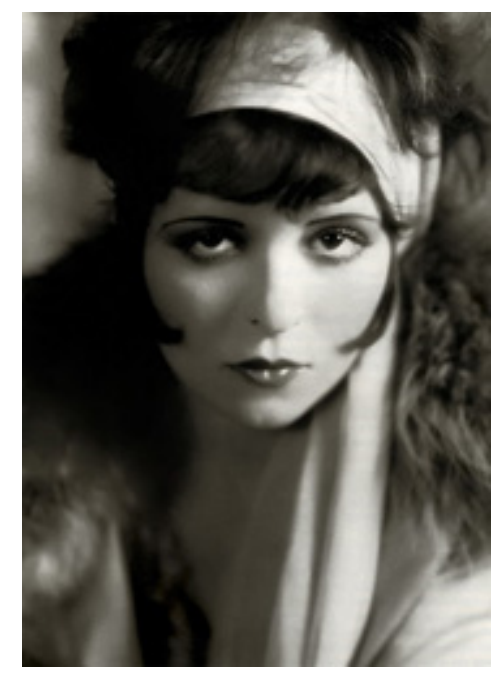

Ilustración 95: Man Ray: Berta Bocado según Vila-Matas en su Versión disidente de Halp.

Así que esta "hermosa mujer española de nombre más bien horrible, Berta Bocado" (18) que espiaba a los antiguos dadaístas — reunidos frente al Cabaret Voltarie para celebrar en pleno invierno de 1924 en Zurich el quinto aniversario de su desaparición - y que actuaba como “una cámara con el diagragma abierto: una cámara pasiva, minuciosa, pensativa" (18), fue fotografiada — según aventura en Vila-Matas en 
su Versión disidente de HALP en la web- por Man Ray, con dos mechones de su cabello indómito formando acariciando sus mejillas y los ojos inmensos mirando al lente, desafiantes.

Berta Bocado es en realidad producto de la fantasía de Vila-Matas quien atribuye a Man Ray haberla fotografiado, realizando de este modo un tipo de apropiación de la foto que posiblemente le tomó a la actriz Louise Brooks (1906-1985), cuya imagen, de vestido negro y sosteniendo el largo collar de perlas, sirve también de portada al propio libro, y su figura no deja de inspirar obras en el arte contemporáneo: el sudafricano William Kentridge (n. 1955) está creando una ópera titulada Lulú inspirada en su aparición en este papel en el film La caja de Pandora. Las mujeres fatales, pieza complementaria e indispensable de la conjura que realizan esas máquinas solteras que son los shandy masculinos, aparecen descritas de un modo correlacionado con La Novia desnudada por sus solteros, aún, de Duchamp: cada una es, en efecto, una "hermosa máquina animada" (23).

La función de esta mujer fatal es movilizar el engranaje de los equívocos para echar a andar la rueda de la literatura portátil y su diversión que en primer lugar, parece ser para el autor. Así por ejemplo, la Bocado confunde a Andrei Biely (1880-1934) nada menos que con Vladimir Ilich Uliánov que aguardaba en Zurich a que estallara la revolución en su país. Picabia le habría pedido coaptarlo para la conspiración, por motivos que están sin duda relacionados con la explicación que Vila-Matas da a su predilección por el escritor en el sitio en la red dedicado a HALP. Evoca en efecto cómo, después de escribir Petersburgo, Biely, cuya verídica crisis nerviosa relacionada con "el ascenso de las lavas del subconsciente" abre la novela, se sentía traspasado por una 
revelación: "El arte es una anamnesis, la invasión de la conciencia artística por un superconsciente, una especie de desposeimiento de sí mismo". Lo curioso es que la confusión entre Biely y nada menos que el mismo Lenin obedece a que éste jugaba a veces al ajedrez (el arte máximo para Duchamp) con Tzara, Arp y Schwitters, incontrovertibles Shandys. En todo caso, si en HALP, la fatal Bocado no logra seducir a Lenin, quien se pasea nerviosamente por la habitación en donde ella intenta hacerlo, con los manuscritos en la mano, no es producto de su falta de pericia como vampiresa sino de la distancia que media entre los perezos shandys y acusiosos, totalitarios ideólogos.

Georgia O'Keefe (1887-1986) se muestra entusiasmada cuando oye hablar a Picabia de máquinas solteras, ficciones y conspiraciones. Lelgoualch, personaje que transmigra de la ficción de Raymond Roussel —decisiva para la propia concepción de $E l$ Gran Vidrio-, a la conjura de Vila-Matas, puntúa musicalmente las palabras, y O'Keefe, incorporándose al mecanismo solteril expone "un concepto que, por estar íntimamente ligado al funcionamiento de las máquinas solteras, no tardó en convertirse en uno de los rasgos más típicamente shandys": su teoría de la sexualidad extrema (24).

Consciente de que era de orden sexual el signo más distintivo de las máquinas solteras, Georgia O'Keefe afirmó que éstas se componían de un conjunto mecánico y de otro orgánico, y que entre ambos conjuntos se anudaban, en círculo cerrado, complejas relaciones de placer y de terror, de éxtasis y de castigo, de vida y muerte (24).

La descripción, sobre todo en su primera parte, es un reflejo del mecanismo La Novia desnudada por sus solteros...Aún, que Duchamp dejó indefinidamente terminada en 1923 - un año antes del inicio del período narrado por HALP-, si bien la continuó hasta 1934 en forma de notas que consignan el proceso de pensamiento que genera y que agrupó en la Caja Verde. 
Todas los máquinas que componen el engranaje mecánico alusivo a lo orgánico de la pieza inconclusa de Duchamp son solteras, aspecto en el que iré profundizando en distintos apartes. Por ahora, basta contemplar, en el plano inferior a los nueve solteros, y separada irremediablemente de éstos por una división insalvable, la novia, provocando el mecanismo deseante al desnudarse y alimentándose de éste, sola e inaccesible. En ese dispositivo erótico lo fascinante es el proceso mental que vive la lúbrica novia, rodeada de nueve máquinas solteras masculinas: ella aparece "desnuda", imperando en el espacio superior donde la acompañan la Vía Láctea y los Pistones de corriente de aire. Los nueve solteros (nueve moldes metálicos planos) se identifican con una suerte de uniformes: sacerdote, mensajero, coracero, gendarme, policía, jefe de estación, criado, repartidor y sepulturero.

En la apócrifa postal que según HALP, Crowley le manda a Picabia, éste incluye una líneas que en realidad parafrasean la declaración que le dio Marcel Duchamp a Pierre Cabanne sobre la ontología del arte, cuando éste le hizo notar que “...todos estamos haciendo cosas. Más que artistas, que suena hueco y pomposo, somos artesanos, es decir, gente que hace cosas" $(81)^{195}$. Los solteros, pues, hacen cosas. A su lado, hay una suerte de trineo que incorpora una rueda de molino, las aspas de unas tijeras y un molinillo de chocolate, creando un mecanismo que se mueve con una denominada "gasolina del amor", el pensamiento deseante. Estamos ante una novia que "aún”, más allá de su deseo no puede ser poseida, pero que se basta a sí misma. Es esa tensión extrema del mecanismo del pensamiento que se desencadena de modo particularmente intenso antes del movimiento, antes de la ejecución misma, lo que a Duchamp le importa del arte y la razón por la cual se obsesionó con el ajedrez. "According to the scenario outlined in The 
Green Box notes, the nine uniformed Bachelors in the lower panel [of the Big Glass] are perpetually thwarted from copulating with the unattainable biomechanical Bride above" (Taylor 23).

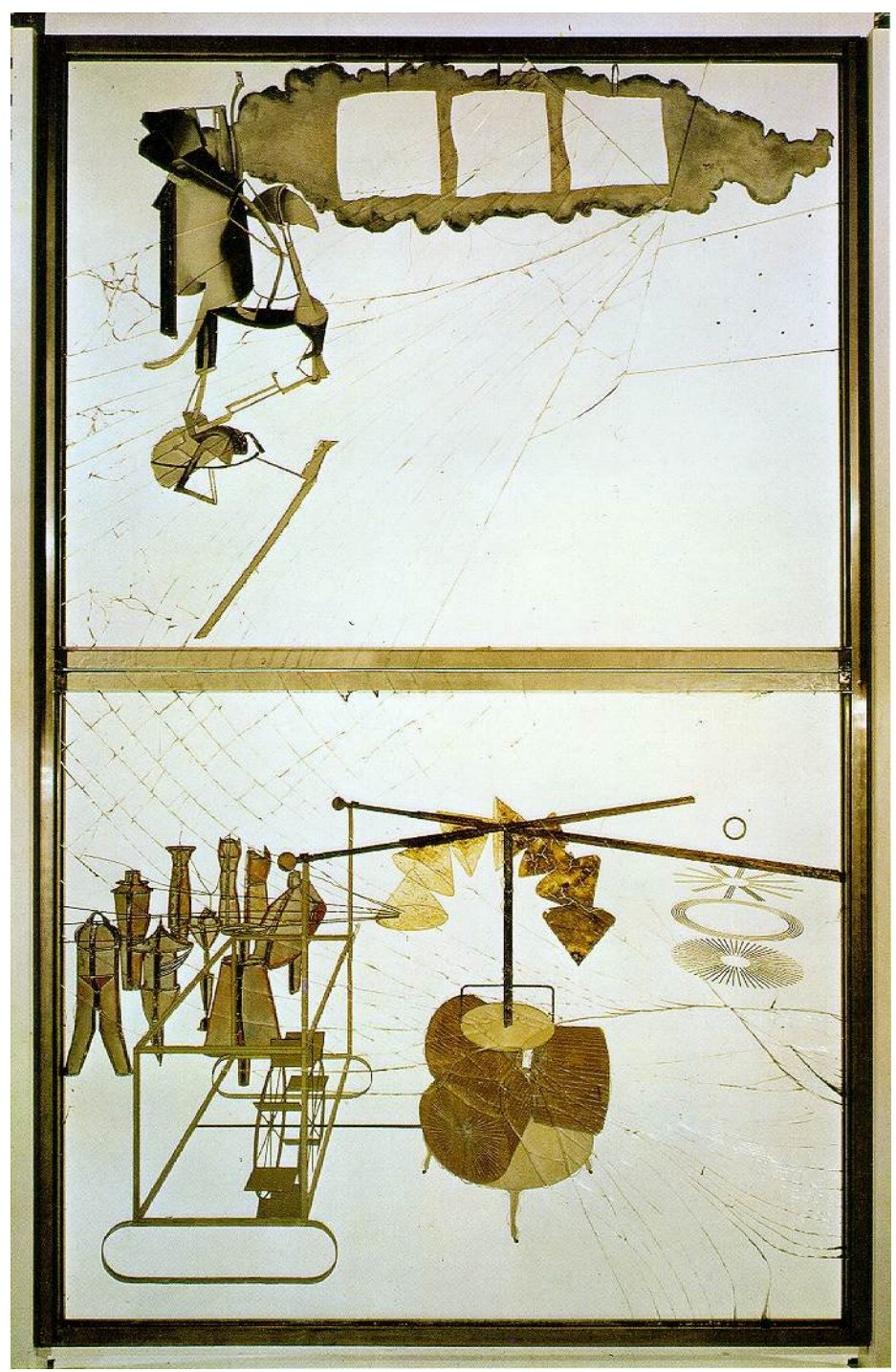

Ilustración 96: Marcel Duchamp : La Mariée mise à nu par ses célibataires, même 1915-1923 Óleo, varnis, hojas de acero, alambre de aluminio y polvo en dos paneles de vidrio

La representación del deseo ya no aparece como era habitual en el arte erótico figurativo los gestos o expresiones sensuales de la corporeidad, y ni siquiera descomponiendo al modo cubista la desnudez de los cuerpos, sino inventando un 
lenguaje para transponer el inagotable juego del deseo humano, el delirio de la imaginación deseante, sobre todo femenina, de tal modo que las complejas e invisibles operaciones mentales que rodean la sexualidad humana — su impulso, pero también su imposibilidad-, se trasvasan a un lenguaje nunca antes asociado con el eros en el que diagramas, letanías, tecnología de maquinarias, vidrio y metal refieren a estados como excitación y represión, virginidad y soltería, deseo y onanismo, orgasmo y soledad.

En el primer texto crítico que se escribió sobre La novia desnudada por sus solteros, aún, La Phare de La Mariée que Breton finalizó en 1934, comprende ya cuánto hay de sorprendente en un cuadro que es un inventario de los elementos de ese desvanecimiento (asociado a las vibraciones espléndidas de la novia) o de la vida sexual imaginada por la novia deseante.

En este desvanecimiento la novia se presenta desnuda bajo dos apariencias: la primera viene de la puesta al desnudo por los solteros, la segunda es la imaginativa [desnudez] voluntaria de la novia. Del acoplamiento de estas dos apariencias de la virginidad pura, de su choque o coalisión, depende todo el desvanecimiento, conjunto que corona y cierra superiormente el cuadro (98).

Pero se advierte que el desvanecimiento sólo obedece aquí al mecanismo de la imaginación deseante. No hay cópula ni consumación del deseo. El signo de la sexualidad tan abiertamente proclamada no deja de ser elusivo, sinónimo de la vida misma que hurta la plenitud de los encuentros o cuela en ellos las imposibilidades. Es posible que, como advierte Octavio Paz en El castillo de la pureza, los solteros sean solo una invención de la novia (Paz 123): corresponden a una imaginación que se autocomplace en su propio deseo y la novia es otra de las "machines célibataires", máquinas solteras, o más bien, es la mujer fatal que las contiene en su mente. Por eso las formas humanas se han reemplazado por "mecanismos delirantes" cuyo funcionamiento - lo 
indican los títulos, cierta metáforas_- "es sobre todo sexual" (22). Pero también se trata de dar a la escultura, lo mismo que Duchamp buscó en la pintura, antes de abandonarla: la cualidad de un retardo. Es una sexualidad retardada, vivida ante todo, con el acicate del deseo, como mirada.

La segunda parte de la teoría de la sexualidad extrema atribuida a O'Keffe, esas "complejas relaciones de placer y terror, de éxtasis y castido, de vida y muerte" (24), animan aquella otra pieza misteriosa en la que Duchamp trabajó secretamente entre 1946 y 1966, año en el cual el narrador sitúa su imborrable (e inexistente) encuentro con Duchamp: Étant donnés: $1^{\circ}$ la chute d'eau, $2^{\circ}$ le gaz d'éclairage ... (Given: 1. The Waterfall, 2. The Illuminating Gas ... ).

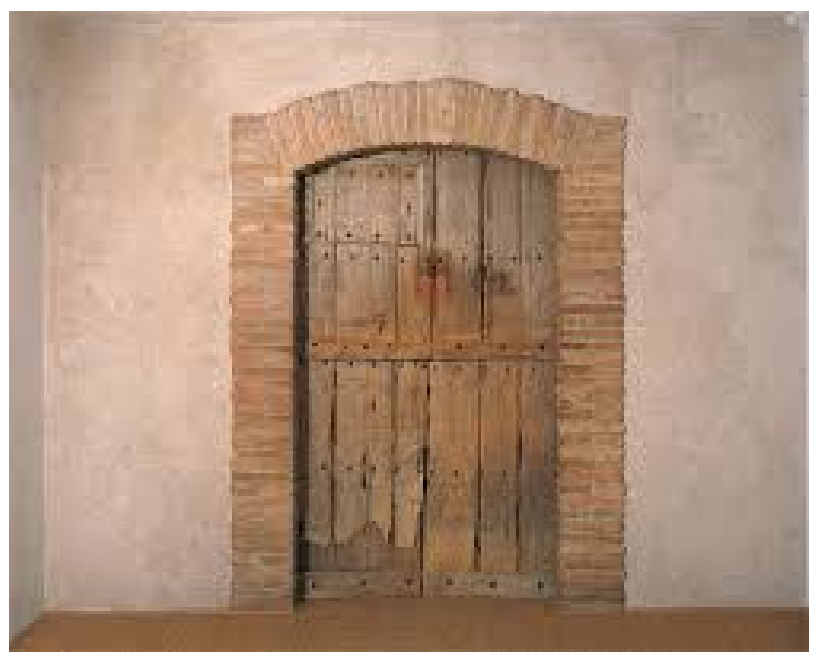

Ilustración 112: Étant donnés: $1^{\circ}$ la chute d'eau, $2^{\circ}$ le gaz d'eclairage

(Given: 1. The Waterfall, 2. The Illuminating Gas...) ${ }^{196}$. 1946-1966. Philadelphia Museum of Art. Vista exterior.

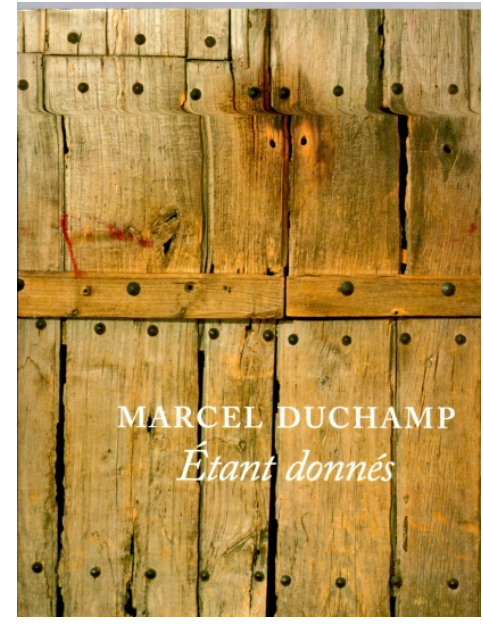

Ilustración 113: Portada del libro de Michael R. Taylor

La intrigante obra que el artista Jasper Johns (n. 1930) definió como "la más extraña obra que pueda haber en cualquier museo" (Tomkins 451), y que el Philadelphia Museum of Art instaló después de la muerte de Duchamp, siguiendo — hasta donde fue 
posible- las minuciosas instrucciones que dejó para ello, se exhibe de manera permanente como una las más icónicas obras, en la sala contigua al Gran vidrio. De este modo, el espectador ha tenido que ver primero, como Duchamp quería, esta pieza que tiene un nombre y una naturaleza doble, que es, de cierto modo, andrógina: La novia desnudada por sus solteros...aún/ El gran vidrio.

Así que sólo después de haber visto a La novia desnudada por sus solteros...aún, y a sus nueve solteros, que quizás sólo son parte de su vehemente imaginación, el espectador pasa a la pequeña habitación donde se instaló la última obra de Duchamp, extrema en su modo de representar el filo entre eros y thanatos y acerca del cual la cual se ha escrito un ingente número de estudios, y el indispensable compendio de Michael R. Taylor publicado por el mismo Philadelpia Museum que atesora ésta y la mayor parte de las obras de Duchamp. Como afirma Taylor en este texto esencial, ninguna fotografía puede comunicar la experiencia visual única de ver en persona la obra: “... this ellaborate three-dimensional aseemblage offers an unforgettable and unstranslatable experience those who peep through the two small holes in the solid wooden wood" (23).

Lo que el espectador ve, al atravesar el obstáculo de la puerta es una mujer desnuda, exangüe - ¿por el éxtasis del placer o por el abandono de un cuerpo inánime?-, acerca de cuyo estado los artistas siguen especulando con obras que refuerzan la continuidad de la fantasía extrema de Alfred Jarry, ${ }^{197} \tan$ influyente para Duchamp y, particularmente el influjo de su historia "The Super Male", que guarda relación con la fantasía de complacer a una mujer exigente hasta dejarla exhausta (William Anastasi). 
En todo caso, el pubis rasurado de la mujer tendida en la hierba, abierto, se ofrece a los ojos del espectador convertido en voyeur, abocado a mirar, de lejos, desde afuera, la intrigante escena llena de complejos detalles y preguntarse por el espacio de la fantasía donde los límites entre la máxima exaltación de la vida y su fin, se diluyen. Si la muchacha desnuda cuya cabeza escapa a nuestra vista, estuviera sin vida, no podría aparecer, como aparece, sosteniendo una lámpara de gas de la cual irradia la luz que nos permite ver su desnudez. De modo que, a diferencia del Gran vidrio, en esta representación tridimensional no estamos ante la expectación del deseo, sino ante la morbidez de un cuerpo exangüe después de su consumación. "Mientras no haya superado el gusto al placer, seré sensible al vértigo del suicidio", decía otro de los conspiradores: Jacques Rigaut.

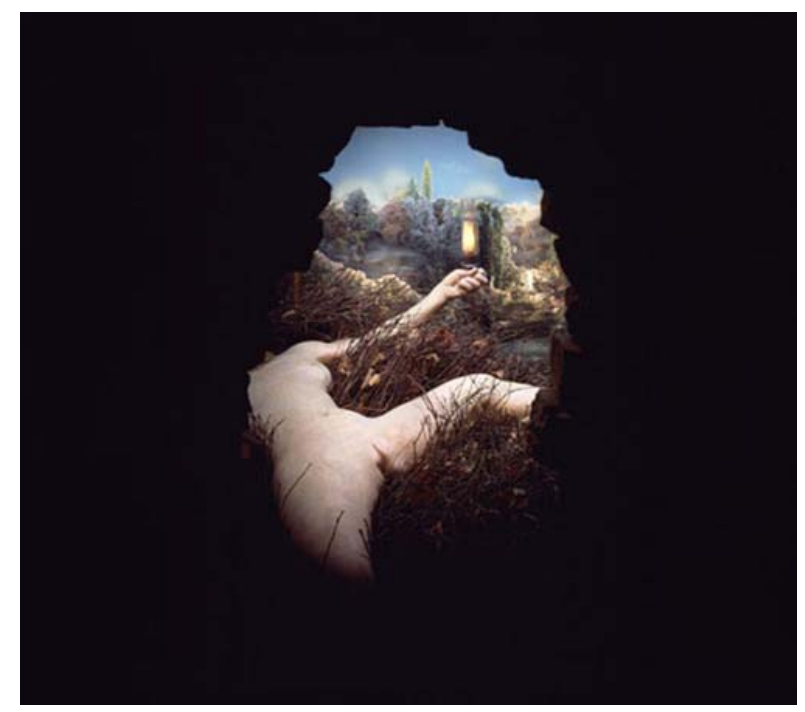

Ilustración 97: Marcel Duchamp : Étant donnés: $1^{\circ}$ la chute d'eau, $2^{\circ}$ le gaz d'éclairage ... (Given: 1. The Waterfall, 2.The Illuminating Gas ... ). 1946-1966. Philadelphia Museum of Art. Vista interior.

Pero no puede esquivarse la latente asociación con el descuartizamiento que hay en la imagen: su poder perturbador reside no tanto en el exponer del sexo rasurado y 
abierto, como en el ocultar la cabeza entre la hierba, porque es ahí, es esa zona oscura para la mirada, en la incertidumbre de si el cuerpo ha sido decapitado, donde la desnudez ofrece una lectura doble, y se asemeja de un modo espantoso a los bellos cuerpos descuartizados, un tópico explorado por varios de los shandy y cuya asociación visual con el tipo de crímen como el que se realizó en 1947 al descuartizar a Elizabeth Short (1924-1947) haciendo con su cuerpo un tableaux surrealista ha sido motivo de diversos estudios. ${ }^{198}$

Vila-Matas ha repetido que le impresionó la fórmula que en la conversación con Cabanne, Duchamp daba a la manera de tener una vida maravillosa: la temprana renuncia a la vida de casado. Cuando éste le recuerda que a sus 25 años ya se le conocía como "el soltero" y que su actitud antifeminista era muy conocida, Duchamp precisa: "No: antimatrimonio, pero no antifeminista. Al contrario, yo era alguien sumamente corriente...". Sus actitudes anticonyugales tenían que ver "con una cuestión de presupuesto, y con una pizca de razonamiento muy lógico: tenía que elegir entre la pintura y otra cosa. Ser artista o casarme......” (25).

En medio del desasosiego de los primeros shandy que arriba a Port Actif, sin saber qué habían venido a hacer tan lejos, el grupo ve pasar a una bellísima extranjera, la O’Keefe, que, según apunta Vila-Matas, se comportaba como "una hermosa máquina animada": una mujer fatal "alta y morena, de extrema sensualidad, una aparición en toda regla" (23). La escena, ficticia en su génesis, puesto que si bien Picabia y Duchamp estuvieron estrechamente vinculados en París y en Nueva York, donde fundaron un capítulo de los Dadá, no viajaron nunca juntos al África, convierte en literatura dos momentos reales de la biografía artística de Duchamp. Eso sí, preservando su espíritu. 
Encarnándolo. El principio de los shandys, "la sexualidad extrema", está vinculando no sólo con el arte a través del Gran Vidrio, sino con su textualidad y, por extensión, con la literatura con "una filosofía de signos plásticos (o lingüísticos), sin cesar destruida, como filosofía, por el humor" (22-3). Las letanías pensadas para la obra incluyen palabras como "vida lenta, círculo vicioso, construcción a buen precio, timón monótono, profesor de cerveza y onanismo", que tienen eco a lo largo de la trama de HALP. Pero, a despecho de la proclamación de la acendrada sexualidad, el erotismo es otra vía perdible no sólo en la obra de Duchamp sino en la novela de Vila-Matas.

De la máquina soltera que preconiza Dulcinea, y que se pone en marcha con el Desnudo descendiendo una escalera y que logra provocar en La novia puesta al desnudo por sus solteros...aún, la aparición de una imagen del deseo interior, según Octavio Paz, puesto que es posible mirar a través del Gran Vidrio, Duchamp pasa a esta obra de índole en cierto modo contraria. Éttant Donné ofrece en primera instancia el obstáculo de la impenetrabilidad visual (una pesada puerta que cierra el paso) sólo para inducir al acercamiento. Los ojos que miran ya no son como en el caso de La novia, invenciones de sí misma, son los del espectador que penetra en su intimidad de este modo y abre una rendija para contemplar, radicalmente, el misterio de la interioridad psíquica asociada al deseo. Y el sexo femenino -lo ha dicho Speranza- es una máquina de mirar. Citando a Amelia Jones, quien precisa cómo, frente a los orificios de esa puerta-obstáculo, el espectador "sólo puede mirar, pero la mirada es rechazada por una hendidura descubierta que no conduce a ninguna parte", de modo que está frente a una máquina de ver lo que nose puede ver, el misterio del sexo femenino (Fuera de campo 23). 


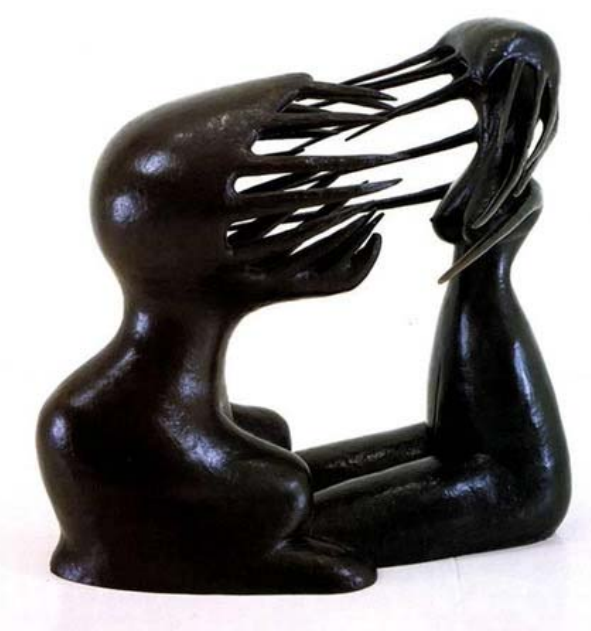

Ilustración 98: María Martins, Impossible III 1946

Si El gran vidrio es el origen del primer principio, la soltería, Éttan Donnés, encarna la vertiginosa sexualidad extrema. Su concepción fue hecha por Duchamp justo en el período en que tuvo una relación amorosa con la escultura brasileña María Martins (1894-1973), de cuyo cuerpo desnudo tomó moldes para otras pequeñas piezas paralelas y a quien conoció durante la apertura de una exhibición de esculturas que contienen en la forma el abismo de la relación preconizada entre "éxtasis y castigo". Más aún, como precisa Taylor, había un violento erotismo en poemas como "Even Long After my death," ${ }^{199}$ que ronda la instalación de Éttan Donnés. En un texto sobre la obra, la página Surrealist NYC precisa cómo mientras los surrealistas regresaron a París después de la guerra, Duchamp permaneció en Nueva York con Martins, y se quedó incluso cuando ella y su esposo —un diplomático brasileño— se marcharon a París en 1948:

In those brief couple of years, he and Maria begin studying life molding to create a plaster cast of her body based on his 1946 sketch, Étants donnés: Maria, la chute d'eau, et la gaz d'eclairage. He also visits La Forestay waterfall near Chexbres in Switzerland which will provide the background for his installation. 
Not surprisingly for Duchamp, he visits the waterfall with his friend and longtime lover in Paris, Mary Reynolds (Ettant donnés).

\section{Otros mecanismos de las vampiresas}

Si cada shandy debía funcionar como una máquina soltera, a su vez, “debía llevar incorporada a su complejo mecanismo alguna que otra vampiresa..." (17). Y no pocas veces, cada mujer fatal tiene a su vez una identidad alterna: a una de las mujeres fatales de HALP, la mulata actirz cubana Rita Malú, un desconocido le revela una identidad alterna: ella es el fantasma que habita su casa. "Ella viaja al fondo de la nada, en las Azores, donde (no) se encuentra con un fantasma que es ella misma", escribe Cristina Núñez Pereira en su blogspot. En otras palabras, cumple la ruta señalada por Baudelaire, que sirve de epígrafe a HALP: “....aun fond le l'nconnu pour trouver du nouveau” (Shangrila Texto Aparte).

De la desafiante declaración de $\mathrm{O}^{\prime}$ Keefe sobre la sexualidad extrema, que el narrador no cuenta directamente sino a través de la voz de Picabia, nace, como he señalado, el mundo de los portátiles, pero al tiempo esta nueva, paródica Eva, introduce en la leve conspiración de los shandy la sombra de la muerte:

En tanto que energía o líbido el amor debe ser desviado de su finalidad genética, eso que entendemos por reproducción, para no buscar más que la autosatisfacción. En una palabra, copular por puro placer, jamás pensando en la descendencia y otras zarandajadas. Esto es lo que yo entiendo por sexualidad extrema (25).

La declaración de Georgia O’Keefe - considerada como una de las indispensables mujeres fatales de la conspiración — de que las máquinas solteras copulan por puro placer, provoca un silencio sugerente que da inicio a la conspiración, pero al tiempo se agazapa en su proclamación un indicador de la cercanía entre eros y muerte. 
En relación con las mujeres fatales me interesa de nuevo destacar la tensión que ellas suponen frente a la contienda con la muerte, una contienda que se da de dos modos: precipitan a las máquinas solteras en ésta — como supuestamente ocurre con Rigaut, quien se suicida en HALP como efecto de la frustrada fuerza de su pasión erótica por $\mathrm{O}^{\prime} \mathrm{Keefe}-\mathrm{o}$, en cambio, ofrecen una fuerza vital que se le opone. Aunque puede no ser suficiente, como se advierte en el párrafo siguiente:

Que las mujeres fatales se instalaran en las máquinas solteriles shandys no eximió a estas últimas de futuras averías irreparables, ya que, en el preciso instante de saberse vivas y portátiles, abrazaron a la muerte, lo que explica tanto la aparición inmediata de la palabra suicidio en su horizonte como el hecho de que uno de los comensales de port Actif, precisamente el que se había enamorado de la mujer fatal [O'Kefee] se hiciera cargo allí mismo de la fatalidad de una oficina portátil, la Agencia General del Suicidio (26).

De O'Keefe, una de las mujeres (reales) fatales de HALP — adscripción que posiblemente ella habría detestado - hace en 1917 un desnudo en acuarela, cuyos trazos abstractos, pueden sugerir siluetas humanas contenidas dentro del cuerpo que se desdobla, en un movimiento que funde la genesis de la abstracción con una figuración poético-erótica, donde los ojos del espectador podrían ver una sucesión de otras siluetas humanas contenidas en la silueta móvil. El narrador cita, como bibliografía esencial, el libro sobre su obra Pictures, que no existe en cuanto tal, si bien hay numerosos estudios sobre su arte, además del que ella escribió en coautoría con Juan Hamilton, su irremplazable asistente de los últimos años en su cabaña de refugio en Nuevo México. En todo caso, el obsesivo afán de jugar a la verosimilitud incorporando recursos del género del ensayo a su novela, se refrenda con la alusión contínua a círculos creativos existentes, cuyas relaciones $y / 0$ reuniones se documentaron en la vida real a menudo fotográficamente. 


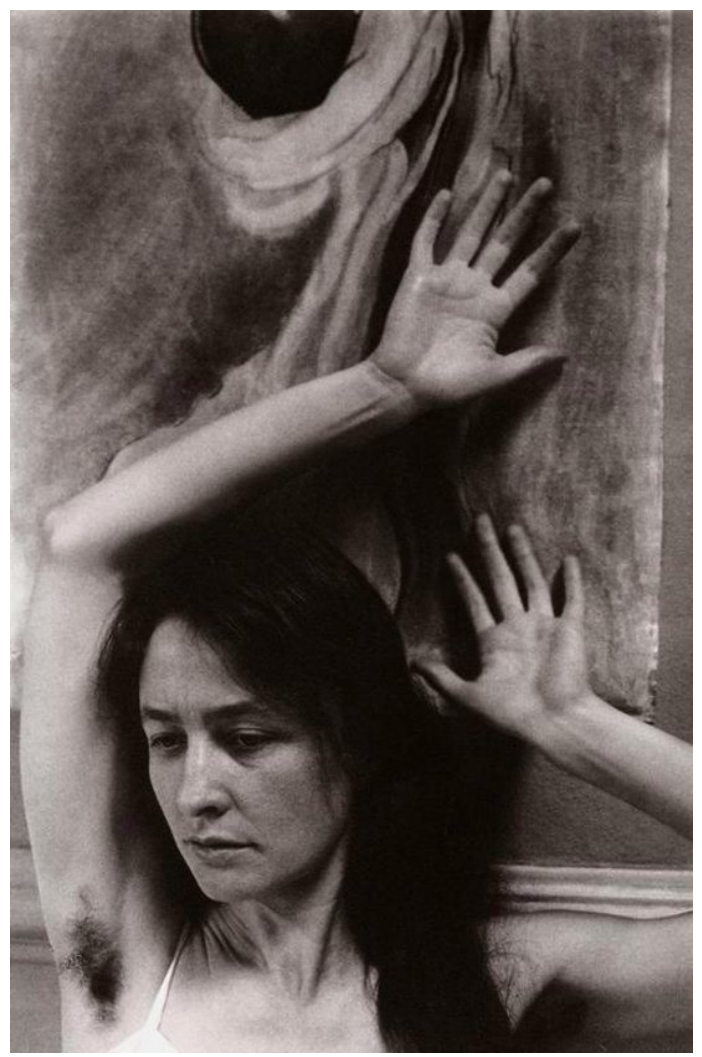

Ilustración 99: Alfred Stieglitz, Portrait of Georgia O'Keefe 1918

Aunque HALP disgrega sobre la especulación obsesiva de Rigaut que en la ficción hace amantes a O'Keefe y William Carlos (1883-1963), hay una conexión — ajena a cualquier romance- entre el erotismo de las flores captadas en un sugestivo primer plano por la irreductible pintora (que responsabilizó de la visión erótica de sus pinturas a la sola mirada del espectador), y la carga erótica de los retratos de mujeres asociadas a flores del gran poeta estadounidense. Ambos, ciertamente, pertenecían al círculo que rodeó las actividades de las galerías del fotógrafo Alfred Stiglitz, 291, y The Intimate Gallery. Fue en la primera donde ella exhibió tempranos trabajos como Nude, Serie VII, poco antes de convertirse en amante de Stiglitz y casarse con él. 
El nexo entre el shandy Man Ray y William Carlos Williams -que junto con artistas y escritores como Marcel Duchamp, Wallace Stevens (1879-1955) y Marianne Moore (1887-1972), conformó ciertamente parte de los "conspiradores" del grupo "The Others", en Nueva York, participantes en la aventura de la revista de Alfred Kreymborg (1883-1966) "Others: A Magazine of the New Verse"- se establece de modo intrincado en HALP a través de la amistad de Man Ray con Rigaut y del argumento narrativo de que éste llegaría a la puerta de la casa del poeta Williams arrastrado por su deseo por Georgia O'Keefe, y por la suposición obsesiva de que ella era la amante del poeta. Lo cierto es que de este modo, sin nombrar en su itinerario a América, la Conspiración Shandy viaja a la historia del Avant-Garde newyorquino. A Williams se le rindieron homenajes en la galería de Stieglitz (1864-1946) como una exhibición en su honor con poemas de Charles Demuth (1883-1935). ${ }^{200}$ Por esa época, en una de sus escapadas a Provincetown, donde coincidía con Eugene O’Neill (1888-1953) habrían podido ver a Louise Bryant (18851936), bañándose desnuda en la playa, como aparece en cierta foto de 1916. La conspiración no es más que la hermosa máquina de la vanguardia sacudiendo las estructuras, pues los protagonistas de los capítulos del dadaísmo y del surrealismo, huyen desde las distintas capitales desde donde intentaban construir defensas durante el ascenso de otros fatales "ismos" totalitarios, antes de desembocar, en número sorprendente, en el puerto de Nueva York. Una y otra vez.

Peter-Cornell Richter describe la pintura de esta época un modo afín a lo que Vila-Matas transmite sobre O'Keefe:

They [the new watercolors] were free, wild and vibrant, suggesting a love of life in the primeval landscape of sandstone (...) It was this love of life that fascinated 
Stieglitz. This was the beginning of what people know as 'O'Keeffe's', he said (50).

Respecto a la avasalladora autonomía de la bella máquina soltera, es coincidente con la perspectiva que aporta Bram Dijkstra, autor de Evil Sisters: The Threat of Female Sexuality and the Cult of Manhood, y de Georgia O'Keeffe and the Eros of Place. En este libro sostiene que, lejos de haber sido formada por la influencia de Stiglitz y la corriente dadaísta europea, ella encontró por sí misma un estilo que provenía entre otras fuentes, por las especulaciones literarias de Edgar Allan Poe (1809-1849) sobre la naturaleza andrógina del alma, así como por sus preocupaciones feministas, entre otros influjos.

The book argues that O'Keeffe's very American search for an organic abstraction of form that would celebrate nature, allowed her to develop a humanist style that challenged the early European modernists' emphasis on mechanistic constructions of form against nature (Berry).

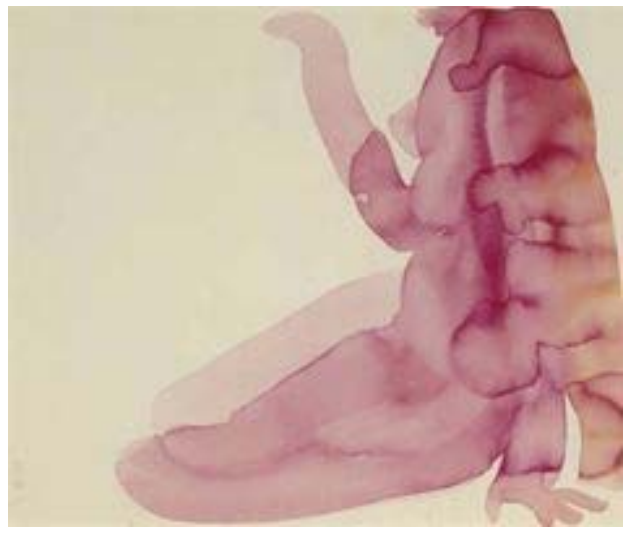

Ilustración 117: Georgia O’Keefe. Nude, Serie VII 1917 Flower Shapes (1919)

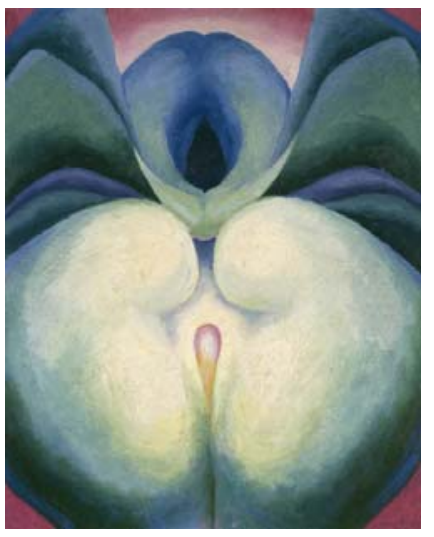

Ilustración 118: Georgia O'Keeffe's Series I WhiteBlue Acuarela. Georgia O'Keefe Museum

En 1924, el año del matrimonio entre O'Keefe y Stiglitz, Man Ray fotografía a William Carlos Williams en París. Hay una fascinación de Vila-Matas por su visión 
poética que le da licencia para crear una intensa relación amorosa ficticia con ella: escoge justamente unos versos de El descenso - El descenso seduce/Como sedujo el ascenso/ Nunca la derrota es sólo derrota, pues/ el mundo que abre es siempre un paraje/ antes/insospechado, como epígrafe del capítulo "Puerto Metafísico", de su libro El viaje vertical. La derrota, de la que no se habla explícitamente en HALP, pero cuyo espíritu determina la dirección del viaje narrativo, es una suerte de elegante renuncia vital asociada al destino de la conjura, pero también a la naturaleza de un descenso.

En el caso de O'Keefe, su desafiante erotismo o la encarnación de la sexualidad extrema no sólo está asociada a sus pinturas, sino a las fotografías legendarias que Stiglitz le hizo y que en su momento constituyeron un escándalo y, por supuesto, a una vida dominada por la necesidad creativa de períodos de soledad, pero no menos abierta a la ruta incierta de su pasión por hombres y mujeres pioneros del advenimiento de la modernidad en su tiempo. Los centenares de fotografías que Stigliz le tomó en la primera década de la relación amorosa que iniciaron en 1918, incluyendo los numerosos desnudos de ella que exhibió en 1920 -aunque sin mencionar explícitamente el nombre de su modelo-, pero también los retratos de sus manos creadoras y de las expresiones de su rostro, convierten a $\mathrm{O}^{\prime} \mathrm{Keffe}$ en una mujer que siendo la figura más extensivamente documentada por un fotógrafo está lejos de ser sólo la modelo. Su obra contribuyó a crear la modernidad en el arte americano. La elección de O'Keefe como una de las mujeres fatales de HALP deriva además de su vida liberal: pasó de su romance con el fotógrafo Paul Strand (1890-1976), a vivir con Stieglitz antes del divorcio de éste, y luego sostuvo fugaces o largas y tormentosas relaciones mientras repartía su tiempo entre Nueva York y las agrestes montañas y desiertos de Nuevo México, donde se quedó una vez varias 
semanas en la casa que D.H. Lawrence (1885-1930) tenía en la región —allí pintó The Lawrence Tree. Pero, no menos cierto es que O'Keeffe — que raramente firmaba sus pinturas, y a cambio las signaba con un $\mathrm{OK}$ en la parte de atrás - se retiraba, sola, durante meses o semanas, para escuchar la música de las flores o de los huesos de animales muertos. Y en esa alternancia entre períodos de exaltación o vida vertiginosa e inmovilidad, se asemeja también a los shandy. Decía que pintaba porque no sabía cantar e introdujo la vibración de la modernidad en el arte americano con ecos tan fuertes que alcanzaron el viejo continente.

O’Keefe es a la vez en HALP la conexión con el círculo de Walter Arensberg (1878-1954), de quien Vila-Matas no menciona ningún dato adicional al nombre, pero que fue ciertamente el coleccionista gracias al cual se conserva en el Philadelphia Museum of Art la mayor parte de la obra de Duchamp. Un círculo que atrajo además a figuras como "Skip Canell” (1887-1957) (su nombre aparece en HALP abreviado, como se le conocía en los círculos íntimos, y con una sola n en lugar de dos, como se llamaba en realidad el poeta), o como la bella y fatal Pola Negri (1897-1987) y Robert Johnson, dos máquinas solteras de la novela. No es gratuito que dos poetas amigos del círculo de Arensberg - Williams y Skipwith Cannell (incluido en la antología "Des Imagistes" que hiciera Ezra Pound, otro Shandy de HALP) vinieran de Filadelfia. Las conexiones que establece Vila-Matas no son arbitrarias. Cuando no responden a la exactitud biográfica, obedecen a un hilo de afinidad $\mathrm{y}$, a menudo, pueden ser incluso refrendadas documentalmente, de tal modo que la ficción pareciera ahondar el conocimiento de lo que no es ficción: existe, por ejemplo, una foto del círculo de amistades de Arensberg que incluye a O'Keefe y a William Carlos Williams junto con Man Ray (que según HALP se 
acerca a O'Keffe a acompañar a Rigaut y fotografiarlo en la puerta de Williams) y, por supuesto, a Duchamp.

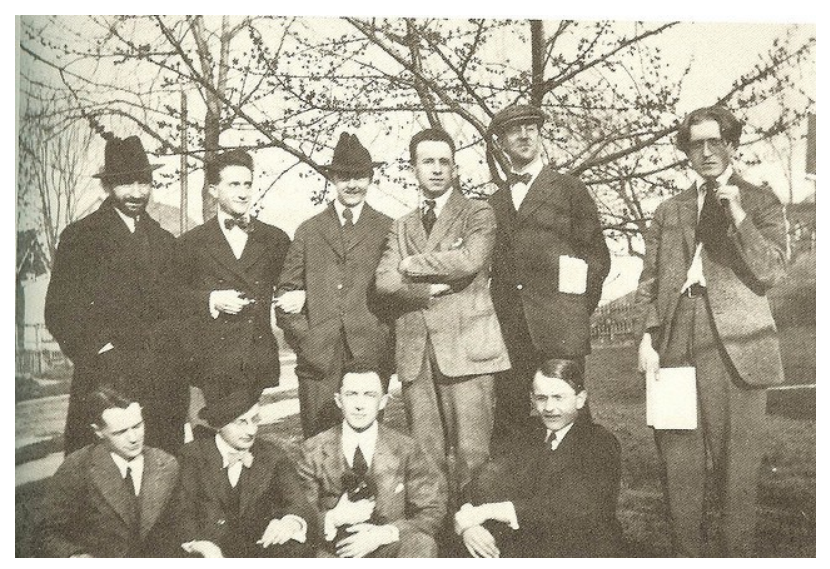

Ilustración 100: Escritores del grupo The Others en la casa de William Carlos Williams.

1916. De izquierda a derecha primera fila abajo: Alanson Hartpence, Alfred Kreymborg, Williams, Skipwith Cannell;

Arriba: Jean Crotti, Marcel Duchamp, Walter Arensberg, Man Ray (?), Pitts Sanborn, Maxwell Bodenheim.

En el libro de Steven Watson, Strange Bedfellows, The First American Avant-

Garde aparece el grupo en una imagen que incluye a los coaptados shandys de VilaMatas, entre éstos a Man Ray, William Carlos Williams, Marcel Duchamp y Walter Arensberg. Prueba de que la conspiración ficticia refleja otros modos de conspiración real, que en última instancia provocaron la entrada en la modernidad y sentaron las bases para el posterior sacudimiento de la posmodernidad. No sólo eso: la propuesta literaria de HALP, en la que el modo de asumir identidades en continuo tránsito llega a ser un mecanismo enloquecido, filtrado por el espejismo incesante de los dobles, acaba sugiriendo una multiplicidad de posibilidades para asumir sucesivamente otras identidades posibles, identidades en vértigo, múltiples, que pueden imaginarse como los shandys mismos sin grandes propósitos, o que pueden albergar un intento de reinvención común. El delirio de imaginar algo nuevo. 
Tan importante es la mención de O’Keefe (que se enlaza con la Novia de Duchamp a través del ingenioso paralelismo entre la obra de El Gran Vidrio y sus palabras sobre la sexualidad extrema, atrás mencionadas) que a su desenfadada declaración se le atribuye la creación de una atmósfera propicia para la formulación de los demás principios de la conspiración Shandy:

La sentencia de Georgia nos unió, de repente, en un perfecto silencio de emboscados, y ya no hubo, aquella noche, más palabras, porque ése nos pareció el registro ideal de voz que podía permitirnos ir lentamente conformando, en el más absoluto y atractivo de los silencios, el resto de los rasgos típicamente portátiles (25).

El resultado de ese silencio de emboscados fueron pues los rasgos portátiles complementarios: ausencia de grandes propósitos, nomadismo infatigable, tensa convivencia con la figura del doble, simpatía por la negritud, y cultivar el arte de la insolencia, además de esa "tensa convivencia con el doble" que anima todo el libro. Estos tres principios se cumplen, casi forzosamente, en el curso de las insólitas travesías de los portátiles, de modo que el viaje configura el sustrato sobre el cual se hace posible la conjura. De modo contradictorio con su declarada adhesión a la vida, varios shandys emprenden viajes o desplazamientos para suicidarse. En la delirante narración de la conjura las muertes de unos y otros se superponen y confunden. Y también de modo contradictorio con la frialdad afectiva que pareciera animar la sexualidad extrema, en uno de los capítulos finales de HALP, en donde embarca en la barca de Noé del submarino Bahnhoff Zoo, a un grupo de gente disímil que es salvada, es decir, admitida como shandy, como Josephine Baker (1906-1975) y Ossip Mandelstam (1891-1938), aparece la vampiresa del cine silente Pola Negri, de la que se enamora perdidamente Antheil (19001959), según HALP, hasta cuando descubre que está aquejada de un extraño mal: 
Ella sí que era, en realidad, una enferma, pues no sabía amar. Y el agua la mataba (...). Al detectar, ya en pleno ocaso y agonía de la sociedad secreta, la presencia de ese mal, de esa extraña enfermedad que, a su vez revelaba la presencia del agua, de la nada y de la muerte, George Antheil quedó visiblemente emocionado y dijo: 'Qué rara es una muerta (104-5).

Así que el mal que aqueja a las mujeres fatales es nada menos que la incapacidad de amar.

\section{Sobre el arte de los suicidas}

El narrador de HALP vincula la apócrifa pasión del poeta surrealista Jacques Rigaut (1889-1929) por O'Keefe, y su suicidio en un lujoso hotel de Palermo que la voz impostada de Blaise Cendrars (1887-1961) narra:

En el hotel de Palermo, la llave, el cerrojo y esa abertura cerrada formaron, en ese instante y sin duda para siempre, un triángulo enigmático, donde a la vez se nos ofrece y se nos niega la obra de Rigaut. En cualquier caso, un suicidio insuperable (35).

La descripción de la escena — la llave, el cerrojo y esa abertura-, apócrifa en cuanto altera el lugar de la muerte de Rigaut e imposta la voz de Cendrars, puede relacionarse con la puerta de Éttan Donnés que Duchamp culminó en 1966, año del imaginario encuentro con él. En HALP, Vila-Matas omite describir la famosa pieza que termina dos años antes de su muerte, pero refleja el mecanismo de visión propuesto en la cita de Cendrars sobre la habitación donde se suicida Rigault. La puerta con la cerradura conectaba a la habitación de una mujer fatal (inexistente), Carla Orengo, por lo que, sin explicitarlo, deja sugerido un mecanismo voyeur que contiene su propia frustación.

Pese a su debilidad, que era extrema, se había arrastrado con su colchón hasta la puerta de comunicación que daba a la habitación de Carla Orengo. Esta puerta siempre había estado abierta, pero fue encontrada cerrada con llave. Un gesto último sobre un colchón, tan grotesco como indescifrable (35). 
Vila-Matas altera el lugar del suicidio del poeta gestor de la agencia dedicada a la perfecta realización de éste, y en lugar de mencionar que ocurrió en París, el 5 de noviembre de 1929, tiempo después de que declarara que consideraba la autodestrucción como acto de fe, lo sitúa en la duración de la conspiración dadaista, que se extiende de 1924 hasta 1927, cuando termina durante un homenaje sevillano a Góngora.

En el capítulo "Suicidios de hotel", donde habla de la relación entre Rigaut, Williams, O'Keefe y Man Ray, y de su apócrifo libro Viajes con Rita Malú, no se narra en cambio el suicidio perfecto que realizó Raymond Rousell, o, mejor dicho, Vila-Matas se apropia de la escena para atribuírsela a Rigaut. Como narra su biógrafo Leonardo Sciacia, el suicidio de Roussel tuvo lugar en un hotel de Palermo con una desmesurada dosis de barbitúricos. Tampoco nombra la dosis letal de barbitúricos que ingirió Walter Benjamín -uno de los Shandys decisivos de HALP, puesto que, siendo un doble de Duchamp, lo es también del narrador- en un hotel de Francia in Port Bou en la frontera entre España y Francia, en el desesperanzador septiembre de 1940. Pero en cambio, sitúa en este lugar su ficticia entrevista con Duchamp.

Sobre la descripción del espacio del suicidio es importante reiterar que una clave interpretativa es su relación con Étant donnés, la última obra de Duchamp en la que la cerradura en la puerta abre paso a la contemplación del eros que empuja al thanatos, y que no sólo se explicita por la mencionada aparición de la O'Keefe en la vida de Rigaut (el juego entre la mujer fatal, la novia y la avería de las máquinas solteras), sino con el uso de elementos, como éste, extraídos de las obras de arte que se traspasan al relato literario. 
Hay una serie de reiteraciones entre las máquinas, el deseo, y el inevitable fin de cada hombre: la máquina soltera, principio de creación de la novia del Gran Vidrio de Duchamp, pasa a identificar la condición de los shandy -su incesante e insaciable deseo- e igualmente se habla de la "barbitúrica danza de la muerte" con la que Lorca representa en el Alambra Hotel, lo que vivió Rigaut, a puerta cerrada. “...Aparecía en escena un aparato eléctrico, inventado por el propio Lorca, cuya misión consistía en irradiar, en cuanto entraba en funcionamiento, un espeluznante frío, de gran intensidad" (107). Al final de la escena, una negra espectral, anuncia el fin de la conjura Shandy. Si el libro presenta diversos inicios para la conjura, también ofrece diversos finales.

Acerca del suicidio de Rigaut, en HALP se narra que Credrars escribió: "Recomiendo a mis amigos que no intenten mejorarlo, pues es tarea del todo imposible y, no hay nada peor que matarse, hacer el ridículo y, para colmo, no enterarse de lo que uno ha hecho" (35-6). Es una declaración que permite conciliar la atención que otorga a la Agencia General del Suicidio - título real de uno de los libros de Jaques Rigaut- y al modo en que éste convierte en una obsesión su cumplimiento perfecto (sin posibilidad de fallar en el intento), con el desdén de los Shandys por el suicidio, puesto que supuestamente son "grandes amantes de la vida" (27).

De hecho, el principio subterráneo es que un arte de vivir requiere del contacto con la muerte como lo sabía Focault, cuyo único ensayo estrictamente literario $-L a$ muerte y el laberinto, 1963- fue precisamente sobre la obra Locus Solus de Rousell, obliga a una meditación sobre el suicidio. El tema, de hecho, se expande en el posterior libro de Vila-Matas, Suicidios ejemplares. Pero en HALP hay una suerte de contención consecuente con la afirmación vital de los Shandys, incluso desde lo fantástico como se 
advierte en las alusiones a los zombis, cuya existencia contradijo Man Ray en un manuscrito referido al Dadá donde dice que no se puede revivir lo que está vivo, ni tampoco lo que está muerto. Es a él a quien se le atribuye el haber descubierto ese rechazo radical al suicidio a raíz de la carta de Rigaut y su voz impostada realiza esta suerte de proclama: "Elegid suntuosos hoteles si queréis abandonar esta vida" (33).

HALP incluye a otro supuesto suicida, el jazzista norteamericano Robert Johnson (1911-1938), por el misterio que rodeó su muerte y que lo convirtió — asunto que no se menciona - en el primero de los músicos del Club 27, conformado por la memoria de esos jóvenes que abrieron la puerta más oscura hacia la eternidad a ese número de años que es también la cifra que incesantemente se repite como parte de la conjura Shandy. Vila-Matas transforma en un aparatoso y sofisticado suicidio con una tetera de plata su envenenamiento por estricnina, como parte de una venganza por su romance con una mujer casada. También le atribuye que acudía a sus citas "con un maletín muy ligero" (31) que la gente suponía lleno de pinturas, pero que en realidad contenía los elementos para un picnic, incluyendo la tetera que pulirá hasta convertirla en proyectil, es decir, que el maletín era portador de la muerte en potencia. En lugar del maletín duchampiano o de la afición de Larbaud "a viajar con un maletín que contenía su ingrávida obra” (41), lo que Johnson cargaba - fuera de la leyenda de origen africano sobre que habría aprendido a tocar instruido por el diablo en un cruce de caminos - eran las letras de Love in Vain: "Yeah, I followed her to the station/ With a suitcase in my hand/ Whoa, it's hard to tell, it's hard to tell/ When all your love's in vain”. Y, además, curiosamente, la última estrofa termina con la imagen del hombre triste en la estación del tren que puede evocar el autorretrato de Duchamp Jeune homme triste dans un train (1911-12) que Johnson no 
debió ver jamás. Y, por supuesto, en medio de las controversiales versiones que rodearon su muerte, no deja de estar asociada la presencia del eros, que la precipita.

En la versión disidente de HALP, Vila-Matas continúa la ficción sobre Jhonson, revelando que en realidad, éste no estuvo nunca en Port Actif, sino que fue Joseph Roth (1894-1939) -“shandy secreto”— quien asistió a la reunión de Berta Bocado y compañía, sólo que haciéndose llamar Robert Jhonson. Anota que la forma de beber de Roth "fue leída por todos como metáfora del suicidio, y eso forjó la falsa leyenda de que Robert Johnson se había suicidado en Port Actif" (Versión disidente). La explicación contiene además una referencia autobiográfica pues esa relación vertiginosa con la bebida llevó a Vila-Matas hasta el límite físico y sólo se detuvo ante la puerta de la muerte.

\section{Nomadismo infatigable}

Como ocurrió en la vida de Duchamp, el viaje activa en HALP la mirada: aun si existe el mecanismo de las máquinas solteras y las hermosas máquinas animadas o las mujeres fatales, la historia no puede contarse sin la movilidad del viaje. Poco después de asistir a la exhibición de locomoción aérea en París en 1912, donde Marcel Duchamp había declarado por primera vez que la pintura se estaba desvaneciendo, se embarcó en un viaje en auto con Apollinaire y Picabia, y al regreso de éste inicia las indagaciones que alimentarán La novia desnudada por sus solteros... aún. Otro viaje, apócrifo, de Duchamp y Picabia en HALP será el pistón que pone en acción la imaginación en movimiento de la Conspiración Shandy.

Sus claves están ligadas no sólo al viaje como estrategia conectada al desplazamiento de identidades sino a los diversos lugares donde se desarrollaron los capítulos del dadaísmo. En relación con el primer aspecto, y considerando que Duchamp 
es el Odradek del narrador, me adentraré en algunos momentos de sus travesías, iluminadores para comprender la trama de HALP, antes de revisar el nomadismo delirante de los conspiradores.

El hecho es que el viaje fue clave en de concepción de las obras de Duchamp. En no pocas ocasiones estos viajes fueron enigmáticos, hechos sin propósito fijo, una deriva en un mar nocturno. Tal como nota Tomkins en su biografía sobre el anartista, en 1912 aborda un tren en dirección a Munich y si bien se sabe que en principio fue recibido en la estación por Max Bergmann (1886-1944), el resto de su vida guardó silencio acerca de los detalles del tiempo a solas que pasó en esta ciudad, y que fue quizás el más prolífico de su vida, puesto que allí concibió el primer estudio de El gran vidrio, que tuvo como antecedentes pinturas que luego se incorporarían transformadas, a la pieza tridimensional: El pasaje de la virgen a novia (1912), el Molinillo de chocolate (1914) y Nueve formas masculinas (1914-1915).

We know next to nothing about how he lived or what he was thinking during this crucial summer - the defining point in his career - and Duchamp cleary wanted in that way. The impulse that made him travel to another city and completely isolated existence, free of family ties or distractions of any kind, also seems to have made him want to preserve that experience, intact and inviolate, for himself alone. He hinted at this in a late filmed interview with the French documentary filmmaker Jean-Marie Drot. 'In 1912 it was a decision for being aline and not knowing where I was going', Ducham said. 'The arist should be alone...Everyone for himself, as in a shipwreck' (Tomkins 93).

De hecho, la primera obra que revela sus incursiones en la posibilidad de convertir la pintura en un medio capaz de transmitir la cuarta dimensión asociada al tiempo, Hombre joven triste en un tren, 1912, es autobiográfica y se refiere a su propia travesía, pero el título, lejos de lo que pudiera pensarse, no tiene que ver con lo sentimental sino con el juego lingüístico entre la pronunciación fonética tren (train) y 
triste (triste) en francés. Apollinaire calificaría al Muchacho triste como el "estado de alma" futurista, como una interpretación cubista de una fórmula futurista... (Cabanne 26). Hasta el final de sus días Duchamp cultivará un placer particular en los juegos sonoros de la lengua que desafían la lectura unívoca, y que, como hemos visto en otros capítulos, están asociados al derrumbamiento mismo de las barreras de la lógica y a la posiblidad de multiplicar los sentidos a un ritmo que libera las razones de la noción de una interpretación inmutable. Filosóficamente la lectura de Henri Poincaré (1854-1912) había instigado en él esa visión, pero fue un espectáculo teatral el que alteró el horizonte de su imaginación.

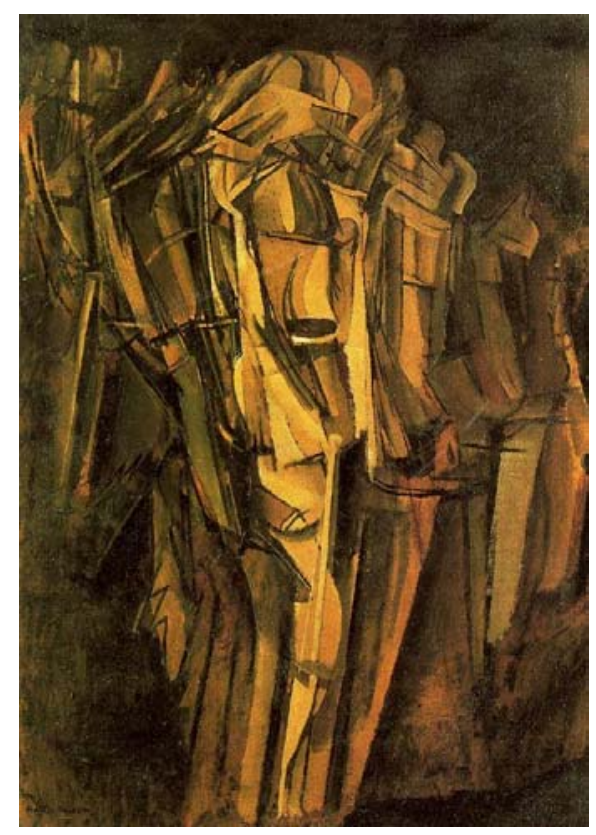

Ilustración 101: Marcel Duchamp, Hombre joven triste en un tren 1912

Ya en esa pieza se puede sentir un primer efecto, sonoro, pero también mental, de un desplazamiento de visión a un continente desconocido del pensamiento abierto por los juegos sonoros del lenguaje que se manifestará luego con mucha mayor fuerza, alejándolo de la pintura sobre lienzo, y de lo hasta entonces concebido como arte. Este 
espectáculo fue, en la vida real, el primer desembarco mental en África, tema clave para HALP.

Para Vila-Matas una primera inicial de revelación sobre ese espacio "africano" que es el continente de otro modo de textualidad fue la conversación con Marcel Duchamp que tuvo Cabanne y por ello resulta enriquecedor comparar las declaraciones que respecto a Roussel éste le da, y el acercamiento a su figura y a las Impresiones de África en HALP, sobre todo en tanto espejo generador de las reflexiones especulares de su propia escritura que hacen eco a ambos creadores. Transcribo la evocación de Duchamp, cuando Cabanne le recuerda que en ese año, cuando conoció a Picabia, asistió con él y su esposa Gabrielle Buffet (1881-1985), y con Apollinaire, al Théâtre Antoine para la representación de Impresiones de África, de Raymond Roussel.

M.D. -Era formidable. En escena había un maniquí y una serpiente que se movían un poquito, era totalmente la locura de lo insólito. No recuerdo mucho el texto. En realidad no se le escuchaba. Eso me sorprendió...

P. C. - ¿Lo que le sorprendió fue el espectáculo como espectáculo antes que el lenguaje?

M. D. - En efecto. Después leí el texto y asocié ambas cosas.

P. C. — ¿El desafío lanzado por Raymond Roussel al lenguaje correspondía, tal vez, al que usted lanzaba en la pintura?

M. D. - Si usted quiere... ¡De verdad que me gustaría que así fuera! (...) Sí, yo creo que sí. No soy yo quien debe decidirlo, pero sería muy simpático, puesto que ese hombre había hecho algo que, verdaderamente, tenía el aspecto revolucionario de un Rimbaud, era una escisión. Ya no se trataba del simbolismo ni siquiera de Mallarmé, cosas que Roussel ignoraba totalmente (26). ${ }^{201}$

Manuel j. Borja Villel, quien como director del Museo Reina Sofía organizó la exhibición Locus Solus. Impresiones de Raymond Roussel, 2012, en la que había una habitación completa dedicada a una reproducción del Gran vidrio, considera que la asistencia a ese espectáculo fue sencillamente un "momento fundacional" para el "cambio de paradigna en las artes que tiene lugar tras la fiesta de la modernidad": 
Desde el Sur al Norte, Roussel parece estarnos advirtiendo, ya en las primeras décadas del pasado siglo, de que las conexiones geográficas, ideológicas, estructurales o de pensamiento, no siempre siguen caminos que se encuentran en la superficie ni dibujan dos ejes perpendiculares como los que dividen la tierra, sino que responden a diagramas más complejos, como los que aplicamos, desde el Museo Reina Sofía, a la historia del arte (Locus solus).

En 1912, un año después de haber pintado a Dulcinea, Duchamp asiste con

Picabia, como a una revelación que comparte con él y su esposa Gabrielle Buffet, y con Apollinaire, a la representación de Impressions d'Afrique, de Raymond Rouseel, uno de los hombres que más admiraría en su vida, por "su imaginación delirante". Cabanne define la experiencia como "un choc déterminant", (un choque determinante) (Cabenne, Duchamp \& Cie, 62). Su impacto sencillamente cambió su visión de lo posible en el arte.

En 1946, evocando la experiencia de ese espectáculo, Duchamp le dijo a James Jhonson Sweeney:

[Pierre] Brisset y Rouseel eran los dos hombres que en aquel tiempo yo admiraba más, por su imaginación delirante [...]. Brisset se ocupaba del análisis filológico del lenguaje -un análisis que consistía en tejer una increíble red de equívocos y juegos de palabras. Era una suerte de Aduanero Rousseau de la filología [...] Pero el responsable, fundamentalmente, de mi Vidrio, La novia puest al desnudo por sus solteros, aun...fue Roussel. Desde que vi su pieza de teatro me di cuenta inmediatamente de las posibilidades que ofrecía su concepción. Sentí que, como pintor, era mejor sufrir la influencia de un escritor que la de otro pintor. Y Roussel me mostró el camino. Fue el principal responsable de mi vidrio (Paz 24).

En la entrevista de Cabanne, cuando éste le pregunta a Duchamp qué es la inteligencia, refiriéndose a que Breton lo consideraba el hombre más inteligente del siglo, no sólo le dice que es lo más elástico que uno puede inventar, sino que interpreta la noción surrealista de inteligencia en estos términos:

Para él, la inteligencia era aquello que la mente de un hombre normal encuentra incomprensible o difícil de entender. Es como una explosión en el significado de ciertas palabras: tienen un mayor valor de lo que significan en el diccionario. Bretón y yo somos hombres del mismo orden, compartimos una visión común, 
por eso pienso que entiendo su idea de la inteligencia: alargada, estirada, extendida, inflada si usted quiere... (Cabbanne 9).

Luego le cuenta que lo divertido de la gente de la literatura de esa época era que cuando se reunían ocurrían como una serie de juegos artificiales verbales, bromas, mentiras, todo dicho con un estilo y un lenguaje imposibles de imitar.

Octavio Paz precisa que El Gran Vidrio es una trasposición en el sentido que daba Mallarmé a esa palabra, del método literario de Roussel a la pintura. Aunque éste no había publicado entonces "Comment j'ai écrit certain de mes libres", en el que explicaba su método único: enfrentar dos palabras de sonido semejante, pero de sentido dispar (exactamente como lo intenta Vila-Matas al añadir la línea "Etrangler l'etrager", asimilada por un sexteto musical experimental) y encontrar en ellas un puente verbal, Duchamp lo comprendió y lo volcó en el arte convirtiéndolo en "la forma más acerada y eficaz de la meta-ironía":

Todo mecanismo debe producir su contraveneno, la meta-ironía. El elemento hilarante no hace más humanas a las máquinas pero las conecta con el centro del hombre, con la fuente de su energía: la indeterminación, la contradicción. Belleza de precisión al servicio de la indeterminación: máquinas contradictorias (Paz 25).

Y el humor, nunca explicitado como principio de HALP, pero omnipresente en toda la obra resume un intento que no es ya el de la obra total de Vargas Llosa (n. 1936), sino una máquina contradictoria. Vila-Matas parte de una operación paralela: usar el Gran vidrio, una pieza artística, para crear una narración que aúna lo delirante con el rigor extremo en un mecanismo que puede falsear lúdicamente anécdotas, citas, fechas y lugares, pero que en última instancia es fiel a la aprehensión de un modo de verdad, que es impronunciable y a la que sólo puede acercarse torciéndole el cuello al lenguaje, haciendo de él un oscuro continente donde se viaja, como en la frase de Baudelaire que 
sirve de epígrafe al libro, sin citarlo, “...au fond d l'Inconnu pour trouver du nouveau” (al fondo de los desconocido para encontrar lo nuevo). Como escribió en Dietario Voluble:

Me reconozco en aquellos escritores lúcidos que sienten que de algún modo la obra está fundada sobre la nada, que un texto para tener validez debe abrir nuevos caminos, debe tratar de decir lo que aún no se ha dicho.

Así que cuando Duchamp viaja a Munich en 1912, llevaba ya ese engranaje de un lenguaje delirante, encadenado no por la lógica, sino por la sonoridad, donde es posible hallar una máquina para pintar, y otros mecanismos humanoides, y donde en cualquier caso, obedeciendo reglas de una dimensión nueva, inventada por su autor; es decir, que emprende un viaje geográfico paralelo al desplazamiento de sus coordenadas mentales. Es por esto que el viaje marca el inicio de la concepción de El Gran Vidrio. En Muchich hizo notas, dibujos, estudios, dibujaba la pared de su apartamento con los trazos iniciales de las primeras investigaciones para la Máquina de los solteros.

Luego, a fines de 1912, viajó con Picabia, y su esposa a las montañas de Jura, e hizo notas que eludían la lógica y el sentido. No mucho después comenzó a pensar en remover los efectos pictóricos y en usar una técnica de dibujo. Fue en ese período cuando, después de asistir a una exhibición de aviación, le dijo a Constantin Brâncuși, una frase ya legendaria acerca de que no era posible hacer nada mejor que un propulsor. No mucho más tarde, el escultor empezó a hacer sus esculturas en forma de pájaros que los oficiales norteamericanos confundieron con partes de avión.

Tras haber logrado ser exhimido del servicio militar durante la Primera Guerra mundial, gracias al escándalo producido en el Armory Show de Nueva York de 1913, con su Desnudo descendiendo la escalera N. 2, y el consecuente mecanismo de activación de 
las ventas de sus obras, emigró a a Estados Unidos en 1915. A su llegada a Nueva York, donde conoció a Man Ray, y a la mecenas Katherine Dreier (1877-1952), descubrió que era una celebridad y se integró a la colonia artística de Ridgefield, New Jersey.

En una carta que escribe desde Nueva York a hermana Suzzanne (1889-1963) que está en París el 15 de enero de 1915 se encuentra la primera vez que Duchamp usó el término readymade, refiriéndose a la Rueda de bicicleta y de Bottle rack, como esculturas que compró ya hechas. Le explica que las firma y les da una inscripción en inglés. Así, por ejemplo, a la pala de nieve le escribió en la parte de abajo "In advance of the broken arm", una traducción del francés, "En avance du bras cassé", que ella no debe intentar entender en el sentido romántico, impresionista o cubista, porque no tiene nada que ver con ello. Luego le anota la siguiente instrucción:

Toma tu misma este botellero. Yo haré un readymade a distancia. Tienes que escribir en la base y en el interior del anillo de abajo en pequeñas letras (el subrayado es mío) pintadas con un pincel para óleo, en color plata y blanco, la fr (tachado) inscripción que te voy a dar después, y firmarás con la misma mano como sigue: [después de] Marcel Duchamp) (Naumann y Obalk 43). ${ }^{202}$

En 1918, Duchamp emprende un misterioso viaje a Buenos Aires, muy poco documentado, a excepción del excelente libro de la argentina Graciela Speranza Fuera de campo. Viaja en un barco en el que está presente la navegación de los viajeros que su admirado Raymond Roussel embarca en sus Impresiones de África, y provoca, sin saberlo, la travesía posterior que emprenden los conjurados Shandy hacia Port Actif, epicentro inicial de la conspiración, y también algo que no podría preveer: su inclusión entre los viajeros de Cortázar que recorren 80 mundos en un tiempo vertiginoso. 
Entre los paratextos que siguen nutriendo el "ensayo" HALP, hay un fragmento tomado de La vuelta al día en ochenta mundos, de Julio Cortázar, que Vila-Matas publica en su página web titulándolo "De otra máquina soltera. Julio Cortázar" donde éste se refiere al viaje de Duchamp a Buenos Aires:

Ese viaje debió responder a la legislación de lo arbitrario cuyas claves seguimos indagando algunos irregulares de la literatura, y por mi parte estoy seguro de que su fatalidad la prueba la primera página de las Impressions d'Afrique: 'El 15 de marzo de 19..., con la intención de hacer un largo viaje por las curiosas regiones de la América del Sud, me embarqué en Marsella a bordo del Lyncée, rápido paquebote de gran tonelaje destinado a la línea de Buenos Aires.' Entre los pasajeros que llenarían con la poesía de lo excepcional el libro incomparable de Raymond Roussel, no podía faltar Duchamp que debió viajar de incógnito pues jamás se habla de él, pero que sin duda jugó al ajedrez con Roussel... (El ayudante de Vilnius).

Como es lógico, precisa Cortázar, y hace eco Vila-Matas, la crítica seria sabe que lo arriba narrado es imposible puesto que el Lyncée era un navío imaginario, y Duchamp y Roussel nunca fueron presentados, aunque el primero, según Cortázar, lo vio una vez en el café de La Régence, jugando al ajedrez con un amigo, pero como precisa el autor cronopio "hay otros para quienes esos inconvenientes físicos no desmienten una realidad más digna de fe" (El ayudante de Vilnius). En su entrevista con Cabbanne, Duchamp le dice que haberlo leído y visto sus obras en el teatro, le bastaba y que no tenía que volverse su íntimo: "Era una actitud, más que una influencia lo que importaba, saber cómo había hecho todo eso, y por qué...”.

Una de las extrañas conexiones que hay entre arte y vida tiene que ver con el argumento de la obra de Roussel, quien sostenía que una obra de literatura no debía contener nada real, ninguna observación del mundo, nada más que combinaciones de objetos imaginarios: un barco que parte para Buenos Aires encalla en las costas de 
África. Y, cuando Duchamp, viviendo en Nueva York, sintió necesidad de ir lo más lejos posible en busca de lo desconocido, terminó eligiendo Buenos Aires, donde acabaría fundando una de las vertientes del arte contemporáneo: las instalaciones construidas a distancia, por instrucciones de correo, como aquella pieza con hilos colgados que atraviesan un pasaje de una habitación, y cuyo eco literario puede encontrarse en la que Oliveira monta en Rayuela, la novela de Cortázar.

Es durante su estancia en Buenos Aires que elabora la primera obra por correo, enviada con instrucciones como un regalo de bodas que debía armar su hermana Suzzane, que era también artista. Con ella sostuvo una afinidad afectiva, poco común en un hombre de inmensa capacidad de desapego, que paradójicamente solía firmar, de modo invariable sus cartas con el adverbio "afectuosamente", que se utiliza justamente como título de Affectionately, Marcel, una selección de su correspondencia compilada por Francis M. Nmaumann y Hector Obalk.

La estancia en Buenos Aires no se prolonga más allá de 1920, no alcanza a los dos años, y el Nueva York de los 20's tampoco lo retiene demasiado tiempo, pese a que ha comenzado a formar una extraordinaria colección de arte moderno con Dreier y Man Ray, para la Société Anonyme. En 1923, cuando abandona el Gran Vidrio, y vuelve a París donde contruye un segundo Disco óptico rotativo, que revela su decisivo interés en las "máquinas de mirar", y los rotorelieves, hace una serie de juguetes ópticos y su "Anémic Cinéma" (1926). Los siguientes 20 años no es que abandone el arte como se ha proclamado, sino que el proceso de la construcción y deconstrucción textual en torno a la obra ocupa su mente. La pregunta esencial que había desembocado en los readymades (palabra que él siempre usó en inglés y que por tanto prefiero a sus traducciones en 
español o francés): “Es posible hacer obras que no sean obras de arte?”, tuvo respuestas cambiantes e involucró conceptos como la belleza de la indiferencia y el método de lo que llamaría "el azar en conserva", pero sin duda lo textual (instrucciones, firma, o versiones escritas) forma parte de su papel de sabotaje de la antigua estética. El encadenamiento de palabras por su sonido, más que por su significado tiene un correlativo en la elección de objetos ya hechos cuya combinación es arbitraria, a menudo cargada de humor y que no obstante sugieren la apertura de una geografía insólita para la mirada.

La exhibición An Unruly History of the Ready Made, 2009, curada por Jessica Morgan a partir de una de las más completas colecciones privadas de arte contemporáneo de toda América, demostraba cómo en el último medio siglo no ha habido una mirada tan capaz de alterar las prácticas artísticas y ejercer una omnipresencia tan poderosa como la de Marcel Duchamp, pese a que en los últimos 20 años de su vida, como el Baterbly más empecinado, solía decir que que estaba dedicado a respirar o a coleccionar ideas. En un artículo que entonces escribí sobre esta muestra que constituyó "una de las aproximaciones más lúcidas, divertidas y completas que se hayan realizado sobre la vasta saga de los herederos de Marcel Duchamp", mencionaba que si él había dado la vuelta a la historia del arte convirtiéndola en el espacio más libre y radical de la cultura, era porque había entrenado nuestra mirada para la "permanente subversión estética", algo que supone otro modo de visión que involucra el proceso de pensamiento agudizado. Duchamp quería usar la palabra 'retardo' en lugar de 'pintura' o ‘cuadro' por su conexión con el tiempo de reflexión sobre la imagen, que era lo que en realidad le interesaba, puesto que el proceso de construcción era infinitamente más importante que el resultado 
final, la aparición de la obra (...) ese retardo lo llevó a continuar escribiendo notas, ideas, diagramas sobre el funcionamiento de la imagen y sobre sus mecanismos de un modo casi oculto, privado.

En 1942, después de vivir tras su retorno a Europa casi dos décadas en Francia en los cuales disfrutó de la compañía de Mary Reynolds (1890-1977) — en un período prácticamente silencioso pues salvo la publicación de la Caja Verde, 1934, con las 96 notas sueltas sobre el Gran Vidrio, no había creado (y no volvería a crear en vida), nada comparable a la revolución de los readymades o a esa máquina soltera andrógina transparente, ni al escándalo estético de su Desnudo bajando la escalera, o de Fontaine; Duchamp busca alejarse de Europa. Habían pasado dos años después del suicidio de Walter Benjamin en Portbou, España, y Francia estaba ocupada por los nazis, pero él no tenía entonces la dimensión del tipo de figuras notables que ayudaba a escapar el Comité de Operaciones de Rescate de Emergencia formado por el legendario Varian Fry (Surrealism NYC Web).

Es entonces, impelido por la necesidad de dejar atrás esa Europa enloquecida, cuando crea la Caja en la Maleta, objeto metonímico por excelencia del traspaso de fronteras llevando consigo toda la geografía del pensamiento que contiene el nuevo paraje del arte contemporáneo. 


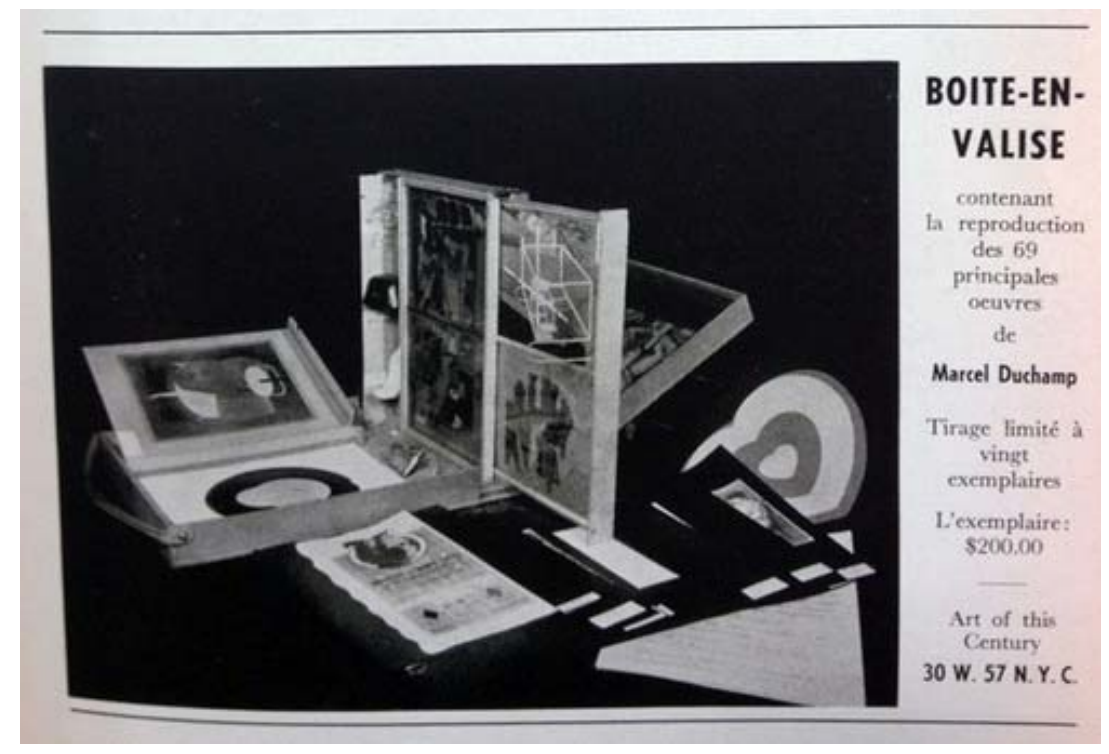

Ilustración 102: Marcel Duchamp. La caja en la maleta 1962. Reproducción en serie.

Duchamp, se las arregla como puede y logra llegar a Nueva York en mayo, con una miniaturización de 69 obras, ahora convertidas en una versión portátil, de las que luego hará otras ediciones como la que se observa en la ilustración. La producción fue tan minuciosa que se ha discutido si podía ser vista sólo como copia reducida. En sí, el concepto — que le fue sugerido por el escritorio móvil de Paul Morand (1888-1976)— era una originalísima práctica artística, una perspectiva lúdica sobre la propia creación, que jugaba con la idea física y simbólica de la levedad, pero cuidando al máximo los detalles de la realización.

Tres meses después de arribar a la Gran Manzana acaba alojado en la casa que compartían Max Ernst y Peggy Guggenheim, mientras ambos están de vacaciones. ${ }^{203}$ El influjo que tenía sobre Breton hace que acabe formando parte del consejo editorial de la revista VVV y colaborando con la organización de First Papers of Surrealism. El curso del viaje que aquí emprende es definido así por la revista Surrealism NYC: "Sympathetic 
to surrealism though never a Bretonian loyalist, Duchamp is able to navigate a subterranean course in New York that will prove more influential to U.S. artists than any of the surrealists" (Surrealism NYC).

Entre 1946 y 1966, el viaje que emprende, mientras para el mundo hay una suerte de nuevo telón negro sobre esos años, ocurre en el interior de su apartamento de Nueva York, en la calle 14, donde sólo viaja hasta su cuarto ${ }^{204}$, como alguna vez declaró Duchamp sin que se comprendiera realmente el sentido de su afirmación, como viajan ciertos shandys, atormentados por sus Odradeks, como veremos. Durante todos esos años Duchamp trabajaba secretamente en Ettant Donnés, que no sólo es, una de las obras más extrañas y perturbadoras de la historia del arte, sino que, contradiciendo de modo absoluto la noción de lo portátil de la Caja en la maleta, ocupaba el cuarto secreto que permaneció, hasta el fin, inaccesible a los visitantes.

Y aquí, resulta indispensable referirse, antes de continuar la travesía por HALP, al Manifiesto de la altermodernidad en el cual Nicolas Borriaud delinea principios que guardan relación indudable con el tema de la ficción extrema aquí planteada y define la noción del "homo viator": 205

We are experiencing the emergence of a global altermodernity. Travel, cultural exchanges and examination of history are not merely fashionable themes, but markers of a profound evolution in our vision of the world and our way of inhabiting it. More generally, our globalised perception calls for new types of representation: our daily lives are played out against a more enormous backdrop than ever before, and depend now on trans-national entities, short or long-distance journeys in a chaotic and teeming universe (...) The artist becomes 'homo viator', the prototype of the contemporary traveller whose passage through signs and formats refers to a contemporary experience of mobility, travel and transpassing. This evolution can be seen in the way works are made: a new type of form is appearing, the journey-form, made of lines drawn both in space and time, materialising trajectories rather than destinations. The form of the work expresses a course, a wandering, rather than a fixed space-time. Altermodern art is thus read 
as a hypertext; artists translate and transcode information from one format to another, and wander in geography as well as in history. This gives rise to practices which might be referred to as 'time-specific', in response to the 'site-specific' work of the 1960s. Flight-lines, translation programmes and chains of heterogeneous elements articulate each other. Our universe becomes a territory all dimensions of which may be travelled both in time and space (Bourriaud)

Esa noción del "homo viator" en una experiencia de movilidad y transpaso, una nueva deriva que también supone la de la identidad misma, ahora multiplicada, inmersa en la noción del doblaje generalizado. Duchamp decía que viajaba hasta su habitación, y varias de sus obras más importantes fueron concebidas en el misterio de viajes que hasta la fecha permanecen situados en un continente desconocido de la imaginación, o configuran más bien la noción de un "África” que es "otra parte”, y que sobre todo, como veremos, tiene una geografía textual. Para transitarla es imperativo comprender que en ese modo de transmigración de identidades, los desplazamientos, tanto geográficos, como temporales y mentales, juegan un papel decisivo.

Esta noción del viaje estructura también HALP y no es azar el juego lingüístico entre el nombre del puerto donde se genera la Conspiración, Port Actif y la palabra que en francés designa lo portátil, portatiff. Podría escribirse un libro sobre los juegos y las bromas lingüísticas de los títulos de las obras de Duchamp, odradek de Vila-Matas que lo contagia. De hecho, una de éstas bromas estructura el mapa de viaje que emprenden los portátiles, viajeros que llevan en sus cabezas la maleta en la que el artista transportó 69 obras suyas en plena guerra contra el totalitarismo.

No quiero terminar este aparte sin mencionar otro de los múltiples orígenes que Vila-Matas da a su Historia abreviada de la literatura portátil: narra que la concibió en 
un viaje a París, donde vio la ya mencionada exhibición de Máquinas solteras de la literatura en el Grand Palais:

Recuerdo que el mismo título de la exposición me intrigaba mucho. Me sorprendió después lo que vi allí. Era yo un admirador de Raymond Roussel y de sus máquinas, y ver alguna de ellas reproducidas en la exposición, al lado de las máquinas de Kafka o de Duchamp, me dejó huella. Me gustaba, por otra parte, el concepto duchampiano de machine célibataire con el que me identificaba. Y, aunque no entendía muy bien qué era exactamente, me gustaba también el concepto de femme fatale y, si la memoria no me traiciona, en aquella exposición había más de una máquina que funcionaba como tal, como mujer fatal (Version disidente).

HALP no sólo reasume la importancia que tenía lo textual en la obra de Duchamp, sino que la revive reconstruyendo la sacudida vital que significó para éste y para Picabia el contacto con la obra de Raymond Roussel. De hecho, la convierte en una herramienta del método de escritura de HALP, y vincula subrepticiamente los juegos de la lengua, liberados del sentido, sonoros, delirantes, al origen mismo de la Conspiración Shandy, que es errante. Ambos elementos, los desplazamientos de la lengua y el carácter errante están unidos a la condición de las ficciones extremas.

\section{La "africanidad" como mapa y método textual}

HALP rastrea fidedignamente la construcción de una conspiración que, en oposición al universo hegemónico de los poderes en conflicto, cambia la atmósfera de las ciudades de la "iluminada Europa nocturna" (9), abriendo paso a la heterotopía, a lo largo de una travesía que parte de una interpolación entre Zurich, Praga y África, y termina en Madrid tras haber realizado una veloz incursión en la puerta de la casa de William Carlos Williams en América. Esa geografía a la deriva conforma un tipo de espacio cultural heterogéneo, lo cual según Michael Focault, nos hace vivir "dentro de una red de 
relaciones que delinean lugares que son irreducibles unos a otros y absolutamente imposibles de superponer" (Focault 22-27).

La trama conspiradora de HALP empieza con el acto voyeur de una española tan bella como imaginaria, Berta Bocado — su nombre ficitico es una broma verbal, aludiendo humorísticamente a que es un bocado deseable y fatal-, quien resulta ser amante de Picabia y, a instancia suya y de Duchamp, espía, como una cámara con el obturador abierto, a Andrei Biely para determinar si es un shandy. La escena del espionaje a quien creía que el arte es una anamnésis, una vía para el desposeimiento de sí mismo del artista, ocurre frente al Cabaret Voltaire en Zurich, donde ciertamente Tzara entró una noche de 1916 cantando melodías sentimentales para dejar luego espacio a actores enmascarados y regresar vestido de payaso.

La fundación del grupo ocurre después de varios equívocos, durante el viaje que habrían emprendido los instigadores Picabia y Duchamp, seguidos por los escritores Paul Morand (cuyo escritorio-móvil inspiró la Caja-maleta de Duchamp, anagrama de lo portátil) y por Jacques Rigault, además del desconocido shandy húngaro llamado Ferenc Szalay - o inexistente, hasta arribar juntos a la desembocadura del río Níger, donde está Port Actif, el lugar de la invención donde fundan la Sociedad de los Artistas Portátiles.

El salto de Zurich — lugar que fue la primera capital delirante del dadaísmo, cuando era una ciudad raptada por múltiples y dispares fuerzas políticas - a un puerto en el continente oscuro cuyo nombre pronunciado resulta homófono con la palabra en francés portatif, portátil, y el relato del modo en que se ha determinado ese punto de partida, atendiendo a una palabra revelada en un sueño de Duchamp, está asociado a dos 
nociones incorporadas a su meta-narrativa. Sobre la primera, como nota Pozuelo Yvancos se refiere a su relación única con el concepto de verosimilitud:

Si Aristóteles vinculó el concepto de verosmilitud (eikós) con el de necesidad (anagkais) regido por la ordenación de los hechos, estructura de las acciones, lo primero que advierte el lector de HALP es que el ensamblaje de sus contigüidades y toda la estructura leve de sus acciones en modo alguno se rige por la idea de necesidad, antes al contrario, por la de azar o gratuidad (33).

Esta idea del azar o la gratuidad era esencial tanto en la selección de los readymades como en las "patadas de todos los géneros", como llamaba Marcel Duchamp a sus juegos de palabras (Cabanne 75). Pero, en medio de ese "carecer de dirección en el seno de un caos de asociaciones que impone su carácter libérrimo" a la novela (Cabanne 36-7) surge, a modo de construcción de una zona, otro orden de asociaciones: un mapa alterno que justamente tiene como punto de origen una África imaginaria, no sólo superpuesta a la real, sino tan móvil que hay momentos en que aparece en una ventana del ghetto de Praga donde el autor de $E l$ Golem improvisa enloquecidos tambores, o en un sótano de los barrios llenos de bares de la misma ciudad donde el ocultista Aleister Crowley ${ }^{206}$ ejecuta una danza que los transporta al corazón del África Central.

Como parte del duchampiano azar en conserva y del humor verbal inseparable del aprendizaje transmitido por Roussel y por el anartista, la determinación del lugar de destino inicial de los conspirados brota en HALP de un palabra encontrada en un sueño que Duchamp le cuenta a Picabia. Al escucharlo, éste éste detecta la clave del mapa, el punto hacia dónde dirigirse:

Le contó Duchamp que había soñado cuatros frases, las tres primeras construidas mediante palabras sometidas al régimen de la coincidencia [método acuñado por Rouseel que deslumbró a Duchamp], frases que reflejaban el lenguaje que cabía esperar del azar en conserva que, como se sabe, siempre fue su gran especialidad (20). 
En realidad, las frases del sueño que Vila-Matas cita son una de esas inscripciones de textos que Duchamp hacía en sus ready-mades. Tristan Tzara las reproduce en su ensayo sobre La novia desnudada por sus solteros, aún, en el que no sólo cuenta que Duchamp había construido él mismo en su apartamento un juego de puertas de madera que funcionaban de tal modo que simultáneamente abrían y cerraban espacios, sino realiza una clasificación reveladora al incluir, entre los readymades, los juegos de palabras o un cierto número de búsquedas verbales especialmente activas. Un ejemplo de éstas son aquellas frases publicadas en el numero 5 de littérature Nouvelle Serie, en octubre de 1922. Las frases originales que HALP evoca se encontraban en realidad en el apartamento de Duchamp, escritas en dos esferas en movimiento, que inicialmente era una de sus obsesiones, paralela a la búsqueda de un modo de representar la cuarta dimensión, el tiempo, en las obras: se aúnanban al dibujo de espiral que está en las esferas y decían, a modo de texto-título: “(primer estado: 1921; segundo momento: Rrose Sélavy et moi estimons les ecohymoses des Esquimaux aux mots exquis)", en español: (Rrose Sélavy y yo estimamos las confusiones de los esquimales sobre las palabras exquisitas).

Vila-Matas no sólo las transporta de una obra real al sueño ficticio de Duchamp en HALP, sino que añade otro juego de palabras iniciales, escogidas por su juego sonoro y la alusión a lo nómade: "Etrangler l'etrager/ Eglise, exil/" y, además, en la segunda línea en que transcribe la inscripción cambia el adjetivo "estimar" por "esquivar": "Rrose Selavy et moi esquivons les ecohymoses des Esquimaux aux mots exquis, y añade luego una línea más, construida a su antojo: 'C'est Biely le plus vieux du Port Atif”' (20). 
En la última palabra, Atif, Picabia ve, como revelación del inmediato destino, Port Actif, en África. La travesía que pareciera descifrar con gratuidad duchampiana funciona realmente con una íntima coherencia relacionada con ese espacio transverso que según Brian Mc Hale caracteriza la metaficción posmoderna y que puede detectarse cuando, como en este caso, el lenguaje redibuja un mapa extraño sobre un espacio familiar.

De este modo, la interpolación ocurre aquí con el espíritu de la zona portátil superpuesto a un África que en realidad es una construcción de lenguaje. Si Picabia y Duchamp son quienes dilucidan en HALP un punto en el continente oscuro como primer lugar de gestación de la conjura, ello obedece ciertamente al impacto que tuvo en su visión asistir a la función de Impressions d'Afrique (Impresiones de África) de Raymond Roussel, que Brian McHale toma como ejemplo de la creación de una zona de heterotopía siguiendo el término acuñado por Focault. África es realmente, “a free, indetermined space, a playground for ontological improvisation.” (54). ¿Qué otra cosa el el topos móvil de HALP que refleja "a una escala en miniatura la estructura de los textos en los que aparece y que anexa al espacio del universo ficcional los espacios de otro estrato ontológico" (56). Ese aumentar la geografía a partir de la anexión del universo ficcional, no es solamente ensanchar su dimensión en un espacio imaginario, sino abrirlo en términos de un paraje de expansión del ser.

Al espacio del universo ficcional se han anexado los espacios de otro estrato ontológico. Entre todos los lugares a donde se encuentran y dispersan los portátiles, lugares que coinciden, por supuesto, con epicentros dadaístas -Zurich, París, Nueva York-, pero también Praga, o un periplo que también incluye el punto costero donde 
desapareció temporalmente alguno, o las callejuelas de Martinica donde otro se refugió, hay dos puertos que marcan la superposición entre lo ficcional y lo ontológico. El primero, por supuesto, es el puerto inventado donde se funda la conspiración Port Actif, y en el cual converge todo el imaginario de Europa a comienzos del siglo XX buscando un África imaginaria, un espacio para transfigurarse en algo desconocido; y el muy real Portbou, el lugar del encuentro ficticio, como he mencionado, entre Duchamp y el narrador, y el lugar donde Walter Benjamin renunció a seguir siendo habitante de un mundo, si es que no fue víctima de un complot o de una accidental sobredosis. En cualquier caso, en ese lugar mítico, donde el filósofo judío alemán no pasó sino el último de sus días, el 26 de septiembre de 1940, cuando ya Hitler avanzaba sobre París, huyendo en una situación límite, el narrador sitúa el principio de la posibilidad de decir lo indecible; es allí donde su palabra de doble duchampiano adquiere el poder de seguir el delirio portátil, y a través del periplo nómade nos asoma al lugar sin límite del pensamiento.

Al tiempo, el propio estrato material del libro, las 127 páginas que juegan con la reiteracion obsesiva del No 27, aparece anexado al mismo espacio de la ficción que es un espacio transverso plagado de esas estrategias de la ficción posmoderna que McHale ha señalado: yuxtaposición, interpolación —de un espacio extraño o ficticio en uno que nos resulta familiar, como ocurre con el África de Roussel—, superimposición — de dos lugares reales que forman un tercero-, y atribuciones equívocas (45). No es extraño que señale que fue Apollinaire uno de los primeros en haber concebido la moderna Europa como una zona de heterotopías (46). 
El hecho de que en las cuatro frases a las que alude como pista original del viaje y que en realidad son sólo una línea que corresponde al segundo momento de una obra de Duchamp — la ya mencionada Rrose Sélavy et moi nous estimons (cambiada por esquivons) les ecchymoses des Esquimaux aux mots exquis) - el mapa se redibuja y, en lugar de llevar como podría pensarse a la tierra de los esquimales, remite por obra de la mano impune del que se apropia y transforma a su antojo la obra o el texto anterior a esa África pasada por el tamiz de un insólito método de escritura.

El gesto de incluir la pista que lleva a Port Actif es paralelo a aquel con el que Duchamp firmó $L H O O Q$, esa reproducción de la Gioconda a la que le añadió un mostacho, y al del mismo Picabia que reprodujo la imagen de memoria y entonces le añadió una barba, pero no tuvo reparo en firmarla a su vez como Duchamp. La impunidad de las apropiaciones, la lúdica como método transformador y libre de toda culpa respecto a la autoría, se convierte en una fuente de creación inagotable, en donde el sí mismo no desaparece del todo: más bien se adhiere a los otros, como si se tratara de celebrar el advenimiento de una suerte de yo colectivo y, en cierto modo, infantil. "Como niños irresponsables se comportaron siempre los escritores portátiles" (12). Y, por supuesto, el mismo autor, que entre otras cosas, no habla nunca explícitamente en HALP del Gran Vidrio, pero se lo apropia a su libre albedrío.

Por otra parte, se advierte que ese preciso texto-título de Duchamp elegido y alterado tiene la peculiaridad de incluirlo a sí mismo (Rrose Sélavy et moi) junto con su heterónimo, la figura femenina de Rrose Selavy, que Man Ray se encargó de volver una aparición, una presencia concreta, a través de las varias fotografías que le tomó a 
Duchamp disfrazado de mujer. En El mal de Montano, Vila-Matas explica la estrategia de los heterónimos ligada a la naturaleza múltiple del lenguaje.

Fernando Pessoa, que percibió muy pronto que la materia verbal [o visual] no podía llegar a ser nunca una materia plenamente transparente $\mathrm{y}$, consciente de esto, se fraccionó él mismo en una serie de personajes heterónimos: toda una estrategia para poder adaptarse a la imposibilidad de afirmarse como un sujeto unitario, compacto y perfectamente perfilado (El mal de Montano 263-4).

En HALP, extiende la estrategia de los heterónimos y su juegos lingüísticos al viaje, en una serie de desplazamientos que multiplican a su vez los desdoblamientos de la identidad. Ese heterónimo femenino de Duchamp que superpone a la ruta hacia África una clave del mismo derrotero de los portátiles puesto que es la andrógina autora de la frase que remite al continente y que, como hemos visto, fonéticamente se escucha en francés como "Eros est la vie": eros es la vida, sostiene la continuidad de uno de los principios vitales que estructuran el curso de los viajes de los shandy, aunque el mismo Duchamp, tan abierto a la contradicción considerara por igual que sexo es sexo (tal como A rose is a rose...). Pero además la selección es significativa porque Duchamp utilizó a su doble femenino como la editora de su material escrito, lo cual refuerza además la noción de que a esa África heterotópica se llega de modo textual.

En El gran vidrio puesto al desnudo por sus verbos, Inocencio Galindo Mateo, escribe acerca de la textualidad de Rrose Sélavy, que aparece como la editora de una edición de 300 ejemplares numerados de El gran vidrio, once años después de su abandono. La Caja verde de 1934 es el título de la caja con 96 artículos sueltos reproducidos en un exacto fac-símil que incluye bordes rotos, tachones, rectificaciones y, ocasionalmente, ilegibles. En ese momento el inacabado Gran Vidrio o La novia desnudada por sus solteros, aún resurge textualmente como una obra de arte que tiene 
una guía que sintetiza de algún modo el conjunto de los instrumentos e invenciones de la vanguardia:

Las formas abstractas o las imágenes cortocircuíticas o el desorden y el azar como método, tienen un significado concreto, referenciable, directa y materialmente con una serie de notas escritas y dibujos en los que se describe una historia, una fábula donde los personajes son el propio lenguaje, el pictórico y el de los conceptos verbales (Galindo 69).

Sin embargo, la guía no sirve como tal, como precisa Galindo. La Caja Verde es un estuche que contiene esas referencias a la obra pintada, pero las notas no están ordenadas y contienen alusiones a elementos que no aparecen en el cuadro y no explican otros que en cambio sí están. El lenguaje está lleno de repeticiones discordantes, de metáforas delirantes. La obra funciona como "una especie de agujero negro que absorbe, neutraliza y devora cualquier luz que se intente arrojar sobre ella” (70). Algo que no excluye — más bien supone la inclusión de otros lenguajes paralelos. De hecho, La caja verde funciona como un misterioso doble textual de La novia desnudada por sus solteros.

Como nota Graciela Speranza:

Duchamp, a su modo, busca una forma ambiciosa de la traducción que reúna palabra e imagen y alcance la 'transmutación' o 'transubstanciación'. El Gran vidrio no sólo es fruto de su voluntad de traducir un lenguaje a otro sino que, mediante una serie de notas que acompañan su ejecución, intenta borrar los límites entre ambos lenguajes (...). Desde esa iluminación inaugural, persigue una continuidad ideal entre visión, palabra e idea, que prefigura la centralidad de la batalla entre lo enunciable y lo visible en el arte y el pensamiento del siglo XX (Fuera de campo 23).

Impunemente Vila-Matas dice que las frases de Duchamp (que él rehízo lúdicamente como mapa para arribar a África) fueron incluidas en la Antología del humor negro donde ciertamente Bretón reunió a algunos de shandys como Duchamp y Picabia, Rigaut y Dalí o Arp, y Apollinaire, y por supuesto Rousell. De éste, el mismo McHale 
señala con notable concisión y claridad, como señalé con anterioridad, pero repito ahora porque es una clave que ilumina también la naturaleza de la ficción extrema, que se caracterizó por anexar el espacio lingüístico al espacio proyectado de sus universos ficcionales. Tal como hace Vila-Matas al intervenir la citada frase sin sentido, pero llena de claves y "juevos" — sí, de esa mezcla entre incomodidad e inospechados disparos del pensamiento que pueden provocar las palabras inventadas, las asociaciones delirantes, y toda esa saga de recursos.

Ambas Áfricas, la de Rousell y la que Vila-Matas incluye en HALP tras advertir que narra una historia europea en sus orígenes, comparten lo que HcHale advierte:

Like Borges's Uqbar, Rouseel's kingdoms of Ponukele and Drelshkaf are mentioned in the same context with a few place-names that belong to the real world and can be found on a map: Merseilles, Tripoli, Porto Novo, Bougie. But the exact geographical disposition of theses kingdoms with respect to known places is impossible to determine, and Roussel has the Emperor of Ponukele's cartographer exploit the indeterminacy of real African frontiers (46).

En HALP, el primer signo "realmente interesante" que según Picabia aparece en Port Actif es "nada menos que un negro que sólo tenía una pierna y tocaba la flauta con su propia tibia: alguien idéntico a Lelgouaclch, personaje de ficción de Impresiones de África, la obra de Raymond Roussel" (23). Ese signo no sólo refiere al interés real que tanto Picabia como Duchamp hallaron en la obra, sino al método de una escritura africanizada, que en cierto modo surge, tal como lo revela Vila-Matas, como un modo de sortear la tentación del suicidio o más bien de cometerlo sobre el papel. Acto que supone diversas alternativas: el silencio radical, la traición al lenguaje mismo, o la derivación hacia el trampantojo o desvarío óptico, y que, de modo consecuente con lo shandy incluye otra variante posible: beber licores fuertes como metal fundido. 
Las tres primeras alternativas reflejan la vida y obra de Duchamp. Basta pensar que lo que él hace, al regresar a París, como hemos visto, después de abandonar el Gran vidrio, son desvaríos ópticos realizados a instancias de Breton. Según el narrador de HALP, todo ello era "un intento general de dejar a un lado ese idioma de la muerte que descubriera Rigaut entre impresiones de África, allá en Port Actif, donde parece que comenzó todo" (37). Es así como cita, sin citarlo, el libro de Roussel, quien por otra parte comparte como sabemos, el destino de los suicidas, a cuyo tema ha dedicado Vila-Matas un libro entero. El suicidio se aparta del campo de visión de Duchamp, y de su arte de vivir, pero en HALP caben una miríada de otros.

No hay que olvidar además, que fue realmente en el norte de África donde Enrique Vila-Matas escribió en 1973, mientras prestaba el servicio militar, su primera ficción, venciendo así su determinación de ser un autor sin obras. Por ese entonces, como él mismo lo evoca en su prefacio a la obra de Jean-Yves Jouannais, "Artistes sans œuvres. I would prefer not to", era determinante para él no sólo la influencia de Duchamp, sino la de Jacques Vaché (1896-1919) quien durante la I Guerra Mundial no había dejado más que unas cartas y dibujos dirigidos a Louis Aragon (1897-1928), Théodore Fraenkel (1896-1964) y a André Breton, quien decidió publicarlas con el título de Cartas de guerra. También le influía la figura de Jacques Rigaut -por quien el parco Duchamp sentía simpatía-, cuya Historia general del suicidio leía repitiéndose la frase, "Vous êtes tous de poètes et moi je suis du côté de la mort" (Ustedes son todos poetas y yo estoy en el lado de la muerte).

Pero el viaje a África le hizo cambiar de lado, pasar del silencio a la literatura aunque ésta desembocara en libros como HALP que en cierto modo rinden homenaje a 
ese modo de aparente suicidio artístico que fue el prolongado silencio de Duchamp, tanto más fascinante porque su "no hacer", como lo recordaría Octavio Paz, marcó tanto el siglo XX, como el imparable hacer de Picasso, e incluso opacó su influencia en el inicio del siglo XXI.

En Phare de la Mariée, André Breton escribió en estos términos sobre él: “Aquellos que lo conocen no tendrán jamás ningún escrúpulo en reconocer que nunca antes ninguna originalidad más profunda ha parecido derramarse más claramente en un ser de un dibujo de negación llevado a lo más alto" (86). Así que África o más bien la africanidad de un espacio heterotópico en el que se superponen imaginarios disímiles se convierte en el punto de partida para la conspiración de HALP, plagada a su vez de referencias especulares, no sólo sobre el proceso de creación literaria del narrador que está contando esa historia, inspirado en la figura ancilar de Duchamp, sino sobre infinidad de textos vanguardistas. Entre éstos, la Antología negra de Blaise Cendrars ((1887-1961), que subvierte a su antojo extendiendo el original saqueo de la oralidad africana que no era sino un simulacro para abrir otra vía de lenguaje y creación de horizontes — en cierto modo la única posible.

Vila-Matas no sólo recuenta sino reescribe o añade historias a esa antología como un modo de redibujar el mapa de esa otra África hecha de un lenguaje liberado de antiguas servidumbres que literalmente transformó la relación de Duchamp con el arte y generó obras que podían haber nacido del encuentro azaroso con un objeto, pero eran maduradas al régimen de una rigurosidad mental fuera de lo común, y proyectadas en versiones alternas como no se habían visto jamás. 


\section{La escritura africana de Cendrars}

El capítulo "Nuevas impresiones de Praga" comienza paradójicamente con una confesión meta-literaria del narrador que dice: “...en algún que otro capítulo de este libro, he utilizado el procedimiento de escritura del que se sirvió Blaise Cendrars para escribir su célebre Antología negra" (66). Y luego, sin ambages, usa por única vez la palabra que subyace en incontables líneas de HALP, "apócrifa”, para calificar de esto la antología que en realidad surgió de esa fascinación del viejo mundo exhausto que volvió los ojos a la fuerza creativa de África, de un modo exotista, pero consciente de ese juego de proyección de los propios imaginarios sobre los mundos perdidos que se buscan y se atribuyen a lo distante, de la notalgia como dolor por la tierra de una inocencia irremediablemente perdida con las guerras del siglo:

Nada menos que una antología apócrifa, pues el proyecto de Cendrars contemplaba la idea de elaborar un libro en el que, simulando que procedían de una recopilación de historias populares africanas, esas leyendas fueran, en realidad, una interpretación muy personal de las historias que los shandys le contaran en el momento del reencuentro en Praga (67).

Una definición que no coincide con la de los editores que destacaban en Cendrars ese rasgo típicamente shandy que es su existencia viajera, pero que consideraban que la obra había tenido el mérito de dar a conocer como literatura lo que antes de él se consideraba sólo un material etnográfico. Lo cierto es que, como anota Mauro Yberra, nunca se adentró en el África Negra. Lo que hizo fue escuchar a los viajeros que habían recogido las tradiciones orales. El propio Cendrars cuenta que extendió su erudicción en la materia "errando por las bibliotecas, sin ser un lingüista ni haber pretendido especializarme", y que su erudicción se había extendido hasta tal punto que en 1919, escribió a la luz de una vela en menos de un mes las 350 páginas apretadas. Su pasión por 
África era la de un niño que repasaba las páginas de una enciclopedia y contemplaba "un grabado que representaba a un gran ídolo de madera replegado al pie de un árbol gigante en la selva virgen, un ídolo cúbico... y yo me escondía al extremo del corredor, temblando" (Yverra). Sin embargo, no está tan lejos Vila-Matas de la apreciación de Jean Cocteau: "Es de todos nosotros quien mejor representa el nuevo exotismo, mezcla de motores y fetiches negros".

El narrador se apropia de los relatos expandiendo su naturaleza de simulación, construida sobre un exotista rescate de la tradición oral africana. En realidad, aunque comienza hablando de la Antología negra de Cendrars, que usaba la aventura de su vida como materia prima, las claves que rodean la descripción metaliteraria del método de la escritura de HALP remiten a los dobles de El Golem que no se menciona, pero sí su autor: Gustav Meyrink (1868-1932), que aparece aquí como el personaje que abre el telón, y nos conduce a su delirante encuentro con Cendrars en una escena que continúa la noción de las referencias no sólo apócrifas, sino enloquecidas, citadas promiscuamente, pero cuidando la afinidad de sentido. Porque si es posible hablar del espacio textual africano desde un cementerio judío en el ghetto de Praga, es porque en última instancia, de lo que se habla es de la alteridad asumida como fusión de identidades múltiples en enloquecido juego de desdoblamientos y apropiaciones y posibilidades, puesto que cada yo es todos los otros.

Según HALP el proceso de creación de la Antología negra se inició en Praga cuando Meyerlink, acodado a la ventana de un invierno, se ve a sí mismo "convertido en una cámara con el obturador abierto" (66) —esa mirada que nos pide Duchamp—, "una actitud intrínsecamente shandy" y descubriendo en la ventana de enfrente a Blaise 
Cendrars empieza a ejecutar una danza africana a la que éste responde enjabonándose de negro el rostro, gesto al cual Meyrinc responde improvisando tambores hasta que Praga se convierte "en un eco salvaje de un suburbio congolés" (66).

Así que el relato de la estadía en África conecta la mirada de Berta Bocado, a la habíamos descubierto espiando frente al Cabaret Voltaire de Zurich, con la mirada como "una cámara con el diafragma abierto, una cámara pasiva, minuciosa, pensativa" (18), con la mirada de Gustav Meyrink, acodado en esa ventana del barrio judío de Praga donde también vivía Athanasius Pernath el joyero y restaurador del Golem, y donde se ve como otra cámara con el obturador abierto. Justo entonces, en su campo de visión, entra justamente Blaise Cendrars, y con él, la cubana Rita Malú, y los cuentos de la Antología negra, donde bailan el eros y la muerte, pero también el humor inescapable.

La locación del primer desplazamiento heterotópico a Africa, el lugar donde ocurre esa yuxtaposición entre Zurich, Praga y el Congo, responde a una verdad ontológica: esa forma de hacer de un locus en una ciudad un espacio que duplica a otro distante es un reflejo exacto del mecanismo de los dobles que permiten los más sorprendentes desplazamientos y superposiciones de la identidad. Ese cambio de sombrero que hay en el Golem y que permite al narrador ser el otro es tan característico de HALP como la propia duda sobre la índole de la realidad, o mejor aún, el asumir que ésta es ante todo textual. De ahí, el epígrafe de Monsieur Teste, de Valery (1881-1957) que elige para la novela: "El infinito, querido, es bien poca cosa; es una cuestión de escritura. El universo sólo existe en el papel”.

Al describir el método de Cendrars, Vila-Matas repite lo que él mismo ha confesado de su proceso de escritura; una confesión que contiene a su vez un eco del azar 
duchampiano pues consiste en "no" escuchar las historias que le cuentan y en cambio, "cazar al vuelo dos o tres palabras de esas historias para construir con ellas, mentalmente, al azar de las ficciones abiertas, relatos muy diferentes a los que, en aquel momento le contaban" (68). Lo mejor de esa acusación de "fraude en toda regla" es que lo continúa como ya es habitual, apropiándose, modificando, añadiendo al texto original la geografía de un relato superpuesto y otros relatos enunciados que nunca se cuentan —como La piel esponjosa de un zombie-, pero de tal modo acodados a su propia ficción que refuerzan ese peculiar tipo de verosimilitud que añade territorios filtrados por el humor.

No es en absoluto extraño que el primer párrafo de HALP en el que se narra el preludio de la conspiración shandy unifique la crisis nerviosa del escritor Andrei Biely (mencionado en la última línea agregada por Vila-Matas a la inscripción de Duchamp donde lo define como "el más viejo de Port Actif"), quien en la novela Petersburgo emplea un método textual en el que los efectos sonoros de las palabras se asocian a colores; con el músico Edgar Varese, pionero de la música electrónica, que introdujo acordes disonantes, polifonías de ritmos complejos y formas musicales en continua evolución que no tenían repeticiones a gran escala; y con Apollinaire, uno de los primeros, según McHale, en haber concebido la Europa moderna como una zona de heterotopía. Su espíritu se resume en la definición de la Antología negra según HALP:

Libro impulsivo y pueril, lúcido y ávido de destrucción, que no le ocupó más de cinco días, que es el tiempo exacto que tardaron los shandys en disfrazarse de figuras esculpidas en los mástiles de las chozas africanas y reagruparse, secreta y ardientemente, en los oscuros dominio del hielo que se rompió en Praga (75).

Cuanto dice el narrador de La antología de Credrars tiene una relación especular con HALP. Es pura meta-literatura. Así, es él mismo quien posse esa "habilidad para 
rescatar palabras de las historias que le contaban sus amigos portátiles" y que le atribuye a Cedrars (68). A esa habilidad hay que sumarle la osadía de sus apropiaciones: según el narrador, el cuento El muerto y la luna, literalmente transcrito del libro de Cedrars, es resultado de las palabras al vuelo que habría cazado cuando se encontró con la bella cubana Rita Malú. Una cita real sirve para atribuirle al libro del cual se toma un origen apócrifo, que a su vez sirve para refrendar, como si fuera real, la existencia ficticia de un personaje que busca deslizarse desde el papel a la realidad.

Del África textual el espacio se superpone luego de nuevo con el de los bares del barrio judío de Praga, shandy por los licores que abundan allí y shandy por tratarse de la tierra de los dobles y de los golems. Allá se encaminan los miembros de la conspiración encabezados por Cendrars tras interrumpir el (inexistente) relato de La piel esponjosa de un zombie, sólo para ceder, una vez más, al impulso shandy de deambular. Siguiendo un leit motiv de la literatura villamatiana, parten del bar y desembocan en un viejo cementerio. Pero más allá de éste, encuentran — no puede ser de otro modo— el "cabaret Zizkov". El nombre obedece al hecho de que ese barrio de Praga, además de albergar el más grande camposanto de la ciudad, Olšany, y el cementerio judío, contiguo a la torre Žižkov, donde se encuentra enterrado Kafka (1883-1924) (homenajeado en HALP con su recurso del método de la complicidad y el juego) concentra uno de los más altos números de tabernas en un distrito europeo.

En ese antro — dice el narrador- alguien les habla de un extranjero que se ha convertido en una máquina de baile y que danza solo en el sótano. En su búsqueda, descienden por el local, hasta alcanzar el final de la escalera donde el aire recuerda al 
corazón del África Central. Al llegar al punto en que baila el forastero, constatan que en efecto,

era Crowley que, al descender al subterráneo y ser alcanzado por el líquido que rezumaban los cristales, se había vuelto negro y movía las rótulas de por lo menos quince maneras distintas, lo que, incluso para un negro de verdad, era un número considerable (75).

Con la danza del ocultista diestro en artes mágicas, los Shandys son transportados de nuevo y Praga y África se superponen: todos se tiznan de negro y Cendrars añade a su antología, gracias a las frases oídas al azar, un nuevo cuento de la tribu babatúa que define el alma de la negritud de un modo que sin duda es especular respecto a HALP: su escritura nace de "una inteligencia que exhibe una experiencia lúdica, condensada en felices relatos" (75). Por supuesto, no es otra felicidad que la de de escuchar y contar historias hasta el fin. En su página virtual, escribe Vila-Matas:

Hasta no hace mucho creía que escribir equivalía a empezar a conocerse a sí mismo; pero a medida que va pasando el tiempo me doy cuenta de que nunca sabré quién soy por culpa de escribir. Y es que tal vez la felicidad, la verdadera felicidad, el mejor premio de todos, sea simplemente esto (Lapresa).

Cristina Oñoro Otero se refiere a cómo el narrador de HALP se concibe a sí mismo como un investigador de la sociedad de conspiradores portátiles cuyas fuentes de información son los propios textos de los personajes implicados, pero la novela constituye "una poética de la ficción de Enrique Vila-Matas en la que los principios defendidos por los portátiles son en realidad un correlato literario de los principios que rigen la escritura del autor" (175). Lo anterior es una arista de la poliédrica verdad literaria que también está conformada por las caras que le añaden la vida y obra de Duchamp, las de otros dobles como Crowley o Walter Benjamín, y las asociaciones enloquecidas de la red de textos literarios que entremezcla impúnemente. Asímismo, su 
ensayo hace un interesante aporte al relacionar el tipo de memoria de la escritura vilamantiana con la "memoria corta" según la caracterización que le dan Felix Guatari (1930-1992) y Gilles Deleuxe (1925-1995), que consideran que está regida por los principios del rizoma que sintetiza de este modo: "1. ${ }^{\circ}$ y 2 . Principio de conexión y heterogeneidad: cualquier punto del rizoma puede ser conectado con cualquier otro." (p.17); 3. " "principio de multiplicidad: [...] una multiplicidad no tiene ni sujeto ni objeto, sino únicamente determinaciones, tamaños, dimensiones que no pueden aumentar sin que ella cambie de naturaleza"(p.19); $4^{\circ}$ un "Principio de ruptura a-significante: frente a los cortes excesivamente significantes que separan las estructuras o atraviesan una"(p.22).. ${ }^{\circ}$ y 6. "Principio de cartografía y de calcomanía: un rizoma no responde a ningún modelo estructural o generativo"(p.27). Por tanto, la memoria rizomática, opuesta radicalmente a la memoria genealógica típica de la Historia, es heterogénea, conectiva y múltiple; opera mediante la ruptura a-significante y sigue el principio de cartografía" (176).

Así, Vila-Matas puede hacer coincidir a Cendrars con Vicente Huidobro (18931948) en su África imaginaria, al poner segundo como narrador de la fiesta de los shandy a la que no asistió, una narración que termina con los disparos en el techo del negro Virgilio — posible alusión a los disparos de los solteros de Duchamp—, y donde menciona que Rita Malú, personaje que ha inspirado a Cedrars, pasa 27 años en un manicomio somalí. Esa noción de que cualquier punto del rizoma puede ser conectado con otro no es tampoco arbitraria, tiene la meticulosidad con la que Duchamp hacía sus reproducciones. Así por ejemplo, 1921, el mismo año en que el creacionista Huidobro organiza una exposición de su colección de esculturas y máscaras africanas, el poeta Cendrars lanza su Antología negra, dos gestos que evidencian esa "simpatía por la 
negritud" que significó para las Vanguardias volcarse en la iconografía y la tradición oral de África.

Lo heterotópico en términos de la yuxtaposición entre la imaginación europea contemporánea y la africana le permite una insólita libertad en los juegos de asociaciones, hasta el punto de atribuir el origen de la "negra espectral" a la iconografía de la mujer desmontable que en realidad forma parte no sólo de la obra de Man Ray, sino de la última obra de Marcel Duchamp, que mantuvo en secreto hasta su muerte y a la que HALP ofrece algunos pasadizos de conexión, ocultos en su laberíntica construcción. En realidad hay una puerta de entrada al África que es subrepticia: es una puerta que sólo se espía por el agujero, bajo la guía de esos otros surrealistas que se alejaron de Breton y se agruparon en torno a la sombra de Georges Bataille (1897-1962). En esa puerta, la oscuridad de lo que se ve através de la máquina de mirar, es absoluta porque muestra que la mujer esculpida en Éttant Donnés es "desmontable" —es decir, separable, portátil, desarmable - y por eso no vemos su cabeza. Esa puerta conduce a la relación entre arte y crimen, a los ensayos que se han escrito conectando el arte surrealista de Ray o de Hans Bellmer con monstruosas escenas de descuartizamientos reales, como la aparición de la Dalia Morgan. Esa puerta equivale literalmente a la habitación prohibida de Barba Azul.

De todos modos, hay que señalar el origen de la "iconografía de la mujer espectral". En el capítulo justamente titulado "La mujer desmontable" de DalíDuchamp: una fraternidad oculta, Francisco Javier San Martín, muestra, entre las versiones de la mujer desmontable, los trabajos conjuntos que hicieron Duchamp y Dalí, para la Venus de Milo con cajones. "Dalí trazó en 1936 los cajones sobre el cuerpo de una reproducción de la Venus y fue Marcel Duchamp quien se encargó de realizar la pieza 
(disminuida de tamaño), de la que por cierto, en 1964, se realizaron varios ejemplares" (43). Atribuye además la concepción de Ettant Donnés a la influencia literaria de un texto de Dalí publicado en la revista Minotaure, donde después de distinguir entre fantasmas y espectors, pasaba a caracterizarlos: "están construidos en el fulgor de un instante, como una aparición", y se les puede aplicar el concepto de extraleve así como adjetivos como "rapidez luminosa", "erección exhibicionista", "instantaneidad rígida, histérica, de mirón", rasgos claves para su visión paranóica, y después de incluir entre los espectros a Picasso, Gala, Harpo Marx (1888-1964) y Marcel Duchamp, se refiere finalmente a la mujer desmontable:

El nuevo atractivo sexual de las mujeres vendrá de la posible utilización de sus capacidades y recursos espectrales, es decir, de su posible disociación. La mujer se volverá espectral por medio de la desarticulación de su cuerpo (...) La mujer es pectral será la mujer desmontable (el subrayado es mío) (San Martin 40).

La multiplicidad de las voces es tan propia de Vila-Matas que no sería posible considerar su literatura sin ese maremagnum no sólo polifónico, sino de referencias literarias y artísticas, y de un cruce continuo de sentidos que desconoce las fronteras entre las estructuras de géneros o entre las artes, y construye una cartografía como ésta de su África, que no responde a ningún modelo estructural, ni obedece en absoluto a la idea de un desarrollo lineal, pues no podría ser posible imaginarlo en un discípulo de Sterne y Duchamp.

\section{Laberinto de Odradeks}

Después de la mención en el prólogo de su nombre, el tremebundo Aleister Crowley hace su primera aparición en HALP en el capítulo "Laberinto de Odradeks", donde Duchamp inicia al narrador en uno de los aspectos más enigmáticos de 
shandysmo: "La existencia de unos inquilinos negros, que se hospedaron en los laberintos interiores de todos los portátiles" (55-56). Y donde, justo en la mitad de las 127 páginas del libro, el Vila-Matas narrador en primera persona plantea la pregunta decisiva, atrás mencionada, que da origen a la narración que está contando: “¿Será Duchamp mi Odradek?" (64), para desechar luego su inquietud de que lo pueda ser Crowley.

Aleister Crowley aparece como un peculiar Odradek: no es una miniatura, sino una figura espectral, que ciertamente se caracteriza, siguiendo sus rastros biográficos, como "amigo de Pessoa", "montañero, satanista, filósofo, domador de leones, pornógrafo, cilista, heroinómano, ajedrecista, espía y ocultista"207 (60), y que además, conduciéndose como un odradek activo y voluntarioso lleva al sedentario (y ficticio) escritor alemán Hermann Kromberg a escalar el pico más alto de Cachemira. Allí, éste escribe en su diario de viaje, desesperado, que no sabe qué hace en aquél pico y no tiene más explicación que el saberse "poseído por un demonio interior que, por lo que puedo ver, es viajero" (61).

En la montaña de Cachemira, Kormberg cree "haber tropezado con el sombrero que años antes Pessoa había abandonado en las nieves”, y al llegar a la cumbre ve a Aleister Crowley rigurosamente vestido de negro ondeando una bandera en la cual, sobre la más feroz de sus calaveras, ha bordado la consigna HACIA UNA PROSA DE SEDA (62), alusión que podría hacer un eco a su conocido Himno a Pan, que lo invoca así en un verso: “...ven através del mar, a mí, a mí/ Ven junto a Apolo vestido de novia (pastora y pitonisa), ven junto a Artemisa, calzado de seda (...)" (Symonds 329). Lo cierto es que las alucinaciones involucran un juego paródico con los reales ascensos de alpinista de Crowley. Específicamente aluden a su fingida desaparición que tuvo lugar en la vida real, 
con Fernando Pessoa como cómplice o testigo, en el lugar conocido como la Boca del Infierno en Portugal.

Lo cierto es que Crowley desedeñaba toda regla que no fuera las de las esotéricas órdenes que fundó, y entre las aventuras de su vida regida por el dios Pan — su himno pagano se leyó en su tumba - está la de haber conducido a Fernando Pessoa a la gruta marina en Cascais, Portugal. Con su complicidad, según algunos, o por simple desconcierto, según otros, como el filólogo Luis Antonio de Villena, la excursión que hicieron en 1930, acabó en una teatral desaparición del primero, que llevó a Pessoa a narrarla a la prensa, dándolo por muerto. Un mes más tarde, Crowley reaparecía en París ante los medios, celebrando su resurrección -y la de sus demás personalidades - con una copa de champaña. Con o sin la aquiescencia de Pessoa (muy posiblemente al menos con la de alguno de sus heterónimos), el episodio que realmente ocurrió demuestra que Crowley descollaba entre los shandys en términos del alto grado de locura y de la insolencia que los caracterizaba. Además de esa aventura, compartían el misterio de las múltiples y eventualmente simultáneas existencias vividas a través de heterónimos que conducían a diversas salidas del laberinto del yo.

En el artículo "Cien años de Fernando Pessoa" evoca las frecuentes entrevistas que tuvo con Crowley en la Lisboa de 1930 y su desaparición en las cuevas cercanas a Cascais en un lugar justamente llamado Boca do Inferno. Así que, como le ocurre al ficticio escritor alemán que acaba llevado por su Odradek Crowley, Pessoa, ocultista y astrólogo más que aficionado, se vio envuelto en la misteriosa excursión El episodio refrenda su visión de la multiplicidad del poeta: 
Pocos poetas nos han enseñado, como Fernando Pessoa, la prodigiosa verdad de un hecho elemental: cada quien somos ciento. Nuestra multiplicidad nos sorprende, a menudo, a nosotros mismos (...) En esa multitud pessoana, cuya cima son los diversos heterónimos líricos ${ }^{208}$, hay una parcela que siempre ha sorprendido, escandalizado o disgustado a los exégetas: la vinculación del poeta con la tradición ocultista (...). Un aspecto de Pessoa creyó en todo esto, frente a otra parte de sí (el elemental Alberto Caeiro) que lo negaba (A.B.C.).

Además de ser figuras espectrales como Crowley, los odradeks pueden tomar la forma de un carrete de hilo o de un alfiler clavado en una cinta. El narrador de HALP lo describe como un "infiltrado" (60), entre otras cosas porque ciertamente lo infiltra en esta historia que duplica el espíritu dadaísta y de otras vanguardias de los años 20 . Su afirmación de que obligaba a otros a iniciarse en la magia sexual es cierta como se verá en el aparte dedicado a las citas bibliográficas.

Los odradeks de HALP rinden homenaje al cuento de Franks Kafka Las preocupaciones de un padre de familia, donde aparecen y se caracterizan como seres movedizos y difíciles de atrapar, que ejercen cierta influencia perturbadora. En su ensayo Domicilio desconocido, Mariola Rosario Padró anota cómo justamente el hecho de que hagan su aparición en Praga remite a su procedencia literaria, ahora plagada de Odradeks que comparten con el del cuento de Kafka el hecho de que viven en un "domicilio desconocido". Destaca cómo Vila-Matas cita textualmente la descripción kafkiana del Odradek, pero lejos del carácter inofensivo del primero, los de HALP son los dueños de las calles de Praga, y pueden llegar a ser un tormento que impulse a quien los alberga a la huída o la desaparición.

Con los odradeks vilamáticos la criatura deja de ser un incidente aislado y se convierte en un espécimen fantástico que puebla, no solo los interiores praguenses donde se mueven los personajes sino que también, al igual que en Kafka, invaden la psiquis de esos personajes desde su aparente desarmada materialidad. El texto mismo funciona como Odradek: inexplicable, indefinible, impenetrable. La 
parodia de Vila-Matas entra en la lengua misma. En la novela ya no hay solamente un Odradek, Odradek singular y con letra mayúscula. Hay odradeks, múltiples odradeks que son el elemento parodiado dentro de la apropiación del relato (Padró).

Como sugiere Padró, el odradek que reescribe Vila-Matas sigue perteneciendo a ese domicilio desconocido entre la intertextualidad y la parodia que "disuelve al Odradek de Kafka y lo convierte en el odradek u odradeks anónimos de un parafraseo lúdico que sella su juego en manos del lector" (Padró). Esa multiplicidad de identidades que tiene como sustrato su construcción verbal es una clave de la ficción extrema que supone el desdoblamiento como acto de libertad incesante.

\section{Crowley, narrador de Historia abreviada de la literatura Portátil}

Rastrear la figura de Crowley en HALP supone ver sus fulgurantes apariciones en la narración como pistas que van dibujando ciertos rasgos de su biografía y asistir al modo en que el Vila-Matas narrador, semejante al autor que también se niega a tener una sola vida, extiende a través de sus apropiaciones y juegos lúdicos su universo hipertextual — término que le acomoda más que a nadie - y de este modo se acerca a Crowley con sus múltiples alias — como Vladimir Svareff, Master Therion, Príncipe Chioa Khan, Baphomet o Lord Boleskine- y su manía declarada de tomar prestados los espectáculos de otras personas y escribir un libro —o fragmentos de éste- en nombre de otros.

Todo un capítulo del libro, precedido de un epígrafe de Borges que habla del traidor que siempre hay en el cónclave, se atribuye a Crowley. Es una larga postal dirigida a Picabia en la que narra las intenciones de Louis Férdinad Céline (1894-1961), de revelar el verdadero nombre de la conjura y la reacción de otros shandys — entre éstos Duchamp, Tzra y Vallejo (1892-1938) — le han quemado el manuscrito traidor, pues pese 
a sus (risibles y no tan veladas) amenazas de muerte no desiste en su propósito. El supuesto empecinamiento de Céline en traicionar la conjura -un real homenaje a las huellas de su lenguaje cruento y rítmico y a su visión nihilista en la novela del siglo XX — se suma a la pesadez de dos profesores madrileños ${ }^{209}$ que insisten en sumarse al grupo y que son calificados de espías. A tal punto exaspera su presencia a los shandys que para rehuírlos salen de expedición hasta un territorio contiguo a las fronteras de la locura y acaban internándose sin pagar, a cambio de contar historias, en el Sanatorio Internacional, situado en las afueras de Praga.

Al director del sanatorio, que no desea que su verdadero nombre sea revelado, lo llaman "Marienbad", un guiño que seguramente alude a la película de Alain Resnais (1922-2014), El año pasado en Marienbad, conectada a la extrañeza y la muerte en la atmósfera del espacio perfecto para éstas: un hotel. El personaje escribe exitosos libros poco portátiles y su último negocio se llama La Sociedad Anónima Kafka. Es en esta postal, escrita por Crowley, con una letra mínima (como la que cultivaba Walter Benjamin) que él mismo terminar por escribir, en una sospechosa o imprudente revelación, el nombre real de la conjura -HYDRE INTIME — tomada de los versos reales de Rimbaud ("Hidra íntima desencajada que mina y desola"). El gesto se asemeja al que en su vida real cumplió Crowley al revelar el surgimiento de sociedades ocultas a las cuales había pertenecido bajo el juramento del secreto.

Según narra HALP, es en ese lugar contiguo a la locura, donde Benjamín comienza a trabajar en la ficticia máquina risueña para detectar libros engorrosos y pesados; Tzara empieza su apócrifa Historia Portátil de la Literatura Abreviada; George Antheil su legendario Ballet Mécanique y se hace "pintor y delirante de lo minúsculo", 
mientras William Carlos Willliams — quien tenía realmente una enorme admiración por la obra experimental del músico, y cultivaba su amistad desde que lo conoció en París en 1924- se entretiene con un “armazón de discos concéntricos, desiguales y giratorios, subdivididos en sectores de palabras latinas" (82).

La trasposición entre actividades y obras descritas que surgen a partir de las que realmente fabricaron como cómplices otros shandy, como es el caso de los discos giratorios de Man Ray y Duchamp realizados por el personaje heterónimo de este último, Rrose Sélavy, cuya tarjeta impresa decía “oculista de precisión”, es un modo de desplazamiento, de locura que refleja la que permite a HALP avanzar en la invención de la conjura.

En el sanatorio - más de una vez estuvo Crowley realmente internado en uno de estos - surgen además las creaciones iniciales y particularmente amadas por Vila-Matas de shandys como el polaco Witold Gombrowickz (1904-|969), quien escribe un libro, calificado de muy breve, incongruente y absurdo - tres características shandy — sobre un bailarín (una alusión a su cuento real El bailarín del abogado Kraykowsky). El juego intertextual funciona como eco de la imagen del mismo Crowley realizando una danza paroxística en frente de los demás conjurados, que evoca la del joven protagonista del cuento de Gombrowickz que en un momento dado, cuando el abogado que ha convertido en el objeto de su obsesión (en el acosado verdugo que no puede liberarse de su indeseada víctima) desencadena al atacarlo una suerte de danza orgiástica que incluye lo incontrolado. Pero además, la naturaleza compulsiva del relato es muy semejante al que Vila-Matas atribuye al inexistente Littbsarski. En ambos textos, un gesto trivial realizado por un desconocido - poner al final de la cola al joven que intenta colarse al principio, o 
derramar una botella de champán frente a un niño - bastan para que aquel sobre quien han recaído esos gestos, dedique la totalidad de su vida no sólo a espiar la del ejecutante de los gestos, sino a desviarla con tal saña que el destino del otro acaba sufriendo un giro total. $^{210}$

Aunque la finalidad del espionaje de otras vidas que realiza Vila-Matas no sea sino un placer estético y literario instigado por esa "caza de libros", que tal como "la caza sexual enriquece la geografía del placer" (120) sólo la obsesiva persecución, por fortuna literaria en este caso, puede permitir acumular tantos detalles sobre la vida y obra de otros como para realizar estas maniobras de funámbulo entre lo ficticio y lo real, sin perder incluso cuando se echa mano de lo absurdo- ese cierto decoro de la verosimilitud.

La ficción extrema en la página de referencias bibliográficas

Una rápida inmersión en algunos de los textos atribuidos o intervenidos y en su relación con la historia de la fulgurante y evanescente visión del mundo dadaísta que alimenta la Historia abreviada de la literatura portátil, permite una exploración puntual entre los recursos de la ficción extrema, del uso de las fuentes que son propias del género del ensayo, y que Vila-Matas toma ingeniosamente prestadas. Así, como se ha visto, puede combinar textos apócrifos con otros que siendo reales sujeta a un modo de apropiación que cuela en ellos la ficción, sin dejar de recurrir a exactas citas bibliográficas que refuerzan la verosimilitud de la conspiración que pretende narrar como si se tratara de un testigo. Es a partir de los libros que reconoce el paraje de la vida de los otros y no teme mezclarlas, confundirlas, reescribirlas, copiarlas, alterarlas, con el gesto del niño que desarma un tren, pero que, en su caso, ni siquiera intenta reacomodar las 
partes en su lugar original, sino que construye un nuevo mecanismo, hecho de felices robos que no cesan de maravillarlo.

Cuando el lector encuentra, al final de la novela, una "Bibliografía esencial", presentada con toda la seriedad del caso, supone que las fuentes como las historias extraídas de éstas, son fidedignas. ¿De otro modo, qué sentido tendría añadir una bibliografía a una obra de ficción? Pero, como precisa Túa Blesa apropiándose de la expresión que Vila-Matas usa para referirse a la Antología negra de Cedrars, el libro es "un fraude en toda regla", y verificar sus datos nos llevaría a "un continuo ir y venir del texto al archivo, una labor incesante de cotejo de datos, de figurarse como historiador" (124), no sólo imposible de cumplir, sino capaz de hacernos extraviar en el laberinto. Y, sin embargo, como he sostenido, el fraude es fiel a lo que define como "shandy", a las múltiples avenidas que toma para acercarse a la tradición literaria que constituye el universo en el papel, y que transportar a ese "espacio para pasear" que es su propio libro.

Así que sin pretender agotar la aproximación a ese listado de referencias bibliográficas, y como ejercicio para asomarse al espacio de su escritura cotejando las afinidades del juego de la invención que le permite al narrador "perderse en el caos del que nacerá, por fin, la literatura portátil” (120), mencionaré en un listado algunos de los libros citados y me detendré en cuatro de éstos para ver desde sus relatos las estrategias de la ficción extrema.

Entre la veintena de libros que Vila-Matas cita como biografía esencial, y que contienen algún elemento apócrifo se encuentran: 
- Historia portátil de la literatura abreviada, incluida en los Siete manifiestos Dadá de Tristan Tzara, que constituye una inserción apócrifa en un texto real acerca de la cual me referí en páginas anteriores.

Eulogy of Descomposure (Elogio del desconcierto), del inexistente autor Ant $(\mathrm{H})$ ony $\operatorname{Typ}(\mathrm{H})$ on, cuyo nombre en clave duchampiana de broma verbal se presta para insólitas interpretaciones. El prólogo se atribuye al gran maestro de los juegos intertextuales apócrifos, Borges, y a su esposa María Kodama, con quien emprendió aventuras como traducir ancestrales tradiciones orales islandesas. En HALP, Anthony Typhon quiso condecorar a George Antheil, desatino por el cual fue inmediatamente expulsado del grupo y huyó a Martinica, donde montó una papelería en un poblado en el que nadie escribía. Su nombre tiene asociaciones fonéticas con la orden hermética Typhonian O.T.O, fundada por un seguidor de Aleister Crowley. O quizás sea un cita al músico Richard Anthony (n. 1938) y su canción Sirop Typhon, donde hay una exaltación de las virtudes del licor, aunque no hay que descartar que estas relaciones coherentes con el universo shandy sean uno de esos felices y gratuitos encuentros que celebra VilaMatas. De todos modos, es el lector-espectador a quien corresponde completar los ejercicios lúdicos. La letra de la mencionada canción dice así:

Le sirop Typhon, Typhon, Typhon,/L'universelle panacée, eh ! eh !/A la cuillère/ $\mathrm{Ou}$ bien dans un verre,/Rien ne pourra nous résister/.../Le vieux Pierre était célibataire/[nótese que cumple el importante precepto Shandy de la soltería] Et il voulait le rester longtemps/Il but un verre, puis un autre verre. Il a 10 femmes et 30 enfants.

- El libro inexistente del real escritor de culto Louis-Ferdinand Céline (18941961), cuya función es legitimar la Conspiración Shandy puesto que se llama "La vrai 
nom du complot portatif (El verdadero nombre del complot portátil), y cuya inexistencia justifica como efecto de que se trata de un manuscrito desaparecido en Praga.”

- El sabotaje de lo instituido (Diario europeo), de Vicente Huidobro, cuya existencia se refrenda en un curioso portal que agrupa libros como El Quijote de Pierre Mendard. Entre las afinidades shandys que se advierten en Huidobro y que justifican la atribución de este libro apócrifo, está esa vocación de sabotaje que se enfila ante el lenguaje; el poeta que proclama su odio por la rutina, el cliché y lo retórico, las momias y los subterráneos de museo, los fósiles literarios y todos los ruidos de cadenas que atan, y declara: "Admiro a los que perciben las relaciones más lejanas/de las cosas. A los que saben escribir versos que se/ resbalan como la sombra de un pájaro en el agua y que sólo advierten los de muy buena vista" ${ }^{211}$.

Ese percibir las relaciones más lejanas de las cosas, bien podría hacerlo otro Odradek del narrador. Pero también está la fragmentación del yo poético del inventor del creacionismo, que, según Dolores M. Kosh, culmina en Altazor, donde su estilo se acerca más al dadaismo y al surrealismo de Tzara y Éluard. O a que en el juego de la lengua con el absurdo “su arbitrariedad es por tanto, prevista y no mecánica” (335).

- Veuves et militaires (Viudas y militares) de Francis Picabia, que según afirma, sigue inédito hasta la fecha.

- Tagebücher del (inexistente) escritor alemán Hermann Kromberg, obviamente editado por Aleister Crowley, un diario apócrifo inventado para reforzar la verosimilitud de una aventura que nunca sucedió del modo en que es narrada, pero que refrenda el influjo que esta figura espectral llegó a tener en un momento sobre Pessoa quien perfectamente podría a su vez haber creado a Kromberg como otro más de sus 
heterónimos, o a Vila-Matas imaginando la invención de Kromberg. El libro apócrifo es un paratexto que contiene en sí una naturaleza meta-textual sobre la propia escritura de HALP. No es un libro precedente el que lo inspira sino una aventura shandy en toda regla, y real, en la que además participa el plural Pessoa que decía ser como una habitación con innumerables espejos fantásticos que dislocan reflejos falsos.

—Pictures (Cuadros), de Georgia O'Keefe, un apócrifo libro de memorias que habría editado por la prestigiosa Universidad de Princenton, ya mencionado en páginas anteriores. Mientras las demás mujeres fatales aparecen y desaparecen como relámpagos, O’Keefe echa a andar con sus palabras la Conspiración Shandy. Y luego anuncia su final no con palabras sino escenificando en el submarino una y otra vez "la muerte, el lenguaje de la muerte, el lenguaje y la muerte del lenguaje (...), esto es, la muerte de Rigaut".

- Pessimism, libro inexistente del verdadero poeta Skip Cannel, publicado por una editorial neoyorquina que se llama nada menos que Indolence.

- Cartas desde Mogadiscio, de la ficticia cubana Rita Malú, que en realidad el autor transpone no de un laberinto de textos sino del de la propia vida, al espacio de su novela.

Me detendré un poco más en los otros cinco textos de los cuales se apropia bien sea a través de intervenciones o de atribuciones ficticias, revisando los dominios de la intertextualidad con respecto a algunos de los principios o aficiones de los shandy: Biographical Memoirs of Extraordinary Shandys (Memorias biográficas de shandys extraordinarios), de Walter de la Mare (1873-1956); Viajes con Rita Malú, de Man Ray (Inexistente); Los disparos del soltero, de Wener Littbarski y Valery Larbaud; 
Shakespeare and Company (Shakespeare y compañía) de Sylvia Beach (intervenido) y Os Bucarestis, de Aleister Crowley.

Walter de la Mare (1873-1956), Memorias biográficas de Shandys extraordinarios es un libro apócrifo que refleja en cierto modo en su título ficticio el intento de HALP y que remite a otro texto real donde se habla de la miniaturización. Este libro que Vila-Matas inventa podría ser parte del Catalogo ragionato di libri introvabili de Albani Paolo, que tanto le gusta a este autor porque contiene un listado de más de mil libros físicamente imposibles de hallar, pero nombrados en el universo literario, como una saga expandida de las apócrifas citas borgianas. Pero de la Mara escribió en cambio una novela surrealista, Memorias de una enana (1922, reeditada por The Press of the Readers Club, 1941), que ofrece parajes de conexión con la Historia Abreviada de la Literatura Portátil. Menciona, en efecto, el apellido shandy en una descripción relacionada con la fascinación de ver el universo a través de lo pequeño (la perspectiva única sobre las cosas desde la mirada de una mujer enana).

Miss $\mathrm{M}$ o Miss Thomasina, descrita como una agraciada victoriana de proporciones perfectas pero de tamaño reducido, supuestamente confía a su amigo Walter Dadus Pollacke la publicación de las memorias, con la precisión de que no deberá hacerlo en ningún caso, hasta que éstas no le incumban ya a ninguno de los implicados. Como este mismo encargado narra en primera persona, lo considera un intermediario que dilatará lo suficiente la aparición de los papeles confiados. Ya desde la explicación de las circunstancias en las cuales recibió sus manuscritos, se advierte al lector contra la imposible pretensión de que la letra abarque por completo la verdad y se remarca, que a fin de cuentas ésta puede ser asunto de perspectiva. 
Again and again as I have pored over the scenes of my memory, I have asked myself: What can life be about? What does it mean? What was my true course? Where my compass? (...) For after all, life's beads are all on one string, however loosely threaded they may seem to be. (...)I have tried to tell nothing but the truth about myself. But I realize that it cannot be the whole truth. For while so engaged (just as when one peers into a looking glass in the moonlight) a something, has at times looked out of some secret den or niche in me, and then has vanished (15).

La diminuta Miss $M$ evoca un momento de su infancia vivido a través de los lentes de un diminuto telescopio que le había enviado su abuelo. Interesa aquí la alusión a la miniaturización no sólo de los objetos sino de la escritura, tema al que Vila-Matas dedica varios apartes filosóficos y empréstito de Duchamp que hace posible La caja en la maleta, donde miniaturiza con extremo cuidado, sus obras principales. El regalo del teslescopio, cuyo efecto fue lograr que sus sueños diarios se multiplicaran, alimenta en Miss M su temprana pasión por mirar el mundo a través de la ventana. En una escena, ella está sentada sobre un recipiente que tiene en el tope una foto coloreada de Mr. Shandy, rodeada por los cepillos y otros accesorios en la mesa de vestir de su padre que se está afeitando, mientras ella lo mira fascinada por su reflejo en el vidrio de aumento y él le hace muecas graciosas por encima de sus gafas. ${ }^{212}$ Hay una apropiación del episodio en la escena en la que Meyric ve desde su ventana a Cendrars que se está afeitando y comienza un juego de muecas, gestos que refieren a la escritura sobre una perspectiva de visión y el campo de cómplicidad e intersección entre dos personajes.

De la Mare (o más exactamente su homónimo Walter Dadus Pollacke, pues así se llama el narrador) precisa que sin que mediara una razón de obvia correspondencia, la escritura de la enana era también diminuta:

Miss M's handwriting was even more minute than one might naturally though, not perhaps justifiably, have anticipated. Her manuscript would, therefore, have 
been difficult enough for aging eyes to decipher, even if it had not been almost inextricably interlined revised and corrected (13).

Vila Matas despliega en varias páginas atención a este rasgo de algunos de los portátiles. Está, por una parte, la obsesión real que tenía Walter Benjamin por escribir páginas de cien renglones. Y también, el caso de Robert Walser (1878-1956), otro de los shandy a quienes rinde homenaje incorporándolos a la conjura. En los manicomios a donde internaron a Walser —el hospicio de Waldau, donde ingresó en 1929 a los 51 años, o el psiquiátrico de Herisau, Appenzell, a donde lo trasladan cuatro años despuésel autor escribía papeles con letras que no tenían más de un milímetro de dimensión.

Por supuesto, la escritura miniaturizada tiene una relación especular con las obras reducidas a la dimensión de lo pequeño, que eran lo único que llevaban en sus ligeros equipajes: “...obras miniaturizadas que reflejaban todas, su absoluto desdén hacia lo que se considera importante, grave, fundamental". Y agrega, de forma no menos especular sobre HALP:

Y que nadie vea en mis palabras una maniobra de distracción para ocultar mi fracaso en las investigaciones. Pienso que, simplemente, el asunto de los maletines no es un enigma ni una cuestión importante y que, de hecho, ni siquiera la historia de la conjura portátil lo es (49-50).

La escritura en miniatura, conectada a la pasión por miniaturizar, a su vez se relaciona con el acto de ocultar, y con la cualidad de lo portátil y la conexa vida errante, al rasgo del "hommo viator" que se observa en las ficciones extremas de nuestro tiempo. A esto se refiere HALP en un párrafo que sintetiza todas estas características:

Walter Benjamin era también alma gemela de Duchamp. Ambos fueron a la vez vagabundos, siempre de camino, y exiliados del mundo del arte al tiempo que coleccionistas cargados de cosas, es decir, de pasiones. Ambos sabían que miniaturizar es hacer portátil, y que ésta es la forma ideal de poseer cosas para un vagabundo o un exiliado (11). 
Varios de los autores de los libros citados tendrán colecciones de miniatura y de hecho, la ficticia máquina risueña de pesar libros, el invento derivado de la Caja en la maleta duchampiana, atribuida a Walter Benjamin, es la que supuestamente resguarda a la sociedad de los portátiles de cualquier farsante. De la Mare vuelve a aparecer, como hipertexto, cuando Vila-Matas explica que la confesión de Aleister Crowley puede contener un sutil homenaje a Bérgamo, ${ }^{213}$ un supuesto relato que habría escrito Walter de la Mare en su villa de Capri: la historia de un shandy imaginario que, al igual que todos los demás portátiles, pasa por la vida con una extraordinaria aversión a la huella personal, a tener un estilo artístico muy definido y fácilmente reconocible. Todo lo contrario de “artistas nada portátiles como Claudel, Giacometti, Chagall o Thomas Mann.” (94). La clasificación, de algún modo desdeñosa, recuerda el gesto con el que Dalí separa los fantasmas como Freud o De Chirico, de los espectros como Gala y Duchamp.

2. Shakespeare y Compañia, de Sylvia Beach. Libro intervenido de modo que funcuina en HALP como hipertexto. En la introducción a la edición publicada por Nebraska Press en 1991 (una edición posterior a la que cita Vila-Matas), James Laughlin (1914-1997) a la norteamericana Sylvia Beach (1887-1962), que llegó a ser la mejor librera del mundo desde ese París que albergó dos décadas cruciales de la Generación Perdida. Además de la inescapable alusión al Ulises de Joyce (1882-1942), la elección de este libro para la biblioteca del narrador de HALP obdecede a una transposición relacionada con la historia de la librería que abrió en 1919 como un espacio de difusión de la literatura inglesa en la Ciudad Luz y acabó convertida en uno de los epicentros culturales de ese París de la época de entreguerras que era una fiesta: en 1936, cuando se 
tambaleaba económicamente, André Gide (1869-1951) se apresuró a evitar su cierre creando el Club de los amigos de Shakespeare and Company que pagaban una cuota anual por atender a las presentaciones de los más importantes autores de la época: entre otros, DH Lawrence, Ernst Hemingway (1899-1961), Ezra Pound (1885-1972), TS Eliot (1888-1965), además del propio Joyce (que habría renunciado a pertenecer a la Conspiración Shandy por un equívoco supuesto de que debería pagar una cuota), y Valéry Larbaud, Man Ray, Aleister Crowley y el músico George Antheil. En suma, el existente Club de los amigos de Shakespeare es sujeto de una transposición textual en HALP para prolongar su espíritu y esparcirlo.

Antheil, el creador de esa "música shandy por excelencia" (39) que es el ballet mecánico, cumple un importante papel en HALP pues trae al campo de acción de los shandys noticias acerca de la supuesta ciencia de la "nicotecnia": un texto sobre las virtudes del tabaco que conecta con otro "del malogrado Anthony Typhon en el que elogiaba al Desconcierto como fuente inagotable de nuevas y estimulantes sensaciones" (38-39). Pero además, la verídica concurrencia de Antheil en la librería Shakespeare and Company de la rue de L'Odeon, lugar donde todos los viernes los shandys se citaban allí para las primeras reuniones secretas HALP, le permite desarrollar un juego verbal que hace eco al significado etílico de shandy relacionado con el licor. Antheil se paseaba por las terrazas de Montparnasse y de Saint-German repartiendo un alfabeto manual de los sordos con doce frases. Leídas verticalmente, cada una formaba la dirección Sept Rue Odeon, es decir la segunda locación real de la librería de Beach. La primera de las frases, escrita en español decía "Si Hablas Alto Nunca Digas Yo”. ¡Es decir, Shandy!” (40). Según HALP, en el número 7 de la rue de L'Odeon el mismo poeta Blaise Cendrars 
preguntaba a los buscadores: “Usted es sordo?”, y, ante la respuesta afirmativa los conducía a la dirección adecuada. Curiosamente, el padre de otro shandy, Max Ernst (1891-1976), enseñaba a hablar a los sordos.

Es también de las memorias de la librera que el narrador de HALP ha encontrado un principio shandy no enunciado pero asociado a lo portátil, como hemos visto: el signo distintivo del amor a las miniaturas, presente en Valery Larbaud, quien en un episodio que podría parecer fantástico, pero es real, le dio a la librera Sylvia Beach, como ella narra en sus memorias, un ejército de soldaditos de juguete liderados por George Washington, montados en caballos de diferentes colores y una compañía de cadetes de West Point, para custodiar la librería. Episodio que HALP fragmenta, se apropia sin alterarlo (55) y reproduce en distintos apartes. Larbaud no sólo supervisó su factura, asegurándose que correspondieran en cada detalle con los uniformes originales, sino pintó cada botón y le explicó a Sylvia que no podía confiar a nadie esta tarea. Ella se encargó de guardar esas fuerzas armadas en un pequeño gabinete de vidrio a la entrada de la librería. Valery poseía una creciente colección de soldados de miniatura y se quejaba de que estaban a punto de desalojarlo de sus habitaciones, pero como ella evoca, era capaz de ir a cualquier lugar del mundo para encontrar un ejemplar raro.

Entre las anécdotas no apócrifas de Vila-Matas está la descripción de la colección de soldados de Larbaud que invadían la casa, y formaban parte de otra pasión de Larbaud: los colores. Pues los contingentes eran azules, amarillos y blancos, incluso en sus gemelos y lazos (42). Larbaud, un soltero en toda regla, solía refugiarse largos períodos de tiempo en su retiro y advertía a sus amigos que nadie sería admitido en éste. Ese amor por colecciones de libros, pasiones y miniaturas lo tiene también el shandy que 
narra la conjura, cuya "biblioteca está llena de libros breves que evocan recuerdos de ciudades en las que aprendió a conocerse: Port Actif, París, Palermo, Nueva York, Viena, Ajaccio, Praga, Triste, Sevilla" (120); y que además coinciden con las narradas por VilaMatas.

Quince años después del que cierre definitivo de la librería que ocurrió en circunstancias relacionadas con la ocupación de París y que ni siquiera alteró el gesto con el que Hemingway procedió en 1944 a liberarla simbólicamente, Beach publicó las famosas memorias del mismo nombre con recuerdos vitales de varios de los personajes que aparecen en HALP, libro reflejo que las ha convertido en un hipotexto para su escritura.

3. Los disparos del soltero de Werner Littbarski y Valery Larbaud. La atribución del libro Los disparos del soltero, a la autoría compartida por Werner Littbarski y el escritor francés Valery Larbaud (1881-1957) es apócrifa, pero corresponde a la inicial identificación que Larbaud tenía entre la generación perdida como un irredento soltero y, por supuesto, a "los disparos de los solteros" que Marcel Duchamp identificó exactamente con este nombre en el Gran Vidrio o La novia desnudada por sus solteros, aún. Estos disparos consisten en una zona de puntos que se encuentran en el extremo superior derecho del vidrio doble y dividido horizontalmente en dos partes iguales por un filo de plomo. La ironía es que los disparos de los solteros — con su alusión seminal— no alcanzan el reino superior de la novia, cuyo placer — sus descargas— son autogeneradas.

Vila-Matas precisa que Larbaud "destacó, desde el primer momento", entre los shandys, no sólo como animador en Shakespeare and Company de las jornadas mundiales de sordos (su alfabeto manual servía para camuflar las instrucciones que llevaban a la 
dirección Sept Rue Odeon, justamente la de la librería de Sylvia Beach), sino como “el artista portátil por excelencia" (41). Esto es, el que reunía todas las características Shandy:

Era extrema su sexualidad y rechazaba radicalmente toda idea de suicidio. Pero es que, además era notable su tensa convivencia con el noble, así como su simpatía por la negritud, su perfecto funcionamiento de máquina soltera, su ausencia de grandes propósitos, su cultivo del arte de la insolencia y su afición a viajar con un maletín que contenía su ingrávida obra (41).

Si el detalle del maletín es un añadido, que sin duda alude a la larga historia de la Caja en la maleta de Duchamp, lo cierto es que Larbaud era un viajero impenitente, sobre todo cuando se trataba de completar su colección de soldados. Se comprende por qué Larbaud entra al contingente de los conspiradores. En HALP, atendiendo a sus reales pasiones literarias conectadas con su talento de políglota y su impresionante labor como traductor, se le atribuye haber captado a otros conspiradores como Savinio (1891-1952), Gómez de la Serna, y un jovencísimo Borges (43), además del inexistente Littbarski.

También Larbaud -el apócrifo coautor de este título- tenía pasión por el juego de los dobles, de modo que a los 27 años atribuyó su Poèmes d'un riche amateur (1908), al heterónimo Archibald Olson Barnabooth, poeta cosmopolita nacido en Arequipa (Perú), que luego publicaría A.O. Barnabooth (1913). Como Larbaud, que se educó en el colegio Sainte-Barbe-des-Champs, en Fontenay-aux-Roses, donde tuvo condiscípulos latinos, dominaba el español. Barnabooth, el seductor, millonario como él mismo lo fuera antes de que acabara con la fortuna heredada de su padre, escribe un diario íntimo y la narración de los viajes que Larbaud emprendió en una obra que preconiza los desbordamientos entre géneros y la confusión entre la propia vida y la ficción. ${ }^{214}$ 
Soltero largo tiempo empedernido, Larbaud escribió sobre los amores de la adolescencia y publicó un libro sobre los felices amantes, "Amants, heureux amants" (1923) que guarda correspondencia con las teorías defendidas en HALP respecto a los amores de las "máquinas solteras" que no buscan como fin la procreación. Y sin duda es una de las figuras literarias esenciales en el viaje no sólo como género sino como leit motiv omnipresente en la narración de la conjura portátil. En los últimos 17 años de su vida, este políglota y viajero exuberante que e sufrió de afasia.

En cuanto al nombre del supuesto coautor del libro inexistente, Werner Littbarski, el mismo Vila-Matas explica de dónde tomó el nombre del personaje: de Oscar Werner (1922-1984) (uno de los actores de Jules et Jim de Truffaut) y Littbarski, en homenaje a un futbolista austríaco. En cuanto a la celebración que en HALP realiza descorchando una botella de champaña al descubrir una errata en La Antorcha, que publicaba ciertamente Karl Kraus (1874-1936), hay que anotar que este escritor, periodista, ensayista, aforista, dramaturgo y poeta austríaco real vivió para luchar sin tregua por la pureza de la lengua y que, como relata Vila-Matas, él mismo dirigió, corrigió, escribió y publicó solo hasta la muerte el mencionado periódico, usándolo como tribuna para sus diatribas contra toda suerte de corrupción lingüística o política. La invención de Littbarski sirve para iniciar una atmósfera etílica indispensable para la fiesta shandy. Descorcha una botella de champaña para celebrar que, tras varios días y noches sin dormir, ha encontrado un error en la publicación de Karl Kraus y celebra el hallazgo junto a Virgilio, su criado brasileño; un gesto que permite constatar su "simpatía por la negritud", un curioso rasgo shandy. Pero la especialidad principal de Littbarski es simular que da fiestas multitudinarias, un simulacro perfecto para ocultar la celebración real de la 
fiesta shandy, según advirtió Larbaud. En la revista que decide editar y que Virgilio encabeza con la declaración "hoy he dejado de tener cualquier tipo de opinión sobre lo que sea" (45) se anuncian, por supuesto, licores fuertes. Littbarski aceptará la invitación a formar parte de "una sociedad secreta que conspiraba para nada y desde la nada" (47). En el capítulo "La fiesta en Viena", el Vila-Matas narrador, dice que lo poco que supo de los preparativos lo debe al libro (existente) Inédit secrets, editado por Miriam Cendrars (1887-1961). A continuación narra que fue en el primer encuentro entre Littbarski y Larbaud que el primero decidió mostrarle "una rara novela que estaba escribiendo" y que se titulaba Los disparos del soltero (47). Este texto en el que venía trabajando desde que tenía uso de razón sólo tenía una cuartilla empapada en vino. Los disparos, según le explicó, son "afortunadas intromisiones en el mundo de su enemigo" (48). Alguien que se ha convertido en éste por el simple hecho de verter en frente suyo, cuando era niño, una botella entera de champán francés. Los disparos se extienden al odio que habría tenido por Kraus debido a que alguien cometió contra él un gesto terrible: derramar champán sobre su uso de razón. La inconsistencia entre la atribución del texto en las referencias bibliográficas a la coautoría de Larbaud y Littbsarski, y la clara explicación de que sólo el segundo lo escribió es una demostración más del desprecio por la seriedad o un desliz consciente para quienes se suben a HALP como a un tren en marcha lleno de falsas estaciones, felices de asumir los juegos de la simulación. En esta parte todas las formas de la transtextualidad gennetiana están presentes y sujetas a la misma movilidad de todas las identidades (reales, literarias o artísticas) en HALPU. Uno de los ritos de la fiesta era intercambiar los maletines de los Shandys que, a diferencia de lo que Miriam Cendrars supuestamente habría imaginado -que debían contener "algo muy importante" 
(49)- no contenían sino tan solo obras miniaturizadas que desdeñan lo que se precia de serlo. La digresión que el narrador cuenta en primera persona, como investigador de la literatura portátil, le sirve para aminorar la misma trascendencia de lo que está contando.

La descripción de la fiesta se deja -apócrifamente- en boca de Vicente Huidobro que la concluye diciendo que él no estaba, para añadir que quien realmente no estaba era Picabia, pero es el que más había escrito sobre la fiesta acaecida el 27 de marzo de 1925. A él se le atribuye el dato de que los convidados o conspiradores eran 27 y que este número -la cifra Shandy — marcó la vida de todos, incluyendo los años exactos que Rita Malú pasó interna en un manicomio somalí. Picabia concluye relatando su diálogo con Scott Fitzgerald (1896-1940) y cómo fue que, cuando el negro Virgilio dio fin a la fiesta, con unos disparos en el techo que pusieron en fuga a todos los convidados, él se quedó simulando que jugaba una partida de ajedrez — la afición que los dadaístas cultivaban con devoción - mientras pronunciaba, en tono exaltado la frase, “a mí me habían invitado de verdad". Vila-Matas no tiene reparo en decir, respecto a la célebre expresión del Gran Gatsby que muestra el vacío de la fiesta modernista, que "no dudó en trasladarla literariamente a la novela que, por aquellos días, estaba escribiendo" (53).

4. Travels with Rita Malú, de Man Ray. Se trata del título inexistente de un libro escrito por el famoso dadaísta, transgresor por excelencia e íntimo amigo de Duchamp, acerca de Rita Malú, una bella amiga de Enrique Vila-Matas que convierte en personaje Shandy, nada menos que en una de las femme fatales de HALP. Como para él la invención de un título es tan definitiva, lo retoma posteriormente, en un interminable juego de citas inexistentes que se refrendan entre sí o que reafirman la frase de Paul Valery que sirve de epílogo al libro -"el universo, querido, es bien poca cosa; es una 
cuestión de escritura. El universo sólo existe sobre el papel”. En efecto, uno de los relatos de Exploradores del abismo se llama como ese mismo título apócrifo, pero ahora habla en singular del viaje de Rita Malú. El libro inexistente pasa así a ser un hipertexto del título real de un relato escrito por Vila-Matas.

Aunque en la página web dedicada a HALP como una "versión disidente", VilaMatas explica que en la vida real, durante las tardes de un verano en Cadaqués de 1970 solía columpiar a Dora, la hija de una pareja de amigos, la cubana Rita Malú y del poeta Douglas Trage, puesto que Rita se hallaba de viaje en París dedicada a la tarea de lograr la traducción — finalmente frustrada — de su libro Cartas desde Mogadiscio; en HALP la convierte en acompañante del fotógrafo Man Ray quien supuestamente relatará "todo, de un modo despiadado, en un divertido libro" (29). No, por supuesto en los inexistentes Viajes con Rita Malú, aunque sí en sus memorias. La mención de Rita Malú, cuyo protagonismo parece insinuar el título, es sólo esto.

El contenido del supuesto libro de viajes de Ray, metaliterariamente, en ese juego especular de ficciones que transitan de los paratextos a los hipertextos, que juegan en el campo expandido de una arquitextualidad entre las artes, descrito en el capítulo "Suicidios de hotel", está centrado en Rigaut y sirve ante todo para trasladar la narración de Europa a la América que acogió a los dadaístas que huían de la guerra. También Ray había nacido en Filadelfia y, si como HALP narra, jugó un papel esencial no sólo en la Conspiración Shandy, paralelo al que tuvo en la gestación del avant garde en Nueva York después del legendario Armory Show de 1913, y entre los movimientos dadaista y surrealista en el país de los 20, no sólo no escribe libros de literatura o viajes, aunque sí su autobiografía, sino que es lo suficiente mordaz para jugar con frases lapidarias que 
aparentemente derruyen el carácter de su arte como en la portada del libro de fotos que hizo con André Breton, "La photographie n'est pas de l'art", en 1937, el mismo año en que publica con Paul Éluard, Les mains libres: dessins. Tristan Tzara fue quien realmente le publicó el primer álbum de fotografía.

Numerosas fotografías de Ray tienen como sustrato las obras de Duchamp -por ejemplo Elevage de poussière, construida como foto aérea de las ruinas de su instalación en polvo, o la foto de la Monalisa con bigotes. A Duchamp lo retrata numerosas veces, entre 1916 y 1965, incluyendo aquellas famosas imágenes suyas como su heterónimo femenino que quizas son el primer registro fotográfico de este travestimiento que VilaMatas extiende y continúa en el propio HALP: Rrose Sélavy. Si esa mujer en la que Duchamp se ha desdoblado lleva sombrero de cinta pintada con abstracciones y cuello de piel, o puede ataviarse con un seductor sombrero negro surrealista: Rrose Selavy, el narrador inventa como escudo de los conspiradores AQUí EL BASTON. Ambos comparten la pasión del ajedrez y hacen obras inspiradas en este juego. También fotografía a Duchamp jugando con Raoul de Roussy y a la plana mayor de los miembros, muy reales, de la apócrifa conspiración: Rigaut, William Carlos Williams, Picabia, Cocteau, Stein, Picasso, Breton, Andre Derain, Ezra Pound, Erik Satie, Kurt Schwitters, Raymond Queneau, Dalí, Edgar Varese, Hans Arp, Max Ernst, Juan Gris, Roland Penrose, entre otras figuras presentes en la novela. Pero además, aunque la novela no se detiene en las obras de Ray y sólo lo identifica una vez como fotógrafo, sin calificativos, la noción de la extrema sexualidad está encarnada en numerosas obras suyas, a veces hechas en "rayogramas", y donde desfilan mujeres fatales semidesnudas como Nusch 
Eluard, Kiki de Montparnasse (1901-1953) o Lee Miller, Marquise Casati (1881-1957), aunque también un drag como Barbette (1898-1973).

5. Aleister Crowley, Os bucarestis (Los bucarestis). Porto editorial, Oporto, 1948. Existen muchas razones por las cuales en HALP este delirante megalómano inglés (18751947) que se inventó a sí mismo ataviándose con la investidura de milenarias traiciones herméticas combinadas a su antojo, fundador de una secta religiosa de origen rabelesiano santificadora del reino de la propia gana, tiene un papel protagónico en la Conspiración Shandy que alcanza su momento cumbre cuando él la disuelve.

Aunque el libro que se le atribuye es imaginario, el asunto de las entidades espirituales asociadas a los dobles y su extraña forma de autoridad sobre la mente humana, tiene que ver con la historia que Crowley narra en sus Confesiones respecto al origen -y al método de escritura, aspecto esencial en la conspiración Shandy- de uno de sus libros más conocidos, The book of Law, la espuria Biblia de los adeptos del culto Thelema, al que dedicó su vida.

Crowley, por supuesto avezado jugador de ajedrez, quien adoraba verse identificado con el número de la Bestia apocalíptica, sostiene que el libro, cuyo título originario era Liber AL vel Legis, le fue dictado en Egipto, tras visitar la estela de la revelación identificada con esa cifra, por una entidad no humana, asociada al antiguo culto egipcio al dios Horus, y que lo escribió en una hora. En sus Confesiones puede leerse la descripción de una relación con la escritura que sobrepasa lo racional y que, sin duda, HALP reasume como un asunto de juego regido por demonios en su antigua excepción pagana: el genio o daimon que inspira o transmite mensajes y que desacraliza la lógica. 
I wrote a number of books in a way which I hardly know how to describe. They were not taken from dictation like 'The Book of the Law' nor were they my own composition. I cannot even call them automatic writing. I can only say that I was not wholly conscious at the time of what I was writing, and I felt that I had no right to 'change' so much as the style of a letter. They were written with the utmost rapidity without pausing for thought for a single moment, and I have not presumed to revise them. Perhaps 'Plenary inspiration' is the only adequate phrase, and this has become so discredited that people are loath to admit the possibility of such a thing (558).

Vila-Matas usurpa la figura de Crowley y lo convierte en narrador robándose esa inspiración plenaria para acrecentar la intensidad polifónica de HALP, sabiendo que poseían además varios rasgos shandy, según Sylvia Beach lo rememora en sus memorias. Hay un pasaje en el que recuenta el poco interés que despertó en ella la publicación de sus Confesiones. La petición de ser su editora se la había planteado agresivamente una de esas mujeres adeptas que solían acompañar a Crowley durante los interregnos en los cuales no iba estaba sumido en un delirium tremens, e internado en un manicomio.

Sylvia Beach reafirma que sin duda Crowley era tan peculiar como se rumoraba en las historias que se escuchaban sobre él y en su propio Diary of a drugfiend. La narración del episodio en que una mujer rubia, agresivamente partidaria de sus escritos, le ofrece la publicación de sus memorias y le extiende un contrato en el que todo estaba detallado por anticipado, tiene un tono de desdén. "A self-mummified-looking man, he was rather repulsive" (94). Es posible que sus declaraciones contra judíos y mujeres incidieran en su percepción de él, aunque también guardaba cierta prevención debido a que algunos de sus amigos comentaban que era un espía del servicio de inteligencia británico — una versión reforzada por posteriores biógrafos-, asunto que ya de por sí dejando de lado sus tratos con lo oculto- le parecía bastante tenebroso, aunque se limitara a comentar que ese caso deberían haber escogido a alguien menos conspicuo. 
Sus relaciones con las mujeres fatales fueron en la numerosos casos bastante fatales para ellas. El cultivo de la sexualidad extrema se conectaba a sus adaptaciones de la antigua magia sexual en las que daba un lugar iniciático a los ritos homosexuales, particularmente después de su relación con el poeta Víctor Neuburg (1883-1940). El hecho de que Vila-Matas lo escoja como el Shandy que revela públicamente la naturaleza de la conspiración deshaciendo de esta forma su índole secreta obedece a la coherencia con detalles de su biografía. No sólo por su aura de espía, o por su afición a fundar sociedades ocultistas o a desempeñar un papel líder en sociedades secretas -como la ocultista Astrum Argentum, que fundó, la Ordo Templi Orientis (O.T.O.) que presidió o como la comuna pseudo-religiosa Cefalu, que asentó en Sicilia antes de que Mussolini lo expulsara de Italia-, sino por su tendencia a desmantelar la privacidad de sus secretos, como cuando reveló informaciones vedadas de la Hermetic Order of the Golden Dawn a donde había sido admitido. Fundó en 2008 una publicación titulada The Equinox con el plan de revelar la historia verdadera de la fundación de esa sociedad secreta.

Vila-Matas convierte en un ingenioso recurso sus planes de revelar la índole de la Conspiración Shandy. Por supuesto, muchas de sus características reales lo hacían un personaje que superaba los habituales cursos de las más raras ficciones. Pero en relación con HALP, lo que cuenta es el efecto de las más imprevistas travesías en la construcción de una vida -a todas luces (y sombras)- extraordinaria. Tanto lo sería que inspiró el protagonista de El mago de Somerset Maugham -entre varias posteriores recreaciones literarias y fílmicas, sin contar su influencia en grupos de rock-, una novela tan próxima a sus aventuras y dislates que el mismo Crowley lo acusó de haberse robado su historia y usado sin autorización uno de sus seudónimos, Oliver Haddo, sino de haber plagiado 
apartes de los libros de otros ocultistas. Lo paradójico es que en sus Confesiones, donde explica que no ve por qué tendría que confinarse a una vida y que le parece que no hay esperanza de persistir en entender el mundo mientras uno insista en mirarlo desde la torre de su propia personalidad, declara:

My technique for borrowing other people's spectacles was to put myself in the place altogether, either by actually adopting a suitable alias or by writing a book in their names. It is a common and legitimate literary device (560).

Esa técnica, sumada a su afición por los alias — tan cercanos a la experiencia del doble - y a su idea de que la habilidad de ver el mundo a través de los ojos de otro hombre garantizaba en gran medida la grandeza de un poeta (aunque pese a sus esfuerzos su propia creación poética no logró convencer a poetas de la talla de William Butler Yeats con quien coincidió en sus primeras adhesiones a las sociedades secretas) es justamente la que realiza Vila-Matas. Una usurpación narrativa que añade otra vuelta de tuerca a sus aventuras, ya de por sí desmesuradas, llenas de hazañas físicas y pasadizos truculentos.

Justamente por la confesa tendencia de Crowley de "tomar prestados otros espectáculos de la gente" (Confesions 560), se le confía en HALP el papel de un Judas que lleva a cumplir el destino de la conjura portátil a través del mecanismo de la traición. Su delación logra que "se convirtiera en la exaltación espectacular de lo que surge y desaparece con la arrogante velocidad del relámpago de la insolencia" (14). La brevedad es pues, una consecuencia de la levedad. Y, por ello, tres años después de que Duchamp tuviera la visión iluminadora de un artista célibe y delirante (que corresponde a la que tuvo Vila-Matas al leer la entrevista en la que Duchamp le aseguraba a Cabanne haber vivido una vida maravillosa) “en el día del homenaje a Góngora en Sevilla, año 1927, el 
satanista Aleister Crowley, acompañándose de un gesto deliberadamente histriónico, disolvió la sociedad de los portátiles" (14).

En el mapa del último shandy

El último shandy, aquel que viaja por los textos y las historias de los demás shandys para conocer su geografía y cuyo rostro es una única máscara, compendio de todos los portátiles, el que finalmente narra su conjura como si se tratara del propio mapa de su vida, no podría ser — de atenernos a las precisiones cronológicas - el propio VilaMatas. Este nace en 1948 mientras al último shandy se lo ve en una fotografía de 1924, con el pelo oscuro y rizado, pero una clave nos dice que puede jugar con el tiempo. En la luz de un cuarto sevillano mira su propia fotografía t época, biografías, catálogos y textos de arte época, biografías, catálogos y textos de arte omada tres años atrás y se le ve (¿se ve?) “sorprendentemente más joven” (118) y su mirada encuentra en las últimas páginas de un volumen que está mirando — justo en las últimas páginas de HALP — donde quien narra cree que ahí podría haber encontrado el mapa de su vida y lo describe: "un laberinto en el que cada relación con un conjurado shandy figuraría como una entrada en la maraña de la ciudad invisible de los portátiles" (119). Es, sin duda, el fundador de la sociedad secreta en la inexistente Port Actif donde se pasea, "ocioso, libre para soñar despierto" y, en todo caso, dispuesto a perderse en el caos de donde nace la literatura portátil. Con ella, ha aprendido a leer el pasado, o más bien a reescribirlo. En ese cuarto de Sevilla el shandy se enfrenta a la necesidad de fijar "límites naturales a la longitud con que él puede hacer explícitas sus ideas sobre la literatura y la vida, y decide concluir el libro que está escribiendo, para que así éste termine justo a tiempo, antes de autodestruirse" (121). Se apresura entonces a hacerlo, con la conciencia de saber que "el verdadero rostro de la 
historia pasa velizmente y que sólo puede retenerse el pasado como una imagen". Y con el resplandor de esa imagen, baja los ojos y esconde la cabeza "tras el muro portátil de su libro" (122) que ahora tenemos en las manos y que sigue andando y permitiéndole no sólo viajar, sino transmigrar del campo de la literatura hacia el del arte que ahora está habitado por su ficción y lo ha convertido en un personaje que aparece en sus escenarios, como puede corresponder en toda regla a quien ha hecho tan portátil la vida maravillosa de Duchamp que ha comenzado a crear una saga de obras portátiles que se exhiben en los espacios donde también aparece él mismo, ya definitivamente infiltrado.

Los deslizamientos del arte a la literatura y viceversa y de la ficción a la realidad se refrentan ciertamente con prácticas como las exhibiciones artísticas que se han realizado invocando ya no sólo la mirada que atraviesa un vidrio, una puerta, o que cruza impunemente el territorio de las invenciones, sino el modo en que este autor español se apropió de ellas para convertirlas en una ficción literaria.

Su literatura, a fin de cuentas, es otra "máquina de símbolos" y deseos, que en el fondo juega, como decía Octavio Paz de Duchamp, con "el absoluto y su máscara: el azar" (19). Los fantasmas que proyecta no sólo usurpan las demarcaciones entre arte y literatura, sino que tornan borrosas las identidades. Por algo dice el crítico Chistopher Domínguez: "No había habido entre nosotros, desde Ramón Gómez de la Serna, un escritor cuya individualidad sea tan proteica y a la vez, cosa curiosa, tan mimética como Enrique Vila-Matas". En cierto modo, actúa como suponía Duchamp del artista: “A la manera de un éter con cualidad de médium: alguien que, desde el laberinto, más allá del espacio y del tiempo, busca su camino hacia un claro" (Cabanne 12). 
Y es que la alegría del juego de la creación literaria, que es la de ser una cámara abierta, pasiva y minuciosa, es contigua, para el último shandy a la que le proporcionó a Duchamp, apenas un día antes de su muerte, el hallazgo de un par de lentes —uno rojo y otro verde - que le permitían mirar el efecto estereoscópico de una chimenea anaglífica en que estaba espiando efectos. Y esto no aminora el efecto de esa alegría que lo llevó a usurpar las referencias históricas de los conspiradores y a coaptarlos partiendo de afiliaciones de la mirada sobre todos esos artistas y escritores "gratuitos y delirantes héroes de esa batalla perdida que es la vida" (15). Retiene por ello ese modo de lucidez contagiosa con la que transita en una zona que retiene el efecto dadaísta y le permite enfrentar arte y escritura como "la experiencia más divertida y también la más radical".

Por eso, ha podido convertir a la artista Sophie Calle (n. 1953) en un personaje literario femenino que lo lleva a copiar los gestos con los que ella interviene en la vida de los otros, sólo para llevarlos y traerlos en esa zona promiscua de tránsito que ha abierto entre arte, texto y vida. Por eso en la exhibición de Dominique Gonzalez-Foerster en el Museo de Arte Contemporáneo de Castilla y León, Nocturama, lo vimos extendiendo el placer de contar historias a la artista, a un curador de alto reconocimiento, Jens Hoffmann, y a uno de los mayores expertos en arte contemporáneo en el mundo, Hans Ulrich Obrist, devoto absoluto de Duchamp. La singular razón de su inclusión es una novela que inventa un capítulo inexistente en la historia real del arte para retener el resplandor del espíritu de un tiempo pasado que por obra suya continúa iluminando el arte contemporáneo.

\footnotetext{
${ }^{167}$ En el blog de Vila-Matas donde configura la "versión disidente" de HALP, la segunda nota sobre el proceso de su escritura es una fotografía de Lawrence Sterne con la aclaración de que es imprescindible su presencia. Y luego, en la nota 16 se apropia de las palabras del narrador de Tristam Shandy para expresar lo
} 
que le ocurre con la construcción de esta re-visión de su propio libro : "Me ocurre algo parecido a aquello que le decía Sterne a sus lectores: que no se dejaran guiar por las apariencias y tuvieran paciencia. Él le decía al lector: "Aguante conmigo y déjeme proseguir y contar mi historia a mi manera. Y si de vez en cuando parece que me entretengo con tonterías por el camino ---- o que a veces durante unos segundos y mientras pasamos de largo, me pongo un cucurucho con un cascabel, ---- no se esfume usted, ---- sino más bien concédame cortésmente crédito y confíe en que en mí hay más sabiduría de la que muestran las apariencias; ---- y a medida que avancemos dando tumbos y a trompicones, bien ríase usted conmigo, o bien hágalo usted de mí, o en suma, haga lo que prefiera ---- pero no pierda usted nunca el humor”.

${ }^{168}$ De cualquier modo, la obra remitía a una figura tutelar para Duchamp e igualmente para dadaístas y surrealistas: Guillaume Apollinaire. Era una instalación en plexiglás que repetía la experiencia formal de su poema Il Pleut.

169 Al respecto, es interesante lo que dice Seigel Jerrold comparando la euforia de Duchamp con la transformación visionaria de Rimbaud: Between Duchamp's pursuit of euphoria and Rimbaud's search for visionary transformation there are many differences, in the means employed and the range of the results sought after, but both aspired to inhabit a world beyond time and space, where ordinary sense experience could not be a guide, and to which both sought access through the power of fantasy, aroused by constant and disorienting sensual stimulation; what made both end up by abandoning the life of making objects was their common attempt to employ these means in the service of a freedom so unencumbered by material limits that it could only be finally obtained by withdrawal from the actual activity - poetry or painting that first appeared to give entry to it. Duchamp's calm indifference toward painting and his contentment with living life as it came actually brought him closer to the spirit of ordinary bohemians than Rimbaud, with his passion for poetic enlightenment, could ever be. Duchamp's career showed that Baudelaire had been more prescient than he knew when he feared that the qualities and activities he valued and cherished under the name of art could not survive the power of attraction that drew modern artists into the bohemian theater of the self » (221).

${ }^{170}$ La famosa frase de la novela obra Baterbly, el escribiente, de Melville ha sido una inspiración contínua para Vila-Matas, quien incluso publicó por su parte la novela Baterbly y Cia, según dice, inspirado por la conclusión que aparece en ese libro de Jouannais respecto a que todos los shandys, habían sido, además de dandys, Baterblys, que siempre "preferirían no hacerlo" (Vilamatas web oficial).

${ }^{171}$ La posibilidad de reinvención de otra realidad sin necesidad de todos los aparatos que exigiría su construcción que "el más grande de entre los escritores que no escribieron nunca" era ciudadano de honor de Glooscap, lugar situado en algún punto de la costa de Canadá. El arquitecto de Glooscap parecía haberse aplicado a esta labor. Según Vila.Matas, el creador de toda esa ciudad, Alain Bublex, llevaba más de una década realizando sobre su espacio urbano mapas (de distintas épocas), pinturas de personajes famosos, cartas postales, libros, aerofiats (o coches utilitarios para las lluviosas carreteras de ese país) creando su historia y costumbres, su geografía, sus habitantes, su mitología y su arquitectura, en fin, todo tipo de documentos.

${ }^{172}$ Las dudas que desata acerca de la existencia de este pintor que ha optado sólo por pintar muebles después de haber renunciado a ser escritor pueden rastrearse en el universo virtual. Encuentro, por ejemplo, una conversación en inglés que me parece reveladora porque refleja el tipo de incertidumbre de las estabilidad de las fronteras entre realidad y ficción que provoca la ficción extrema: "Did Clement Cadou exist?", asked someone (ask.metafilter.com) arguing: "In Enrique Vila-Matas novel Bartleby \& co. everyone seems to be real. He talks about Duchamp, for example, and about B. Traven, the mysterious author of Treasure of the Sierra Madre. But he also talks about Clément Cadou, a supposed painter who only painted furniture and dubbed them "self-portraits" and whose epitaph was about himself, as a piece of furniture. Is Cadou real? If I try to Google Cadou or look for him in Google Book search, all i get is references to Vila-Matas. Cadou was supposedly a would-be writer who, after meeting the writer Witold Gombrowicz, decided that he (Cadou) was no more than a piece of furniture and thereafter painted only 
furniture and referred to himself as furniture in his epitaph. Is Cadou real? Or, is he an invention of VilaMatas?". Su origen, se remite a la versión que da Jouannais, de que Félicien Marbeou cuando el autor de Madame Bovary visitó la casa de sus padres y estuvo casi son dirigirle la palabra, éste pensó que "no era más que una sombra, un mueble del comedor en el que sus padres habían recibido al gran Flaubert" (Blog en su web). Alguien, en todo caso le contesta a quien hace la pregunta: "I'll continue digging around for Clement Cadou info, because my searches were really intriguing...", y otro usuario finalmente concluye: "If he were real, he would have been written about somewhere, and a Google Books search turns up nothing but your novel. (A fair number of Cadous, but no other Clements.) (see E. L. Doctorow)". Además de Cadou, otro autor añadido en el libro de Vila-Matas, Baterbly y Cia., es Roberto Moretti, autor del Instituto Pierre Menard, donde los alumnos aprenden a rechazar una multitud de proyectos.

${ }^{173}$ Entre los veinte libros que Vila-Matas cita como biografía esencial se encuentran el Tristam Shandy, de Lawrence Sterne, cuya referencia inspiradora fue la segunda parte de Don Quijote; y la Historia portátil de la literatura abreviada, incluida en los Siete manifiestos Dadá. El espía de los realistas y una historia inédita, de J.J, Pauvert; Viajes con Rita Malú, de Man Ray; las Castas desde Mogadiscio, de Malú; Los disparos del soltero, de Wener Littbarski y Valery Larbaud; La antología negra, de Blaise Cendrars; Pictures, el Libro de memorias, de Georgia O'Keefe; el Diario europeo, de Vicente Huidobro, y Tagebücher, de Paul Klee; el libro Shakerspeare y Compañía, de Sylvia Beach; y Memorias biográficas de Shandys extraordinarios, de Walter de la Mare. Esto sin contar dos textos de cuya procedencia $-\mathrm{y}$ o existencia- no puede estarse seguro: La crai nom du complot portatif, de Louis- Ferdinad Céline, manuscrito desaparecido en Praga; y Veuves et militaires, de Francis Picabia, en supuesta vía de publicación. Además, se incluyen otros libros de Skip Canell, Maurice Blanchot, Jaques Rigaut, Ant(H)ony Typ(h)on, y del fatídico Alister Crowley.

${ }^{174}$ En realidad, 24 años después de haber publicado HALP, Vila-Matas publicó en el suplemento Babelia, de El País (18 de abril de 2009) el artículo "Una vida absolutamente maravillosa », que resulta clave para comprender el géneris de la novela. Aunque si no lo hubiera explicitado, para quienes conocieran la entrevista que le hizo Pierre Cabanne a Marcel Duchamp, sería de todos modos fácilmente reconocible la relación entre ciertos principios de la vida y la obra de Duchamp y los que estructuran la comunidad de espíritu de los conjurados.

175 En 1975, el director de la Bienal de Venecia, Harald Szeemann curó la exhibición Junggesellenmaschinen/ Les Machines célibataires "articulada en torno a objetos de complejo funcionamiento simbólico nacidos a partir de descripciones literarias". (Manuel J. Borja-Villel, prefacio).

${ }^{176}$ En su conversación con Cabanne, Duchamp dice que le molesta la palabra ser, en la cual la gente tiene una creencia moldeada al hierro. "Nunca nadie piensa en no creer en el "yo soy”, ¿no?”. Y, cuando éste le pregunta cuál es entonces la palabra más poética, le responde: "No tengo idea. No tengo un manual. En cualquier caso, deberían ser palabras distorsionadas por su significado (...) juegos de palabras. Asonancias/ rimas, cosas como esas, como el retraso/ tardanza en el Vidrio, eso me gusta mucho. "Opuesto", eso es signifi cativo". (Cabanne, 83).

${ }^{177}$ La relación de Duchamp con su readymade (ése fue su término original) más controversial e icónico, Fontaine, formado por un urinal, es ejemplar: lo presentó en 1917 a la exhibición de la Société des artistes indépendants de Nueva York, donde actuaba como jurado y, dado que no fue aceptado, consideró la única salida coherente renunciar a ese rol. Objetó la censura de la que había sido objeto su urinal, bajo el argumento de que era obscena y/o no era una obra de arte, en un artículo anónimo, "que indudablemente fue escrito por el mismo Duchamp", según la curadora inglesa Jessica Morgan. Cita el texto aparecido en la revista The Blind Man en mayo de 1917: Duchamp escribió: "El hecho de que el sr. Mutt haya hecho o no la fuente con sus propias manos no tiene importancia. La escogió él. Retomó un artículo de la vida cotidiana y lo colocó para que su significado utilitario desapareciese bajo un título y perspectiva nuevos, creando así un nuevo pensamiento acerca del mismo objeto" (Morgan, 13). No hay que olvidar que la 
actitud de indiferencia frente a la autoría, o a la noción de originalidad de la obra está en la base de la relación de Duchamp con el urinal, y marca una inquietante ambigüedad: no recogió la obra en la galería 291, aunque sí le pidió a Stiglitz fotografiarla y, posteriormente mandó a hacer — paradójicamente fabricadas - algunas copias de la pieza. Sabía que no eran "originales" en el sentido convencional de la palabra aunque "reconoció la importancia de limitar la producción de "ready-mades" a uno o dos al año, perspicaz y consciente del peligro de repetir ese gesto hasta el punto en que llegara a perderse esa deseada "indiferencia" (Morgan, 14).

${ }^{178}$ En el volumen X, de The Cambridge History of English and American Literature se encuentra un interesante comentario del espíritu del shandysmo, realizado por: "Goethe found not only the most characteristic, but, also, the most helpful, quality of Sterne's genius - that from which there is most to be learned for the practical conduct of our lives. The very detachment from all that is commonly reckoned to belong to the serious interests of life, the readiness to escape from that for which other men are striving and fighting, to withdraw into the citadel of our bare, naked self and let the world go its way, to count all for naught, so long as our own ideal is kept intact, had, for him, a moral worth, a "liberating" value, which it was hard to overrate. (...) He recognized and he was right in recognizing, that, of all men who ever wrote, Sterne was the most firmly possessed of it himself, and the most able, by the magic of his art, to awaken the sense of it in others. "Shandyism," he says, in the words of Sterne himself, "is the incapacity for fixing the mind on a serious object for two minutes together." And Sterne himself he defines as "a free spirit," "a model in nothing, in everything an awakener and suggester." (Werke, 200-205).

${ }^{179}$ En la sustentación teórica de la obra interactiva Very Nervous Systems (1986-1990) el artista canadiense David Rokeby, cita tanto a Duchamp, con su visión de que el espectador hace la obra, como a Laurence Sterne y su Tristram Shandy, finalizado en 1766, como una obra en la que las expectativas y supuestos del espectador se dirigen de un modo sorprendentemente post-moderno. Alude a la página en blanco en la que Sterne pide al lector pintar la mujer de quien se enamoró su tío guiándose por su propia fantasía de tal modo que éste comprenda cuán difícil era para su tío Toby resistirse a ella. Escribe: “...the reader takes the role of universal renderer, using his or her imagination to construct a subjective world upon the skeleton of the text. For a brief moment, Sterne clarifies the mirror provided by the text, showing us ourselves staring into the page. Marcel Duchamp expresses the idea of the artwork as a mirror in his work The Bride Stripped Bare by Her Bachelors, Even. In his discussion of this work, Octavio Paz notes: «Duchamp's painting is a transparent glass; as a genuine monument it is inseparable from the place it occupies and the space that surrounds it; it is an incomplete painting that is perpetually completing itself. Because it is an image that reflects the image of whoever contemplates it, we are never able to look at it without seeing ourselves».

${ }^{180}$ La tonalidad verde le interesaba a Duchamp no como color en sí, sino porque era producto de la iluminación nocturna que provenía de las lámparas de gas y que permitía alterar la tonalidad de una pintura pues al ser realizada bajo ese efecto se tendía a los tonos que a plena luz del día resultaban opaceos. De hecho Duchamp admiraba a Valloton porque en una época en la que todo era verde y rojo pintaba con una paleta de tonos fríos, apagados, preludiendo al cubismo.

${ }^{181}$ En el prólogo con que Cervantes inicia las aventuras del Quijote señala al lector que su materia es la mentira. El mismo autor que se pretende distinto de Miguel de Cervantes invita al lector a ser libremente arte y parte (pues al fin y al cabo dará un veredicto) de un invento donde todo lo narrado es incierto. Pero justo por ello, esa historia nunca antes contada se anuncia como un divertimento. Nada mejor que entretenerse en la desfachatez con que se advierten los embustes y entran a escena las imágenes reflejas de un libro que se deleita en la creación de falacias en torno a su propia naturaleza. El narrador del Quijote encargado de escribir el prólogo tiene cuidado en enlazar la baja ralea de su experimento literario con la originalidad de su escritura. Advierte así al lector que escuchará asuntos "nunca imaginados de otro alguno, bien como quien se engendró en una cárcel" (9). Esa explicación sobre las circunstancias de creación de una obra surgida al margen del bienestar, espuria, en cierto modo, es coherente con el modo de dirigirse al lector para proponerle, como actitud de lectura, la misma irreverencia con que confiesa haber 
escrito el libro: "Y sabes lo que comúnmente se dice: que debajo de mi manto al rey mato, todo lo cual te exenta y hace libre de todo respeto y obligación" (10). La primera señal de alarma respecto a la credibilidad que pueda atribuirse al libro, o a la liberalidad con que se ha hecho uso antojadizo de los recursos literarios, aparece cuando el supuesto autor - todavía sin nombre - se describe pasmado ante el texto - "la pluma en la oreja, el codo en el bufete y la mano en la mejilla" (10) - y confiesa haber hallado la salida al impase acatando el supuesto consejo de un amigo que viéndolo en esta circunstancia le habría propuesto una fórmula para lidiar con la tarea de buscar comentarios elogiosos que sirvan de preámbulo a su libro como se estila entonces. Hasta el más incauto lector advierte que el dicho amigo es una invención humorística y aquí comienza su confusión no sólo por la índole del consejo, sino porque desde el mismo prólogo se perfila la incertidumbre sobre lo que puede o no creer. Ante el desdén que al narrador le provoca "andarme buscando autores que digan lo que yo me sé decir sin ellos"(11), la falsificación es la solución perfecta. La salida propuesta: hacer sonetos, epigramas, elogios, y bautizarlos con el nombre que a bien tenga ("El emperador de Trapisonda", por ejemplo), sin temer a los bachilleres que descubran el embuste, contiene ya el juego de dobleces que voltean el derecho y el revés de la propia naturaleza de la ficción. La abierta confesión de la mentira no sólo niega el carácter de oculto que el supuesto ardid debe tener para ser eficaz y burla por anticipado toda suspicacia, de modo que termina siendo la enunciación de una verdad. El resultado de tanta torcedura - la mentira que revela lo real- es que al cabo el lector se torna un confidente, un inadvertido cómplice de cada fechoría narrativa.

182 elogiosos que sirvan de preámbulo a su libro como se estila entonces. Hasta el más incauto lector advierte que el dicho amigo es una invención humorística y aquí comienza su confusión no sólo por la índole del consejo, sino porque desde el mismo prólogo se perfila la incertidumbre sobre lo que puede o no creer. Ante el desdén que al narrador le provoca "andarme buscando autores que digan lo que yo me sé decir sin ellos"(11), la falsificación es la solución perfecta. La salida propuesta: hacer sonetos, epigramas, elogios, y bautizarlos con el nombre que a bien tenga ("El emperador de Trapisonda", por ejemplo), sin temer a los bachilleres que descubran el embuste, contiene ya el juego de dobleces que voltean el derecho y el revés de la propia naturaleza de la ficción. La abierta confesión de la mentira no sólo niega el carácter de oculto que el supuesto ardid debe tener para ser eficaz y burla por anticipado toda suspicacia, de modo que termina siendo la enunciación de una verdad. El resultado de tanta torcedura — la mentira que revela lo real- es que al cabo el lector se torna un confidente, un inadvertido cómplice de cada fechoría narrativa.

${ }^{183}$ La cifra es inexacta. Si el encuentro tuvo lugar en el último día del verano 1966, 27 años del suicidio de Walter Benjamín, éste tendría que haber muerto en 1943, cuando en realidad, ingiere píldoras en el Hotel de Francia de Portbou a fines de septiembre de 1940. Se forza para perpetuar la aparición reiterativa del número 27 , a cuyo significado aludiremos luego, pero que, entre otras cosas, se asocia a la edad en que murieron los músicos del Club 27. Roberth Jhonson, personaje de la conjura, entre otros. Por otra parte, 1966 es -clave oculta- la fecha en que Cabanne realizó la conversación con Duchamp, que nunca se menciona y, además es la fecha en la que éste termina su última obra, Étant donnés: $1^{\circ}$ la chute d'eau $/ 2^{\circ}$ le gaz d'éclairage.

${ }^{184}$ Sólo décadas después, cuando se localizaron los papeles de su defunción se pudo recobrar su figura, conmemorada con la construcción de un memorial hecho por el escultor judío Dani Karavan en el cementerio del pueblo.

185 El título es una broma lingüística con el sonido de la pronunciación de las letras L.H.O.O.Q., en francés : "Elle a chaud au cul",una expresión que Duchamp tradujo luego como "there is fire down below" (Schwarz 203). La obra introduce el juego andrógino que está presente también en otras piezas y que puede decirse en cierto modo de La novia desnudada por sus solteros ... aún, como mecanismo que contiene la imaginación femenina, privilegiada por el título, en un juego interpretativo que es incesante.

${ }^{186}$ Speranza sintetiza el "efecto Duchamp" en tres rasgos notorios de la estética de la segunda mitad del siglo: "el impacto irreversible de la reproducción en el arte, los movimientos decisivos de las artes hacia 
afuera de sus campos específicos -literalmente, un hors du champ- y, sobre todo, un giro claro de buena parte de las artes hacia la cosa mentales, o, más precisamente, un giro conceptual" (Fuera de campo 21-2).

${ }^{187}$ Refiriéndose a los textos posteriores escritos sobre el dadaísmo, John Alford comenta que si bien la fuente clásica en inglés es "Memoirs of Dada-ism", de Tzara, publicadas como un apéndice de Axel's Castle, de Edmund Wilson, el hecho es que ningún participante puede escribir la historia de Dadá, que fue menos "un movimiento" que un drama. "There is no solution to this "mystery", as there is none to tragedy or tragi-comedy; only a climax, and a hint of a re-beginning in a somewhat altered situation" (271). No obstante, ninguna de las guías para remontar HALP, como son "The Dada Painters and Poets", editado por Robert Motherwell, Dada in París, de Michel Sanouillet, o el catálogo Dada, editado por Leah Dickerman, incluye, entre las figuras claves del dadaísmo a Crowley, cuya inserción es otro juego de los desdoblamientos de la identidad de Vila-Matas.

${ }^{188} \mathrm{He}$ traducido del texto original : “J'écris ce manifeste pour montrer qu'on peut faire les actions opposées ensenble, dans une seule fraîche respiration; je suis contre l'action; pour la cotinuella contradiction, pour l'affirmation aussai, je ne suis ni por ni contre et je n'explique pas car je hais le bon sens".

${ }^{189}$ El texto original dice: "En donnant à l'art l'impulsion de la suprême simplicité: nouveauté, on est humain et vrai envers l'amusement, impulsif, vibrant pour crucifier l'ennui'.

${ }^{190} \mathrm{El}$ texto original dice : "Un tablau est l'art de faire se recontres deux lignes géométriquement constatées parallèles, sur una toile, devant nous yeux, dans la réalité d'un monde transposé suivant de nouvelles conditions et possibilités. Ce monde n'est pas spécifié ni défini dans l'oeuvre, il appartient dans ses innombrables variations au spectateur".

${ }^{191}$ El texto original dice: "Il nous faut des ouvres fortes, droites, précises et à jamais incomprises".

192 El poeta surrealista francés la retrata como aristócrata, reina de Francia en su Aforismo 13 en el que juega con un anagrama del nombre de Duchamp. Asímismo, el poeta estoniano surrealista Ilmar Laaban escribió un homenaje lúdico al doble femenino de Duchamp llamado "Rroosi Selaviste".

${ }^{193}$ Belle da Costa Green (1883-1950), añadió en realidad el apellido da Costa para sugerir que venía de Portugal y justificar así su piel morena. Es famosa la respuesta que dio cuando le preguntaron si ella y el multimillonario J.P. Morgan habían sido amantes: "We tried", fue todo lo que dijo, pero en su herencia le dejó una notable cantidad de dinero. Sostuvo un largo romance con el experto en el arte renacentista Bernard Berenson.

${ }^{194}$ Stephen Jay Gould escribe: "The case for viewing Duchamp's Belle Haleine bottle as an ironic commentary upon his feelings for Belle Greene and her efforts, as a light-skinned African American, to pass for white gains great strength, as Bonnie Garner has shown, by linking the otherwise lame 1921 "Negro pun" to Belle Haleine. Even though uncertainty surrounds the timing of Duchamp's signature for Rrose (with the double R) Sélavy on the box of Belle Haleine, scholars agree that Duchamp used the double $\mathrm{R}$ for the first time when he wrote the Negro pun. (The double R represents an important argument in Garner's case because, in her effort to pass, Belle Greene dropped the final " $r$ " of her famous father's name, Richard Greener, the first African American graduate from Harvard". ("From the Bitter Negro Pun to the Beautiful Breath Bottle" Web).

${ }^{195}$ Duchamp le dice a Cabanne que le choca la palabra creación porque no cree en la función creativa del artista, que es un hombre como cualquier otro, cuyo trabajo es hacer ciertas cosas, del mismo modo en que el hombre de negocios también hace ciertas cosas. Y concluye: "Por otro lado, la palabra 'arte' me interesa mucho más. Viene del sánscrito y significa 'haciendo'. Ahora todo el mundo hace algo, y aquellos que hacen algo sobre tela y con un marco son llamados artistas. Antes eran llamados artesanos y prefiero ese término. Todos somos artesanos, en una vida civil, militar o artística" (8). 
${ }^{196}$ Los materiales empleados, según la referencia del Philadelphia Museum of Art son : "wooden door, iron nails, bricks, and stucco; (interior) bricks, velvet, wood, parchment over an armature of lead, steel, brass, synthetic putties and adhesives, aluminum sheet, welded steel-wire screen, and wood; Peg-Board, hair, oil paint, plastic, steel binder clips, plastic clothespins, twigs, leaves, glass, plywood, brass piano hinge, nails, screws, cotton, collotype prints, acrylic varnish, chalk, graphite, paper, cardboard, tape, pen ink, electric light fixtures, gas lamp (Bec Auer type), foam rubber, cork, electric motor, cookie tin, and linoleum » (Web).

${ }^{197}$ Duchamp declaró abiertamente que Rabelais y Alfred Jarry (1873-1907) eran sus dioses (Tomkins 73) y la conexión entre éste último y Éttant Donnés ha sido estudiada en interesantes ensayos como "Alfred Jarry and l'Accident of Duchamp" de William Anastasi, o inspirado obras chocantes de artistas que prefiero no mencionar. Lo cierto es que mientras trabajaba secretamente durante 20 años en esta instalación única en su estudio de la calle 14 de Nueva York, donde la obra ocupaba una habitación completa, como se puntualiza en la página virtual de la revista Surrealist NYC, en ese período, "the blackout remained so complete that it's easy to ignore those long years in Manhattan spent experimenting with materials and solving problems in between chess moves and reading Alfred Jarry". Puntualiza Anastasi Williams : An example of inversion occurs in a Duchamp note treating an image from a pivotal scene in Jarry's science fiction novel, The Supermale. A five-man bicycle team of inconceivable potency is engaged in a cosmic race, sometimes exceeding the speed of light, with a train on a ten-thousand-mile elliptical course. When they reach the apogee, which represents the fourth dimension, Jarry describes a tower, "shaped like a truncated cone." In Duchamp's writings for the large glass, with their "heaps of notes on the fourth dimension," he makes reference instead to a "conical trunk." Igualmente señala otra coincidencia: "The English title for The Large Glass is The Bride Stripped Bare By Her Bachelors, Even. In Jarry's first novel, the autobiographical Days and Nights, a licentious young artist's model named Huppe is itching to entertain five lovers in the studio where she poses. One of the chosen, introduced as "the Jewish eunuch Severus Altmensch," is understandably hesitant. Sengle, the Jarryesque hero of the novel, dreams up a ruse to permit all present to see the naked body of Severus (...) The inversion here is that a male ("bachelor") is being stripped by a female ("bride"). In a number of Jarry's novels hyper-sexual females who are not brides are referred to as such. Another figurative foretaste of Duchamp, here sans inversion, is the central presence of one "bride" and multiple 'bachelors,' with copulation their sole raison d'être". (Anastasi Web). Esa angustia frente a las mujeres hiper exigentes está presente también en la vagina dentada que obsesiona a Masson y en la mujer hambrienta, la mantis que aparece en las pesadillas de Matta, y que devora a su amante (Francisco Javier San Martín 39).

${ }^{198}$ El libro Exquisite Corpse. Surrealism and the Black Dhalia Murder, de Mark Nelson y Sarah Hudson Bayliss afirma: "Someone familiar with surrealism inspiraded by the strains of the uncanny and of violent eroticism that run trhoughout surrealist art, may have tried to create a horrific masterpiece fron the body of a your woman (99). La pregunta que queda es si, como aseguran los autores, y lo refrendan con imágenes de estremecedora similitud entre la escena del crimen de la Dalia Negra y Ettant Donnés, su asesinato no fue una inspiración estética decisiva para esta obra. Igualmente evocan la relación que había entre Man Ray y el supuesto asesino, George Hodel. Por otra parte, en su inquietante libro Dali-Duchamp : una fraternidad oculta, Francisco Javier San Martín traza la génesis estética de las mujeres sometidas al poder sadomasoquista.

199 'eEven long after my death/Long after your death/I want to torture you./ I want the thought of me/ to coil around your body like a serpent of fire/without burning you./I want to see you lost, asphyxiated, wander/in the murky haze/woven by my desires./ For you, I want long sleepless nights,/ filled by the roaring tom-tom of storms/Far away, invisible, unknown./ Then, I want the nostalgia of my presence to paralyze you" (Maria Martins citada por Taylor 26).

${ }^{200}$ Lo había conocido en Filadelfia. La obra, "Figure 5 in Gold", uno de los ocho retratos abstractos que hizo de sus amigos, construido como una acumulación de imágenes inspirados en el nombre y la obra del 
poeta y, particularmente en su poema "The Great Figure", sobre un camión con el número estampado y luces rojas encendidas que corre en las lluviosas calles neoyorquinas.

${ }^{201}$ En esta cita no sigo la versión traducida por la editorial Alias porque prefiero no distraer la atención con el uso de términos excesivamente coloquiales, traducidos al habla del D.F. Por eso, específicamente en este diálogo uso la versión publicada por la editorial Anagrama.

202 "Prends pour toi ce porte bouteilles. J'én fais un "Readymadre" à distance. Tu inscrirás en bas et à l'interiur du cerde du bas, en petites letters (el subrayado es mío) peintes avec un pinceau à l'huile en coleur blanc d'argent la phr (tachado) inscription que je vais te donner ci après, et tu sigueras de la même écriture comme suit: [d'après] Marcel Duchamp

${ }^{203}$ Ernst no escapa en los Estados Unidos del tipo de sospecha que despertaba en Francia. La revista NYC Surrealism narra que es viaje de vacaciones fue súbitamente interrumpido por los interogatorios de la policía norteamericana, preocupada por la posibilidad de que él estuviera mandando señales a submarinos enemigos.

${ }^{204}$ No es el único momento de su vida en que lo hace. Escribe Jerrold Seigel: "Under an appearance of almost romantic timidity, he possessed an exacting dialectical mind, in love with philosophical speculations and absolute conclusions (....) Duchamp enclosed himself in the solitude of his studio at Neuilly, keeping in touch with only a few friends, among whom we were numbered. Sometimes he "took a trip" to his room. (The Private Worlds of Marcel Duchamp Web).

${ }^{205}$ Según el teórico francés, un nuevo tipo de modernidad está reconfiguando la era de la globalización en la forma de la "cultura altermoderna". Una cultura en la cual el viaje y la migración afectan la manera en que vivimos mientras surge un universalismo basado en un modo de traducciones, subtitulado y doblaje generalizado. Según Borriaud es por ello que el arte actual está explorando los vínculos que se entretejen entre texto e imagen, tiempo y espacio, en un paraje cultural saturado de signos donde emergen nuevas formas de expresión y comunicación. (Borriaud Web).

${ }^{206}$ Sólo por esta faceta puede conectarse realmente al dadaísmo, pero su vínculo con Duchamp parece reducurse al haber sido también contratado por la fatal y detestada Bella da Costa, que tenía sangre africana.

${ }^{207}$ Salvo lo de domador de leones, que habría que investigar, Crowley corresponde a la descripción dada por el narrador.

${ }^{208}$ Mencioné una lista de éstos en el capítulo dedicado a Max Aub.

${ }^{209}$ Posiblemente una encarnación del lenguaje académico que para Vila-Matas asesina la imaginación literaria.

${ }^{210}$ El abogado Karaykowski se tendrá que esconder en un refugio perdido de los Cárpatos buscando que el joven lo olvide, pero éste no sólo está dispuesto a morir emprendiendo su búsqueda, sino que hace arreglos para que, en caso de que algo infausto suceda, su cadáver sea remitido al abogado. De un modo semejante, en el relato apócrifo que Vila-Matas inserta un personaje consagra la totalidad de sus días a amargar la vida de otro que jamás puede identificarlo, pero que es consciente de que alguien maniobra "fuera de su vista y alcance", y se dedica "con especial obstinación y notable éxito, a amargarle la vida".

${ }^{211}$ George Yudice retoma la cita de este poema que hace Caraciolo Trejo y comenta cómo si bien compartió en París diversos rasgos de estilo compartidos por los escritores que colaboraron con la revista Nod Sud, como Sopault, Tzara, Apollinaire o Breton y que aplicaban a su relación con la lengua 
procedimientos análogos al cubismo pictórico, Huidobro fue fiel a la proclamación de su poema : Non serviam, y mantuvo una autononía irreductible (22-8).

${ }^{212}$ La historia, que ganó el premio James Tait Black Memorial Prize en el mismo año de su publicación (1922) refleja la imposibilidad de hallar un lugar en el mundo, pues como nota en la introducción de la edición de 1941, Carl Van Doren, ella no tiene el consuelo de Gulliver de pensar que los gigantes son los anormales, ni de retornar a un mundo en el que sus dimensiones sean corrientes.

${ }^{213}$ La alusión evoca posiblemente los versos en donde De la Mare juega fonéticamente con el ritmo de una lengua esquiva al sentido "Do diddle di do/Poor Jim Jay/Got stuck fast In Yesterday" y con la noción de la rústica y melódica danza de la tradición folclórica popular de esa ciudad que Shakespeare menciona en $E l$ sueño de una noche de verano. Esto es : la noción del ritmo enloquecido que desplaza las coordinadas de la razón.

${ }^{214}$ Además de la vasta empresa de traducir El Ulises de Joyce, Larbaud tradujo a autores como el poeta modernista José Asunción Silva; al español inventor de las greguerías, Ramón Gómez de la Serna; al humanista mexicano Alfonso Reyes; al argentino Ricardo Guiraldes, autor de la novela de gauchos Don Segundo Sombra, y a Mariano Azuela, autor de una de las primeras novelas de la Revolución Mexicana. 


\title{
OTROS CASOS DE FICCIÓN EXTREMA: ESCRITORES, ARTISTAS Y OTROS HACEDORES INVENTADOS
}

\begin{abstract}
"En la literatura en castellano, donde la palabra experimental parece un insulto, es notable la existencia de Mario Bellatin que cada cierto tiempo reformula la idea de lo que es un escritor y lo que implica el acto de escribir".

(Ivan Thays)

"Existe en la escritura una especie de juego de diferentes, pero idénticos, similar a la manera como apreciamos los rostros de los demás”.
\end{abstract}

(Mario Bellatin).

La invención de identidades móviles y alternas de escritores, artistas y otros hacedores surgidos de la ficción extrema que se insertan de diversos modos en la realidad, no fue sólo una expresión de esas búsquedas alucinantes de las vanguardias del siglo XX que arrojaron el reino de la verdad de los dominios de la razón, sino que se multiplica en este tiempo de globalización donde tras el túnel de la posmodernidad hay quienes advierten, como Nicolas Borriaud, el advenimiento de una altermodernidad que, en cierta parte, se refleja justo en este ejercicio. Estamos ante una desestabilización de las fronteras, incluyendo las que establecían límites entre los géneros propios de cada arte. Hoy están sujetos a un proceso vertiginoso de interpolaciones que sacude los propios territorios fronterizos del arte y la literatura, de un modo que extiende las posibilidades de la ficción extrema y estremece nuestra comprensión e interacción con la realidad.

Cito un texto de Graciela Speranza que se titula justamente "Ficciones de lo real" y que contiene, como un espejo, el resultado de mi propio tránsito en coincidencia con este tiempo común:

Arte y anti-arte, arte de lo ya hecho e incluso de lo no hecho conviven hoy en una esfera gaseosa en la que no hay un afuera del arte en realidad, sino construcciones de lo real con las que el arte anuda lo visible, lo enunciable y lo realizable para que aparezca lo que no se puede ver, enunciar o realizar. A ese sin sentido con que el arte está dentro y fuera del mundo, a ese 'medio maestro' que está más allá 
de los medios y lenguajes, a ese modo del disenso en el consenso, llamémoslo, provisoriamente, ficción (Speranza Ficciones de lo real).

A modo de epílogo he propuesto detenerme en tres casos de ficción extrema que son indicativos de un fenómeno mucho más vasto y mencionar brevemente otros dos. El primero es el del escritor mexicano de origen peruano Mario Bellatin (n.1960) y el modo en que extiende las posibilidades focalizadoras de la imaginación a partir del ejercicio fotográfico en su novela Shiki Nagaoka, una nariz de ficción, 2006. Me referiré también muy brevemente al modo en que en otros textos ha usado la inserción de la fotografía para extender las fronteras de la literatura hacia registros alternos, en un combate con la imposibilidad del lenguaje de decir lo indecible; algo nada extraño en un autor que explora modos de escribir sin escribir, formas de traducir lo intraducible ${ }^{215}$.

El segundo caso se refiere a la invención del artista Juan Trepadori realizada conjuntamente por los artistas conceptuales que conformaron en la década de los $80^{\prime}$ s el New York Graphic Workshop (NYGW) en Nueva York: la argentina Liliana Porter (n.1941), el uruguayo Luis Camnitzer (n.1937) y el venezolano José Guillermo Castillo (1938-1999). Además incluiré la invención de la artista uruguaya Alicia Mihai Gazcue (n. 1949), fraguada a su vez por la misma Porter y por la investigadora y artista uruguaya Ana Tiscornia (n.1951).

El tercer caso es la invención del personaje de lucha libre Amorales vs Amorales, creado por el artista mexicano Carlos Amorales (n.1970), interpretado durante un período de tiempo por un escritor mexicano y cuya identidad motivó una controversia sobre la posesión de la identidad fraguada como un modo de insertarse en el campo fértil de la cultura popular mexicana. Son casos que iluminan la naturaleza de la ficción extrema en 
Latinoamérica, que por supuesto se extiende, con otras variantes, en incontables lugares de la creación contemporánea. ${ }^{216}$ Igualmente, abordaré los rasgos por los cuales he considerado tanto a Rubén Torres Llorca (n.1957) como a Carlos Amorales (n.1972) artistas que se acercan, en el caso del primero, o practican de un modo revelador, la ficción extrema.

\section{El desdoblamiento de Mario Bellatin en la figura Shiki Nagaoka}

Hay una afinidad entre esa ave de extrañas características ${ }^{217}$ que transita entre varias historias de Mario Bellatin y que siendo impar — tiene dientes en el pico causantes de un dolor que nadie sabe aliviar- pasa desapercibida; y la rareza de los ejercicios de $\operatorname{libertad}^{218}$ que este mismo autor realiza tanto en su escritura como en su díscola relación con el mundo editorial. Pero transgredir los pactos habituales o las convenciones que consideramos normales, no equivale a la abolición de las reglas. Por el contrario, Bellatin ha vivido abocado a la disciplinada construcción de un sistema literario de reglas propias que sostienen un universo autónomo —no es azar que imagine una novela escrita en un lenguaje inventado e indescifrable-, cuya mayor prueba es el intento de escribir lo indecible desde el borde del abismo o balanceándose en la tensión de la delgada cuerda floja de la lógica habitual.

De algún modo misterioso, regido por lo que hay de verdadero en ese intento, logra hacer aparecer, sobre los residuos de todas las realidades que convoca, un modo de verdad humana que conmueve. Así, construye en sus libros e incluso en el modo de publicarlos o distribuirlos, sistemas de significación propios, con la coherencia y precisión de relojero que exigía Allan Poe de los cuentos perfectos. Y esa extraña 
concepción de lo que es o no posible no sólo en el espacio intrínseco de la literatura, sino el entorno que rodea las transacciones editoriales del libro, aumenta las dimensiones de la ficción extrema.

Bellatin sostiene que a menudo, abrumados por nociones preestablecidas sobre cómo funcionan las cosas, "no sólo no escuchamos críticamente, sino ni siquiera imaginamos la posibilidad de que éstas puedan ocurrir de otro modo" (Herrera Los cien mil libros). Fue así como, buscando abrir la imaginación a otros modos posibles de creación y de vida, fundó la Escuela Dinámica de Escritores de Ciudad de México, donde estaba prohibido escribir. En ese mismo sentido resulta esencial evocar el mecanismo que inventó en 1986 para publicar Mujeres de sal, un texto que no le permitía avanzar hasta cuando pudiera deshacerse de él, entregarlo a los lectores que multiplicarían su continuidad. Siendo entonces un autor inexistente para el mundo editorial le propuso a un editor publicarlo si lograba vender por anticipado los ejemplares que se publicarían. Así se ingenió un sistema de bonos y 800 futuros lectores adquirieron en el término de una semana el libro que iba a imprimirse después.

En 2010, cuando cumplió 50 años, y ya había publicado con prestigiosas editoriales obras como Efecto invernadero, Canon perpetuo, Salón de belleza nominada al Premio Médicis a la mejor novela extranjera editada en Francia en el 2000, Flores -ganadora del premio Xavier Villaurrutia de México en 2001- Poeta ciego, El jardin de la señora Murakami, Shiki Nagaoka: una nariz de ficción, La Escuela del dolor humano de Sechuán, Jacobo el mutante, Condición de las flores, Perros héroes, Lecciones para una liebre muerta, Damas chinas y El Gran Vidrio, y había sido traducido al francés, inglés y alemán, hizo un proyecto híbrido acompañado de un 
manifiesto que divulgó en presentaciones personales o en el sistema de redes: Los cien mil libros de Mario Bellatin. Para llevarlo a cabo intervino su estudio —ubicado en una construcción que a su vez cumplía un siglo de haber sido edificada - y removió varias paredes para construir los anaqueles, diseñados por el artista Ernesto Azcárate, que albergan esa cantidad de libros: cien títulos auto-editados en tirajes de mil.

En lugar del sistema de registro legal, cada uno lleva su huella personal y en la primera página se advierte "este libro no es gratuito". Lo cual significa que no se comercializa masivamente y que no sólo tiene un valor monetario: puede ser negociado de modo individual, ofrecido a cambio de transacciones determinadas con cada lector potencial. Asistí a la presentación de su proyecto en Miami en 2010, cuando lo mostró en una cajamaleta duchampiana que contenía sus libros portátiles publicados en papel bond ahuesado de 90 gramos, y lo oí anunciar que no tenían un precio fijo. Los lectores interesados podían ofrecerle una cantidad que deseaban pagar para adquirir así libros entre los cuales estaba uno que en sí una intervención del de la obra más conocida del mismo Duchamp: La novia desnudada por sus solteros...así (en lugar de aun o incluso). Además del placer de sus ficciones, a menudo extremas porque buscan formas no desgastadas, los compradores que establecen una relación directa con él para adquirir su libro entran a ser parte de una manera de modificar las reglas establecidas.

El proyecto combina el performance artístico con la idea del taller artesanal de edición; cada título es en cierto modo un "no libro", pues carece de imágenes en la portada y otros recursos mercantiles (Thays); y además, ha sido diseñado en un tamaño portátil que permite a su autor en un momento dado transportar en un solo maletín la totalidad de su obra, impresa ahora con una tipografía cuyos signos distintivos son la enumeración de los 
fragmentos y el reemplazo de los puntos finales o de los lugares donde el texto es omitido por el signo visual de las tijeras.

Es lícito inferir que los omitidos fueron recortados de los lugares que indica la figura de una tijera en diversas partes del escrito durante un proceso de reescritura y edición. Además de evidenciar el trabajo del autor, así como la construcción y reconstrucción del texto (lejos está de la narrativa de Bellatin cualquier tipo de artilugio o estrategia para atrapar al lector, de sumirlo en suspenso o encelar un factor sorpresa), lo que esta lista provee, y la figura de las tijeras sitúa, lo que se resalta y pone en evidencia son las omisiones, los silencios que en él habitan (Hernando Sierra).

El letrero que precede a la lectura de cada ejemplar — "Los derechos de este texto pertenecen al autor"- - se cumple de tal modo que Bellatin se abroga el derecho incesante de reescribir, fragmentar, e intervenir todos los libros que ha publicado, sometiéndolos a un proceso inusual, convirtiéndolos en obra incesantemente abierta y no sólo en libros en extremo portátiles, sino en objetos para la interacción directa entre el autor y el lector. En Pájaro transparente, menciona la idea de una escritura en "el aire" por fuera del sistema editorial donde es posible publicar fragmentos, entresacar textos, reinsertarlos, hacer operaciones libres (25). ${ }^{219}$

El proyecto fue crucial para su participación, como curador, en la realización de Documenta 13, la relevante bienal de arte contemporáneo mundial, en la cual se presentaron otros cien gestos afines al suyo, bajo el concepto de que las notas funcionaban como una suerte de ficción de las ideas, ${ }^{220}$ y una noción conexa a la extensión de la ficción extrema:

The notebook project is a reflection on the state of art history. It shows the forming of thinking in an unassuming way, the awakening of a readiness in writing, for propositions whose contour and arguments are still in a state of becoming. It is getting ready for a transformation of the text that will affect the thinking involved with matter, objects, life and art - with culture today (100 Notizen - 100 Gedanken / 100 Notes - 100 Thoughts). 
La idea de Bellatin se relaciona con el concepto de instantaneidad: ubicar la escritura en el fluir de un presente siempre mutante, asaltar las nociones establecidas de todo cuanto consideramos literatura: desde el título — consideremos el número 5: El niño deseaba una bicicleta para su cumpleaños. Lo expresó en voz alta. Cuando aquel día llegó sus padres le obsequiaron una de manubrios altos — hasta el límite mismo de los dominios literarios. Antes de adentrarnos en el ejercicio de ficción extrema que cumple en Shiki Nagaoka. Una nariz de ficción, a modo de preludio clave, transcribo la visión que tiene Graciela Speranza de Bellatin y sus transgresiones e incluyo dos imágenes que la reafirman:

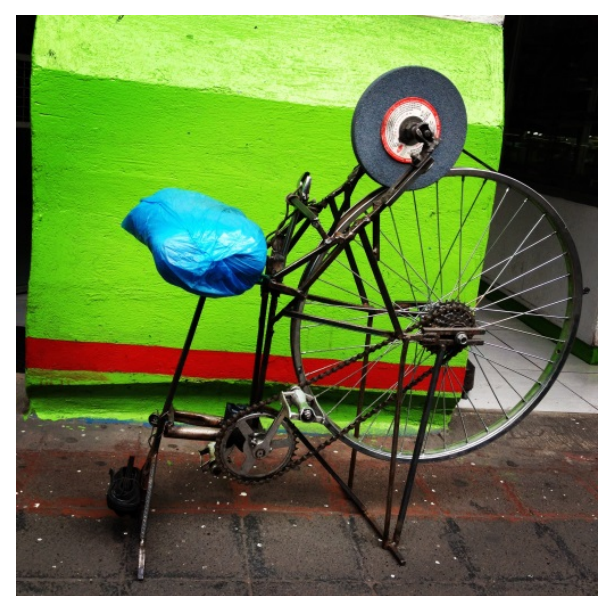

Ilustración 103: Mario Bellatin: La Biclicleta de Duchamp

Construida por Bellatin con restos de su propia bicicleta

Duchampiano confeso, el escritor peruano-mexicano Mario Bellatin realizó la empresa a su modo, en una serie proliferante de prácticas en las que la literatura quiere salirse de sí, mediante máscaras que deforman la figura clásica del escritor y desafían la tiranía del yo. Artista inclasificable, ha compuesto extraños artefactos narrativos con texto e imágenes que solo con muchas licencias podríamos seguir llamando novelas: ha ideado todo tipo de performances inspiradas por los libros desde congresos de dobles de escritores al sampling en vivo de sus propios textos; ha dirigido la poco ortodoxa Escuela Dinámica de Escritores en la que existe una única prohibición: escribir; ha actuado en films en los que es y no es Mario Bellatin; y ha expandido así la figura estática del escritor sentado frente a la página en blanco con una serie de figuras complementarias 
que, como en el retrato de Duchamp, lo facetan y lo transforman: el cronista, el fotógrafo, el artista conceptual, el traductor, el montajista, el DJ, el director de escuela, el performer, el actor (...) Todo relato de la experiencia vivida es fatalmente ficción, pero Bellatin extrema los mecanismos de la autoficción (Speranza Ficciones de lo real).

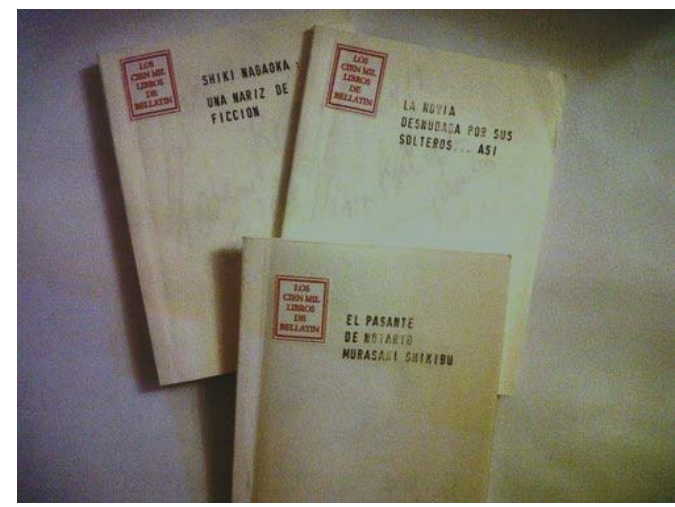

Ilustración 104: Mario Bellatin: Tres libros del proyecto "Los cien mil libros de Mario Bellatin" 2010

Ciertamente, este escritor nacido en Perú, radicado en México y habitante de ese no-lugar desde donde se escribe la ficción extrema, escribe con una mano de hierro que no tiembla al cortar el ojo de quien lo lee: subvierte las fronteras entre géneros y artes, altera las reglas que los distinguen, y puede llevar más lejos de lo pensable la libertad de lo apócrifo, tal y como se advierte en el evento que originó la escritura de Shiki Nagaoka: una nariz de ficción y que surgió tras una suerte de pugilato con la audiencia de un evento literario en Nueva York sobre hasta qué punto el aura que rodea a un escritor de prestigio puede llevar a quienes lo escuchan a aceptar pasivamente la existencia real de cualquier ficción que se le presente como tal.

Invitado al evento donde los escritores debían describir la influencia de un autor determinante en su formación, Bellatin fraguó la invención del escritor japonés Shiki Nagaoka, cuya nariz excedía en tamaño la del vanidoso sacerdote zen protagonista de la novela La nariz, la del mismo Cyrano de Bergerac, y era incluso más contrahecha que la 
de Tristram Shandy, arruinada por el obstetra que atendió su nacimiento, pero ignoró las teorías del padre del personaje de Lawrence Sterne respecto a las ventajas de una nariz larga en la vida de un hombre. Bellatin cuenta que cuando se lo describía al público le sorprendía que debido al encantamiento de la autoridad de un escritor reconocido nadie pusiera en tela de juicio la existencia real de Nagaoka (Herrera Los cien mil libros).

Como narró The New York Times en un artículo que lo calificaba como "una de las voces líderes en la ficción experimental en español”, a raíz de que al final de la sesión, durante las preguntas y respuestas, no se hizo evidente, como esperaba, la imposibilidad de la existencia de este autor, Bellatin decidió continuar su historia y escribió una biografía imaginaria con documentos textuales, fotos y bibliografía sobre este autor japonés ficticio que concibió con un defecto físico congénito —un rasgo que comparte con él, puesto que nació sin el antebrazo derecho- y con la similar capacidad de incluir en sus obras lenguajes intraducibles. Al menos para quienes no tengan una nariz descomunal para la ficción.

Abordaré su historia centrándome particularmente en la relación que hay entre el texto y las fotografías que más allá del juego con su inserción en la realidad, funcionan como herramientas alternas para su deconstrucción. Lo meta-literario es aquí además meta-fotográfico. De hecho tomaré otros textos especulares sobre la relación entre literatura y fotografía provenientes particularmente de la primera parte de Pájaro Transparente, 2006, cuyos fragmentos reflejan la relación de deslizamientos que hay entre palabras e imágenes, ficción y realidad, en su obra. 


\section{Ficcionalizar el documento fotográfico, documentar la ficción literaria}

La frase con la que Mario Bellatin comienza la biografía apócrifa de Shiki Nagaoka es una anticipada reafirmación de su existencia real, aclarando que si ésta fue puesta en duda, fue justo a causa de su extraña nariz. De este modo, predispone al lector a aceptar cualquier grado de extrañeza, como posible o más aún, cierta: "Lo extraño del físico de Nagaoka Shiki, evidenciado en la presencia de una nariz descomunal, hizo que fuera considerado por muchos como un personaje de ficción" (11). De hecho, su hermana falsificará unas de las fotografías justamente para evitar que la existencia del escritor siga generando incredulidad. Anota Heather Cleary en este respecto:

Games are always a serious matter when they are played by the Mexican writer Mario Bellatin, whose particular brand of sport takes aim at the fine but carefully guarded line between fiction and reality (...).In other words, what we have here is a biography based on a fiction and supported by documentary evidence known to have been falsified but which is, nonetheless, the central character's last defense against being remembered as an invention. This elaborate play is all the more effective for its presentation in Bellatin's understated prose. Shook does an excellent job of preserving his crisp, deadpan delivery while still allowing the reader to sense the occasional smile twitch at the corners of his mouth. Shiki Nagaoka: A Nose for Fiction is not only a well-constructed metafictional diversion, but also an important new perspective on one of the most creative and controversial writers working today (Cleary).

El epígrafe que precede al texto remite a su vez a la explícita relación hipertextual con el relato La nariz del escritor japonés Ryūnosuke Akutagawa (1892-1927), conocido como el pionero del cuento corto en su país, y quien, antes de suicidarse con una dosis de barbitúricos a los 35 años, había enriquecido el modernismo en la literatura japonesa. Sus reconocidos relatos, como la versión que hizo del ladrón de Rashōmon basada en la literatura tradicional de su país, y La arboleda (llevada al cine en Rashōmon de Akira 
Kurosawa), suponían la práctica consciente de la escritura como palimpsesto que igual podía construir sobre los rastros de la literatura inglesa que enseñó - introdujo la poesía de William Butler Yeats en el Japón - o de milenarios textos de otros períodos de la literatura china y japonesa. Como sería natural en cualquiera de los personajes de Bellatin, su madre enloqueció después de su nacimiento. El fragmento que Bellatin usa como epígrafe y sobre todo como recurso para explicitar desde el inicio las cartas del juego hipertextual, donde lo que se vela es lo que escapa al lenguaje, se refiere a la paradójica actitud humana frente a la desgracia de los otros. Dice que ésta despierta compasión cuando es insuperable, pero en cambio, cuando se ha superado, suscita no sólo indiferencia sino el deseo inconsciente de que vuelva a cercar a quien la padeció.

En el relato de Akutagawa, un vanidoso sacerdote zen del período Heian de la historia del Japón (entre el siglo VIII y el siglo XII), vive obsesionado por la extrema longitud de su nariz hasta cuando halla un método para acortarla, pero entonces las preocupaciones mentales no cesan sino se acrecientan pues los demás creen que ahora luce peor. Bellatin comienza su relato poniendo en boca de las parteras que atienden el difícil parto de Shiki Nagaoka, la posibilidad de que ésta sea un castigo por el entusiasmo de su madre y de los de su clase frente a las tendencias modernistas de Japón. A lo largo del texto la nariz se va convirtiendo en rasgo metonímico de todo lo extranjerizante, lo extraño, lo que introduce un modo de descontinuidad con la tradición y define, en cierto modo, la otredad, también referida a cuanto está fuera de la normalidad y constituye por tanto una anomalía. Entre los 10 y los 20 años, Nagaoka escribe 800 relatos cortos sobre el tema de su nariz, si bien, aclara en un giro humorístico que seguramente evoca a Sterne, algunos eran de carácter erótico, también protagonizados por su nariz. El tópico 
de la relación entre pene y nariz que igualmente se encuentra en el Tristram Shandy es un divertimento que eligiera el peso de lo indecible que a cambio tensa el hilo de sus historias.

De este modo, con esa obsesiva escritura que regresa a la deformidad de su nariz, la narración de su infancia puede identificarse con la descripción que el autor hace del libro que Nagaoka escribirá muchos años después en una lengua de su invención: "Un bello ensayo sobre las relaciones entre la escritura y los defectos físicos ${ }^{221}$, y sobre cómo la literatura que de allí surge debe distanciarse de la realidad apelando al lenguaje, en este caso al no-lenguaje" (37), o a instancias de lenguaje que transgreden no sólo los registros habituales sino las estructuras de su confinamiento en determinados campos. El nolenguaje, lo indecible, está conectado a la necesidad de hallar sistemas de signos paralelos, formas de una traducción que parte de la noción bellatiana de que ninguna escritura es una transcripción originaria de lo que realmente sucede en el mundo humano.

El narrador señala algo crucial: Nagaoka escribía sus textos literarios en inglés o francés para luego pasarlos a su lengua materna como un modo de lograr que todo lo que saliera de su pluma pareciera una traducción. En su ensayo Tratado de la lengua vigilada logró poner por escrito las ideas que sustentaron ese ejercicio y afirma que "sólo por medio de la lectura de textos traducidos puede hacerse evidente la real esencia de lo literario que de ninguna manera está en el lenguaje". Sólo "haciendo circular los relatos de una caligrafía occidental a ideogramas tradicionales es posible conocer las verdaderas posibilidades artísticas de cualquier obra" (13). Lo que Shiki Nagaoka propone va incluso más allá: hacer circular estos alfabetos al lenguaje de la fotografía, para cercar, por decirlo de algún modo, lo indecible en cualquier medio. El presupuesto de todas estas operaciones es el 
aceptar que la traducción es, en última instancia, la condición de todo cuanto se escribe. No sólo ello, como apunta Rachel Weiss con relación al tema general de la traducción: “...also informs or underlies many of the processes by which art and culture are created and velidated, and through which they circulate in the word. In each act of reception there is a kind of translation (...)" (I).

Con otro tipo de humor, dice Bellatin: "Si consideramos La nariz, de Rynosuke Akutagawa, como un relato inspirado en la vida de nuestro autor, daremos como cierto que las plegarias que Shiki Nagaoka llevaba a la práctica varias horas seguidas satisfacían las expectativas de ciertos fieles...” (17). Así, invierte la relación hipertextual con el relato de Akutagawa de 1916, declarando como precedente la biografía apócrifa de Nagaoka publicada en 2002. El recurso una vez más establece un linaje que remite en apariencia a su propio conocimiento de la literatura de los escritores japoneses del siglo XX. Pero es indispensable comprender que en el diálogo que sostiene con estos ${ }^{222}$ ejercitando un placer similar al de auscultar en lo distante y lo distinto con el que varios autores japoneses se asomaron a la literatura occidental, no lo guía en absoluto el deseo de emular lo oriental, sino la intención consciente de situar en lo remoto geográfica, cultural, vitalmente la orilla de lo indecible, de lo abisal en la lengua. De ahí también la predilección por los escritores suicidas: Yukio Mishima, pero también César Moro han sido figuras en las cuales se ha desdoblado en sus novelas. Ya sea porque se balancean en el límite de la nada, y encarnan esa tensión entre la belleza y la muerte que tanto le interesa, o porque habiendo cruzado el último límite reaparecen en la obra de Bellatin como ocurre en su Álbum ilustrado de Mishima con el vacío de un miembro faltante (Yukio descabezado), con la consciencia de su propia incompletud que suele faltar 
habitualmente a los seres humanos, y que es casi imposible de nombrar. La convicción de que "the only thing real was a gaping void, An unfathomable and infinite space" (López Alfonso). Un vacío recurrente, disperso, que asalta todo, pero en el cual puede insertarse el propio vacío de las imágenes, quizás como un modo de dilación. En La condición de las flores Bellatin habla en algún momento de la búsqueda de "lo hindú" que puede compararse con el espacio de la imaginación distante que el África de Raymond Russel abrió para Marcel Duchamp. Al fin y al cabo, también Bird, el protagonista de Kenzaburo Oé, quiere irse a África para escribir sus propias Impresiones de África. Así que de lo que habla Bellatin es de un continente que flota sobre la imposibilidad del lenguaje y que reinventa lo africano, lo hindú o lo japonés ${ }^{223}$, mientras no logra fraguar otra lengua inimaginada.

Continuando con el nivel del juego hipertextual explícito, Bellatin evoca a Akutagawa. El narrador escribe: "Extrañamente, pese a ese aparente apego a las lenguas foráneas, Shiki Nagaoka en ningún momento dejó translucir en su trabajo la más mínima influencia de literaturas ajenas. En cada uno de sus textos fue extremadamente fiel a las líneas narrativas propias de su estirpe" (13). Akutagawa, ciertamente, enseñaba inglés, pero muchas de sus historias cortas, incluida Rashōmon, retomaban historias de piezas clásicas de los períodos Heian, Edo o Meiji e hizo kaikus que firmaba como Gaiki. Nagaoka por su parte, destruyó numerosos escritos que no le satisfacían y quiso emprender una versión "masculina" del famoso Genji Monogotari, la primera novela de la historia del mundo, escrita por Murasaki Shikibu (978-1014 o 1025), durante el período Heian, y hacer una versión nacional de En busca del tiempo perdido, obra que marcó tanto al poeta surrealista César Moro, también homosexual como Shiki Nagaoka, y 
cuyo espíritu evoca en esa atmósfera de irrealidad de Efecto de invernadero que corresponde a un capítulo de su biografía. ${ }^{224}$ No obstante, al darse cuenta de la semejanza entre su obra y la de Proust, Nagaoka casi enloquece y en el intento de quemar todo lo escrito provoca un incendio en las afueras del monasterio a donde ha decidido guarecerse pese a los propios deseos de su familia que aparentemente lo repudia por esta elección.

Dice el narrador que la nariz alcanza en el monasterio un tamaño tan descomunal que llega a sobrepasar su mentón. Y añade ingeniosamente: "Esos datos no deben ser ciertos, pues en las fotografías de madurez que se conservan del escritor se ve una nariz algo excepcional pero de ninguna manera poseedora de las características que se le atribuyen" (19). El tono redispone a aceptar la verosimilitud de la cierta existencia de Nagaoka y de su nariz. Entonces, el narrador pasa a contar los procedimientos a los que éste se somete para encogerla -como el protagonista de Akutagawa para recortarla—con detalles no sólo repugnantes sobre los procedimientos, sino francamente delirantes, pues en este punto llega a afirmar que si un criado no le sostenía la nariz, Nagaoka era incapaz de probar bocado. Finalmente, debido a un estornudo del niño que realiza tareas menores en el monasterio y que se había ofrecido a sostenerle la nariz para que pudiera comer, la nariz cae estruendosamente dentro del plato y el accidente provoca una catarsis que va más allá de la hilaridad generalizada: es una carnavalesca sucesión de burlas zaherientes por parte de los monjes que llevan 13 años ejercitando la templanza al contener el natural deseo de referirse a su risible defecto físico: "La escena era de una bufonada tal, que es difícil imaginarse a la víctima como el serio creador obsesionado por las relaciones entre el lenguaje, la fotografía y la literatura" (20). 
Shiki Nagaoka, que no cuenta ya con el ala protectora del monje que lo recibió y que incluso, apreciaba en él ese cierto impulso de unión mística, y llegó a fabricar aceites para su extraña nariz, se retira del monasterio de Ike-no-wo. Si bien Akutagawa, el escritor real, nunca buscó el refugio de un monasterio, éste es el escenario del protagonista de La nariz. Pero a diferencia de este autor y su personaje, el de Bellatin comienza a desarrollar un interés en la fotografía que se menciona de modo paralelo a su evocación homoerótica de un criado deforme y gordo con el cual solía retratarse, si bien, éste no sólo rechazaba sus continuos requerimientos, sino que se complació en sujetarlo a la humillación de una acusación pública, lo cual fue la verdadera razón del repudio familiar. La nostalgia por la imagen del sirviente se explica en la búsqueda de unidad, que no por sórdida es menos cierta. Nagaoka buscaba confundir en una sola imagen su nariz defectuosa con el cuerpo repulsivo del otro.

El narrador explica que la inclinación por lo fotográfico surgía del mismo interés por lo literario: "Consideraba un privilegio contar con imágenes visuales enteras que, de algún modo, reproducían al instante lo que las palabras y los ideogramas tardaban tanto en representar" (15). La idea del instante perfecto, sobre la cual edificó Cartier-Bresson su visión, funciona aquí como un substituto que ocupa el vacío de la misma imposibilidad del lenguaje. Si no llega a disiparlo, desplaza, como veremos, el propio procedimiento de la escritura, invirtiendo su génesis misma. En el caso de Bellatin el uso de las fotografías no es el de una ingeniosa ilustración que añade verosimilitud a la ficción literaria. Es un intento de traducción de lo indecible a otro lenguaje, y es también un ejercicio que desplaza la producción del hecho literario, del acto de contar, a la vertiginosa captación visual del instante que incluso puede llegar a preceder al mismo relato. 
En Pájaro transparente hay una serie de fragmentos reflejos que amplían esta

noción de la batalla entre el vacío y el lenguaje:

Esos narradores escribían desde el silencio, desde la carencia, desde la falta tanto en su acepción de vacío como de infracción- donde el lenguaje nunca es lo suficientemente escaso, tiene siempre demasiadas posibilidades, y eso es un problema irresoluble para expresar lo que se quiere comunicar: precisamente aquello que no se puede decir (...). Yo había detectado que existía una búsqueda constante de escribir sin escribir, de resaltar los vacíos, las omisiones, antes que las presencias. Quizá por eso el narrador de esos libros buscó muchas veces escribir sin necesidad de utilizar las palabras. Hizo uso de elementos propios de otros medios, tales como cámaras fotográficas o puestas en escena para seguir construyendo sus estructuras narrativas (109).

El caso es que tras haber sido expulsado del monasterio Nagaoka no vuelve a tocar en su escritura el tema de la nariz. Y es justo entonces —en 1933, precisa el narrador-, desde un afuera de esa relación entre defecto físico y escritura de la cual surge esa literatura que debe distanciarse de la realidad apelando a un no-lenguaje, cuando comienza su plena consagración a la afición popular de la fotografía e instala un kiosko para la venta de rollos y revelado. El desempeño en este oficio aminora la sensación de culpa que le provoca la escritura. Un sentimiento que su fiel hermana, Etsuko Nagaoka, atribuye al rechazo de los padres. En su nuevo oficio, Nagaoka concibe la idea de un libro cuyo tema se relacione "precisamente con el gran número de fotografías que vio pasar delante de sus ojos" (24), un procedimiento semejante al que el mismo Bellatin sugiere haber usado en Los fantasmas del masajista, 2009, y que Nagaoka justifica invocando los tankas. ${ }^{225}$ De modo paralelo a la búsqueda de estos por reunir la naturaleza circundante en "un todo artístico", lo que Nagaoka persigue es:

La creación de un compendio, abordando las imágenes que le ofrecía la naturaleza después de pasar por la mirada de una cámara. (...) Quizá por eso le llamó tanto la atención, cuando abandonó el monasterio después de trece años, la popularización de la técnica fotográfica. Le impresionó comprobar que algo tan misterioso y 
poseedor de tantas potencialidades narrativas, se hubiera convertido en una afición de uso doméstico (15).

De nuevo aquí, la noción de compendio, equivalente a sumario, a síntesis de una totalidad de elementos, se deposita en el carácter instantáneo de la mirada de la cámara, como atributo del mismo artefacto, sin que se le otorgue el carácter de un arte sólo creado por expertos, puesto que es un dispositivo de uso doméstico. Como en el legendario cuento de Julio Cortázar, Las babas del diablo lo que se nos revela es que la cámara ve que lo que el ojo no ve. En La condición de las flores escribe: “Atrisbando por el visor es como se descubren las verdades ocultas" (28). Y él mismo ha recurrido incluso a cámaras comercializadas para niños cuando se trata de fotografiar lo que no sólo son paratextos de sus novelas, sino anzuelos que pescan, viva, la criatura del instante y le hacen narrar. ${ }^{226}$

Un día, el escritor Tanizaki Junichiro (1886-1965) arriba al kiosko de Nagaoka con la intención de revelar unos rollos. Sin que Nagaoka conozca su oficio literario siente el deseo de espiar en la serie de fotografías de todo tipo de baños que según el narrador Junichiro ha hecho. ${ }^{227}$ La ausencia de este registro visual en la historia de la literatura y de la fotografía es suplida por Bellatin en los insertos fotográficos y, por otra parte, no es menos cierto que en su ensayo el Elogio de las sombras, Junichiro usa justamente minuciosas descripciones de baños para hablar del dilema entre la apertura a la cultura occidental jalonada por las promesas que hace un siglo planteaba la modernidad, y la preservación de la ancestral riqueza de las tradiciones propias. Lo definitivo de ese único encuentro entre Nagaoka y Tanizaki Junichiro es la confesión de este último de haber “descubierto en la fotografía un aliado que ya no podría abandonar” (25). Nagaoka infiere algo que marcará en adelante su relación con ambas artes: "La obsesión por aquellos 
baños y la profusión de detalles captados, tenían que ver con el uso de la foto como un elemento de manipulación de la realidad" (26). Este elemento, referido a la posibilidad de intervenir en lo real es justamente una declaración especular de la propia relación del autor, Mario Bellatin, con la posibilidad de ficcionalizar a través del dispositivo de la cámara la realidad, y a su vez otorgar a las ficciones literarias un perturbador registro documental que desestabiliza el propio orden de su naturaleza y su lugar de ubicación.

Durante la guerra, mientras pasa algún tiempo en un refugio antiaéreo, Nagaoka piensa en "las palabras y la necesidad de traducir los textos de una lengua a otra" (27). Se refiere a la lengua fotográfica. Pues la necesidad de esa "traducción" surge cuando está sintiendo nostalgia, más que por la presencia de un sirviente gordo y deforme con el cual se retrataba antes de que éste denunciara públicamente que era objeto de sus proposiciones sexuales, por las imágenes de ambos, tal y como quedaron registrados en las fotografías (antes del macabro asesinato del delator, que al final se revela fraguado por Nagaoka). Esa forma de memoria de "aquellos que ven", para usar la expresión de Mieke Bal, y en la que reposa, en un sentido más amplio la mediación de quien sostiene la mirada de los eventos, se extiende en las fotografías que acompañan el libro de un modo que supone un desplazamiento de la focalización interna —el Nagaoka que rememora esas fotos, por ejemplo- a la focalización externa que surge en las fotos donde es retratado. El punto de vista desde el cual son vistos los elementos de la narración no es el de Nagaoka sino el del narrador-fotógrafo o compilador de imágenes que provoca una memoria concebida como un acto de visión del pasado, pero que como acto se sitúa en la memoria del presente y supone el acto narrativo de hacer converger los elementos en una historia (Mielke Bal 46-47). Pero esa historia tiene justamente ese otro 
correlativo visual y por tanto puede ser recordada desde el espejo alterado que son las fotografías y puede ser contada dos veces. Las fotografías en las que Nagaoki se mira a sí mismo en el relato guardan una correlación con el estadio del espejo lacaniano porque le dan una visión de una totalidad de sí mismo y del otro que es incluso más ficticia de lo habitual porque ha sido justamente él quien ha ordenado su muerte. No obstante, cuando lo vemos mirándose mirar al otro (que ha destruido) y evocarlo en la nostalgia de una unidad casi idílica comprendemos de modo más fuerte la ficción de la mirada, en el espejo de la fotografía. Es revelador cotejar esta noción focalizadora con el título No. 50 de los Cien mil libros de Mario Bellatin es este: Las líneas de expresión que aparecían en el rostro de un retrato que le tomó a su abuela. O con el libro No. 99 que lo complementa: La presencia en su vida de la abuela fotografiada es uno de los recuerdos agradables que guarda de sí mismo. Ese modo de alcanzar al otro que inventamos en un tiempo pasado es a fin de cuentas un retrato de la propia imagen, y a través del ejercicio narrativo que desatan las fotografías puede multiplicar los espejos en la escritura misma.

En la posguerra, Shiki Nagaoka publica el libro Fotos y palabras, traducido al inglés y al español por las prestigiosas editoriales Life y Espasa-Calpe. Según comenta el narrador, este "canto a la reconstrucción de un país", hecho a partir de semblanzas cotidianas que logran "mostrar casi de una forma global a su pequeña sociedad" influyó al "renombrado cineasta Ozu Kenzó quien habría usado su estética para la filmación de su famosa película Tarde de otoño" (28). Aunque el director sea inexistente, la invocación del recurso de autoridad, mezclado con referencias reales, hace deslizar la obra de Shiki Nagaoka hacia el terreno de la realidad, pero más que como recuento de lo sucedido, como introducción en un modo de visión alterna. De hecho, según el narrador, 
la influencia mundial de Fotos y palabras, se extiende hasta México, donde marca nada menos que a la extraordinaria obra fotográfica de Juan Rulfo (1917-1986). Quien quiera que haya contemplado sus imágenes puede atestiguar el poder de su poética del silencio en la inmensidad del paisaje, o en la conjunción de elementos tan dispares e inseparables como la piedra y la luz en la arquitectura mexicana; pero también escuchar, desde esa mirada, las inaudibles voces de la tierra jaliciense donde hablaban interminablemente Susana San Juan y los demás muertos.

Por supuesto, la cita que Bellatin atribuye a una carta fechada de Rulfo en 1952 y enviada a José María Arguedas (1911-1969), en la que éste le confiesa el influjo que ha ejercido Nagaoka sobre él es obviamente apócrifa, pero revela el propio magma que han dejado las imágenes de Rulfo en el inventor de Nagaoka. Según narra, en esa misma carta le anuncia además a Arguedas la aparición de una novela extensa y "totalizante" (de nuevo la mención a esa aspiración) que consolidará definitivamente su pensamiento, si bien para lograrla requiere la mediación de la fotografía. Es decir que, ateniéndonos a las fechas, atribuye a las fotografías de Nagaoka, realizadas a partir de 1933 según la novela (pero ejecutadas en parte por Bellatin hacia 2008), el paso decisivo que le permite a Rulfo finalizar los relatos de El llano en llamas, que fueron publicados en 1953, y su novela definitiva, Pedro Páramo, que salió a la luz en 1955. Lo cierto es que Rulfo tomaba fotos de manera paralela a la escritura de sus textos, desde 1930, y ya en 1949 había publicado una docena de imágenes en la revista América, donde colaboraba.

Un archivo de miles de negativos conforma el poderoso legado visual de Rulfo que se suma a la tradición de uno de los países donde ha existido ciertamente un linaje fotográfico perfectamente reconstruible y compartido por creadores que junto con Rulfo 
sintieron profunda afinidad por las imágenes de Henri Cartier-Bersson. Es un linaje no de influencias sino de aprendizajes personales, directos, pasados mano a mano, que se remonta a 1923 —el año en que Edward Weston y Tina Modotti descubren el paisaje alucinante de México, donde ella se "reinventa como fotógrafa" y no sólo se convierte en una aprendiz que lo anticipa en la realización de los primeras naturalezas muertas, sino que años más tarde hará algunas de las fotografías más poderosas de la épica de comienzos de siglo, hasta cuando deja su cámara e implementos fotográficos en manos de otro aprendiz, Manuel Álvarez Bravo. Mario Bellatin escribe un texto alucinante sobre la obra de la penúltima aprendiz: Graciela Iturbide, ${ }^{228}$ quien a su vez recibió el legado directo de Álvarez Bravo, casado con Lola quien bajo su guía llegó a ser también otra asombrosa fotógrafa. En "Un texto para Graciela Iturbide. Para la serie Juchitan", Bellatin la retrata formando con sus manos el visor de una cámara en una sesión de fotos en la que ella jamás oprime el obturador, porque la mirada que sostiene sobre el mundo es la operación esencial y por eso puede ser la fotógrafa soñada capaz de que una mujer fotografiada retoque, en lugar suyo, la foto imaginaria que le tomó. Y es Graciela también la fotógrafa en la que Bellatin deposita el único archivo fotográfico del ave de plumaje blanco y celeste y dientes que crecen incesantemente en su pico, atormentándolo por las caries de las que nadie se ocupa, pero que no le impiden ser feliz.

La mención del proverbialmente silencioso Rulfo se extiende al diario íntimo de Arguedas, también escritor suicida y a quien el narrador atribuye otra cita espejo de su afición por la mirada de la cámara: “...poder ver la realidad modificada, no sólo por el lente del fotógrafo sino por la palabra escrita que acompaña estas imágenes, es un camino que potencia infinitamente las posibilidades narrativas de la propia realidad" (30). Así 
que estamos en un territorio donde las palabras "acompañan" a las imágenes y la realidad ha sido modificada por el encuadre que la somete a una selección. Una operación que funciona de un modo paralelo a la que cumplía Marcel Duchamp al escoger un objeto con indiferencia, de tal modo que no siendo arte en sí, gracias a la mediación de la mirada acababa siendo introducido en el sistema artístico.

Bellatin asegura que tanto Shiki Nagaoka, quien muere atracado por unos drogadictos que asaltan el kiosko, como Arguedas, quien se suicida "por sentirse incapacitado para colocar en palabras la angustia que lo atenazaba tanto a él como a su sociedad entera", y el mismo Rulfo, quien se apaga "en medio de la depresión motivada por no poder crear una obra de carácter totalizante" (37) sostienen una idea acerca del poder de la fotografía. Los tres coinciden, sin lugar a dudas con el narrador, en que "la fotografía narrativa intenta realmente establecer un nuevo tipo de medio alterno a la palabra escrita y quizá aquella sea la forma en que sean concebidos los libros en el futuro" (30). Una literatura que apela al no-lenguaje (verbal) y que sin duda es un modo más de comunicar lo incomunicable. "Eso" que expresa en el libro fundamental que Shiki Nagaoka escribió y que "lamentablemente no existe en ninguna lengua conocida" (32). Así que si en el ejercicio que realiza de la ficción extrema, lo determinante, por encima de las estrategias de deslizamiento de la ficción en la realidad es el capturar la "ficcionalidad" de lo real, estamos ante un modo de traspasar creativamente, desde ese engarzamiento de la cámara y el texto, el límite doble de la inestabilidad de la mirada y la incomunicabilidad del lenguaje. Es justamente a partir del libro Fotos y palabras de Shiki Nagaoka y de su Diario póstumo, publicado por su hermana, que surgieron los 
nagaokistas, quienes creen que Nagaoka hizo algunas fotografías que de cierta manera buscaban ilustrar sus teorías sobre la imagen y las palabras.

Se dice que se trataba de instantáneas en blanco y negro donde, sobre un fondo brumoso, flotaban algunas letras y ciertos caracteres orientales. La niebla de los fondos de las imágenes parecía tener como fin demostrar que las letras y los caracteres habían aparecido de la nada, como convocados por una asociación natural de los objetos (35).

A su vez cierto escritor mexicano que pasa tiempo recluido en Tezpotlán ha hallado la clave del libro intraducible de Nagaoka que habla de la necesidad de escribir sobre la realidad partiendo de un no-lenguaje, y de la importancia de traducir y retraducir los textos (40). Esta noción, ya mencionada, es una condición que parte de que todo lenguaje es un modo de traducir aquello inaccesible que hay en el mundo humano. Una traducción que es un ejercicio de deconstrucción de la escritura a partir de la conjugación con otros modos de lenguaje.

La noción se entronca con los enunciados que planteó Nicolas Borriaud en su Manifiesto de la altermodernidad. Situando el advenimiento de una cultura altermoderna en el contexto de la era de la globalización habla de la emergencia de:

Un nuevo universalismo basado en traducciones, subtitulado y un doblaje generalizado (...) El arte de hoy explora los vínculos que texto e imagen, tiempo y espacio entretejen entre sí mismos. Los artistas están respondiendo a una nueva percepción globalizada. Atraviesan un paisaje cultural saturado con signos y crean nuevos patrones entre múltiples formatos de expresión y comunicación (Borriaud).

Esa exploración de los vínculos entre texto e imagen, tiempo y espacio, que se cumple en un deambular en un nuevo paisaje cultural, remite justamente a los ejercicios de la ficción extrema, que no son solamente un divertimento, sino, como se advierte en 
Bellatin, un modo alterno de tocar la realidad, de comunicar sus fragmentos, y, en última instancia, de expandir sus posibilidades.

Siguiendo las estrategias de las que se vale la ficción extrema, Bellatin no sólo alaba la fidelidad de la hermana de Nagaoka, quien "se empeñó hasta el final en rescatar la figura de su hermano de las garras de las leyes de la ficción en las que insistentemente parece querer ser enmarcado este personaje" (38), sino incluye un listado de los libros de Nagaoka: Monogatarutsis de juventud, Tratado de la lengua vigilada, Fotos y palabras y Diario póstumo, y otro, complementario, de las obras de estudio sobre Shiki Nagaoka, que reseña siguiendo la metodología del caso. Menciona así las "Conclusiones del I Seminario de Nagaokistas. París, 1999”, junto con un título Literatura japonesa de posguerra, atribuido al gran experto en el tema, el académico norteamericano nacido en Japón Donald Keene, y quien finalmente renunció a su ciudadanía americana para pasar los últimos años de su vida en su isla natal. Incluye el libro apócrifo de Etsuko Nagaoka, Shiki Nagaoka: el escritor pegado a una nariz, y finalmente una revisión del existente crítico mexicano Pablo Soler Frost. Además, el narrador sostiene que Ximena Berecochea -ensayista autora de Presencia ausente. Juan Rulfo Fotógrafo- está realizando la recuperación iconográfica de Nagaoka.

A estas obras citadas que hábilmente combinan referencias apócrifas y reales fraguadas con la astucia exigida para su verosimilitud se suman una serie de documentaciones que conforman un archivo de consulta cuya función aparente es reforzar la prueba de la existencia de Nagaoka, empeñándose en arrancarlo de las garras de la ficción. Podemos clasificar estos materiales así: 
- Documentos literarios y fotografías de diversos autores: documento de la expulsión de Shiki Nagaoka del monasterio, libro Fotos y palabras; comentario aparecido en el diario de circulación nacional; crítica de Tomonoma-shimpo sobre el libro Tratado de la lengua vigilada; textos de arrepentimiento por sus inclinaciones modernizantes, de los artistas del Mundo Flotante redactados después de la guerra; reparto de la película Tarde de otoño del director Ozu Kenzó; libro de Etsuko Nagaoka, Shiki Nagaoka: el escritor pegado a una nariz; fragmentos rescatados de la hoguera que Shiki Nagaoka hizo con sus manuscritos; inserción en el diario local donde se da cuenta del repudio familiar hacia Shiki Nagaoka por abrazar la vida religiosa; símbolo con el que se conoce el libro intraducible de Shiki Nagaoka; grabados populares que se hicieron a partir de las denuncias del sirviente; fotos tomadas por los clientes del kiosco que Shiki Nagaoka nunca entregó a sus propietarios, fotos tomadas por Tanizaki Junichiro.

- Retratos: fotografías de Zenchi Fukuda y Zenchi Sachiko, padres de Shiki Nagaoka (el pie de foto destaca la modernidad de las costumbres en el uso de guantes y lentes del padre, y el labial que lleva la madre); retrato de Nagaoka en la graduación de la quinta promoción de la escuela de lenguas extranjeras Lord Byron; fotografía de Shiki Nagaoka manipulada por su hermana, Etsuko, con el fin de evitar que el autor fuera considerado un personaje de ficción; fotografía de Nagaoka y el joven sirviente que lo denunció ante las autoridades del cantón; figura póstuma del prior Takematsu-Akai, reverenciada especialmente en la zona montañosa del país; foto de la nieta de Etsuko sosteniendo el Diario póstumo de su tío abuelo, Shiki Nagaoka; fieles que se acercaban al monasterio para depositar sus votos a Shiki Nagaoka. 
- Espacios arquitectónicos: Edificio donde se reúnen los Nagaokistas en el Barrio Latino de París, aspecto del templo budista de Ike-no-wo, estudio en Tepoztlán del autor mexicano que aventuró una teoría sobre el libro indescifrable; parque ubicado en el Barrio de la Nariz donde se encuentra la tumba de Shiki Nagaoka.

- Paisajes: Foto de la península de Ikeno, canal que cruza el monasterio budista de Ike-no-wo; bosque alrededor del monasterio que corrió peligro de ser incendiado.

- Objetos de ambientación: Detalles de las obras de arte de los padres de Shiki Nagaoka, donde se resaltan las cualidades propias de una nariz.

- Herramientas asociadas al cuidado de la nariz: aparato para escribir sin ser molestado por la nariz; copa donde el prior Takematsu-Akai guardaba los aceites de su invención; cuenco que contenía el agua hervida necesaria para el tratamiento de la nariz; pinzas y vaso preparado para recibir la grasa eliminada por medio del tratamiento; espejo que usó Shiki Nagaoka para apreciar los resultados experimentados en su nariz.

- Otros objetos personales del autor: Caja donde se guardaban las ropas que le servían a Shiki Nagaoka para hacerse pasar por su hermano gemelo, ropa para este disfraz, calzado que el autor se colocó a diario para ir a trabajar al kiosco fotográfico, vajilla que utilizó Shiki Nagaoka en la casa donde pasó sus últimos años.

Pero más allá de este "loable" empeño, calificado así por el narrador cuando lo refiere a Etsuko, las fotografías flotan sobre lo indecible, puesto que de lo que tratan las fotos y palabras de Mario Bellatin es del afán por abarcar una totalidad inasible recurriendo al proceso de traducción entre dos lenguajes de naturaleza diversa. En uno de los incontables textos engañosos (y no obstante ciertos en los niveles más profundos de la psiquis) que Mario Bellatin ha escrito, el ensayo De cómo conocí a Aldo Chaparro, 
atribuye a este reconocido artista contemporáneo que tuvo entre sus proyectos, la construcción de objeto artístico que reemplazaría el antebrazo que le falta a Bellatin ${ }^{229}$, uno de los ejes esenciales de su propia creación. Su oficio, dice, ha consistido en "colocar un universo terrible por delante, como una suerte de protección contra el horror que ese mismo mundo iba estableciendo" (Herrera, A-cercamiento a Bellatin).

\section{Otros fragmentos especulares de la relación entre no-lenguaje y la mirada de la cámara}

En un texto donde Mario Bellatin sintetiza lo que podría ser el espacio visual de la "mansión de la literatura" escribe que la imagina con techos altos, paredes oscuras, sin ninguna decoración inútil. Allí empujaría a las sombras todo cuanto se destaca de manera excesiva. Sintetizar la escritura de Bellatin es una tarea casi imposible porque nada sobra en su lenguaje.

Me remito a un grupo diverso de experiencias que iluminan otros modos de relación entre la escritura de Bellatin y la fotografía. Su inserción en la obra puede ocurrir en un rango que varía desde la potencialidad cifrada en la sola mención de una fotógrafa en un paratexto de la obra, como ocurre con la escueta dedicatoria de Canon perpetuo a la fotógrafa peruana Alicia Benavides, ${ }^{230}$ hasta la incorporación visual de todo un grupo de fotografías tomadas por él mismo, que funcionan como extensión del límite del lenguaje verbal, como traducción a otro lenguaje, que puede a su vez derivar en el performance, y permanecer en una suerte de estado de suspensión hasta que un nuevo lanzamiento del libro provoque algún acto artístico-teatral. En relación con la historia de “nuestra mujer”, protagonista de Cánon perpetuo sólo quiero apuntar que ella pierde el lenguaje en el intento de volver a escuchar el sonido de su voz cuando era niña. Así que 
la dedicatoria del relato que desemboca en el no lenguaje, sólo el balbucear asombrado a quien realizó algunos de los retratos fotográficos más poderosos de Julio Ramón Ribeyro.

Junto al fotógrafo Jean Marc Bustamante (n.1952) hizo un libro objeto que consistía en una edición de veinte ejemplares con fotos originales del autor de una serie de "casas mudas, sin ninguna característica particular que pudiera estandarizar las intenciones del fotógrafo" (Pájaro transparente 123). Y vio en esas imágenes que no parecían comunicar nada un espacio perfecto para insomnes: "Diseñadas para poder construir en la noches una realidad paralela regida por reglas propias, que no son ni las del sueño ni las de la vigilia”. Entonces, recordó un ejercicio anterior en el que había intentado reconstruir la metamorfosis, utilizando las mismas palabras que había empleado Kafka, pero eludiendo la anécdota de la transformación. El resultado era el relato de alguien que no puede conciliar el sueño y experimenta, alterados sus sentidos hasta llegar a una percepción deformada. Por eso, acompañó las imágenes de casas para insomnes con aquel texto, "que al mismo tiempo que intentaba ser fiel a Kafka, estaba totalmente transformado" (Bellatin Pájaro transparente 123). El ejercicio supone la evocación de un texto ya escrito que reaparece a partir de la neutralidad de una imagen fotográfica y provoca una narración en la que lo visual y lo textual se intersectan.

Otro proyecto que forma parte del proyecto Toluca Editions ${ }^{231}$ en el que un fotógrafo y un escritor construyen una visión que se presenta en un diseño creado particularmente para esa íntima colaboración fue el que Bellatin realizó a partir de las fotografías que tomó en la morgue Andrés Serrano (n.1950), uno de esos artistas a los que el signo de la transgresión se les ha adherido al punto en que se convierte en una vestidura impuesta de la que no logran despojarse. ${ }^{232}$ Eran imágenes de la conocida serie 
que Serrano tomó en la morgue en $1992,{ }^{233}$ pero que habían sido autocensuradas y sólo accedió a imprimirlas puesto que en el proyecto la edición de las imágenes proscritas sería limitadísima. Dice Bellatin que ante estas imágenes sólo pudo construir un grupo de textos de carácter infantil. Los editores describen así el contenido del proyecto que conformó el volúmen 9:

Mario Bellatin describes a miniature form of humanity seen through the magnifying glass of a chiropodist, a menace that carries with it the threat of death from which the characters vainly attempt to escape. The last of the five tales ends with the pendulum swing of a woman's body in long black skirts, dangling in mid-air. The five photographs by Andres Serrano are part of the emblematic series entitled Morgues from 1992 (...). In each of the five fragments, the text spreads out over fake anatomical parts and the typography chosen for the title incorporates elements from surgery such as the blades of a scalpel and bone fragments... (Toluca Editions).

Si en el caso del diálogo con las imágenes innombrables de Serrano, el texto es posterior a estas fotografías que no son suyas, en Los fantasmas del masajista, Bellatin incluye una serie de fotografias probablemente propias pues no se les atribuye autoría alguna, aunque ciertas imágenes, como la del loro, son fotos de imágenes encontradas. En este texto Bellatin escribe con su alfabeto de silencios encabalgados a las palabras, intentando dar espacio al dolor humano, a la sensación de que nadie puede hacer nada para extinguirlo, salvo abrir interregnos de alivio siempre circundados por lo inexorable. La llamada del vacío se traduce al final en una foto que bien podría ser de un álbum turístico pero que apunta al anticipado e inaudible grito del vértigo cubriendo todo el innecesario ruido de la existencia. Como lectora y conociendo los recursos del autor, tengo la sensación de que estas fotos antecedieron al texto y que aquí ha cumplido su idea de lo que pueden ser los procedimientos de la escritura del futuro. Me atengo a uno de los títulos enumerados en los Cien libros de Mario Bellatin: 81- "Coloco las fotos ampliadas 
sobre mi mesa de trabajo con la esperanza de que surja una escritura a partir del orden que impone lo visual”.

Pero los editores sugieren otra posibilidad no menos interesante: la continuidad y, a un tiempo, la reescritura de la historia de Los fantasmas del masajista, a partir del recomienzo que impone la presencia de las fotografías:

Los límites del cuerpo, su destino, después de la muerte, el sentido de cada existencia, atraviesan una narración intensa y lacónica, que al final vuelve a comenzar, pero esta vez con fotografías, suerte de fantasmas de una escritura infinita, que desafían lo escrito, dislocan cada encuadre y extreman la ficción (Bellatin, Los fantasmas del masajista).

Algunas de estas fotografías, que ciertamente extreman la ficción, como Espacio para las camillas individuales, son borrosas, una decisión estética que se aviene bien a la verosimilitud, pues la imprecisión permite ajustar la imaginación a la posibilidad de la existencia de lo descrito, y los pie de fotos, tan poéticos como imprecisos — por ejemplo, Lugar perfecto para saltar al vacio — se protegen así: no pueden ser contradecidos. Hay también nítidas fotografías de calles, como Punto de la ciudad donde comenzaron a instalarse los karaokes, y retratos: la espalda de un hombre en ropa interior sentado en un lugar, que se convierte en la espalda del protagonista, João, en el sueño relatado o Una de las mujeres de edad madura que acostumbran acudir vestidas de muchachas a las fiestas populares. Algunas fotografías, como la anterior, son a colores, y si bien su autoría no se aclara en ningún momento, se asemejan a los registros documentales urbanos que toma Bellatin mientras deambula, en bicicleta, por las calles del D.F. Contienen el humor, la mordacidad, el registro de lo increíblemente ridícula que puede ser la realidad o de los ingeniosos juegos verbales resultantes de un encuadre. La fotografía en blanco y negro de un altivo hombre joven de perfil se titula Hombre que 
todavia guarda la ilusión de considerarse completo. La dedicatoria del libro es un paratexto que puede revelar más sobre su concepción: está dedicado a Vivi Tellas, directora de teatro experimental y curadora, que trabaja en la noción duchampiana de teatro encontrado con no actores, y quien dirigió una versión fragmentaria de La casa de Bernarda Alba, de Federico García Lorca, en colaboración con el artista argentino Guillermo Kuitca. Tellas organiza talleres de biodrama donde invita a directores/as experimentados a trabajar, como el mismo relato de Bellatin lo hace, con historias propias o familiares, archivos fotográficos, y con todo aquel material de la vida diaria que el participante considere como una 'evidencia' de teatralidad. En los talleres se usan cartas, escritos encontrados, relatos que se repiten, distintas versiones de una misma historia, fotos o cualquier otro hallazgo (Tellas). La idea de ready-made se traslada a la realidad entera como depósito infinito de materiales encontrados que el encuadre de la mirada traslada a otro ámbito.

El proceso de la relación entre fotos y palabras en Perros héroes ha sido descrito por el mismo Bellatin quien narra que respondió a un anuncio de periódico donde se ofrecían perros malinois entrenados. Al acudir a la cita descubrió que el entrenador era un hombre inmóvil que ayudado por un enfermero demostraba cómo podría anticipar la conducta de los animales entrenados. Por algún error, Bellatin fue mordido y escribió la experiencia sin regresar hasta cuando había ya entregado al texto al editor. Entonces tuvo el impulso de volver para constatar la diferencia entre esa realidad y su relato.

Con mucho asombro advertí que en el texto se encontraba retratada esa realidad hasta en sus mínimos aspectos. Volví con una cámara de fotos e hice algunas imágenes al azar. Cuando las vi me di cuenta de que la ficción que expresaban esas fotos, supuestamente sacadas estrictamente de la realidad, era perfecta. 
Decidí por eso incluirlas en el libro y hacerlas pasar como verdaderas instalaciones (Pájaro transparente 113).

Luego, no contento con insertar las fotografías a modo de instalaciones en el libro, acordó con algunos directores de teatro que anunciaran la puesta en escena del libro con el nombre de Bellatin en cartelera. La presentación no se realizó nunca de modo que los estrenos pasaron como si sólo se hubieran realizado en un día, pero entraron a formar parte del pasado. Narra Bellatin:

Un reconocido crítico de teatro, quien participaba en la idea, publicó en una importante revista sus comentarios acerca de las diferentes obras. Según su texto había estado presente en simultáneo en todos los estrenos. Se creó entonces la ilusión de que se había llevado a cabo una obra que buscaba remarcar las característica principal del personaje, la inmovilidad, para lo cual nos servíamos de un grupo de perros adiestrados para que se quedaran inmóviles sobre unos pedestales en actitudes de amenaza hacia el público (Pájaro transparente 114).

Cuando la editorial presentó el libro, se anunció que habría una reconstrucción de la obra para quienes se la habían perdido. La lectura se hizo en una antigua iglesia del siglo XVI, y el montaje se hizo a través de la lectura. Bellatin le dio una orden a un perro malinois de saltar sobre el altar y quedarse estático mientras el texto se leía. ${ }^{234}$ Si lo fotográfico no pertenece tanto al orden del registro — razón por la cual imagina a Graciela Iturbide haciendo fotografías sin oprimir el obturador-, el texto a su vez es el registro de una mirada que puede velar el límite entre ficción y realidad también a través de ejercicios que están situados después o antes de la escritura en sí.

Otro ejercicio, según lo narró el mismo Bellatin en una entrevista:

En el último tiempo he escrito unos libros pequeños donde aparece un yo constante, fortísimo, insoportable, que hizo posible un nuevo libro que se llamará El gran vidrio. Trata de tres episodios autobiográficos, que se titulan "La piel luminosa", "La verdadera enfermedad de la Sheika" y "Yo era un personaje moderno". Es un libro que busca lo más personal de uno, que son los sueños, donde ni siquiera interviene la conciencia para elegir el tema. Para separar un 
texto de otro hay una serie de fotos conmigo: foto busto, foto perfil, etcétera. Y con eso se acabó esta búsqueda de mi voz, que en el fondo también es falsa, porque con El gran vidrio me burlo de la biografía al colocar situaciones totalmente imposibles. En un relato soy una niña que se convierte en marioneta y tiene una novia alemana y luego tiene 50 años y después vuelve a ser niña (Herrera, A-cercamiento)

¿Un ejercicio de ficción extrema?”, le pregunté en esa misma entrevista y me dijo, sin titubear, una frase muy cercana a la que atribuyó al diario póstumo de Arguedas: "La extrema ficción que parece muy alejada de la realidad, se convierte en el único modo —cuando todos los demás están gastados — de modificarla”.

\section{La ineludible cuestión de los dobles}

La noción de identidades dobles o múltiples se remonta a tradiciones tan antiguas como diversas — basta pensar en lo que media del dopelgänger germánico y al doble en la mitología egipcia o escandinava - pero resurge como una constante, como una suerte de significativa coincidencia, en los deslizamientos del arte y la literatura o viceversa que expanden el campo de la ficción extrema ${ }^{235}$. En el caso de Bellatin, por una parte, como advierte Francisco J. López Alfonso, se percibe en textos como La escuela del dolor humano.

The constant shifts in narrator, a complexity to which is assed the fact that these narrators in turn are characters who shift identities, as assortment of different, yet identical ones. The chaos begins to dissolve when, among the different stories, it becomes possible to recognize the story that functions as a frame: it's the one about the boy with the prosthetic arm... (24).

Por otra parte, más allá de sus desdoblamientos de narrador, o de su incesante modo de cotejar la obra en diálogo con su propia vida (Obra reunida 29), es preciso citar un evento paradigmático que supone un desplazamiento de ese diálogo entre obra y vida, a su intervención, a modo de performance artístico, en el cual el escritor deconstruyó la 
mirada habitual sobre la relación entre autor y texto desde lo cotidiano asumido como espacio para el performance. ${ }^{236}$

El relato de esta intervención, aparecido en diversos textos, como Pájaro Transparente, reaparece en el segundo volumen de su Obra reunida, en el capítulo “Escribir sin escribir”, bajo el subtítulo "Lo raro es ser un escritor raro". Podría llamarse “De cómo organicé un congreso de dobles". Precisa en la introducción que se ha dado un relieve excesivo a la presencia del autor y sus circunstancias y que fue como parte de su indagación entre esta presencia y el texto que aceptó ser curador de una muestra de arte asumiendo que actuaría como autor y la muestra resultante sería la obra. Así surgió un congreso de escritores que esta vez no estarían físicamente presentes: en lugar suyo, estarían representados por dobles, entrenados para llevar sólo sus ideas, de tal modo que el curador, por su parte, podría "constatar lo que ocurría con los textos una vez que estuvieran huérfanos de sus autores" (9). En ese sentido el focalizador, el punto desde el cual, siguiendo a Mieke Bal, ${ }^{237}$ son vistos los demás elementos, sería en principio el propio Bellatin, pero desde luego, el mismo proceso era un acto narrativo pues configuraba una historia que podría ser recordada desde tantos puntos de vista como participantes y eventualmente contada.

Los dobles pasaron un período en una "tensa convivencia con el autor" parafraseando a Vila-Matas, todo con el fin de aprender de memoria diez textos que repitieron al público en una sala de París. A su vez, Bellatin documentó sus encuentros fotográficamente. Como era de esperarse, el día de la inauguración, los profesores europeos que se habían desplazado desde otras ciudades para conocer en persona a determinados autores mexicanos, o que estaban investigándolos, no pudieron menos que 
quejarse. En lugar de Sergio Pitol, aparecía una mujer joven que ofrecía sus libros, sostenía por lo menos una decena de consideraciones y opiniones del autor y podía referir en su lugar alguna anécdota de vida. Lo mismo, un hombre bastante mayor podía aparecer en lugar de Jorge Volpi, escritor nacido en 1968, como la mayoría de sus compañeros del movimiento Crack. Si bien los dobles estaban autorizados por los originales para re-presentarlos, la audiencia se sintió defraudada. Faltaba el rostro que buscaban. Escribe Bellatin:

Me pareció importante esa queja, la de la ausencia de los cuerpos de los escritores programados. De allí surgía la pregunta de qué era lo que realmente se espera del evento literario. Si son ideas, como se supone, se encontraban éstas presentes. Allí estaban los cuarenta temas fundamentales en ese momento para los verdaderos autores. El congreso de dobles me despejó algunas dudas. Entre otras, pude comprobar la importancia real que adquirían esos textos cuando eran dejados a merced de sus propias reglas, sujetos sólo a las instrucciones de uso que habían proporcionado los creadores para su difusión (Obra reunida 212)

En cierto modo, cumplió así el propósito — paralelo al de Duchamp de hacer un arte que no fuera arte - de escribir sin escribir, y encontró, más allá de la escritura, por fuera del espacio narratológico de sus textos, un medio para desplazar hacia otro registro el tema de la presencia del autor. En ese evento, paradójicamente, la distancia entre el escritor y el narrador de sus libros que busca infatigablemente usar otros medios como cámaras fotográficas o puestas en escena para extender sus estructuras narrativas es casi indistinguible.

Por otra parte, en sus propias apariciones en público por escritor, a partir de la idea del vacío, del cual nace su escritura, y que de hecho ha fotografiado en imágenes que transmiten su propia imposibilidad - como ocurre con la idea de traspasar el vacío de una pierna faltante a un orificio en una estructura circular de cemento - fragua un modo 
de performance en torno a su presentación. Prepara una serie de diapositivas que toma de la realidad inmediata, incluyendo láminas escolares, o imágenes de baja resolución tomadas de Internet que fotografía y graba su voz de manera casera. Durante la presentación reproduce el sonido de su voz y pasa silenciosamente las imágenes proyectadas en una conjunción que es aleatoria, posiblemente disruptiva, pero que al tiempo puede construir infinidad de líneas de opciones narrativas que aparece y se dispersan, pero pueden provocar experiencias alternas en los observadores.

Yo permanezco mudo y ausente. Tratando de que el universo tan peculiar que van creando estas imágenes enfrentadas con el texto operen en los espectadores. Constato entonces que de esa forma lo dicho adquiere una dimensión de la que carece el texto si es dicho de la manera tradicional (...) el elemento que más me interesa de ese tipo de intervenciones es la aparición del azar para modificar siempre las intenciones iniciales (Obra reunida 221).

El autor, focalizador, provoca una visión, y el receptor construye algo otro frente a lo que Duchamp habría llamado el azar en conserva. De este modo, Bellatin puede deslizarse hacia el campo de la fotografía en una serie de posibilidades multiplicadas respecto al texto que a su vez inciden en este: puede configurar una prueba de existencia, más que de la ficción en sí, de lo que ésta contiene de indecible; puede construir con las imágenes la opción de un relato paralelo, como continuación que ejerce una función disruptiva en el texto; o puede explorar simultáneamente la posibilidad de crear textos partiendo de imágenes que anteceden, desatan y en definitiva alteran el acto textual de narrar.

Es posible que entre las criaturas que transitan en sus textos, además del ave de rarísimas características, la más semejante a un doble de Bellatin, o al menos la que se acerca más a la posibilidad de decir desde el silencio y la desaparición, lo que el autor 
intenta nombrar no sólo con la palabra sino con todos los juegos que invocan deslizamientos a otros lenguajes, sea el extraño insecto del cuento Bola negra: una criatura única que acaba devorándose a sí misma de tal modo que el entomólogo que la ha hallado y que la transporta cuidadosamente no puede dar más prueba de la forma extraordinaria de su existencia que una residual bola negra.

Si lo que importa es abrir una mirada de las cosas que no pretende en absoluto ser estable sino por el contrario, hacer parpadear la realidad, esa mirada puede surgir de un desplazamiento que elige las imágenes escogidas dentro de modos variables de azar como desencadenantes de un proceso de escritura que no necesariamente llega a ser transcrito en el papel. De un modo paralelo a las vanguardias que buscaron hace un siglo pintar sin pintar, Mario Bellatin busca formas de escribir sin escribir, o más bien de una suerte de escritura extendida que puede entrar en juego con imágenes que no son ilustraciones de una narración verbal, sino ventanas que agolpan una multiplicidad de miradas, o que incluso puede transformarse en performance artístico en el que explora, desde otro lenguaje, esa posibilidad siempre esquiva de la desaparición del autor.

Lo que Mario Bellatin ha conseguido es una suerte de maestría en el tránsito que realiza guiado por reglas propias, en el vasto espacio de ficción paralelo $\mathrm{a}-\mathrm{o}$ ¿intersectado con? - la realidad, algo que, según él mismo, no sólo puede hallarse en los libros y en el arte, sino en los espacios religiosos, en los cuartos oscuros, en los estados exaltados, en las casas de terror de los campos feriales (La condición de las flores 9), o, de nuevo, en esa coherencia entre esa manera rara de pensar su obra literaria que lo lleva a vivirla extendiendo la experiencia de la escritura hacia otras artes hasta extraviarse en las fronteras que las separan. 
Esa construcción de universos literarios con pasadizos abiertos a otras artes y capaces de desafiar el límite entre ficción y realidad que suponen no sólo otro entendimiento sino posibilidades para reinventar o subvertir las relaciones con la realidad. Algo que, como lo comprendió perfectamente el narrador que cuenta la historia de su apócrifo escritor favorito, Shiki Nagaoka tiene una implicación extrema: "Ver la realidad modificada es potenciar infinitamente sus posibilidades". La cita completa, posiblemente apócrifa, proviene de una frase atribuida a una fuente cuyo enunciado ya es en sí un oxímoron: el Diario póstumo de José María Arguedas:

Poder ver la realidad modificada no sólo por el lente del fotógrafo sino por la palabra escrita que acompaña estas imágenes, es un camino que potencia infinitamente las posibilidades narrativas de la propia realidad (30).

$\mathrm{Y}$, sin embargo, contiene como nítido reflejo en el espejo, la imagen de esa totalidad que persigue entre fotos y palabras, dispersos en los fragmentos de biografías alternativas y de textos que se rehacen o cambian de lugar incesantemente. No encuentro mejor cierre sobre esta aproximación a la intención que articula imágenes y palabras, que un fragmento de su ensayo "Escribir sin escribir" publicado en Obra reunida 2:

Lo más impresionante de determinado proceso de escritura es que después de levantar fronteras para todo, de crear una serie de sistemas que permiten entender el mundo como una gran maquinaria, se advierte que no existe ningún límite. Es ése el punto donde se abren todas las posibilidades, y no queda otro recurso sino el de cobijarse bajo un orden trascendente. Esto puede estar cercano a la experiencia mística, en la que después de una serie de privaciones y luchas contra la libertad individual se encuentra el infinito.... (11).

\section{Una inmersión vertiginosa en otros casos de ficción extrema}

Ruben Torres Llorca: One Of Us Can Be Wrong And Other Essays fue el título de la exhibición en 2012 de este artista cubano con el cual empieza Luis Camnitzer su libro 
New Art of Cuba, un clásico publicado en 1994, que describió su incidencia y la de otros artistas de esa generación formada por la Revolución de 1959, que participaron en la díscola exhibición Volúmen I y marcaron el salto hacia el arte contemporáneo que se dio a comienzos de los ochentas.

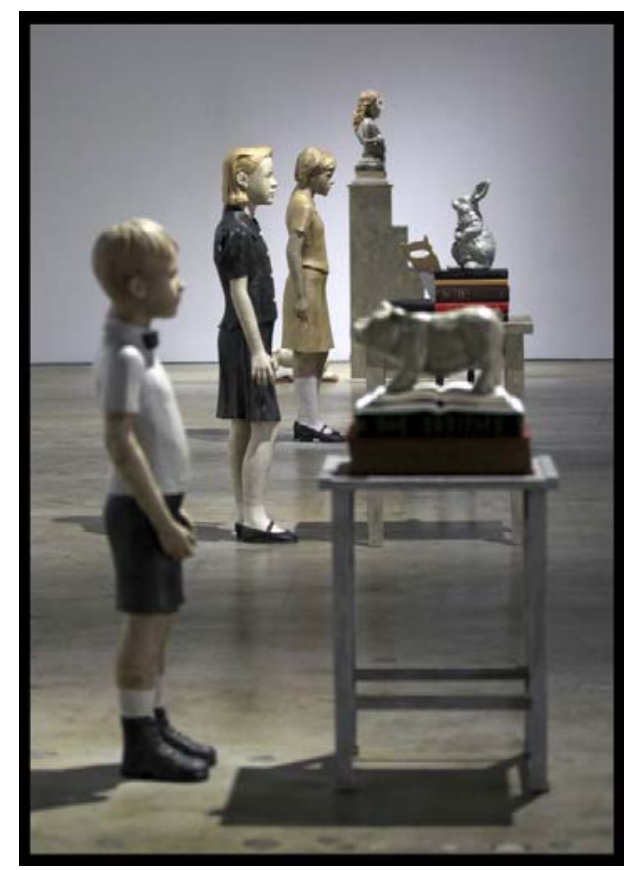

Ilustración 105: Rubén Torres Llorca: Detalle de la exhibición One of Us Can Be Wrong 2012

La exhibición, cuyo título incluye la alusión a un género literario como el ensayo, fue anunciada en estos términos:

A solo show that takes the continuity of 'hypertextual' mediums and plays in the work by Rubén Torres Llorca to new frontiers. For the first time in his installations, Torres Llorca introduces life-size sculptures of human figures as well as pages of cherished texts as a tribute to Julio Cortázar, who continued to depict the streets of dream cities until shortly before his death and could not ultimately witness the extinction of political imagination (Miami Art Guides).

Como Duchamp, que no recurría tanto a la relación hipertextual con el arte como con la literatura, Torres Llorca alimentó su obra desde la adolescencia con referencias fílmicas y literarias, a menudo apócrifas, en un libre juego de apropiaciones y 
atribuciones que saquean los imaginarios de la cultura, desde la Alicia de Lewis Carrol, hasta las ficciones cortazarianas, desvalijando por igual a Borges y a Bioy Casares, o a la revista Time en una libre configuración que acaba por dibujar el mapa de un mundo incierto.

Pero para entender el valor de lo apócrifo es clave remontarse a su descubrimiento de lo apócrifo, en La Habana de fines de los setentas, cuando tanto Borges como Bioy Casares (o como el mismo José Lezama Lima) eran autores cubiertos por el silencio. Torres Llorca cree que las Ruinas circulares fue el único cuento de Borges que se publicó en la Cuba de su juventud. Por las consabidas razones de su orientación política era mal visto leerlo, pero esa generación formada en la Revolución desconfiaba tanto de los héroes impuestos, como de las razones que pesaban sobre los condenados a algún modo de ostracismo. "No teníamos 20 años pero estábamos en contacto con intelectuales y escritores que hablaban de Bioy Casares y de Borges y te pasaban ediciones tempranas de la Argentina. En Cuba el tiempo sobraba y leíamos" (Herrera, entrevista personal). De hecho, aún conserva, en Miami, a donde llegó en esa desbandada que siguió al Período Especial que comenzó con la caída del Muro de Berlín, una edición de 1957, exactamente el año de su nacimiento, de la antología Cuentos breves y extraordinarios de Borges y Bioy Casares, publicada por la editorial Losada de Buenos Aires. Sin Internet, leyendo furtivamente a Borges, había ya descubierto, con una mezcla de asombro y celebración la posibilidad de usar el conocimiento para hacer trampas a la memoria histórica. Evoca que fue buscando alguna de las numerosas referencias borgianas a Tomás de Quincey que comprendió la naturaleza de los juegos apócrifos, y a partir de ahí, su obra tendió a 
aventurarse en lugares desde los cuales es posible asaltar las autorías, las fronteras entre campos, e incluso entre lo representado y lo real.

Primero comenzó a utilizar en sus obras apropiaciones literarias sin mencionar la autoría, como fue el caso del verso del español Pere Gimferrer (n.1945):

El hombre decapitado de la escultura "Si pierdo la memoria, qué pureza" (1982), título tomado de un poema de Pere Gimferrer [a quien no cita], formó parte de una exhibición individual que se llamó El hombre incompleto, y que constituía una desarticulación de la idea del hombre del futuro, el hombre socialista. De-construía así la parafernalia de los actos patrióticos públicos con un busto martirizado: la cabeza está sobre un pedestal, pero lleva una corona de espinas en la frente -el crucificado- $-y$ detrás ondea una tela roja con las letras amarillas típicas de la bandera comunista (Herrera, Paradojas del arte cubano 4).

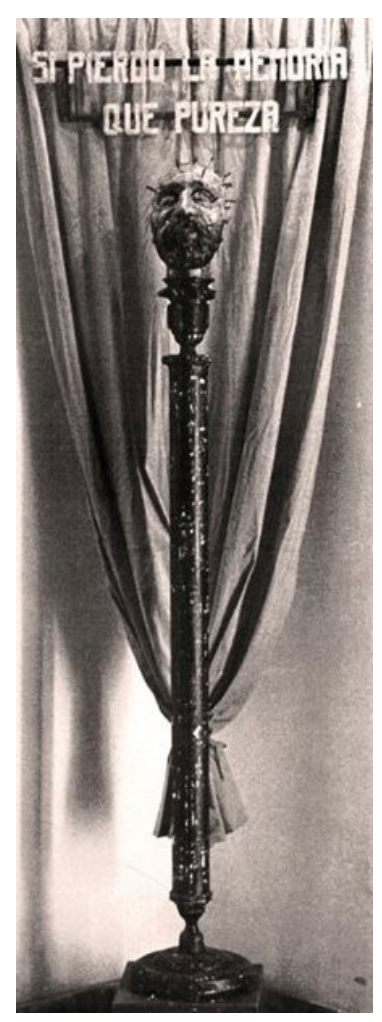

Ilustración 106: Rubén Torres Llorca, Si pierdo la Memoria qué pureza 1982

Además de la transposición del título literario a una obra de arte, ha insertado historias completas tomadas de la antología de los cuentos breves en 
piezas de arte que no funcionan como instalaciones literales, que desbordan la noción de la ilustración e incluso de la recreación unívoca en otro lenguaje del universo contenido en un relato de máxima concentración. No estamos solamente ante las relaciones del arte y la literatura que se remontan a la práctica del écfrasis y que alteraran el orden habitual de esta posibilidad al realizar la representación visual de una representación verbal. ${ }^{238}$ Lejos de la representación literal de los elementos narrativos contenidos en la historia, nos asomamos a un vasto juego de asociaciones que van desde lo afectivo hasta lo filosófico y que incluyen múltiples referencias literarias y culturales a menudo entrecruzadas. Por ejemplo, realiza un comentario paródico de la competencia en el mercado del arte parafraseando una frase del cuento de hadas de "Blanca Nieves y los siete enanitos" en una instalación de esculturas donde la figura de la Alicia de Carroll sostiene un animal muerto y el conejo de las horas se ha duplicado en dos inútiles guardianes: dos conejos también muertos: "Mirror mirror on the wall: Who is the fairest artist of them all?".

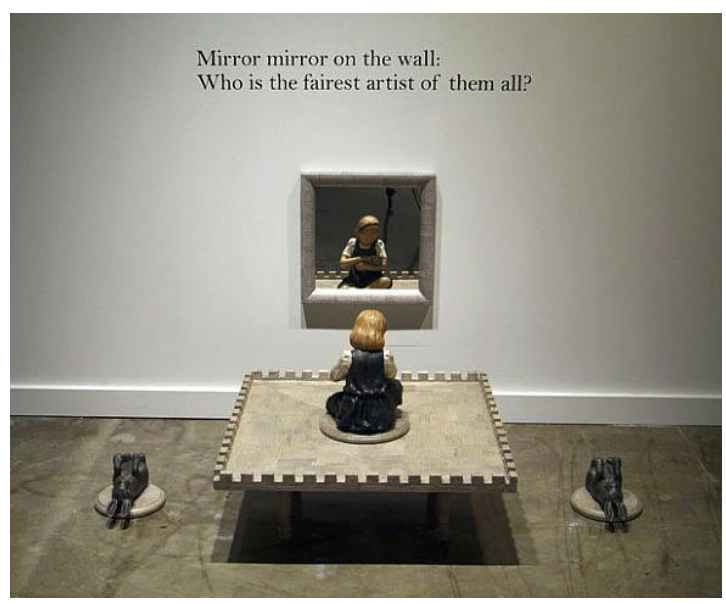

Ilustración 107: Rubén Torres Llorca, Mirror mirror on the Wall Medio mixto, 2012 
Ha reproducido, enteros, relatos cortos tomados de la mencionada antología, porque contienen en unas líneas todos los elementos estructurales de una historia, como el que podía leerse en la pared de una instalación de sus instalaciones en el Frost Art Museum, Rubén Torres Llorca. Easy to build, curada por Elizabeth Cerejido: "Una dama de calidad se enamoró con tanto frenesí de un predicador puritano que rogó a su marido que le permitiera usar de la cama para procrear un ángel o un santo; pero, concedida la venia, el parto fue normal". Otros cuentos kafkianos de pocas líneas han reaparecido en contextos diversos.

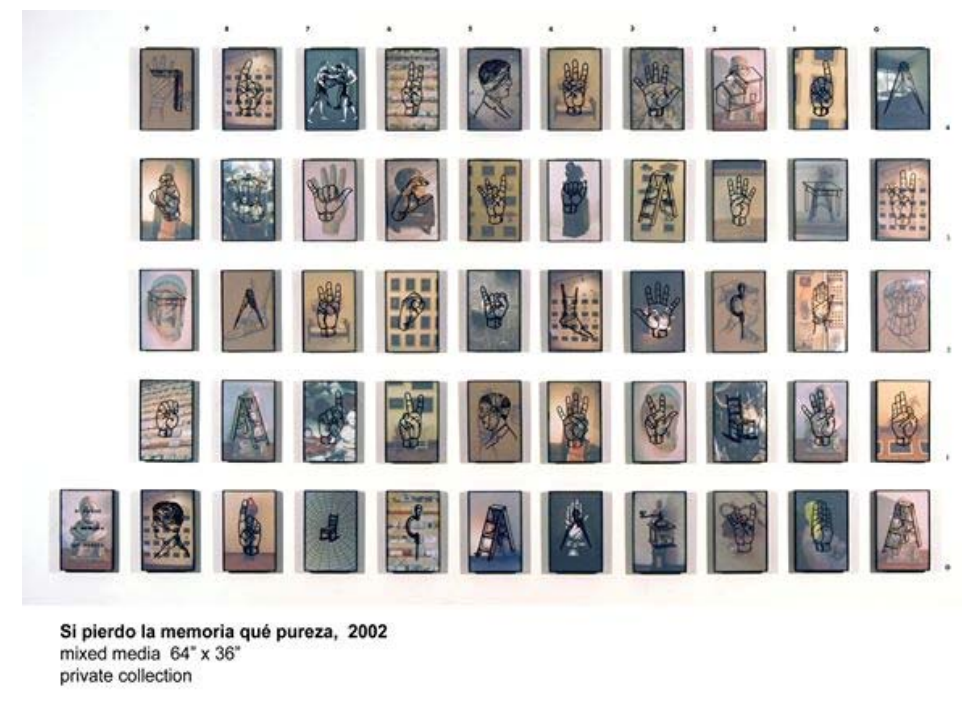

Ilustración 108: Rubén Torres Lloca, Si pierdo la memoria qué pureza 2002

La relación de deslizamientos del arte en la literatura surge por un modo de acercamiento que tiene el potencial de arrojar nuevas miradas que alteran incluso el sentido del relato al transformar el contexto en el cual se inscribe. Lo mismo ocurre con la frase de Dylan Thomas: "Make me a Mask" o con el título de la obra de Charles 
Bukowski What Matters Most is How Well You Walk Through the Fire. Esas frases le resultan icónicas, en sí mismas.

Creo que en Borges hubo siempre la osadía de la irreverencia culta: yo tengo en mí, la biblioteca más vasta, por tanto yo puedo jugar con todo. Al apropiarte la obra sin nombrar al autor, de algún modo, asumes la autoría (Herrera, entrevista personal).

Pero sus acercamientos visuales introducen incesantemente variables sobre la constante de la repetición que resulta clave en el artista que escribe y crea obras diversas que se titulan Todas las noches regreso.

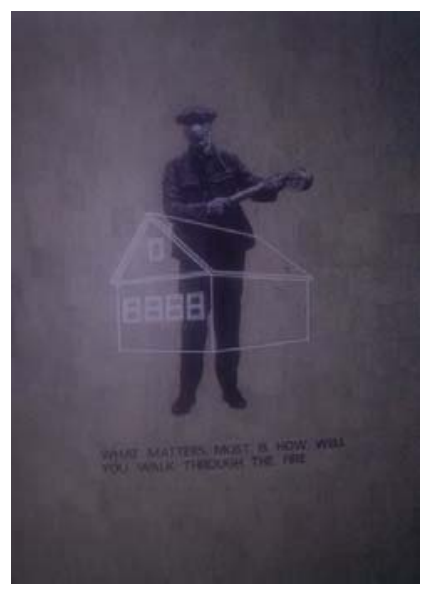

Ilustración 109. Rubén Torres Llorca, What Matters Most is how Well you Walk through the Fire, s.f.

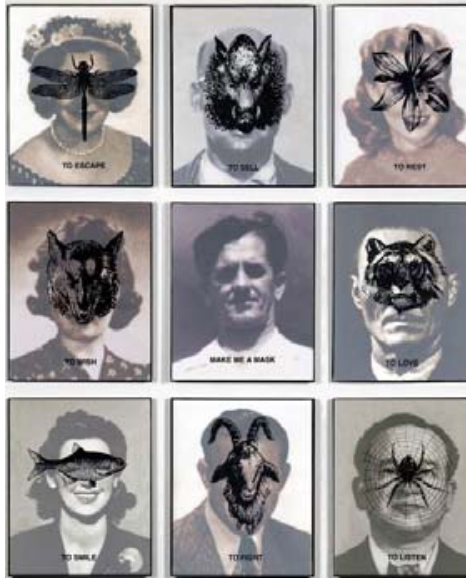

Ilustración 110: Rubén Torres Llorca, Make me a Mask. 2005, Medio Mixto

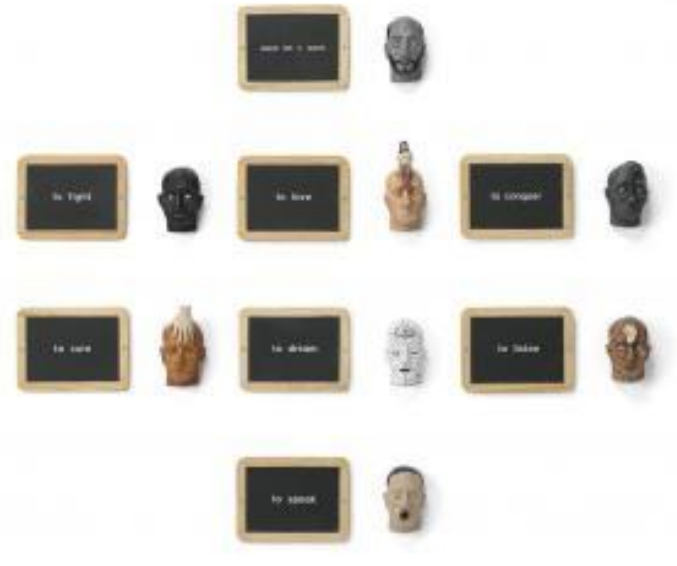

Ilustración 111: Rubén Torres Llorca, Make me a Mask 1996, Instalación con 16 elementos. 
Mandred Pfister comprende estos juegos hipertextuales que incluyen tanto el archivo de los textos como el de las imágenes, y que, como sabemos, abren la puerta no sólo a lo reflexivo sino a lo apócrifo y a los deslizamientos en la realidad o al borronamiento entre lo que es o no ficción:

La noción misma de un archivo de textos re-utilizados, re-performados, re-ciclados, a través de los siglos, está endeudada con las teorías de la intertextualidad, como lo está también la noción de la cultural, no como un texto estético, sino como una performance, y re-performance de sus textos e imágenes fundacionales (12).

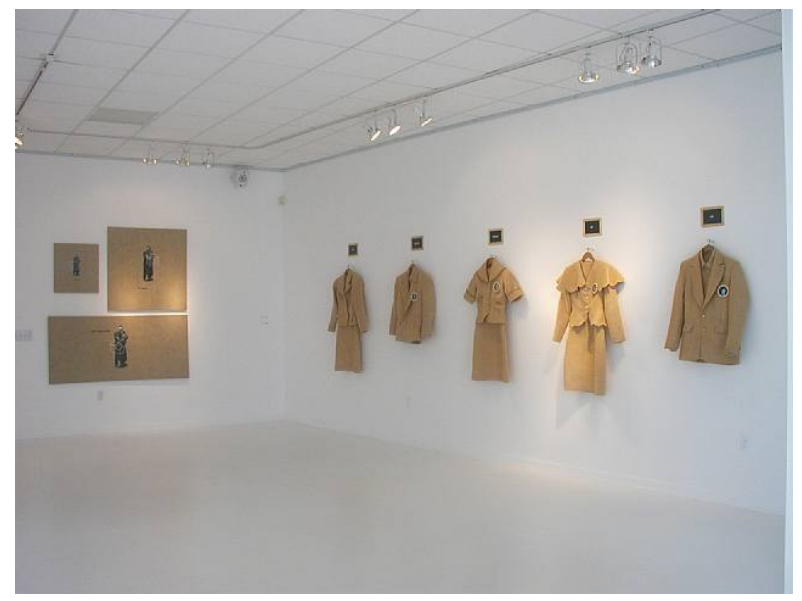

Ilustración 112: Rubén Torres Llorca. Panorama colección privada.

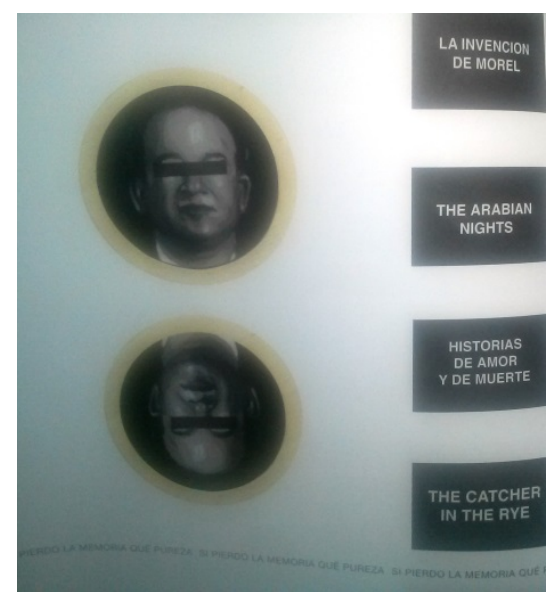

Ilustración 113: Página del catálogo Rubén Torres Llorca. Modelo para armar. Frost Art Museum, 2006 
Torres Llorca reconoce que la influencia decisiva, lo que le transfirió una claridad que a partir de ahí marcaría el tránsito de sus apropiaciones fue la lectura de Pierre Mennard, autor del Quijote: la libertad de jugar con las mismas apropiaciones intertextuales que pueden aparecer en obras distintas construidas también en tiempos diversos. La idea de cometer un crimen ficticio, de saquear fuentes de otros campos y mezclarlas a su antojo y de demostrar cómo se transforma la misma frase en un contexto diferente, está conectada a la relación de la posibilidad de subvertir los significados, los discursos, de traficar en lo oculto con un material precioso — como aquél ejemplar de Borges y Bioy Casares - y de minar los diversos sistemas de códigos. A menudo, las apropiaciones desembocan en obras de arte que contienen en alguna medida la atmósfera del cine noir (su conocimiento paralelo del cine clásico es vastísimo) hasta apuntar, finalmente, al abismo de la historia escrita como otra ficción: las fronteras últimas de los juegos hipertextuales que cumplen una función especular sobre la sociedad. Una pieza de Torres Llorca puede combinar una frase de Bertold Bretch - “QQué delito es robar un banco, en comparación con fundarlo?"- con un retrato de un actor de los años dorados del cine norteamericano y luego reaparecer en otro contexto, sin mencionar la fuente. 


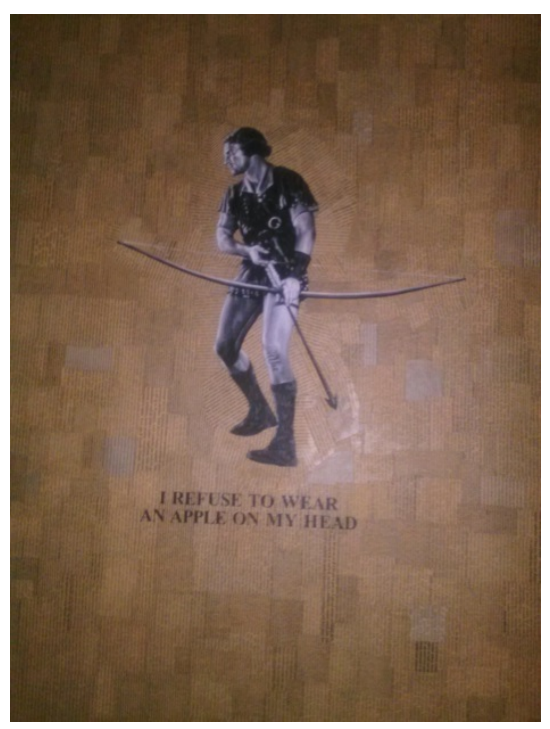

Ilustración 114: Rubén Torres

Llorca: I refuse to Wear an Appleon my Head 2004, medio mixto

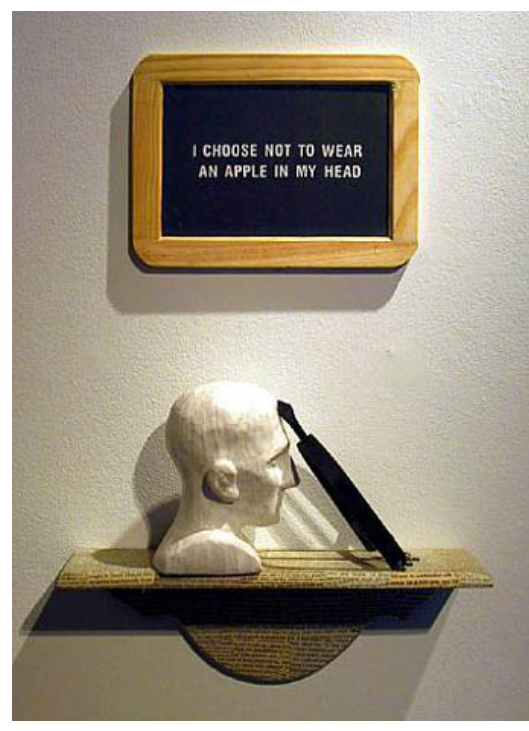

Ilustración 134: Rubén Torres Llorca: I Choose Not to Wear an Apple in My Head 2004, Medio mixto

Pero también puede atribuirles apócrifamente a determinados escritores frases que podrían haber pronunciado, dado su estilo, su modo de construir imágenes o visiones, pero que son en realidad suyas: corresponden a usa visión. Como sostenía Marcel Proust, el estilo de un escritor o el color de una pintura no es una cuestión de técnica sino de visión. De este modo, puede usar en una pieza la frase: "Hansel and Grethel are lost in the wood. End of the story", atribuido a Patricia Highsmith, o: "Is Not Love if They Pay You For It", a Boris Vian y luego buscar el acercamiento a la obra visual, con la convicción de que la obra surge de la intersección y por tanto, varía sus posibilidades de sentido en la medida en que cualquiera de los elementos cambian. Al fin y al cabo, más que jugar con las apropiaciones de una cita literal lo que toma, asegura, es "el modus operandis, el código" (Herrera, entrevista personal). A partir de este juego produce prácticas artísticas que multiplican las aristas interpretativas y que legitiman los juegos apócrifos, su carácter nómade y sus diversas impugnaciones. 
Estamos frente a una obra hecha en la última frontera del desencanto donde sólo queda el placer de los juegos de la creación, el rescoldo de un horizonte que se evoca a partir de la hipertextualidad con otras artes, cine o literatura, en una suerte de género mixto que encara con refinada capacidad intelectual y con innegable habilidad artesanal, el agotamiento y la privación, no sólo de las grandes narrativas que derivaron en pesadillas, sino de ese mucho más sutil 'Caballo de Troya' que es el juego omnipotente del mercado. Torres Llorca, quien tituló justamente una obra anterior así - con una figura que también escogió Lucy Lippard en un ensayo sobre arte activista y poder- es uno de los artistas más capaces de crear una meta-narrativa sobre la relación entre el arte y la historia política de un tiempo controlado por el omnipotente mercado (...) El arte deviene en una suerte de ficción policíaca, en la constatación de una culpabilidad que en cierto modo remite al poder, y particularmente a los grandes vendedores de las ficciones históricas, pero no menos a la corrosión de los vínculos en un sistema global donde la impostura agrieta por igual los mundos privados (Herrera, Rubén Torres Llorca, Artefactos 6).

En una obra de 2012, titulada "Final de juego", usó literalmente las páginas de Julio Cortázar y las intervino, alterando el orden material, como si fuera una puesta en escena de la sugerencia para el lector hecha en Rayuela, pero a la vez, convirtiéndolas en una instalación artística, en un objeto que contenía a su vez la huella de sus manos, sus dibujos. La obra señala, de modo especular, cómo cada obra suya contiene un artefacto para desarmar, al menos mental-mente, la articulación de un tiempo sin salidas históricas. La propia libertad de creación sugiere, de modo consecuente con la visión de Cortázar, la posibilidad de establecer órdenes alternos: una función de "arte-facto" imaginativo para transitar por la realidad. 


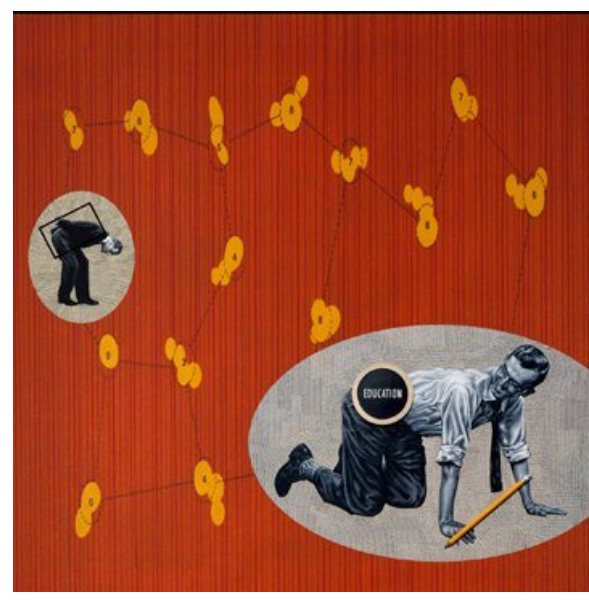

Ilustración 115: Rubén Torres Llorca: Keep Moving Like a Shark 2002, Medio mixto

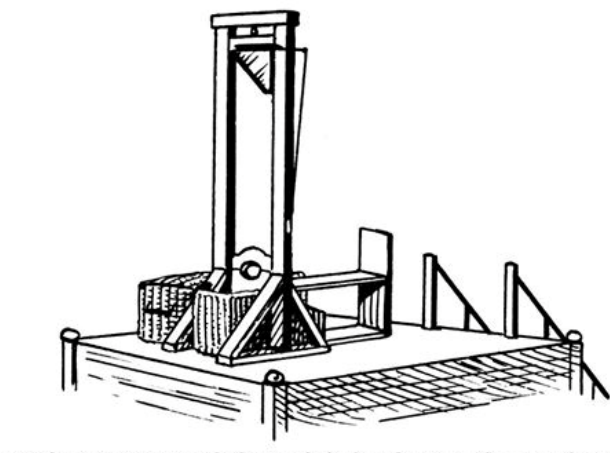

WORK IN PROGRESS / ESTA ES TU OBRA

Ilustración 116: Rubén Torres Llorca: Work in Progress/Esta es tu obra

Una variante de las libertades extremas de lo apócrifo han sido las recientes obras que Rubén Torres Llorca publica en los nuevos medios como si se tratara de cuadros, esculturas e instalaciones de grandes dimensiones que en realidad construye ya como reproducciones, apropiándose de obras anteriores, mezclándolas, alterando las fechas, en un vasto juego de referencias análogo al uso de la libertad de reutilización de las propias ficciones que hace Mario Bellatin, haciendo móviles los relatos, los títulos, las escenas, con la convicción de que basta la ficción que supone su existencia virtual para darles múltiples y alternos modos de existencia. 


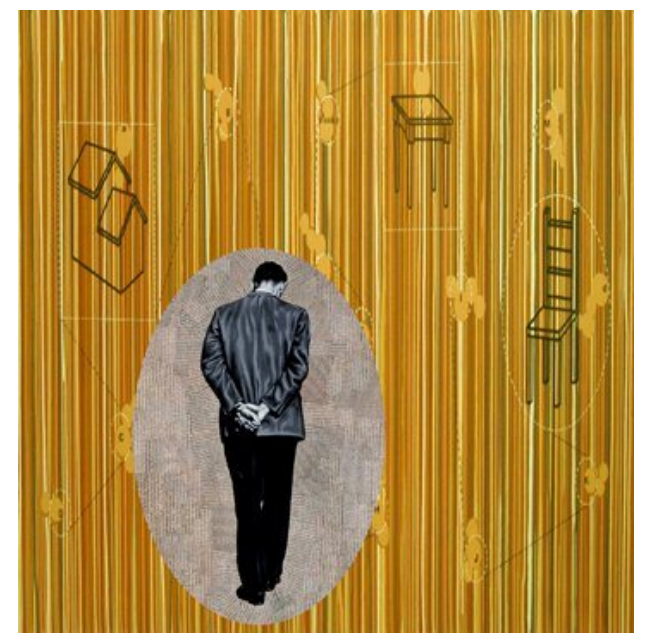

Ilustración 117: Rubén Torres Llorca: Better Days Ahead 2001, Medio mixto.

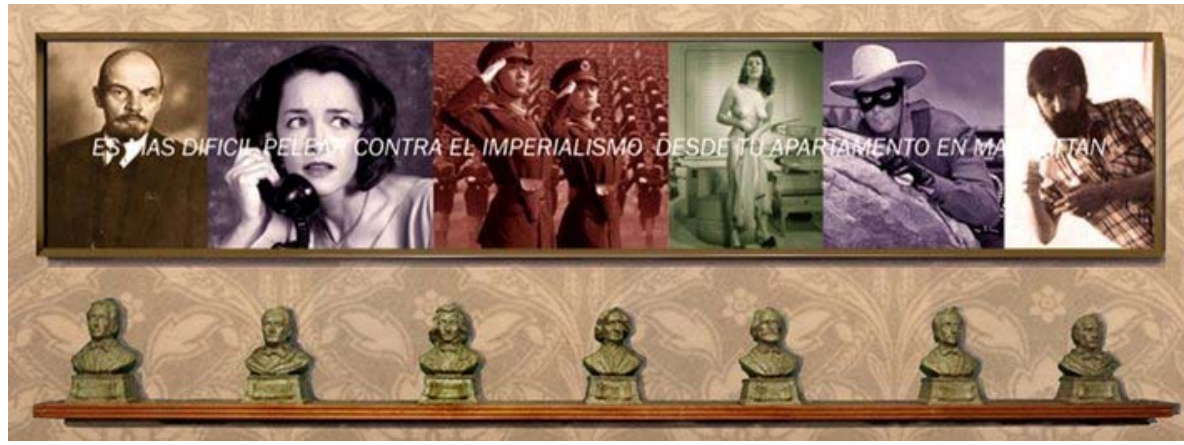

Ilustración 118: Rubén Torres Llorca: Es más dificil pelear contra el imperialismo desde tu apartamento en Manhattan,

1994, Media mixta

Carlos Amorales (n. 1970), uno de los artistas mexicanos más reconocidos de su generación, es idóneo para hablar de las prácticas artísticas que rebasan el mundo del arte para insertarse de un modo insólito en diversos campos o redes sociales, con un efecto que aún está por entenderse. Néstor García Canclini y Graciela Speranza han recurrido a su obra, vasta, compleja, lúdica, lúcida, demoledora, para aproximarse al modo en que se está construyendo un cambio de consecuencias imprevisibles, que incluye la práctica que yo designo como ficción extrema y que el primero ubica en el territorio de una sociedad 
sin grandes relatos donde el arte acrecienta su interacción con otros reinos, y que la segunda describe en su Atlas portátil de América Latina. El tipo de movilidad que caracteriza su obra tiene que ver con la constante transgresión de fronteras -entre realidad y ficción, entre afirmación y desvanecimiento de la identidad, entre lo popular y lo culto, arte, disqueras, literatura y cine- que él se encarga de borrar, casi siempre, a través de la suplantación o de formas de desdoblamientos. Cuando trasplanta sus obras del territorio de la ficción al de la realidad, lo hace de tal modo que se mimetizan con esta última, funcionan "como si" fueran lo que pretenden ser.

De hecho, su original apellido construido con una simple A. que resuena con el signo del anarquismo estético que encarna, y que antepone al muy común Morales, es señal de un tipo de identidad que se superpuso al nombre con que figura en los registros civiles, ${ }^{239}$ y comenzó a tener un reconocimiento mundial con el performance de un enmascarado protagonista de la lucha libre que desplazó las fronteras entre las ficciones artísticas y el mundo del entretenimiento popular con la creación de un carácter que se insertó en la realidad. En uno de sus viajes a México, mientras estudiaba en Amsterdam, adquirió una máscara y comenzó a ensayar su desdoblamiento y el de otros en este personaje. Luego, dejó un doble suyo en Ámsterdam, donde estudiaba arte, como parte de su proyecto de graduación -Gabriel Lester, un escritor y cineasta que convino con él asumir el personaje del luchador Amorales- y se vino a México dispuesto a apropiarse de los secretos del mundo de la lucha libre.

La idea de la máscara surgió porque buscaba un tipo de arte que pudiera adaptar a su vida, algo que no tuviera que realizar sólo en el espacio de un estudio, sino que pudiera hacer todo el tiempo. La máscara era como un icono, una herramienta que podía 
llevarse en la mochila, ponerse o no, jugar con ella en cualquier momento. Estando en Ámsterdam durante un viaje a México consiguió una máscara de luchador y comenzó a jugar con ella y a invitar a un grupo de gente a usarla. Acabó proponiendo en la universidad un proyecto de investigación en México sobre el mundo de la lucha libre. Le fascinaban las apropiaciones que los protagonistas de la lucha libre hacían de los acontecimientos del mundo, el modo en que asumían el papel de un talibán, o de un narco, identidades tenebrosas que adherían a sus personajes gracias a las máscaras. Lo que él buscaba al combinar la sofisticada propuesta conceptual, con la pasión de una de las prácticas más populares de México, era justamente crear, a partir de una máscara de sí mismo, una identidad prestable.

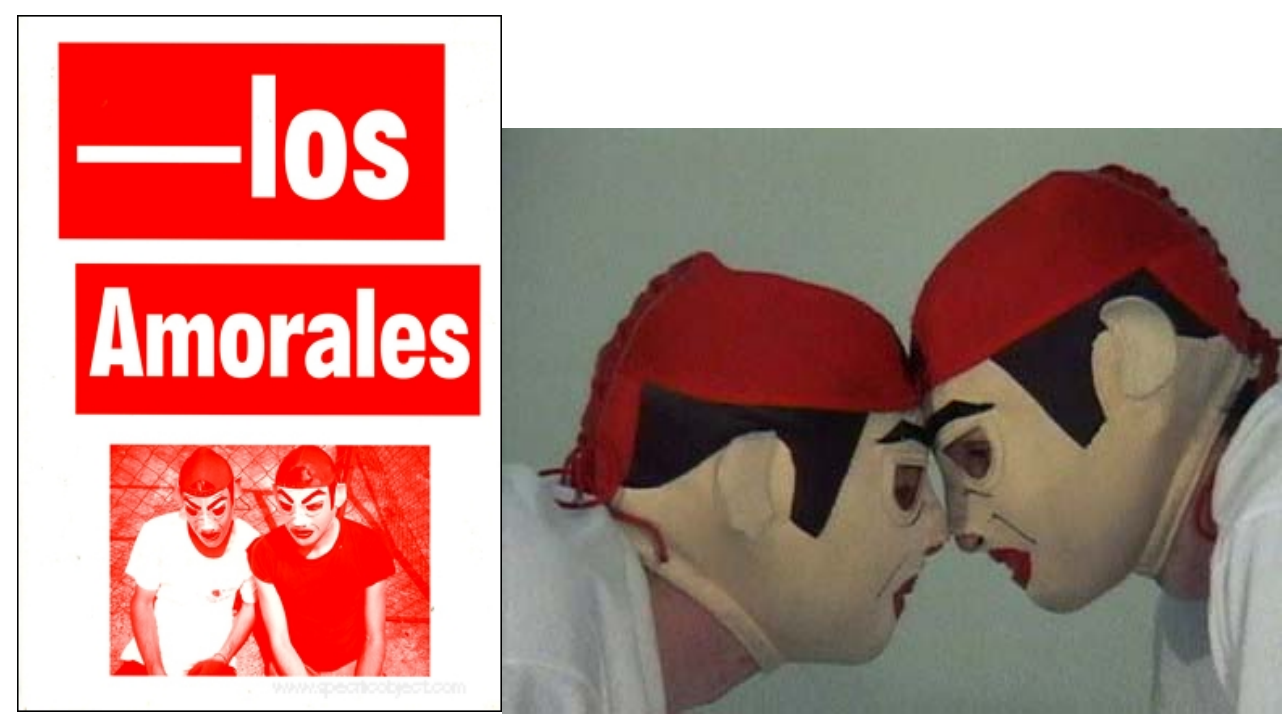

Ilustración 119: Carlos Amorales: Poster de luchadores
Ilustración 140: Carlos Amorales: Amorales Vs Amorales, 2003.

La revista Contemporary Art describía su personaje así:

Growing out of a series of experiments with the mask, a fictional character behind a mask called 'Amorales' was created and lent to different individuals to perform in various situations where it was continuously emptied and filled up again with different 'contents' working almost invisibly, as a catalyst, within restricted 
frameworks. Using fictional identity as a 'working tool' Carlos Amorales found Mexican wrestling (lucha libre) offering that complex but flexible structure that helped him to develop his experiments further. The black and white reincarnations of confronting powers of Evil and Good exposed the archetypal aspects of relevant social and political positions.

With 'Amorales' the artist escaped his presence into a mutual projection between art and wrestling, acting as $\mathrm{MC}$, commentator or the catalyst of events. The 'Amorales' series developed a unique way of (self-) portraiture relating to possible re-contextualization and re-presentation of the problem of identity reflected in the constant transformation and overlapping of real and fictional, both in the framework of the ring and the white cube (Carlos Amorales Interim).

El personaje que finalmente creó y su función, Amorales vs Amorales, se impuso al punto de que interpretarlo llegó a ser una especie de premio para los luchadores en México, y en todo caso, una identidad con la cual, quien quiere que la asumía -como si se tratara del anillo maldito de El Señor de los anillos- se identificaba a tal punto que pretendía quedársela. En un punto, surgió una tensión entre el doble de Amorales que se había quedado en Ámsterdam, ciudad de donde era originario, Gabriel Lester (n.1972) y él, sobre a quién pertenecía el personaje, y el conflicto se dirimió estéticamente. Para desterrarlo de la realidad y convertirlo en una ficción pasada, tuvo que recurrir al performance de un enfrentamiento y derrotarlo. En 2003, su performance de lucha libre fue escenificado en tres de los principales museos del mundo: la Tate Modern Gallery de Londres, el Centro Pompidou de París y el San Francisco Museum of Modern Art.

El enmascarado lo devolvió a las fuentes gráficas de sus indagaciones, marcadas por la experiencia del terremoto de 1985 de Ciudad de México, donde vivió el extraño sentido estético del caos. En la ciudad derruida, en los edificios cuarteados, en la destrucción sintió la insinuación de otro orden posible acrecentada por el sentido ético que se despertó en las experiencias de la población civil, ajenas a la intervención estatal. 
Construyó con un equipo de colaboradores un "archivo líquido", de enorme movilidad, pero que permitía reconocer la fuente figurativa de pájaros, arañas, insectos, lobos y numerosas criaturas que disponía en conformaciones que tenían una belleza amenazante y se conectan a incontables relatos de horror o de narraciones apocalípticas. Formas que no obstante siendo bellas eran invasivas o arrasaban. Esas imágenes comenzaron a inundar los grandes espacios del mundo artístico, y en un momento paradójico, una famosa casa de modas realizó una verdadera apropiación de sus instalaciones.

Luego demostró con el sello "Nuevos Ricos", un sello ficticio creado con Julián Lede y André Pahl que llegó a representar bandas provenientes de México, Holanda, Rusia, Colombia y Alemania y que supuso un ejercicio de piratería disquera validado desde la práctica artística. Era posible filtrarse en la industria disquera auspiciando, como una invención artística y, por tanto, eludiendo regulaciones normativas, derechos de autor y otros obstáculos para insertar grupos de rock y diseñadores en la realidad de un modo alterno. ${ }^{240} \mathrm{Y}$ a partir de ahí ha hecho múltiples proyectos que implican formas insólitas de traducción de unos lenguajes a otros, invenciones de signos, desplazamientos incesantes de la identidad y un continuo movimiento de la imaginación que abre fisuras en la realidad.

Algo maravilloso en el proceso creativo de este artista que antes de los 20 años vivió en Londres en una comuna experimental financiada por un millonario, es su capacidad de desestructurar las ficciones extremas o de dejarlas atrás. Cuando Nuevos Ricos se estaba convirtiendo en una disquera oficial, abandonó su gestión. Cuando Dior se apropió de sus instalaciones de mariposas negras y sus dibujos híbridos construidos con el archivo líquido de imágenes que había ido construyendo para crear obras futuras, 
se empezaron a volver una marca, comenzó a buscar en la tipografía otro lenguaje y derivó en los Oulipos y en una autor de culto como Ulises Carrión. Amorales puede pasar de las prensas de impresión que rehacen diarios extemporáneos o traducen un libro a imágenes abstractas, a instalaciones musicales donde se escucha la altísima nota de un sentido inaudible y convocar luego la poética de lo que no puede ni quiere explicar en un filme experimental. Menciono algunos proyectos sólo para asomarme a los umbrales donde diversos modos multiplicados de ficciones extremas ensayan otras incursiones en lo desconocido.

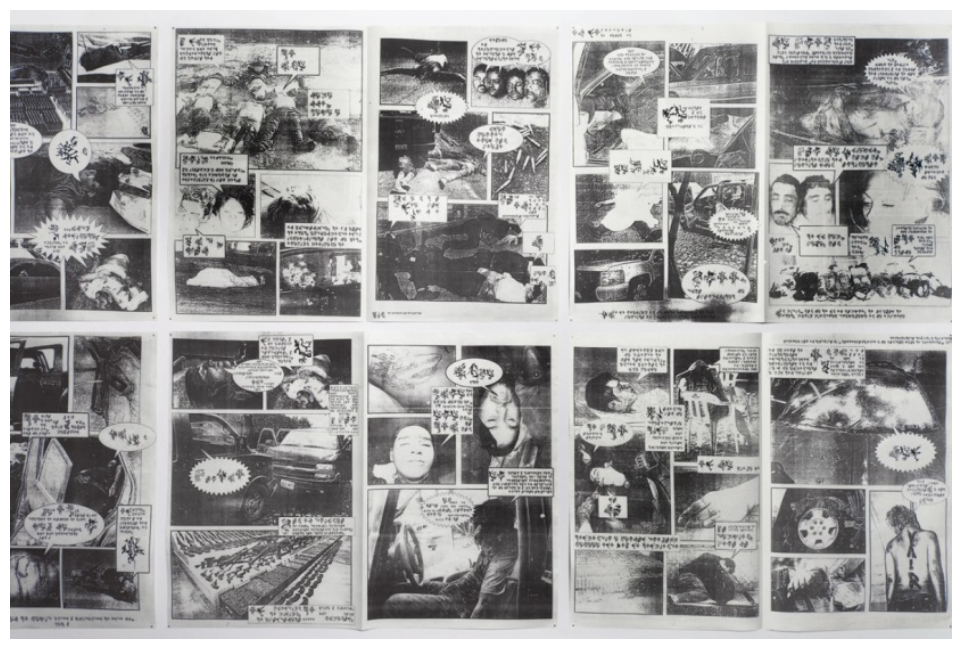

Ilustración 141: Carlos Amorales: La lengua de los muertos, Fotonovela, 2012

La lengua de los muertos es una fotonovela que crea secuencias con las imágenes de los muertos en la guerra de los narcos tomadas de Internet y otros medios. Las apropiaciones que hace de lo fantástico dando a los asesinados una existencia en un trasmundo, se acaballan sobre una realidad violenta que los medios han convertido en un espectáculo mediático. Amorales presenta, a través de la recopilación serial de las imágenes de los muertos "una manera codificada de matar" que contrasta con un lenguaje abstracto - una tipografía derivada de su archivo líquido, pero ya sin rasgos reconocibles- 
que usa como la ininteligible "Lengua de muertos" que da título a la fotonovela. Amorales explica así la obra:

La obra -dice Amorales- se plantea desde un punto de vista fantástico. Los muertos están hablando un lenguaje que no entendemos. Pero en realidad nos hablan del capitalismo salvaje, del neoliberalismo, de esa hiper-competencia que lleva a esa pesadilla, porque la guerra del narco es una guerra económica (Herrera, Amorales: rastros).

Es un modo de "pasar por alto, en silencio" sobre un presente del que no se puede hablar y permite entender esa idea de García Canclini de que el arte trabaja ahora en las huellas de lo ingobernable. Frente a la anarquía sangrienta de los narcos que no abre sino cierra posibilidades, su intento es quizá una estética de lo que no se entiende y de lo que incluso resiste el discurso. Lo cierto es que hay una forma de resistencia en ese lenguaje críptico que pone en boca de los muertos, pero que también instala en otras piezas, y que se deriva de las matrices que alguna vez fueron pájaros o arañas reconocibles y ahora configuran una tipografía cerrada, una suerte de alfabeto pictográfico -surgido casi por una clasificación hecha al azar — que puede usar para "traducir" obras de literatura. 


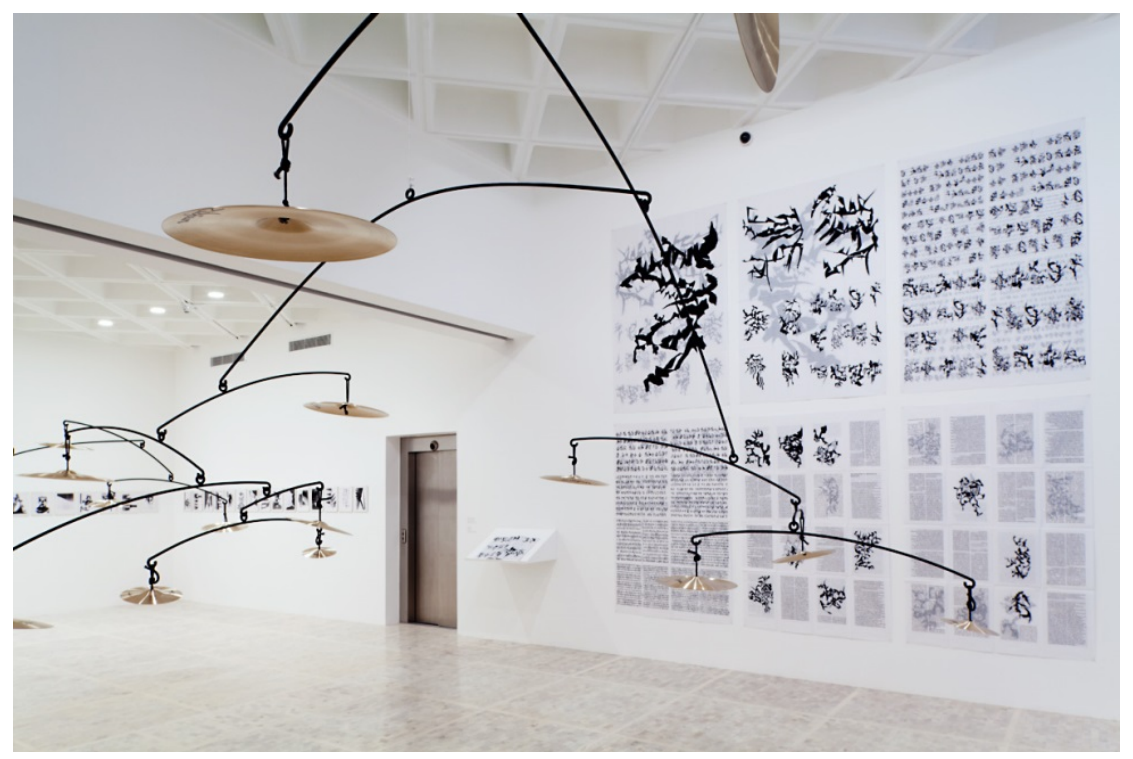

Ilustración 142: Carlos Amorales: Vagabundo en Francia 2012

Sobre la obra derivada de una construcción tipográfica única, Vagabundo en Francisa y Bélgica el mismo Amorales explica que se basa en el cuento del mismo nombre escrito por Roberto Bolaño (1953-2003) a partir del descubrimiento de un viejo ejemplar de la revista Luna Park, que incluía trabajos de escritura asémica (donde el texto es el dibujo y al revés también) de artistas y escritores como Roberto Altmann, Frédéric Baal, Roland Barthes, Jacques Calonne, entre otros. En el texto el narrador se obsesiona con Henri Lefebvre y parte a buscar infructuosamente sus restos por Francia y Bélgica. Amorales utilizó una serie de caracteres, derivados de la fragmentación de su archivo de imágenes hasta que se volvieron imágenes parecidas a caracteres pictográficos. Luego sustituyó la tipografía del texto de Bolaño por estos nuevos caracteres para transformarlo en tres posters, impresos por ambos lados, que muestran el desarrollo descendiente y sistemático, como un zoom, de la escala de estas 
imágenes/caracteres hasta llegar al tamaño necesario para ser comprendidas como un texto.

Con estos carteles se formó un libro de 96 páginas que a pesar de su abstracción representa, como en una suerte de criptograma, el texto que escribiera Bolaño, sugiriendo que este nuevo libro es a su vez la obra que de Lefebvre buscaba, a manera de bucle tautológico (Herrera, entrevista personal).

El libro no tiene portada, lo que sugiere que podría ser un inserto por ejemplo, para una compilación de cuentos. La obra fue impresa en serigrafía sobre papel de plotter y consta de dos partes, una que son los posters y la otra que es su transformación en libro. Ambas han sido incluidas en una caja de cartón y el libro se muestra en una mesa. En esa búsqueda de lo que puede ser un neo-tipógrafo del tercer milenio, con la creación de un sistema de escritura oscura -con antecesores como Henry Michaux, o León Ferraricuya fuente no es ya reconocible, y que tiene su particular manera de "narrar" lo social está viva la idea de la posibilidad de traducir a un lenguaje extraño, ininteligible, lo que no se entiende, o no explicar: lo indecible. $\mathrm{Y}$ ello abre la posibilidad de explorar intersticios en campos colindantes como la música ${ }^{241}$ y de buscar otros creadores de códigos propios capaces de ir, como Rimbaud, en busca de lo desconocido para encontrar lo nuevo. 


\section{CONCLUSIONES}

Esos ejercicios de la ficción extrema que formaron parte del giro radical de las vanguardias de comienzos del siglo $\mathrm{XX}$, continúan, se multiplican e incluso se radicalizan aún más en la actualidad donde nos abocamos a una transformación impredecible. Quizás el fin de la posmodernidad abra paso a un modo de altermodernidad en donde cada vez estará más presente su influjo. Más allá del terreno de la escritura transpasada por otros textos, más allá incluso de la escritura transpasada por el arte y del arte transpasdo por la literatura, nos situamos ante la realidad transpasada, interporlada por las ficciones, en un juego de referencias donde todo está en un "más allá de": las ficciones extremas y sus espejos móviles de imágenes e identidades multiplicadas devienen en un modo de crítica fantástica de la época, un modelo para sitiar y desarmar no sólo el mecanismo de las ficciones, sino para construir ficciones que funcionan como arte-factos que se insertan en la realidad a través de un juego de duplicaciones que la torna incierta. Y, desde todos los sinónimos asociados a esta condición —insegura, dudosa, precaria, aleatoria, fortuita, contingente - el mundo se convierte en un terreno interpolado por ficciones que ensanchan la posibilidad de reimaginarlo. La sola existencia de ese modo doble de imaginación, que supone una puesta en cuestión del límite de lo real, un espejo de su condición porosa, y la creación de un mapa de lo real que es consciente de las falacias de su duplicación, implica una crítica de la distinción habitual entre ficción y realidad.

"Se llega a ser artista o escritor aprendiendo a tratar con lo que es como si pudiera no ser y con lo que no es como si pudiera llegar a ser”, escribió Néstor García Canclini en 
El mundo entero como lugar extraño (77). La frase, que transforma la realidad en vaciamiento, y lo vacío en potencia, y que sugiere las posibilidades de la imaginación que acechan en las fronteras entre ficción y realidad, me remite a Max Aub, Leonora Carrington y Enrique Villa-Matas, así como a otros autores que han abordado ejercicios de la ficción extrema: Mario Bellatin, Luis Camnitzer, Liliana Porter, Ana Tiscornia, Rubén Torres Llorca y Carlos Amorales, aunque desde luego son sólo ejemplos de una práctica cada vez más extendida. ${ }^{242}$ Son autores transeúntes a los que hemos descubierto, extraviados en esas orillas de la literatura y el arte, que ellos mismos cruzaron $-\mathrm{y}$ entrecruzaron - como si sus demarcaciones pudieran no ser, sólo para ensanchar los territorios de lo potencial, de eso que puede llegar a ser en los vastos mapas del mundo contenido en sus obras, que en conjunto, abarcan temáticamente un siglo de ficciones extremas.

Vuelvo a las palabras de Graciela Speranza:

Empujados por el deseo de ser otro, las artes visuales - pero también la literatura y el cine - se lanzan hacia el afuera de sus lenguajes y sus medios específicos, y encuentran en el fuera de campo una energía estética y crítica liberadora. Los campos estéticos se expanden... (Fuera de campo 24).

Estamos ante un campo de relaciones expandidas entre arte y literatura que alteran la línea lábil que separa ficción y realidad e involucra múltiples modos de desplazamiento hacia un afuera de las fronteras que en última instancia permite concebir lo alterno como una visión no sólo lúdica, sino de un potencial crítico que se relaciona con la afirmación de Canclini: "También en el arte y la literatura contemporáneos se reelabora la cuestión de los fundamentos de la existencia y de lo social" (68). 
Néstor García Canclini asume en La sociedad sin relato un juego de citas que remite a otras citas, y a otras, pero no para formar la figura de la serpiente que se muerde la cola, sino para apuntar hacia una expansión de la mirada. Cita así la pregunta que hizo Raphael Cuir, en la École des hautes études en sciences sociales de París — “¿Por qué hay arte y no más bien nada?"- interrogación planteada, como palimpsesto, sobre las previas preguntas de Leibniz que enfrentaba el "algo" a nada, y de Heidegger, y trae luego a colación la respuesta paródica de Jacques Henric: “¿No será la función del arte insuflar nada donde hay alguna cosa?" (69), para derivar de nuevo a otra voz, la de Norbert Hillaire, quien concluye: "El arte es siempre una catástrofe de sentido" (70), y justo ahí, desemboca Canclini en esa catástrofe que propiciaron las máquinas solteras de Duchamp, inspiración crucial para que Vila-Matas contara su Historia abreviada de la literatura portátil. La catástrofe de sentido supone una crítica de la época pero también un modo de acechanza sobre lo que potencialmente puede llegar a ser.

Como sucedió hace un siglo con el fervor vanguardista, nos encontramos ante uno de esos momentos de desplazamientos paradigmáticos que rompen y transforman el canon y definen una nueva época en la transformación de la relación misma con los campos creativos. La crítica especular que surge como ejercicio vertebral en el que incluso involuntariamente - desemboca la ficción extrema conduce en última instancia al desmantelamiento del carácter unívoco de la realidad. Pero es una crítica que puede desdoblarse en meta-crítica, que danza entre lo lúdico y lo paródico y que recurre a estrategias que desafían lo permitido y lo prohibido en múltiples niveles:

-El saqueo hipertextual del arte y la literatura que trastoca la autoría y permite deslizarse de la ficción a la realidad incluso hasta volverla vida. 
-Los juegos apócrifos llevados al límite;

- Aproximaciones lúdicas al límite último del sentido en el lenguaje verbal.

-La con-fusión de géneros en un doble sentido: asumir la impostura de un determinado género para inducir a confusión, y su astuta fusión, ligada a la ruptura de los cánones tradicionales.

- El borronamiento de la diferencia entre copia y original, o la suplantación de la primera por el segundo.

-El asalto ontológico a la visión unívoca del ser a partir de desdoblamientos en identidades múltiples y la consecuente construcción de una alteridad nómada.

-El desafío de la frontera entre ficción y realidad de un modo que cambia la pregunta de las vanguardias, --“¿Qué es arte y que no?”-- Por la de “¿Qué es real y qué es ficticio?”.

Pero en cada uno de estos niveles no estamos sólo ante la extensión del simulacro como un fuego fatuo: en la ficción extrema el surgimiento de la crítica especular (que es lúdica, paródica y a veces ficticia) con-mueve los límites de la creación para revelar la ficcionalización del mundo y situarnos en el umbral de algún modo de reinvención de la realidad. Así, al demoler el muro de contención que la separa de la ficción, y las mismas fronteras entre las artes, se toman prestadas herramientas que van y vienen de la literatura al arte y que permiten una suerte de alquimia al ser transplantadas a otro campo, no para construir grandes relatos sino para abrir boquetes y pasar continuamente de un lado al otro. El tránsito da otro vuelo a la imaginación, elimina ciertas restricciones como las convenciones del mundo editorial o del texto o la obra finalizados y en poder de un público, lo cual permite a Bellatin o a Torres Llorca seguir regresando libremente al 
territorio de sus ficciones para rehacerlas, reubicarlas, darles otra movilidad, reinventar los códigos de su circulación en el mundo del arte o de la literatura. Y el gesto de apropiación de su autoría, sin constituir un manifiesto, socava las delimitaciones habituales, cumple la función de alumbrar otras posibilidades.

No es tampoco un entretenimiento futil crear colectivamente un personaje como Alicia Mihai Gazcue, si su propia creación interroga a las instituciones y refleja el propio proceso de organización de los discursos en el arte. Cada práctica de ficción extrema remite en última instancia a una crítica especular que instaura una duda sobre las mismas demoliciones de sentido que se convirtieron en paradigmas.

\section{Palimpsestos de ficciones y su convergencia en modos de verdad vital}

El transcurso por esas zonas refundidas, confundidas y refundadas entre el arte y la literatura permite el reconocimiento de las argucias de las cuales se han servido estos autores para borrar las fronteras impuestas a los campos y aventurarse libremente entre éstos, de un modo que tiende a adelgazarse las paredes que impedían advertir el latido de la propia vida en las habitaciones comunicantes del arte y la literatura. En HALP se abraza el caos para jugar con la posibilidad de inventar una vida maravillosa, que en realidad ya estaba trazada por la insólita libertad mental de Marcel Duchamp, el primer transeúnte que dio continuidad a una obra visual en la forma de notas textuales contenidas en una caja, y quien al término de sus días insólitos, en los cuales trabajó 20 años en una obra que mantuvo voluntariamente en secreto hasta su muerte, afirmaba

justamente haber vivido esa vida maravillosa. A su modo, la tuvieron también Leonora Carrington, que sostuvo en sus cuadros y libros universos que contenían una miríada de 
mitos del mundo, y su propia manera de habitarlo, con una lucidez vigilante y con la convicción de que éramos una clase de animales tan soberbios que ignorábamos el lenguaje de las demás criaturas, a las que hizo guardianas de la entrada y la salida al mundo de las palabras y las imágenes en sus universos conectados. Y también alcanzó una forma de vida maravillosa Max Aub, con el atrevimiento de una imaginación que desconociendo las fronteras entre campos y géneros, se inventó no un personaje, sino un artista con fotografías que testimonian su vida en el París de las primeras vanguardias, con una obra completa, creada como el modo más sagaz de emprender una tarea de crítica de la época y de su arte que puede definirse con dos atributos de la ficción extrema que practicaron nuestros autores: lúcida y lúdica. Max Aub fue llamado "el más audaz de los impostores"; lo que la crítica ha dicho de Vila-Matas, podría resumirse en el epíteto “el de las mil voces"; mientras Leonora fue justamente llamada por Octavio Paz, "Bruja embrujada", "sonámbula escapada de un poema de Yeats": todos son transformados vitalmente por sus propias ficciones $\mathrm{y}$, sin abolir la distinción entre autor y narrador, no es únicamente este último el que se transforma en los ejercicios de la ficción extrema. Sus practicantes suelen ofrecer visiones que contienen formas de verdad cercanas a la vida, y paradójicamente acogen lo apócrifo y/o lo fantástico para decirla mejor.

Estos avezados transeúntes se deslizan de las artes a la literatura y viceversa, transponiendo sus estrategias, un procedimiento del cual depende en buena medida su inserción en la realidad. En los casos de Aub y Vila-Matas, ambos maestros del uso del apócrifo, primero han afilado esa herramienta en lo literario para dar a sus invenciones un aura incontrastable de realidad. A los dos, de hecho, puede aplicarse el uso que señala Alan Pauls para definir el procedimiento borgiano en El acercamiento a Almostásim: 
"Cristales de realidad que brillan, indiscutibles, en medio de un contexto de imaginación o de falacias, para volverlo convincente, 'real', y, al mismo tiempo, para volverse ellos mismos, a su vez, inesperadamente sospechosos" (117). Y ambos, como hemos visto, han tenido experiencias similares a la que tuvo Borges tras mencionar en ese relato los nombres de un editor y una escritora real, acerca de un autor y libro apócrifos que recreó tomando prestadas palabras de otros libros. Tan convincente resultó su argumento, impostado como crítica literaria, que el propio Bioy Casares había ordenado la compra de un ejemplar (Pauls 117). Una historia semejante vivió, como hemos visto, Aub con su amigo Esteban Salazar y Chapela, quien tuvo que escribirle una carta disculpándose por la ingenuidad con que había confiado en la existencia de Jusep Torres Campalans; VilaMatas declaró por su parte que sus "mezclas de ficción y realidad han respirado siempre el aire de lo auténtico":

A veces en mis conferencias la gente se ha reído cuando, después de contar una anécdota personal, quizás extraña, hago un inciso para aclarar que lo que he contado me pasó de verdad. De verdad, les repito. La aclaración les hace reír. La primera vez que rieron me sorprendió mucho porque no sabía de qué reían. Quizás la clave está en lo cerca que me sitúo de cierta verdad (Miguel Ángel Muñoz Enrique Vila-Matas).

Su declaración alumbra un aspecto clave: si sus juegos hipertextuales llegan a ser tan convincentes que es difícil diferenciar ficción y realidad, también ello obedece a que sus invenciones contienen esa "cierta" verdad vital que puede ofrecer una visión incisiva de lo real. De ahí la distinción que hace la voz de Jusep Torres Campalans: "Ojo: mentir, inventar; no falsear —que es engañar, falsificar—" (242). De modo semejante, en las más delirantes imágenes de la obra literaria o artística de Leonora, como aquel cuadro de la Cena de Lord Candlestick, esas mujeres de cuellos tan largos como caballos que se llevan 
a la boca criaturas vivas, son una insurrección real contra la estructura hegemónica y patriarcal del mundo del cual provenía, y tanto en los cuadros como en los cuentos entre los cuales van y vienen caballos indomables, éstos se rebelan contra la locura de un mundo encabritado que por poco la arroja para siempre al encierro de un manicomio en el remoto sur del África.

Bellatin, por su parte, se desdobla ciertamente en sus personajes más fantásticos y afila las estrategias visuales no tanto para prolongar el encantamiento inicial que le permite pasarlos como reales, como para multiplicar en otros lenguajes aquello que es tan verdadero como incomunicable. Esa cierta verdad es inseparable también de Alicia Mihai Gazcue y la búsqueda real por la conexión entre los desdoblamientos y las posibilidades de la permanente reinvención estética y vital. Y lo es, por igual, de los ejercicios de libertad que Amorales busca en desdoblamientos de identidades o lenguajes, incluyendo los modos de construcción de otros códigos de lenguaje.

La ficción extrema no sólo exige una coherencia con lo que, dada una visión de mundo, podría haber sido posible, sino una correspondencia interior con el alma $-\mathrm{o}$ si se prefiere con el código interno - de lo que se narra o representa. Esta correspondencia es un eje subterráneo, pero clave en la ficción extrema. Por ejemplo, la elección de Portbou como el lugar de la entrevista entre el narrador de la Historia abreviada de la literatura portátil y Duchamp ejemplifica este modo de correspondencia, pues tratándose de una falsa entrevista, el lugar escogido no sólo es real, sino que contiene un pasaje hacia uno de los suicidios más dolorosos de nuestro tiempo: la muerte de Walter Benjamin, empujado al límite de la desesperación por el horror nazi y la impasibilidad de gran parte de la humanidad. No por lúdico, es menos profundo el homenaje que se rinde al gran 
filósofo que sintió un inusitado entusiasmo con el advenimiento del surrealismo. Esa correspondencia de espíritu responde no al estilo sino a la visión interior de mundo que define el lugar de un hombre o mujer en el mundo.

Por eso ante todo el despliegue de recursos que hace Max Aub llenando de ingentes notas, de fuentes que documentan el tránsito nómade de Jusep Torres Campalans de España a México, y el modo en que finalmente optó por abandonar la pintura modernista, ante la cual fue sintiendo un progresivo hastío, para aislarse del mundo en la región de Chiapas, no hay que olvidar que la invención de ese retiro extremo guarda una profunda correspondencia con la experiencia real del exilio, no sólo personal, sino de toda la generación de expatriados españoles que tras la derrota de la República se refugiaron en México.

Los cuentos surrealistas de Leonora guardan también relación con el género fantástico y contienen el diálogo que desde su infancia emprendió con figuras tutelares como Lewis Carroll. Pero más allá las adscripciones que le incomodaban, de las filiaciones que admitía con placer, y de sus mismas rupturas con las reglas —algunos cuentos como el de La casa del miedo acaban en un punto que desafía la expectativa del lector ante el género-; la fuerza de las figuras híbridas, con características humanas, como los caballos o hienas que hablan en sus historias y que lo hacen también en sus cuadros, aunque de otro modo, proviene de la correspondencia real de su propia relación con los animales. Estaba convencida de que éstos hablaban y se sentía a menudo avergonzada de pertenecer a una especie tan insensible como la humana. La contigüidad entre algunos de sus cuentos y cuadros permitiría extender sus relatos a partir de un juego de superposición de imágenes entre esas figuras de un bestiario personal que van y vienen 
de uno a otro campo. Los caballos son una expresión paradigmática de su carácter indomesticable y la hiena que amamanta y que aparece en su primer autorretrato $L a$ posada del caballo del amanecer, vuelve a aparecer — junto a los caballos - 20 años después, en El gran adiós. Hay en toda su literatura y arte, plagado de fabulaciones, de diálogos con El Bosco o Brueghel, y con las vertientes de milenarias tradiciones del conocimiento, no sólo una insistencia en "decir verdad", la "parresía” griega, sino en impedir que se la arrebaten, pues está asociada al sentido de una indoblegable libertad que le permite construir ese modo de correspondencia con una visión de mundo que conmueve y, por tanto, no sólo convence, sino permanece.

\section{La libertad de jugar en los archivos del mundo}

Ahora bien, como señala Gerald Genette, si para transformar un texto, puede bastar con un gesto simple y mecánico, para "imitarlo, en cambio, es preciso adquirir un dominio al menos parcial, del dominio de aquel de sus caracteres que se ha elegido para la imitación" (16). Si cualquier escritor que se enfrente a un tema debe tener un conocimiento suficiente de éste para resultar convincente, en el caso de la ficción extrema ese conocimiento exige la pericia necesaria, casi la conversión o el desdoblamiento de la identidad, para hacerlo pasar por real. Y no sólo en el propio campo de la literatura, sino en el de las artes.

Aub refleja un vasto conocimiento de las vanguardias, particularmente del desarrollo de las etapas iniciales del cubismo y de las distintas vertientes que se desprendieron de éste, pero no menor es su relación con el simbolismo que le antecedió y frente al cual en cierto modo reaccionó, o del neoplasticismo de Piet Mondrian, por el cual se inclina Jusep Torres Campalans antes de abandonar la pintura. Vitalmente, la fuga 
de este último reduplica su propia huída de la Europa en guerra y su desencanto. VilaMatas conoce tan extensivamente la vida e historia de los dadaístas, y particularmente la de esa partícula suelta que fue siempre Duchamp, sin que por ello dejara de llegar a encarnar el arquetipo del sueño y el desdén de la visión Dadá, que puede asumirse, en el papel del narrador, como su doble. El conocimiento de Leonora, por su parte, es el de un espíritu que era surrealista, antes del surrealismo, y que siendo refractaria a cualquier clasificación, enriqueció la literatura y el arte del movimiento con iconografías que contenían capas sobre capas de imaginarios de culturas como la céltica y helénica, entre otras, pero también las de las tradiciones alquímicas, y su propia ironización visual y textual del tiempo en que vivía. Modos de una verdad vital no sólo permanecen intocados por la ingeniosa trama de mentiras y se preservan en las escenas más delirantes o fantásticas, sino que constituyen el núcleo desde el cual las ficciones extremas contienen el poder de conmover a quien las transita y la misma visión de los contextos en los cuales se insertan. Y esto ocurre también en Shiki Nagaoka, en la invención de Alicia Mihai Gazcue, como en los tránsitos entre lenguajes de Torres Llorca o Amorales. Todos buscan de algún modo formas alternas de contener lo irreductible y/o lo indecible que, al tiempo, burla las convenciones de los archivos visuales y literarios.

El tipo de hipertextualidad con el que construyen sus visiones proviene de una inmensa biblioteca del mundo, pero el palimpsesto que escriben o pintan, fotografían o imprimen no sólo contiene un tránsito entre libros, sino un diálogo tan intenso como vivo con un museo visual que no tiene locación fija, pero sí lo que Speranza llama "las supervivencias fantasmales de otros tiempos que anidan en las imágenes", esos palimpsestos iconográficos que también alimentan la literatura de los autores. Si bien es 
cierto que Genette incluyó las ilustraciones entre los recursos paratextuales, no estamos aquí frente al tipo habitual de ilustraciones, no sólo porque pueden ser apócrifas como lo son en el caso de Aub, o porque suponen la conversión de experimentos visuales en un texto de referencias enloquecidas pero de extraordinaria coherencia, como en el caso de Vila-Matas, sino porque la relación entre imágenes y palabras no es aquí literal, ni referencial: es un palimpsesto que ocupa los lugares intersticiales, que de algún modo flota sobre las huellas anteriores, fantasmagóricas, pues no se fija. Funcionan más como ventanas que agolpan una multiplicidad de miradas. Es una relación de acercamiento que sucede con una consciencia de lo mutable. Pensémos por ejemplo en las apropiaciones de textos literarios que Torres Llorca inserta una y otra vez en piezas distintas, de un modo tan recurrente como diverso.

Pero desde luego, los practicantes de la ficción extrema se mueven con inaudita libertad tanto en la biblioteca en cuestión como con lo que ha conformado el cuerpo de conocimientos iconográficos, con sus clasificaciones, con su relación con la historia del arte e incluso con el trabajo de subvertir los ordenamientos que se han impuesto a la cultura visual. Leonora llenó sus obras y sus cuadros de cocinas en las que podían prepararse potajes grotescos, difíciles de digerir, tanto por su carácter insólito como por la misma insurrección que suponía, quizás sin proponérselo, inundar de ese espacio femenino los archivos surrealistas, cuyo ordenamiento se hacía bajo la imposición de la visión bretoniana e inexcusablemente machista. Por su parte, la referencia de las máquinas solteras de Vila-Matas e incluso la del erotismo encarnado por las mujeres fatales, son "principios" no enunciados pero convertidos indudablemente en obras en la historia del dadaísmo y del surrealismo, y, a su vez, transformados de nuevo en literatura, 
en un transcurso que regresa al origen textual, puesto que el mismo Duchamp se inspiró en la puesta en escena de las Impresiones de África de Raymond Rouseel para concebir su obra. Pero no menos se alimenta de su vida en un tiempo regido por esa fascinación por las máquinas que encandiló a los futuristas. Los seres híbridos por Leonora provienen a su vez, entre otras fuentes, de las tradiciones orales irlandesas y de la literatura de Johnathan Swift, aunque también, de nuevo, de su experiencia vital. La entera biografía apócrifa de Jusep Torres Campalans podría leerse como un extendido comentario al avance de las vanguardias, pero también está escrito sobre lo acuñado en el género de las biografías decimonónicas y contiene muchas claves de su propia existencia nómada. Por eso, la triada ineludible de la ficción extrema, que de otro modo no lograría deslizarse en los territorios de lo real, es la conjunción magistral entre arte, literatura y vida, donde alienta una verdad cierta que se reafirma en ese tránsito por la memoria literaria y artística.

El palimpsesto de la ficción extrema se construye así, con la biblioteca del mundo — aunque también puede ser con una sola sección de ésta-, con un archivo visual por el que se transita con facilidad, o que incluso se conoce profundamente, y con el mundo de la vida. Pero la relación con ambas bibliotecas, o entre la biblioteca y el museo, se cumple subvirtiendo el archivo tal y como lo entiende Michael Foucault: "The archive is first the law of what can be said, the system that governs the appearance of statements as unique events (...) it's the general system of the formation and transformation of statements" (The history 28-29). Es la posibilidad de la interpolación de los juegos de tránsito del arte y la literatura y de la ficción misma - esa "introducción de un espacio extraño en un espacio familiar" (McHale 46) - lo que permite desestabilizar el archivo, subvertirlo con un orden de extrañeza con el que no resulta fácil lidiar, justamente por su 
modo de crear otros campos de relación con la realidad y con las mismas historias del arte y de la literatura. A estos autores puede caberles la afirmación sobre el propósito de los conspiradores shandy: "Estremecer los límites de las realidad".

Ciertamente, con sus extendidos juegos de apócrifos o con sus tránsitos sin restricciones entre campos, los practicantes de la ficción extrema acaban por provocar transgresiones narrativas o visuales, que pueden llegar a insertar un modo de mentiras en las memorias de la historia del arte o de la literatura, e incluso de la historia misma, pero su interpolación está guiada por un modo de verdad que abre accesos alternos a éstas y sacude los órdenes hegemónicos con las osadas imposturas de la imaginación.

\section{Deslizamientos radicales en las fronteras entre géneros}

En el marco de ese tránsito entre los campos del arte y la literatura, capaz de subvertir la distinción entre realidad y ficción en sus archivos, una estrategia recurrente es la con-fusión entre géneros que se realiza haciendo pasar una relación hipertextual por otra, enmascarándola de tal modo que el resultado incide radicalmente en el modo en que el lector/espectador puede aproximarse al trabajo de la ficción extrema.

Así, Aub se enmascara bajo la figura del biógrafo que entrevista al biografiado, Jusep Torres Campalans, consulta su diario, revisa las notas que escribió el gran experto en su obra, Richard H. Town, realiza juiciosamente una cronología y tras incluir notas de pie aclaratorias a lo largo del libro, transcribe el listado de las obras de Jusep Torres Campalans, además de una serie de críticas de autores impostados o de textos cómplices hechos con la aquiescencia de intelectuales amigos. Todo es una impostura. La investidura del biógrafo, cada una de esas secciones constitutivas del cuerpo del libro, el prólogo —que es un género en sí-y los demás paratextos, incluyendo las obras plásticas 
que son, desde luego, más que ilustraciones, lo inscriben en el género biográfico, como si fuera un continuador de la tradición inaugurada por Giorgio Vasari en el Renacimiento. Por otra parte, los cuadros realmente hechos y, en ese sentido ciertos, son el elemento magistral para la inserción de JTC, que llegó a ser considerado tan real que no le faltaron compradores en las exposiciones que tuvo. Pero sobre todo son un modo de ficción crítica que pone en cuestión el arte de su propio tiempo.

La hipertextualidad que está bajo la máscara del biógrafo, se remonta en realidad a los diversos textos con los cuales Aub dialoga: hay momentos como en el prólogo en que sostiene frente a El Quijote una relación textual de pastiche, donde hay una abierta imitación de estilo, pero también parodia momentos de la historia del arte como la creación de Las señoritas de Avignon, al recrearlos en otro contexto, o los transforma, como hace con el Mar de Mondrian en una gráfica sintética y de humor leve. El tono irónico — si bien cumplido de tal modo que se inclina más a lo lúdico que a lo satíricoes vital para la ejecución de la meta-crítica que cumple: crítica sobre la crítica, crítica sobre el arte de su tiempo, crítica sobre las obras apócrifas, entre otra serie de ejercicios que a su vez incluyen, en la novela revestida de biografía, el ensayo, realizado con tanta o mayor acuciosidad que los cuadros. Los pinta a partir de esas particulares relaciones de hipertextualidad que son las apropiaciones artísticas, como pastiches que imitan el estilo o que llegan a la franca copia, aunque tiene la osadía de insinuar que fue Jusep Torres Campalans el iniciador del cubismo.

Algunas apropiaciones pictóricas tienen relaciones de travestimiento con el género (movimiento artístico) en el que el biógrafo o algún crítico o el mismo artista los inscribe. Así, hay momentos en que Aub describe una obra cubista, pero estamos ante 
una caricaturización del cubismo, o incluso, ante una pieza que ni siquiera lo es, y que se hace pasar por ejemplo de esta tendencia, no por desconocimiento de los referentes artísticos, sino como extensión del mismo juego de deconstrucciones que anima a quien concibió una vida imaginaria alterna y ajena al mundanal ruido, refundido entre la gente chamula en ese tiempo en fuga de los exiliados de dos grandes guerras de la primera mitad del siglo XX.

Vila-Matas igualmente imposta la tarea del narrador testigo que se ha entrevistado con Marcel Duchamp, y recuenta la historia de los portátiles que fraguaron la Conspiración Shandy induciendo desde el inicio a la confusión del género en que puede inscribirse su texto: comienza así a narrar el primer capítulo de la novela, bajo el título de prólogo, y en éste van desfilando no sólo los personajes existentes, sino hechos que sucedieron, anotaciones verídicas de influencias artísticas —es cierto que Paul Morand influyó en la concepción de la Caja en la maleta de Duchamp- que explican perfectamente por qué algunos editores de las versiones traducidas han publicado el libro en la sección de ensayos. Por otra parte, con no menos astucia incluye un listado de veinte obras citadas, entre las cuales hay libros existentes de autores que también lo son, textos apócrifos que inserta en bibliografías reales, autores inexistentes, y autores reales con libros apócrifos. Pero realizar esa pesquisa para cualquier lector no sólo sería exhaustivo, sino que posiblemente, no se le ocurriría. El mismo Vila-Matas ha narrado anécdotas en las que se constata la confusión felizmente inducida en sus lectores.

Bellatin refleja en la vida y obra de Shiki Nagaoka y en la documentación fotográfica que la sustenta la relación especular con su propio proceso de escritura, y la batalla contra el vacío de un lenguaje que se desdobla en un intento de buscar cómo 
traducir a imágenes o palabras lo que no puede decirse. Puede deslizarse hacia el campo de la fotografía para configurar una prueba de existencia, no tanto de la ficción en sí, como de lo que ésta contiene de indecible; puede construir con las imágenes un relato paralelo, que ejerce una función disruptiva en el texto y multiplica sus sentidos; o puede explorar simultáneamente la posibilidad de crear textos partiendo de imágenes que anteceden, desatan y en definitiva alteran el acto textual de narrar. Liliana Porter, Luis Camnitzer y José Castillo estudiaron el archivo de la gráfica dominante en los sesenta para deconstruirlo con su personaje ficticio, pero también para burlar la imposibilidad de insertar en el mercado de entonces sus propias prácticas conceptuales y convertir en rentable su conocimiento crítico de un modo que echó mano de la creación de un carácter literario y en ese sólo acto, era ya un germen de crítica institucional, y a la vez, un dispositivo prestable. La duplicación o el desdoblamiento proviene del escudriño en la biblioteca y el archivo, pero también de una forma de crítica a los modos de venta y circulación. Amorales construye una identidad prestable que se sale del campo del arte hacia el de la cultura popular y también saquea en los anaqueles menos consultados prácticas de lenguaje que permitieron otras aproximaciones a lo real. Torres Llorca ficcionaliza no sólo con el libre uso de lo apócrifo tomado de las historias del cine o la literatura, sino ensaya creaciones que han abolido la noción de original para ser sólo representación y que no por ello pierden su capacidad de una visión crítica sobre los propios mecanismos del arte o de la historia misma. A menudo la razón poética preconiza, desbordando las demarcaciones entre géneros y campos, el espacio de una libertad que se resiste a ser invadida por la norma y que reafirma, en la última frontera, 
como lo hace la ficticia Mihai Gazcue, que invirtió también el proceso de la obra original y la reproducción, la posibilidad de abrir fisuras en el campo de la realidad circundante.

Sostiene Genette que en "último término, la determinación del estatuto genérico de un texto no es asunto suyo [del autor], sino del lector, del crítico, del público, que están en su derecho de rechazar el estatuto reivindicado por vía paratextual" (13). Es en esa determinación que se produce el deslizamiento de la ficción en la realidad independientemente de que se trate de un crítico que decide incluir al pintor apócrifo en una antología de artistas reales, o de un lector ingenuo que cree a pie juntillas lo que el autor declara. Pero desde luego, son los indicios paratextuales los que orientan o extravían al lector para su propio placer y del autor, si llega a saber cuan eficaz ha sido su empeño. Al propio Enrique Vila-Matas, cuando leyó esa pieza magistral que es Nocturno de Bujara, de Sergio Pitol, le sucedió lo que relata: “Asistí impávido a cómo el narrador pasaba, de forma pasmosa, del ensayo al relato de ficción sin que ni tan siquiera yo, lector muy atento, lo notara" (Miguel Ángel Muñoz Enrique Vila-Matas).

Ahora bien, no sólo es en el receptor en quien descansa finalmente la responsabilidad de ubicar un texto dentro de un género determinado, sino que la hipertextualidad es transgenérica, como ocurre en los casos de la parodia, el pastiche o el travestimiento (Genette 19). El primero y el último, parodia y travestimiento, son frecuentes en HALP; no así el pastiche, puesto que Vila-Matas ha construido un estilo inconfundible, una voz hecha con la suma de incontables voces. Pero, insisto de nuevo, una de las fuentes más poderosas de la verosimilitud de HALP, que incluso se sobrepone a las delirantes narraciones de los episodios de los odradeks — suerte de dobles que provienen del universo kafkiano y de la tradición popular alemana, aunque también se 
emparentan con El Gólem de Meyrink - es la verdadera adhesión al espíritu que inspiró el dadaísmo y luego el surrealismo. Hay episodios reales de sus representantes que podrían inscribirse en los capítulos más fantásticos de HALP sin que desentonaran en absoluto: basta pensar en la imagen de Dalí en traje de buzo asfixiándose sin que lo advirtieran en una de esas inauguraciones precedidas por el escándalo. Si resulta posible transgredir las convenciones de los géneros y derribar sus fronteras o confundirlas es porque hay una cierta verdad en el ejercicio de la ficción extrema que se urde con la propia vida en juego con el ensanchamiento de los parajes de tránsito entre la biblioteca y el archivo visual del mundo. Algo que también supone un abrevarse en el pasado para remontar el presente. Como señala Graciela Speranza:

(...) Son, en ese sentido, obras de escritores y artistas contemporáneos, si por contemporáneo se entiende, como lo hace Giorgio Agamben, artistas intempestivos, que están en su tiempo pero también pueden mirarlo con cierta distancia, percibir no solo sus luces sino también su oscuridad, atender a los signos del presente pero también de otros tiempos, y renovar el diálogo con el pasado de modos insospechados... (Speranza Morfologías 4).

\section{La puerta del juego}

En toda la índole de la ficción extrema se advierte el sentido del juego en su acepción más poderosa. Es una lúdica que no pide permiso para alcanzar la máxima libertad imaginativa desde cuyo umbral tiene la osadía de colarse en la realidad. Un humor inescapable, modulado en múltiples tonalidades forma parte de las reglas de ese juego que acoge la ironía y que realiza afirmaciones que pueden llegar a ser tan desconcertantes como ciertas. A quien se haya sumergido en los cuentos de Leonora, escuchar la declaración que hizo: “Una vez un perro le ladró a una máscara que hice, ha sido el comentario más honorable que he recibido" (Grimber 89), va a parecerle 
seguramente mordaz, pero comprenderá que en el contexto de su universo, es rigurosamente cierta. La leerá en una clave que modula el juego de la verdad. Como dice este último: “...para escribir hay que divertirse. Pasarlo mal es un mal asunto. Y nada me ha divertido siempre más que adentrarme en aventuras literarias ligadas a las vitales" (Miguel Angel Muñoz Enrique Vila-Matas, Web). Aub no sólo diseñó geniales juegos de cartas, sino que ingresó, en juego, a la Real Academia de la Lengua Española, con un discurso impostado de ingreso a ésta, que muchos años después Antonio Muñoz Molina acabó por convertir en verdad, al declararse el heredero de una silla que habría podido ocupar de no haber caído la República española. La idea del juego, le resultaba tan placentera a Aub que llegó a sentir culpa de sus desdoblamientos ficticios, convencido de que su deber, después de haber visto el horror, era novelizar la historia, pero cuando logró retornar a su magnífica habilidad de impostor, captó, en el juego de desdoblamiento de Jusep Torres Campalans, cuánta verdad hay en la aseveración de Genette de que lo cómico es la espalda de lo trágico. No son juegos banales: son demoliciones de una noción inamovible de realidad que nos descubren cómo ni el presente, ni el pasado histórico, son inconmovibles; cómo, finalmente es posible remover sus demarcaciones e insertarles otro modo de verdad posible.

Una Leonora Carrington mayor de 90 años, pero no menos aguda, le pregunta, a quien la entrevistaba para el film documental El juego surrealista (2012), si recuerda aquél juego de identidades en el que alguien inquiere: “¿Et si vous étiez une fleur? ( $\mathrm{Y}$ si fueras una flor)?” Y luego continúa describiendo el juego en español: “¿Y si fueras un insecto?”, La pregunta hecha por esta fantástica creadora, que a los 20 años, jugando a ser una "caballa", asombró a los surrealistas que le doblaban la edad, y que continúa 
asombrando en las diversas ciudades del mundo donde se exhiben sus obras — deberían mostrarse en conjunción con la lectura de sus cuentos-reaviva ese potencial del juego que está ligado, por su naturaleza, a la ficción extrema, que al fin y al cabo es un juego extendido sobre los dominios de lo real: ¿Y si abriéramos una puerta como la que se ingenió Duchamp, que simultáneamente estaba abierta y cerrada, para entrar y salir de la realidad como hacen ciertas criaturas en los cuadros de Leonora?, ¿y si transpasáramos los límites de los campos del conocimiento?, ¿y si nos coláramos en la realidad como si no fuéramos ficciones?, ¿y si nos imagináramos que hay otros modos de ver el mundo?, ¿y si detrás de toda esta mentira que nos complacemos en inventar hubiera verdades que nos hablaran de lo que debemos salvar?

El juego vuelve a alumbrar los intersticios de algo posible en un mundo sin grandes relatos. No es casual que Doris Sommer dedique en su libro más reciente varias páginas al Friedrich Schiller que en la noche en que escuchó que Luis XVI había sido ejecutado, comenzó a escribir Letters on the Aesthetic Education of Man. Distanciándose de la visión que presenta sobre él Johan Huizinga en El elemento de juego de la cultura, exalta al sensitivo filósofo y poeta alemán que recobró la noción de gozo, y cita cómo un pragmático como John Daway, y un post-marxista como Jacques Rancière lo han reconocido como mentor. Retoma entonces aquél pasaje donde Schiller extiende una "interdisciplinary, enduring, almost eerily contemporary invitation to loosen up and play" $(135-6)$.

El texto de Rancière adopta de hecho una posición sugestiva sobre la paradoja y la promesa que plantea Schiller: 
He declares that 'Man is only completely human when he plays', and assures us that this paradox is capable 'of bearing the whole edifice of the art of the beautiful and of the still more difficult art of living'. We could reformulate this thought as follows: there exists a specific sensory experience - the aesthetic - that holds the promise of both a new world of Art and a new life for individuals and the community. There are different ways of coming to terms with this statement and this promise. You can say that they virtually define the 'aesthetic illusion' as a device which merely serves to mask the reality that aesthetic judgement is structured by class domination. In my view that is not the most productive approach... (Rancière Dissensus).

Si el hombre sólo es "plenamente humano cuando juega", cuando puede reinventarse e imaginar mundos posibles, no sólo no es inocua toda esta función del juego involucrada en la ficción extrema, sino indispensable para el futuro: necesitamos esa lúdica capaz de conmover los imaginarios de mundo que destilan las obras de Aub, Leonora y Vila-Matas, y que también está presente en los trabajos de Bellatin, Porter, Camnitzer, Tiscornia, Torres Llorca, Amorales y tantos otros.

\section{Lengua lúdica móvil, múltiple y transmigrante}

No es azar que Max Aub, Leonora Carrington y Enrique Vila-Matas compartan una relación de placer y lúdica con el lenguaje y, como en el mismo caso de Duchamp, sus obras reflejen un agudo ejercitarse en los juegos de la lengua. Pueden desatarla, volverla sólo ritmo, y seguirla incluso cuando se aboca a esa libertad extrema que encuentra cuando aniquila la lógica y propicia esa renovadora "catástrofe de sentido" a la que se refería Canclini. Amorales de nutre de los Oulipo y del artista ligado a Fluxus, Ulises Carrión (México, 1941-1989), uno de los grandes precursores de las modalidades de la ficción extrema, y del desbordamiento de los confines del lenguaje textual, para asumir sus juegos de traducciones del lenguaje literario en formas tipográficas que a su

vez derivan en impresiones abstractas. El personaje de Bellatin, Shiki Nagaoka, no sólo 
trabaja en su libro Fotos y palabras, sino que escribe un libro en un lenguaje de su invención. La creación de un sistema de reglas propias, también en los dominios de la palabra, con su asalto a la lógica, entrecruza en algún punto, la práctica de la ficción extrema.

En cada uno de los capítulos se encuentran múltiples alusiones al placer ante los juegos verbales que cumple un papel clave en la desestabilización de las ficciones habituales y de la realidad misma. ¿Por qué elige justamente Vila-Matas el término extraño, enrrarecido de "Hydra íntima" como el nombre secreto de la conspiración portátil? El verso, tomado de Rimbaud, es travestido para dar otra resonancia a la tarea de los shandys en el mundo. ¿Y qué decir de los juegos de palabras inexistentes que Leonora puede insertar en sus historias extendiendo la tradición del non-sense de Carrol, pero sobre todo los dominios de la libertad imaginativa? Incontables títulos de Duchamp, y su propio nombre en el desdoblamiento de un personaje femenino, Rrose Sèlavy, propician un extendido juego verbal. No menos se complace Aub en los afinamientos de la multiplicación del sentido lingüístico. Un cuento muy corto que transcribe Gennette, explica parte de ese deleite compartido por Aub, Leonora y Vila-Matas.

Cuando Su Tung-P'O fue encerrado en la prisión imperial acusado de traición, escribió un poema expresando su resignación ante el pensamiento de la muerte. Contrariamente a sus temores, fue liberado, y escribió entonces un poema expresando su alegría con las mismas palabras rimadas (48).

Entre todos estos autores de ficciones extremas está presente, derivado de la misma posibilidad de juego ya no sólo con lo lingüístico, sino con las múltiples formas de lenguaje, la noción de un amplio concepto de traducción que va mucho más allá de la idea de verter un texto proveniente de un idioma a otro. Es una visión más amplia que 
supone justamente en primer lugar la consciencia de que toda escritura es desde su origen traducción y contiene su propia imposiblidad de transcribir lo que es, más que como una aproximación en la que siempre se cuela algún modo de esa traición que tantos autores han señalado al referirse a la idea clásica de traducción. Pero aquí, se trata de que los lenguajes transmigrantes de un campo a otro que ya nacen como traducción en su origen, son doblemente traducidos, desdoblados, sujetos a un nomadismo que marca sus desadaptaciones, sus vacíos, pero también la extensión de una ruta que llena de nuevas significaciones y potencializa las ficciones. Hay una traducción en los desplazamientos de las criaturas híbridas que transitan en Leonora de los cuentos a las pinturas o visceversa, y, desde luego, en la mirada crítica de Aub sobre las vanguardias que traduce en cuadros. Y hay, desde luego, una traducción que vertió los aprendizajes de la lengua alucinada, atravesada por el absurdo de Roussel en El Gran Vidrio de Duchamp y luego hay otra traducción en la trasposición de su parafernalia a la construcción de la Conspiración Shandy. Y la hay también en esos acercamientos que realiza Torres Llorca al texto literario asaltado y transformado con el continuo cambio de contextos en los cuales se inserta, o en las narrativas dobles o más bien múltiples que abren las fotos que Bellatin inserta en la biografía de Shiki Nagaoka en otros textos.

Los juegos de la lengua, sonoros, incluso liberados del sentido, suelen vincularse a ficciones que son tan polifónicas como errantes. Repetir aquí las múltiples voces que Aub, cita, transporta a otro contexto, usuplanta, inventa, hasta crear el concierto polifónico que narra la vida de Jusep Torres Campalans, ocuparía muchas páginas justamente ya escritas. Leonora reúne una de las más curiosas formas de polifonías pues en sus páginas, desdoblándose en todos los otros que podría haber sido, hablan las coles, 
hablan todas las criaturas animales que existen, y hablan también las lenguas que censuran o imponen, a las que acaba por vencer a menudo, cubriéndolas de murmullos que se resisten a ser silenciados. En Vila-Matas la polifonía es de tal grado que acaba por constituir su propio estilo, conformado por esa "multiplicación de voces y vidas que somos cada uno de nosotros": "Toda mi obra está contenida en Una casa para siempre, en ese libro tan maravillosamente imperfecto. Porque toda mi narrativa está llena de voces, digamos que interiores" (Miguel Ángel Muñoz Vila-Matas). Y sin duda, la razón por la cual tiene una debilidad por el libro de Rodrigo Fresán La velocidad de las cosas, puede atribuirse, letra por letra, a su propia obra:

Un libro de relatos en el que observo una gran amalgama de voces diferentes, como si el autor se fragmentara en una poderosa multiplicación de voces y vidas, muy distintas entre ellas, pero creando la impresión de una extraña unidad muy fragmentada (...) (Miguel Angel Muñoz Enrique Vila-Matas).

Lengua lúdica y voces polifónicas son indisociables de las identidades multiplicadas y móviles que a su vez se aúnan al carácter de lo errante —al término inexistente errancia, que debería ser acogido como neologismo-, de igual modo inseparable de la condición de las ficciones extremas.

\section{Identidades multiplicadas y móviles}

Los desdoblamientos son un eje crucial de la ficción extrema. La duplicidad, o más aún, la multiplicidad de identidades, conexa al mismo carácter dialógico de la polifonía, extiende el carnaval de las voces a la posibilidad de identidades alternas, de vidas imaginarias, que además, pueden deslizarse a lo real, y reescribirlo con su presencia enrrarecida. Es como si, en un ejercicio extremo de la imaginación, en un tiempo en que pareciera que ésta se encuentra exhausta, a través de la ficción que lleva el arte y la a 
otros confines, ese modo de usar la alteridad enloquecida, acabara por sugerir la visión de lo alterno en la realidad.

Como sugiere Pablo Baler:

The multiplication of one in many will allow artists to express themselves as foreigners, to change ethnicity or gender, thus cultivating the place of the other, forcing the extraction, the analysis, and the development of narratives usually discouraged by the 'intelligentsia' and the webs of power . In their isolation and the exacerbation of individualism, to be many is at the same time a form of teamwork. Artists will be able to explicitly occupy the scenario of ethical and aesthetic conflicts and negotiations that underlie every work of art. They could place themselves at the crossroads of these intercultural dynamics and resolve to challenge them by consolidating cartographies, putting diverse hypotheses to the test (2709-2714).

Hay una omnipresencia de ese desdoblamiento de identidades reflejas en espejos transformativos, en los textos y obras consideradas, como se advierte en el caso de Aub desdoblado en Jusep Torres Campalans que a su vez es otro que duplica la trayectoria de Picasso; o en el caso de los personajes femeninos y masculinos en los que Leonora se desdobla, cuando no asume la doble identidad de un caballo blanco, o es una mujer o un adolescente con cabeza de caballo; o, en el caso del narrador de HALP de Vila-Matas que descubre que su doble es Duchamp, y que a su vez este es alma gemela de Walter Benjamin, pero teme que pueda estar también bajo el influjo del odradek Aleister Crowley, que de cualquier modo se posesiona de Pessoa. Sin contar cómo a cada máquina soltera, suele acompañarla no sólo una vampiresa sino alguna forma de doble. Bellatin, por su parte, no usa los nombres propios con mayúsculas para señalar que cada personaje es quien nombra y cualquier otro y que de igual manera todos son él mismo porque no estamos frente a un "yo soy otro" sino soy otros. Es una alteridad distinta del concepto de otredad porque supone un borronamiento de las fronteras de la identidad; es, 
en principio, una otredad que no está afuera, sino adentro, y que supone la multiplicación de las posibilidades, el juego de las vidas paralelas, un nomadismo ontológico, que, por supuesto, no deja de ofrecer la posibilidad de que, siendo otros en sí, pueda imaginarse no tanto la aceptación de la diferencia como el encarnarla, con lo cual habría interesantes posibilidades éticas. Amorales se formó en Londres, estudió en Amsterdán, provenía de una familia de artistas e intelectuales, pero se desdobló en un personaje de la lucha libre, y luego en una suerte de productor rockero y luego en un tipógrafo enloquecido que puede reimprimir antiguos textos anarquistas o crear códigos vectoriales para traducir un libro de Bolaño a un lenguaje abstracto, sin contar otros proyectos donde las partituras musicales se van borrando. Lo cierto es que cada uno de estos practicantes de la ficción extrema ha transitado en un número mucho mayor de desdoblamientos, o experiencias con dobles, y heterónimos de las que aquí menciono. Porter fue una de las creadoras de Trepadori y luego ha prestado su aliento y su imaginación para dar vida real a Ana Mihai Gazcué junto con Tiscornia y ha de estar vigilante a no traspasarle aquellas ideas que alimentan una obra independiente, sin permitir por ello que caiga en la mediocridad que caracterizaba al pintor uruguayo que se aisló del mundo en Lisboa.

Lo esencial es la comprensión de que esa posibilidad de la imaginación desatada que permite desdoblarse, multiplicarse, no ya en otro sino en otros, ya sea a través de fantásticos alter-egos o de apropiaciones de otros reales, implica una escisión en el concepto de las identidades fijas, ${ }^{243}$ un fortalecimiento de la polifonía, un ejercicio de libertad creadora que en última instancia puede configuar una estrategia que abre fisuras no sólo en la memoria de la historia o de los campos del arte y la literatura, sino en las hegemonías del mundo. Algo semejante a un enorme concierto de la alteridad en donde el 
rasgo de la movilidad es determinante, no sólo en un sentido de tránsito hacia otras posibilidades de identidad, sino también a contínuos desplazamientos físicos.

Por esos juegos del azar en conserva, fue contada por primera vez en el mismo número 41 de la Revista Otra Parte dedicada a la "Crítica/Ficción", donde Mario Bellatin escribió acerca de un encuentro con Pierre Cabanne que tuvo lugar en Buenos Aires. El famoso entrevistador de Marcel Duchamp se presentó con un artefacto con una pantalla en la cual podía verse una “especie de película de la realidad” (Bellatin, Una cabeza picoteada Web). Y dentro de ésta, surgió nada menos que el mismo Duchamp, sacado de la tumba, si bien con la cabeza picoteada por los pájaros, pero sin ninguna afección en su pensamiento vertiginoso. De hecho, fue ahí mismo cuando comenzó a contarle a Bellatin la película de su arte, su deseo de crear sin crear, y, poco a poco, empezó, como había hecho con el narrador de Vila-Matas, a convertirse en el doble de Bellatin, de tal modo que era imposible diferenciar quién era el autor de qué, o mejor dicho, Duchamp se apropiaba de las novelas de Bellatin o éste se convertía a su vez en el Odradek del artisano.

El juego de los dobles supone también el nomadismo de la imaginación. Por la comprensión de lo alterno y de lo errante que hay en el Manifiesto de Alteridad propuesto por Nicolás Borriaud en el marco de la cuarta edición de la Tate Triennial en 2009, y porque ambas nociones son determinantes en las obras de Max Aub, Leonora Carrington y Enrique Vila-Matas, propongo detenernos en una visión que creo, puede contener los derroteros futuros de la ficción extrema.

Nicolás Borriaud entrevee como el advenimiento de la altermodernidad o del arte altermoderno que supone la hibridización cultural conectada con el saqueo sin fronteras 
de textos y obras; el viaje como una estrategia productora de formas y obras, y los formatos expandidos del arte (Borriaud Altermodern Manifesto). Estas tres características se cumplen en las ficciones extremas de los autores estudiados que perfilan la posibilidad de la multiplicación de la otredad. Si la identidad misma entra en el juego del borramiento entre la ficción y la realidad, surge una expansión de los límites mismos de la imaginación y nos avocamos a la continua opción de reinventarse no sólo en el campo de la escritura misma sino viajando del arte a la literatura y de las fronteras de estos campos, diluidas por acción de la misma ficción extrema, a los múltiples espacios de la vida.

La idea de "la conexión del arte con la intensidad del presente" que esboza Graciela Sacco en su Atlas portátil de América Latina (157) viajera pardigmática de ese tránsito que va de la literatura al arte, y que acometió la tarea de escribir los meses que Duchamp pasó en esa “África” que queda está localizada en Buenos Aires, cuando se embarcó, como los miembros de la Conspiración Shandy, hacia un ignoto Port Actif puerto portátil— es esencial para la comprensión última de la naturaleza de la ficción extrema. Su propuesta, complejizar "las redes de conexiones con relaciones flexibles que preservan la autonomía relativa de la esfera propia, y aumentan al mismo tiempo, la tensión y variedad de los enlaces", y que amplía, sin perder su singularidad, "ese horizonte de lo diverso" que hace tanto intuyó Bajtín en su concierto polifónico, culmina en la visión con-movedora de un "arte que configura el mundo que lleva a cuestas" (13).

En el confín de las ficciones extremas habita la imaginación necesaria para transformar las fronteras en pasajes y configurar un espacio capaz de mantener volver 
portátil la apertura a todos los otros que nos contienen y cuyas voces errantes nos permiten abrir la puerta del juego común otros futuros posibles.

\section{El estremecimiento de la realidad}

La visión cubista nos enseñó a aproximarnos a la realidad de modo simultáneos desde diversas perspectivas y no sólo abrió la posibilidad de yuxtaponerlas, sino de asaltar e incorporar los reductos del lenguaje usados como signos gráficos y como multiplicadores de sentido. En ese juego de desdoblamientos de Aub en Torres Campalans en Picasso y en su deserción última de todos los ismos nos abocamos a un modo de parodia que se regodea primero en el carnaval de la modernidad y luego la niega afirmando en cambio la naturaleza última de la ficción extrema y la crítica de su propio tiempo en el acorde más alto del movimiento de fuga. En los desdoblamientos de Leonora Carrington en la mujer-caballo, o en los míticos caballos dobles -blancos, negros, a veces bermelló-- por los que se remontó de la literatura al arte y visceversa, acompañada en un tramo esencial de Max Ernst y su criatura doble, Loplop, el pájaro superior, el anverso y el reverso de los mundos soñados y vividos y los lenguajes inventados para salvar la pesadilla del mundo enloquecido no son facetas inseparables del reino de lo surreal, sino modos de doblegar las trampas de la realidad. Al enarnar las ficciones extremas con los tránsitos de sus criaturas indómitas de los cuentos a las pinturas y visceversa derribó las barricadas de contención de las visiones monolíticas y constituyó una unidad última de la imaginación literaria y artística, y de su repercusión en la biografía personal y la vida en común. 
Al erradicar la belleza aboliendo la diferencia entre un objeto de arte y cualquier cosa tomada indiferentemente de la vida real, Duchamp abrió paso al borronamiento de las fronteras entre lo que es arte y lo que no, e hizo posible obras de arte que se asemejaban de modo exacto a cualquier objeto anodino de la realidad (el pop) en un movimiento al cual siguió lo que Arthur C Danto define como la consciencia autoreflexiva del arte de los setentas, después de lo cual cualquier cosa se hizo factible (What art is $\mathrm{x}$ ). Pero, como dice él mismo "Anything cannot be art" (xii). De modo paralelo, en ese giro radical en la concepción del arte que se inició con las vanguardias del siglo XX fue determinante el espíritu de los juegos más extremos del lenguaje Latremont, Apollinaire, Roussel, entre otros nombres totémicos- junto con el desarrollo de toda una maquinaria que extendió hasta lo insólito nuestros sentidos -la grabación de los sonidos o de las imágenes en movimiento- y los soportes para prolongar su permanencia. Las más grandes rupturas implicaron un desbordamiento de los propios marcos de contención, modos de sublevación contra géneros y fronteras y de un tipo de puesta en cuestión de los límites entre campos que acaba por desembocar en formas de ejercicio de la ficción extrema que pudiendo ser originadas en la literatura o en el arte, se desplazan de uno a otro campo y, en cualquier caso, acaban por producir una experiencia que torna maleable la noción monolítica de la realidad. La inserción de un modo de ficción que la altera refleja simultáneamente cuánto hay de ficticio en su propia construcción: los ejercicios de la ficción extrema son inseparables de la vida porque se construyen como una visión que estremece la naturaleza y los límites de la realidad.

Los trabajos de desdoblamiento del narrador de Vila-Matas en Duchamp y en su espíritu gemelo Walter Benjamin, recuperan las claves de su formidable tarea 
demoledora, pero sobre todo insinúan la visión de una poética que permite asaltar la realidad desde una parodia posmodernista que se acoge a las características que le atribuye Linda Hutcheon: "es desconstructivamente crítica y constructivamente creativa a la vez, haciendo paradójicamente que tengamos conciencia tanto de los límites como de los poderes de la representación en cualquier medio" (192). Y abre así el campo para la celebración de un modo de alteridad que supone las identidades múltiples, los tránsitos lúdicos y poéticos entre los lenguajes, y un paisaje semejante al de la escultura que Dani Karavan (n. 1930) instaló en Portbou en homenaje a Benjamin: un tunel hacia la vastedad del mar como inmensa metáfora de los espacios por navegar que la historia le arrebató, pero que arte, literatura y filosofía, le devuelven, a través nuestro.

Podría afirmarse que esa capacidad de estremecimiento confiere a la relación entre el arte y la literatura de nuestro tiempo la dimensión más prodigiosa de la imaginación: la posibilidad de reinventar sus propias definiciones y su modo de deslizarse al campo mismo de la vida. La relación hipertextual extendida a los pasajes vertiginosos entre el arte y la literatura, entre el campo de la ficción y el campo de la vida, presupone una amplificada forma de especularidad y un incesante ejercicio metacrítico, porque desde su campo, máscara y espejo se multiplican y autocontienen pero también propician la incesante posibilidad de modos de reinvención del ser. Inéditos sentidos de libertad.

\footnotetext{
${ }^{215}$ Si bien la recurrencia a lo fotográfico ha sido estudiado por autoras como Kathryn Méndez, quien acierta al señalar: "The camera is another autobiográfical signature of Bellatin" (99), el análisis suele limitarse a considerar que tanto en Shiki Nagaoka como en el relato La clase muerta, donde el narrador describe films no revelados como imágenes que nunca existieron, el uso de la fotografía es un recurso para probar que las historias son verdad. Esta función opera en un primer nivel de lectura, pero las implicaciones de la fotografía giran más en torno a la exploración de lo que hay de comunicable en la experiencia humana. Es un "decir" en el límite donde Wittgeinstein exortaba a callar. Señala Méndez también que en lugar de lo que considera el habitual papel de la fotografía -mostrar verdad y otorgar inmortalidad-Bellatin usa las
} 
imágenes para una función contraria: "Many of his novels also rely heavily on the use of photography as a way of mocking reality and they are loaded with autobiographical references about the author himself" (99100).

${ }^{216}$ Los casos de Reena Spaulings o de Claire Fontaine, figuras que sintetizan de otro modo las múltiples identidades de quienes las faguan son una modalidad paralela y ofrecen también un interesante desplazamiento autoral.

${ }^{217}$ De hecho, invitado por la revista Letras libres a un ejercicio que consistió en convocar a cuatro escritores para crear un nuevo bestiario fantástico, Mario Bellatin se explayó en la naturaleza de esa ave que había aparecido en varias páginas suyas y la llamó Abestús o roca. Tomo algunos de sus rasgos: "Ave originaria del Istmo de Tehuantepec que sólo ha sido fotografiada en una ocasión". Aclara que su tamaño es el mayor de las aves y que a pesar de tener alas no vuela, pues su cuerpo tiene forma cilíndrica.

Aludiendo a su relato Bola negra dice que un joven científico lo llevó a una casa en Juchitán, donde "una fotógrafa sumamente reconocida" (evidentemente Graciela Iturbide no sólo por la locación de las fotografías sino porque menciona luego su libro Eyes to Fly With), la fotografió pero que no ha publicado las imágenes porque la ciencia no admite su existencia. No obstante, viéndola de cerca pudo notar sus rasgos: sus plumas celestes y blancas, el piso rosa que en la punta llega casi al rojo. Se sabe también que guarda los huevos debajo del ala y los empolla mientras camina y que pequeños dientes en el pico le crecen en forma constante, y le causan graves sufrimientos. La fotógrafa y el científico lograron llevarlo al hospital para hacerle una radiografía y ella descubrió que "a pesar de las apariencias -era algo penoso ver los grandes dientes sobresaliendo del pico y las alas engordadas por la oculta presencia de los huevos- el ave era feliz" ("Bestiario Fantástico" Web).

${ }^{218}$ Paradójicamente, su literatura suele desarrollarse a menudo en espacios de confinamiento. Como certeramente notan J. López Alonso y Méndez. En incluso sus personajes llegan a preferir el encierro frente al mundo de afuera. Nada interfiere sin embargo la consciencia del vacío desde el cual ejercen modos no enajenables de libertad. Como anota el primero los personajes se hacen eco de la voz del joven Werter: "Curl up inside my shell and ther I discover a whole world" (24).

${ }^{219}$ Como remarca Francisco J. López Alfonso, el libro Condición de las flores, subtitulado “Apostillas", ejemplifica el juego que desafía las restricciones editoriales de los textos ya publicados. Se supone que el proyecto editorial consiste en publicar los borradores de obras como Canon, Efecto y Poeta, anotados e interpretados por una investigadora argentina, Graciela Goldchulk, quien participa en el juego del novelista. "This apocrypha -if only because of what its editing date refers to- is a good example of the way that Bellatin takes up his texsts again and reworks them (29). La misma investigadora, en un texto su texto "El realismo minimalista de Mario Bellatin: lecciones y proposiciones" aclara: "Sin duda Bellatin participa de untipo de movimientos artístico-culturales tanto como científico-tecnológicos que Ladaga caracteriza como "constructivistas", "colaborativos" y generadores de "ecosistemasculturales", pero mi apreciación es que en su caso lo que hay es un diálogo distanciado con estos movimientos, en tanto su proyecto se diferencia de otros a partir del lugar de su inscripción, que es siempre literario. Por lo tanto, no nos interesa desmentir larelación que efectivamente tienen las "acciones literarias" de Bellatin con otras manifestaciones artísticas, sino que nos importa ver qué le dicen a la literatura". (Goldchulk Web)

${ }^{220}$ La nota de prensa con la cual en el website de dOCUMENTA (13) se difundió el proyecto, dice: "A notebook is a picture in history. Notes are the fictions of ideas. A note is an idea that occurs in the mind as a shape and does not exist yet for the world. When it does, it changes everything and nothing is ever the same again. True - only a small part of the world is affected at first by a note, but since a note embodies the art of the possible, the whole world could change due to a note, to a fiction. A collection of notes is written outside the realm of style and at the same time it constitutes an anthology or an atlas of primary sources - a necessary companion to understand the relationship between experience, images and thoughts. Notes are mild. They always start in the middle - a result of day-dreaming and semi-consciousness - instead of 
starting at the beginning, like the conscious writing of history or the exercise of reasoning out an argument. A note is instead a "multitudinous" middle

${ }^{221}$ Susan Antebi realiza un amplio estudio de la relación entre la literatura de Mario Bellatin y la condición de la diferencia física en Carnal Inscriptions: Spanish American Narratives of Corporeal Difference and Disability (New Concepts in Latino American Cultures), 2009, considerado por Susan Schweik “A breakthrough book in literary disability theory. In addition to bringing our attention to an array of fascinating texts, Antebi offers broadly usable paradigms, particularly because her focus is so often on contemporary forms that daily catch the eye: freak shows, talk shows, performance art pieces, testimonio. Carnal Inscriptions is a politically astute and ethically grounded work of criticism by one of the most original, sophisticated and exciting new voices in disability studies in the humanities". Por su parte, Sander L. Gilman remarca: " (...) is the first English-language study to deal with the representation of physical difference, real and imagined, in contemporary Spanish American fiction.This book is a major contribution to cultural studies and the function of disability discourses in Spanish American writing".

${ }^{222}$ Incluyendo al gran novelista Yukio Mishima, que se suicidó con el ritual del harakiri y sepuku y cuyo espectro sin cabeza retorna en El álbum ilustrado de Mishima de Bellatin.

${ }^{223}$ Existen varios estudios sobre el orientalismo de Mario Bellatin, tema que no es el enfoque de este estudio. Pero para considerar este aspecto puede consultarse el libro de Rebecca Riger Tsurumi, The Closed Hand: Images of the Japanese in Modern Peruvian Literature o el libro de Araceli Tinajero Orientalismo en el modernismo hispanoamericano.

${ }^{224}$ En el curso de una entrevista personal, Bellatin se refirió al sistema "muy sabio" de la Escuela de Cine de San Antonio de los Baños en Cuba: una escuela -con buenos profesores- donde los extranjeros están encerrados a 30 kilómetros de La Habana para hacerlos vivir un mundo muy cómodo y ajeno a la realidad cubana. No soporté la locura colectiva de ese encierro donde de cualquier modo descubrió que el montaje lo es todo. Dejó la escuela con la complicidad de un grupo de escritores cubanos y vivió del modo más invisible posible escribiendo Efecto de invernadero, donde ensayó formas narrativas y una voz de la que difícilmente se desprendería. Escribió dos mil páginas hablando de los últimos días del poeta peruano surrealista César Moro (en su hogar de la Bajada de los Baños, en Barranco) y del "efecto de invernadero" que había descubierto en la isla: basta una minucia, los 40 años de un régimen dictatorial, para romper esos valores que suponemos parte de la humanidad o al menos producto de un aprendizaje de siglos. Pero ni en éste relato ni en Cánon perpetuo, donde también está presente el mismo efecto de invernadero, le interesaba explicitar ningún comentario político. Lo que entregó al lector, una selección de fragmentos decisivos de las dos mil páginas que escribió es un sistema de escritura en el que no hay ningún espacio-tiempo identificable, pero a cambio se sumerge en un raro tratado sobre la condición humana (Herrera, $A$ cercamiento Web).

${ }^{225}$ Murasaki Shikibu, la autora del Gengi Monogotari, usa numerosos tankas propios o tomados de otros poetas en su protonovela.

${ }^{226}$ En La condición de las flores Mario Bellatin precisa uno de los procesos de relación con entre imágenes fotografiadas y textos: "Encuentro esta pequeña caja de plástico llena de subterfugios, de trucos a ejecutar, de secretos que debo ir develando mientras busco las imágenes... La supuesta investigación literaria necesaria para algunos escritores- en este caso se enmarca dentro de los claroscuros de una caja cerrada premunida de un obturador". Si las fotos elegidas van ordenando la narración, las fotos desechadas se convierten "en el borrador del texto" (15).

${ }^{227}$ En "In Praise of Shadows", Junichiro Tanizaki (Leete's Island Books, 1977) escribe una reflexión sobre la arquitectura de los baños japoneses tradicionales y su propia dificultad de decidir entre las ventajas de ésta y las de la modernidad. El texto es un artefacto para este debate: "Japanese toilet is truly a place of spiritual repose. It always stands apart from the main building, at the end of a corridor, in a grove fragrant 
with leaves and moss. No words can describe that sensation as one sits in the dim light, basking in the faint glow reflected from the shoji, lost in meditation or gazing out at the garden. The novelist Natsume Sōsekicounted his morning trips to the toilet a great pleasure, "a physiological delight" he called it. And surely there could be no better place to savor this pleasure than a Japanese toilet where, surrounded by tranquil walls and finely grained wood, one looks out upon blue skies and green leave... I love to listen from such a toilet to the sound of softly falling rain, especially if it is a toilet of the Kantō region, with its long, narrow windows at floor level; there one can listen with such a sense of intimacy to the raindrops falling from the eaves and the trees, seeping into the earth as they wash over the base of a stone lantern and freshen the moss about the stepping stones. And the toilet is the perfect place to listen to the chirping of insects or the song of the birds, to view the moon, or to enjoy any of those poignant moments that mark the change of the seasons. Concluye que de todos los elementos de la arquitectura japonesa, el baño es el más estético y que los antepasados convirtieron ese espacio en un lugar elegante repleto de asociaciones con la belleza de la naturaleza. Sin embargo, tras concluir que el baño japonés es sinónimo de perfección, al menos en un tempo, en una casa ordinaria no es fácil mantenerlo limpio y es más eficiente instalar los modernos elementos sanitarios aún al precio de destuir el buen gusto y la belleza de la naturaleza. Así que el mismo las instaló cuando construyó su casa, si bien evitó usar baldosas. http://revistaerrata.com/ediciones/errata-8-intertransdisciplinariedad/ficciones-de-lo-real/

${ }^{228}$ A su vez, Graciela Iturbide depositará el legado, en conjunción con Pedro Reyes, en los ojos del adolescente que pasa largas horas en su casa-taller, y que llegará a ser con el tiempo, el primer artista mexicano en tener una exposición individual en el Museum of Modern Art después de Diego Rivera: Gabriel Orozco.

${ }^{229}$ En Pájaro transparente, Bellatin narra que tras haber buscado llevar hasta el límite de lo falso un brazo artificial buscando en Berlín a un mascarero que decoró el agresivo garfio que usaba entonces con piedras de fantasía, comprendió que su próximo brazo debía provenir del arte y recurrió para ello al artista peruanomexicano Aldo Chaparro, quien exploraba entonces ideas en torno al cuerpo humano y sus búsquedas de supervivencia. Así había hecho ya unas casa portátil para desamparador, una caja de madera con música y colores donde la gente podía entrar para escapar del mundo cotidiano, un uninario con agujeros para quienes necesitaban tener sexo clandestino. De esa idearon una serie de brazos y manos posibles, que tenían una doble función práctica y artística: existe un esbozo de brazo que permite portar de manera oculta un celular, una navaja suiza, un i-pod, un lapicero y un exhalador de gases para prevenir cualquier agresión.

${ }^{230}$ Algunas de las mejores fotos del novelista peruano Julio Ramón Ribeyro fueron tomadas por Alicia Benavides en los setenta.

${ }^{231}$ La casa editorial fue fundada en París por Alexis Frabry y Olivier Andreotti con la idea de que el libro de artista del siglo 20 tiene que ser un objeto de arte híbrido que tome un nueva posición en este campo.

${ }^{232}$ En una conversación telefónica que sostuve con Andrés Serrano en 2005 me dijo: "Si Annie Leibovitz o cualquiera hace un retrato no está sujeto a que le digan: 'Oh, no es suficiente'. Pero Andres Serrano no puede tomar un retrato porque le da la maldita gana. Claro que America tiene ironía, pero la gente en el mundo del arte espera más [transgresión] de mí que de otros artistas". (Herrera, Andrés Serrano Web).

${ }^{233}$ Pensar en Andrés Serrano hace evocar el epigrama de Teodoro W. Adorno: "Toda obra de arte es un delito no cometido". A los 37 años, después de hacer fotos que nadie veía, mientras repartía comida china en Queens o trabajaba de obrero, su obra Piss Christ se convirtió en sinónimo de la crisis en la institución National Endowment of the Arts. En la soledad de sus procesos creativos, donde enfrentaba las obsesiones que hallaba en el sótano de su propia mente, Serrano convirtió en materiales pictóricos las intocables sustancias de desecho corporales; hizo visibles las perversiones, tan presentes como veladas en la historia de la sexualidad humana; miró los rostros de los hombres y mujeres sin techo, que se esquivan en las calles; penetró en los lugares que no se pisan, como la morgue, y allí, no sólo captó las imágenes de la muerte, que nadie quiere enfrentar, sino exploró esa innombrable tendencia del ojo humano a recrearse en el horror de 
la que habla Susan Sontag. Su cámara funciona como los ojos de la oscuridad, se mueve certeramente en lo encubierto. La repulsión-fascinación que provoca con un arte que propone la belleza del mal y que profana los límites, indiferente a la naturaleza de algo sagrado o inviolable, supone el acto de apertura al caos que pregonaron los surrealistas. En términos psicoanalíticos - una veta que interesa particularmente a Serranoel quebrantamiento de la ley social es por una parte la afirmación de la autonomía ("el arte es un reino por sí mismo regido por sus propias leyes", proclamaba Kandinsky), pero a la vez el simbólico asesinato del padre, un filo incierto donde la vulnerabilidad de lo humano (y del propio arte) se agudiza.

${ }^{234}$ En cambio, el proceso de montaje teatral de Salón de belleza ocurrió como una constatación de que el texto hacía uso de un imaginario colectivo porque en cada ciudad había un moridero semejante al que Bellatin había creado en el espacio que daba título al libro y hacer las lecturas en estos escenarios que parecían haber sido contenidos con anticipación en la novela, o haberla inspirado, era parte de una forma de inevitable fusión entre ficción y realidad.

${ }^{235}$ En la misma casa editorial que publicó Pájaro transparente, de Bellatin, se editó el libro El Affaire Skeffington, de María Moreno. Aunque no es un libro que se deslice en el arte, sí juega con la noción de modos de traducción y duplicación entre lenguajes y me interesa citar la declaración de la autora sobre su procedimiento: "Es una novela en donde el personaje escribe algo que no parece muy bien traducido y del que no hay original ni figura el traductor. Lo que más me impresiona es recordar los referentes absolutamente autobiográficos pero donde personajes y escenas son ficciones hechas en base a una investigación estricta. Es un golem berreta de google" (María Moreno Telam Web).

${ }^{236}$ Nota también López Alfonso que en Lecciones para una liebre muerta que Mario Bellatin asumio su nombre propio como el del narrador. El título se dervia del famoso performance del artista Joseph Beuys con una liebre muerta y su tema permitiría una disertación completa. Señala este autor que la novela, "ends with the understanding that its numerois stories, in a complex game of doubles, are like the distorted reflections in a broken mirror, although it is not clear who the person looking into it is. That is to say, Bellatin brillantly thematizes identiti's dilution, the so-called death of the subject, while at the same time explaining the schizophrenic nature of postmodern writing" (26). Yo señalaría que más allá de ese punto de disolución puede suponerse el advenimiento de lo altermoderno. Un tránsito hacia otros modos de creación de la obra y la vida misma.

${ }^{237}$ Coincido aquí con Mieke Bal en la convenciencia de usar el término focalización no sólo por la diferencia de significados que hay entre la significación de "perspectiva" en la literatura y en el arte, sino por la razón que ofrece: “....it also accounts for the cross-disciplinary move I made in the late eighties from literature to visual arts. As I see it, at the heart of focalization and hence of both linguistic narrative and visual art, is a hub that shifts and destabilizes the gaze." (42)

${ }^{238}$ La tradición clásica habla de écfrasis cuando un texto verbal describe una obra de arte visual. Decía Louis Aragon el Les Collages: "Écrite et peindre, un seul mot signifiait l'un et l'autre dans l'ancienne Égypte”. Y, dentro de esta práctica, hay casos como el de Gerges de Scudéry (1601-1667) que en Le Cabinet de monsieur de Scudéry, 1646, presenta una visita ficcional de un gabinete de curiosidades. "Le lecteur découvre des poèmes décrivant une collection de tableaux semi-imaginaries "es par des peintres français, italiens, allemands et hollandais" (Maurisson 38).

${ }^{239}$ El primer acto de ficción fue la invención de un nombre que no sólo le permitió liberarse de su historia familiar (era hijo de dos artistas a los que no quería parecerse), sino empezar un tipo extraño de invención de sí mismo: cuanto más lejos estaba de sus condiciones reales, más semejante era a su propio ser. A los 19 años se marchó a Londres y empezó un periplo semejante: cuanto más distante estuviera de México, más se iba a aproximar a zonas poco exploradas del D.F. Pero igual, a medida que se encontrara con sus submundos - llenos de iconografías que parodian el terror y de ritos en torno a la música - iba a estar menos confinado a sus fronteras, más convertido en un transeúnte del territorio de la subcultura que en buena parte es virtual y funciona como una tribu planetaria. En Londres, hizo los oficios típicos de un 
inmigrante en Europa. Lo inusual era que los hacía en un lugar de ciencia ficción: una especie de comuna financiada por un millonario que quería crear una biósfera en una construcción donde vivieran científicos. Tenía comunidades experimentales en distintos lugares del mundo. "El proyecto no funcionó finalmente pero lo bueno fue que decidieron hacer una obra de teatro y me responsabilizaron de la escenografía. Descubrí un arte complejo y me apasioné muchísimo. Salí con la idea de ser escenógrafo, pero era muy difícil hacer escenarios para teatro sin una compañía de teatro, y lo que hice -casi por economía- fue ponerme a pintar" (Amorales, entrevista abril de 2008).

${ }^{240}$ En el catálogo de la exhibición Extranjerías y otros extrañamientos, en el Museo Universitario de Arte Contemporáneo de la Ciudad de México, curada en 2012 por Néstor García Canclini y Andrea Giunta, se interrogan sobre el modo en que las tecnologías han cambiado las formas de representación del mundo y reflexionan sobre las peculiaridades de la obra de Carlos Amorales. El artista presentó una instalación con 14 figuras murales híbridas - mitad humanos, mitad pájaros—, y dispuso sobre estas miles de CDs copiados intervenidos con colores y formas abstractas pintados a mano. "La piratería es un hecho que la lectura poética permite convertir en programa: el ideal de establecer universos de escuchas, audiencias que descalzan las fronteras jurídicas para crear comunidades definidas por los mismos gustos musicales" (4). Comentan que en Cuba la pieza provocó un comportamiento cercano al saqueo, en Puerto Rico dio lugar a un clima de fiesta, pero en Buenos Aires la Fundación Telefónica, la institución en la que se exhibió, se preocupó por la controversia que podría generar una exposición de música pirata. Amorales optó por quemar allí los CDs con la música de Nuevos Ricos.

${ }^{241}$ Amorales grabó en una pieza de video, a modo de teatro de sombras, al compositor guatemalteco Joaquín Orellana, mientras éste ejecutaba su propia versión del Aprendiz de Brujo. Orellana ha inventado instrumentos que replican las posibilidades de los electrónicos y halló un camino conectado a las experiencias culturales de origen y de su formación en el Instituto Torcuato di Tella de Argentina, un modo de crear un sistema propio de notación en su música ultra-contemporánea.

${ }^{242}$ El mismo Luis Camnitzer señala prácticas de ficción extrema: la osadía de Minerva Cuevas, que diseñó un sistema de código de barras bajo el amparo de su práctica artística que permitía al comprador adquirirlos pero que abría fisuras en las regulaciones comerciales que suelen regir este tipo de registros. Siendo arte lo que de otra manera sería un fraude adquiere una naturaleza reflexiva sobre el funcionamiento del sistema de mercado. Su propuesta se acerca a formas imaginativas de movilizar la redistribución de bienes que fue en cierto modo lo que Trepadori alcanzó en tanto generó recursos a partir de una impostura. El dúo creado por Jacques Servin e Igor Vamos, The Yes Men, ha propiciado numerosas prácticas artísticas infiltrándose en la lógica de las corporaciones y organizaciones a través de páginas de Internet que asemejan y parodian las que controlan impuestos, o explotan petróleo. La idea de que las mentiras permiten exponer la verdad los ha llevado a lograr una alta exposición mediática a partir de la confusión de identidades como una máscara para revelar, desde la parodia, modus operandi que provocan daños sociales o ambientales. Suelen crear sitios web que son confundidos con los de los organismos sobre los cuales dirigen el potencial de sus ficciones. Dan conferencias que extreman la lógica del capitalismo salvaje. Así, una obra suya consistió en argumentar seriamente que dado que el cuerpo humano dirigere sólo un tercio del material nutritivo de los alimentos, si se reciclaran las materias fecales y se sometieran a un porceso de destilación quedaría valor nutritivo para alimentar a los pobres. La parodia llevada hasta el fin con total seriedad cumple una función especular y revela, desde el humor más negro, las zonas oscuras del mundo. El propio Camnitzer evoca a un arquitecto y artista conceptual olvidado, Jorge Bonino (1935-1990), a quien, pese a haber participado en un film dirigido por Marta Minujin. "nunca se le ha dado el crédito que merecía". Entre sus obras, solía dar conferencias en un idioma inventado. Camnitzer lo llevó a una de sus clases y lo presentó como un antropólogo especializado en en las costumbres de danza de los indios patagones. No había ninguna palabra que tuviera sentido, pero la realizaba con toda la modulación y acompañada de dibujos y diagramas. "Llegó a extenderse unos 15 minutos. Hasta que la clase se dio cuenta de que era una broma: muchos críticos de arte escriben así" (Camnitzer, entrevista, septiembre 5 de 2014). El mexicano Pablo Helguera (n.1971) también ha organizado conferencias ficticias que tienden a desestructurar la pasividad con la cual se reciben los discursos impartidos por supuestos expertos en estos contextos. 
${ }^{243}$ Si habitamos un mundo cada vez más virtual, donde se hacen cada vez más débiles las fronteras de la ficción y la realidad, o hay una suerte de contigüidad creada también por los nuevos medios que no tiene comparación con ningún momento anterior, no menos cierto es que el juego de las identidades múltiples puede ser comprendido con una naturalidad que habría sido impensable en cualquier otro tiempo, y configurar nuevas formas de protección y proyección que apenas estamos configurando. 


\section{OBRAS CITADAS}

100 Notizen - 100 Gedanken / 100 Notes - 100 Thoughts, presentation of the project at DOCUMENTA (13). 15 de octubre de 2011. Web.

"1937 / 1940 : Max Ernst, à Saint-Martin d'Ardèche et au camp des Milles." Galerie Alain Paire (2014). Web.

Aberth, Susan L. "Leonora Carrington's La Cuna.” Christies (2012). Web.

Aberth, Susan L. "The Alchemical Kitchen: At Home with Leonora Carrington" Nierik (2013): 7-15. Web.

Aberth, L. Susan. Surrealism, Alchemy and Art. New York: Lund Humphries, 2004. Impreso.

Actas del Congreso Internacional. "Max Aub y El laberinto Español." Ed. Cecilio Alonso. Valencia: Colección de actas y congresos. 1996. Impreso.

Alameda, Zoé. "El diálogo supratemporal frente a la impostura literaria. Claves para descifrar la obra de Enrique Vila-Matas." Grand Séminaire de Neuchâtel: Coloquio Internacional Enrique Vila-Matas", 2-3 de diciembre de 2002. Madrid: Arco/Libros, 2007. Impreso.

Amor, Inés. "A Tribute to Leonora Carrington," Leonora Carrington. A Retrospective Exhibition. Center for Inter-American Relations, New York City: Center for InterAmerican Relations, 1976. Impreso.

Anastasi, William. "Duchamp on the Jarry Road," Artforum, September 1991. Web.

Anderson, Darran. "Leonora Carrington: The Celtic Surrealist" Studio International (2013). Web.

Andrade, Lourdes. Leonora Carrington. Historia en dos tiempos. México D.F: Círculo de Arte, 1998. Impreso.

Andrade, Lourdes. Leyendas de la Novia del Viento. Leonora Carrington escritora. Mexico D.F: Consejo Nacional para la Cultura y las Artes y Artes de México, 2001. Impreso.

Ángel Sáinz, José. El retorno de Max Aub o la poética de un imposible. Mary Washington College. Web. 
Arrabal Fernando et al. La revolución surrealista a través de André Breton. Caracas: Monte Ávila Editores, C.A., 1970. Impreso.

Arranz Lago, David. "Indagaciones lingüísticas en Crímenes ejemplares de Max Aub”, Congreso Internacional del Centenario Max Aub, testigo del siglo XX. Valencia, abril de 2003. Web.

Aub, Max. Crímenes ejemplares. Segorbe: Fundación Max Aub, 2001. Impreso.

Aub, Max. Jusep Torres Campalans. Barcelona: Biblioteca Letras del exilio. Plaza\&Janes, 1984. Impreso.

Aub, Max. Dos vidas imaginarias. Jusep Torres Campalans. Vida y obra de Luis Álvarez Petreña. Epílogo de Antonio Muñoz Molina. Barcelona: RBA, 2011. Impreso.

Aub, Max. La gallina ciega. Barcelona: Alba. 1995. Impreso.

Aub, Max. Luis Buñuel, Novela. Madrid: Cuadernos del Vigía. 2013. Impreso.

Bajtín, M. M. Estética de la creación verbal. Duodécima edición en español. Buenos Aires: Siglo XXI Editores, 2005. Impreso.

Bal, Miekel. Looking in the Art of Viewing. Intro. Norman Brysson. Nueva York: Routledge, 2001. Impreso.

Baler, Pablo. The Next Thing: Art in the Twenty-first Century. Teaneck: Farleigh Dickinson University Press, Madison. Edición en Kindle. 2013.

Ballester, Torrente Gonzalo. El Quijote como juego y otros trabajos críticos. Barcelona: Ediciones Destino, S.A. ,1984. Impreso.

Bartra, Agustí. ¿Para qué sirve la poesía? Madrid: Siglo veintiuno editores, 1999. Impreso.

Bearse, Grace M. Reviewed work(s): “La broma literaria en nuestros días: Max Aub, Francisco Ayala, Ricardo Gullón, Carlos Ripoll, César Tiempo”. Hispania 64.3 (1981): 481. Impreso.

Beilin, Katarzyna Olga. Conversaciones literarias con novelistas contemporáneos. Rochester: Tamesis, 2004. Impreso

Bellatin, Mario. Los fantasmas del masajista. Buenos Aires: Eterna Cadencia, 2009.

Bellatin, Mario. Obra reunida 2. Ciudad de México: Alfaguara, 2014. 
Bellatin, Mario. Pájaro Transparente. Buenos Aires: Casa Mansalva, 2006.

Bellatin, Mario. "Shiki Nagaoka: A Nose for Fiction (an excerpt)." Trans. David Shook. World Literature Today 85.6 (2011): 17+. Academic OneFile. Web. 13 Oct. 2014.

Bellatin, Mario. Shiki Nagaoka: una nariz de ficción. Lima: Fondo Editorial de la Pontificia Universidad Católica de Perú, 2002.

Bellatin, Mario, Soler Frost Pablo, Amara, Luigi y Uribe, Álvaro. "Bestiario fantástico", Letras libres, junio de 2008. Web.

Benjamin, Walter. "Calle de dirección única". Obras, IV, 1 (23-89), Madrid: Abada, 2010. Trad. Jorge Navarro Pérez. Impreso.

Berger, Barbara. Comp. Max Ernst. Dream and Revolution. Stockholm: Exhibition at Moderna Museet (2009). Web.

Bischoff, Ulrich. Max Ernst. 1891-1976, Más allá de la pintura. Alemania: Ed. Köln Taschen, 2003. Impreso.

Blake, Robin. Essential Modern Art. Parragon: London, 2001. Impreso.

Blesa, Túa. "Un fraude en toda regla: Historia abreviada de la Literatura portátil, 1" Homenaje a Gaudioso Giménez. Zaragoza: Universidad de Zaragoza (123-133), 2003. Impreso.

Bois, Ive Alain. "Toward the Abolition of Form" Inventing Abstraction 1910-1925. How a Radical Idea Changed Modern Art. Ed. Leah Dickerman. Published in conjunction with the exhibition "Inventing Abstraction at the Museum of Modern Art", December 23, 2012-April 15, 2013. The Museum of Modern Art, MoMA: New York, 2013: 226- 237. Impreso.

Borges, Jorge Luis. Cervantes y el Quijote. Edición compilada y realizada por Sara Luisa del Carril y Mercedes Rubio de Zocchi. Buenos Aires: Emecé Editores, S.A., 2005. Impreso.

Borriaud, Nicolas. "Altermodern Manifesto" Altermodern: Tate Triennial 2009. Londres: Tate Modern (2009). Web.

Brenda, Marshall. Teaching the Postmodern. Fiction and Theory. New York: Routledge, 1992. Impreso.

Breton, André. Le Surrealisme et la Peinture. Paris: Gallimard, 1967. Impreso. 
Brian McHale. Postmodernist Fiction. Nueva York: Methuen: 1987. Impreso.

Cabanne, Pierre. Duchamp and Cie. Paris: Pierre Terrail, 1999. Impreso.

Calvo Revilla, Ana María. "Ficción y realidad en Jusep Torres Campalans de Max Aub", El correo de Euclides: anuario científico de la Fundación Max Aub 1 (2006): 428-440. Web.

Camnitzer, Luis. Conceptualism in Latin American Art: Didactics of Liberation. Austin: University of Texas Press, 2007. Impreso.

Camnitzer, Luis. New Art from Cuba. Austin: University of Texas Press, 1994.

Cañas, Dionisio. "La dialéctica de la identidad en la poesía contemporánea. La persona, la máscara". Hispanic Review 52.1 (1984): 100-102. Web.

Caravaggio, Jean. Cervantes. Trad. Mauro Armiño. Madrid: Espasa Calpe, S.A. 2003. Impreso.

Carrington, Leonora. El séptimo caballo y otros cuentos. México D.F: Siglo veintiuno editores, Traducción de Francisco Torres Oliver y Stella Mastrangelo, 1992. Impreso.

Carrington, Leonora. La casa del miedo. Memorias de abajo. México D.F: Siglo veintiuno editores. Traducción de Francisco Torres Oliver, 1992. Impreso.

Carrington, Leonora. La dama oval. México D.F.: Ediciones Era, 1965. Impreso.

Carrington, Leonora. Memorias de abajo. Madrid: Siruela, 1992. Impreso.

Carrington, Leonora. "The Cabbage is a Rose" (1975), Ed. Penelope Rosemont. Surrealist Women: An International Anthology, Austin. University of Texas Press, 1998. Impreso.

Carrington, Leonora. Dibujos, pinturas y grabado. México D.F: Taller Gráfica Bordes, 2007. Impreso.

Carsten-Peter Warncke. Picasso. Madrid: Taschen's 25th anniversary special editions. 2006. Impreso.

Cervantes Saavedra, Miguel. El ingenioso hidalgo Don Quijote de la Mancha. Edición popular ilustrada con grabados. Madrid: Saturnino Calleja, Editor, 1905. Impreso. 
Chadwick, Whitney. Leonora Carrington. La realidad de la imaginación. México D.F: Dirección General de Publicaciones del Consejo Nacional para la Cultura y las Artes y Ediciones Era, 1994. Impreso.

Chadwick, Whitney "Evolution of a Feminist Consciousness" Women's Art Journal 7.1 (1986). Web.

Chadwick, Whitney. "D'un jour à l'autre: A Tale of Love, War and Friendship." Papers of Surrealism 9.1 (2011). Web.

Cherem, Sylvia. "La última Surrealista". Gatopardo (2003): 45-53, 284. Web.

Cherem, Sylvia. Trazos y revelaciones. Entrevistas a diez artistas mexicanos. México D.F.: Fondo de Cultura Económica, 2004. Impreso.

Cherem, Sylvia. "Fallece Chiki Weisz". La Reforma (2007). Impreso.

Cleary, Heater. “Mario Bellatin's Shiki Nagaoka: a Nose for Fiction”, agosto de 2013. Wordswithoutborders, Web.

Conley, Katharine. "Carrington's Kitchen". Papers of Surrealism 10 (2013). Web.

Cros, Caroline. Marcel Duchamp. Londres: Reaktion Books, 2006. Impreso.

Danto C Arthur. "After the End of Art. Contemporary Art and the Pale of History." The A.W. Mellon Lectures in the Fine Arts. Jersey: Princenton University Press, 1997. Impreso.

Danto C. Arthur. What Art Is. New Haven: Yale University Press, 2013.

Derant, Jean-Philippe. "The Symbolic and the Material: A Review of Jacques Ranciere's Aisthesis: Scenes from the Aesthetic Regime of Art" Parrhesia, 18 (2013).

Dickerman, Leah. "Dada". National Gallery of Art, Washington: D.A.P. Inc, 2006. Impreso

Dickerman, Leah. Editor. Dada: Zurich, Berlin, Hannover, Cologne, New York, Paris, Washington: National Gallery of Art, 2006. Impreso.

Dijkstra, Bram. Georgia O'Keeffe and the Eros of Place. Princenton: Princeton University Press, 1999. Impreso.

Eburne, Jonathan. "Breton's Wall, Carrington's Kitchen: Surrealism and the Archive"Erudit. Intermédialités: histoire et théorie des arts, des lettres et des 
techniques / Intermediality: History and Theory of the Arts, Literature and Technologies 18 (2011): 17-43. Web.

Edward, James. "Introduction" Leonora Carrington. A Retrospective Exhibition. Center for Inter-American Relations, New York City, November 26-January 4, 1976. University Art Museum, The University of Texas at Austin. January 18-February 29, 1976. Impreso.

Eluard, Paul. El poeta y su sombra. Fragmentos para un arte poético. Barcelona: Icaria editorial S.A., 1981. Impreso.

Ernst, "Catalogue.” The Museum of Modern Art, 1961. Impreso.

Faber, Sebastiaan. Exile and Cultural Hegemony: Spanish Intellectuals in Mexico, 1939 1975. Nashville: Vanderbilt University Press, 2002. Impreso.

Faber, Sebastiaan. "Un pasado que no fue, un futuro imposible: juegos parahistoricos en los cuentos del exilio de Max Aub." Explicación de Textos Literarios 29.1 (2000). Impreso.

Fernández Martínez, Dolores. "Max Aub y Ana María Merkel. Ficción y realidad de una artista desconocida." Estudio de los Exilios y Migraciones Ibéricos Contemporáneos (AEMIC). Universidad de Alcalá de Henares. Olivar 3.3 (2002): 95-116. Web.

Fernández Martínez, Dolores. "Relación con el país de acogida: el debate artístico mexicano en la obra de Max Aub." Ed. Manuel Aznar Soler El exilio literario español de 1939: actas del Primer Congreso Internacional (Bellaterra, 27 de noviembre- 1 de diciembre de 1995). Vol. 1. San Cugat del Vallès, Barcelona: Universitat Autònoma de Barcelona, 1998. Impreso.

Friedman, Samantha. "Avant abstraction. Kupka and Mondrian Represent". moma.org, January 24, 2013. Web.

Fontana Soler, S. "San Juán de Max Aub”. revista.abretelibro.com, Junio de 2014. Web.

Foucault, Michel. Las palabras y las cosas. Una arqueología de las ciencias humanas. Trad. Elsa Cecilia Frost. Buenos Aires: Ed. Siglo XXI., 1968. Impreso.

Foucault, Michael. Nietzsche, la genealogía, la historia. Valencia: Pre-Textos, 2004. Impreso.

Foucault, Michael. "The Historical a priori and the Archive". The Archive. Ed. Charles Merewether. Londres: White Chapel \& MIT Press, 2006. Impreso. 
Gale, Mathew. “Do you Know my Aunt Eliza?” Tate Modern (2005). Web.

García Canclini, Nestor. El mundo entero como lugar extraño. Barcelona: Editorial Gedisa, 2014. Impreso.

García-Caro, Pedro. "Lujuria Roja. Aub visto por Ripstein.” Ciberletras 10 (2003). Web.

Garcia Haymes, Mateo. "La revista Martín Fierro ante la emergencia de las industrias culturales (1924-1927)", Letras Históricas 4, enero-junio (2011): 75-93. Web.

García Terres, Jaime. "La Historia." Cuadernos Americanos 32.2 (1973): 68-70. Impreso.

Genette, Gerard. Palimpsestos. Literatura en segundo grado. Trad. Celia Fernández. Madrid: Taurus, 1989. Impreso.

Goldchulk, Graciela. "El realismo minimalista de Mario Bellatin: lecciones y proposiciones", enero 27, 2012. Scribd, Web.

Goldman, Mathew. The Sun and the Moon: The Remarkable True Account of Hoaxers, Showmen, Dueling Journalists, and Lunar Man-Bats in Nineteenth-Century New York. New York: Basic Books, 2008. Impreso.

Gombrich. E.H. La historia del arte. Buenos Aires: Editorial Sudamericana, 2007. Impreso.

Gómez Haro, Germaine. "Leonora Carrington, la inasible.” La Jornada semanal (2011): 857. Web.

Gould, Stephen Jay. "From the Bitter Negro Pun to the Beautiful Breath Bottle". The Marcel Duchamp Studies Online Journal (2000). Web

Grant, Kim. Surrealism and the Visual Arts: Theory and Reception. New York: Cambridge University Press, 2005. Impreso.

Grillo, Rosa María. "La poética del falso: Max Aub tra gioco ed impegno." Atti del convegno Salermo, 14-15 marzo 1994. Biblioteca Virtual Miguel de Cervantes, 2002. Web.

Grimberg, Salomon, ed. Leonora Carrington, What She Might Be. Dallas: Dallas Museum of Art, 2008. Impreso.

Haffé. L.C. Picasso. París: Garzanti, 1973. Impreso.

Hernández, Felisberto. "Explicación falsa de mis cuentos," Entregas de la Licorne 5- 6 (Septiembre 1955): 97. Web. 
Herrera, Adriana. "A-cercamiento a Mario Bellatin" La otra esquina de las palabras, blog. Diciembre 11 de 2009.

Herrera, Adriana. Entrevista electrónica con Ana Tiscornia. Septiembre 5 de 2014.

Herrera, Adriana. Entrevista personal con Leonora Carrington. Mayo 20 de 2009.

Herrera, Adriana. Entrevista personal con Liliana Porter y Ana Tiscornia. Septiembre 2 de 2014.

Herrera, Adriana. Entrevista con Luis Camnitzer. Septiembre 2 de 2014.

Herrera, Adriana. Entrevista personal con Ruben Torres Llorca. Junio 2014.

Herrera, Adriana. Entrevista personal con Max Aub, nieto. Septiembre, 2006.

Herrera, Adriana. "Estética y política en el mundo actual." Poder y Negocios. Octubre 7 de 2008. Web.

Herrera, Adriana. "Leonora." Poder y Negocios (2011). Web.

Herrera, Adriana "Leonora Carrington. La novia del viento." Poder y Dinero (2009). Web.

Herrera, Adriana. "Los cien mil libros de Mario Bellatin", Diario La Opinión, 28 de noviembre de 2010.

Herrera, Adriana. "Los artefactos conceptuales de Rubén Torres Llorca", Ruben Torres Llorca. One of Us Can Be Wrong and Other Essays. Miami: Juan Ruiz Gallery, 2012. Impreso.

Herrera, Adriana. "Paradojas del arte cubano de la generación disidente de los 80", Sin Fronteras, Florida State University (2010). Web.

"Historia de la filosofia- Tomo III- Jordano Bruno." e-torre de babel. nd. Web.

Irizarry, Estelle. La broma literaria en nuestros días: Max Aub, Francisco Ayala, Ricardo Gullón, Carlos Ripoll, César Tiempo. New York: Eliseo Torres \& Sons, 1979. Impreso.

Irizarry, Estelle. "Cuatro bromas literarias de nuestros tiempos". Actas del Sexto Congreso Internacional de Hispanistas. Eds. Evelyn Rugg y Alan M. Gordon, 1980. Biblioteca Virtual Miguel de Cervantes. 402-405. Web. 
Jhonson, Reed. "Leonora Carrington's Spectral Presences." Los Angeles Times May 09, 2008. Web.

Jouannais, Jean-Yves. “Artistes sans oeuvres. I Would prefer not to.” Verticales (2009). Web.

Juan-Navarro, Santiago. Archival Reflections. Postmodern Fictions of the Americas (SelfReflexivity, Historical Revisionism, Utopia). Lewisburg: Bucknell University Press, Londres: Associated University Presses, 2000. Impreso.

Jusep Torres Campalans. Ingenio de la Vanguardia. Madrid: Museo Nacional Centro de Arte Reina Sofía, 2003. Impreso.

Kaplan, Janeth A. Unexpected Journeys: The Art and Life of Remedios Varo. New York: Abbeville Press, 1988. Impreso.

Kristeva, Julia, Semiótica, v. 1, trad. de José Martín Arancibia. Madrid: Fundamentos, 1978. Impreso.

La Colina, José. “Ernst. Poeta del Collage”. Letras Libres (2010). Web.

Lapresa, Josu. "Enrique Vila-Matas: Después del colapso.” Rollingstones. Mayo de 2010. Web.

Leclerc, Andre. Hyperion Miniatures: Picasso. New York: The Hyperion Press, s.f. Impreso.

Lepetit, Patrick. The Esoteric Secrets of Surrealism: Origins, Magic, and Secret Societies. Rochester: Inner Traditions International, 2014. Impreso.

Litvak, Lily Imágenes y textos: estudios sobre literatura y pintura 1849-1936. Atlanta: Rodopi, 1994. Impreso.

López Alfonso, Francisco J. "Mario Bellatin". The Contemporary Spanish-American Novel. Bolaño and After. Ed. Will H. Corral, Juan E. de Castro y Nocholas Birns. Nueva York: Bloomsbury Academic, 2013. Impreso.

Mahon, Alyce. Eroticism and Art. New York: Oxford University Press. 2007. Impreso.

Mailer, Norman. Picasso. Retrato del artista joven. Buenos Aires: Alfaguara, 1997. Impreso.

Malgat, André Malraux y Max Aub. La República Española. Crisol de una amistad. Cartas, notas y testimonios (1938-1972). Trad. Antoni Cisteró. Barcelona: Angle Editorial, 1990. Impreso. 
Malgat, Gérard. Max Aub y Francia o la esperanza traicionada. Sevilla: Renacimiento, 2007. Impreso.

Mandiá, Diana. “Gilberto Bosques, el Schlinder mexicano de cuerpo entero". DomingoEl Universal, 30 de marzo de 2014. Web.

Mantilla, Ruiz. "En la Guerra civil de Cartier-Bresson”. El País, 14 de mayo de 2010. Web.

Martín-Domínguez, Javier. Leonora Carrington. El juego Surrealista. Film. 80 minutos 2012

Martínez-Bonati, Félix. Don Quixote and the Poetics of the Novel. Trad. Dian Fox. Ithaca: Cornell University Press, 1992. Impreso.

Mas i Usó, Pasqual. Lo real de la ficción: De Max Aub a Antonio Muñoz Molina. Valencia: Congreso Internacional del Centenario "Max Aub, testigo del siglo XX'. 2003. Web.

Maurisson, Charlotte. "Écrire sur la peinture", Anthologie par Charlotte Maurisson. Paris: Gallimard, 2006.

"Max Ernst: Loplop presenta una flor o Figura antropomórfica y flor concha (1930)." historiadelarte.us. Web.

McAra, Catriona. "Surrealism's Curiosity: Lewis Carroll and the Femme-Enfant." Papers of Surrealism 9 (2011). Web.

McDaniel Tarver, Gina. "The Trepadori Project" The New York Graphic Workshop, 1964-1970. Ed. Gabriel Pérez-Barreiro, Úrsula Dávila Villa y Gina Mc Daniel Tarver. Austin: Blanton Museum of Art, The University of Texas, 2009. Impreso.

McRandle, Paul. "Marcel Duchamp: Étants donnés". Surrealist NYC. Febrero 17 de 2013. Web.

McRandle, Paul. "Scavenging the marvelous from the terrain of trauma" Surrealist NYC (2014). Web.

Méndez, Kathryn. "Mario Bellatin: Ghosts, the Human Body, and the Spaces Where they Meet", Orientalisms of the Hispanic and Luso-Brazilian World, Araceli Tinajero and Dr. Lakra. Nueva York: Paperback, 2014.

Moorhead, Joanna. "Leonora Carrington obituary”. The Guardian (2011). Web.

Moorhead, Joanna. “The surrealist muses who roared”. The Guardian (2010). Web. 
Montagu, Jemima. The Surrealists. Revolutionaries in Art \& Writing 1919-1935. London: Tate Publishing, 2002. Impreso.

Montiel Rayo, Francisca. "Mérimeé frente a Victor Hugo: la correspondencia entre Esteban Salazar Chapela y Max Aub", Escritores, editoriales y revistas del exilio republicano de 1939. Ed. Manuel Aznar Soler, 2006. 245-272. Impreso.

Morgan, Jessica. An unruly history of the readymade. Jumex: México, 2008. Impreso

Muñoz, Miguel Ángel. "Vila-Matas: la cultura visual no es nada sin el soporte del pensamiento", El sindrome Chéjov. Blogspot. Marzo 15 de 2010.

Muñoz Molina, Antonio. Against Irrationality. Interview with Adriana Herrera. Poder (2007): 74-77. Impreso.

Naumann, Fancis y Hector Obalak. Affectionately, Marcel. Amsterdam: Ludion, 2000. Impreso.

Nevala-Lee, Alec. The Icon Thief. Nueva York: Penguin Books, 2012. Impreso.

Núñez Pereira, Cristina. "Leonora Carrington”. Shangrila.textosaparte. Web.

Oleza Simó, Juan. "Antagonismo de apócrifos”, Blanco y Negro Cultural (ABC), 25 de enero de 2003, 6. Web.

Oleza Simó, Juan. "Luis Álvarez Petreña o la tragicomedia del yo", Actas del I Congreso Internacional sobre Max Aub. Valencia: Ayuntamiento, 1996.93-102. Web.

Oñoro Otero, Cristina: "Imaginar la memoria: los recuerdos inventados de Enrique VilaMatas", Haciendo camino en la investigación literaria. Asociación Aleph. Archivos del congreso, 2005. Impreso.

Otxoa, Julia. "Juego y laberinto en la obra de Enrique Vilamatas" Enrique Vila-Matas : Grand Séminaire de Neuchâtel : Coloquio Internacional Enrique Vila-Matas. Madrid : Arco/Libros ; Neuchâtel: Universidad de Neuchâtel, 2-3 de diciembre de 2002. Impreso.

Pacheco, José Emilio. Entrevista personal. 22 de junio, 2007.

Padilla, Ignacio. El diablo y Cervantes. México: Fondo de Cultura Económica, 2005. Impreso

Padró, Mariola Rosario. "Domicilio desconocido: Odradek como frontera entre la Intertextualidad y la parodia en historia abreviada de la Literatura portátil de enrique vila-matas". VIII Edición de la Gaceta hispánica de Madrid. Marzo de 2013. Web. 
Pauls, Alan. El factor Borges. Barcelona: Anagrama, 2004. Impreso.

Paz, Octavio. Apariencia desnuda. La obra de Marcel Duchamp. México D.F.: Era, 1978. Impreso.

Paz, Octavio. "Obras completas". Los privilegios de la vista I. Arte moderno universal. Fondo de Cultura Económica, 1994. Impreso.

Pauls, Alan. "El virus Duchamp". Página 12. 15 de septiembre de 1999. Web.

Pérez-Estévez, Antonio. "El diálogo como lectura en Gadamer". Ciudad Redonda: Marzo 2000. Web.

Pérez Olivares, José. “De Max Torres Campalans a Jusep Aub”, La Jiribilla 107, (2003). Web.

Pfister, Manfred. "Criterios", Intertextualität 1: La teoría de la intertextualidad en Alemania. Trad. Desiderio Navarro. La Habana, 2004. Impreso.

Picasso, Pablo. The artist and his model. 180 drawings. New York: Dover Publications, INC. 1994. Impreso.

Picasso. A Postcard book. Philadelphia: Running Press Book Publishers, 1988. Impreso.

Porter, Liliana y Tiscornia, Ana. "Axonometry of the Future; or, Prophecies for the Twenty-First Century" The Next Thing. Art in the Twenty-First Century. Ed. Pablo Baler. Teaneck: Farleigh Dickinson University Press, Madison. Version en Kindle, 2013. Impreso.

Porter, Liliana. Liliana Porter in conversation with Inés Katzenstein. / en conversación con Inés Katzenstein. Intro. Gregory Volk, Seatle: Marquand Books, 2014. Colección Patricia Phelps de Cisneros. Impreso.

Pozuelo Yvancos, J. M. "Vila-Matas en su red literaria." La menzogna 1. Universidad de Neuchâtel, 2 y 3 de diciembre de 2002. Ed Maria Grazia Profe. Impreso.

Raay van Stefan, Moorhead Joanna, and Teresa Arcq, eds. Surreal Friends: Leonora Carrington, Remedios Varos and Kati Horna. London: Lund Humphries with Pallant House, 2010. Impreso.

Rancière, Jacques. The Names of History: On The Poetics of Knowledge. Minneapolis: University of Minnesota Press, 1994. Impreso. 
Rancière, Jacques "The Aesthetic Revolution and its Outcomes". New Left Review. AprilMarch 2002. Web

Rangel, Gabriela. "What You See Is Not What It Is: An Interview with Alicia Mihai Gazcue", Review: Literature and Arts of the Americas. 43:2. (2010): 226-232. Impreso.

Raynal, Maurice, Jacques Lassaigne, Schmalenbach Werner, et al. History of modern painting from Picasso to Surrealism. Geneva: Skira, 1950. Impreso.

Richardson, John. A Life of Picasso, The Cubist Rebel 1907-1916. New York: Alfred A. Knopf. 1991. Impreso.

Ripstein, Arturo. "Entrevista con Max Aub". Conversaciones Buñuel. Cinta No 15. Lado B. Valencia: Fundación Max Aub.

Riquer, Martin de. Aproximación al Quijote. Navarra: Salvat Editores S.A, 1970. Impreso.

Ritcher, Peter-Cornell. Georgia O'Keeffe and Alfred Stieglitz. New York: Prestel Verlag, 2001. Trad. Ishbel Flett. Impreso.

Roca, Jose. "Reflexiones Críticas desde Colombia" Columna de Arena. 18 febrero de 2008. Web.

Roche, Julotte. Max y Leonora. Relato biográfico.. Mexico D.F.: Ediciones Era. Traducción de Tessa Brisac, 2001. Impreso.

Rodríguez, Juan. "La aportación del exilio republicano español al cine mexicano" Cine español en el exilio, 1936-1939. Ed. Roman Gubern. Barcelona : Lumen, 1976. Web.

Rokeby, David. "Transforming Mirrors. Subjectivity and Control in Interactive Media". Static Square Space. Web.

Romero Jodar, Andrés. "Reflexiones sobre la identidad con Doctor Pasavento de Enrique Vila-Matas" Revistas Científicas Complutenses 8 (2010). Web.

Romero, Keith Delmari. "Fantasmagoría de la modernidad". Revista de la Universidad de México 89 (2011): 42-48. Impreso.

Rubin Suleman, Susan. "El pájaro superior conoce a la novia del viento", (117-142), Los otros importantes / the Other Important: Creatividad y Relaciones Intimas, Madrid: Feminismos, 2007. Impreso. 
Russell, John. Max Ernst, Life and Work. Harry Abrams: First American Edition edition, 1967. Impreso.

Rusell, John. "Behind the Magical Images of Max Ernst" The New York Times (1983).Web.

Sáenz, G. Pilar. "De ambiguedades y violaciones en el arte de narrar". AIH. Actas XII (1995): 238-242. Web.

Sánchez, Miguel Ángel. "Max-Aub 1. Biografía”. Fundación Max Aub. Web.

San Martín, Francisco Javier. Dali-Duchamp: una fraternidad oculta. Madrid: Alianza Editorial, 2004. Impreso.

Sanouillet, Michel. Dada in Paris. Cambridge: MIT Press. Revised and expanded by Anne Sanouillet. Trans. Sharmila Ganguly, 2012. Impreso.

Santander, Roberto y Abadía Martín. "Sin Borges Hablaríamos En Inglés". La periódica revisión dominical. Octubre 30 2008. Web.

Santarcangeli, Paolo. El libro de los laberintos. Madrid: Ediciones Siruela. 1997. Impreso.

Samperio, Guillermo. "Max Aub o el drama del eterno exiliado". INBA, Coordinación Nacional de Literatura, (2014). Web.

Savater, Fernando. "Imaginación o barbarie”, El país, 25 de enero de 1998, Web.

Shmoop Editorial Team. "The Life and Opinions of Tristram Shandy, Gentleman", Shmoop.com . Shmoop University, Inc., 11 Nov (2008) 15 Oct. 2014. Web.

Seigel, Jerrold. The Private Worlds of Marcel Duchamp: Desire, Liberation, and the Self in Modern Culture. Berkeley: University of California Press, 1995. Impreso.

Sierra, Hernando. "Los cien mil libros de Mario Bellatin”, Revista de Investigación Dialéctica, (2012): 223 -226. Web.

Soldevila Durante, I., "El compromiso de la imaginación. Vida y obra de Max Aub". Fundación Max Aub (1999). Web.

Soldevilla Durante, Ignacio y Fernández Martínez, Dolores. Max Aub: 25 años después. Series: Cursos de verano de El Escorial. Madrid : Editorial Complutense, 1999. Impreso. 
Soldevila, Ignacio. “La obra narrativa de Max Aub (1929-1969)”. Hispania 58.1 (1975): 225. Impreso.

Sommer, Doris. The Work of Art in the World. Civic Agency and Public humanities. Durham \& Londres: Duke University Press, 2014. Impreso.

Speranza, Graciela. Atlas portátil de América Latina. Arte y ficciones errantes. Barcelona: Anagrama, 2012. Impreso.

Speranza, Graciela. "Ficciones de lo real” ERRATA 8, Inter/transdisciplinariedad. 2014. Web.

Speranza, Graciela. Fuera de campo. Literatura y arte argentinos después de Duchamp. Barcelona: Anagrama, 2006. Impreso.

Speranza, Graciela. "Topologías contemporáneas. Nuevas configuraciones del tiempo y el espacio en la narrativa y el arte latinoamericano" Seminario Universidad de Buenos Aires, Facultad de Filosofía y Letras. Buenos Aires, 2013.

Spies, Werner. Max Ernst-Loplop: The Artist in the Third Person. New York: George Braziller, 1983. Impreso.

Suárez, Andrés y Ana Casas. Cuadernos de narrativa. Madrid: Arco/Libros S.L: 2007. (ed). Enrique Vila-Matas. Impreso.

Taylor, Michael R. Marcel Duchamp. Etant donnés. Con ensayos de Andrew Lins, Melissa S. Meighan, Beth A. Price, Ken Sutherland, Scott Homolka, y Elena Torok. Philadelphia: Philadelphia Museum of Art, 2009. Impreso.

Thays, Ivan. "Los cien mil libros de Mario Bellatin", El País. Blogs. Cultura. Marzo 21 de 2012. Web.

Toriz, Rafael. "Los encantos de la hechicera", Casa del tiempo. Revista de la Universidad Autónoma de México 3 (2014): 63-65. Web.

Tovar Marín, Virginia. "El movimiento cubista". Junta de Castilla y León: La página del arte y la cultura en español. Web.

Trapiello, Andrés. Las vidas de Miguel de Cervantes. Barcelona: Ediciones Destino, 2005. Impreso.

Turkel, Gregory Daniel. "The Message of Surrealist Art: Automatism, Juxtaposition and Dreams". Dan Turkel (2009). Web. 
Urrutia, Elena. "Leonora Carrington, artista y escritora" Jornada Semanal (2001). Web.

Valls, Vicente María Angeles. "Las versiones ilustradas en la obra de Max Aub". El Correo de Euclides: anuario científico de la Fundación Max Aub 4 (2009): 88-99. Web.

Vila-Matas, Enrique. “Al revés”, El País, 27 de abril de 2010. Web.

Vila-Matas, Enrique. Aunque no entendamos nada. Santiago de Chile: Lorn Ediciones 2003. Impreso.

Vila-Matas, Enrique. "Baterbly y Compania” Enrique Vila-Matas (2000). Web.

Vila-Matas, Enrique. "Dicenda" Cuadernos de Filología Hispánica. 28: 247-265 Web.

Vila-Matas, Enrique. El ayudante de vilnius. Un blog de Enrique Vila-Matas. Web.

Vila-Matas, Enrique. El viaje vertical. Madrid: Quinteto, 2006. Impreso.

Vila-Matas, Enrique. “En el país de Tristam”, Letras libres, marzo de 2004. Web.

Vila-Matas, Enrique. Historia abreviada de la literatura portátil. Barcelona: Anagrama, 2005. Impreso.

Vila-Matas, Enrique. "Una vida absolutamente maravillosa" El país, Babelia. 18 de abril de 2009. Web.

Vila-Matas, Enrique. "Versión disidente de la Historia abreviada de la literatura portátill" Enrique Vila-Matas. Web.

Vílchez Ruiz, Carmen E. "Literatura y pintura. Jusep Torres Campalans, una novela cubista". Arbor. Ciencia, pensamiento y Cultura. 183.726 (2007): 503-510. Web.

Viñals, Carole. "André Malraux y Max Aub: dos visiones de la guerra civil española". Creathis, Universite de Lille III (2007). Web.

Von Thummel's Sammtliche Werke, A.M. "Sterne and the Novel of His Time". The Cambridge History of English and American Literature XLII, ii : 200-205. Charleston: Nabu Press, 2012. Impreso.

Wahnón, Sultana. Discurso "El campo y las cenizas. Imágenes del Holocausto en la poesía española de posguerra". Academia de Buenas Letras de Granada (2010). Web.

Waldberg, Patrick. "Surrealismo", J. Pijoan. Historia del arte. Tomo 10. Barcelona: Salvat Editores, S.A., 1970. Impreso. 
Warlik, M. E. Max Ernst and Alchemy: A Magician in Search of Myth. New York: The Solomon R. Guggenheim Foundation, 1975. Impreso.

Warncke, Carsten-Peter. Picasso. Madrid: Taschen, 2006. Impreso.

Warner, Marina, “Leonora Carrington's spirit bestiary; or the art of playing makebelieve", Leonora Carrington: Paintings, Drawings, and Sculptures 1940-1990, ed. Andrea Schlieker. London: Serpentine Gallery, 1991. Impreso.

Warner, Marina "Introduction". Leonora Carrington, The House of Fear: Notes from Down Below. Trans. Katherine Talbot and Marina Warner. New York: E.P.Dutton, 1988. Impreso.

Watson, Steve. Strange Bedfellows. The First American Avant-Garce. Nueva York: Abbeville Press Publishers, 1991. Impreso.

Weiss, Rachel. "Introduction on art", Artist, Latin America and Other Utopias by Luis Camnitzer. Austin University of Texas Press, 2009. Web.

Zavala. M, Iris. "Bajtin y sus apócrifos o en-el-nombre-del-Padre."En Bajtin y sus apócrifos. Ed. Iris M Zavala, Tatiana Bubnova, et al. Barcelona: Anthropos, 1996. Impreso. 
VITA

ADRIANA HERRERA

Born, Bogota, Colombia

$1981-1983$

Letters and Philosophy

Universidad Santo Tomás de Aquino

1985

B.A., Social Communications

Universidad Jorge Tadeo Lozano

Bogotá, Colombia

1984

1989

1992

Philosophy and History professor

Colegio Junin

Providencia Island, Colombia

Art History under the direction of Francisco Gil-Tovar

Courses at Galeria Dinners

Bogotá, Colombia

Post-graduate studies in Literature and visual culture

Universidad Externado de Colombia

Post-graduate studies in Literature Pontificia Universidad

Javeriana de Bogotá

Bogotá, Colombia

1995

1989-1997

1996-1998

Writing and Pre-Hispanic literatura profesor

Pontificia Universidad Javeriana de Bogotá

Bogotá, Colombia

Epistemology, Comunications and Literature theory, PreHispanic literature professor

Universidad Jorge Tadeo Lozano

Bogota, Colombia

Editor

Women Institute of Colombia

Bogota, Colombia

1998

Researcher

"Investigation about communication strategies for marginal female populations in search of employment" -"Workshops on the relationship between gender and media"

UNESCO- Instituto Nacional para la Equidad de la Mujer 
Bogota, Colombia

2008

Teaching Assistant

Florida International University

Miami, Florida

$2011-2014$

Curator: "Post-Utopic Cuban Art" (Houston Art Fair

Houston, Texas), "Maria Thereza Negreiros: Offerings"

(Frost Art Museum, Miami, Florida). Member of Aluna

Curatorial Collective curating many exhibitions including

"Seminal Art" Museum of Contemporary Art Siberia

Novosibirk, Russia; "Sonia Falcone \& Damien Hirst"

Montenegro, Monaco.

2000-2013

Art and Literature Critic (El Nuevo Herald

Miami, Florida). Editor (Arte al Día International)

PUBLICATIONS

Herrera, Adriana. (2003). Sembrando vida: jovenes a contrapelo del conflicto en Colombia. Bemposta-Terres de Hommes. Bogota, Colombia.

Herrera, Adriana. (2008). "Elena Garro y la desmitificación de la memoria de los intelectuales mexicanos en la Guerra Civil Española". Elena Garro: yo quiero que haya mundo, Anthology by Patricia Rosas Lopategi. Porrua, Mexico City, Mexico.

Herrera, Adriana. (2010). "Antonieta Rivas Mercado: la ruta del escándalo en su vida y su escritura". Femenine Transgression/Transgresion Femenina, Anthology by Patricia Rosas Lopategui. Floricanto-Berkeley Press: 15-34. Berkeley, California.

Herrera, Adriana. (2010). "Cristina Rivera Garza: la escritura bífida”. De Sor Juana al siglo XXI: 21 escritoras mexicanas revolucionarias. Universidad autónoma de Nuevo Leon, Monterrey, Mexico. Vol. 2:397-400.

Herrera, Adriana. (2010). "Gonzalo Lebrija or the Lightness of Adventure". Gonzalo Lebrija. As Time Goes By. Other Criteria. London, UK.

Herrera, Adriana (2011). Amparo Garzón. Realismo Mágico/ Magic Realism. Autores Editores, Bogotá, Colombia.

Herrera, Adriana. (2011). "A la orilla de los otros/At the Shore of Others". The Island Rape. Nesolectura exercises around Bill Viola. Deputy ministry of Culture of the Canary Islands. Canary Islans, Spain. Lecture at MOCA Miami. 